UNIVERSIDAD DE SALAMANCA

ORE FACULTAD DE TRADUCCIÓN Y DOCUMENTACIÓN DEPARTAMENTO DE BIBLIOTECONOMÍA Y DOCUMENTACIÓN DOUTORADO EM METODOLOGIAS E LINHAS DE INVESTIGAÇÃO EM BIBLIOTECONOMIA E DOCUMENTAÇÃO

\title{
VISIBILIDADE E USABILIDADE DOS ARQUIVOS ESPANHÓIS EM REDE
}

\author{
CLÁUDIA ALBUQUERQUE VERARDI
}

SALAMANCA 


\title{
UNIVERSIDAD DE SALAMANCA
}

FACULTAD DE TRADUCIÓN Y DOCUMENTACIÓN

DEPARTAMENTO DE BIBLIOTECONOMÍA Y DOCUMENTACIÓN

DOUTORADO EM METODOLOGIAS E LINHAS DE INVESTIGAÇÃO EM

BIBLIOTECONOMIA E DOCUMENTAÇÃO

\author{
CLÁUDIA ALBUQUERQUE VERARDI
}

\section{VISIBILIDADE E USABILIDADE DOS ARQUIVOS ESPANHÓIS EM REDE}

\begin{abstract}
Tese de Doutorado em Linhas de investigação em Biblioteconomia e Documentação, cód. 59754, apresentada ao Programa de Doutorado do Terceiro Ciclo da Universidade de Salamanca, como exigência para a obtenção do título de Doutora.
\end{abstract}

Orientador: Dr. Jose Antonio Montoya Frías

Co-orientadora: Dra Manuela Moro Cabero

Salamanca 


\title{
Trabalho de Investigação apresentado por:
}

\author{
Cláudia Albuquerque Verardi
}

Orientado por:

Dr. Jose Antonio Montoya Frías

Dra . Manuela Moro Cabero

Salamanca

2011 
Verardi, Cláudia Albuquerque.

Visibilidade e Usabilidade dos Arquivos espanhóis em Rede./ Cláudia Albuquerque Verardi. -

Salamanca, 2011.

1. Trabalho de Investigação 2. Avaliação de sites 3. Critérios de avaliação

4. Usabilidade 5. Visibilidade

I. Título. II. Biblioteconomia III. Arquivos 
O segredo do sucesso é a constância do propósito.

Bejamin Disraeli 


\section{AGRADECIMENTOS}

\section{A Deus que sempre guia meus caminhos!}

Aos meus orientadores José Antônio Frias Montoya e Manuela Moro Cabero, que dedicaram tempo e paciência desde a escolha do tema até a conclusão da tese;

À minha família, que sempre esteve ao meu lado mesmo quando estive distante. Especialmente à minha filha Îtala Verardi que soube compreender minha ausência durante esses anos e cujo amor move minha vida;

Aos amigos que entenderam, muitas vezes, as inquietudes, as reclamações, as lágrimas e ainda são meus amigos;

A Gicélia, amiga de sempre, que aceitou ser uma das avaliadoras na primeira etapa da pesquisa e sempre torceu por mim.

A Virgínia Barbosa, anjo bom que me ajudou solicitamente sempre que precisei.

A Dalson, Flávio Cireno, Cristiano, Catão, Esdras, Luciano, Carlos, Eliane, Verônica e outros profissionais que colaboraram comigo e sem os quais não poderia concluir este trabalho;

Aos estagiários da Fundação Joaquim Nabuco e alunos da Universidade Federal que participaram dos Testes com usuários;

A Solange Carvalho, que aceitou o desafio de ser a revisora da tese;

A todos que direta ou indiretamente me ajudaram com palavras, orações ou ainda com orientações em aspectos que não compreendia no caminho da realização deste trabalho;

Especialmente agradeço a Marcos Galindo, que enxergou a profissional em meio a toda dificuldade que apresentava com a investigação, reconheceu meu valor e me encorajou a seguir em frente, oferecendo sua ajuda preciosa;

Finalmente agradeço aos amigos visíveis e "invisíveis", que me auxiliaram na concretização deste sonho e aos anjos que Deus colocou no meu caminho para que fosse possível a vitória final. 


\section{RESUMO}

Este trabalho trata de critérios de avaliação de páginas Web, mais especificamente de Visibilidade e Usabilidade. O tema da avaliação de páginas Web vem sendo estudado por muitos autores, porém, a pesquisa tem caráter inovador por dedicar-se à sites de Arquivos Espanhóis disponíveis em rede. As aidéias defendidas neste estudo refletem a prática de uma vivência profissional aliada ao saber acadêmico adquirido pelos ensinamentos dos mestres da Universidad de Salamanca, representa ainda o descortinar do universo da Arquivologia face às novas formas de pesquisa impostas pela "Sociedade da Informação". A investigação centrou-se nas seguintes questões: diante da expectativa atual da sociedade estes centros estão caminhando lado a lado com as novas tecnologias de informação e comunicação, disponibilizando seus serviços através da internet; boa parte dos Arquivos espanhóis está em rede e se faz necessário avaliar a qualidade destes sites principalmente através de sua visibilidade e usabilidade considerando a perspectiva dos usuários uma vez que o objetivo de sua criação é a satisfação dos seus anseios e necessidades informativas. O trabalho baseou-se em pesquisa bibliográfica, questionários aplicados por amostragem não probabilística junto a prováveis usuários e por fim, questionários elaborados para avaliar sites aplicados a profissionais da área de informática os quais foram nomeados "avaliadores" dos sites objeto deste estudo. Após as análises quantitativas e qualitativas dos dados, pôde-se comparar os resultados do teste com usuários, através do qual se verificou a maneira com que eles interatuam com as interfaces dos sites, com os resultados das análises dos avaliadores. Concluiu-se que a qualidade dos sites está diretamente relacionada com a usabilidade destes e que da visibilidade depende a disseminação de seus fundos, funções e serviços.

PALAVRAS-CHAVE: Arquivos Espanhóis. Avaliação de Sites. Usabilidade. Visibilidade. 


\section{RESUMEN}

Se estudian los criterios para evaluar las páginas Web, concretamente la visibilidad y usabilidad. Este tema ha sido estudiado por muchos autores, sin embargo, la investigación es innovadora porque se centra en los sitios web de archivos españoles, ya que estos centros están trabajando con las nuevas tecnologías de información y de comunicación, ofreciendo sus servicios a través de Internet. Gran parte de los archivos españoles está disponible en red y es necesario evaluar la calidad de estos sitios, principalmente a través de su visibilidad y usabilidad teniendo en cuenta la perspectiva de los usuarios una vez que el objeto de su creación es el cumplimiento de sus aspiraciones y necesidades de información. Las técnicas de recogida de información empleadas han sido la revisión de la literatura, los cuestionarios para los probables usuarios finales y los cuestionarios utilizados para evaluar los sitios por los profesionales de la informática que aqui se denominan "evaluadores" de los sitios objeto de este estudio. Después del análisis cuantitativo y cualitativo de los datos, fue posible comparar los resultados del test con usuarios, lo que permitió conocer la forma en que interactúan con las interfaces de los sitios, con los resultados del análisis de los evaluadores. Se concluyó que la calidad de los sitios está directamente relacionada con la usabilidad y visibilidad y que de estas depende la difusión de sus fondos, funciones y servicios.

PALABRAS-CLAVE: Archivos Españoles. Evaluación de Sitios Web. Usabilidad. Visibilidad. 


\section{LISTA DE TABELAS}

Tabela 1 - Peso dos critérios

Tabela 2 - Distribuição dos participantes por sexo

Tabela 3 - Faixa etária dos participantes do teste

Tabela 4 - Nível de formação dos usuários

Tabela 5 - Experiência em buscas pela Internet

Tabela 6 - Motores de busca mais utilizados pelos usuários

Tabela 7 - Posição dos sites nos buscadores da Internet

Tabela 8 - Identificação do ícone de busca na homepage do site

Tabela 9 - Informações sobre o MCU nos sites avaliados

Tabela 10 - Sites com conteúdo semelhante

Tabela 11 - Linguagem do site

Tabela 12 - Área de acesso restrito nos sites avaliados

Tabela 13 - Visualização das atualizações e novidades dos sites avaliados

Tabela 14 - Navegação nas páginas Web avaliadas

Tabela 15 - Erro ou confusão visual nos sites avaliados

Tabela 16 - Escala de pontuação de Nieto Caraveo e Díaz Villa (2005)

Tabela 17 - Síntese das notas atribuídas pelos avaliadores

Tabela 18 - Pontuação por avaliador da Avaliação Preliminar

Tabela 19 - Pontuação por critérios 
Tabela 21 - Pontuação dos resultados dos critérios - ACMC

Tabela 22 - Pontuação dos resultados dos critérios - ACA

Tabela 23 - Pontuação dos resultados dos critérios - ARCV

Tabela 24 - Pontuação dos resultados dos critérios - AGI

Tabela 25 - Pontuação dos resultados dos critérios - AGA

Tabela 26 - Pontuação dos resultados dos critérios - AGS

Tabela 27 - Pontuação dos resultados dos critérios - AHN

Tabela 28 - Pontuação dos resultados dos critérios - AHPA 280

Tabela 29 - Pontuação dos resultados dos critérios - AHPG

Tabela 30 - Pontuação dos resultados dos critérios - AHPV

283

Tabela 31 - Pontuação dos resultados dos critérios - CDMH 285

Tabela 32 - Pontuação dos resultados dos critérios - SNAHN

286

Tabela 33 - Estatística descritiva - Tempo de Avaliação do site

293

Tabela 34 - Estatística descritiva - Tempo de avaliação por Usuário

294

Tabela 35 - Estatística descritiva - Tempo de avaliação por Arquivo

296

Tabela 36 - Primeira Impressão - AHN

299

Tabela 37 - Primeira Impressão - ADS 300

Tabela 38 - Primeira Impressão - AVME 301

Tabela 39 - Primeira Impressão - AHPH 301

Tabela 40 - Primeira Impressão - AHEV 302

Tabela 41 - Primeira Impressão - AHA 303

Tabela 42 - Primeira Impressão - AGMA 
Tabela 43 - Primeira Impressão - AUS

Tabela 44 - Primeira Impressão - AGS 305

Tabela 45 - Primeira Impressão - MAS 305

Tabela 46 - Primeira Impressão - AEG 306

Tabela 47 - Primeira Impressão - AHPG 307

Tabela 48 - Primeira Impressão - AHVL 307

Tabela 49 - Primeira Impressão - AHPGR 308

Tabela 50 - Ferramenta de busca - Usuários 309

Tabela 51 - Coerência dos Links 311

Tabela 52 - Coerência dos Links por arquivo 311

Tabela 53 - Necessidade de treinamento 312

Tabela 54 - Necessidade de treinamento por arquivo 313

Tabela 55 - Linguagem do site $\quad 315$

Tabela 56 - Impressão Geral- AHN 317

Tabela 57 - Impressão Geral - ADS 317

Tabela 58 - Impressão Geral- AVME 318

Tabela 59 - Impressão Geral - AHPH 319

Tabela 60 - Impressão Geral - AHEV 319

Tabela 61 - Impressão Geral - AHA 320

Tabela 62 - Impressão Geral - AGMA 320

Tabela 63 - Impressão Geral - AUS 321

Tabela 64 - Impressão Geral - AGS 322 
Tabela 65 - Impressão Geral - MAS

Tabela 66 - Impressão Geral - AEG

Tabela 67 - Impressão Geral - AHPG

Tabela 68 - Impressão Geral - AHVL 324

Tabela 69 - Impressão Geral - AHPGR 325

Tabela 70 - Estatística descritiva - Visibilidade 326

Tabela 71 - Média da Visibilidade por variável 326

Tabela 72 - Estatística descritiva - Visibilidade por Avaliador

Tabela 73 - Metadados padronizados por Arquivo

Tabela 74 - Informações sobre a instituição por Arquivo

Tabela 75 - Autenticidade por Arquivo

Tabela 76 - Posição natural nos motores de busca por Arquivo

Tabela 77 - Pontuação das Heurísticas

Tabela 78 - Heurísticas por avaliador 336

Tabela 79 - Média das Heurísticas

Tabela 80 - Linguagem Natural — Pontuação de cada avaliador

Tabela 81 - Liberdade de circulação e controle de ações Pontuação

Tabela 82 - Consistência nas convenções adotadas

Tabela 83 - Disponibilização, clareza e precisão dos links

Tabela 84- Natureza estética e simplicidade da interface

Tabela 85 - Visibilidade

Tabela 86 - Instruções e documentação 
Tabela 87 - Pontuação Heurísticas por Avaliador - ADS

Tabela 88 - Pontuação Heurísticas por Avaliador - AEG

Tabela 89 - Pontuação Heurísticas por Avaliador - AGMA

Tabela 90 - Pontuação Heurísticas por Avaliador - AGS

Tabela 91 - Pontuação Heurísticas por Avaliador - AHA 359

Tabela 92 - Pontuação Heurísticas por Avaliador - AHEV 360

Tabela 93 - Pontuação Heurísticas por Avaliador - AHN 361

Tabela 94 - Pontuação Heurísticas por Avaliador - AHPG 363

Tabela 95 - Pontuação Heurísticas por Avaliador - AHPGR

Tabela 96 - Pontuação Heurísticas por Avaliador - AHPH

Tabela 97 - Pontuação Heurísticas por Avaliador - AHVL 366

Tabela 98 - Pontuação Heurísticas por Avaliador - MAS 368

Tabela 99 - Pontuação Heurísticas por Avaliador - AUS 369

Tabela 100 - Pontuação Heurísticas por Avaliador - AVME 


\section{LISTA DE QUADROS}

Quadro 1 - Níveis de implantação de gestão de Documentos

Quadro 2 - Limitações dos usuários

Quadro 3 - Leis Estatais espanholas

Quadro 4 - Ordens Ministeriais Espanholas

Quadro 5 - Decretos Reais espanhóis

Quadro 6-Decretos e Leis Andaluzia

Quadro 7 - Decreto, lei e ordem autonômicos de Aragão

Quadro 8 - Lei Autonômica Astúrias

Quadro 9 - Lei Autonômica Canárias

Quadro 10 - Leis e Decreto Cantábria

Quadro 11 - Leis e Decreto Castela-La Mancha

Quadro 12 - Leis e Decretos Castela e Leão

Quadro 13 - Leis autonômicas da Catalunha

Quadro 14 - Decretos Autonômicos da Catalunha

Quadro 15 - Leis Autônomas de Extremadura

Quadro 16 - Decreto Autonômico de Galícia

Quadro 17 - Leis autônomas das Ilhas Baleares

Quadro 18 - Lei Autonômica de La Rioja

Quadro 19 - Lei Autonômica de Madrid

Quadro 20 - Lei Autonômica de Murcia 
Quadro 22 - Lei Autônoma do País Basco

Quadro 23 - Decretos Autônomos do País Basco

Quadro 24 - Decretos e Lei Autonômica de Valencia

Quadro 25 - Etapas de transferência da informação segundo Gilbert e

Cordey-Hayes (1996)

Quadro 26 - Critérios de avaliação propostos por Gutierrez (2002)

Quadro 27- Critérios externos em links

Quadro 28 - Links de Arquivos espanhóis

Quadro 29 - Comunidades da Espanha versus capitais

Quadro 30 - Agrupamento dos sites pela facilidade de localização

Quadro 31 - síntese da classificação dos sites avaliados

Quadro 32 - Heurísticas e indicadores

Quadro 33 - Síntese das heurísticas que tendem a problemas maiores 


\section{LISTA DE FIGURAS}

Figura 1 - Os dez Motores de buscas mais utilizados

Figura 2 - Fases do Ciclo de Vida dos Documentos

Figura 3 - Expectativa de uso da Internet em 2010

Fig. 4 - O Questionário BRACAD.

Figura 5 - Homepage do site do MCU

Figura 6 - Arquivos e Centros Estatais dirigidos pelo MCU

Figura 7 - Foto do Teste com usuários da UFPE 204

Figura 8 - Homepage do Archivo Historico Nacional

Figura 9 - Homepage do Archivo de Diputación de Sevilla

Figura 10 - Homepage do Archivo Vasco de la Música Eresbil

Figura 11 - Homepage do Archivo Histórico Provincial de Huesca

Figura 12 - Homepage do Archivo Histórico Eclesiástico de Vizcaya

Figura 13 - Homepage do Archivo Histórico de Asturias

222

Figura 14 - Homepage do Archivo General Militar de Ávila

Figura 15 - Homepage do Archivo de la Universidad de Salamanca

Figura 16 - Homepage do Archivo General de Simancas 233

Figura 17 - Homepage do Archivo Municipal de Santander 236

Figura 18 - Homepage do Arquivo da Emigración Galega

Figura 19 - Homepage do Archivo Histórico de Protocolos de

Gipuzcoa

Figura 20 - Homepage do Archivo de Hullera Vasco-Leonesa 
Figura 21 - Homepage do Archivo Histórico Provincial de Granada

Figura 22 - Foto do Teste com usuários da Fundaj (estagiários) 


\section{LISTA DE GRÁFICOS}

Gráfico 1 - Média por avaliador da Avaliação Preliminar 262

Gráfico 2 - Média por critério Avaliação Preliminar 263

Gráfico 3 - Pontuação dos resultados dos critérios por avaliador - ACMC 268

Gráfico 4 - Pontuação dos resultados dos critérios por avaliador - ACA 270

Gráfico 5 - Pontuação dos resultados dos critérios por avaliador - ARCV 272

Gráfico 6 - Pontuação dos resultados dos critérios por avaliador - AGI 274

Gráfico 7 - Pontuação dos resultados dos critérios por avaliador - AGA 275

Gráfico 8 - Pontuação dos resultados dos critérios por avaliador - AGS $\quad 277$

Gráfico 9 - Pontuação dos resultados dos critérios por avaliador - AHN 279

Gráfico 10 - Pontuação dos resultados dos critérios por avaliador - AHPA 280

Gráfico 11 - Pontuação dos resultados dos critérios por avaliador - AHPG 282

Gráfico 12 - Pontuação dos resultados dos critérios por avaliador - AHPV 284

Gráfico 13 - Pontuação dos resultados dos critérios por avaliador - CDMH 286

Gráfico 14 - Pontuação dos resultados dos critérios por avaliador -SNAHN 287

Gráfico 15 - Tempo de avaliação por Usuário 295

Gráfico 16 - Tempo de avaliação 296

Gráfico 17 - Posição do site nos buscadores 298

Gráfico 18 - Ferramenta de busca - Usuários 310

Gráfico 19 - Coerência dos Links 312

Gráfico 20 - Necessidade de treinamento 314

Gráfico 21 - Visibilidade por arquivo $\quad 327$ 
Gráfico 22 - Metadados padronizados

Gráfico 23 - Informações sobre a instituição

Gráfico 24 - Autenticidade

Gráfico 25 - Posição natural nos motores de busca

Gráfico 26 - Avaliação Heurística por avaliador

Gráfico 27 - Pontuação das Heurísticas

Gráfico 28 - Linguagem Natural - pontuação de cada Arquivo

Gráfico 29 - Liberdade de circulação e controle de ações

Gráfico 30 - Consistência nas convenções

Gráfico 31 -Disponibilização, clareza e precisão dos links

Gráfico 32 - Natureza estética e simplicidade da interface

Gráfico 33-Visibilidade - Pontuação de cada avaliador por arquivo

Gráfico 34 - Instruções e documentação

Gráfico 35 - Avaliação Heurísticas por Avaliador - ADS

Gráfico 36 - Avaliação Heurísticas por Avaliador - AEG

Gráfico 37 - Avaliação Heurísticas por Avaliador - AGMA

Gráfico 38 - Avaliação Heurísticas por Avaliador - AGS 358

Gráfico 39 - Avaliação Heurísticas por Avaliador - AHA 360

Gráfico 40 - Avaliação Heurísticas por Avaliador - AHEV

Gráfico 41 - Avaliação Heurísticas por Avaliador - AHN

Gráfico 42 - Avaliação Heurísticas por Avaliador - AHPG 
Gráfico 44 - Avaliação Heurísticas por Avaliador - AHPH

Gráfico 45 - Avaliação Heurísticas por Avaliador - AHVL

Gráfico 46 - Avaliação Heurísticas por Avaliador - MAS

Gráfico 47 - Avaliação Heurísticas por Avaliador - AUS

Gráfico 48 - Avaliação Heurísticas por Avaliador - AVME 


\section{LISTA DE SIGLAS}

ABNT

ACAL

ANABAD

ARPA

ARPANet

AWPR

BOPA

CGls

CIDA

CNEDA

DC

EAD

EUA

Fundaj

GED

HTML

ICA

IHC

IP

$\operatorname{ISAD}(\mathrm{G})$
Associação Brasileira de Normas Técnicas

Associação dos Arquivistas de Castela e Leão

Federación Española de Asociaciones de Archiveros,

Bibliotecarios,Arqueólogos, Museólogos y Documentalistas

Projetos de Pesquisa Avançada

Advanced Research Projects Agency Network

Appian Web Personalization Report

Boletim Oficial do Principado de Astúrias

Common Gateway Interface

Centro de Informação documental de Arquivos

Comisión de Normas Españolas de Descripción Archivística

Dublin Core

Encoded Archival Description

Estados Unidos da América

Fundação Joaquim Nabuco

Gerenciamento Eletrônico de Documentos

HyperText Markup Language

International Council on Archives

Interação Homem-computador

Internet Protocol

Norma geral internacional de descrição arquivística 
ISAAR (CPF) Norma Internacional de Registo de Autoridade Arquivística para Pessoas Colectivas, Pessoas Singulares e Famílias

ISO International Organization for Standardization

LAN Local Area Networks

MCU Ministerio de Cultura (Espanha)

MEMEX Memória extensiva

MPRC Machine Peadable Catalog Format

NEDA Normas Espanholas de Descrição Arquivística

ONU Organização das Nações Unidas

OPAC Catálogo público de acesso online

SQL L Linguagem de consulta estruturada

TCP/IP Transmission Control Protocol/ Internet Protocol

TIC Tecnologias de informação e comunicação

RI Recuperação de Informação

SQL L Linguagem de consulta estruturada

TEl Text Encoding Interative

UFPE Universidade Federal de Pernambuco

URSS União das Repúblicas Socialistas Sovieticas

USAL Universidade de Salamanca

WWW World Wide Web 
LISTA DE ABREVIATURAS

ACA Archivo de la Corona de Aragón

ACMC Archivo Central del Ministério de Cultura

ADS Archivo de la Diputación de Sevilla

AEG Arquivo da Emigración Galega

AGA Archivo General de la Administración

AGI Archivo General de Indias

AGMA Archivo General Militar de Ávila

AGS Archivo General de Simancas

AHA Archivo Histórico de Asturias

AHN Archivo Histórico Nacional

AHPA Archivo Histórico Provincial de Álava

AHPG Archivo Histórico de Protocolos de Gipuzcoa

AHPGR Archivo Histórico Provincial de Granada

AHPH Archivo Histórico Provincial de Huesca

AHPV Archivo Histórico Provincial de Vizcaya

AHVL Archivo de Hullera Vasco-Leonesa

AMS Archivo Municipal de Santander

ARCV Archivo de la Real Chancillería de Valladolid

AUS Archivo de la Universidad de Salamanca

AVME Archivo Vasco de la Musica Eresbil

$\mathrm{CDMH}$ Centro Documental de la Memoria Histórica 
SNAHN Sección Nobleza Archivo Histórico Nacional 


\section{SUMÁRIO}

Lista de Tabelas

Lista de Quadros

Lista de Figuras

Lista de Gráficos

Lista de Siglas

Lista de Abreviaturas

1 INTRODUÇÃO À INVESTIGAÇÃO 28

1.1 MOTIVAÇÃO 29

1.2 DEFINIÇÃO DO PROBLEMA, QUESTIONAMENTOS DA 29 INVESTIGAÇÃO E HIPÓTESES

1.3 OBJETIVOS DA INVESTIGAÇÃO 32

1.4 JUSTIFICATIVA DA INVESTIGAÇÃO 33

1.5 LIMITAÇÕES DO ESTUDO 35

1.6 ASPECTOS METODOLÓGICOS DA INVESTIGAÇÃO 35

1.6.1 Considerações preliminares 36

1.6.2 Procedimento metodológico 45

1.7 ESTRUTURA CAPITULAR 47

$\begin{array}{ll}1.8 \text { RESULTADOS ESPERADOS } & 48\end{array}$

2 ARQUIVOS: do tradicional ao virtual 49

2.1 IMPORTÂNCIA HISTÓRICA DOS ARQUIVOS 50

2.2 NASCIMENTO DO ARQUIVO ADMINISTRATIVO 57

2.3 GESTÃO DA INFORMAÇÃO 64 
2.6 TRANSPARÊNCIA, QUALIDADE INFORMATIVA E LEGISLAÇÃO 78

2.6.1 Legislação que afeta os Arquivos da Espanha 85

2.6.2 Legislação de Arquivos das Comunidades Autônomas 93

2.7 DESCRIÇÃO ARQUIVÍSTICA E O PROCESSO DE NORMALIZAÇÃO

3 COMUNICAÇÃO E INFORMAÇÃO

3.1 INTRODUÇÃO À COMUNICAÇÃO E INFORMAÇÃO

3.2 REDE DE ALCANCE MUNDIAL E INTERAÇÃO HUMANA

3.3 CONCEITO DE REDE

3.4 REVOLUÇÃO DA INFORMAÇÃO

3.4.1 Recuperação de Informação

3.4.2 Interação Humano-Computador

4. AVALIAÇÃO DE SITES 
5 TRILHANDO OS CAMINHOS DA METODOLOGIA

5.1 INTRODUÇÃO À METODOLOGIA

5.2 PROCEDIMENTOS PARA A COLETA DE DADOS

5.3 DESCRIÇÃO DA AVALIAÇÃO PRELIMINAR

5.4.1 Da escolha dos critérios de avaliação investigação 
5.4.4.6 Archivo Histórico de Asturias (AHA)

5.4.4.7 Archivo General Militar de Avila (AGMA)

5.4.4.8 Archivo de la Universidad de Salamanca (AUS)

228

5.4.4.9 Archivo General de Simancas (AGS)

231

5.4.4.10 Archivo Municipal de Santander (AMS)

234

5.4.4.11 Arquivo da Emigración Galega (AEG)

236

5.4.4.12 Archivo Histórico de Protocolos de Gipuzkoa (AHPG)

238

5.4.4.13 Archivo de Hullera Vasco-Leonesa (AHVL)

5.4.4.14 Archivo Histórico Provincial de Granada (AHPGR)

6. ANÁLISE E INTERPRETAÇÃO DOS DADOS

6.1 APRESENTAÇÃO DOS RESULTADOS DO TESTE DE USUÁRIOS NA UFPE - AVALIAÇÃO PRELIMINAR

6.2 APRESENTAÇÃO DOS RESULTADOS FORNECIDOS PELOS

AVALIADORES - AVALIAÇÃO PRELIMINAR

6.3 DISCUSSÃO INICIAL DA AVALIAÇÃO PROPRIAMENTE DITA

6.3.1 Análise dos resultados do teste de usuários

6.3.2 Análise dos Resultados dos Avaliadores

6.3.2.1 Resultados da Avaliação de Visibilidade

6.3.2.2 Resultados da Avaliação Heurística

6.4 Discussão geral dos resultados

7. CONSIDERAÇÕES FINAIS

7.1 OBSERVAÇÕES, CONCLUSÕES E RECOMENDAÇÕES 
Capítulo 1

\section{INTRODUÇÃO À INVESTIGAÇÃO}

Este capítulo pretende apresentar a motivação, definição do problema, questionamentos e hipóteses, objetivos, justificativa, limitações do estudo, aspectos metodológicos, estrutura capitular e resultados esperados da investigação de que trata este estudo resgatando a bibliografia da área. 


\subsection{MOTIVAÇÃO}

O significado das coisas não está nas coisas em si, mas sim em nossa atitude com relação a elas. (Antoine de Saint-Exupéry)

A temática desenvolvida neste estudo emergiu inicialmente, a partir da própria experiência profissional adquirida durante a especialização em Organização de Arquivos realizada na USP- São Paulo.

A formação em Biblioteconomia e a dedicação profissional à área de Arquivologia e Biblioteconomia, bem como a participação em diversos eventos na área, nos últimos anos, cursando o doutorado, motivaram a escolha de disciplinas afins e o interesse em investigar um tema afim. Decidiu-se inicialmente fazer um levantamento da literatura a respeito de centros arquivísticos espanhóis de uma maneira geral. Nessa vivência, a sensibilidade da percepção pessoal detectou pontos carentes na literatura a respeito dos sites desses centros. O que mais chamou a atenção neste aspecto foi a dificuldade de encontrar uma literatura abrangente em matéria de avaliação dos sites em questão. Assim, neste trabalho, adotou-se uma postura aberta e de desconhecimento diante do novo, considerando aprendizado também as hipóteses prévias, deixando de lado os juízos de valor, para que a pesquisa adquirisse o caráter espontâneo próprio das novas experiências.

Diante do quadro situacional apresentado, não representa um despropósito afirmar que a formação pessoal e profissional como bibliotecária e a especialização realizada na USP, favoreceu o processo de ensino/aprendizagem. Adentrar, entretanto, no campo da tecnologia sempre pressupõe um esforço extra para os profissionais da área de Humanas. Pode-se afirmar que, ao longo da investigação, observou-se que foi construído um mito em torno da situação dos Arquivos perpetuado pela limitação dos usuários, em relação ao acesso aos seus fundos, ou seja, em plena era da linguagem digital, ainda não se prioriza tais centros no momento da busca por informação. 
Para compreender tais pressuposições, e conhecer a realidade atual da dinâmica de recuperação de informação que envolve os Arquivos, lança-se mão de uma proposta de trabalho que investiga a qualidade do site do Arquivo, voltando-se especificamente aos aspectos que dizem respeito à sua visibilidade e usabilidade.

Nessa perspectiva, averigua-se o discurso desenvolvido pelos autores que anteriormente trataram do tema de avaliação de sites, buscando-se oferecer uma nova visão, dessa vez direcionada a sites de Arquivos, mais especificamente, os espanhóis.

Faz-se necessário esclarecer que neste estudo utiliza-se a maiusculação da inicial do termo "Arquivo" quando se faz referência a um centro ou instituição arquivística tal qual recomenda Heredia Herrera (2007) para diferenciar este primeiro do termo "arquivo" usado para referir-se a documento(s).

\subsection{DEFINIÇÃO DO PROBLEMA, QUESTIONAMENTOS DA INVESTIGAÇÃO E HIPÓTESES}

A grande variedade de informação disponível online culmina na liberdade expressiva de cada site, por conta disso, o ciberusuário necessita de alguns indicadores que o auxiliem na garantia da qualidade da informação existente.

Entendendo qualidade de um site como um conjunto de fatores através do qual se pode assegurar a sua confiabilidade, os elementos intrinsecamente associados à informação determinam a eficácia e a eficiência do site em relação ao usuário.

No que diz respeito aos sites de Arquivos, tais afirmações suscitaram alguns questionamentos: Os sites de arquivos cumprem com os requisitos necessários para uma boa usabilidade? Os sites dos Arquivos espanhóis possuem uma boa visibilidade em rede, de maneira que permitam que sejam conhecidos e, portanto, utilizados? 
Através de uma investigação acurada, pretende-se responder a questões dessa natureza a fim de que se possa desvendar a real situação dos sites dos Arquivos Espanhóis disponíveis em rede.

A partir das indagações, anteriormente dispostas, se puderam construir algumas hipóteses para o presente estudo:

\section{$\checkmark$ Hipóteses gerais:}

1. A maioria dos Arquivos espanhóis possui páginas Web, o que, de certa forma, é um elemento facilitador para o usuário no momento da pesquisa;

2. Os sites que possuem melhor visibilidade são os que estão subsidiados pelo Ministério de Cultura da Espanha;

3. A maioria dos Sites não permite a visualização dos documentos em tela, fator que pode comprometer sua usabilidade.

Neste seguimento propõem-se as Hipóteses específicas:

Os sites de arquivos espanhóis em sua maioria:

1. Têm metadados que facilitam aos motores de busca sua identificação (Metadados padronizados);

2. Trazem informações sobre o arquivo e/ou sobre a instituição à qual estão ligados (Informações sobre a instituição que hospeda ou cria a página Web do Arquivo);

3. Apresentam certificações de autenticidade (Garantia de autenticidade);

4. Aparecem entre os primeiros resultados da busca através dos motores de busca, quer dizer, na primeira página de resultados antes da dobra ( $\mathrm{A}$ página Web do arquivo está em posição natural nos resultados das buscas através do motor de busca Google?);

5. Utilizam uma linguagem familiar ao usuário (Linguagem natural); 
6. Apresentam mecanismos compreensíveis e facilmente localizáveis de navegação (Liberdade de circulação e controle de ações);

7. Cumprem com as definições previamente convencionadas resultando em uniformidade em todo o sistema (Consistência nas convenções adotadas);

8. Disponibilizam com clareza e precisão seus links, ou seja, eles indicam claramente o que o usuário encontrará ao clicar sobre o mesmo (Disponibilização, clareza e precisão dos links);

9. Oferecem ao usuário apenas informações relevantes ou necessárias (Natureza estética e simplicidade da interface);

10.Possuem recursos de acessibilidade, ou seja, leva em conta um grupo especial de usuários, como por exemplo: deficientes visuais (Visibilidade);

11.Possuem Instruções fáceis de encontrar e relacionadas às tarefas que o usuário executa, contendo os passos para a realização de um determinado objetivo, porém não devem ser demasiado extensas (Instrução e Documentação).

Com base nessas hipóteses, construíram-se os objetivos desta investigação, descritos a seguir.

\subsection{OBJETIVOS DA INVESTIGAÇÃO}

No âmbito geral, a pesquisa busca conceituar a Internet como veículo de comunicação em rede; apresentar uma proposta de avaliação de sites de Arquivos e, por fim, avaliar sites de Arquivos espanhóis. Este estudo visa, especificamente, avaliar sites ativos de Arquivos espanhóis, segundo os critérios Usabilidade e Visibilidade de avaliação de sites, analisando o fenômeno desde de uma perspectiva multidimensional, considerando a percepção dos usuários. 


\subsection{JUSTIFICATIVA DA INVESTIGAÇÃO}

No atual mundo globalizado, em que as informações são disseminadas numa grande velocidade e em diversas áreas de conhecimento, a exemplo da educação, qualquer sistema de informação globalizado, como é o caso dos sistemas Web, transpõem fronteiras geográficas e culturais, pois são acessados via Internet em todos os continentes.

$\mathrm{Na}$ área arquivística, na Espanha e em todo o mundo, busca-se uma normalização tanto da tarefa de arquivar como da disponibilização dos documentos arquivados e a Internet vem a ser o canal como paradigma do acesso sem barreiras a todos os tipos de Arquivo, cumprindo de maneira mais viável ao que propõe a legislação da Espanha no que respeita ao direito de acesso dos cidadãos aos documentos. Esse direito é garantido pelo artigo $105 \mathrm{~b}$ da Constituição espanhola de 1978, pela lei 30/1992 de 26 de novembro, de regime jurídico das administrações públicas e do procedimento administrativo comum e, finalmente pela lei 10/2001, de 13 de julho, de arquivos e documentos.

Esta pesquisa se justifica pela escassez de estudos que vivenciaram a experiência de avaliar a qualidade de sites pelos critérios da Usabilidade e Visibilidade de Arquivos espanhóis, em páginas Web de arquivos, mais especificamente de Arquivos espanhóis. Compreende-se que este estudo poderá agregar valor à qualidade dos serviços arquivísticos como parte de trabalhos mais aprofundados a respeito de Websites de Arquivos, que avaliam os Arquivos através de outros critérios de qualidade. Ademais, servirá de grande contribuição para a sociedade em geral que se beneficiará, como principal usuária dos Arquivos, em termos de qualidade de serviços e rapidez na recuperação da informação e transparência informativa.

Diversos trabalhos foram dedicados à avaliação de bibliotecas digitais (AMÂNDIO, 2007; MELO ALVES e QUIROA HERRERA, 2007; AITTA, KALEVA e KORTELAINEN, 2007; GALLEGO LORENZO, 2005, entre outros), porém, os estudos relativos a Arquivos em rede são escassos e no caso da Espanha, podemos encontrar raros estudos específicos de critérios de qualidade aplicados a Arquivos. Como exemplo disso, destacamos o trabalho de María García 
González e Celia Chaín Navarro (2009), que trata do estado atual dos Websites de três Arquivos Históricos nacionais espanhóis: Archivo Histórico Nacional, Archivo General de Índias, Archivo General de Simancas. As autoras objetivam em seu estudo verificar a qualidade da informação oferecidas por tais Arquivos.

Vale salientar que os critérios para a avaliação dos sites aqui considerados foram estudados à luz da área de Biblioteconomia e Documentação e não especificamente para o contexto arquivístico. A importância da visibilidade dos arquivos disponíveis na rede consiste exatamente em que se tornem conhecidos e disponíveis e a usablilidade representa a oportunidade de que a rede os torne mais axequíveis e seu conteúdo mais acessível.

A relevância deste estudo se verifica ainda por sua contribuição para a divulgação dos sites espanhóis dessas instituições, uma vez que foram realizadas buscas profícuas em rede e disponibilizadas as informações tanto sobre os sites quanto sobre os diretórios de Arquivos para os usuários que de certo modo, contribui para melhorar sua visibilidade.

O grau de inovação previsto neste estudo consiste em que a literatura na área é limitada em termos de pesquisas realizadas a respeito de Arquivos no que se refere à avaliação de suas páginas Web. Ambos os critérios refletem na qualidade do serviço e na imagem desses centros. Portanto a inovação se justifica pela escassez de trabalhos direcionados ao tema, sobretudo relativos aos sites espanhóis.

Conhecendo o grau de visibilidade e usabilidade dos Arquivos estudados, através de critérios previamente estabelecidos, os criadores das páginas bem como aqueles que a atualizam terão em mãos uma importante ferramenta para reformular alguns aspectos dessas páginas bem como, aperfeiçoar a qualidade geral do site, a partir da melhoria de seu conteúdo, seu desenho, da reformulação da atenção ao cliente, etc.

Não se pode olvidar que a Espanha é um país de destaque no mundo ocidental e o rico patrimônio documental dos Arquivos pode despertar o interesse a partir de pesquisas como esta que os ponham em evidência. Afinal, quando um pesquisador começa a levantar questões sobre um determinado tema, ele passa a aguçar a curiosidade intelectual de outros pesquisadores. Tudo isso vai refletir 
no conhecimento da historiografia espanhola contida nesses fundos documentais, tonando-os mais conhecidos dentro da própria Espanha, no Brasil e no mundo, ao tempo em que valoriza a cultura espanhola, pois entendível é que guardam memória de uma nação.

\subsection{LIMITAÇÕES DO ESTUDO}

A distância entre o Brasil e a Espanha tem imposto uma pequena limitação às investigações quanto à realização de um contato presencial com os Arquivos. Ainda que o desejo inicial fosse realizar o teste de usuários também com usuários espanhóis para confrontar os resultados com os obtidos no teste realizado com usuários brasileiros, essa limitação física dificultou o processo e a pesquisa se baseou na percepção dos usuários brasileiros.

Outro fator condicionante de limitação à pesquisa de tais sites é o próprio caráter flutuante das informações disponíveis na Internet, uma vez que o que se vê em determinado momento, facilmente pode ser modificado e até mesmo desaparecer em outro imediatamente posterior, fazendo com que o estudo desse ambiente Web se torne rapidamente obsoleto podendo afetar particularmente 0 objeto de estudo dessa pesquisa, os sites de Aquivos.

\subsection{ASPECTOS METODOLÓGICOS DA INVESTIGAÇÃO}

Antes de se apresentar os procedimentos metodológicos da investigação, é pertinente tecer algumas considerações sobre a origem dos Arquivos e a sua importância como fonte de informação, motores de busca e arquivos disponíveis em rede para melhor compreensão dos procedimentos de composição do corpus para análise. 


\subsubsection{Considerações preliminares}

Desde os tempos mais remotos a.C., tem-se notícias de centros de guarda de documentos importantes dos egípcios e cópias dos principais documentos da época, porém tais documentos tinham o acesso restrito para consulta sobre seus sucessores ou descendentes. Com o passar do tempo, foram se formando novos centros, ou seja, os Arquivos, onde eram guardados os principais documentos mantidos em locais secretos com acesso restrito apenas aos grandes líderes. Com a evolução das telecomunicações, pouco a pouco os Arquivos foram se modificando e permitindo a consulta a seus fundos transformando-se em centros de informação.

Nos países que são considerados democráticos, entre eles a Espanha, a informação é um dos elementos mais importantes para garantir o cumprimento da democracia. Os Arquivos e os centros de documentação, segundo Serraller Ibánez (1999, p. 70), constituem alguns dos sistemas mais amplos de conhecimento e obtenção de informação de todas as épocas, inclusive a atual.

Toda informação produzida pelo governo através das leis e normas, por exemplo, pode ser útil a todo e qualquer cidadão na medida em que ele toma conhecimento de seus direitos e deveres. "Los Gobiernos son grandes fuentes de información, la producen y ésto es en parte de gran importancia para los ciudadanos" (SERRALLER IBÁNEZ, 1999, p. 72) ${ }^{1}$.

A importância dos Arquivos como fontes de informação para os cidadãos em geral, consiste principalmente no fato de se poder encontrar reunidos em um mesmo lugar as informações necessárias para se esclarecer um fato histórico ou se conhecer a origem de alguma localidade, ou mesmo solucionar dúvidas a respeito de propriedades ou títulos. Portanto, o grande desafio dos Arquivistas e demais profissionais que trabalham com a informação na sociedade atual, de acordo com Serraller Ibánez (1999, p. 76), é tentar defender os direitos dos cidadãos à informação verdadeira, livre de manipulações por causa de interesses de qualquer ordem.

\footnotetext{
${ }^{1}$ Os Governos constituem grandes fontes de informação, pois a produzem e isso é de grande importância para os cidadãos. (Tradução nossa)
} 
O sistema das organizações está diretamente relacionado à reelaboração das estruturas provenientes da comunicação. Segundo Kunzler (2004, citado por LIMA; CARVALHO; LIMA, 2010, p. 11), uma simples informação pode provocar mudança no sistema, pois se trata de uma "diferença que provoca diferenças", ou seja, o sistema muda quando muda o estímulo provocado pela comunicação.

A administração das organizações trata da interação entre sujeitos independentes. Conforme Vizeu (2009, citado por LIMA, CARVALHO e LIMA, 2010, p. 20), há uma tendência "natural" a que os membros de uma organização trabalhem em prol dos interesses da organização. Os gestores são motivados para o êxito das organizações e essas, por sua vez, buscam o êxito por meio da aceitação de seus públicos.

Numa organização, como em todas as práticas sociais, a linguagem desempenha papel fundamental, servindo à expressão comunicativa, à representação dos objetos e à integração entre os sujeitos. Dessa forma, a linguagem é o meio utilizado pelos gestores a direcionar a organização no cumprimento eficiente de suas finalidades. Como característica intríseca do ser humano, ela possibilita a expressão do pensamento, ao mesmo tempo em que viabiliza a comunicação entre os sujeitos que trabalham numa mesma organização, sendo pois fundamental para produção dos valores e dos conhecimentos. Quando se perde a autonomia numa organização, em termos de livre expressão do pensamento, conforme Lima; Carvalho e Lima (2010), os valores e conhecimentos são empobrecidos, dificultando assim a melhoria dos serviços ou os processos de inovações dentro das organizações.

A qualidade nos serviços de unidade de informação sempre foi um requisito muito debatido mesmo antes do advento da Internet, porém, com a criação do WWW, passou-se a exigir cada vez mais, qualidade dos centros de informação como Bibliotecas, Arquivos, etc.. o que impulsionou uma nova forma de buscar e trabalhar com a informação que, por sua vez, passou a exigir maior desenvolvimento das tecnologias para acompanhar o crescimento das buscas. A "Sociedade da Informação" conta que a informação esteja disponível em fontes distintas, porém isso gera, às vezes, uma espécie de "caos informativo" uma vez que hoje em dia o homem está imerso em uma desmensurada "sobrecarga de informação" (JIMÉNEZ PIANO; ORTIZ-REPISO JIMENÉZ, 2007, p.18). Apesar de 
todo esse avanço tecnológico devemos considerar que a World Wibe Web (WWW), ou simplesmente Web, foi criada apenas como um ambiente para publicação de documentos em formato de texto e HTML (Hipertext Markup Language) e, portanto, a interação com usuários era limitada a ler e imprimir texto ou selecionar links para outros documentos. Em seguida, vieram os formulários e programas CGls (Common Gateway Interface) que permitiram a entrada de dados do usuário e a integração com aplicações de bancos de dados.

Segundo Rubio Liniers et al (1998, p. 153), os catálogos públicos de acesso em rede das bibliotecas são pioneiros na Internet, disponibilizados gratuitamente.

As bibliotecas fornecem, através desses catálogos eletrônicos, uma infinidade de recursos para a recuperação de informação. No entanto, como é usual em quase todos os centros de informação, bibliotecas e Arquivos, corroborando com Mariel Dominguez (2008), quando os documentos são raros há uma limitação de acesso imposta aos usuários. "Los libros electrónicos y las colecciones periódicas en línea a las que los usuários pueden tener acceso remoto gratuito se están convirtiendo en uno de los principales servicios de las bibliotecas públicas" ${ }^{2}$ (FORD, 2001, citado por MARIEL DOMíNGUEZ, 2008, p. $68)$.

Ainda segundo Mariel Domínguez ${ }^{3}$, em países desenvolvidos, grande parte do acervo das bibliotecas está digitalizada ou microfilmada, facilitando a sua disponibilização por meio digital, prevendo para um futuro próximo que as bibliotecas com menos recursos possam aderir a tal prática.

Essas observações levam a refletir que as bibliotecas em relação aos usuários sempre caminharam de uma forma natural ou sempre tentaram acompanhar o progresso e se adaptar às novas tecnologias conforme exigência da Sociedade da Informação.

Após examinar vastamente a produção científica da are, López Gómez (2008, p. 37) observa que há certa resistência dos Arquivos no que se refere às inovações tecnológicas:

\footnotetext{
${ }^{2}$ Os livros eletrônicos e periódicos on-line aos quais os usuários podem ter acesso remoto gratuito estão se tornando um dos principais serviços das bibliotecas públicas. (Tradução nossa).

${ }^{3}$ Idem, p. 69.
} 
Teoría y práctica archivística se complementan, pero junto al avance en los conocimientos y renovación de los usos archivísticos se observan fuertes reticencias a la innovación, escudándose en la tradición y en la costumbre, aunque del análisis de ambas no resulte especial antigüedad de las mismas ${ }^{4}$

Embora com certa resistência, nos últimos anos, os Arquivos, a exemplo das bibliotecas, vêm criando seus sites e disponibilizando informações em rede.

Los archivos nacionales de EE.UU (NARA, National Archieves and Record administration, http://www.nara.gov) e del Reino Unido (Royal Comission on historical manuscripts, http://www.hmc.gov.uc) muestran con una estructura mui avanzada las posibilidades de Internet en el ámbito de los archivos (RUBIO LINIERS et al, 1998, p. 153)

Esses Arquivos estão disponibilizados em rede, oferecendo ao usuário diversas possibilidades de resgate da informação contida nos mesmos.

Martínez Raduà (1996 citado por MARTíNEZ RADUÀ, 1998, p. 55) afirma que realizou um estudo que procurava identificar a presença do mundo da arquivística na internet, em que tratava sobre os sites dos Arquivos. Nesse estudo, observava-se que o panorama espanhol naquele momento se reduzia praticamente a duas instituições arquivísticas: Pontos de Informação Cultural do Centro de Informação documental de Arquivos (CIDA) e o Arquivo Municipal de Vila-Real (Castelão).

Como se pode inferir a partir do texto a seguir, somente é possível construir um sistema de informação significativo se houver compreensão do processo da informação: "... si no se comprende la conducta informativa no es posible diseñar sistemas de información significativos ni estos pueden utilizarse razonablemente" (ROMANOS DE TIRATEL, 2000, citado por MARIEL DOMíNGUEZ, 2008, p. 60). Assim, o sistema de informação deve contemplar o usuário, ou seja, os sites de Arquivos devem estar direcionados para os usuários os quais utilizarão as informações desses sites disponíveis em rede. A Usabilidade, portanto, é

\footnotetext{
${ }^{4}$ A teoria e a prática Arquivística se complementam, mas com o avanço dos conhecimentos e renovação das aplicações arquivísticas, observa-se forte resistência à inovação, escondida por trás da tradição e do costume, embora que ambas as questões não sejam tão antigas. (Tradução nossa)

${ }^{5}$ Os Arquivos nacionais dos Estados Unidos e do Reino Unido oferecem uma estrutura muito avançada com relação à disponibilização de informação na internet no âmbito de Arquivos. (Tradução nossa)

${ }^{6}$ Se não se compreende o comportamento da informação não é possível projetar sistemas de informação significativos nem estes podem ser utilizados razoavelmente. (Tradução nossa)
} 
considerada um dos aspectos fundamentais para medir a satisfação de usuários, bem como os diversos contextos de utilização de um site específico entre outros sites. A satisfação do usuário é um dos mais importantes critérios globais de qualidade.

A organização e guarda dos documentos e Arquivos, em sua primeira fase, estão diretamente relacionadas ao usuário. Desde a fase da recepção e registro dos documentos, os arquivistas dão um tratamento padrão, visando o atendimento ao usuário.

Segundo Borràs Goméz (2000, p.4), os usuários tendem a ser um pouco relutantes em relação ao "Arquivo". Cabe aos arquivistas motivar o seu interesse através das ferramentas de tratamento adequadas aos documentos e da gestão documental. Para tanto, faz-se necessária a formação desses usuários por meio da aprendizagem adequada do programa de gestão de documentos de Arquivos, pois eles serão os principais aliados na implementação do sistema e a sua relação com o serviço de Arquivo será duradoura.

No processo de criação dos serviços de Arquivos oferecidos em rede, é imprescindível que se considere o usuário, de maneira que ele passe a ter uma visão diferenciada do Arquivo que não a de um "templo inacessível, aumentando a sua confiança nas fontes de informação oferecida pelo Arquivo acessado.

Pode-se tomar por exemplo de Arquivos que se desenvolvem em consonância com o usuário, os Arquivos universitários.

\begin{abstract}
La formación de los usuarios en la gestión de documentos y archivos ocupa un lugar preeminente en las funciones recientes de los archivos y archiveros de las universidades, y sólo mediante la dedicación de recursos, la innovación pedagógica, el reconocimiento institucional y La conciencia de los profesionales, alcanzaremos los retos y objetivos programados (BORRÀS GÓMEZ, 2000, p.14) ${ }^{7}$
\end{abstract}

Dessa forma, observa-se que, nas universidades, a preocupação primeira quanto à gestão dos documentos e Arquivos é o usuário para o qual estão voltados todos os recursos inovadores. Eis porque todo 0 interesse no

\footnotetext{
7 O treinamento dos usuários na gestão de documentos e arquivos estão na vanguarda das recentes funções dos arquivos e arquivistas de universidades, e somente através da dedicação de recursos, inovação pedagógica, o reconhecimento institucional e a conscientização dos profissionais permite cumprir as metas e os objetivos esperados (Tradução nossa).
} 
treinamento do usuário: para que ele possa utilizar e a partir de então, melhor aproveitar tais recursos.

Lopez Gomez (2008, p.6) aponta como avanço na situação arquivística espanhola, a incorporação ao ensino universitário, de cursos de especialização, programas de mestrado e proliferação da lógica da investigação por parte do corpo docente, que se soma às desempenhadas por profissionais do setor.

Os dados da Internet sofrem constantes modificações e atualizações tendo em vista o crescente número de visitantes e os recursos da aplicação aliados à inovação da tecnologia. Desse modo, observa-se que o conceito de usabilidade é variável em função dessa realidade. Por esse mesmo motivo, a usabilidade não é algo que garanta uma constância, uma vez que é sempre mutável e flexível.

Normalmente, durante o desenvolvimento de uma interface, utiliza-se uma série de métodos de avaliação, e métodos de interação com usuários em laboratórios de usabilidade ou através do método tradicional nesse tipo de análise, que consiste no uso de um questionário para avaliar a satisfação do usuário. Os métodos apresentados auxiliam na identificação de uma série específica de problemas relacionados à Usabilidade. O que alguns usuários consideram como erros, entretanto, poderá ser a solução para outros, levando em conta que tal interpretação é bastante subjetiva.

Conforme Scolari (2004 citado por PINTO, 2008, p. 5), interface, no sentido utilizado no Dicionário de Inglês The Oxford English Dictionary, significava no século XIX uma superfície que une duas porções de matéria ou espaços com limite comum. ${ }^{8}$

Esta ideia foi retomada no domínio da informática enquanto referência a um artefacto material que permite um intercâmbio de dados entre dois sistemas diferentes. Em Annals of_ew York of Science, um trabalho publicado em 1964, a interface é descrita como uma série de componentes que ligam o computador digital e o meio analógico entre si, e que controlam e convertem os dados. (PINTO, 2008, p.5)

A informação como fator fundamental para gerar conhecimento é um grande aliado da "Sociedade da Informação" em que o uso das Tecnologias de

8 Cf. Scolari, Carlos. (2004). Hacer Clic: Hacia una sociosemiótica de las interacciones digitales.Barcelona: Gedisa. 256 p. 
Informação e Comunicação incentiva o desenvolvimento científico e tecnológico, fazendo circular a informação gerada.

A pesquisa e a localização da informação na Web crescem a cada dia, exigindo mais esforços para atender às exigências de interatividade dos usuários, além de ter que cumprir o requisito fundamental de eficácia com rapidez.

Algumas das questões relativas ao projeto da Interface afetam à eficiência na hora de localizar a informação, como por exemplo:

1. O usuário está apto a utilizar os sistemas disponíveis na internet?

2. O processo de interação homem-máquina é eficaz? Permite alcançar os objetivos?

3. Exige esforço ou conhecimento prévio do usuário para realizar suas tarefas?

4. O estilo e aspectos estéticos da página são agradáveis e não confusos?

Para responder a esses questionamentos surgem os testes de Usabilidade (ver Cap 4) já que não apenas os usuários finais, mas também as instituições dependem dessas avaliações para melhor proveito dos seus recursos informativos.

Quando o advento da Internet teve seu início, uma minoria privilegiada de usuários podia acessar às informações disponíveis: os pesquisadores de Universidade ou laboratórios científicos, que não tinham, portanto, nenhuma dificuldade para encontrar a informação desejada. Em contrapartida, atualmente se faz necessário utilizar um mecanismo de busca para filtrar a informação na Internet uma vez que a quantidade de informação disponível é incontrolável.

Em primeiro lugar foram utilizados os diretórios para facilitar o acesso à informação disponível na rede, sendo o Yahoo o primeiro a operar em 1994. Os links eram agrupados por tópico, porém não se caracterizava como um mecanismo de busca como é conhecido hoje em dia, pois os links eram apresentados por pesquisadores. Como o número de links começou a crescer, seus idealizadores tiveram que incorporar um buscador para este diretório. $\mathrm{Na}$ atualidade os diretórios perderam muito da popularidade inicial por não poder 
resgatar a mesma quantidade de informação que um mecanismo de busca. Por exemplo, temos o Open Directory Projet que, segundo a própria página, ${ }^{9}$ é o maior e mais abrangente diretório da Web atualmente editado e mantido por uma vasta comunidade global de editores voluntários que contém aproximadamente 5 milhões de documentos enquanto o Google, mais de 8 bilhões. ${ }^{10}$

O Projeto Google, segundo Casares (2010?), começou a ser desenvolvido, em janeiro de 1996, por Segey Brin e Larry Page na Universidade de Standford. Chamava-se BackRub e calculava a importância dos links que recebia. Larry Page, nessa época, fabricou um computador com peças de lego e tecnologia antiga que mais tarde se converteria no atual Google, motor de busca que apresenta uma interface muito clara e simples e resultados muito relevantes. $O$ segredo dos resultados se deve à tecnologia PageRank (patenteado em 2001), que implementou o sistema no qual não se tinha somente em conta os fatores da própria página em que se buscava informação, mas também os demais fatores externos que davam maior ou menor importância ao Website. Todos os motores de busca utilizam na atualidade, uma tecnologia similar a essa. Isso justifica a credibilidade conferida ao Google no momento da busca da informação pela internet.

Em relação ao volume de pesquisas realizadas através de motores de buscas, podemos apresentar os seguintes dados percentuais:

9 Disponível em: http://www.dmoz.org/World/Portugu\%c3\%aas/about.html. Acesso em: 20 setembro 2009.

${ }_{10}$ Cf. breve história dos mecanismos de busca. Disponível em: http://www.paginauno.com/tutoriais/historia-mecanismos-de-busca.php. Acesso em: 29 abril 2010. 


\begin{tabular}{|l|l|l|l|}
\hline \multicolumn{4}{|c|}{ Top 10 Search Providers for February 2010, Ranked by Searches (U.S.) } \\
\hline Rank & \multicolumn{1}{|c|}{ Provider } & Searches (000) & Share of Searches \\
\hline & All Search & $9,174,408$ & $100.0 \%$ \\
\hline 1 & Google Search & $5,980,116$ & $65.2 \%$ \\
\hline 2 & Yahoo! Search & $1,294,261$ & $14.1 \%$ \\
\hline 3 & MSNWindows Live/Bing Search & $1,142,344$ & $12.5 \%$ \\
\hline 4 & AOL Search & 206,969 & $2.3 \%$ \\
\hline 5 & Ask.com Search & 175,074 & $1.9 \%$ \\
\hline 6 & My Web Search Search & 91,288 & $1.0 \%$ \\
\hline 7 & Comcast Search & 55,122 & $0.6 \%$ \\
\hline 8 & Yellow Pages Search & 27,002 & $0.3 \%$ \\
\hline 9 & NexTag Search & 26,461 & $0.3 \%$ \\
\hline 10 & WhitePages.com Network Search & 24,681 & $0.3 \%$ \\
\hline Source: & The Nielsen Company & & \\
\hline & & & \\
\hline
\end{tabular}

\section{Figura 1: Os dez Motores de buscas mais utilizados}

Fonte: The Nielsen Company: Dados de pesquisa realizada em fevereiro de 2010 nos Estados Unidos,extraídos do Relatório de Nielsen de 15/03/2010, atualizado em abril de 2010.

As pesquisas desse relatório representam o número de Consultas realizadas no motor de busca. Aproximadamente 6,0 mil milhões de pesquisas foram realizadas no Google Search, o que representa $65,2 \%$ de todas as buscas feitas durante o período de tempo determinado.

Além dos resultados demonstrados nesta pesquisa, constata-se que alguns mecanismos de busca utilizam os resultados obtidos em um desses três mais importantes. Por exemplo, o mecanismo de busca da AOL (search.aol.com) utiliza o banco de dados do Google, enquanto o AltaVista e o Lycos usam o banco de dados do Yahoo. ${ }^{11}$ Portanto, por estar entre os buscadores mais utilizados, o Google e o Yahoo foram os selecionados para servir de base para a pesquisa realizada neste estudo.

Com relação à escolha de avaliadores e usuários brasileiros para participarem da Pesquisa, vale a pena salientar que existem fortes laços entre 0 Brasil e a Espanha. Há que se considerar que mais da metade do território brasileiro já pertencera à Espanha por ocasião do Tratado de Tordesilhas. Em reconhecimento a essa ligação e devido aos interesses mútuos em termos de

${ }^{11}$ Cf. BREVE história dos mecanismos de busca (2010). 
ensino e pesquisa, foi firmado um acordo entre esses dois países em que a língua espanhola foi sugerido o Espanhol como segunda língua falada no Brasil. O então presidente da República, Luiz Inácio Lula da Silva, sancionou a Lei 1.161/2005 que obriga a escola a oferecer a oportunidade ao aluno de optar por aprender espanhol, inserindo-a junto ao inglês. (Cf. Anexo 1)

\subsubsection{Procedimento metodológico}

Ao analisar a bibliografia produzida na área, foi observado que desde os estudos pioneiros, a criação e o desenvolvimento das páginas Web passavam por questões sobre a sua usabilidade, tendo como comprovar este fato através dos estudos de usuário. Por esse motivo decidiu-se eleger uma parcela de possíveis usuários (aqui chamados de "usuários potenciais"), das páginas Web dos Arquivos avaliados para o estudo de campo.

Nessa perspectiva, iniciou-se uma investigação avaliativa, com uma pesquisa empírica-analítica, de abordagem quanti-qualitativa, uma vez que se recorreu à análise estatística dos dados, com utilização de gráficos e tabelas, e também porque não se dispensou o olhar interpretativo do pesquisador.

Para concretização deste estudo, necessitou-se realizar duas avaliações, para tornar mais abrangente o universo da pesquisa. A primeira, nomeada avaliação preliminar e a segunda avaliação propriamente dita.

Quanto ao universo amostral, optamos pelo método não-probabilístico do tipo "amostra por conveniência" em que foram selecionados, na primeira avaliação, 20 usuários potenciais e 5 avaliadores. Posteriormente, selecionou-se 15 usuários potenciais e 4 avaliadores, quantitativo considerado suficiente para uma amostra intencional. É pertinente esclarecer que nesse tipo de amostra, é possível que os resultados apresentem diferenças, caso o público seja heterogêneo. 
Para a avaliação propriamente dita, uma parcela dos participantes foi contactada por intermédio do professor Marcos Galindo ${ }^{12}$ da Universidade Federal de Pernambuco, o qual convidou os seus alunos de mestrado em Ciência da Informação a participarem do teste de usuários, conforme se esclarece no capítulo da Metodologia (Cf. Cap. 5). Foram convidados também a compor o universo dos usuários, alguns estagiários e funcionários da Fundação Joaquim Nabuco (Fundaj) lotado na Diretoria de Pesquisas Sociais (Dipes) e na Diretoria de Documentação (Didoc), com a permissão de suas respectivas chefias imediatas.

Previamente ao teste, todos preencheram uma ficha social: uma para os usuários (Cf. Apêndice A) e outra para os avaliadores (Cf. Apêndice B) e assinaram os respectivos termos de consentimento livre e esclarecido, conforme o modelo apresentado para os usuários (Cf. Apêndice C) e o apresentado para os avaliadores (Cf. Apêndice D).

A avaliação da qualidade de cada Arquivo foi feita por quatro "observadores-avaliadores", e os resultados do teste com usuários estão devidamente descritos no Capítulo 5.

\subsection{ESTRUTURA CAPITULAR}

Este estudo está dividido em três etapas: a primeira consiste em verificar a bibliografia nacional e internacional a respeito dos critérios de avaliação de páginas Web e realizar conjuntamente um levantamento da bibliografia a respeito de avaliações de sites de bibliotecas e Arquivos, em fontes impressas (livros, periódicos, etc.) e eletrônicas (bases de dados); a segunda consiste na seleção de critérios para a avaliação das páginas Web de Arquivos espanhóis, objeto deste estudo e, por fim, na terceira etapa, realiza-se as análise a partir da avaliação de sites de Arquivos por especialistas na área de informática bem como

\footnotetext{
${ }^{12}$ Marcos Galindo é chefe do Departamento de Ciência da Informação e professor do Curso de Bacharelado em Biblioteconomia e do Curso Gestão da Informação da Universidade Federal de Pernambuco.
} 
a análise das respostas obtidas através de testes de "usuários potenciais" de Arquivos $^{13}$.

O primeiro capítulo apresenta a introdução contendo os informes necessários à construção deste estudo: motivação, definição do problema, questionamento da investigação e hipótese, objetivos, justificativas, limitações do estudo, aspectos metodológicos (em que são pincelados os passos da pesquisa, os quais serão demonstrados com mais detalhes no capítulo da Metodologia), estrutura capitular e os resultados esperados.

O segundo capítulo apresenta um breve repasso da história do Arquivo desde a sua origem, passando pela evolução tecnológica com a gestão da informação e a legislação de Arquivos até o Arquivo disponível em rede.

O terceiro capítulo intitulado "Comunicação e Informação" trata da disseminação da informação a partir do quadro evolutivo da Informação, passando advento da Internet e seu alcance global. Traz à tona a questão da democratização da informação, da interação humano-computador, revolucionando o conceito de sociedade que passa a se caracterizar como "Sociedade da Informação". Este capítulo ao tratar introdução das novas tecnologias e das mídias digitais também aborda o novo conceito de recuperação da informação e a adaptação dos serviços de Arquivo à nova realidade digital.

O quarto capítulo aborda sobre a avaliação de sites, com explanação sobre os critérios de avaliação de páginas Web e as categorias e indicadores, sobretudo os que servirão de base para a análise dos sites de Arquivos espanhóis, objeto de estudo desta pesquisa, a saber: Usabilidade e Visibilidade.

O quinto capítulo, reservado à Metodologia, apresenta os procedimentos utilizados na definição do caráter da pesquisa e explica a necessidade de duas avaliações: avaliação preliminar e avaliação propriamente dita. Apresenta para as duas avaliações os procedimentos para a escolha dos critérios de avaliação, bem como para a coleta e análise dos dados.

O sexto capítulo trata da apresentação e análise dos resultados, tanto da avaliação preliminar quanto da avaliação propriamente dita.

\footnotetext{
${ }^{13}$ Denomina-se aqui "usuário potencial" todo estudante universitário ou pesquisador que em algum momento poderá vir a ser um usuário real de sites de Arquivo, estando estes localizados em qualquer parte do mundo.
} 
O sétimo e último capítulo trata das considerações finais em que são pontuados os resultados das análises e apresentada a visão geral a respeito dos sites avaliados bem como apontadas possíveis sugestões de melhoria em aspectos que influem na sua visibilidade e usabilidade.

\subsection{RESULTADOS ESPERADOS}

Pretende-se conhecer a qualidade dos sites de Arquivos espanhóis valendo-se dos critérios de Visibilidade e Usabilidade. Neste estudo, entretanto, não se pretende esgotar o tema em questão, tampouco ser menos ou mais abrangente que outro qualquer, mas contribuir com a escassa literatura nesse domínio do conhecimento, por ser pouco explorada, abrindo assim uma janela para os Arquivos consolidarem de vez o seu espaço no mundo cibernético. $O$ estudo em tela poderá ainda servir de base para se repensar o papel dos Arquivos na Sociedade da Informação bem como ser utilizado para corrigir as possíveis falhas ou melhorar o sistema de recuperação de informação dos sites avaliados. 
Capítulo 2

\section{ARQUIVOS: DO TRADICIONAL AO VIRTUAL}

Este Capítulo faz um repasso sobre a história do Arquivo, apresentando sua importância até alcançar a era da digitalização. Discorre-se sobre questões pontuais como transparência, qualidade da informação e a legislação a respeito dos arquivos espanhóis. 


\title{
2.1 IMPORTÂNCIA HISTÓRICA DOS ARQUIVOS
}

\author{
Os arquivos constituem a memória das nações e \\ das sociedades, formam a sua identidade, e são a \\ pedra angular da sociedade da informação... \\ ICA - International Council on Archives
}

Para ressaltar a importância dos Arquivos nas Administrações e no cotidiano dos cidadãos como coadjuvantes na história da humanidade, do seu país e do seu povo, faz-se pertinente um repasso da História do Arquivo.

Do latim archívum, Arquivo significa o lugar onde se guardam os documentos ${ }^{14}$. A sua origem histórica remete às civilizações do Médio Oriente, há cerca de 6 mil anos. Ao longo da história, os arquivos se passaram por diferentes suportes, das placas de argila, do papiro, do papel, entre outros, até uma variedade de suportes existentes hoje. Os arquivos surgiram espontaneamente nos palácios e nos templos, os mais antigos, há cerca de 4.000 anos a.C., com as civilizações da Mesopotâmia, no Vale do Nilo. Foram descorbertos vários vestígios dos primeiros Arquivos nas cidades antigas de Elba, Lagash, Maari, Ninive, Ugarit, etc.

No palácio de Elba na Síria encontraram-se, graças à arqueologia, numerosas placas de argila, dispostas em estantes de madeira e em diferentes salas, grandes volumes de documentos, missivas governamentais, sentenças judiciais, cartas, actos privados, etc. (REIS, 2006).

De maneira que sua organização já tinha um grau superior, pois encontraram-se léxicos e catálogos descritivos. Estes arquivos se destacavam em importância tanto pelas placas de argila quanto pela complexidade de sua

\footnotetext{
${ }^{14}$ Para evitar o equívoco semântico que possa suscitar a palavra arquivo, decidiu-se neste estudo utilizar o recurso da Maiusculação para referir-se a Arquivo como local de guarda de documentos diferente de outras concepções da palavra arquivo.
} 
estrutura organizacional e funcional. Tais arquivos ficaram conhecidos como "arquivos de palácios ou arquivos de placas de argila."15

Segundo Durkheim (1992, p.16), o Arquivo de Simancas, de Valladolid na Espanha, criado em 1542, constitui o primeiro exemplo clássico de um Arquivo de Estado; sua criação teve um caráter inovador, uma vez que o Estado Espanhol era recente. Afirma ainda que o seu o regulamento interno (Instrucción para el Gobierno Del Archivo de Simancas), de 1588, é talvez o primeiro documento de arquivo de que se tem conhecimento. De acordo com Mariz (2005, p. 32) ${ }^{16}$, o Arquivo de Simancas é um referencial na história da Arquivística por guardar a memória do passado mesmo tendo o seu acervo um caráter privado cujo acesso dependia do soberano. O passado tem influência direta na construção do futuro que o reinterpreta constantemente, sendo portanto "parte integrante e significativa da história" (LE GOFF, 2003, p. 25).

Conforme afirmação de Bellotto (2004, p. 23), a dissimetria entre administração e história em relação aos documentos, é tão-somente uma questão de tempo, haja vista os Arquivos serem um fenômeno natural e espontâneo, desde o aparecimento da escrita quando surgiu também a ideia de guardar, reunir e organizar os suportes de escrita existentes naquela época. A preocupação em conservar essa "memória" marca a afirmação do homem na sociedade.

Com relação à conservação e à preservação dos documentos de Arquivos, tal como o ser humano, os documentos têm um tempo de vida que vai do momento em que são gerados até o envelhecimento natural, por conseguinte, necessita de cuidados.

De acordo com Ribeiro (2005, p.8), tradicionalmente os arquivistas alemães se preocupam mais com a preservação que com as eliminações ao contrário da política da Inglaterra de eliminação que consiste em destruir tudo o que não tem interesse legal, histórico, estatístico, econômico ou que não sirva para qualquer fim oficial. A partir dos anos cinquenta do século $X X$ surgiu uma perspectiva melhor fundamentada em pressupostos que orientam a avaliação através do americano Teodore R. Schellenberg, num estudo que veio a ser a

\footnotetext{
${ }^{15}$ Idem.

${ }^{16} \mathrm{~A}$ autora analisa o papel do Arquivo de Simancas como pioneiro deste resgate da memória do passado mesmo possuindo regras para seu acesso, nesta intenção busca apoio na Historiografia.
} 
principal referência para os arquivistas americanos e refletiu sobre a Arquivologia de outros países.

Conforme a supracitada autora, Schellenberg considerou a existência de um valor primário (para a entidade produtora) e um valor secundário (para a investigação), além de fazer distinção entre "valor evidencial" e "valor informativo", como aspectos contidos no valor secundário, significando, de certo modo, a incorporação dos critérios alemães.

Na década de 1980, o desenvolvimento das novas tecnologias sucitou a ideia da morte do documento impresso. No século XXI, em tempos de tecnologias, urge que os conhecimentos se atualizem, eis porque a emergência de adaptação a tais inovações tecnológicas.

Segundo McDonald (1998, citado por JARDIM, 2001, p.23), é possível que uma gestão deficiente no que se refere à informação arquivística acarrete significativos impactos em diversos domínios, a saber: Meio-ambiente, Recursos Naturais, Saúde, Transporte, Política Econômica e Social, Recursos Humanos, Financeiros e Materiais.

A utilização das TICs para a criação de documentos e a gestão eletrônica da documentação, obriga a repensar a atuação dos especialistas em informação e documentação. Segundo Bustelo Ruesta (1997, p. 45), no plano teórico, se propõe mudanças no conceito de documento e arquivo, e na teoria do ciclo vital dos documentos; no plano prático, propõem-se estratégias para a preservação e gestão dos documentos eletrônicos.

A rápida evolução das tecnologias da informação obriga muitas vezes tanto os arquivistas quanto os usuários de Arquivo a assimilar as novidades com grande velocidade e aprender a selecionar e utilizar os produtos e serviços informáticos para, dessa maneira, realmente adaptar-se à gestão eletrônica dos documentos.

Conforme Spinelli Junior (1997, p. 11), para conservação do patrimônio cultural, deve-se administrá-lo, com segurança, ter recurso suficiente e conhecer bem a infraestrutura do ambiente a partir de conhecimentos técnicos e científicos.

Para melhor longevidade dos documentos de arquivo, cabem algumas observações: é preciso, cuidar dos documentos em sua fase intermediária e 
permanente; utilizar bem as técnicas de tratamento arquivístico e, sobretudo, incentivar a política de conservação preventiva. Para garantir a eficiência de tais sugestões, é importante organizar a documentação e fazer a sua manutenção, reduzir a massa documental, elevar o índice de recuperação da informação e preservar a documentação de valor permanente.

Ainda sobre a preservação de documentos, dois aspectos devem ser considerados: a conservação e a restauração. A conservação diz respeito às ideias de preservação, proteção e manutenção dos bens culturais. Sua importância está em preservar o bem da ação do ambiente, para que cedo não venha a deteriorar-se. O objetivo precípuo da conservação é a longevidade do documento, para tanto se faz necessário observar as condições do ambiente, do manuseio e do armazenamento. A limpeza periódica e sua manutenção é a palavra-chave da prevenção. A restauração, por sua vez, diz respeito à revitalização do documento, que apresenta sinais de envelhecimento $e$ deterioração. É importante no trabalho de restauração, paciência, habilidade e amor à arte (CEDOC, 2010? $)^{17}$ haja vista se tratar de remontar a história do documento, descobrir a tecnologia utilizada em sua fabricação ou mesmo saber que técnica de impressão fora utilizada para depois planejar a sua conservação, para que assim, o objeto restaurado não reapresente os sinais de deterioração. Poucos são os técnicos dessa área, e para formar um bom restaurador demanda tempo, por conseguinte é melhor preservar a ter que restaurar a obra no futuro.

Os romanos possuíam uma noção mais esclarecida do que se deveria arquivar, eliminando assim os documentos que julgavam desnecessários ou menos importantes. Deve-se ao Cônsul Valerius Publicoa, em 509 a.C., a criação do primeiro arquivo da Roma antiga.

Todo legado histórico que se traduz como bem cultural, testemunho ou prova de contínuo desenvolvimento cultural da humanidade, é de responsabilidade de todos e isto implica na disponibilidade ao uso, sob critérios determinados que garantam sua transmissão às gerações futuras (SPINELLI JUNIOR, 1997, p. 12).

\footnotetext{
${ }^{17}$ O Centro de documentação da Universidade de Brasília - UnB é o órgão que trata de recolher, preservar e garantir o acesso aos documentos de interesse da Universidade.
} 
O autor destaca a importância do arquivo para a evolução da humanidade no que diz respeito ao resgate histórico que deve ser transmitido de geração a geração.

Segundo Reis (2006), os arquivos romanos seguem, a exemplo dos gregos, seu funcionamento em templos, no Templo de Saturno, junto ao erário público, local onde eram guardadas as Tabulae Publicae, que passaram a ser conhecidas como Tabularium, atualmente localizado no Capitólio, edifício construído cerca de 78 a.C por ordem do imperador. Os romanos criaram os Arquivos Centrais, implantando em cada corpo de magistrado um arquivo específico. O Tabularium, com a função de Arquivo Central do Estado, compunha-se de escritórios dos funcionários públicos, já com a importância de um grande serviço público. Tendo sido este definido um regimento próprio para o arquivista, que possuía já funções de âmbito de conservação, reprodução e validação de documentos. Os documentos diplomáticos eram conservados no Templo de Júpiter e os testamentos no de Vesta.

(...) Um dos grandes feitos dos romanos nesta área, é o fato de terem
instaurado uma verdadeira rede de arquivos, assim um pouco por todo o
Império vê-se o aparecimento de Tabularius nas cidades provinciais mais
importantes, nos quais se recolhia a legislação, a jurisprudência e a
documentação da administração provincial, assim como surge também
os arquivos dos municípios e os arquivos privados, fruto do
desenvolvimento do Direito, e que constituíam um instrumento
fundamental para a garantia da propriedade dos cidadãos. Referindo-se
a organização romana desenvolveu-se o conceito do Arquivo Público,
pois apesar dos arquivos centrais terem sido criados para uso estatal,
abriram as portas à sociedade, funcionando como garantia de prova para
a reclamação de direitos dos cidadãos (REIS, 2006).

A administração romana à época do Império foi próspera no domínio dos Arquivos. Alguns critérios usados pelos romanos na organização de arquivos ainda permanecem válidos. Criaram uma rede de serviços proprios e um corpo profissional especializado. Além dos Arquivos Centrais, instituíram a criação de um arquivo para cada corpo de magistrados, chamado de Arquivo de Governadores provinciais.

Com a Idade Média, o conceito de arquivo foi cristalizado, significando na Época Medieval o espaço ou serviço onde se preservam registros antigos, ou seja começa-se a difundir a ideia de arquivo como espaço ou serviço onde se recolhem documentos de valor, por constituírem prova ou memória de fatos do 
passado, sob as designações de origem Pré-Clássica, como um Santuário ou Tesouro. E isso gera uma certa ambiguidade entre biblioteca e arquivo.

Sua função, naquela época, era de "guardador de memórias". O Scriptorium, como era conhecido, tinha relação com um local apropriado para escrever e se referia usualmente a um quarto nos mosteiros medievais da Europa onde os monges copistas se recolhiam quando escreviam os manuscritos, de modo que o scriptorium era "um complemento da biblioteca" Esse ambiente reservado onde se resguardava o saber serviu de inspiração para muitos autores a exemplo de Umberto Eco em seu famoso clássico O Nome da Rosa. ${ }^{18}$

Sendo os arquivos na sua maioria provenientes das classes religiosas, de ordem eclesiástica, guardavam documentos relacionados com a Igreja e documentos relativos à dinastia. Com o redescobrimento do Direito Romano, no Século XII, a história dos arquivos passa a uma nova fase, voltando a ter um pouco do prestígio adquirido na antiguidade (REIS, 2006).

A prática dos registros começou a partir do século XIII, com os livros nos quais se transcreviam os documentos outorgados por uma autoridade, ou entidade, nomeadamente nas Chancelarias, e outras instituições. Naquela época as unidades administrativas dessas estruturas dividiam-se já em secções orgânicas, e com funcionários especializados (arquivistas) e normas especificas sobre arquivamento.

O Scriptorium era um ambiente de interação intelectual em que se dispunham à sociedade os códices que constituíam grande parte da produção escrita medieval. Com a elevação demográfica e a criação de universidades, a sociedade se torna mais exigente, tornando a produção escrita mais sofisticada.

Até o final do século XVIII, o mundo ocidental valorizava o passado, uma época em que os ancestrais viviam felizes e inocentes.

"... A constatação de que a visão de um mesmo passado muda com o tempo, pois o historiador subordina-se a ele, preso que está ao presente, fato que o leva ao ceticismo sobre o passado, necessitando de certo esforço para dirimir a referência ao presente. Dessa forma, "o interesse no passado está em esclarecer o presente" (LE GOFF, 2003, p. 13).

\footnotetext{
18 Cf. Significado de Scriptorium. Disponivel em: http://www.proac.uff.br/scriptorium/index.php?option=com_content\&task=blogsection\&id=11\&ltemi $\mathrm{d}=69$. Acesso em: 22 ago 2010.
} 
Com a era moderna houve um aumento considerável de documentos provindos de diferentes arquivos para um mesmo depósito é a época dos Arquivos Estatais e Reais que concentravam toda a documentação provinda de diversas Regiões, secretárias de Estado, administração regionais, protocolos notariais, etc. Com o desenvolvimento dos Arquivos Reais, onde era salvaguardado o caráter reservado da documentação, prática exigida pelos reis, o acesso aos documentos passou a ser limitado, pois era o rei quem determinava quem poderia ou não aceder à informação. Após a Revolução Francesa, no entanto, houve muita mudança nesse quadro, pois foi criado o Arquivo da Nação:

A Revolução Francesa traduz-se em mudanças significativas para os arquivos, porém, não isentas de contradições e de aplicação imediata, já que só em meados do século XIX surgem, de fato, salas para consulta nos arquivos (SILVA et. al., 1999, p. 102 citado por MARIZ, 2005, p. 33).

A Ciência Histórica, desde a antiguidade, reuniu documentos escritos e os propagou, superou os limites impostos pela transmissão oral do passado.

A Constituição de Arquivos e Bibliotecas forneceu assim, os materiais da história. Foram elaborados métodos de crítica científica, conferindo à história um de seus aspectos de ciência em sentido técnico, a partir dos primeiros e incertos passos da Idade Média (Guenée), mas sobretudo depois do final do século XVII, com Du Cange, Mabilon e os beneditinos de Saint-Maur, Muratori, etc. (LE GOFF, 2003, p. 9).

Quanto aos conceitos fundamentais de documento, arquivo, unidade documental, unidade arquivística, Lopez Gomez (2008, p.12-13) destaca as contribuições de Arago e Fuster (1969), bem como uma contribuição mais recente, um livro seu em colaboração com Olga Gallego ${ }^{19}$, que, Antonia Heredia Herrera $^{20}$ recomenda como leitura obrigatória para que se torne inevitalvelmente uma referência nesta área.

Algumas questões como a aplicação do princípio da proveniência e os regulamentos do Arquivo Real de Barcelona, hoje Coroa de Aragão, do Arquivo Geral de Simancas e do Arquivo Geral de Indias, ajudaram a situar dentro do

\footnotetext{
${ }^{19}$ Referência apresentada por López Gómez (2008): Gallego Domínguez, O. P. López Gómez, 'Archivos y Documentación', en Actas de las $3^{\underline{a}} \mathrm{~s}$ Jornadas Españolas de Documentación Automatizada. "Documat 90", I, (Palma: Universitat de les Illes Balears, 1990), pp. 268-325. López Gómez, P., O. Gallego Domínguez, El Documento de archivo. Un estudio (A Coruña: Universidade da Coruña. Servizo de Publicacións, 2007).

${ }^{20}$ Professora de Arquivística em Sevilha. Autora de diversas obras publicadas sobre Arquivos, sendo uma das mais recentes Que és un archivo?(2007).
} 
plano internacional a história da Arquivística espanhola (LÓPEZ GÓMEZ, 2008, p.10).

Conforme as considerações de Focault e Le Goff, o documento exprime o poder da sociedade do passado sobre a memória e o futuro, tratando-se, portanto, de um "monumento" (LE GOFF, 2003, p. 10).

Os documentos de Arquivo são usualmente originais, uma vez que são comprobatórios de fatos históricos ou justificam a existência de uma entidade sendo ela pública ou privada, podendo se apresentar nas mais diversas formas e suportes. Portanto, é de extrema importância estar atento à noção de respect des fonds.

\begin{abstract}
A relação que os documentos mantém entre si no interior do conjunto arquivístico formando uma unidade é essencial, já que um documento isolado não permitiria uma visão integral das atividades do órgão e/ou pessoa física. Esse princípio de relação orgânica que permeia o acervo faz com que cada um dos documentos seja absolutamente singular (MARIZ, 2005, p. 19).
\end{abstract}

A presença dos documentos nos fundos de arquivos bem como em bibliotecas, esclarece Le Goff (2003, p. 534), depende de causas humanas que não fogem à análise e que os problemas postos em sua transmissão, não são apenas de ordem técnica, pois os mesmos tocam no mais íntimo da vida do passado, colocando em jogo nada mais, nada menos que a passagem da recordação através das gerações.

\title{
2.2 NASCIMENTO DO ARQUIVO ADMINISTRATIVO
}

Os arquivos são gerados a partir da produção de documentos da própria Administração. Alguns autores, a exemplo de Jardim (1996) e Shellemberg (1959) citados por Le Goff (2003, p. 537), chamam a atenção para os dois conceitos de valor dos Arquivos: primário e secundário: O primário se refere àqueles arquivos que interessam à própria administração que os produziu e o conceito secundário se refere aos arquivos que interessam a outras entidades do governo e também ao público por diferentes motivos de quem os produziu. 


\begin{abstract}
O documento não é inócuo. É, antes de mais nada, o resultado de uma montagem, consciente ou inconsciente da história, da época, da sociedade que o produziram, mas também das épocas sucessivas durante as quais continuou a viver, talvez esquecido, durante as quais continuou a ser manipulado, ainda que pelo silêncio. O documento é uma coisa que fica, que dura, e o testemunho, o ensinamento (para evocar a etimologia) que ele traz devem ser em primeiro lugar analisados, desmistificando-Ihe o seu significado aparente. $\mathrm{O}$ documento é monumento. Resulta do esforço das sociedades históricas para impor ao futuro - voluntária ou involuntariamente - determinada imagem de si próprias (LE GOFF, 2003, p. 538).
\end{abstract}

Para o autor supracitado, os documentos arquivados têm um valor histórico, haja vista guardarem a memória das sociedades.

Os Arquivos Administrativos são altamente descentralizados e contém uma variada gama de informações sobre a instituição de origem, é conveniente, portanto, fazer com que os usuários tomem conhecimento da existência dos serviços oferecidos pelos referidos Arquivos, uma vez que podem ocasionalmente vir a complementar as informações encontradas nos Arquivos Históricos. Sempre que possível as atividades dos Arquivos Administrativos, dos Arquivos Históricos e da Gestão de documentos deverão complementarem-se (TAYLOR, 1984, p.21).

Conforme Castro; Castro e Gasparian (2007, p. 15), a formação do Arquivo de uma entidade tem início nos documentos produzidos ou recebidos e seguem para o Arquivo Corrente, sendo classificados conforme os seguintes itens: assuntos, funções, estruturas, atividades, espécies documentais. Após a classificação eles são avaliados, de acordo com a classificação. Na sequência, passam ao Arquivo Intermediário, criado especificamente para aguardar os prazos da Tabela de Temporalidade, e as recomendações de guardar o documento para sempre ou eliminar, conservando apenas a informação através dos meios tecnológicos (microfilme, digitalização). Afirmam ainda esses autores que os documentos são recolhidos ao Arquivo Permanente conforme a Tabela de Temporalidade.

De acordo com Llansó Sanjuan (2006, p.42), vários autores abordaram dentro de uma perspectiva metodológica a categorização por fases do ciclo de vida dos documentos, porém, dentro do contexto internacional prevalece a 
formulada por James B. Rhoads ${ }^{21}$, que distingue quatro fases no ciclo de vida dos documentos: fase de criação, a fase de utilização e manutenção, fase de disponibilização e fase de gestão de documentos de valor permanente (Figura 2).

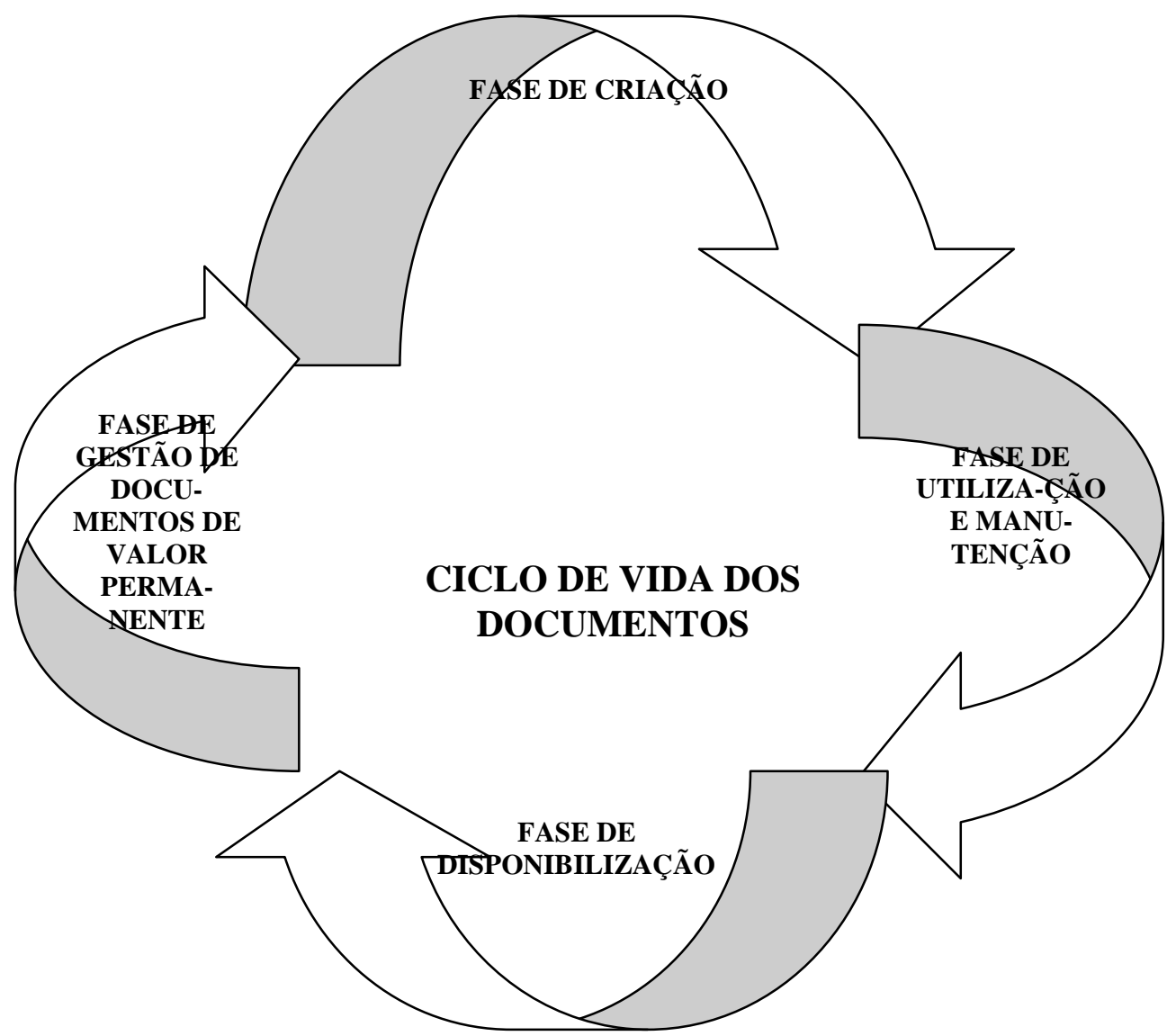

Figura 2 - Fases do Ciclo de Vida dos Documentos

Assim, segundo Martins (2005, p. 17) pode-se conceituar Arquivo Corrente ou de Gestão, como de "Primeira Idade ou Ativo" que têm vínculo direto com os propósitos imediatos dos usuários. Por conta da demanda de uso e de sua vigência, esse tipo de Arquivo se conserva junto aos órgãos produtores; Arquivo intermediário, como de "Segunda Idade ou Semiativo", são aqueles pouco usados pela administração que aguardam por um curto período de tempo a sua finalização; já Arquivo Permanente, segundo esse mesmo autor, de "Terceira

${ }^{21}$ Cf. Referência fornecida por Llansó (2006): James B. Rhoads: La función de la gestión de documentos y archivos en los sistemas nacionales de información: un estudio del RAMP. París: Programa General de Información y UNISIST, Unesco, 1983. 
Idade ou Histórico", são os conjuntos de documentos de valor, custodiados em caráter definitivo, cujo acesso é público.

Segundo Llansó Sanjuan (2006, p.56), o conceito de gestão integral perpassa por três ações: 1) pede uma unidade e continuidade de intervenções no conjunto documental; 2) articula e estrutura as atividades em um programa de organização de Arquivos e 3 ) integra valor primário e valor secundário que os Arquivos apresentam.

Em finais do século $X X$, houve uma crise nos modelos de gestão dos documentos, a qual desencadeou uma reflexão sobre o papel das instituições arquivistas dentro dessa gestão, ao se repensar os mais desenvolvidos modelos no panorama internacional, a exemplo da América do Norte, cujos arquivistas priorizaram o atendimento às expectativas do usuário, com o máximo de eficácia nas respostas, buscando conformar-se à nova realidade. A questão está centrada na "origem da arquivística moderna, isto é, na teoria das três idades e ciclo de vida dos documentos." Llansó Sanjuan (2006, p.55-56).

Em muitos países, as operações de arquivamento que vão desde o período da criação de documentos até a sua eliminação ou transferência para um Arquivo Histórico são incluídas no conceito de "Gestão de documentos", fato que não coincide com o modelo de vanguarda Norte-Americano, porém, essas contribuições devem ser consideradas para enriquecer o conceito.

A Arquivística na Espanha recebeu influência da Alemanha, Itália e França, grande parte do mundo anglo-saxão, e, especialmente nestes últimos tempos, dos EUA. A base teórica, de acordo com Cook (citado por López Gómez, 2008, p.3), foi estruturada dentro do contexto italo-hispânico, que inclui também os países latino-americanos que possuem laços históricos com a Espanha, semelhanças na organização administrativa e, por conseguinte, na produção documental bem como problemas semelhantes, como por exemplo, o acúmulo de fontes documentais de caráter histórico por não possuir normas para as transferências e expurgo.

Neste sentido, conforme afirma James Rhoads (1983; 1989 citado por LLANSÓ SANJUAN, 2006, p.41-42), a diversidade internacional existente aponta 
para quatro níveis de implantação da gestão de documentos, como se observa no Quadro 1 a seguir.

\begin{tabular}{|c|c|c|c|}
\hline Nível mínimo & $\begin{array}{l}\text { Nivel mínimo } \\
\text { incrementado }\end{array}$ & Nivel intermediário & Nivel ótimo \\
\hline $\begin{array}{l}\text { Países que possuem } \\
\text { instrumentos como } \\
\text { calendário de conser- } \\
\text { conservação ou tabe- } \\
\text { las de avaliação de } \\
\text { documentos e transfe- } \\
\text { e transferem os } \\
\text { documentos de valor } \\
\text { permanente para os } \\
\text { Arquivos Nacionais. }\end{array}$ & $\begin{array}{l}\text { Países que incor- } \\
\text { poram aos elemen- } \\
\text { tos do nível mínimo } \\
\text { um ou mais depó- } \\
\text { sitos } \\
\text { intermediários. }\end{array}$ & $\begin{array}{l}\text { Países que incluem além } \\
\text { dos elementos do nível } \\
\text { mínimo incrementado, } \\
\text { subprogramas básicos, } \\
\text { como a concepção e } \\
\text { gestão de formulários, } \\
\text { gerenciamento de } \\
\text { correspondência e } \\
\text { relatórios, } \\
\text { desenvolvimento de } \\
\text { sistema de arquivos e } \\
\text { recuperação de } \\
\text { documentos, } \\
\text { gerenciamento de } \\
\text { registros, programa para } \\
\text { documentos essenciais e } \\
\text { planejamento contra } \\
\text { possíveis desastres. }\end{array}$ & $\begin{array}{l}\text { Países que } \\
\text { somam aos níveis } \\
\text { níveis anteriores, a } \\
\text { gestão de } \\
\text { diretrizes, correio } \\
\text { correio, telecomu- } \\
\text { nicações e máquin } \\
\text { e máquinas de } \\
\text { reprodução de } \\
\text { documentos, } \\
\text { sistemas de } \\
\text { gerenciamento de } \\
\text { informações e uso } \\
\text { de processamento } \\
\text { de texto na } \\
\text { geração de } \\
\text { correspondência, } \\
\text { relatórios e di- } \\
\text { retrizes e } \\
\text { preenchimento de } \\
\text { formulários; } \\
\text { utilizando os } \\
\text { sistemas } \\
\text { análise, } \\
\text { automação e } \\
\text { reprografia em } \\
\text { várias aplicações. }\end{array}$ \\
\hline
\end{tabular}

\section{Quadro 1 - Níveis de implantação de gestão de Documentos}

Fonte: LLansó (2006, p. 41) - adaptação nossa.

A respeito dos documentos administrativos, Lopez Gomez (2008, p.13) cita algumas contribuições bibliográficas, a saber: Paola Carucci et al (1994) e Torreblanca y Mendo (1994). ${ }^{22}$

A partir da década de 1960, o termo documento sofreu um verdadeiro alargamento quando o interesse da memória e da história não se limitava aos grandes homens e aos importantes fatos históricos mas sim, interessava-se por

\footnotetext{
22 Referência apresentada por López Gómez (2008): Carucci, P. [et al.], Documento y archivo de gestión. Diplomática de ahora mismo (Carmona: S\&C ediciones. Universidad Internacional Menéndez Pelayo,1994).- Torreblanca, López A., C. Mendo Carmona, 'Estructura del expediente administrativo según las fuentes legales', en Carucci, P. [et al.] Documento y archivo de gestión. Diplomática de ahora mismo... p. 107-170
} 
todos os homens, constituindo uma verdadeira revolução documental. "O registro paroquial, em que são assinalados, por paróquia, os nascimentos, os matrimônios e as mortes, marca a entrada na história das "massas dormentes" e inaugura a era da documentação de massa" (LE GOFF, 2003, p. 531).

No Manual para Arquivos eletrônicos do Conselho Internacional de Arquivos Correntes consta que é papel dos Arquivistas se envolverem com a história do documento de arquivo a partir de seus primeiros momentos de vida, em sua fase preliminar até que invenção seja potencializada. Como estratégia de gestão de documentos de arquivo, deve-se considerar o benefício de uma intervenção precoce dos arquivos. ${ }^{23}$

Muitos autores estão em conformidade com esse raciocínio e reconhecem a importância do profissional da informação no processo de implantação de um sistema de gestão, concordando que os arquivistas são especialistas na identificação, classificação e valorização dos documentos e na utilização de recursos para sua conservação e acesso.

Los profesionales de los archivos son expertos em la identificación, clasificación y valoración de los documentos y em los requisitos necesarios para su conservación y acceso. Por ello deben jugar um papel fundamental em los proyectos para el desarrollo de la administración electrónica llevados a cabo por las distintas instituciones (BECANA SANAHUJA, 2008, p. 69). ${ }^{24}$

Conforme a colocação acima, os arquivistas devem acompanhar os projetos de desenvolvimento tecnológicos das instituições arquivistas, pois eles detêm o conhecimento necessário para garantir a conservação dos documentos e torná-los acessíveis.

Segundo Llansó Sanjuan (2006, p.64), Carol Couture e Jean-Yves Rousseau definem a "Política de tratamento de documentos" como um esforço conjunto de estabelecer os meios que permitirão a relação custo-eficácia dos documentos produzidos ou acumulados por uma administração.

\footnotetext{
${ }^{23}$ Idem, p. 17

${ }^{24}$ Os profissionais dos arquivos são especialistas na identificação, classificação e valoração dos documentos e nos requisitos necessários à sua conservação e acesso. Por isso desempenham papel fundamental nos projetos para o desenvolvimento da administração eletrônica concluídos pelas distintas instituições.
} 
É cabível de registro pontuar alguns dos princípios para elaboração de programas de gestão de documentos de arquivos, como sugerido por Castro; Castro; Gasparin ${ }^{25}$ :

1. Documentos de Arquivo são produzidos, recebidos e utilizados na condução das atividades de uma organização, que deve produzir e manter os documentos de arquivo fidedignos, autênticos e utilizáveis, bem como proteger a integridade desses documentos durante o tempo necessário, ou seja, o prazo de vida do documento.

2. As regras para produzir e integrar, no Sistema de Arquivos, documentos e os respectivos metadados ${ }^{26}$, devem seguir os procedimentos contábeis, fiscais, e jurídicos desde que os documentos em pauta, sejam de valor probatório;

3. Os documentos de arquivo vital para o contínuo funcionamento da organização devem ser identificados, protegidos e acessíveis à informação.

Tais princípios se fundamentam na norma ISO 15489-1 (2001) $)^{27}$, que suporta uma excelente estrutura para desenvolver programa de gestão de documentos de Arquivo. Essa norma considera duas perspectivas, entre outros pontos, a Perspectiva da Administração Pública e a Perspectiva Arquivística.

A primeira perspectiva, a da Administração Pública, envolve os objetivos da instituição, a sua relação com os Arquivos e o caminho percorrido para atingir seus objetivos, bem como as estratégias para aproximar o cidadão da Administração.

Com relação à Perspectiva Arquivística, é preciso compreender o posicionamento dos arquivistas dentro das Administrações, uma vez que eles dependem tanto de oportunidades oferecidas quanto do perfil dos usuários que buscam os Arquivos.

\footnotetext{
${ }^{25}$ Op. cit.

${ }^{26}$ Cf. Metadados no Capítulo 4 - Critérios de avaliação.

${ }^{27}$ ISO 15489-1 (2001) é primeira parte da Norma Internacional que trata de informação e documentação. Gerenciamento de Registros.
} 
Com o tempo, tais estratégias aproximarão o cidadão da Administração Pública, haja vista o aumento do grau de confiança entre os interagentes em relação aos produtos e serviços. Conscientes de seus direitos, os cidadãos terão paulatinamente acesso à informação do governo e, na sequência, os serviços prestados a esses cidadãos serão melhorados com a disponibilização de documentos eletrônicos.

La función social de los archivos rebasa su espacio físico; su finalidad no es la conservación, ni la organización, sino el uso social. Sólo los archivos pueden rescatar para el futuro inmediato o remoto el patrimonio documental que preserva la historia ${ }^{28}$ (RAMIRÉZ LÓPEZ, 2000, p.18).

Há que se considerar, conforme Bustelo Ruesta (1997, p.50), na nova gestão eletrônica, dois tipos de profissionais: os especialistas em tecnologia da informação, ou seja, os Web designers, ou engenheiros de telecomunicações e os records management. Esses profissionais devem trabalhar conjuntamente, no universo da formulação teórica e prática de gestão de documentos, para implantação dos sistemas de Arquivo.

\subsection{GESTÃO DA INFORMAÇÃO}

A aproximação entre a Administração e os cidadãos envolve a "Política de tratamento de documentos", em que se buscarão os meios necessários para que a informação seja de fato democratizada.

Carol Couture e Jean-Yves Rousseau ${ }^{29}$ citados por Llansó Sanjuan (2006, p.64) definem a "Política de tratamento de documentos" como um esforço conjunto para estabelecer os meios que permitirão a relação custo-eficácia dos documentos produzidos ou acumulados por uma administração.

\footnotetext{
${ }^{28}$ A função social dos Arquivos ultrapassa seu espaço físico; sua finalidade não é a conservação, nem a organização, e sim, o uso social. Somente os Arquivos podem resgatar para o futuro imediato ou remoto, o patrimônio documental que preserva a história (Tradução nossa).

${ }^{29}$ Trata-se de uma das mais importantes obras sobre o tema, publicado em 1982, com reedições posteriores, que, segundo Llansó Sanjuan (2006, p.64) não foi suficientemente valorizada na América Latina Cf.: Couture, C. y Rousseau, J. Les archives au XX è siècle. Montréal: Université de Montréal (1982): 13-25.
} 
Os modelos de gestão de documentos dos sistemas arquivísticos devem possuir características que reflitam a "Política de tratamento dos documentos" da qual deriva.

La política de tratamiento de los documentos debe tener por objetivo la planificación, el establecimiento y el apoyo de todos los medios (reglamentación-estructura-programa) que hará posible un control racional, eficaz y rentable de la creación, de la utilización, de la recuperación y de la conservación a plazo más o menos largo de los documentos que esa Administración produce o recibe en el ejercicio de sus actividades $^{30}$ (LLANSÓ SANJUAN, 2006, p.64).

No início dos anos 1990, os records management evoluíram para Information Resources Management quando voltaram sua atenção para o Knowledge Management, ou seja, para a Gestão do Conhecimento, um novo conceito que envolve outros profissionais da informação, tais como bibliotecários, arquivistas e claro, como consequência da dinâmica das novas tecnologias, profissionais de informática e gestores de sistemas de informação (LLANSÓ SANJUAN, 2006, p.50).

Segundo Becana Sanahuja (2008, p.71), o papel dos arquivistas na gestão documental é colaborar com os especialistas em informática e com os administradores, através de seu conhecimento global dos documentos produzidos na Instituição, suas habilidades para a sistematização e descrição, e de busca e recuperação, para juntos alcançarem um bom sistema de gestão de documentos e garantir os direitos e deveres da própria instituição e dos cidadãos, mantendo os registros documentais para que possam ser utilizados nas futuras pesquisas culturais, científicas ou técnicas.

Quanto às necessidades fundamentais dos usuários,

(...) los usuarios tienen niveles distintos de necesidades según sus disciplinas, conceptos de valor y funciones en la sociedad...Pero hay que distinguir entre el acceso intelectual y el hecho de "facilitarlos" físicamente, como hay que distinguir entre ese acceso intelectual y el hecho de que el usuario se sienta plena o parcialmente atendido en sus necesidades (TAYLOR, 1984, p.16) ${ }^{31}$.

30 A política de tratamento de documentos deve ter como objetivo o planejamento, o estabelecimento e o apoio de todos os meios (regulamentação-estrutura-programa) que permita um controle racional, eficaz e de baixo custo da criação, da utilização, recuperação e conservação de longo prazo dos documentos longos que a Gestão produz ou recebe no exercício das suas actividades (Tradução nossa).

${ }^{31}$ [...] os usuários têm diferentes níveis distintos de necessidades de acordo com suas disciplinas, conceitos de valor e função na sociedade... Mas é preciso distinguir entre esse acesso intelectual 
De acordo com Taylor (1984, p.16), os usuários têm a tendência de apresentar suas necessidades de modo fragmentado, como se fossem itens soltos, porém, suas reais necessidades apenas a partir de uma maior compreensão do usuário enquanto pessoa, poderão ser conhecidas.

Conforme sinaliza Jardim (2001, p. 5), tudo que envolve a prática da Arquivologia da Biblioteconomia, Documentação e da Ciência da informação tem como prioridade o acesso dentro dos processos de uso e transferência da informação, em que há dois sujeitos envolvidos: o profissional da informação e o usuário, em torno do qual se justifica todos os serviços.

Ao refletir sobre a necessidade básica dos usuários menos familiarizados com os Arquivos, Taylor (1984, p.17) considera de extrema importância que eles estabeleçam uma relação mais pessoal com o arquivista, a fim de criar um clima de confiança já que primeiramente eles precisam conhecer e entender 0 procedimento do Arquivo, antes que possam surgir suas reais necessidades. $O$ que de fato interessa nesse processo é que a disponibilização de documentos e quaisquer outras fontes de informação de fato possa satisfazer às necessidades do usuário.

Lo que nos ocupa, es, de hecho, una obra de arte que apunta a producir un efecto: el empleo de documentos y otras fuentes del saber para producir uma transcripción coherente de la complejidad humana mediante una formulación generalizada que pueda aprehender y utilizar el lector (TAYLOR, 1984, p.16) ${ }^{32}$

Dessa forma, os arquivistas deveriam estar preocupados com a interação entre os conteúdos dos documentos e sua utilidade com o fim precípuo de atender às necesidades específicas dos usuários, além de otimizar o acesso aos documentos.

Há que se considerar uma distinção entre o usuário compilador, que segundo Delmas citado por Taylor (1984, p. 21) trata-se daquele que procura documentos jurídicos e administrativos inacessíveis ao público e o usuário leitor,

e o fato de disponibilizá-lo fisicamente, como é preciso distinguir entre o acesso intelectual e o fato de que o usuário se sinta totalmente ou parcialmente atendido em suas necessidades.(Tradução nossa)

${ }^{32} \mathrm{O}$ que nos interessa é, de fato, uma obra de arte que tem como objetivo produzir um efeito: a utilização de documentos e outras fontes de conhecimento para a produção de uma transcrição coerente da complexidade humana por uma formulação generalizada que o leitor possa captar e fazer uso destas fontes. (Tradução nossa). 
cujo interesse centra-se em informações de Arquivos Históricos. Para esse autor, é desnecessário a criação de arquivos separados, pois o cidadão vai buscar solução para suas dúvidas mais comuns nos Arquivos Administrativos.

Ainda sobre o papel dos arquivistas dentro da gestão de arquivos, o aspecto mais importante dessa gestão de Arquivos é salvaguardar os documentos de conservação permanente e criar subsídios para que se possa vincular os documentos originais aos documentos eletrônicos, uma vez que a capacidade de fornecer e administrar esse serviço determina sua importância dentro da Administração, apoiando-a no cumprimento de seu papel no que se refere à transparência informativa.

Castro; Castro e Gasparian (2007, p. 23) fazem uma observação a respeito do profissional de Arquivo europeu, segundo o qual o Arquivista é o profissional que lida com Arquivo Histórico (permanente). Seguindo essa linha de raciocínio, infere-se que a Espanha, o arquivista se dedica principalmente aos cuidados dos fundos arquivistícos de Terceira Idade.

Em muitos países, no entanto, o Gerenciamento Eletrônico de Documentos (GED), o chamado Records management trata dos documentos em todo o seu ciclo de vida. O fundamento básico da gestão de documentos é a gestão do próprio conhecimento da Organização, dessa forma é possível preservar o patrimônio informativo e seu posterior resgate eletrônico, assegurando que a informação seja repassada quando o usuário assim o necessite. Pode-se definir o Gerenciamento de Registros como:

[...] campo da gestão responsável pelo eficiente e sistemático controle de criação, recepção, manutenção, utilização e disposição de registros, incluindo os processos de captação e manutenção de provas e informações sobre atividades empresariais e operações na forma de registros (ISO 15489, 2001).

Conforme essa mesma ISO, registros são informações criadas, recebidas e mantidas mediante profissionais da informação pelas organizações ou pessoas no cumprimento de suas obrigações legais ou mesmo na operação de negócios.

Os Registros, segundo o Conselho Internacional de Arquivos (ICA), Comissão de Electronic Records, são definidos como "uma informação gravada, produzida ou recebida no início ou na conclusão de uma atividade institucional ou individual, que compreende o conteúdo, o contexto e a estrutura suficientes para 
comprovar a atividade". Simplificando, um registro pode ser definido como "a evidência ou a prova de um acontecimento".

De acordo com Llansó Sanjuan (2006, p.41), o Conselho Internacional de Arquivos no Dicionário de Terminologia Arquivística (1984), além de definir os records management, define a "gestão de documentos, como a área de gestão administrativa responsável pela obtenção da economia bem como pela eficácia na criação, manutenção, utilização e disponibilização dos documentos. O autor afirma ainda que as Agências internacionais: Unesco e o Conselho Internacional de Arquivos, através de suas publicações que abordam a questão, contribuem para a generalização do conceito de "gestão de documentos" e divulgação do modelo Norte-Americano, demonstrando a liderança dos Estados Unidos nesta prática $^{33}$.

Conforme afirma esse mesmo autor ${ }^{34}$, desde 0 século XIX 0 desaparecimento do Arquivo Geral Central (que deixou o sistema sem Arquivo intermediário durante trinta anos), as mudanças bruscas de regime e as transformações administrativas (Lei de Procedimento Administrativo de 1958, por exemplo), as ocorrências políticas em 1931, de 1936-39 e em 1977, bem como o conceito historicista da profissão de arquivista são apontados como os principais causadores da acumulação de fundos que constitui um obstáculo para a definição de um modelo espanhol de gestão de documentos que corresponda a sua longa tradição de Arquivos administrativos e sua estrutura de rede. Esta situação tem incitado a violação das regras e prazos de transferências, em muitos casos, a falta de Arquivos Centrais em órgãos da Administração Central periférica, carência crônica de pessoal qualificado em Arquivos adminisrativos, falta de instalações adequadas e suficientes, falta de padronização e racionalização do processo administrativo.

\footnotetext{
${ }^{33} \mathrm{O}$ autor sugere consultar outra obra de sua própria autoria que se dedica especificamente ao tema de Gestão de documentos: Llansó, J. Gestión de documentos. Definición y análisis de modelos: Bergara: Departamento de Cultura del Gobierno Vasco, 1993.

${ }^{34}$ Id. Ibid, p.59-60.
} 


\subsection{FUNÇÃO ATUAL DOS ARQUIVOS PÚBLICOS}

O mundo dos arquivos está cheio de sutis diferenças e distintas realidades, mas existe uma tentativa, em nível globalizado, de estruturar de forma lógica essa dispersão de maneira a diminuir as situações que impedem o desenvolvimento do sistema de Arquivos. Um Sistema de Arquivos é uma estrutura ordenada, composta de determinados elementos destinada ao cumprimento de determinados fins e objetivos. Este conceito, no entanto, não é facilmente aplicado à realidade arquivística espanhola, uma vez que existem certas indefinições com relação a esses elementos, dada à enorme diversidade de modelos com estruturas e legislações próprias.

Além de servir para recolher, custodiar e preservar seus fundos documentais, a função atual dos arquivos públicos é dar projeção social à informação contida nesses fundos através da democratização dos mesmos pela difusão cultural e disponibilização máxima da informação. Nessa perspectiva, os Arquivos contribuem fortemente com disseminação da informação entre os pesquisadores, os cidadãos comuns e os historiadores, pois existe uma nova visão em relação à imagem dos Arquivos: o seu papel com relação à pesquisa histórica com função educativa, recebendo uma nova classe de usuário: o cidadão comum. Fato este que justifica a atual diversidade dos usuários dos Arquivos públicos, pois os mesmos podem estar à procura de documentos que comprovem seus direitos ou deveres, podem estar em busca de conhecimentos gerais ou históricos.

Se ha servido a la sociedad científica de manera aceptable, se ha justificado ante la sociedad la permanencia de los archivos y de los documentos como soporte de la investigación social, del conocimiento que la sociedad necesita para avanzar en su propio conocimiento y en la proyección de su desarrollo a partir de bases objetivas ${ }^{35}$. (VILLABUENA BAZÁN, 2000, p. 22).

Segundo Martínez Garcia (1999), os Arquivos seguem ocupando uma posição inferior dentro da Administração pública e se veem ameaçados pelas

\footnotetext{
${ }^{35}$ Os Arquivos e os documentos têm servido como suporte para a investigação social, do conhecimento que a sociedade necessita para que possa avançar no seu autoconhecimento e na projeção de seu desenvolvimento a partir de bases objetivas, justificando a importância de sua permanência para a sociedade. (Tradução nossa).
} 
mudanças ocorridas na sociedade atual, bem como perderam campo inclusive na pesquisa histórica, em virtude de as novas e mais modernas fontes históricas serem mais fáceis de usar e de interpretar. O autor afirma ainda que:

El Archivo también dejó de ser, hace tiempo, la única fuente de consulta para la busqueda de información, ante la proliferación de bases de datos y de redes de información que surgen a nuestro alrededor (MARTÍNEZ GARCIA, 1999, p.90). ${ }^{36}$

Em que pese o posicionamento do supracitado autor, os Arquivos devem caminhar ao lado da Administração Pública e se adaptarem às novas tecnologias, uma vez que representam o resgate das fontes informacionais, ao tempo em que mantêm o seu valor histórico, como também se apropriar desses recursos para que melhor atendam aos seus objetivos.

A missão dos Arquivos das Administrações consiste basicamente em organizar e gerenciar, coerentemente, a informação contida nos documentos, de maneira que se possam recuperar os dados de forma eficaz. Os conteúdos desses documentos são provas testemunhais e justificam os direitos e deveres dos cidadãos dentro do seu relacionamento com o Estado. As Instituições públicas guardam tais documentos para garantir o acesso aos interessados.

[...] los documentos, desde el mismo momento em que se generan, son patrimônio histórico; y como bienes culturales son fuente primaria para la investigación histórica y elementos utilizables en las actividades dirigidas a la difusión cultural (MARTíNEZ GARCIA, 1999, p.91) ${ }^{37}$.

A consulta aos Arquivos públicos espanhóis permite aos cidadãos adquirir informação necessária para que possam tanto conhecer seu próprio passado como também conhecer a identidade coletiva do seu povo.

Os arquivistas vêm refletindo sobre a nova realidade imposta pela sociedade da informação e o papel dos Arquivos neste processo. Segundo informa Martínez Garcia (1999, p. 96), muitos autores se dedicaram a escrever artigos sobre a legislação espanhola sobre Arquivos citando alguns que se

\footnotetext{
${ }^{36}$ O Arquivo também deixou de ser, há muito tempo, a única fonte de consulta para a busca de informação diante da proliferação de bases de dados e de redes de informação que surgem ao nosso redor. (Tradução nossa).

${ }^{37} \mathrm{~A}$ partir do momento em que são gerados, os documentos tornam-se patrimônio histórico e, como bens culturais, constituem fote primária para a investigação histórica, servindo de base para as atividades dirigidas à difusão cultural. (Tradução nossa).
} 
detiveram na legislação que afeta aos Arquivos em geral (Angel Sanchez Blanco, Araceli García Rodriguez entre outros). Tais autores dedicaram-se a escrever sobre a legislação de uma determinada comunidade em especial, a exemplo de Simó Rodríguez ${ }^{38}$.

Em relação às tentativas para definir o sistema espanhol de Arquivos, os autores ao estudar a legislação da Espanha em matéria de Arquivos, explicam ou tentam explicar, o que é um sistema arquivístico e do que ele se compõe, porém se limitam por fim ao seu caso particular sem conseguir definir o contexto geral:

\begin{abstract}
Las comunidades, em cumplimiento de su capacidad legal para desarrollar jurídicamente seus archivos, han utilizado profusamente leyes, decretos y ordenes fundamentados em enunciados legales entresacados de las leyes coordinadoras promulgadas por el Estado y, sin embargo, por cuestiones más relacionadas com intereses políticos que con critérios técnicos se han obstinado em crear estructuras independientes entre si. (MARTÍNEZ GARCIA 1999, p. 97).
\end{abstract}

Segundo Martínez Garcia (1999, p. 98), o Sistema arquivístico espanhol está estreitamente ligado à situação atual política em que se manisfestam opiniões heterogêneas sobre o modelo do Estado, o que reflete diretamente no mundo dos Arquivos e seus profissionais. Essa realidade arquivística está pautada na Constituição Espanhola de 1978 sobre o desenvolvimento estatutário das Comunidades Autônomas, que tentam, apesar da descentralização e do emaranhado de responsabilidades, interesses comuns e particulares, desenvolverem-se em interação com o Estado, uma vez que autonomia e descentralização são características marcantes na situação arquivística espanhola.

\title{
2.5 ADMINISTRAÇÃO ELETRÔNICA
}

Conforme Alvarez Garcia; González Seco; Velasco Suárez (2009, p. 29), antes de entrar em vigor a Lei 11 de 22 junho de 2007 de Administração

\footnotetext{
${ }^{38}$ Cf.Referência apresentada por Martínez Garcia (1999,p. 96): SIMÓ RODRÍGUEZ, Manuel. 12 años de Legislación atonômica em Andalucía: um balance. Actas Del VI Congreso Nacional de Archivos, Bibliotecas, Centros de Documentación y Museos en el estado de las autonomias (ANABAD), Murcia: Consejería de Cultura y Educación, 1996, p. 137-146).
} 
Eletrônica, as administrações, por meio de seus sites, esforçavam-se para grarantir a cidadania através da Internet. O objetivo da Lei era modernizar as administrações de maneira que o cidadão pudesse ter acesso aos diversos trâmites, disponibilizados na Web, de maneira confortável, a exemplo de consultar uma Lei ou até mesmo solicitar algum documento sem se deslocar. Aquele cidadão simples receptor de informação é substituído pelo cidadão interativo, acostumado a contactar várias empresas antes de adquirir bens e serviços.

Entre a difusão da informação e a possibilidade de gestão dessas informações por terceiros, com adaptações que viabilizasse o acesso em Rede, experimentou-se um grande avanço. Os profissionais da informação neste processo, corroborando os supracitados autores, são praticamente obrigados a participarem da gestão da informação desde o momento de sua criação até a conversão em formato "telemático", mais ainda, intervindo nos processos que decidem a forma e os meios através dos quais serão gerados.

Segundo Alvarez Garcia; González Seco; Velasco Suárez (2009, p. 33), para elevar o grau de satisfação do usuário em relação ao site, faz-se necessários certos procedimentos administrativos no que se refere aos objetivos para que se possam assegurar os direitos dos cidadãos no que diz respeito a sua integração à Administração Pública.

Embora os profissionais de Arquivo tenham responsabilidade como guardiães dos princípios da Arquivística e também com a custódia dos Arquivos antigos, bem como sua acessibilidade, atual e futura, o ciberespaço surge como um desafio, pois resguarda o conhecimento e a experiência que envolve as três idades dos Arquivos, portanto os Sistemas, com o passar dos anos, são construídos, reconstruídos e desenvolvidos. "A área digital é desafiante e demanda o conhecimento e a experiência abrangentes das três idades. Sistemas são construídos, reconstruídos e desenvolvidos todo o tempo" (CASTRO; CASTRO; GASPARIN, 2007, p.15).

Com relação à Usabilidade e Visibilidade (por meio da Difusão), o portal corporativo, conforme Alvarez Garcia; González Seco; Velasco Suárez (2009, p. 35) deve, sobretudo, viabilizar ao usuário o acesso a um grande volume de informação e facilitar a recuperação de informação através das TIC como veículo 
de acesso, ainda que o usuário tenha pouca experiência (Ver sobre Usabilidade e Visibilidade no Capítulo 4, seção 4.1.6).

Todos os usuários que acessam ao portal não possuem o mesmo perfil, tampouco têm necessidades idênticas de informações, por isso o site deve oferecer diferentes possibilidades de navegação para atender às suas expectativas.

Um bom exemplo desse esforço coletivo dos produtores de informação quanto ao atendimento satisfatório ao cidadão pode ser visto na administração do Principado de Astúrias que, segundo informam Alvarez Garcia; González Seco; Velasco Suárez (2009, p. 30), são gerenciados dentro de um mesmo serviço, o Serviço de Publicações, Arquivos administrativos e Documentação, o Boletim Oficial do Principado de Astúrias (BOPA) e os conteúdos do portal corporativo de Astúrias: Astúrias.es e o catálogo de serviços, que representa o único acesso aos serviços eletrônicos, o que significa que tem importância vital neste portal. Mesmo assim, vale pontuar que, em termos de administração eletrônica, seus catálogos de serviços se destacam em todos os rankings nacionais dos portais de Arquivos espanhóis ${ }^{39}$.

Cada vez se torna mais estreita a relação entre Arquivo e cidadão, pois com o advento da Internet e disseminação da informação o Arquivo ganha dimensões sociais e culturais infinitamente mais amplas do que na fase que o antecede. Neste crescimento informacional tanto as bibliotecas, centros de documentação e os arquivos são responsáveis pela recuperação e divulgação da informação.

Num mundo cada dia mais multidisciplinar, os documentos de Arquivo também exercem fundamental papel na recuperação e disseminação de informações e a Informática é a chave para o grande elo de comunicação com o usuário e o Arquivo.

Le Goff (2003), consciente da expansão da memória histórica, contribuiu para a reflexão sobre a revolução documental. Não haveria passado de intenções individuais isoladas de alguns historiadores, no que se refere ao tratamento

\footnotetext{
${ }^{39}$ Id. Ibid. (2009, p. 36)
} 
artesanal tradicional do documento, se não houvesse ocorrido quase que concomitantemente uma revolução tecnológica, com a aparição do computador.

Duranti (c. 1994 citado por BELLOTTO, 2004, p.299) faz lembrar que as tecnologias atuais elevaram consideravelmente a capacidade de gerar, reunir, examinar e utilizar uma diversidade de dados que viabilizem o acesso à informação já que permite um tratamento e disponibilização acelerados por meio de operações eletrônicas e mecânicas.

Pensar em documentos, nos dias atuais, não se trata apenas de visualizar o que se pode tocar, porém pode-se pesquisar muito mais documentos ao mesmo tempo uma vez que ultrapassou-se a limitação física. Atualmente os documentos ultrapassam apenas os registros em papel, abrangendo também as palavras, os gestos, como os registros dos arquivos orais, ou seja, o próprio processo de arquivar documentos foi revolucionado pelo computador (LE GOFF, 2003, p. 10).

Os Arquivos foram pouco a pouco se modernizando e aderindo às tecnologias modernas, bem como disponibilizando seus fundos através de suas páginas Web para adequar-se a um mundo globalizado cada vez mais exigente.

Las tecnologías de la información e Internet no sólo constituyen una herramienta para facilitar el trabajo de gestión de los archivos, sino que se han convertido en un elemento útil para el desarrollo de las sociedades y para dar a conocer los servicios y productos que ofrecen

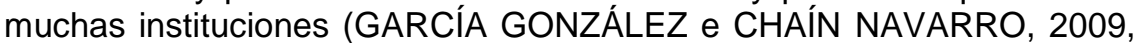
p.6) $)^{40}$

A maneira como disponibilizam as informações sobre Arquivo, além da qualidade dos bancos de dados virtuais, determina o quanto é relevante e útil esse papel de disseminador na "Era da Informática" e também pode levar à satisfação dos usuários haja vista a transparência das informacões.

Os meios automáticos, que começaram a ser associados ao tratamento da informação vieram revolucionar os processos até aí usados e fizeram surgir novas abordagens dos documentos, sobretudo dirigidas aos conteúdos informativos, já que a informação ganhou um estatuto de 'recurso' indissociável da investigação e do desenvolvimento (SILVA et al. 1999, 132 citado por MARIZ, 2005, p. 21).

\footnotetext{
${ }^{40}$ As tecnologias da informação e internet não apenas constituem uma ferramenta para facilitar o trabalho de gestão dos arquivos, mas também se converteram em um elemento útil para o desenvolvimento das sociedades e para divulgar os serviços e produtos que oferecem muitas instituições (Tradução nossa).
} 
O novo documento é armazenado e manejado nos bancos de dados. Ele exige uma nova erudição, que balbucia ainda e que deve responder simultaneamente às exigências do computador e à crítica da sua sempre crescente influência sobre a memória coletiva (LE GOFF, 2003, p. 53233).

O novo documento, ou "documento eletrônico" passa a revolucionar a informação e a modificar o cenário da sociedade.

A respeito da utilização da Internet como fonte de informação e como meio de comunicação, através do envio de dados de recursos de informação impressos por meio eletrônico, listas de discussão e treinamento do usuário por intermédio de prestadoras de serviços, consulta ao catálogo e reserva de livros através do site da instituição, corroborando Mariel Domínguez (2008), a vantagem dos serviços em rede consiste na disponibilização dos serviços a qualquer momento evitando o deslocamento do usuário à instituição e a desvantagem é a perda do contato humano. No entanto, para se adaptar às exigências da Sociedade da informação faz-se necessária, cada vez mais, uma mudança na postura dos usuários e dos profissionais da informação para se adaptar a essa realidade.

\begin{abstract}
Según señalan diversos autores, esa tradición larga y estable en el diseño de una red se adelanta casi en un siglo a las formulaciones de la archivística internacional en lo que se refiere a la teoría de las tres edades de los documentos: la creación del Archivo General Central de Alcalá de Henares en 1858 supuso la aparición del primer archivo intermedio de la historia ${ }^{41}$ (LLANSÓ SANJUAN 2006, p. 59).
\end{abstract}

É importante salientar, porém, que a rapidez com que a Internet circula as informações e as torna conhecidas, da mesma forma, essas informações podem também ser modificadas e consequentemente se tornam desatualizadas.

No caso dos arquivos, não se deve assumir que a Internet se converteu em uma nova via de acesso e uma nova frente de trabalho, que se soma e complementa o acesso tradicional (GARCÍA GONZÁLEZ; CHAÍN NAVARRO, 2009, p.6). Nada se compara ao prazer de tomar nas mãos um documento para leitura e análise, e por esse motivo, alguns autores se dedicam atualmente a

\footnotetext{
${ }^{41}$ Segundo salientam vários autores, a longa e estável tradição na concepção de uma rede está quase um século à frente das formulações da arquivística internacional em relação à teoria das três idades dos documentos: a criação do Arquivo Geral de Alcalá de Henares, em 1858, marcou a aparição do primeiro Arquivo intermediário da história (Tradução nossa).
} 
estudar até que ponto a Internet e os documentos online podem substituir os livros e os documentos em papel. Entende-se que essa questão é muito mais ampla e pode gerar ainda muitas discussões e controvérsias, no entanto, o fato é que, muitas vezes, o fator delimitador físico ou financeiro é minimizado com a Internet, já que se pode consultar um documento de outro país, por exemplo, sem o desconforto do descolamento, gerando economia de tempo e dinheiro.

Ainda que a Internet amplie seu raio de ação, seu âmbito natural de influência atualmente está num setor delimitado de usuários.

Devido à tremenda variedade de situações que podemos encontrar, tornase condição necessária saber interpretar e adaptar as pautas de atuação à realidade de cada arquivo. Se tivéssemos que escolher um marco ideal, seria o de um arquivo onde encontremos o melhor equilíbrio entre volume de gestão e recursos (CERDÁ DÍAZ, 2008 citado por GARCÍA GONZÁLEZ; CHAÍN NAVARRO, 2009, p. 6).

\begin{abstract}
O objetivo último da organização de um conjunto documental arquivístico é permitir o acesso às informações contidas nos documentos. Para que os arquivos ou as informações arquivísticas sejam acessíveis é preciso existir instrumentos que permitam esse acesso. Na perspectiva do arquivista, isto é, no que depende diretamente de seu trabalho profissional, é no que depende diretamente de seu trabalho profissional, é no acesso intelectual e físico que se concentra sua intervenção. Isso porque, embora ele deva estimular e ser parte atuante na proposição de políticas nacionais de arquivo, incluindo questões de acesso, não é de sua responsabilidade direta a elaboração de leis (RODRIGUES, 2003, p. 227). ${ }^{42}$
\end{abstract}

O acesso aos documentos deve ser a premissa primordial de toda e qualquer instituição arquivística tendo em conta que o papel de disseminação não tem valor secundário e sim, primário. Esse acesso deve dar-se de forma menos burocrática e mais democrática possível, por conta disso, a maioria dos Arquivos busca alternativas para modernizar-se e integrar-se às novas tecnologias.

Um aspecto fundamental dentro da estratégia da Comissão de Novas Tecnologias, são as ações destinadas a modernizar a administração, que exigem uma adaptação das entidades locais para a utilização das TICs e para a

\footnotetext{
${ }^{42}$ Também citado por Mariz (2005, p. 36), a autora faz referência a esta citação como uma síntese representativa do que se encontra na literatura da área.
} 
prestação de serviços tanto para a Administração Pública, como para os cidadãos e empresas, devendo o Governo Local estar atento ao novo quadro legislativo (BECANA SANAHUJA, 2008, p.65).

No caso específico da Catalunha e da Espanha em geral, onde a situação é mais precária do que em outros países ocidentais, devem ser acrescentadas às causas deste atraso o baixo grau de organização de seus arquivos. Não se pode prever como será a informatização dos serviços de um Arquivo, se eles não estão regulados e se os fundos documentais não estiverem classificados e inventariados. Como disse Ramon Alberch (1993, citado por PERPINYÀ MORERA, p. 113), esta situação precária é um resultado direto da política de negligência da época de Franco no que se refere aos arquivos. Segundo esse mesmo autor, tardou vinte anos, desde o advento da democracia, para que se começasse a corrigir esta situação, pois somente após a aprovação das leis de Arquivos, criação de serviços de arquivos para o governo Catalão, a formação específica dos profissionais, a criação de uma associação profissional de arquivistas e de acesso aos principais serviços profissionais de arquivos começaram a pintar uma perspectiva mais otimista desse quadro.

Muitos Arquivos, além dos históricos, decidiram fazer-se conhecer através da Internet e por esta etapa se produziu, entre outros motivos, pela necessidade de satisfazer as necessidades de informação dos usuários (GONZÁLEZ; NAVARRO, 2009, p. 6).

\begin{abstract}
Os usuários de arquivo são muito diversificados e no que se refere às instituições arquivísticas públicas, "o usuário de um arquivo público é, sem sombra de dúvida, dos mais heterogêneos, ou seja, qualquer um de nós (GUIMARÃES; SILVA, 1996, p. 83 citado por MARIZ, 2005, p. 37).
\end{abstract}

À medida que a Internet vai crescendo, será mais e mais necessário para os profissionais da documentação dispor de critérios sólidos para saber avaliar recursos digitais e determinar seu valor ou sua capacidade relativa para cumprir seus objetivos (CODINA, 2000, p. 12). Essa providência refletirá diretamente nos usuários que se beneficiarão com esses recursos digitais.

Embora a maioria dos Arquivos já possua página Web, ainda se observa a necessidade de ampliar as informações arquivísticas na Internet. A respeito do 
caráter único que tem os documentos de Arquivo e a atuação dos mesmos, discorre-se:

\begin{abstract}
Através dos milênios, os arquivos têm representado, alternada e cumulativamente, os arsenais da administração, do direito, da história, da cultura e da informação. A razão pela qual eles puderam servir a tantas finalidades é que os materiais arquivísticos, ou registros documentais representam um tipo de conhecimento único: gerados ou recebidos no curso das atividades pessoais ou institucionais, como seus instrumentos e subprodutos, os registros documentais são as provas primordiais para as suposições ou conclusões relativas a essas atividades e às situações que elas contribuíram para criar, eliminar, manter ou modificar. A partir destas provas, as intenções, ações, transações e fatos podem ser comparados, analisados e avaliados, e seu sentido histórico pode ser estabelecido. Essa capacidade dos registros documentais de capturar os fatos, suas causas e conseqüências, e de preservar e estender no tempo a memória e a evidência desses fatos, deriva da relação espacial entre os documentos e a atividade da qual eles resultam... (DURANTI, 1994, p. 50 citada por MARIZ, 2005, p. 18).
\end{abstract}

Infere-se, a partir disso, que os Arquivos estão presentes em todos os setores da vida dos cidadãos, sejam eles fruto das suas atividades pessoais ou das atividades da Administração da qual fazem parte, essa capacidade informativa dos Arquivos garante a preservação da memória no tempo e no espaço.

\title{
2.6 TRANSPARÊNCIA, QUALIDADE INFORMATIVA E LEGISLAÇÃO
}

No mundo contemporâneo globalizado, a informação é tema de variados debates no âmbito econômico, social, político, cultural e, obviamente, científico e tecnológico.

Informações estratégicas distinguem os países, os centros de pesquisa e de formação. Corroborando Jardim (2001, p.1), os detentores das novas tecnologias têm vantagem sobre os demais que delas se distanciam, estando estes últimos propensos a serem excluídos da Sociedade da Informação. Essa situação configura um exorbitante quadro de desigualdade social, haja vista a necessidade de se compartilhar informação em prol do bem comum. $O$ autor informa ainda que, segundo o relatório da ONU, divulgado em 2000, especialistas de 17 países do mundo confirmam que 276 milhões de pessoas, ou seja, um 
quantitativo inferior a $5 \%$ da população global, utilizam a rede mundial de informação (Internet). Somente para situar os países de destaque, na utilização da internet, cita-se: a Alemanha, Reino Unido, Itália, França, Holanda, Espanha, Canadá e Estados Unidos, os quais concentram mais de $89 \%$ de internautas do mundo.

Passada uma década do referido relatório, o quantitativo cresceu para sete milhões de usuários no mundo inteiro, mesmo assim, há uma enorme quantidade de países aquém dessa prática. Conforme estudo divulgado pela ITU International Telecommunication Union $(2010)^{43}$, a expectativa para o uso de Internet até o final do ano de 2010 era de dois bilhões, prevendo que $76 \%$ da população dos países de primeiro mundo estariam conectados. Tais dados podem ser visualizados na figura a seguir:

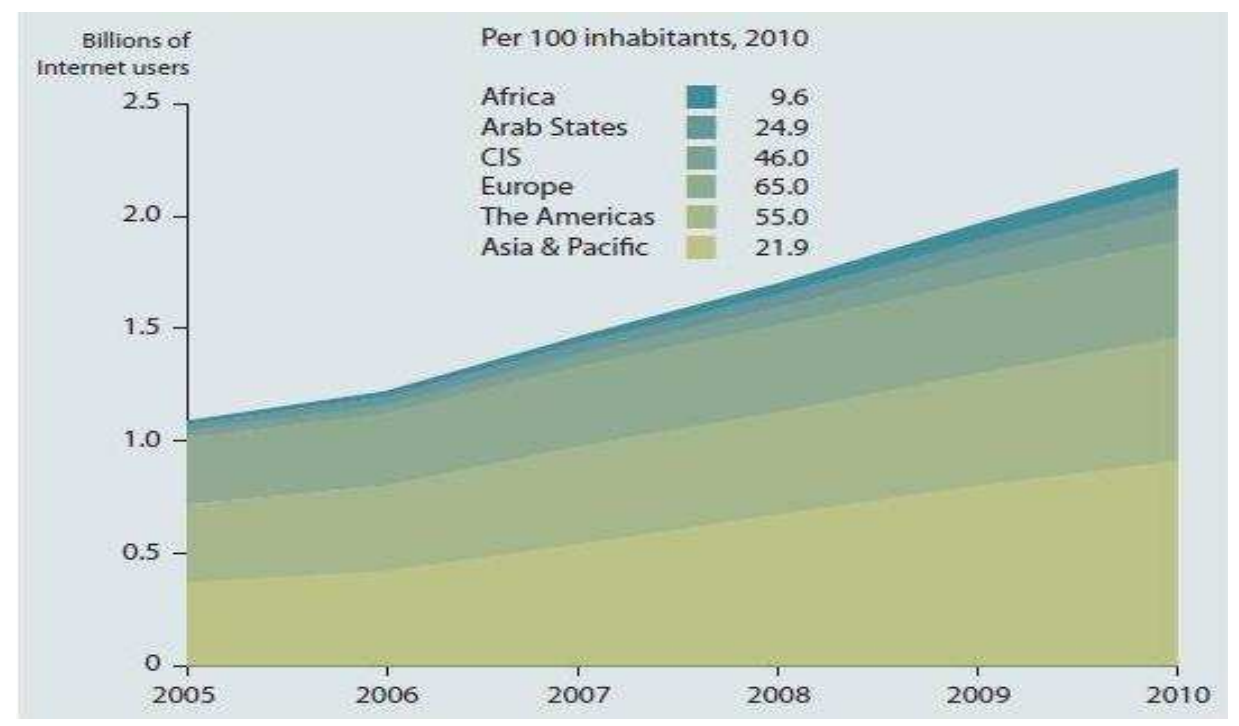

Figura 3 - Expectativa de uso da Internet em 2010.

Fonte: The world in 2010: ICT Facts and figures - 20/10/2010 (p.4)

Como se pode observar, $65 \%$ dos europeus utilizam a internet, contra $9,6 \%$ dos africanos, donde se pode inferir que a exclusão digital ainda é uma realidade concreta.

Dentro do novo contexto da Sociedade da Informação, os governos têm grande responsabilidade no que se refere à transparência da informação, além de

\footnotetext{
${ }^{43}$ União Internacional de Telecomunicação (Tradução nossa).
} 
serem responsáveis pelo crescimento da economia e pelas melhorias sociais, aspectos estes, que dizem respeito a todo e qualquer cidadão. Portanto, os cidadãos do mundo globalizado exigem das administrações uma postura de trabalho transparente que demonstre a eficácia e eficiência de seus atos.

\begin{abstract}
La información del sector público implica también un nuevo modelo de comunicación con los ciudadanos en tanto que se adentra en la transparência de las propias instituciones, y en este sentido no hay que olvidar que estos avances se observan ya en Europa desde el propio Tratado de Maastricht (1992) o el Tratado de Amsterdam, 1997 (MUÑOZ-CAÑAVATE, 2009, p..475-476). ${ }^{44}$
\end{abstract}

Para garantir essa transparência, surgiu a ideia de "governo eletrônico" (Egov) em Washington, 1999, quando Al Gore, vice-presidente dos EUA, abriu o Fórum Global sobre Reinvenção do Governo. De acordo com Agner (2010? p.1-2) Essa ideia objetivava informar serviços e produtos dos órgãos públicos por meio eletrônico e isso seria possível em todo tempo e em qualquer local e para ser usado por qualquer pessoa, viabilizando assim o processo de inclusão digital.

Somando-se aos esforços do Governo Eletrônico, portanto, o advento da Internet veio a garantir a possibilidade de concretizar essa transparência informativa, uma vez que qualquer cidadão passou a ter acesso às informações produzidas pelos órgãos do governo, de maneira rápida e democrática.

Os sites do Governo são os responsáveis por garantir essa transparência aos cidadãos, dessa forma, quando existem problemas em sua criação ou execução, pode afetar aos usuários, gerando problemas de exclusão, uma vez que a informação disponibilizada pode não ser acessada, fato este que vai de encontro à proposta do governo eletrônico. Portanto faz-se necessário um bom planejamento para a construção e manutenção desses sites.

Segundo Muñoz-Cañavate (2009, p. 476), na década de 1990, a Comissão Europeia elaborou o documento conhecido como "o Livro Verde da informação no setor público", sob o título $A$ informação do setor público: um recurso fundamental para a Europa, publicado em 1998. Nesse documento é ressaltada a

\footnotetext{
${ }^{44}$ A informação do setor público envolve também um novo modelo de comunicação com os cidadãos uma vez que entra na transparência das próprias Instituições, e nesse sentido não se deve esquecer que estes progressos já são visíveis na Europa desde o próprio Tratato de Maastricht (1992) e do Tratado de Amsterdam, 1997. (Tradução nossa)
} 
relevância da informação para a livre circulação de mercadorias e pessoas. 0 documento afirma ainda que:

\begin{abstract}
la información pública en Europa se encuentra fragmentada y dispersa, de tal forma que de lo que se trata no es de que los Estados miembros produzcan más información, sino de que la información que ya está disponible para el público sea más clara y accesible a sus usuarios potenciales ${ }^{45}$
\end{abstract}

Essa afirmação incorre diretamente na transparência administrativa que não somente justifica as atividades da instituição como garante o direito à informação a todos os cidadãos.

No entanto, parece ser uma opinião generalizada, na percepção de PERPINYÀ MORERA (1997), que os Arquivos estejam muito lentos na aplicação das novas tecnologias e muitos autores analisaram quais são as causas desse atraso nas práticas arquivísticas: O'Nell salientou que, em 1996, um artigo sobre a automação de instrumentos de descrição apresentou como causa o custo para essa inovação somado aos limitados recursos econômicos disponíveis nos Arquivos, bem como o reconhecimento pelos arquivistas dos problemas que envolvem a disponibilização de Arquivos em rede, apontando a própria natureza dos fundos arquivísticos. Outros autores, a exemplo de Cruz (1994) atribuem a responsabilidade sobre o tema ao espírito conservador dos arquivistas, somado aos limitados recursos disponíveis (baixo grau de padronização e pouca consideração dos Arquivos como base de recursos de informação) bem como a baixa pressão dos usuários tradicionais, já que os usuários reais de Arquivo normalmente não têm uma visão desses centros associada à tecnologia.

Em relação à temida exclusão digital, vale dizer que não se trata apenas da chegada ou não da tecnologia, mas é importante esclarecer que a exclusão se produz em outros aspectos tais como o nível econômico e cultural. Assim, "es

\footnotetext{
${ }^{45}$ Idem. A informação pública na Europa estava fragmentada e dispersa, de modo que a questão não é que os Estados-Membros devam produzir mais informações, mas que as informações que já estejam disponíveis para o público sejam mais claras e acessíveis a seus usuários potenciais (Tradução nossa).
} 
necesario velar porque esta formación llegue a todos los sectores de población"46BECANA SANAHUJA (2008, p. 52).

\begin{abstract}
Essa nova sociedade, conhecida como Sociedade da Informação, trouxe as tecnologias da informação e comunicação (TIC), as quais vieram a atender a necessidade de se acessar o grande número de informações circulantes no mundo. Um dos fatores cruciais para obtenção do sucesso na sociedade da informação é o acesso e utilização das TIC, é indispensável que elas estejam disponíveis ao maior número de pessoas possível contribuindo assim para o combate a exclusão digital e conseqüentemente a social. (RODRIGUES; BECHER, 2009, p.2).
\end{abstract}

Cabe às bibliotecas e aos Arquivos públicos trabalhar em prol da inclusão digital, pois é uma forma de contribuir com a Sociedade da Informação, auxiliando os usuários a encontrar, selecionar e melhor utilizar às informações disponíveis em rede.

Segundo Ocaña Lacal (2007), em se tratando de arquivos, a legislação espanhola, a partir da Constituição de 1978, deixa a desejar, em termos de escassez e deficiência conceitual com limitada visão cultural. Ele afirma que "a promulgação da Constituição de 1978 representou um novo modelo de Estado e, portanto, um novo quadro para os arquivos espanhóis" e, como ocorre em todos os âmbitos administrativos, existem problemas conceituais e estruturais em virtude da realidade anterior.

López Gómez (2008, p.5), por sua vêz, ressalta que importantes fatores provocaram um enorme avanço na Arquivística espanhola a partir dos anos 1980, após a promulgação da Constituição de 1978 e o consequente desenvolvimento da Legislação, uma vez que a mudança da estrutura administrativa do país, que o dividiu em regiões autônomas, resultou na proliferação de Arquivos, redes, sistemas e subsistemas arquivísticos e, consequentemente, no rápido aumento dos profissionais da área e suas associações que, por sua vez, passaram a gerar suas próprias revistas e boletins informativos.

Soma-se a isso, a incorporação dos profissionais às tendências modernas do âmbito anglo-saxão, especialmente dos EUA, e mais recentemente do Canadá e da Austrália, a saber: Cox (2005); Ellis (1993); O' Toole (2006); Rousseau e Couture (2003), além do uso indiscriminado de princípios e técnicas de

\footnotetext{
${ }^{46}$ É necessário garantir que esta formação chegue a todos os setores da população (Tradução nossa).
} 
arquivamento, em especial o da procedência, a introdução de normas de utilização comum a toda a comunidade arquivística, afinadas com as recomendações internacionais e a introdução de novas tecnologias, que inserem os Arquivos na sociedade da informação (LOPEZ GOMEZ, 2008, p.5-6).

Os avanços em matéria arquivística, na Espanha, segundo Ocaña Lacal (2007), levaram à aparição de novas normas como consequência do desenvolvimento da administração eletrônica, que é a nova realidade dos arquivos e seus profissionais.

Segundo afirma Becana Sanahuja (2009), desde 2007, com a entrada em vigor da lei de Acesso Eletrônico dos Cidadãos aos Serviços Públicos, a Administração de Huesca teve que redefinir suas metas e programas digitais para atender a essa nova exigência da legislação, momento este em que o Arquivo passou a desempenhar um importante papel no que se refere à catalogação, normalização e adaptação dos procedimentos e definição de estruturas de dados necessárias para garantir a integridade, guarda e recuperação dos documentos eletrônicos gerados. Dessa forma, pode-se supor que, a partir de então, as administrações espanholas tiveram que passar por processo semelhante até se adaptar às novas tecnologias.

De acordo com Perpinyà Morera (1997, p. 113), até o ano de 1990 não havia um plano abrangente para a automação de Arquivos quando Assumpció Colomer realizou um trabalho de Investigação no I Mestrado de Arquivística da Catalunha sobre o grau e o tipo de informatização dos arquivos catalães. Segundo os resultados desta pesquisa, na Catalunha, não havia um projeto global para os Arquivos e apenas três arquivos, Arxiu Municipal de Figueres, Arxiu Provincial de l'Escola Pia de Barcelona i Arxiu de la Diputació de Girona (Arquivo Municipal de Figueres, Arquivo Provincial da Escola Pia de Barcelona e Arquivo Provincial de Girona) realizavam algumas tarefas de Sistemas de Gestão Documental de Arquivos. A mesma pesquisa também fornece dados a partir de duas experiências de informatização de registros de Arquivos: Arxiu Municipal de Salt e Arxiu Municipal de Mataró. (Arquivo Municipal e Arquivo Municipal, em Salt Mataró). O autor afirma ainda que, em 1996, apesar de o quadro ainda ser precário foram criados projetos de informatização. 
Os ciberusuários, de acordo com Hassan Montero (2002), ao ler uma página Web, não seguem a mesma sequência da leitura tradicional em papel, pois eles têm metas a cumprir enão desejam desperdiçar tempo para atingir seus objetivos, isto faz com que eles ao visitar um site, não tomem conhecimento de todo seu conteúdo ou links.

Complementando a afirmação anterior, pode-se dizer que não é possível prever qual será o caminho que o usuário usará durante a varredura visual da página, mas se pode prever as áreas que mais chamam a sua atenção durante suas pesquisas on-line.

Nos sites, existe uma hierarquia visual em que o ciberusuário pode identificar com maior clareza a informação que deseja, segundo Hassan Montero (2002), existem áreas da interface da página que dão maior status para as informações, bem como elementos de relação hierárquica que estabelem relações entre os conteúdos.

El problema es que el usuario en la Web no es único ni uniforme. Cada usuario que visite el sitio Web tendrá necesidades, expectativas y comportamientos diferentes, por lo que el diseño de la información debe realizarse para satisfacer al mayor número de usuarios posibles. (HASSAN MONTERO, 2002). ${ }^{47}$

Devido a essa diversidade de usuários, a preocupação com a satisfação de suas expectativas engloba também a questão da acessibilidade e as deficiências que os mesmos podem ter tanto no que se refere a limitações físicas quanto de outra ordem.

Essas diferenças próprias da diversidade humana compõem o objeto de estudo da Ergonomia, uma vez que, "Ergonomia é um corpo de conhecimentos sobre as habilidades humanas, limitações humanas e outras características humanas que são relevantes para o design" (CHAPANIS citado por BINS ELY et al., 2006, p.2).

Esses autores classificam quatro categorias de Restrições das limitações dos usuários, segundo a percepção, a compreensão e a ação do indivíduo no

\footnotetext{
${ }^{47}$ O problema é que o usuário da Web não é único nem uniforme. Cada usuário do site terá necessidades, expectativas e comportamentos diferentes, de modo que o design da informação deve ser feito para satisfazer o maior número possível de usuários. (Tradução nossa).
} 
ambiente que podem auxiliar a direcionar os projetos de interface às necessidades dos usuários, como se pode observar no quadro a seguir:

\begin{tabular}{|l|l|}
\hline \multicolumn{1}{|c|}{ CATEGORIAS DE RESTRIÇÕES } & \multicolumn{1}{|c|}{ CARACTERÍSTICAS } \\
\hline Restrição sensorial & $\begin{array}{l}\text { Dizem respeito às dificuldades na percepção das } \\
\text { informações do meio ambiente devido a } \\
\text { limitações nos sistemas sensoriais (auditivo,visual, } \\
\text { paladar/olfato, háptico e orientação) }\end{array}$ \\
\hline Restrição psico-cognitiva & $\begin{array}{l}\text { Referem-se às dificuldades no tratamento das } \\
\text { informações recebidas ou na sua comunicação } \\
\text { através da produção lingüística devido a limitações } \\
\text { no sistema cognitivo (aprendizado). }\end{array}$ \\
\hline Restrição físico-motora & $\begin{array}{l}\text { Trata-se do impedimento ou dificuldades } \\
\text { encontradas em relação ao desenvolvimento de } \\
\text { atividades que dependam de força física, } \\
\text { coordenação motora, precisão ou mobilidade. }\end{array}$ \\
\hline Restrições Múltiplas & $\begin{array}{l}\text { Diz respeito à associação de mais de um tipo de } \\
\text { restrição de natureza diversa. }\end{array}$ \\
\hline
\end{tabular}

Quadro 2 - Limitações dos usuários.

Fonte: Informações contidas em: Bins Ely et al (2006)

Dessa maneira percebe-se que a acessibilidade está diretamente relacionada com a prática da inclusão, que corresponde à condição de igualdade e a possibilidade de participação de todos sem discriminação, eliminando quaisquer barreiras existentes.

No que diz respeito ao acesso aos documentos de Arquivos, a Legislação espanhola afeta direta ou indiretamente esse processo, portanto expõe-se o tema mais detidamente a seguir.

\subsubsection{Legislação que afeta os Arquivos da Espanha}

A necessidade de conservar documentos originais, que conferem crédito às resoluções dos representantes do poder, vem desde a época feudal (séculos XI e XII), quando se definia a formação dos municípios e seus órgãos de governo, com eleição de seus próprios representantes. As leis de acesso à informação 
existem em quase todos os países do mundo e visam garantir a transparência Administrativa das Administrações.

Quando se configura um novo Estado, no século XIX e a partir da queda do Antigo Regime, surge o interesse pela história nacional. Para atender ao Estado Liberal, carente de fontes documentais, os documentos municipais passam a ser foco de interesse. Mediante o Real Decreto 553/2004, de 17 de abril, foi criado o Ministério de Cultura, e, em 4 de julho de 2008, foi desenvolvida a sua estrutura básica através do Real Decreto 1132/2008, tendo sido estabelecida as funções e competências de seus núcleos de direção.

Entre as funções que correspondem à Direção Geral do Livro, Arquivos e Bibliotecas se encontram a de promover a conservação do patrimônio documental e sua disseminação nacional e internacionalmente.

Além das leis anteriormente citadas, o Ministério de Cultura criou em 2005, o Real Decreto 760/2005, de 24 de junho, através do qual cria o "Patronato del Archivo General de Indias."

A Ordem CUL/3150/2008, de 29 de outubro, publicada no Boletim Oficial do Estado de 5 de novembro de 2008, altera a Ordem CUL/4411/2004, de 29 de dezembro, publicada no Boletim Oficial do Estado de 8 de janeiro de 2005, que fixa as bases que controlam as subvenções públicas do Ministério de Cultura, através de concorrência competitiva.

Conforme o previsto no ponto terceiro, apartado 2 , da citada ordem e amparado no disposto no artigo 149, parágrafo 1.28 e no artigo 149, parágrafo 2 da Constituição Espanhola (Cf. Anexo 2), o Estado considera o serviço da cultura como dever e atribuição essencial e facilita a comunicação cultural entre as Comunidades Autônomas.

No final do século $X I X$ e princípios do século $X X$, há um crescimento cultural dos municípios e regiões da Espanha. Nessa nova conjuntura, há adaptação das cidades à nova realidade de seus serviços de arquivos.

O direito de acesso dos cidadãos aos documentos é garantido pelo artigo 105 b da Constituição espanhola de 1978 (Cf. Anexo 3), pela lei 30/1992 de 26 de novembro, de regime jurídico das administrações públicas e do procedimento administrativo comum e, finalmente pela lei 10/2001, de 13 de julho, de arquivos e 
documentos. Dessa forma, todas as pessoas podem ter acesso a qualquer documento da administração pública, desde que não tenha limitação legal devidamente justificada. Ocaña Lacal (1999, p.174) reflete a respeito do artigo 37 dessa Lei, sugerindo que os arquivistas, por meio das Associações, impusessem o papel de "defendores do direito à informação" aos cidadãos.

Las Administraciones Públicas no se han caracterizado hasta la fecha, en términos generales y salvo contadas excepciones, por su interés ni por su acierto en establecer Sistemas Archivísticos coherentes y eficaces que permitiesen ejercer un efectivo control sobre la documentación producida o reunida en el ejercicio de sus actividades con vistas al cumplimiento de las funciones de sus archivos: apoyo activo a la gestión de las Administraciones, información al ciudadano y ejercício de la acción cultural y de la conservación del Patrimônio Documental en beneficio de las generaciones futuras. (OCAÑA LACAL, 1999, p. 199) ${ }^{48}$

A Administração eletrônica envolve a utilização das TIC para a prestação de serviços à Administração Pública, às empresas e, sobretudo, aos cidadãos. Todas as ações destinadas a modernizar a Administração e informatizar os processos internos do governo, segundo Becana Sanahuja (2008, p. 65), exigem que o governo local esteja atento ao quadro legislativo.

Esse mesmo autor faz referência à Lei Lei 56/2007, de 23 de dezembro, de Medidas de Impulso à Sociedade da Informação: critérios de acessibilidade nos portais das Administrações Públicas que indiretamente afeta aos Arquivos.

$\mathrm{Na}$ Espanha, o acesso aos arquivos sempre esteve atrelado ao contexto político desde o século XIX, segundo Ocaña Lacal (1999, p. 175), porém, a promulgação da Constituição de 1978 veio a garantir a democratização desses centros.

La promulgación de la Constitución de 1978 supuso la consideración explícita del derecho de acceso a los documentos administrativos como medio para la democratización de las Administraciones Públicas. ${ }^{49}$

\footnotetext{
${ }^{48}$ Em termos gerais, as Administrações Públicas não se caracterizam, até o presente momento, com raras exceções, por seu interesse ou por seu sucesso em estabelecer a coerência e a eficácia dos sistemas de arquivo que permitam exercer um controloe efetivo sobre os documentos produzidos ou recolhidos no decurso das suas atividades com vistas a cumprir as funções de seus arquivos: apoio ativo à gestão das Administrações, informação aos cidadãos e exercício da ação cultural e preservação do patrimônio documental para benefício das gerações futuras. (Tradução nossa).

${ }^{49}$ A promulgação da Constituição de 1978 presumiu a consideração explícita do direito de acesso aos documentos administrativos, como forma de democratizar as Administrações Públicas.(Tradução nossa).
} 
A Constituição espanhola garante garante o direito de acesso à cultura, portanto qualquer cidadão, a qualquer momento, pode, despertar algum interesse legítimo pelos documentos de arquivo. Complementando esta afirmação, Ocaña Lacal (1999, p.182), relembra que o artigo 20 da Constituição espanhola consagra o direito de todos os cidadãos à informação,e este constitui um direito fundamental e inclui, por sua vez, o direito de acessar os documentos de arquivo.

Além da Constituição, existem ainda várias ações que visam aproximar os serviços públicos da sociedade da informação, entre os quais, pode-se destacar:

1. O Plano de Ação "eEuropa" $(2005)^{50}$, cujo objetivo é estimular o desenvolvimento dos serviços de Internet, e a utilização de técnicas modernas e ágeis;

2. Uma iniciativa europeia $(2010)^{51}$, para gerar crescimento e emprego, com o propósito de coordenar a ação dos Estados-membros para facilitar a concentração das iniciativas digitais diante dos desafios impostos pela Sociedade da Informação;

3. O plano nacional $\operatorname{AVANZA}^{52}$ para a utilização adequada das TIC potencializando o crescimento econômico e garantindo aos cidadãos 0 direito de acesso às informações digitais com o fim de promover a igualdade social e regional e melhorar o bem-estar e qualidade de vida dos cidadãos.

Ocaña Lacal (2007), por sua vez, analisa a legislação que regula a Administração eletrônica e o direito de acesso aos documentos de arquivo e faz um balanço da situação, citando as seguintes leis e decretos:

1. Lei de 9 de setembro de 1857 , de instrução pública, Seção segunda, Título IV, colocada em prática pelo Decreto de 8 de maio de 1858, que ditam normas para a organização do arquivos e Bibliotecas do Reino;

\footnotetext{
${ }^{50}$ Mais informações sobre o Plano no site: http://europa.eu/scadplus/leg/es/lvb/l24226.htm.

${ }^{51}$ Mais informações no site:: http://europa.eu/scadplus/leg/es/cha/c11328.htm.

${ }^{52}$ Mais informações sobre o Plano no site: http://www.planavanza.es/AvanzaLocal
} 
2. Real Decreto de 21 de novembro de 1901 que aprova "o regulamento para a administração dos arquivos do Estado servidos pelo Corpo Facultativo de Arquivistas, bibliotecários e Arqueólogos;

3. Decreto de 24 de julho de 1947 sobre ordenação dos arquivos e Bibliotecas do Tesouro histórico-documental e bibliográfico;

4. Lei de 17 de julho de 1958 de Procedimento Administrativo (Padronização e racionalização dos ministérios);

5. Decreto de 8 de maio de 1969 que cria o Arquivo Geral da Administração Civil do Estado;

6. Lei de 30 de junho de 1984 que passava a cargo do Corpo facultativo de Arquivistas (criado pela lei anterior) além dos Arquivos Históricos, os dos mais diferentes ministérios, menos os militares;

7. Lei 11 de 22 de junho de 2007 , de acesso eletrônico dos cidadãos e servidores públicos cujo objetivo é "Facilitar o acesso por meios eletrônicos dos cidadãos à informação e ao procedimento administrativo, com especial atenção à eliminação das barreiras que limitem este acesso."

Mais adiante, em outra obra, o supracitado autor ainda faz referência a diversos outros trabalhos relacionados à caracterização e funcionamento das Administrações Públicas, condenando a reduzida participação dos arquivistas em relação aos trabalhos na área de legislação que, direta ou indiretamente, afeta os Arquivos. Neste sentido, cita alguns trabalhos realizados por arquivistas a respeito do acesso aos documentos desde a aprovação da constituição de 1978 da Espanha (OCAÑA LACAL, 1999, p. 174):

- P. Serra Navarro: Los Archivos y El acceso a La documentación, Madrid, Ministério de Cultura, 1980

- M. C. Sáez Lorenzo: El derecho de acceso de los ciudadanos a los documentos administrativos, Madrid , 1982

- J. R. Cruz Mundet: El Derecho de acceso a La documentación pública em Biduma, n. 2 (1988), p. 107-120 
- A. García Rodriguez. A Realidad y El deseo em El acceso a los archivos de gestión: referencia a La situación andaluza, Carmona, 1989.

- Textos e Comunicações publicadas em Lligal: Revista Catalana d'arxivistica, números 3 e 4, 1991 durante as III Jornadas de Arquivística de Catalunha, organizada pela AAC, bem como as que aparecem nas Atas do $\checkmark$ Congresso Nacional de ANABAD, celebrado em Zaragoza, também em 1991, e que foram publicados no Boletim da ANABAD XLI (1991), número 3-4, jul./dic..

Entre os textos e artigos que constituem fontes de informação sobre a situação da Espanha, em termos de acesso à informação, de acordo com a Asociación Española de Documentación e Información - SEDIC (2009), p.4 $4^{53}$ destacam-se:

1 - Sustentia \& Open Society Justice Initiative. Transparencia y silencio. Estudio sobre el acceso a la información en España. Madrid, octubre de 2005

2.- MORAGA, Eva. Parámetros internacionales en el derecho de acceso: la legislación española frente al resto de legislaciones europeas. I Jornadas de la AEFP sobre Acceso a documentos públicos. Madrid, marzo 2009.

3.- FERNÁNDEZ RAMOS, Severiano. El acceso a los documentos públicos en la legislación española. I Jornadas de la AEFP sobre Acceso a documentos públicos. Madrid, marzo 2009.

4.- GÓMEZ-LLERA GARCIA-NAVA, Eduardo. El problema del acceso a la documentación en los archivos históricos. I Jornadas de la AEFP sobre Acceso a documentos públicos. Madrid, marzo 2009.

5.- MONCAYOLA MARTín, Ana. Derecho de acceso a los archivos y derecho a la intimidad tras la Constitución de 1978. I Jornadas de la AEFP sobre Acceso a documentos públicos. Madrid, marzo 2009.

${ }^{53}$ Cf.: http://www.sedic.es/FOIA-Informe-completo.pdf 
6.- GONZÁLEZ QUINTANA, Antonio. Los límites del secreto oficial: documentos clasificados y documentos inaccesibles en los archivos del Ministerio de Defensa. I Jornadas de la AEFP sobre Acceso a documentos públicos. Madrid, marzo 2009.

Ocaña Lacal $^{54}$ sugere ainda consultar algumas páginas Webs de associações, plataformas e orgãos:

- Ministerio de Industria, Turismo y Comercio. Proyecto APORTA sobre Reutilización de la información del Sector Público ${ }^{55}$

- Archiveros Españoles de la Función Pública, AEFP ${ }^{56}$

- Coalición Pro Acceso ${ }^{57}$

De acordo com Ocaña Lacal (1999, p.175) um rápido, porém completo, repasso da legislação de acesso aos arquivos públicos na Espanha desde o século XVIII foi realizado por S.Férnandez Ramos ${ }^{58}$ bem como por Llanso I Sanjuan ${ }^{59}$.

De acordo com Borruel López e Ocaña Lacal (1995, p. 206) um novo conceito de Patrimônio surgiu a partir da promulgação da Lei 16/1995, de 25 de junho do Patrimônio Histórico Espanhol, que de acordo com seu artigo 49, parágrafo 2, é constituído pelos documentos de qualquer época gerados, conservados ou reunidos no exercício de suas atividades por qualquer órgão ou entidade de caráter público, pelas pessoas jurídicas em cujo capital participe majoritariamente o Estado ou outras entidades públicas e pelas pessoas privadas, físicas ou jurídicas, gestoras de serviços públicos relacionados com a gestão de ditos serviços.

\footnotetext{
${ }^{54}$ Op. cit.

${ }^{55}$ URL: www.aporta.es.

${ }^{56}$ URL: www.aefp.org.es

57 URL: www.proacceso.org/

58 Referência fornecida por Ocaña Lacal (1999, p. 175): S.Férnandez Ramos. El derecho de acceso a los documentos administrativos, Madrid, 1997, p. 282-294

${ }^{59}$ Referência fornecida por Ocaña Lacal (1999, p.175): Llanso I Sanjuan, L'accés a la documentació a l'Estat espanyol: una panoràmica històrica" en Lligall. Revista Catalana d'Arxivística, 3, (1991), p. 3
} 
Quanto à legislação estatal da Espanha relativa a Arquivos, podem-se destacar duas leis, quatro ordens ministeriais e onze decretos, como demonstrado nos Quadros 3, 4 e 5 a seguir. ${ }^{60}$

\begin{tabular}{|c|c|}
\hline \multicolumn{2}{|c|}{ LEIS } \\
\hline $\begin{array}{c}\text { Ley 16/1995, de 25 de junio } \\
\text { Número B.O.E: 155, 29/06/1985 } \\
\text { Número Disposición: 16/1985 }\end{array}$ & Do Patrimônio Histórico Espanhol \\
\hline $\begin{array}{c}\text { Ley 21/2005, de 17 de noviembre } \\
\text { Número B.O.E: 276 18/11/2005 } \\
\text { Número Disponível: 21/2005 }\end{array}$ & $\begin{array}{c}\text { Da restituição à Generalitat de Catalunha dos documentos apreendidos por } \\
\text { ocasião da Guerra Civil, guardados no Arquivo Geral da Guerra Civil Espanhola } \\
\text { e da criação do Centro Documental da Memória Histórica. }\end{array}$ \\
\hline
\end{tabular}

Quadro 3 - Leis Estatais espanholas relativas a Arquivos

\begin{tabular}{|c|c|}
\hline \multicolumn{2}{|r|}{ ORDENS MINISTERIAIS } \\
\hline $\begin{array}{l}\text { Ordem de } 25 \text { de novembro de } 1996 . \\
\text { Número B.O.E: } 289,30 / 11 / 1996 \\
\text { Número Disponível: 25/11/1996 }\end{array}$ & $\begin{array}{c}\text { Através da qual se regula a composição e funções da Junta Superior de } \\
\text { Arquivos. }\end{array}$ \\
\hline $\begin{array}{l}\text { Ordem de } 20 \text { de setembro de } 1999 . \\
\text { Número B.O.E: } 240,7 / 10 / 1999 \\
\text { Número Disponível: 20/9/1999 }\end{array}$ & A respeito da composição da Junta Superior de Arquivos \\
\hline $\begin{array}{c}\text { Ordem CUL/1014/2007, de } 30 \text { de março, } \\
\text { Número B.O.E: } 93,18 / 04 / 2007 \text { Número Disponível: } \\
\text { CUL-1014-2007 }\end{array}$ & $\begin{array}{c}\text { Através da qual se constitui a Comissão Espanhola sobre a digitalização e a } \\
\text { acessibilidade online do material cultural e a conservação digital. }\end{array}$ \\
\hline $\begin{array}{l}\text { Ordem CUL/1524/2007, de } 25 \text { de maio } \\
\text { Número B.O.E: } 131,01 / 06 / 2007\end{array}$ & $\begin{array}{c}\text { Através da qual se cria a Comissão de Normas Espanholas de Descrição } \\
\text { Arquivística }\end{array}$ \\
\hline
\end{tabular}

Quadro 4 - Ordens Ministeriais Espanholas relativas a Arquivos

${ }^{60}$ Essas informações foram extraídas do site do MCU. Disponível em: http://www.mcu.es/ 


\begin{tabular}{|c|c|}
\hline \multicolumn{2}{|r|}{ DECRETOS REAIS } \\
\hline $\begin{array}{l}\text { Real Decreto } 111 / 1986 \text {, de } 10 \text { de janeiro } \\
\text { Número B.O.E: } 24,28 / 01 / 1986 \\
\text { Número Disponível: } 111 / 1986\end{array}$ & $\begin{array}{l}\text { Desenvolvimento parcial da Lei } 16 / 1985 \text {, de } 25 \text { de junho, do Patrimônio } \\
\text { Histórico Espanhol. }\end{array}$ \\
\hline $\begin{array}{l}\text { Real Decreto } 2598 / 1998 \text {, de } 4 \text { dezembro } \\
\text { Número B.O.E: } 303,19 / 12 / 1998 \\
\text { Número Disponível: } 2598 / 1998\end{array}$ & Através do qual se aprova o Regulamento dos Arquivos Militares. \\
\hline $\begin{array}{l}\text { Real Decreto } 1969 / 1999 \text {, de } 23 \text { de dezembro } \\
\text { Número B.O.E: } 11,13 / 01 / 2000 \\
\text { Número Disponível: } 1969 / 1999\end{array}$ & $\begin{array}{c}\text { Através do qual se regula a expedição da carteira nacional de pesquisador } \\
\text { para a consulta nos Arquivos de titulariedade estatal e nos aderidos ao } \\
\text { sistema arquivístico español. }\end{array}$ \\
\hline $\begin{array}{l}\text { Real Decreto } 139 / 2000 \text {, de } 4 \text { de febrero } \\
\text { Número B.O.E: } 36,11 / 02 / 2000 \\
\text { Número Disponível: } 139 / 2000\end{array}$ & $\begin{array}{l}\text { Através do qual se regula a composição, funcionamento e poderes da } \\
\text { Comissão Superior Quassificadora de documentos administrativos. }\end{array}$ \\
\hline $\begin{array}{l}\text { Real Decreto } 1164 / 2002 \text {, de } 8 \text { de novembro } \\
\text { Número B.O.E: } 274,15 / 11 / 2002 \\
\text { Número Disponível: } 1164 / 2002\end{array}$ & $\begin{array}{l}\text { Através do qual se regulamenta a consenvação do patrimonio documental com } \\
\text { valor histórico, o controle da eliminação de outros documentos da } \\
\text { Administração Geral do Estado e seus orgãos públicos e a conservação de } \\
\text { documentos administrativos em suporte diferente do original. }\end{array}$ \\
\hline $\begin{array}{l}\text { Real Decreto } 760 / 2005 \text {, de } 24 \text { de junio } \\
\text { Número B.O.E: } 151,25 / 06 / 2005\end{array}$ & Cria o Patronato do Arquivo Geral das Índias \\
\hline $\begin{array}{l}\text { Real Decreto 937/2003, de } 18 \text { de julio Número B.O.E: } \\
\qquad 181,30 / 07 / 2003\end{array}$ & De modernização dos arquivos judiciais. \\
\hline $\begin{array}{l}\text { Decreto } 1267 / 2006 \text {, de } 8 \text { de noviembre } \\
\text { Número B.O.E: } 268,09 / 11 / 2006\end{array}$ & Que cria o Patronato do Arquivo da Coroa de Aragão \\
\hline $\begin{array}{l}\text { Real Decreto } 1266 / 2006 \text {, de } 8 \text { de noviembre } \\
\text { Número B.O.E: } 284,28 / 11 / 2006\end{array}$ & $\begin{array}{l}\text { Regula a emissão do cartão nacional de pesquisador para a consulta nos } \\
\text { arquivos de titulariedade estatal e nos agregados ao sistema arquivístico } \\
\text { español, no que se refere a arquivos de titulariedade dependentes do Ministério } \\
\text { de Cultura }\end{array}$ \\
\hline $\begin{array}{c}\text { Real Decreto } 697 / 2007 \\
\text { Número B.O.E: } 143,15 / 06 / 2007\end{array}$ & Que cria o Centro Documental da memoria Histórica \\
\hline $\begin{array}{l}\text { Real Decreto } 1401 / 2007 \text {, de } 29 \text { de octubre } \\
\text { Número B.O.E: } 267,07 / 11 / 2007\end{array}$ & $\begin{array}{c}\text { Que regula a composição, funcionamento e poderes da comissão Superior } \\
\text { clasificadora de documentos administrativos }\end{array}$ \\
\hline
\end{tabular}

Quadro 5 - Decretos Reais espanhóis relativos a Arquivos

\subsubsection{Legislação de Arquivos das Comunidades Autônomas}

A Constituição espanhola (Lei 30/1992, de 26 de novembro, do Regime Jurídico das Administrações Públicas e do procedimento administrativo comum) regula o acesso aos arquivos. Os arquivos da administração local, no entanto, são definidos e regulados pelas administrações autônomas.

O direito ao acesso aos documentos de Arquivos foram garantidos inicialmente pela administração local e pelos arquivos municipais. 
Os arquivos estão definidos na legislação espanhola no artigo 59 da lei 16/1985, de 25 de junho, do patrimônio histórico espanhol. Esse artigo, porém, faz referência apenas aos arquivos estatais.

O Patrimônio histórico, na Espanha, refere-se aos bens tanto materiais como imateriais, que foram acumulados ao longo dos anos. Tais bens são classificados em artístico, histórico, paleontológico, arqueológico, documental, bibliográfico, técnico ou científico. Essa diversidade de bens explica o significado mais recente e de uso internacional: bens culturais.

Universalmente, quando se denomina algum bem como Patrimônio da Humanidade, significa que necessita de proteção, por se tratar de um bem de interesse internacional.

A tutela do Patrimônio histórico, na Espanha, está descentralizada nas Comunidades Autônomas, por isso a maioria delas desenvolveu legislação própria.

Apresentam-se a seguir algumas dessas Leis, Decretos e Ordens das Comunidades Autônomas que dizem respeito a Arquivos, publicadas no Boletim Oficial do Estado:

- Com relação à comunidade de Andaluzia, encontram-se dois decretos e duas leis a respeito de Arquivos, como demonstrado no quadro 6 a seguir:

\begin{tabular}{|c|c|}
\hline \multicolumn{2}{|l|}{ ANDALUZIA } \\
\hline DECRETO AUTONÔMICO & LEI AUTONÔMICA \\
\hline $\begin{array}{l}\text { Decreto } 97 / 2000 \text {, de } 6 \text { março de } 2000 \text {. Aprova o Regulamento } \\
\text { do Sistema Andaluz de Arquivos e desenvolvimento da Lei } \\
\text { 3/1984, de 9-1-1984 de Arquivos } \\
\text { Número B.O.J.A: } 43,11 / 4 / 2000\end{array}$ & $\begin{array}{l}\text { Lei } 3 / 1984 \text {, de } 9 \text { janeiro de } 1984 \text {. Lei de } \\
\text { Arquivos de Andaluzia } \\
\text { Número B.O.E: } 25,30 / 1 / 1984 \\
\text { Número B.O.J.A: } 4,10 / 1 / 1984 \\
\text { Número Disponível: } 3 / 1984\end{array}$ \\
\hline \multicolumn{2}{|c|}{ Número Disponível: $97 / 2000$} \\
\hline $\begin{array}{l}\text { Decreto } 258 / 1994 \text {, de } 6 \text { setembro de } 1994 \text {. Integra o Sistema } \\
\text { Andaluz de Arquivos e o Sistema Bibliotecário de Andaluzia, } \\
\text { os arquivos e bibliotecas de titularidade estatal geridos pela } \\
\text { Junta de Andaluzia } \\
\text { Número B.O.J.A: } 169,26 / 10 / 1994 \\
\text { Número Disponível: } 258 / 1994\end{array}$ & $\begin{array}{l}\text { Lei } 14 / 2007 \text {, de } 26 \text { de novembro de } 2007 . \\
\text { Regulamenta o Patrimônio Histórico de } \\
\text { Andalucía } \\
\text { Número B.O.E: } 38,13 / 02 / 2008 \\
\text { Número B.O.J.A: } 248,19 / 12 / 2007 \\
\text { Número Disponível: } 14 / 2007\end{array}$ \\
\hline
\end{tabular}

Quadro 6 - Decretos e Leis Andaluzia 
- No que diz respeito à Comunidade Autônoma de Aragão, a legislação de Arquivos está concretizada através de um decreto, uma lei e uma ordem Autônomicos, conforme demonstrado a seguir:

\begin{tabular}{|c|c|c|}
\hline \multicolumn{2}{|c|}{ ARAGÃO } \\
\hline DECRETO AUTONÔMICO & LEI AUTONÔMICA & ORDEM AUTONÔMICA \\
\hline $\begin{array}{c}\text { Decreto 34/1987, de } 1 \text { abril 1987. Desenvolve } \\
\text { parcialmente a Lei } 28 \text { novembro 1986, que } \\
\text { regulamenta os Arquivos de Aragão }\end{array}$ & Lei 6/1986, de 28 de novembro de 1986. & Ordem de 7 julho de 2003. Aprova \\
Número B.O.A: 42, 13/4/1987 & Regulamenta os Arquivos de Aragão & modelo de Regulamento dos \\
Número Disponível: 34/1987 & Número B.O.A: $301,17 / 12 / 1986$ & Archivos Comarcais de Aragão \\
& Número Disponível: $6 / 1986$ & Número Disponível: $7 / 7 / 2003$ \\
& & \\
\end{tabular}

Quadro 7 - Decreto, lei e ordem autonômicos de Aragão

- Para a Comunidade de Asturias, encontra-se apenas uma Lei Autonômica que rege o Patrimônio Cultura de Astúrias como um todo, conforme se apresenta no quadro 8 a seguir:

\begin{tabular}{|c|c|}
\hline \multicolumn{2}{|c|}{ ASTURIAS } \\
\hline & Lei 1/2001, de 6 março de 2001. Normas \\
& reguladoras do Patrimônio Cultural de Astúrias \\
& Número B.O.E: $135,06 / 06 / 2001$ \\
LEI AUTONÔMICA & Número. B.A: $75,30 / 03 / 2001$ \\
& Número Disponível: $1 / 2001$ \\
\hline
\end{tabular}

Quadro 8 - Lei Autonômica Astúrias

- Os Arquivos de Canarias bem como todo seu Patrimônio Documental é regulamentado pela Lei Autonômica citada a seguir:

\begin{tabular}{|c|c|}
\hline \multicolumn{2}{|c|}{ CANÁRIAS } \\
\hline & $\begin{array}{c}\text { Lei 3/1990, de } 22 \text { fevereiro de 1990. Normas } \\
\text { reguladoras do Patrimônio Documental e Arquivos } \\
\text { de Canárias }\end{array}$ \\
& $\begin{array}{c}\text { Número B.O.E: } 92,17 / 4 / 1990 \\
\text { Número B.O.C: } 27,2 / 3 / 1990\end{array}$ \\
\hline
\end{tabular}

Quadro 9 - Lei Autonômica Canárias

- A Comunidade Autônoma de Cantábria possui duas Leis Autonômicas e um Decreto Autonômico que regem seu Patrimônio 
Histórico e Cultural e seus Arquivos, como se pode observar no Quadro 10 a seguir:

\begin{tabular}{|c|c|}
\hline \multicolumn{2}{|c|}{ CANTÁBRIA } \\
\hline DECRETO AUTONÔMICO & LEI AUTONÔMICA \\
\hline & Lei 11/1998, de 13 outubro de 1998. Lei do \\
Patrimônio Cultural de Cantábria \\
Decreto 36/2001, de 2 de maio de 2001. & Número B.O.E: 1, 12/1/1999 \\
Desenvolvimento parcial da Lei de Cantábria & Número B.O.C.A.N.T: $240,2 / 12 / 1998$ \\
11/1998, de 13-10-1998, de Patrimônio & Número Disponível: $11 / 1998$ \\
Cultural & \\
Número B.O.C.A.N.T: 89, 10/5/2001 & Lei 3/2002, de 28 junho de 2002. Arquivos de \\
Número Disponível: 36/2001 & Cantábria \\
\cline { 2 - 2 } & Número B.O.E: 176, 24/7/2002 \\
& Número B.O.C.A.N.T: 131, 9/7/2002 \\
& Número Disponível: 3/2002 \\
\hline
\end{tabular}

\section{Quadro 10 - Leis e Decreto Cantábria}

- A Comunidade de Castela-La Mancha possui um Decreto e duas Leis Autonômicas que regulam o funcionamento dos Arquivos e do Patrimônio Histórico, como se pode observar a seguir.

\begin{tabular}{|c|c|}
\hline \multicolumn{2}{|c|}{ CASTELA-LA MANCHA } \\
\hline DECRETO AUTONÔMICO & LEI AUTONÔMICA \\
\hline & $\begin{array}{c}\text { Lei 4/1990, de } 30 \text { maio de 1990. Regulamento do } \\
\text { Patrimônio Histórico de Castilla-La Mancha }\end{array}$ \\
Número B.O.E: 221, 14/9/1990 \\
Decreto 6/2005, de 18 enero 2005. Aprova o & Número B.O.C.C.L.M: 41, 13/6/1990 \\
Regulamento do funcionamento e & Número Disponível: 4/1990 \\
composição do Conselho de Arquivos de & \\
Castela-La Mancha & \\
Número B.O.C.C.L.M: $18,26 / 1 / 2005$ & Lei 19/2002, de 24 outubro de 2002. Archivos \\
Número Disponivel: 6/2005 & Públicos de Castela-La Mancha \\
\cline { 2 - 2 } & Número B.O.E: 301, 17/12/2002 \\
& Número Disponível: $19 / 2002$ \\
\hline
\end{tabular}

Quadro 11 - Leis e Decreto Castela-La Mancha 
- A Comunidade Autônoma de Castela e Leão, com relação à Legislação de Arquivos, possui dois Decretos e duas Leis Autonômicas, dispostos no Quadro 12:

\begin{tabular}{|c|c|}
\hline \multicolumn{2}{|c|}{ CASTELA E LEÃO } \\
\hline DECRETO AUTONÔMICO & LEI AUTONÔMICA \\
\hline $\begin{array}{l}\text { Decreto 221/1994, de } 6 \text { outubro de } 1994 . \\
\text { Estrutura e funções do Arquivo Geral de } \\
\text { Castela e Leão e articulação com os } \\
\text { Arquivos Históricos Provinciais da } \\
\text { Comunidade } \\
\text { Número B.O.C.Y.L: } 197,11 / 10 / 1994 \\
\text { Número Disponível: } 221 / 1994\end{array}$ & $\begin{array}{l}\text { Ley 6/1991, de } 19 \text { abril } 1991 \text {. Regula los Archivos y } \\
\text { el Patrimonio Documental de Castilla y León } \\
\text { Número B.O.E: } 134,5 / 06 / 1991 \text { Número, } \\
\text { B.O.C.Y.L: } 91,15 / 05 / 1991 \\
\text { Número Disponível: 6/1991 }\end{array}$ \\
\hline $\begin{array}{l}\text { Decreto 115/1996, de } 2 \text { maio de } 1996 . \\
\text { Regulamento do Sistema de Arquivos de } \\
\text { Castela e Leão } \\
\text { Número B.O.C.Y.L: } 87,8 / 5 / 1996 \\
\text { Número Disponível: } 115 / 1996\end{array}$ & $\begin{array}{c}\text { Ley } 12 / 2002 \text {, de } 11 \text { julio } 2002 \text {. Patrimonio Cultural } \\
\text { de Castela e Leão } \\
\text { Número B.O.E: } 183,1 / 8 / 2002 \\
\text { Número B.O.C.Y.L: } 139,19 / 07 / 2002 \\
\text { Número Disponível: } 12 / 2002\end{array}$ \\
\hline
\end{tabular}

\section{Quadro 12 - Leis e Decretos Castela e Leão}

- Com relação à legislação de arquivos da Comunidade da Catalunha, encontra-se duas leis autonómicas e cinco decretos autonómicos, conforme demonstra-se nos quadros a seguir:

\section{LEIS AUTONÔMICAS}

Lei 9/1993, de 30 setembro de 1993. Regulamenta o patrimônio cultural catalão

Número B.O.E: $264,4 / 11 / 1993$

Número D.O.G.C: $1807,11 / 10 / 1993$

Número Disponível: 9/1993

Lei 10/2001, de 13 julho de 2001. Arquivos e documentos de Catalunha

Número B.O.E: $206,28 / 8 / 2001$

Número D.O.G.C: 3437 , 24/7/2001

Número Disponível: 10/2001

Quadro 13 - Leis autonômicas da Catalunha 


\section{DECRETOS AUTONÔMICOS}

Decreto 110/1988, de 5 de maio de 1988. Regulamenta a organização da Rede de Arquivos Históricos Comarcais de Catalunha

Número D.O.G.C: $995,25 / 5 / 1988$

Número Disponível: 110/1988

Decreto 75/2009, de 12 maio. Garantia da Generalitad de Catalunha para obras de interesse cultural relevante

Número D.O.G.C: $5380,15 / 5 / 2009$

Número Disponível: $75 / 2009$

Decreto 190/2009, de 9 diciembre. Regulamenta requisitos de arquivos do Sistema de Arquivos de Catalunha, do procedimento de integração e do Registro de Arquivos de Catalunha

Número D.O.G.C: $5524,11 / 12 / 2009$

Número Disponível: 190

Decreto 183/2008, de 9 de setembro, da Generalitad de Catalunha. Procedimento para a restituição às pessoas físicas ou jurídicas de caráter privado dos documentos apreendidos por motivo da guerra Civil.

Número D.O.G.C: $5216,16 / 9 / 2008$

Número Disponível: 183/2008

Decreto 117/1990, de 3 de maio de 1990. Sobre a avaliação e seleção de documentação da Administração pública de Catalunha

Número D.O.G.C: $1297,25 / 5 / 1990$

Número Disponível: 117/1990

\section{Quadro 14 - Decretos Autonômicos da Catalunha}

- A comunidade de Extremadura apresenta duas Leis Autonômicas que regem seu Patrimônio Histórico e Cultural e seus Arquivos, como se observa no quadro 15 a seguir.

\begin{tabular}{|c|}
\hline EXTREMADURA \\
\hline LEI AUTONÔMICA \\
\hline Lei 2/1999, de 29 de março de 1999. Lei do Patrimônio Histórico e Cultural de Extremadura \\
Número B.O.E: $139,11 / 6 / 1999$ \\
Número D.O.E: $59,22 / 5 / 1999$ \\
Número Disponível: $2 / 1999$ \\
\\
\hline Lei 2/2007, de 12 de abril, de arquivos e patrimônio documental de Extremadura \\
Número B.O.E: $127,28 / 05 / 2007$ \\
Número D.O.E: $48,26 / 04 / 2007$ \\
Número Disponível: $2 / 2007$ \\
\end{tabular}

Quadro 15 - Leis Autônomas de Extremadura 
- A Comunidade de Galícia possui um Decreto Autonômico que regulamenta o sistema de Arquivos:

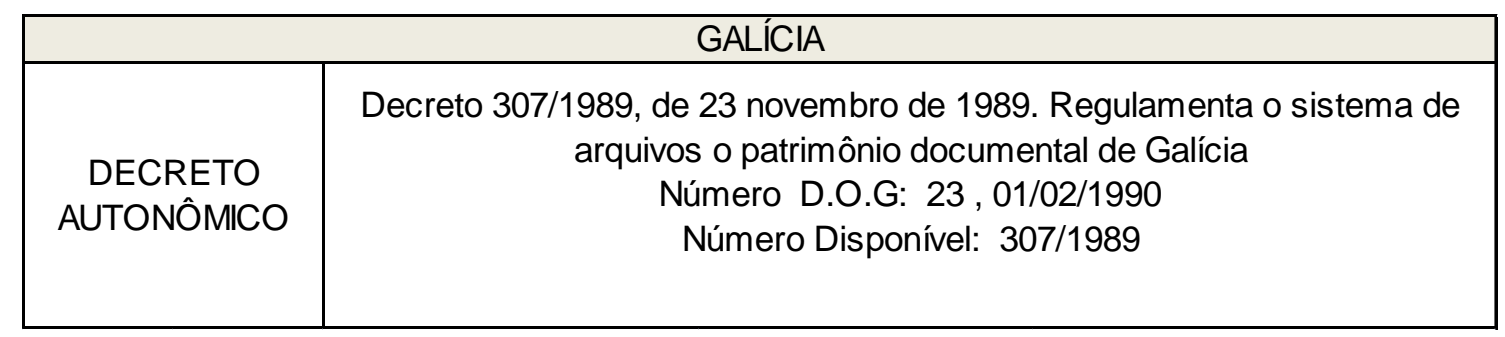

Quadro 16 - Decreto Autonômico de Galícia

- A Comunidade Autônoma das llhas baleares regula o Patrimônio Histórico e Arquivos por meio de duas Leis Autonômicas, como se verifica a seguir:

\begin{tabular}{|c|}
\hline ILHAS BALEARES \\
\hline Lei Autonómica \\
\hline Lel 12/1998, de 21 dezembro de 1998. Lei do Patrimônio Histórico das llhas Baleares \\
Número B.O.E: $31,5 / 2 / 1999$ \\
Número B.O.I.B: $165,29 / 12 / 1998$ \\
Número Disponível: $12 / 1998$ \\
\\
\hline Lei 15/2006, de 17 de outubro, de arquivos e patrimônio documental das lhas Baleares \\
Número B.O.E: $285,29 / 11 / 2006$ \\
Número B.O.I.B: $152,28 / 10 / 2006$ \\
Número Disponível: $15 / 2006$ \\
\end{tabular}

Quadro 17 - Leis autônomas das llhas Baleares

- Para a Comunidade Autônoma de Rioja encontra-se uma Lei Autonômica que rege os Arquivos e o Patrimônio Documental: 


\begin{tabular}{|c|}
\hline LA RIOJA \\
\hline Lei Autonômica \\
\hline Lei 4/1994, de 24 maio de 1994. Arquivos e Patrimônio Documental da Rioja \\
Número B.O.E: $144,17 / 6 / 1994$ \\
Número B.O.R: $67,28 / 5 / 1994$ \\
Número Disponível: 4/1994 \\
\hline
\end{tabular}

Quadro 18 - Lei Autonômica de La Rioja

- A Comunidade Autônoma de Madrid possui uma Lei Autonômica que regulamenta seus Arquivos e seu Patrimônio Documental, conforme se observa no Quadro 19 a seguir.

\begin{tabular}{|c|}
\hline MADRID \\
\hline Lei Autonômica \\
\hline Lei 4/1993, de 21 de abril de 1993. Regulamenta os Arquivos e Patrimônio Documental da \\
Comunidade de Madri \\
Número B.O.E: $138,10 / 6 / 1993$ \\
Número B.O.C.M: $101,30 / 4 / 1993$ \\
Número Disponível: 4/1993] \\
\hline
\end{tabular}

Quadro 19 - Lei Autonômica de Madrid

- A Comunidade Autônoma de Múrcia em materia de legislação de Arquivos, apresenta uma Lei Autonômica que também regulamenta o Patrimônio Documental da Região.

\begin{tabular}{|c|}
\hline MURCIA \\
\hline Lei Autonômica \\
\hline Lei 6/1990, de 11 abril de 1990. Regulamenta os Arquivos e o Patrimônio Documental da \\
Região de Múrcia \\
Número B.O.E: $170,17 / 7 / 1990$ \\
Número B.O.R.M: $116,22 / 5 / 1990$ \\
Número Disponível: $6 / 1990$ \\
\hline
\end{tabular}

Quadro 20 - Lei Autonômica de Murcia

- A Comunidade Autônoma de Navarra, em materia de Arquivos, apresenta uma Lei e um Decreto Foral: 


\begin{tabular}{|l|c|}
\hline \multicolumn{2}{|c|}{ NAVARRA } \\
\hline \multicolumn{1}{|c|}{ Decreto Autonômico } & Lei Foral \\
\hline Decreto Foral $75 / 2006$, de 30 outubro de & \\
2006. Aprova o Regulamento que regula a & Lei Foral 12/2007, de 4 de abril, de Arquivos e \\
composição, organização e funcionamento & Documentos de Navarra \\
da Comissão de Evaluação Documental de & Número B.O.E: $113,11 / 5 / 2007$ \\
Navarra & Número B.O.N: $48,18 / 4 / 2007$ \\
Número B.O.N: $139,20 / 11 / 2006$ & Número Disponível: $12 / 2007$ \\
Número Disponível: $75 / 2006$ & \\
& \\
\hline
\end{tabular}

Quadro 21 - Decreto e Lei Foral de Navarra

- Com relação à Comunidade Autônoma do País Basco, encontra-se uma Lei Autonômica e três Decretos Autonômicos que regulam o Patrimônio Cultural Basco e os Arquivos da Administração Pública, segundo demonstra-se nos quadros 22 e 23 a seguir.

Lei Autonómica

Lei 7/1990, de 3 de julho de 1990. Regulamento do Patrimônio Cultural Basco

Número B.O.P.V: $157,6 / 8 / 1990$

Número Disponível: $7 / 1990$

Quadro 22 - Lei Autônoma do País Basco 


\begin{tabular}{|c|}
\hline Decretos Autonômicos \\
\hline $\begin{array}{c}\text { Decreto } 27 / 2008 \text {, de } 5 \text { de fevereiro de } 2008 \text {. Altera e consolida as normas de } \\
\text { organização e funcionamento da cultura basca }\end{array}$ \\
\hline $\begin{array}{l}\text { Número B.O.P.V: } 33,15 / 2 / 2008 \\
\text { Número Disponível: } 27 / 2008\end{array}$ \\
\hline $\begin{array}{c}\text { Decreto } 232 / 2000 \text {, de } 21 \text { de novembro de } 2000 \text {. Aprova o regulamento para o } \\
\text { arquivamento e as regras que regem o patrimonio documental do País Basco. } \\
\text { Número B.O.P.V: } 235,11 / 12 / 2000 \\
\text { Número Disponível: } 232 / 2000\end{array}$ \\
\hline $\begin{array}{l}\text { Decreto } 174 / 2003 \text {, de } 22 \text { julio } 2003 \text {. Organização e funcionamento do } \\
\text { Sistema de Arquivamento da Administração Pública da Comunidade } \\
\text { Autônoma do País Basco } \\
\text { Número B.O.P.V: } 163,22 / 8 / 2003 \\
\text { Número Disponível: } 174 / 2003\end{array}$ \\
\hline
\end{tabular}

Quadro 23 - Decretos Autônomos do País Basco

- A Comunidade Autônoma de Valencia possui um Decreto e uma Lei Autonômica que regula o Patrimônio documental dos Arquivos Públicos e o Patrimônio Cultural valenciano, conforme observa-se a seguir.

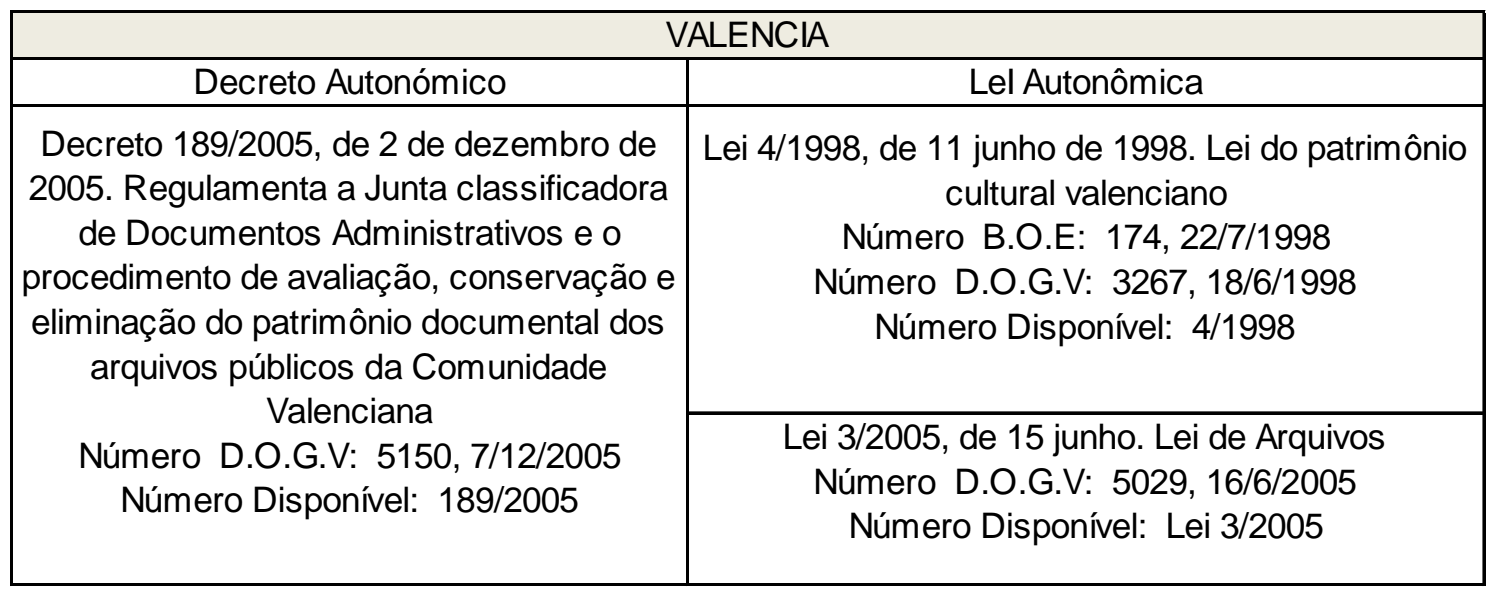

Quadro 24 - Decretos e Lei Autonômica de Valencia 


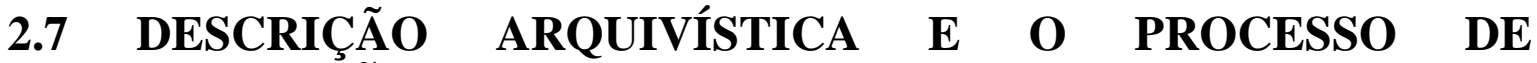 NORMALIZAÇÃO}

Os documentos de Arquivo podem servir de suporte tanto para preencher lacunas da vida dos cidadãos, quanto, num âmbito mais abrangente, para contar a história de seu país. Portanto, os Arquivos devem estar vinculados à memória Histórica das Nações e suas Administrações e, aos direitos dos cidadãos garantidos pela Constituição, e neste sentido, a Lei espanhola 30/1992, de Regime Jurídico das Administrações Públicas e do Procedimento Administrativo Comum, entre outras mais específicas, veio, segundo López Gómez (2008, p.33), garantir o direito dos espanhóis e extrangeiros ao acesso aos documentos sem discriminação política ou acadêmica.

A influência da Europa Central na arquivologia espanhola veio dos Estados Unidos e foi filtrada por Schellenberg ${ }^{61}(1958,1961)$, cujo conhecimento se deu através de peculiares traduções do Inglês; a influência italiana, já antiga, foi renovada no ano de 1961 e influência francesa veio através do "Manuel d'Archivistique", publicado em 1970; a influência holandesa, através do Manual publicado em 1989, não teve efeito sobre a comunidade arquivística espanhola, uma vez que só havia uma tradução brasileira, disponível bem depois de sua publicação que data de 1898, tampouco teve repercussão a influência alemã nos arquivos espanhóis (LOPEZ GOMEZ, 2008, p.5).

Os preceitos constitucionais, referentes ao direito de acesso a Arquivos e registros públicos e os aspectos relacionados com a organização e funcionamento eficaz das Administrações Públicas, segundo Borruel López e Ocaña Lacal (1995, p. 206), vieram a desenvolver-se a partir da promulgação da Lei 30/1992, anteriormente citada, mais especificamente contidas na Exposição de motivos artigos 35, 37, 38 e Título VI.

O processo de normalização arquivística passa pelo direito de acesso aos documentos, uma vez que não teria sentido todo esse processo se não objetivasse o posterior resgate dos documentos para disponibilizá-los aos usuários.

\footnotetext{
${ }^{61}$ Schellemberg, Theodore R., 1903-1970 - O "Pai da avaliação de Arquivos americanos."
} 
De acordo López Gómez (2008, p.33), pode ser encontrada uma recopilação sobre o acesso aos Arquivos, tanto no aspecto bibliográfico quanto legal, na Revista Tria (1994) e uma visão histórica do acesso aos Arquivos na Espanha, em LLansó i San Juan (1991) ${ }^{62}$, na Revista Catalã de Arquivística: Lligall.

Ainda sobre o acesso aos Arquivos, o supracitado autor comenta que os problemas de acesso aos Arquivos municipais foram discutidos no $\mathrm{V}$ Congresso Nacional da Anabad, que aconteceu em Saragoça, em 1991, onde se destacaram trabalhos sobre aspectos gerais, que são também comuns a todos os Arquivos, bem como outros trabalhos, a exemplo de Luis Martínez García que trata de aspectos específicos dos Arquivos municipais.

Documentos arquivísticos são segundo Bellotto (2004), os documentos produzidos no curso das funções que os respaldam como tal, ao tempo em que conservam relações orgânicas entre si.

O grande desafio dos arquivistas e bibliotecários é a gerência dos documentos eletrônicos, os quais são partes do cotidiano dos indivíduos e estão em constante crescimento.

A disponibilização dos fundos arquivísticos para o público vem sendo tema de discussão sobretudo após a Segunda Guerra Mundial, quando se produziu abundante literatura tanto a nível nacional quanto internacional que influenciaram a arquivística espanhola.

Quizás entre las primeras, por su proximidad geográfica y administrativa, sea la francesa la de mayor influencia sobre España. El Consejo de Europa y la Unión Europea también han dado recomendaciones al respecto. Aunque por lo general se centra el tema del acceso a los archivos en la legislación, incluyendo el reglamento de los archivos, otras dificultades se han señalado, que van desde el simple conocimiento de su existencia a las barreras económicas (LÓPEZ GÓMEZ, 2008, p.33). ${ }^{63}$

\footnotetext{
62 Referência fornecida por López Goméz (2008): Llansó i San Juán, J., 'L’accés a la documentació a l'Estat Espanyol. Una panorámica histórica', Lligall. Revista catalana d'Arxivística 3 (1991): 13-29.

63Talvez entre as primeiras, devido à sua proximidade geográfica e administrativa, a literatura francesa seja a de maior influência na Espanha. O Conselho da Europa e a União Europeia deram também recomendações a esse respeito. Embora geralmente se concentre na questão do acesso aos arquivos na legislação, incluindo a regulação dos arquivos, outras dificuldades foram relatadas, que vão desde o simples conhecimento de sua existência às barreiras econômicas. (Tradução nossa)
} 
A preocupação com o acesso aos documentos incide diretamente na necessidade de padronização em nível nacional e internacional para que os documentos possam de fato se tornar disponíveis aos cidadãos em geral, que são todos prováveis usuários de Arquivos.

A Descrição Arquivística situa o pesquisador em relação ao ambiente e ao sistema de arquivo que o criou. Através do controle descritivo das fontes e coleções documentais dos Arquivos, o desenvolvimento de catálogos e de ferramentas descritivas dos documentos, torna-se um ponto de referência de valor imponderável para os pesquisadores, garantindo que não haja vetos arbitrários de acesso aos documentos (LÓPEZ GÓMEZ, 2008, p.34)

As normas de Descrição Arquivísticas para documentos de Arquivo foram criadas desde os anos 1980. No caso da descrição das páginas Web de Arquivos, os padrões de metadados servem para descrever os documentos eletrônicos. "Os metadados provêm a ligação essencial entre o criador e o usuário da informação"(YAMAOKA, 2007). Machine Peadable Catalog Format (MPRC); Encoded Archival Description (EAD); Text Encoding Interative (TEI), Dublin Core (DC) são alguns exemplos de padrões de metadados ${ }^{64}$.

Segundo Carbone (1993), a Arquivística, com seus próprios meios, oferece os encaminhamentos à pesquisa e procura garantir que se tenha acesso aos documentos. A descrição Arquivística é o registro descritivo das informações dos documentos e dos fundos arquivísticos. A partir de inventários, catálogos etc, explicam os documentos de Arquivos em relação à localização, identificação e gestão dos mesmos.

Essas atividades de descrição são de grande relevância à medida que favorece o acesso e a compreensão dos acervos arquivísticos.

A Descrição Arquivística é aplicada em todas as etapas em que ocorre o tratamento do Arquivo (LOPES, 1996 apud HAGEN, 1998). Segundo esse autor, o processo de descrição tem início desde a classificação passando pela avaliação até os instrumentos de busca específicos. Os documentos eletrônicos obedecem a um padrão e a recuperação das informações é possível pelos instrumentos de pesquisa.

${ }^{64}$ Os metadados são as documentações necessárias para viabilizam o entendimento da informação contidas nos dados. 
De acordo com Severiano Vicente Hernandez (1991), entre os anos 1979 e 1986, encontra-se, uma explosão de manuais produzidos por um pequeno grupo de arquivistas ligados à $A N A B A D^{65}$ e a Vicenta Cortés Alonso, que trouxe as técnicas inovadoras contidas nos "Princípios arquivísticos de ordenação" de Schellenberg dos Estados Unidos para a Espanha. (LÓPEZ GÓMEZ, 2008, p. 6).

De acordo com Villabuena Bazán (2000, p. 22):

(...) la normatividad influye de una o otra forma en nuestra existencia, ya sea individual o colectiva; aunque no siempre de una manera consciente 0 apreciable, puesto que la reglamentación es parte de la vida cotidiana aun cuando uno la asuma así inconscientemente ${ }^{66}$.

Os catálogos e outros instrumentos de descrição documental são fundamentais para o pesquisador, pois é um ponto de referência no qual se pode encontrar o que se deseja com menor esforço.

A descrição consiste em uma das principais atividades Arquivísticas, e tem estreita relação com a organização, tem sido tratada, portanto, no âmbito das orientações universais que se baseia no princípio do conhecimento geral para se chegar ao particular, portanto se faz necessário estabelecer critérios para regular a descrição, buscando elementos padronizadores para estabelecer caracterizações objetivas quando aplicados aos fundos de Arquivo (VILLABUENA BAZÁN, 2000, p. 23).

Segundo López Gómez (2008, p. 29), o Primeiro Colóquio Internacional de Arquivística, realizado em 1990, foi dedicado à descrição nos Arquivos: padronização, mecanização, e a descrição em arquivos administrativos e históricos, a descrição das massas e séries documentais determinadas, e a rentabilidade dos instrumentos tradicionais juntamente com os instrumentos de controle e monitoramento dos registros na administração moderna, foram alguns dos temas de grande interesse desse evento.

\footnotetext{
${ }^{65}$ ANABAD é a sigla que da Confederación Española de Asociaciones de Archiveros, Bibliotecarios, Museólogos y Documentalistas.

66 ... a normatividade influencia de uma forma ou outra nossa existência, tanto individual quanto coletiva; embora não sempre de uma maneira consciente ou significativa, já que o regulamento faz parte da vida cotidiana mesmo quando o assumimos inconscientemente (Tradução nossa).
} 
O site do MCU possui um Diretório de nome "Normas archivísticas ${ }^{67 "}$, destinado a difundir eletronicamente as normas técnicas arquivísticas bem como documentos profissionais de Arquivos. Apresenta-se a seguir as normas de descrição arquivística utilizadas na Espanha:

1. Norma para a elaboração de pontos de acesso normalizados de instituições, pessoas, famílias, lugares e matérias no sistema de descrição arquivística dos arquivos estatais. Esta Norma foi elaborada pela Subdireção Geral dos Arquivos Estatais do Ministério de Cultura em 2010.

2. Norma ISDF: Norma Internacional para a descrição de funções elaborada pelo Comitê de Boas Práticas e Normas Profissionais em Dresde, Alemanha, em maio de 2007, que trata das relações entre as Instituições, as funções e os documentos de Arquivo.

3. Norma ISDIAH: Norma Internacional para descrever as Instituições que guardam fundos de arquivo. Adotada pelo Comitê de Boas Práticas e Normas

Profissionais em Londres, Reino Unido, em março de 2008, trata principalmente da vinculação da descrição da Instituição que tem a custódia dos fundos de Arquivo aos recursos arquivísticos e seus produtores.

4. ISAD (G): Norma Internacional Geral de Descrição Arquivística. Foi adotada pelo comitê de Normas de Descrição em Estocolmo, na Suécia, em 1999 e a $2^{\mathrm{a}}$ edição, versão espanhola, data de 2000.

5. ISAAR (CPF): International Standard Archival Autorithy Records for Corporate Bodies, Persons and Families. Trata-se da Norma Internacional sobre os registros de Autoridade de Arquivos relativos a Instituições, pessoas e famílias. A 2.. edição, versão Espanhola, data de 2004.

${ }^{67}$ Cf.: http://www.mcu.es/archivos/CE/RecProf/NormasDocumentos.html 
6. Norma ISO 15489: Sobre Informação e documentação e Gestão de documentos.

7. Guidelines on best practices for using electronic information. DLMFORUM Electronic Records. Estas normas ensinam como lidar com os dados legíveis por máquina e os chamados documentos eletrônicos.

8. Norma Española de Descripción Archivística (NEDA): Análise e proposta de desenvolvimento das Normas Espanholas de Descripción Archivística (NEDA) $2006^{68}$

A Norma Geral Internacional de Descrição Arquivística - ISAD (G) foi criada em 1992, fruto do trabalho de uma comissão formada por representantes de vários países, e surgiu na Espanha no final de 1993. Alguns anos mais tarde, em 1996, criou-se a Norma Internacional de Registro de Autoridade Arquivística para Entidades Coletivas, Pessoas e Famílias, ISAAR (CPF), cujas metodologias são utilizadas na Biblioteconomia.

A primeira é responsável pela padronização das descrições arquivísticas em fundos, com regras que servem para gerar normas locais. Entre essas descrições, há hierarquização em sua estrutura, a qual é apresentada em quatro regras básicas:

1. Apresentar descrição hierárquica do geral para o particular;

2. Utilizar informação pertinente ao nível de descrição;

3. Identificar o nível da descrição;

4. Não utilizar informações repetidas em distintos níveis de descrição.

A ISAD (G), de acordo com Villabuena Bazán (2000, p.23), baseia-se e se relaciona com a aplicação do princípio da procedência para estabelecer os diversos níveis hierárquicos em uma forma conhecida como a descrição multinível.

${ }^{68}$ Cf. Santamaría Gallo (2006) 
Faz-se necessário um maior aprofundamento da normalização da terminologia arquivística. $\mathrm{Na}$ classificação arquivística, deve-se definir precisamente as atividades, afinal a ISAD (G) é a norma universal de referência básica para a atividade de descrição de arquivos.

A segunda norma, a ISAAR (CPF) trata dos pontos de acesso na descrição arquivística com o fim precípuo de esclarecer a prática na gestão dos arquivos.

As duas normas mencionadas ISAAR (CPF) e ISAD (G) são complementares em alguns aspectos, uma vez que possibilitam a relação entre os documentos e as autoridades produtoras.

A ISAAR (CPF) envolve três áreas: Controle de Autoridade, Informação e Notas. A ISAD $(G)$, por sua vez, envolve quatro áreas, a saber: Identificação, Descrição, Relações e Controle. Além de em uma seção complementar, Relações das entidades coletivas, pessoa e família com a documentação de arquivos e outros recursos.

Um dos mais importantes documentos técnicos, nos últimos anos, na Espanha em matéria de Arquivos - o Modelo conceptual de descripción archivística y requisitos de datos básicos de las descripciones de documentos de archivo, agentes y funciones - Parte 1: Tipos de entidad, é um projeto final, resultado do trabalho feito pela Comisión de Normas Españolas de Descripción Archivística - CNEDA, correspondendo à primeira atividade do projecto NEDA-I ${ }^{69}$.

A CNEDA foi criada através de um despacho do Ministério da Cultura BOE ( $\cong$ 131, de $1 \cong$ junho de 2007), concebido com caráter de grupo de trabalho, é composto por Abelardo Santamaría Gallo como presidente, Ramon Martín Suquía, como vice-presidente, Isabel Ceballos Aragón como secretaria, e como membros: Antonia Heredia Herrera, Javier Barbadillo Alonso, Alejandro Delgado Gómez, Juan José Generelo Lanaspa, Pedro López Gómez, María Josefa Villanueva Toledo. Esta Comissão tem a função de assessorar a redação, manutenção revisão, bem como ações necessária para difusão das Normas Espanholas de Descrição Arquivística (NEDA).

${ }^{69}$ Cf. Comisión de Normas Españolas de Descripción Archivística. Proyecto NEDA-I, URL: http://www.mcu.es/archivos/docs/MC/ProyectoNEDA_I_170907.pdf 
Santamaría Gallo (2006) através de sua proposta inicial sobre as normas espanholas de descrição arquivística, sugere novos desenhos de sistemas de informação para a melhor adaptação dos arquivos ao mundo tecnológico. Esta proposta tem como base: as normas arquivísticas internacionais já aprovadas (ISAD (G)2, ISAAR(CPF)2, EAD e outras em fase de desenvolvimento (EAC, ISAF, etc.); a prática arquivística espanhola nos processos técnicos de identificação e descrição dos fundos e coleções; a experiência acumulada no desenvolvimento de sistemas de informação arquivística; a documentação gerada durante o projecto NEDA1 bem como seus resultados; esforços normativos regionais e nacionais (MDM, NODAC, DACS, RAD2, etc); a normalização da descrição bibliográfica a nível internacional e nacional (FRBR, FRAR, Declaração dos Princípios Internacionais de Catalogação: ISBDs, GARR, GSARE, MARC21, $\mathrm{RC}, \mathrm{RDA}$, etc $)^{70}$.

A proposta de Abelardo Santamaría Gallo objetiva principalmente promover a implementação de práticas arquivísticas adequadas e de forma homogênea nos processos técnicos de identificação e descrição dos fundos e coleções, visando melhorar o acesso dos usuários aos recursos de arquivamento e; Incentivar a padronização das entradas e saídas dos dados de descrição nos sistemas de informação arquivística para facilitar o intercâmbio de informação e comunicação, com a finalidade de melhorar a transferência de informação descritiva em todo o ciclo de vida do documento, alterar alguns outros sistemas, etc. bem como, contribuir para a construção de bases de dados e arquivos de autoridade coletiva, integrados e sistemas unificados de Informação arquivística.

Vem de longe a necessidade de normalizar as descrições documentais, Vicenta Cortés, em 1961, durante a famosa Reunião Interamericana em Washington, já discutia a padronização das entradas catalográficas. Com a introdução da Informática, os Arquivos passaram a ter de enfrentar tanto a normalização como a informatização na descrição. (LÓPEZ GÓMEZ 2008, p.30).

Os arquivistas devem observar acuradamente as redes, a fim de disponibilizar e gerenciar melhor os seus acervos. Normalmente este processo está atrelado à utilização de metadados, que servem para recuperar informações

${ }^{70}$ Cf. Santamaría Gallo (2006, p. 17) 
digitais, bem como organizá-las, de maneira que se reduzam os esforços e facilite a manutenção dos dados. 


\section{Capítulo 3}

\section{COMUNICAÇÃO E INFORMAÇÃO}

Neste capítulo, faz-se um breve relato sobre a disseminação da informação, com a evolução da comunicação. Ao longo dos anos, a comunicação foi evoluindo e chegou ao seu auge, durante o século XX, especialmente na década de 1960, em que foi observado um verdadeiro boom nas telecomunicações. 


\title{
3.1 INTRODUÇÃO À COMUNICAÇÃO E INFORMAÇÃO
}

\author{
Knowledge is of two kinds. We know a subject ourselves, \\ Or we know where we can find information upon it.
}

(Samuel Jonhson)

Em consequência da evolução da comunicação, surgiu a Word Wibe Web ou comumente conhecida por WWW ou ainda Web. De início, foi criada apenas como um ambiente para a publicação de documentos em formato HTML (Hipertext Markup Language) e a interação com o usuário era limitada, isto é, restringia-se apenas a leitura e impressão de textos bem como a seleção de links para outros documentos.

Em fase posterior, passou-se a utilizar a interface CGls (Common Gateway Interface) que apresenta uma evolução, pois possibilita a entrada de dados do usuário e a sua interação com aplicações de bancos de dados.

Essa evolução do processamento da informação vem impulsionando o crescimento social. Essa nova estrutura organizacional originou-se a partir de três bases:

[...] a primeira delas é a convergência das informações para o formato digital, através de fotos, textos, vídeos e outros que podem ser acessados e transmitidos de maneira igual através de um computador; a segunda é o crescimento do comércio de computadores, o que tem gerado uma maior queda nos preços de comercialização dessa ferramenta valiosa para os serviços desta sociedade; e a terceira é a grande explosão da internet para a qual não existe distância nem fronteira entre os países, e vêm sendo utilizada cada vez mais e com uma maior frequência (RODRIGUES; BECHER, 2009, p.4).

Como se pode perceber pela citação acima, tudo o que envolve a informação na atualidade está direcionado para a informatização, isto é, todas as organizações filantrópicas, instituições científicas, empresas, o cidadão comum, enfim, todas as entidades apresentam propósito semelhante: buscar uma visão 
democratizadora da informação, reduzindo assim o tempo e o espaço, reduzindo barreiras, tornando a informação um bem comum dentro de numa sociedade globalizada.

\subsection{REDE DE ALCANCE MUNDIAL E INTERAÇÃO HUMANA}

Durante a chamada "Guerra Fria" entre a extinta União Soviética (URSS) e os Estados Unidos da América (USA), temendo um ataque os americanos criaram, em 1955, a Defense Advanced Research Projects Agency (uma Agência de Projetos de Pesquisa Avançada - ARPA).

(...) em 1962, quando os americanos planejaram um sistema de comunicação militar que não pudesse ser interrompido por bombas ou qualquer outro tipo de ataque. Os tempos eram o da chamada "guerra fria", período em que Estados Unidos e Rússia, então as duas maiores potências mundiais, disputavam com unhas e dentes a supremacia no planeta. Nessa mesma época o americano Paul Baran havia idealizado um sistema composto por computadores interligados entre si, onde cada máquina poderia orientar o trabalho das outras (DANNEMANN, 2008) ${ }^{71}$ :

Depois surgiu o ARPANet em 1969, quando a Agência de Pesquisas e Projetos Avançados (ARPANet - sigla inglesa) ligou os computadores de quatro grandes universidades americanas: Califórnia, Santa Bárbara, Utah e Instituto de Pesquisas de Stanford aos dos centros militares. Quatro anos depois, outras conexões foram estabelecidas com outros centros universitários da Inglaterra e Noruega. Em 1975, contabilizou-se cerca de cem sites e os pesquisadores que trabalhavam na ARPANet estudaram sobre o modo como o crescimento da rede alterou a maneira de utilizá-la e o aumento de sua velocidade.

Na Suíça, a Web foi desenvolvida no ano de 1990, surgindo então a linguagem HTML por Tim Berners Lee, no Laboratório CERN. No ano de 1993, surgiu o primeiro browser multimídia: o Mosaic. Depois disso (da criação desse browser), outras novidades vêm emergindo na Web numa velocidade extraordinária. Em um curto espaço de tempo, houve um crescimento

\footnotetext{
${ }^{71}$ Disponível em:

http://www.fernandodannemann.recantodasletras.com.br/visualizar.php?idt=1336665
} 
considerável de servidores Web aumentando exponencialmente e alcançando à casa do milhão. existe somente uma rede única e global e pública o conjunto de todas as redes, a Internet. A palavra Internet é tradicionalmente escrita com a primeira letra maiúscula, como um nome próprio.

Veja-se a concepção a seguir:

A Web tornou-se rapidamente um poderoso meio de divulgação de informação. Uma informação publicada em HTML pode ser acessada em poucos minutos por pessoas em qualquer parte do mundo, em diferentes plataformas (PC, Mac, Sun, Silicon Graphics,...) (MARTINEZ, 2000, p.2).

Sendo a maior rede de computadores em escala global, a Internet torna-se plataforma de uso das organizações do governo, instituições de pesquisa e universidades. Há algum tempo pelo grande sucesso de seus aspectos voltados à multimídia, a World Wide Web chamou a atenção e despertou o interesse das organizações comerciais, que adotaram a Web e impulsionaram de forma fantástica o seu célere crescimento nos últimos anos:

A publicidade on-line manifestou-se, em sua primeira forma, nos próprios sites de empresas que marcavam sua presença na rede com o propósito de oferecer informações úteis a respeito de seus produtos e serviços, na maioria relacionados com Internet e informática (PINHO, 2000, p. 92).

A Internet (interconnected network of computers) caracteriza-se por ser uma rede de computadores interligados que trocam informações entre si. Esses computadores podem ser de qualquer tipo, arquitetura, marca ou modelo. Podem dividir-se em microcomputadores ou computadores de grande porte. Podem fazer uso de qualquer processador e, portanto, qualquer sistema operacional. Podem ainda usar qualquer software que possibilita comunicação entre servidores e clientes. Tais computadores estão interligados por linha comum de telefone, linhas privadas de comunicação, canais de satélite, cabos submarinos, cabos ópticos e outros meios de comunicação.

[...] A palavra internet é proveniente da expressão internetwork que significa comunicação entre redes. Uma maneira simples de visualizar a Internet é considerar uma nuvem com computadores conectados a ela (ALVES JÚNIOR, 2007, p.35).

Existem várias concepções a respeito da Internet em vários graus de abrangência e complexidade levando-se em conta que vários autores buscaram 
defini-la. A maneira mais simples de entendê-la, porém, é pensando em um complexo de informações interligadas que estão disponíveis a todos.

\begin{abstract}
$\mathrm{Na}$ concepção da internet propriamente dita, estiveram presentes intenções, valores e atitudes científicas e acadêmicas muito mais interessadas nas pessoas, no bem-estar, no puro desenvolvimento e também na sedução da descoberta por parte daqueles, como Robert Kahn, Vint Cerf, Tom Jennings, Mark Horton, Bill Joy, Richard Stallman,Ted Nelson, Linus Torvalds, Tim Berners-Lee, que desbravaram o terreno para a democrática rede global, visando, de fato, o prazer da comunicação e da partilha de recursos (BESSA, 2008, p.6).
\end{abstract}

Conforme a supracitada autora, a ideia da Internet está essencialmente atrelada à interação, ao desenvolvimento e à dissiminação das conquistas, refletindo assim uma posição otimista dos criadores da Web.

Segundo afirmam Rodrigues e Becher (2009, p. 1): "O principal canal por onde circulam as informações nessa sociedade é a internet - rede mundial de computadores, capaz de transferi-las a uma velocidade inimaginável anos atrás".

Com relação aos movimentos sociais, Castells (2000, p. 13), afirma que: "Internet es la estructura organizativa y el instrumento de comunicación que permite la flexibilidad y la temporalidad de la movilización, pero manteniendo al mismo tiempo un carácter de coordinación y una capacidad de enfoque de esa movilización $^{72 "}$.

"Internet es una red informática global que conecta redes locales alrededor

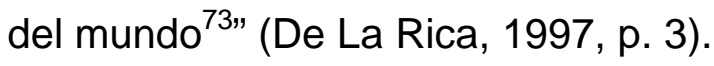

A Wikipédia ${ }^{74}$ define a internet como apanhado de redes ligadas entre si por TCP/IP: "A Internet é um conglomerado de redes em escala mundial de milhões de computadores interligados pelo TCP/IP que permite o acesso a informações e todo tipo de transferência de dados". Diz ainda que ela tem uma variadade de recursos e serviços, entre os quais estão os documentos interligados por "hiperligações da World Wibe Web, e a infraestrutura para

\footnotetext{
72 Internet é a estrutura organizacional e a ferramenta de comunicação que permite flexibilidade e mobilização, mantendo o carácter de coordenação e a capacidade de focar a mobilização.(Tradução nossa)

73 Internet é uma rede informática global que conecta redes locais ao redor do mundo (Tradução nossa).

${ }_{74}$ A Wikipedia é uma enciclopédia livre que contando com colaboradores aborda cientificamente diversos temas. Cf.: <http://pt.wikipedia.org/wiki/Internet>
} 
suportar correio eletrônico e serviços como comunicação instantânea e compartilhamento de arquivos."

Para finalizar com uma abordagem mais técnica, veja-se a seguir como Monteiro (2001, p. 1) entende a Internet:

\begin{abstract}
A Internet (ou a "Rede" como também é conhecida) é um sistema de redes de computadores interconectadas de proporções mundiais, atingindo mais de 150 países e reunindo cerca de 300 milhões de computadores $^{75}$ e mais de 400 milhões de usuários.
\end{abstract}

O que se pode inferir a respeito das concepções desses autores é que a internet, cujo foco é a informação, tem como função a interação entre as pessoas, além da disseminação global do conhecimento.

Com relação à interação humana, Almeida (2010), avaliando o trabalho de Primo $^{76}$ (2007), observa que o autor relaciona e discute criticamente formas propostas por alguns teóricos que estudaram proficuamente o tema e assim vai aplainando com clareza o terreno para a sua própria proposta dos tipos de interação que existe. No âmbito desse cenário, destacam-se e questionam-se as três situações interativas pensadas por John Thompson, os tipos de sistemas de Raymond Williams, em relação à televisão, as características determinantes para os sistemas interativos de Andrew Lippman, o "cubo da interatividade" de Jens Jensen, entre outras várias propostas executadas para explicar e diferenciar os tipos e graus de interação.

A autora expõe o pensamento de Primo sobre a interatividade: "Questionar a interatividade, segundo Primo, significa se aproximar do todo complexo que envolve a produção, disponibilização, troca e ação no ambiente em rede, através dos processos dialógicos, respeitando uma dinâmica que é antes de tudo um acontecimento relacional e não um fim em si mesmo". Conclui afirmando que Primo condena a passividade sugerida pelos meios de comunicação de massa, indicando que as pessoas que participam da comunicação agem como propulsores de relações cognitivas baseadas em trocas.

\footnotetext{
75 Monteiro (2001, p.1) fornece a referência: DIZARD Jr., Wilson. A nova mídia: a comunicação de massa na era da informação. Rio de Janeiro: Jorge Zahar Ed., 2000.

*Seguramente estes dados do ano de 2000 já se multiplicaram e não refletem a realidade.

76 Primo em parceria com Luciano Coelho, criaram o primeiro robô do mundo a simular diálogos em língua portuguesa na Web, chamado "Cybelle".
} 
Veja-se a seguir o que diz o filósofo da informação a respeito da questão do "interfaceamento":

Se todo processo é interfaceamento, e, portanto tradução, é porque nenhuma mensagem se transmite tal qual, em um meio condutor neutro, mas antes deve ultrapassar descontinuidades que a metamorfoseam. A própria mensagem é uma movente descontinuidade sobre um canal e seu efeito será o de produzir outras diferenças (LÉVY, 1999, p. 183).

Conforme o autor acima referenciado, não há transmissão fiel de nenhuma mensagem, pois não há tradução idêntica, portanto, independentemente do seu mediador, uma mensagem pode sofrer descontinuidade e acarretar diferenças.

É reconhecendo esse cenário que Primo (2007 citado por ALMEIDA, 2010) destaca enfaticamente a relevância da interatividade - um dos conceitos mais importantes para a pesquisa na área de tecnologias digitais. Deve-se admitir o grau de dificuldade quando se trata de definir claramente o que vem a ser interatividade, pois há relacionado a esse conceito uma vasta utilização com variados sentidos, o que inclui a sua exploração como efeito de marketing positivo. No caso em que uma empresa, por exemplo, quer dar a impressão de produto recém-lançado e que estabelece intimidade com o consumidor, o uso publicitário da palavra "interativo" atrai o interesse do consumidor, pois é um termo que pressupõe avanço, relacionamento e aproximação pessoal, no consenso comum.

Segundo ressalta Almeida $(2010)^{77}$, em um outro contexto, percebe-se 0 alargamento da utilização da ideia de interatividade como conceito, no entanto, é como se esse conceito já estivesse esgotado e que sua tradução fosse dada como geral e simbólica por toda a comunidade acadêmica. Em outras palavras, isso implica dizer que muitos pesquisadores se esquecem de travar o embate com o motor da tecnologia, a interatividade, e por diversas vezes, solucionam esse "problema", direcionando o entendimento conceitual para um esclarecimento superficial e tecnicista do conceito, tratando a interatividade como uma possibilidade de meio ou suporte.

Outro fator diferencial e curioso na discussão de Primo (2007 citado por ALMEIDA, 2010) é fazer ressalvas à relevância da interpessoalidade que ocorre nos processos interativos mediados por computador. Um processo de

${ }^{77}$ Op. Cit. 
comunicação extremamente complexo, do ponto de vista relacional e cognitivo que implica, em outras palavras, a interação entre pessoas no ciberespaço.

De acordo com Lévy (1995), o virtual não é o oposto de real, mas sim tudo aquilo que tem potencialidade para existir, portanto, o virtual poderia ser considerado uma potência, um "devir outro do ser humano". Para o autor, as tecnologias de comunicação, de fato, vieram transformar o comportamento das civilizações e a chamada Era do virtual levou a sociedade a uma "instabilidade social" marcada por sua movimentação pelas diferentes regiões do mundo. Dessa forma, os cidadãos passam a ter participação ativa no desenvolvimento da sociedade contemporânea.

A definição de laço social passa pela ideia de interação social, sendo denominado laço relacional, em contrapartida ao laço associativo, aquele que está relacionado apenas ao pertencer (a algum lugar, por exemplo). Os laços associativos apresentam-se em meras conexões formais, que independem de ato de vontade do indivíduo, assim como de custo e investimento.

Os laços sociais podem ser fortes ou fracos. Laços fortes são aqueles caracterizados pela intimidade, pela proximidade e pela intencionalidade por criar e manter uma interação entre as partes. Os laços fracos, por outro lado, sinalizam-se por relações esparsas, que não traduzem proximidade e intimidade. As interações sociais que ocorrem na Internet (em Weblogs, Fotologs e no Orkut) constituem efetivamente laços fortes.

\footnotetext{
Nos últimos anos, a metáfora da rede tem sido observada com atenção renovada, especialmente no que tange à sua aplicação aos sistemas complexos. Uma grande parcela destes estudos dedica-se a tentar compreender as características e propriedades dessas redes, a partir do estudo de suas partes em interação (Barabási, 2003). Vários estudiosos passaram a aplicar a metáfora para os agrupamentos sociais (Watts, 1999 e 2003; Adamic e Adar, 2004; Wellman, 2001 e 2003) e, a partir dessa visão, compreender como as estruturas sociais emergiam (RECUERO, 2007, p.2).
}

Segundo Pinho (2000, p.92), primordialmente a publicidade era concebida como um instrumento da moderna comunicação de marketing, e a partir da propaganda interativa na rede, e, mediante as novas tecnologias, permitiu-se uma transformação no veículo de comunicação publicitária. O autor enfatiza ainda, que as novas tecnologias elaboradas para a Web, são altamente promissoras para 
que a publicidade, de forma efetiva, execute o seu papel na construção de marcas e no relacionamento estável e consistente com os consumidores e demais públicos-alvo.

A mídia digital, que se tornou evidente no final do século $X X$, estabeleceu um cenário caracterizado pela potencialização da circulação de informações, com base em estruturas complexas de redes, assim como do multiplicar de mídias com base em uma plataforma única de linguagem, a digital. Além de ampliar extraordinariamente a emissão e recepção, deu início a uma conversa global, gerando um grande impacto em muitas áreas do conhecimento humano, nas relações sociais, e, de forma mais abrangente, nas relações empresariais.

Os fluxos de informações operando em tempo real possibilitaram uma revolução organizacional. Não obstante a própria indústria da comunicação, que conquistou mercados e produziu modelos de negócios, assim como os sistemas de busca, canais de vendas via Internet, provedores de conteúdo e acesso, entre muitos outros, empresas dos mais diversos setores aprimoraram seu relacionamento com clientes/usuários graças, entre outros aspectos, à informação digital.

Dessa forma, para alcançar maior número de usuários, as bibliotecas e arquivos passaram a integrar-se cada vez mais no mundo da Internet disponibilizando seus acervos e fundos nesse ambiente virtual.

\subsection{CONCEITO DE REDE}

Genericamente a palavra "rede" define um conjunto de entidades, objetos, pessoas, etc, interligados uns aos outros permitindo circular elementos materiais ou imateriais entre cada uma destas entidades, de acordo com regras bem definidas.

O Dicionário Houaiss apresenta a seguinte definição de rede: "sistema constituído pela interligação de dois ou mais computadores e seus periféricos, 
com o objetivo de comunicação, compartilhamento e intercâmbio de dados" (HOUAISS, 2009).

Uma rede (network) é de um conjunto de computadores e periféricos conectados uns aos outros e as tarefas que permitem ligar um computador ao outro para partilhar os recursos em rede são recursos de Instação ou, Network em inglês.

Redes complexas, redes de conexão, redes sociais ou simplesmente redes, é uma recente área interdisciplinar que envolve o formalismo matemático da Teoria dos Grafos e a análise baseada em ferramentas da Mecânica Estatística. Uma rede é um conjunto de elementos que são associados a nós ou vértices cuja ligação entre si se dá por meio de uma aresta (ALVES JÚNIOR, 2007, p.10).

Para a Antropologia o conceito de rede passa por "análise e descrição daqueles processos sociais que envolvem conexões que transpassam os limites de grupos e categorias" (BARNES, 1987, citado por ACIOLI, 2007, p.2).

Logo, trabalhar com a ideia de redes significa trabalhar de forma articulada com a ideia de informação em sua forma mais democrática, portanto: "O termo rede sugere ainda fluxo, movimento, indicando uma aproximação com as mais variadas áreas de conhecimento....78

No âmbito da Sociologia, desde a sua origem, as Redes Sociais possuem um dilema teórico:

\begin{abstract}
A introdução da noção de rede nos estudos sociológicos constitui, logo, um trunfo importante para se avançar a discussão sobre as mobilizações sociais a favor da cidadania, no contexto de sociedades nacionais e mundializadas cujos fluxos permanentes de informações diversas são incorporados e advêm de um processo cultural que excede as memórias nacionais (das lutas sociais, das tradições etc.) e sobretudo a tradição de racionalidade instrumental do sistema burocrático (MARTINS, 2008, p.11-12).
\end{abstract}

Como demonstrado no texto acima, a grande questão que se estabelece tem relação com a identidade cultural, uma vez que as redes sociais atravessam fronteiras em que o fluxo de informação sobre os usos e costumes dos diversos locais do globo não se pode conter e, portanto, é possível que ocorra a influência da tradição cultural de um país para outro. Para finalizar, constatou-se que o conceito de rede em si mesmo já traz a ideia da disseminação da informação.

${ }^{78}$ ACIOLI, 2007, p. 2 (Op. cit.). 
Com o surgimento das mídias digitais, em especial a Internet, até pelo fato de tratar-se de uma mídia globalizada, que possibilita o acesso a organizações regionais tenham acesso ao mesmo meio que uma empresa multinacional com um custo relativamente baixo, oportunizando uma empresa local a tornar-se global, colaborando assim para o desenvolvimento da região na qual está fisicamente situada.

Para abordar as possibilidades de comunicação com o usuário é necessário compreender o panorama atual da cultura digital, na chamada "Sociedade da Informação".

De acordo com Carniello e Zulietti (2007, p. 4), nos anos 1970, Elisabeth Noelle-Neuman $(1995)^{79}$ sugeriu a teoria da Espiral do Silêncio, que evidenciava que a opinião individual era silenciada pela opinião de um grupo de indivíduos, devido a discordância sobre algum assunto comprometeria a aceitação social do mesmo. Escassos, também, eram os canais disponíveis que as pessoas comuns tinham para expressar suas ideias, considerando que o acesso às mídias era privilégio de jornalistas e conglomerados de empresas de mídia.

Com o surgimento das mídias digitais conectadas em rede, cada indivíduo tem a possibilidade de possuir aparelhos eletrônicos diversos, sejam eles computadores ou mesmo aparelhos portáteis sem fio, a exemplo dos celulares.

A livre expressão é o fenômeno manifestado nos blogs, fóruns de discussão, sites pessoais e outros formatos de comunicação via Internet.

Um dos principais efeitos da difusão dos aparelhos de comunicação com base na linguagem digital é o desprendimento do espaço físico (aqui) e da temporalidade (agora), pois se torna real a probabilidade de não estar presente para recriar o diálogo com eficácia nunca alcançada por outras mídias eletrônicas.

O tempo real muda tudo na comunicação. Muda a forma, o conteúdo, o valor e o negócio da comunicação. Muda a forma porque a ausência de bastidores elimina a possibilidade de correção de defeitos e, portanto, a perfeição só será possível na ficção e não mais na realidade das relações (GUIMARÃES, 2002 citado por CARNIELLO; ZULIETTI 2007, p. 4).

79 Referência fornecida por Carniello e Zulietti (2007, p. 4): NOELLE-NEUMAN, E. La espiral del silencio: opinión pública, nuestra piel social. Barcelona: Paidós, 1995. 
Neste cenário, os Arquivos, assim como as empresas, encontram um novo tipo de consumidor: um consumidor expert, familiarizado com as mídias. Isso porque as mídias digitais viabilizam possibilidades de leituras e interação antes submergidas nas mídias de massa. Um leitor navegador fundamentalmente apresenta uma atitude muito mais ativa do que um telespectador de um programa televisivo, por exemplo, considerando que ele pode optar por trilhas de leitura em meio a uma infinidade de sites que se atualizam e se reconfiguram constantemente, tornando assim intermináveis as possibilidades de satisfazer suas necessidades informacionais.

Outro fator, que faz o novo "consumidor" possuir uma postura mais crítica, é a profusão dos mecanismos de produção, gerada, entre outros fatores, pelo aparecimento das mídias digitais. Na atualidade, o fácil acesso às mídias de produção de informação faz com que se possa levar aos lares ou ao ambiente de trabalho toda a informação que necessita podendo divulgar suas imagens ou seus vídeos em escala global através de sites como o youtube por exemplo, bem como ter acesso a artigos científicos ou outros documentos de Centros de Documentação, Bibliotecas e Arquivos.

A interação entre as mídias com base na linguagem digital viabilizou a construção do conjunto de valores que permeiam a sociedade, haja vista a partilha de funções, que podem ser compreendidas como uma integração dessas mídias, o que leva à compreensão de multimídia. Esses novos lugares permitem novas explicações assim como novas formas de contextualização" (BRODY, 1999, p.139-140).

\subsection{REVOLUÇÃO DA INFORMAÇÃO}

Vive-se em uma época em que todos os continentes conferem prioridade à informação. Com a evolução tecnológica a chamada sociedade da informação, foi capaz de, por intermédio da Internet, disseminar o conhecimento com uma velocidade tal, que as pessoas são levadas a uma necessidade de atualização constante das informações que circulam pelo globo. Para tanto, é condição sine 
qua non a familiaridade com as tecnologias da informação e comunicação (TIC). Nessa perspectiva, na luta contra a exclusão digital, há de se considerar também a questão da inclusão social.

Conforme Le Coadic (2004, p.4), informação é um conhecimento registrado em forma de texto, o qual pode ser impresso, digital, oral ou audiovisual contido em um suporte.

De um modo geral, pode-se dizer que a Informação é qualquer manifestação que se preste a informar, comunicar, indicar e esclarecer qualquer tipo de atividade, além de transformar conceitos e estruturas quando aplicados em contextos específicos. Por esta razão, Cohen (2002), já relatava a relevância do contexto da informação, pois existem ocasiões em que a importância de uma informação muda de status ou se extingue, pois uma informação é muito útil a certas pessoas e não ter nenhuma importância para outras.

Com a explosão informacional, devido à grande massa documental produzida a partir do século XIX, também houve um crescimento exponencial nas formas de tratamento dos documentos e divulgação da informação.

Mostafa (1994, p. 22) aponta que principalmente, nas décadas de 1960/70, praticamente todas as disciplinas científicas transformaram a informação numa espécie de epicentro epistemológico.

Quanto ao significado deste conceito, à luz da Epistemologia, pode-se dizer que todo conhecimento torna-se um autoconhecimento, devido à pertinente conexão do meio com o indivíduo que, por sua vez, pertence ao próprio meio. Essa interação torna-se racionalmente necessária e mais um elemento entre os muitos integrantes do mundo da vida, destacando que o homem faz parte desse universo. Assim, há uma adaptação do indivíduo observador ao meio, e vice versa. Ele modifica o meio e é por ele modificado (TRINDADE, 2007, p. 97)

A Epistemologia é um ramo da filosofia que estuda a origem, a estrutura, os métodos e a validade do conhecimento, motivo pelo qual também é tipicamente conhecida por filosofia do conhecimento. Portanto, estudar algum tema à luz da Epistemologia é estudar a lógica teórica e prática do mesmo, este conceito pode ter sua origem a partir de Platão, pois ele opõe a crença ou opinião 
ao conhecimento. Uma vez que a crença é um ponto de vista subjetivo e o conhecimento é a crença justificada, por assim dizer.

O fato é que toda mudança tecnológica importante provoca, certo tempo depois, mudanças sociais ainda mais importantes, e as mudanças sociais que a Internet causou já são notadas com clareza.

De acordo com Mariz (2005, p. 15), a chamada "Revolução da Informação", que possui também um "gatilho" e símbolo, o computador, também percorreu a exemplo das revoluções da imprensa e da industrial, uma trajetória semelhante às citadas. Os processos não sofreram grandes alterações, apenas foram informatizados, os softwares nada mais fazem do que processar cada vez mais rápido as rotinas, ou seja, apenas se realiza o "antigo" de maneira diferenciada.

No que se refere à resistência às mudanças o conservadorismo das pessoas incide especialmente no campo das interfaces de usuário. Poderíamos dizer que uma melhora na ergonomia sobre uma interface de usuário tem uma probabilidade de êxito inversamente proporcional ao tempo necessário para aprender a nova interface. Sobre esta ótica podemos avaliar muitos fenômenos sociotecnológicos que parecem surpreendentes à primeira vista. Stephenson $(2003)^{80}$ cria uma divertidíssima analogia entre os sistemas operativos dos computadores e diversos tipos de veículos, e se surpreende que a gente pague pelos "monovolumes" com os que representam a Windows mais que os "esportivos" do Apple.

A Web permitiu a navegação não linear por um espaço amplo de informação multimídia. Em relação ao meio digital, veja-se a distinção de leitura a seguir:

\begin{abstract}
A linguagem da nova mídia está sendo descoberta e, para complicar, é mutável (vai evoluindo com a tecnologia e a experiência). Não se lê na Web do mesmo jeito que se faz no meio impresso. Portanto, não se deve escrever na Web do mesmo jeito do que, no meio impresso. O papel absorve luz, a tela do computador emite. A partir deste ponto, começam muitas diferenças. Até recentemente muitos dos sites na Web procuravam imitar o meio impresso. Aos poucos, está se descobrindo a linguagem da nova mídia, em certos aspectos parecido com o rádio, em certos aspectos com a televisão, em certos aspectos com nada que se tenha conhecido até então (MARTINEZ, 2000, p. 9).
\end{abstract}

\footnotetext{
${ }^{80}$ Citado também por Francisco Serradilla, doutor em Informática, em seu blog. Disponível em: http://librodenotas.com/computacion/. Acesso em: 13 abr. 2010.
} 
Como referenciado pelo autor, a linguagem midiática vem evoluindo a cada dia. A sua leitura é diferente e consequentemente escrever nesse suporte também. A linguagem HTML e suas Interfaces tridimensionais estão sendo cada vez mais utilizadas. A hipermídia agrupa os atributos de não-linearidade do hipertexto. Só que a diferença deste, envolve outras mídias além do texto: imagens, sons, vídeo, animações.

\begin{abstract}
A hipermídia é uma tecnologia que permite leitura e escrita não linear, o que favorece o desenvolvimento de um pensamento complexo. É muito difícil prever as ações do usuário no hiperespaço. Em cada nó de informação, normalmente ele se depara com muitas possibilidades de escolha para conduzir sua própria navegação (LEÃO, 1999 citado por MARTINEZ, 2000, p. 9) ${ }^{81}$.
\end{abstract}

A linguagem HTML vem evoluindo e as Interfaces tridimensionais estão sendo cada vez mais utilizadas. Este fato nos leva a uma reflexão: Até que ponto os fundos de Arquivo podem ser disponibilizados em uma página de Internet sem perder seu valor testemunhal? O poder tocar num documento sempre foi o ponto forte dos usuários de Arquivo, já que seus fundos são fruto de atividades desenvolvidas em instituições e têm caráter histórico. Nesse sentido, para alcançar maior número de usuários os arquivos passaram a integrar-se cada vez mais no mundo da Internet disponibilizando seus acervos e fundos na Internet até a visualização dos documentos, o que constitui um grande avanço para a democratização dos mesmos, ou seja, cumprir seu papel no que diz respeito à disseminação da Informação de uma maneira globalizada.

\title{
3.4.1 Recuperação de Informação
}

A expressão Information Retrieval (Recuperação de Informação) foi criada em 1951 por Calvin Mooers.

A Recuperação de Informação trata dos aspectos intelectuais da descrição da informação e sua especificação para busca, e também de

${ }_{81}$ Cf. Trabalho baseado em tese financiada pela Fundação de amparo à Pesquisa do Estado de São Paulo (Fapesp): LEÃO, Lúcia. O labirinto da hipermídia: arquitetura e navegação no ciberespaço. Editora Luminuras Ltda. 1999. 
qualquer sistema, técnicas ou máquinas que são empregadas para realizar esta operação (MOOERS, 1951 citado por FERNEDA, 2003, p.11).

Segundo o princípio ao qual atribuiu o seu próprio nome, a Lei de Mooers postula: "Um sistema de recuperação de informações terá a tendência de não ser usado se é mais irritante e problemático para um usuário obter a informação do que não obtê-la" (MOOERS, 1960 citado por DIAS, 2003).

A Lei de Mooers está voltada para o processamento e uso da informação pelo usuário e não para a funcionalidade do sistema de recuperação de informações.

O usuário é a peça-chave em relação aos processos de criação dos sistemas, portanto as interfaces devem ser projetadas para atender às suas necessidades. Segundo Oliveira (2004, citado por SILVA; DIAS; SENA JÚNIOR, 2008, p. 2), "os sistemas que tendem a incomodar ou frustrar os usuários não podem ser sistemas eficazes, seja qual for seu grau de elegância técnica e de eficácia no processamento de dados". Essa afirmação leva à Lei de Mooers, pois defende que um sistema de informação não será usado se for mais difícil obter a informação do que não obtê-la (SARACEVIC, 1996; DIAS, 2002 citados por SILVA; DIAS; SENA JÚNIOR, 2008, p. 3).

No que respeita à recuperação de informação, a preocupação também deve ser um resultado que atenda às expectativas dos usuários.

Segundo Ferneda (2003, p. 11-12), o foco na recuperação da informação provocou questionamentos que foram estudados por diversos autores. "Maron e Kuhns (1960) publicaram os princípios básicos do modelo probabilístico para a recuperação de informação, que mais de 15 anos depois seria formalmente definido por Robertson e Jones (1976, p.11)". A autora continua informando que, segundo Salton (1971), a pesquisa de Gerard Salton resultou no Projeto Smart (Sistem for the Manipulation and Retrieval of Text) que produziu um modelo de recuperação de informação, inúmeros artigos científicos, além de criar e aprimorar diversas técnicas computacionais e o sistema Smart ${ }^{82}$.

\footnotetext{
${ }^{82}$ O sistema Smart, desde de sua criação, incluía termos de indexação através de mecanismos de análise linguística, servindo até hoje como referência para outros sistemas de recuperação de informação (Cf. FERNEDA, 2005, p. 45).
} 
Segundo essa autora, o sistema Smart, desde de sua criação, incluía termos de indexação através de mecanismos de análise linguística.

Atualmente, a maioria dos Arquivos, na Espanha, a exemplo das bibliotecas, trabalham em prol do usuário com a preocupação de serem os mais democráticos possíveis cumprindo com as exigências do seu caráter social, garantido pela legislação vigente. Para cumprir com seu papel difusor, os Arquivos também devem estar atentos ao modo como as informações referentes aos seus fundos podem ser recuperadas. A Recuperação de Informação (RI) é uma área da informática voltada para 0 armazenamento e recuperação automática de informação contida em documentos. Trata-se de uma ciência, que busca através de metadados que descrevem os documentos e os buscam em base de dados, que tanto podem ser interligados em rede de hipermídia como a WWW ou independentes.

Os sistemas de Recuperação, por conseguinte, constituem-se no elo mais importante entre a informação e o usuário. Há vários recursos utilizados na busca de informações disponíveis na Internet, assim como distintos mecanismos e diretórios que viabilizam a recuperação da informação na Web e sua disseminação.

Sobre os mecanismos de busca existentes, há alguns estudos que merecem destaque pela sua abrangência e profundidade. Um dos trabalhos considerados pelos pesquisadores de grande importância na área, por sua complexidade, é a compilação How to Choose a Search Engine or Research Database $^{83}$ (COHEN, 1999), que especifica tanto as categorias como o tipo de informação desejada, além de apresentar quais são os mecanismos que poderão ser utilizados pelo usuário na recuperação de informação.

As bases de dados de Arquivos também exercem função relevante na recuperação das informações. As informações de Arquivo disponibilizadas na Internet promovem crescimento da interação com o usuário, reduzindo a distância entre eles.

\footnotetext{
${ }^{83}$ Obra que trata da escolha adequada do motor de busca e ensina a pesquisar em banco de dados.
} 
As bases de dados são registros em estrutura regular que permitem a sua reorganização e produção de informação que geralmente agrupa registros utilizáveis para um mesmo fim.

Segundo Sayão (1996), as bases de dados são os repositórios dos conhecimentos consensuais gerados pela ciência moderna, constituindo, dessa forma, a memória da ciência oficialmente aceita. São suportadas por uma tecnologia que permite a simulação, a ilusão de um diálogo, de uma interação em tempo real em uma linguagem que está cada vez mais próxima das linguagens naturais. Complementando seu pensamento, o autor se refere às bases de dados como: A metáfora da memória da ciência que se pratica hoje reunindo os testemunhos de pesquisadores com uma linguagem própria, "que parece ser mais um instrumento na eterna busca da pedra filosofal da ciência, que é a busca da ordem, do enquadramento, da classificação em um mundo cada vez mais desordenado e mais entrópico" (SAYÃO, 1996, p. 317).

Um ambiente de biblioteca pode ser alterado com a introdução das bases de dados: "[...] a coleção de dados que serve de suporte a um sistema de recuperação de informações" (CUNHA, 1984). 


\begin{tabular}{|l|l|}
\hline $\begin{array}{l}\text { 1. Aquisição de informação de um agente } \\
\text { externo; }\end{array}$ & $\begin{array}{l}\text { Estas duas primeiras etapas se referem a } \\
\text { quando e como os vários intermediários } \\
\text { adquirem e transmitem informaçães que estão } \\
\text { dispostos a compartilhar e que aspectos da } \\
\text { informação são compartilhados. }\end{array}$ \\
\cline { 1 - 1 } $\begin{array}{l}\text { 2. Comunicação desta informação para o } \\
\text { resto da organização; }\end{array}$ & $\begin{array}{l}\text { A terceira etapa consiste na implementação } \\
\text { de um modelo de boas práticas. }\end{array}$ \\
\hline $\begin{array}{l}\text { 3. Aplicação e, em seguida, aprovação e da } \\
\text { informação na organização; }\end{array}$ & $\begin{array}{l}\text { A quarta etapa é, sem dúvida, a fase mais } \\
\text { importante da transferência do conhecimento, } \\
\text { uma vez que representa o processo de } \\
\text { aprendizagem cumulativo que envolve } \\
\text { mudanças nas habilidades dos indivíduos e } \\
\text { atitudes } \\
\text { e rotinas organizacionais como um resultado } \\
\text { direto do uso de } \\
\text { conhecimentos adquiridos. }\end{array}$ \\
\hline 4.assimilação dessas informações
\end{tabular}

Quadro 25 - Etapas de transferência da informação segundo Gilbert e Cordey-Hayes (1996) - a autora

Todo o fluxo da comunicação universal envolve a premissa de reduzir as barreiras presentes na transferência de conhecimento na "Sociedade da Informação". Baseando-se nesse conceito, as bases de dados que são quem de fato interpretam a informação dentro do processo da transferência de conhecimentos exercem um importante papel difusor.

Este processo de interpretação em si mesmo, de acordo com Gilbert e Cordey-Hayes (1996, p.302), consiste num processo de aprendizagem internalizada pelo ator (indivíduo ou organização).

De acordo com Novelino (1996, p. 37), o processo de representação da informação envolve dois passos: 1) análise do assunto de um documento e a colocação do resultado desta análise numa expressão linguística e 2) atribuição de conceito ao documento analisado. 


\subsubsection{Interação Humano-Computador}

Em todo o processo de busca de informação, além das questões da representação do próprio documento, entra em questão a expectativa do usuário. Esse conceito ao documento em parte depende da satisfação da necessidade de informação do usuário.

Os arquivistas costumam se preocupar com medidas e quantidades exatas e se perguntam se apesar de todos os esforços desprendidos estarão realmente satisfeitas as necessidades do pesquisador, já que as solicitações deste contêm em si mesmas certas limitações. Há que se considerar também as limitações do próprio usuário quando da descrição de suas necessidades imediatas. Dentro dessa perspectiva, os pedidos de material não significam exatamente que as necessidades foram satisfeitas, e essa dificuldade em comunicar o que realmente deseja pode causar no usuário uma sensação de indiferença em relação ao seu problema. Portanto, para solucionar tal impasse, faz-se necessário orientar os usuários sobre os serviços e recursos que possui o Arquivo para que eles possam trabalhar em parceria com o pessoal de Arquivo (TAYLOR, 1984, p.20).

Bettiol (1990) faz uma revisão de estudos estrangeiros sobre necessidades de informação, onde são enfocados muitos aspectos sobre a definição do tema numa área de difícil definição. A conclusão que a autora considerou mais plausível para uma definição sobre necessidade de informação é a de que varia de grau de intensidade de uma para outra pessoa, é independente na sua essência e pode ser alterada dependendo do ambiente sócio-político-cultural que afeta o usuário.

Hyodo (2009) analisa os artigos publicados na revista brasileira Ciência da Informação, no período 1997-2007, por meio das pesquisas sobre as necessidade de informação do usuário, com a finalidade de identificar outros estudos que deram suporte às pesquisas relacionadas a bibliotecas e serviços de informação. A conclusão desse estudo comprova que ainda não existe uma base teórica nacional a exemplo do que também revela a literatura estrangeira sobre o tema.

Segundo Bettiol (1990, p. 60), é comum se encontrar estudos a respeito de uso e usuários de bibliotecas públicas. A pesquisa de Zweilzig e Dervin (1977) 
identificou 16 estudos relacionados a usuários de bibliotecas públicas, contendo a avaliação de uso dessas bibliotecas por meio das respectivas estatísticas de circulação.

Os estudos sobre usuários de bibliotecas ou Arquivos nos remetem ao papel da informação na vida dos mesmos e a maneira como as instituições informativas interagem com o usuário, na busca e recuperação de informação, considerando a importância da Interface de usuário.

A interface de usuário, por conseguinte, é uma parte essencial de um sistema Web bem sucedido, pois é por meio dela que o usuário pode realizar suas tarefas de maneira eficiente e satisfatória.

O objetivo precípuo da área de Interação Humano-Computador (IHC) é fornecer, aos pesquisadores e desenvolvedores Web, informações necessárias para prever os resultados práticos do fenômeno da interação entre o usuário e o sistema (SOUSA, 1999). Isso justifica a preocupação dos pesquisadores dessa área quanto ao design de interfaces de usuário.

Entende-se por interface, o mecanismo que liga dois sistemas.

\begin{abstract}
No processo de interação usuário-sistema a interface é o combinado de software e hardware necessário para viabilizar e facilitar os processos de comunicação entre o usuário e a aplicação. A interface entre usuários e sistemas computacionais diferencia-se das interfaces de máquinas convencionais por exigir dos usuários um maior esforço cognitivo em atividades de interpretação e expressão das informações que o sistema processa (NORMAN, 1986).
\end{abstract}

A interface de usuário oferece as funções de aplicação, bem como os comandos e as mensagens auxiliares que formam o sistema, por meio dos quais interage com o usuário. Portanto o design de interfaces de usuário é um dos pontos mais importantes na área da Interação Humano-Computador (HumanComputer Interation). Dentro desse tema, existe uma área complementarmente preocupada em comunicar os modelos de interação para o usuário: a Engenharia Semiótica. Segundo Souza et al. (1999) a Engenharia Semiótica objetiva explorar a metacomunicação dos sistemas oferecendo ao Webdesigner os instrumentos para que ele ensine aos usuários como projetou o sistema e que soluções apresentam para os possíveis problemas e dificuldades de interação com o mesmo. 
Conforme Ferreira (1999), os catálogos online (OPACS) são o resultado de mais de duas décadas de automação de bibliotecas e são considerados instrumentos de busca e fontes de informação por meio dos quais os usuários podem ter acesso à descrição de qualquer material da biblioteca que possua esse serviço. Segundo esse autor, o desenvolvimento dos métodos para a disseminação dos documentos seria uma das maiores preocupações do século $\mathrm{XXI}$, nessa área, considerando o catálogo online de grande valor no processo de distribuição e transferência da informação.

$\mathrm{Na}$ maioria dos sistemas de recuperação da informação e através dos catálogos online, o usuário tem acesso às informações através de expressões podendo-se utilizar operadores boleanos lógicos para ligar os elementos e escolher os campos para delimitar as buscas.

Com o aumento da quantidade de documento disponibilizados, não é suficiente predizer um ou mais termos utilizados para indexar os documentos desejados, é necessário também evitar a recuperação de documentos não-relevantes, minimizando o esforço da tarefa de verificar a relevância de tais documentos (FERNEDA, 2003, p. 17).

O sistema de busca ${ }^{84}$ compara as representações dos documentos com a expressão de busca utilizada pelo usuário e posteriormente recupera a informação desejada por este (ao menos é isso que se espera). Esse processo, no entanto, não garante que os documentos recuperados sejam de fato relevantes. Os resultados da busca são geralmente expressos por meio de uma lista de referências de documentos, cujo êxito de sua recuperação se mede pela relação entre os documentos que são relevantes e os que não são; os que são recuperados e os que não são (LE COADIC, 2004, p. 80). Deve-se, contudo, considerar a natureza subjetiva do aspecto "relevância".

Para finalizar, é relevante ratificar que a eficiência de um sistema de recuperação de informação depende muito do modelo de recuperação de informação utilizado. $O$ modelo em questão deve basear-se, na verdade, no modelo mental dos usuários, não discrepando das características e funcionalidade da Interface Humano-Computador (IHC), pois essa compatibilidade entre usuário-sistema se refletirá na capacidade de uso, ou seja, na usabilidade

\footnotetext{
${ }^{84} \mathrm{~A}$ função buscar pode aparecer de maneira distinta de acordo com o motor de busca utilizado.
} 
do sistema. No processo de recuperação da informação, a Usabilidade envolve o usuário, a busca de informação e os resultados. (Cf. Capítulo 4).

Na opinião de Jiménez Piano e Ortiz-Repiso Jiménez (2007, p. 245), não é possível voltar atrás no terreno da difusão da informação que havia antes do fenômeno da Internet e da Web, considerando a rapidez com que se produzem mudanças, é necessário criar instrumentos de avaliação e controle para incrementar o desenvolvimento científico e aproximar-se da verdadeira sociedade da informação e do conhecimento.

No caso dos Arquivos, devido à grande variedade de situações existentes, é necessário adaptar-se à nova Sociedade da Informação dentro da realidade de cada situação.

"Si tuviéramos que elegir un marco ideal, sería el de un archivo donde encontremos el mejor equilibrio entre volumen de gestión y recursos" (CERDÁ DíAZ, 2002, p. 4$)^{85}$.

Os Arquivos normalmente não são competitivos entre si mas todos têm, enquanto fontes de informação valiosa que são, a necessidade de fazer-se conhecer e ser valorizado, neste sentido devem lutar para encontrar esse equilíbrio de recursos e boa gestão de seu acervo documental.

Neste propósito de tornarem-se conhecidos, muitos Arquivos, Históricos ou não, segundo García González e Chaín Navarro (2009, p. 6), decidiram criar suas páginas na Internet, sobretudo para satisfazer as necessidades de informação dos usuários e, neste sentido, a meta é o acesso virtual aos documentos e aos serviços dos Arquivos, portanto, essas interfaces devem estar em equilíbrio com a formação do usuário.

\footnotetext{
${ }^{85}$ Se fosse para escolher um marco ideal, este seria um arquivo onde se encontrasse maior equilíbrio entre gestão e recursos (Tradução nossa).
} 
Capítulo 4

\section{AVALIAÇÃO DE SITES}

Este capítulo apresenta os critérios de avaliação de sites, mas detidamente a usabilidade e a visibilidade em torno dos quais se concentra este estudo. 


\subsection{AVALIANDO SITES}

Lo importante es no dejar de hacerse preguntas.

(Albert Einstein)

Ao partir do princípio de que qualquer site disponível na Internet pode ser avaliado, muitos autores se dedicaram a discorrer sobre essa temática.

Segundo Ribeiro (2005, p. 3), uma referência obrigatória em matéria de avaliação de informação é o clássico livro de Lancaster ${ }^{86}$ (1993), obra que traz muito conhecimento e uma análise profunda dos serviços que devem ser avaliados, considerando os problemas abordados na área de Gestão, que foi editado em 1988 e revisto em 1993, e concentra orientações e procedimentos práticos para qualquer tipo de contexto bibliotecário, podendo ser aplicado a outros tipos de serviço de informação.

Apesar de existir grande diversidade de experiências sobre avaliação de sistemas de informação, este capítulo não pretende resgatar a bibliografia da área, e sim, apresentar alguns dos autores e seus critérios que vão orientar as avaliações dos sites dos Arquivos espanhóis, objeto desse estudo.

\subsection{CRITÉRIOS DE AVALIAÇÃO DE PÁGINAS WEB (SITES)}

Na última década, surgiu na Europa a preocupação com a Gestão da Qualidade quando as empresas começaram a montar estratégias para implementar os métodos de trabalho e assim melhorar o desempenho global da empresa. Logo depois, essa preocupação com a Qualidade Total de produtos e serviços passou a ser uma preocupação mundial. Nesse sentido, com o crescimento galopante de informações disponíveis na Internet, os criadores de

\footnotetext{
${ }^{86}$ Referência fornecida por Ribeiro (2005, p. 3): LANCASTER, F. W. - If you want to evaluate your library... 2nd ed. London: Library Association Publishing, 1993. ISBN 1-85604-083-6.
} 
Websites começaram a se preocupar com a o fator qualidade, sobretudo pensando no público a que se destina.

Segundo Negrete Gutiérrez (2002, p. 54), bibliotecários e/ou documentalistas estão ampliando a gama de recursos que podem oferecer aos usuários, ao tornar disponíveis recursos em formato digital, pois apresenta grande vantagem sobre os materiais impressos, devido à facilidade com que a informação é localizada e manipulada. Obter informação por meio digital para satisfazer à demanda, no entanto, requer no caso das Bibliotecas e Arquivos, por exemplo, como pressuposto suficiente, infraestrutura adequada de equipe, programas, apoio profissional e licenças de acesso a diversos serviços e produtos que se oferecem atualmente. Em face dessas condições, a seleção de recursos digitais, sobretudo dos recursos de informação acessíveis por meio de um site, torna-se mais complexa devido às várias características desses tipos de recursos, além das necessidades específicas de ferramentas ou equipamentos de acesso.

Los recursos electrónicos/digitales, indudablemente, están impactando no solamente a la organización de la biblioteca, la estructura de sus departamentos, sus funciones, procesos y el modo en que se ofrecem los servicios a los usuarios, sino también al sistema de comunicación tradicional ${ }^{87}$ (NEGRETE GUTIÉRREZ, 2002, p. 54).

$\mathrm{Na}$ atualidade, a seleção de recursos exige um maior compromisso profissional dos responsáveis na tomada de decisões, devido, especialmente, aos seguintes motivos:

[...] al crescimiento exponencial de la información em línea, a La existencia de una tipología documental múltiple, a la inestabilidad debida a continuas actualizaciones que conlleva su disponibilidad temporal, y al requerimiento de confiabilidad $^{88}$ (GARDUÑO citado por NEGRETE GUTIÉRREZ, 2002, p.55).

A disseminação galopante das informações no ciberespaço exige dos profissionais de informação, entre outros requisitos, uma atenção redobrada com respeito às constantes atualizações informacionais e variações tecnológicas.

\footnotetext{
${ }^{87}$ Os recursos eletrônico/digitais, indubitavelmente, estão impactando não somente à organização da biblioteca, a estrutura de seus departamentos, suas funções, processos e o modo em que se oferecem os serviços aos usuários, mas também ao sistema de comunicação tradicional (Tradução nossa).

${ }^{88}$ [...] ao crescimento exponencial da informação on-line, a existência de uma variada tipologia documental, à instabilidade devido às constantes atualizações que envolvem sua disponibilidade sazonal, e a exigência de confiabilidade. (Tradução nossa).
} 
Sobre a satisfação do usuário diversos autores passaram a concentrar seus estudos nos critérios mais adequados para se avaliar uma página Web levando em consideração a influência direta de sua ineficácia ou ineficiência nos resultados pretendidos na busca por informações.

Ribeiro $(2005$, p.5) afirma que a fundamentação para todo o trabalho de avaliação dos sistemas de recuperação da informação tem como base estudos que datam dos anos cinquenta e sessenta e destaca alguns projetos:

\begin{abstract}
as referências fundamentais nesta matéria continuam a ser os célebres Projetos de Cranfield I e II, desenvolvidos por Cyril Cleverdon entre 1957-1963, o Projecto SMART, concebido por Gerard Salton entre 1965 e 1968, e a avaliação do Sistema MEDLARS (Medical Literature Analysis and Retrieval System), levada a efeito por F. W. Lancaster, nos anos de 1966 e 1967(RIBEIRO, 2005, p. 5) ${ }^{89}$.
\end{abstract}

Não há, porém, uma uniformidade quanto ao melhor critério a ser utilizado para avaliar um site.

\begin{abstract}
Não somente existe pouca concordância entre as fontes sobre quais critérios são mais importantes ou mais apropriados para avaliar um site, como também poucos desses critérios aparecem em revisões, sugerindo uma falta de consenso continuada (SWEETLAND, 2001, citado por FURQUIM, 2004, p. 49).
\end{abstract}

$\mathrm{Na}$ avaliação de páginas Web, faz-se necessário que as Instituições que estão entre elas e as informações, ou seja, os Arquivos, as Bibliotecas ou Centros de Documentação, por exemplo, conheçam suas dificuldades ou carências para que, a partir desses estudos, possam melhorar os serviços oferecidos aos seus usuários, e também possam se moldar às exigências da competitividade atual, aproveitando ao máximo seus recursos.

"Os novos critérios aplicáveis à informação eletrônica tem gerado grande quantidade de informação, porém existe uma grande falta de homogeneidade e sistematização nos estudos que se tem realizados sobre a avaliação de Websites" (JIMÉNEZ PIANO; ORTIZ-REPISO JIMÉNEZ, 2007, p.71). Segundo tais autoras, a maior parte da bibliografia sobre avaliação de Websites conta com uma estrutura parecida, cujo resultado consta de uma lista de critérios constituídos por

\footnotetext{
${ }^{89}$ Segundo o referido autor, existe muita informação publicada sobre esses projetos, seja para descrever os métodos, criticar os resultados ou discutir metodologias e métodos de avaliação de sistemas de informação.
} 
indicadores e os quais formam um questionário com um modo de pontuação ou não.

Ainda a respeito dos distintos critérios de avaliação das páginas Web, o fato de não haver coincidências entre os critérios específicos na literatura de referência, dificulta a sua sistematização. "Os critérios específicos que se encontram na bibliografia são de difícil sistematização, pois em nenhum caso coincidem totalmente" (GORDON-MURNAME, 1999 citado por JIMÉNEZ PIANO; ORTIZ-REPISO JIMÉNEZ, 2007, p. 72).

Em cada critério, assinalam-se várias perguntas ou questionamentos que o avaliador deverá responder (CODINA, 2000, p.29-30; KOVACS, 2000, p. 345-347; White e CRAWFORD, 1997, p. 53-57 citado por NEGRETE GUTIÉRREZ, 1999, p.58)

Gutierrez (2002, p. 59) considera os seguintes critérios: Conteúdo, Autoria, Atualização, Facilidade de uso, Apresentação, Interatividade e Adequação. A autora apresenta também as perguntas pertinentes a cada critério, também chamados neste trabalho "indicadores".

Essas informações foram dispostas em um quadro para facilitar a visualização dos indicadores de cada critério, conforme observamos a seguir:

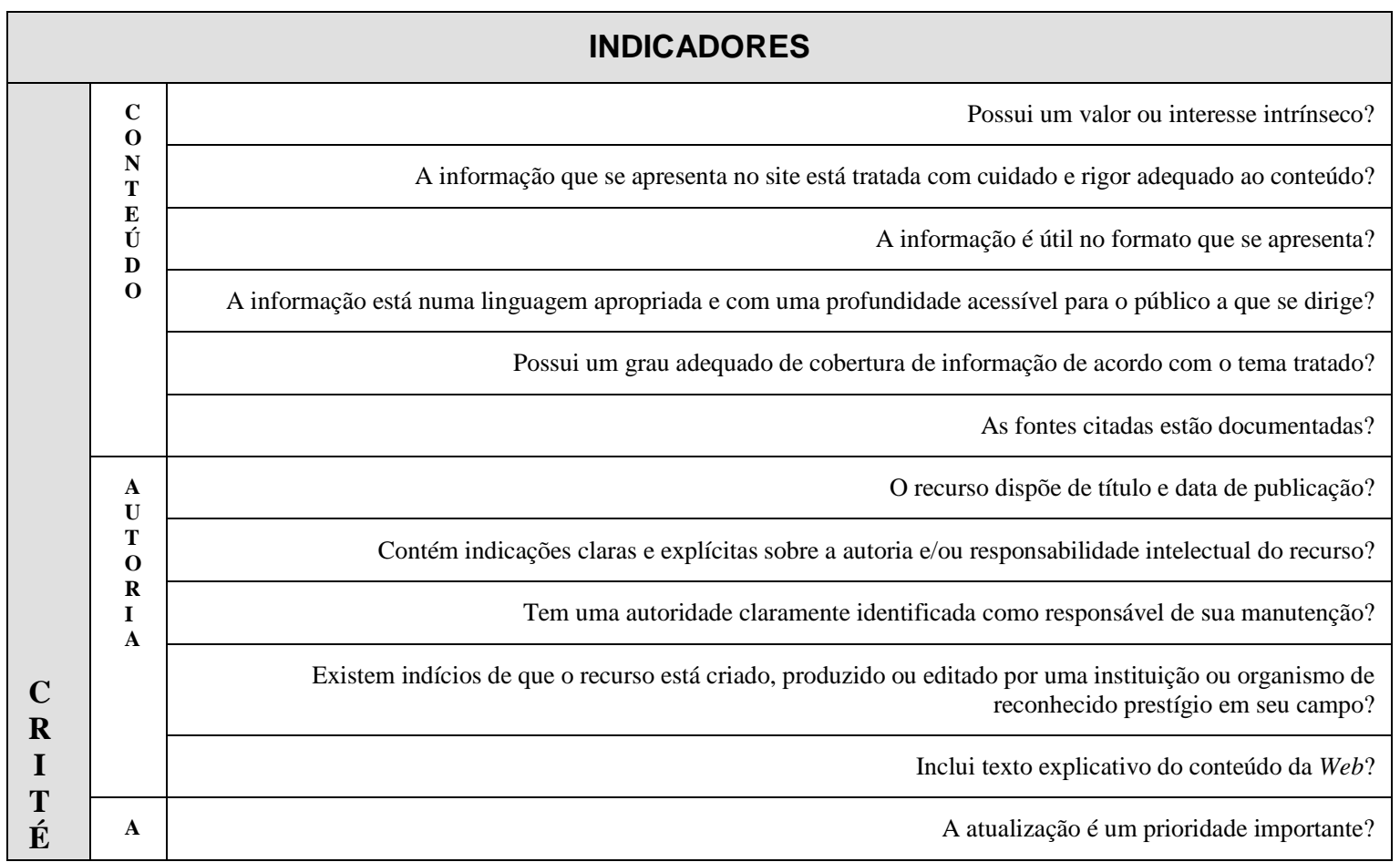




\begin{tabular}{|c|c|c|}
\hline $\mathbf{R}$ & $\begin{array}{l}\mathbf{T} \\
\mathbf{U}\end{array}$ & A informação é atualizada regulamente? \\
\hline $\mathbf{O}$ & $\mathbf{L}$ & Aparece claramente a data em que a fonte foi atualizada pela última vez? \\
\hline & $\begin{array}{l}\mathbf{Z} \\
\mathbf{A} \\
\mathbf{C} \\
\tilde{\mathbf{A}} \\
\mathbf{O}\end{array}$ & Aparecem as datas das revisões dos links externos? \\
\hline & $\mathbf{F}$ & O site está acessível para usuários com necessidades especiais? \\
\hline & C & Está claro como navegar através das páginas do recurso? \\
\hline & I & O site está bem organizado ao largo de linhas lógicos? \\
\hline & $\begin{array}{l}\text { A } \\
\text { D }\end{array}$ & Apresenta um mapa do site? \\
\hline & $\mathbf{E}$ & Os botões e itens dos menus estão claramente etiquetados e de maneira útil? \\
\hline & $\mathbf{E}$ & Se o site usa "frames" estão aplicados de maneiras significativas que ajudam a navegação? \\
\hline & $\begin{array}{l}\mathbf{U} \\
\mathbf{S}\end{array}$ & Existe uma percentagem alta de links mortos ou inativos interna ou externamente? \\
\hline & & A recuperação da informação é feita através de busca por palavras ou frases? \\
\hline & & É possível utilizar operadores booleanos? É possível utilizar outros operadores? \\
\hline & & Existe ajudas e sistemas de recuperação de informação adicionais? \\
\hline & & É rápido o carregamento da página? Que faz com que seja demorado o carregamento da página? \\
\hline & A & A informação está apresentada clara e logicamente em um formato útil para a audiência a que vai dirigida? \\
\hline & $\begin{array}{l}\mathbf{R} \\
\mathbf{E}\end{array}$ & O recurso possui um sumário geral que representa seu conteúdo global? \\
\hline & $\mathbf{E}$ & A interface é clara e fácil de usar? \\
\hline & T & Os elementos da navegação são claramente identificados? \\
\hline & Cֶ̃ & Os links a outras páginas são fáceis de encontrar? \\
\hline & & Como aparece o site no "browser" (navegador)? \\
\hline & & Está disponível a versão "somente texto" no site? \\
\hline & & $\begin{array}{l}\text { Os usuários com necessidades especiais teriam dificuldade para usar o site? (Problemas potenciais: letra pequena, } \\
\text { pouco uso de espaço em branco, "frames", falta de cor de contraste entre elementos, etc). }\end{array}$ \\
\hline & & O recurso contém algum tipo de índice temático, alfabético, de nomes, etc? \\
\hline & & Se usam os mesmos códigos textuais e icônicos para representar as mesmas funções, ações ou dados? \\
\hline & I & Se pode perguntar, sugerir ou enviar mensagens ao administrador do site? \\
\hline & $\mathbf{E}$ & Se pode realizar alguma classe de atividade ou transações? \\
\hline & $\begin{array}{l}\mathbf{A} \\
\mathbf{T}\end{array}$ & Permite carregar software ou ficheiros gráficos? \\
\hline & V & Contém links externos? Os links são avaliados? \\
\hline & $\begin{array}{l}\text { D } \\
\text { A }\end{array}$ & \\
\hline & $\mathbf{E}$ & \\
\hline & A & O recurso é aproveitado pelas características únicas do meio? \\
\hline & $\mathbf{E}$ & obra impressa ou não impressa que apresenta a informação de maneira melhor do que a que existe no \\
\hline
\end{tabular}




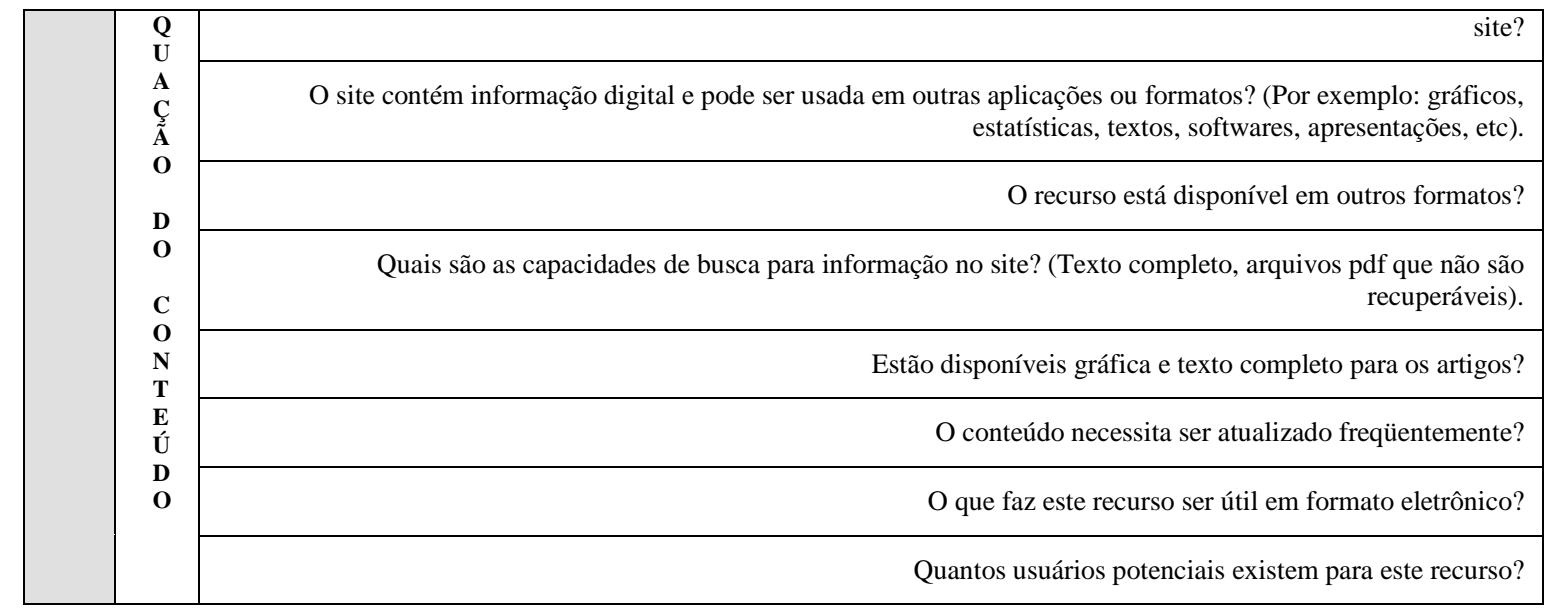

Quadro 26 - Critérios de avaliação propostos por Gutierrez (2002) (autoria nossa)

Jiménez Piano e Ortiz-Repiso Jiménez (2007), por sua vez, analisaram uma extensa bibliografia a respeito dos critérios de avaliação de páginas Web, que os levaram à revisão e ao estudo de 110 sites ou artigos de periódicos, 68 dos quais apresentavam cada qual uma lista de critérios específicos para a avaliação de sites, chegando à conclusão de que a maioria dos autores são de universidades norte-americanas e que na maioria dos casos a avaliação se centra em sites científicos. Observaram também que apesar de não coincidirem na terminologia, quase todos consideram os mesmos elementos utilizando nomes diferentes. Os termos escolhidos finalmente foram: Critério, Categoria e Indicador (do mais geral ao mais específico). Das 68 listas de critérios analisadas por Jiménez Piano e Ortiz-Repiso Jimenéz (2007), 83\% são dos Estados Unidos e Canadá, 9\% da Europa, 7\% da Oceania e 1\% sem registros de procedência. Segundo Jiménez Piano e Ortiz-Repiso Jiménez (2007) a lista de critérios de Lluis Codina (2000, p. 24) foi a primeira a ser publicada em espanhol e é especialmente importante devido às reflexões metodológicas que contém.

Jiménez Piano e Ortiz-Repiso Jiménez (2007) analisaram os critérios apresentados nestas listas e seus elementos, escolhendo enfim os que mais foram citados e considerados de grande importância pelos autores. Os critérios escolhidos formam o acrônimo BRACAD: Busca e Recuperação de informação; Autoridade; Conteúdo; Administração e Desenho. Estes cinco critérios se dividem em vinte e uma categorias com seus indicadores. Apresentamos abaixo um esquema geral do questionário BRACAD: 


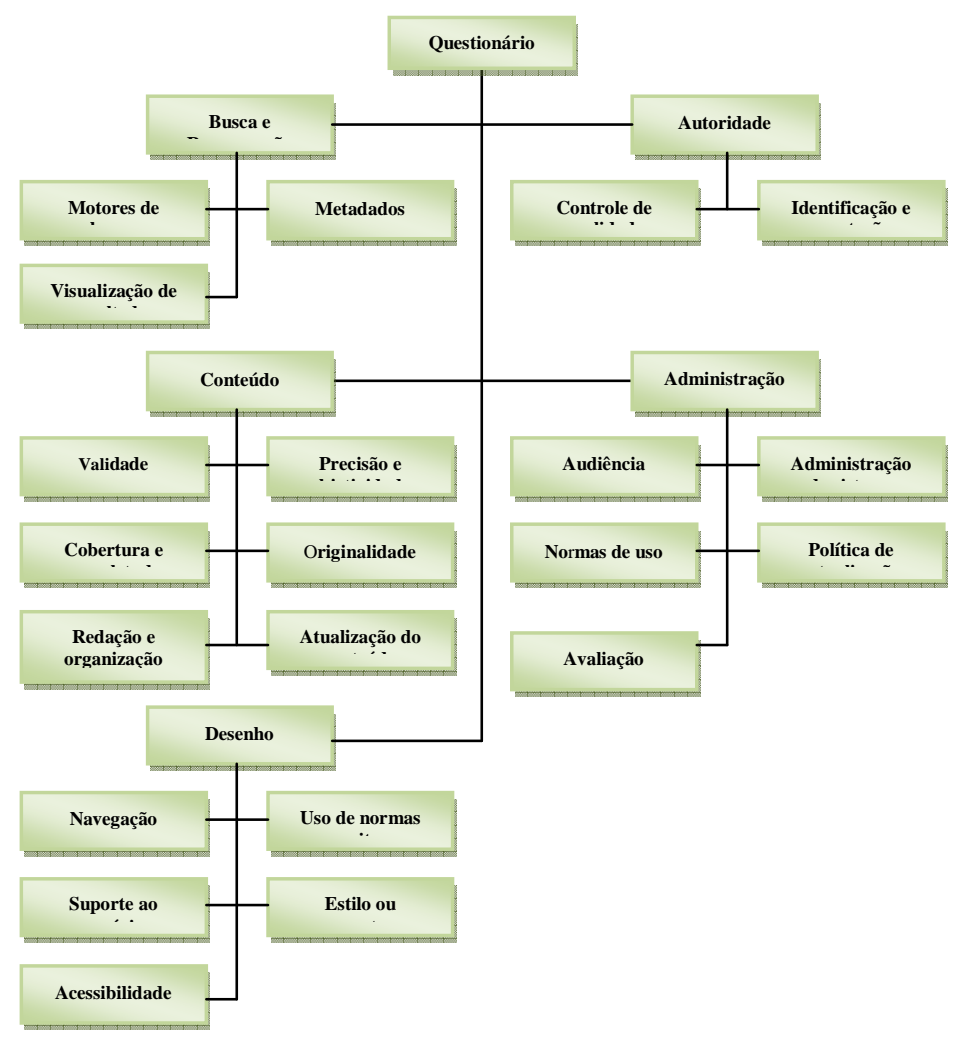

Figura 4: O Questionário BRACAD. Fonte: Jiménez Piano e Ortiz-Repiso Jiménez (2007, p. 90).

A forma minuciosa como Jiménez Piano e Ortiz-Repiso Jiménez (2007) tratam o tema, contrastando opiniões de diversos autores e também verificando estudos comparados entre Websites, resulta numa obra sólida, confiável e completa sobre avaliação de páginas Web. Pois, como afirma Codina (2007) $)^{90}$ : "A obra de Jiménez Piano e Ortiz-Repiso Jiménez é "...o estado da arte na disciplina de avaliação de sites".

Algumas das categorias desses critérios, bem como seus respectivos indicadores, coincidem com algumas das 113 Diretrizes apresentadas por Nielsen e Tahir (2002) e afetam diretamente a Usabilidade e a Visibilidade de um site. Os autores catalogaram 113 guidelines particularmente voltadas para a Web, compilando as melhores práticas de usabilidade. Os autores indicam que, além do uso de guidelines, ainda devem ser utilizadas formas que forneçam resultados

90 Luís Codina da Universidade Pompeu Fabra, autor de importantes trabalhos a respeito de avaliação de qualidade de Websites, foi o autor do prólogo do livro de Jiménez Piano e OrtizRepiso Jiménez: Evaluación y calidad de sedes Web (2007). 
para serem aplicados no ciclo de desenvolvimento do site e até mesmo após sua disponibilização em rede.

A exemplo de outras páginas Web em rede, os sites de arquivo também podem e devem ser avaliados utilizando-se critérios baseados em indicadores de qualidade. Muitos autores apresentaram listas de critérios de avaliação de páginas Web, muitas delas coincidentes em alguns pontos.

Em matéria de Arquivos, são escassas as pesquisas realizadas no sentido de avaliar suas páginas Web. Destaca-se o Modelo de avaliação proposto por García González e Chaín Navarro (2009), composto por 6 parâmetros, com 59 indicadores. Esse modelo foi construído baseado em outros estudos já realizados (CERDÁ DÍAZ, 2003) e (MÁS, 2007). A partir de tais estudos, foi desenvolvida uma ferramenta útil para uma análise específica. No contexto dessa análise, a avaliação sugere três níveis de pontuação para os indicadores apresentados:

Nível 0: não aparece

Nível 1: Aparece incompleto

Nível 2: Está presente e atualizado

As autoras deram a cada indicador a pontuação correspondente, depois somaram todas as qualificações e dividiram entre o número total de indicadores que constituem esse parâmetro para obter os resultados médios. Da mesma forma, para obter uma visão global de cada Arquivo analisado, somaram os resultados obtidos em cada parâmetro e dividiram entre o número total de parâmetros.

Para a avaliação preliminar, com a ajuda de um especialista em criação, desenvolvimento e manutenção de sites, selecionamos parte dos critérios e indicadores recomendados pelos autores, dado que este trabalho se propõe especialmente a estudar a Usabilidade e a Visibilidade de páginas Web de Arquivos, sem pretender uma análise profunda de cada critério. Considerou-se, entretanto, que cada um dos critérios escolhidos tem influência direta ou indireta na Usabilidade de um site e, por conseguinte, afeta a sua Visibilidade, devido ao 
número de vezes que acessam uma página Web por considerá-la de boa qualidade e de fácil uso.

Valendo-se da versão simplificada do Questionário BRACAD, dentro de cada uma das categorias dos seus respectivos critérios, utilizou-se apenas um ou dois indicadores, considerados de maior relevância ${ }^{91}$ para obter uma visão geral da qualidade dos sites selecionados para este estudo. Apresentamos a seguir os critérios e os respectivos indicadores utilizados justificando a escolha dos mesmos.

\subsubsection{Critério Busca e recuperação de informação}

Dentro do critério "Busca e recuperação de Informação" temos as seguintes categorias: 1- Motores de buscas; 2-Metadados; 3-Vizualização dos resultados.

1) Na Categoria Motores de buscas foram selecionados dois indicadores:

a. Dispõe de um motor de busca?

b. Diferencia entre busca simples e avançada?

O primeiro item (a) é considerado muito importante porque, na maioria dos casos, os usuários, cada vez mais exigentes, desejam encontrar facilmente o que busca. Segundo Nielsen ${ }^{92}$, os usuários estão mais "egoístas", e a mudança no comportamento dos usuários pode ser confirmado com base nos dados

\footnotetext{
${ }^{91}$ Apesar da relatividade do conceito de relevância, vale salientar que foram considerados outros autores apesar de a proposta se basear na estrutura apresentada na versão simplificada de Bracad, desse modo, os critérios, categorias e indicadores escolhidos com a ajuda de um especialista em construção e manutenção de Websites, foram aqueles que poderiam ser medidos pelos avaliadores dos sites objeto deste estudo na avaliação preliminar, a fim de se fazer uma análise geral, ou seja, obter uma visão global da qualidade desses sites.

92 Os usuários da internet estão mais egoístas, diz especialista: Entrevista à BBC Brasil, Estadão Online, Caderno Economia/Tecnologia, 24/5/2008.

Disponível em: http://www.estadao.com.br/noticias/tecnologia,usuarios-da-internet-estao-maisegoistas-diz-especialista, 177426,0.htm. Acesso em 6 Ago. 2009.
} 
levantados por relatórios. O primeiro se relaciona ao êxito dos usuários ao atingir seus objetivos quando estão on-line, os dados de 2008 indicam que $75 \%$ atingiram suas metas comparados aos $60 \%$ em 1999. Tais dados indicam que os usuários atualmente desejam ir diretamente ao ponto e não navegar à deriva. Ainda, segundo o relatório de 2008 , atualmente $60 \%$ dos usuários utilizam um link que os leva diretamente à página que buscam dentro de um site, apontando ainda que $25 \%$ das pessoas navegam através da página Web, porém as demais utilizam mecanismos de busca para chegar diretamente ao destino de seu interesse.

O Item "b" revela a preocupação em especificar as buscas feitas pelos usuários, melhorando significativamente sua satisfação em relação aos resultados obtidos.

2) Na Categoria Metadados foram selecionados dois indicadores:

a) Conta com metadados normalizados?

b) Insere metadados em cada seção principal?

Os metadados são ferramentas essenciais à estruturação de conteúdos na Web normalizando e os tornando mais visíveis pelos sistemas de buscas. Tais ferramentas são utilizadas tanto para organização e estruturação de conteúdos de bibliotecas, quanto para criação de sistemas eletrônicos.

Os motores de busca fazem uma varredura inicial nos metadados para encontrar elementos solicitados na busca, o que justifica a importância da página Web conter metadados e os manter a cada seção principal para que tenha mais visibilidade no ambiente da rede.

3) $\mathrm{Na}$ Categoria Visualização dos resultados foram selecionados dois indicadores:

a) Permite diferentes modos de ordenar os resultados?

b) Dispõe de alternativas quando o resultado é 0 ? 
A ordem dos resultados tem sua importância no momento em que se pretende avaliar os resultados por datas ou por ordem alfabética ou ainda se deseja fazer uma lista por relevância.

A importância de um Website oferecer alternativas quando o resultado é zero, reside na oportunidade de o usuário refazer sua busca, a partir das sugestões do próprio site sem com isso sentir-se desestimulado a alcançar o seu objetivo. Por essa razão, muitos sites utilizam esta alternativa.

\subsubsection{Critério Autoridade}

Dentro do Critério Autoridade, foram selecionadas as seguintes Categorías: 1) Identificação e Reputação; 2) Controle de qualidade.

1) Em Identificação e Reputação foram selecionados dois indicadores:

a) Indica com clareza quem são os autores ou colaboradores de cada seção da página?

Segundo Jiménez Piano e Ortiz-Repiso Jiménez (2007, p. 149): “[...] La identificación clara de los distintos contribuidores y la declaración explícita de su experiencia y pericia profesional son el único médio de garantizar El carácter científico de la información que ofrecen." ${ }^{, 93}$

b) Existem informações sobre a instituição que abriga ou cria a página do Arquivo?

\footnotetext{
${ }^{93}$ [...] a identificação clara dos distintos contribuidores e a declaração explícita de sua experiência e perícia profissional são o único meio de garantir o caráter científico da informação que oferecem. (Tradução nossa)
} 
Este indicador é importante na medida em que demonstra se existe alguma maneira de confiar na Instituição que abriga ou cria a página Web, pois consequentemente se poderá confiar na página em si mesma com relação à Identificação e reputação da autoridade.

2) $\mathrm{Na}$ Categoria Controle de qualidade utilizou-se o seguinte indicador:

- O site aparece em outras páginas de qualidade através de link (Visibilidade)?

Este indicador demonstra que boa parte da Visibilidade de um site depende de poder ser visualizada facilmente em outros sites de qualidade, ou seja, fiáveis e bem estruturados.

\subsubsection{Critério Conteúdo}

Para Nielsen $^{94}$ (2000 citado por PINTO, 2008, p. 9), os usuários visitam um determinado portal pelo seu contéudo, pois o design serve unicamente para facilitar o acesso aos conteúdos.

No critério "Conteúdo," a categoria "Validade" foi preterida, que pelo grau de complexidade foge ao propósito desta avaliação, uma vez que este critério interessa muito mais aos Web designers na hora em que estão construindo a página do que aos usuários finais.

A validade, obriga a examinar algumas contribuições concretas, comprovando se em sua introdução declaram os objetivos e a metodologia do trabalho, assim como a exposição do método de recolhida dos dados. Mais fácil resulta comprovar a existência habitual da bibliografia nas contribuições, assim como o uso de um estilo correto de citação de referências (JIMÉNEZ PIANO; ORTIZ-REPISO JIMÉNEZ, 2007, p. 165).

94 Cf. Nielsen, Jakob. Designing Web Usability: The Practice of Simplicity. Indianapolis: New Riders Press, 2000. 
Finalmente decidiu-se que os critérios de Autoridade e Administração através de seus indicadores ajudam a comprovar o caráter de autenticidade, autoria e qualidade.

1) Na Categoria Precisão e Objetividade, selecionou-se o indicador:

- A qualidade se mantém regular ao largo de todo o site?

Está claro que a confiabilidade do site está diretamente ligada à qualidade, a qual deve ser mantida da tela de início até o final para que possua consistência, assegurando uma navegação precisa e cômoda para o usuário. "Os requisitos do software são a base a partir da qual a qualidade é medida. A falta de conformidade aos requisitos significa falta de qualidade" (MORAES; WERNECK, 2009).

2) Na Categoria Cobertura e Exaustividade selecionou-se o seguinte indicador:

- Os temas apresentados no site têm extensão e profundidades suficientes?

O Usuário normalmente prefere encontrar tudo o que necessita em um único site, ainda que, para isto tenha que navegar por links relacionados ao mesmo para obter toda a extensão e profundidade no tema que deseja. Isso garante a fidelidade do usuário na hora de buscar o site em outras ocasiões.

3) Na categoria Originalidade selecionou-se o indicador:

- É um site único ou singular quanto ao tema ou ao tratamento do mesmo?

Quanto a esse item, veja-se a afirmação a seguir:

Com el epígrafe originalidad pretendemos valorar especialmente aquella información única, que no aparece repetida en muchos lugares de la red. También tenemos en cuenta el que la información esté elaborada y no se 
reduzca a una mera lista de enlaces o una simple sede publicitaria ${ }^{95}$ (JIMÉNEZ PIANO e ORTIZ-REPISO JIMÉNEZ, 2007, p. 165).

Ainda que não se discorde de Jiménez Piano e Ortiz-Repiso Jiménez, considerou-se que o fator "exclusividade" pode interferir negativamente no processo de busca por informações nos Arquivos, visto que se ocorre uma falha na manutenção ou atualização dentro da Instituição que abriga a página Web não se pode aceder ao conteúdo da mesma, a exemplo dos Arquivos estatais espanhóis que estão dentro de um único site ${ }^{96}$.

4) Na categoria Redação e Organização Intelectual, selecionou-se o indicador:

- Emprega uma linguagem apropriada, clara e simples para o conteúdo do site?

Os criadores do conteúdo para a Web necessitam tornar suas produções compreensíveis e navegáveis, empregando uma linguagem clara e tornando disponíveis meios de navegação e propriedade da informação apresentada. Proporcionar mecanismos para a orientação da página e ferramentas de navegação são fatores que maximizam a acessibilidade à rede ao garantir a visibilidade e a navegabilidade do site, já que sem estes elementos, os usuários podem, por exemplo, não compreender tabelas, listas o menus extensos (CONFORTO; SANTAROSA, 2002, p.10).

5) Na categoria Atualização do conteúdo, foram selecionados dois indicadores:

a) Indica explicitamente a data da criação intelectual?

b) Apresenta a data da última modificação?

Em relação a essa categoria Jiménez Piano e Ortiz-Repiso Jiménez (2007, p. 165) chamam a atenção para a diferença entre a atualização do conteúdo e a do recurso, considerando de grande importância as atualizações, sobretudo porque qualquer contribuição científica deve refletir os avanços na matéria.

\footnotetext{
${ }^{95}$ Com a categoria Originalidade pretende-se identificar especialmente aquela informação única, que não aparece repetida em muitos lugares da rede. Também tem-se em conta que a informação esteja elaborada e não se reduza a uma mera lista de links ou a um simples site publicitário (Tradução nossa).

96 URL do MCU: www.mcu.es.
} 
O primeiro item (a) se refere à data de criação do conteúdo das páginas Web, enquanto o segundo se refere à data da última modificação feita na mesma.

As datas de criação e atualização são muito importantes para que os usuários possam comprovar o grau de confiabilidade do conteúdo.

\subsubsection{Critério Administração}

Neste Critério selecionamos as Categorias: 1) Audiência, 2) Administração do sistema, 3) Normas de uso, 4) Política de atualização.

1) Na Categoria Audiência, selecionamos o indicador:

- Existe informação útil para diferentes tipos de usuários?

Cada site normalmente está direcionado a um público com preferências e interesses distintos. Para que a informação seja útil é importante uma comunicação adequada com cada perfil da audiência. Relevância é a palavra mágica que soluciona a questão básica da audiência. É necessário trabalhar a segmentação: a idade, sexo, menos-valia, localização geográfica ou perfil acadêmico, por exemplo, para identificar e oferecer conteúdo relevante para distintos tipos de usuários, pois quanto mais personalizada for a página Web melhores serão os resultados.

2) Na categoria Administração do sistema selecionamos o indicador:

- Existe alguma garantia de autenticidade, como certificações, etc.?

Da mesma maneira que ocorre com a questão de autoridade do conteúdo, a página Web também necessita apresentar certificações para atestar sua autenticidade e fiabilidade. 
3) Na categoria Normas de uso selecionamos o indicador:

- O acesso geral não está limitado a uma determinada categoria de usuários (por exemplo: somente para os associados)?

Em relação a essa categoria, Jiménez Piano e Ortiz-Repiso Jiménez (2007, p.184) afirmam que não existe dificuldade na sua verificação, pois as normas costumam aparecer em lugares bem visíveis para que as condições de uso estejam claras.

A questão do acesso geral não ter limitações incorre na democratização da informação proposta pelo "mundo cibernético". Entendese que não ter limitações de acesso representa seu caráter democrático cumprindo seu papel de disseminador do conhecimento. Por outro lado, sistemas de acesso privativo garantem a privacidade e seguridade de informações exclusivas de cada usuário, preservando seus dados pessoais, por exemplo.

4) Na categoria Política de atualização selecionamos o indicador:

- Aparecem em destaque as informações recentes ou as novidades?

Normalmente os sites apresentam as novidades em um apartado na página de início. Estar em constante diálogo com o usuário é essencial em relação à sua satisfação, sobretudo no que diz respeito às atualizações e novidades, pois indica que o site como um todo está sempre atualizado. 


\title{
4.2.5 Critério Desenho
}

Dentro dessa categoria encontramos cinco subcategorias: Navegação, Assistência ao usuário, Acessibilidade, Uso de normas aceitas, Aspectos estéticos.

$\mathrm{Na}$ categoria Navegação, foram selecionados dois indicadores:

a) A navegação é intuitiva e, portanto, não precisa formação anterior nem exige esforço por parte do usuário?

A navegação representa uma das maiores vantagens da informação na Web e do hipertexto, e desperta grandes expectativas de acesso rápido a resultados satisfatórios, sendo, portanto, a que gera maior frustração, desorientação e extrapolação cognitiva quando os links não funcionam ou quando o sistema está mal desenhado (JIMÉNEZ PIANO; ORTIZREPISO JIMÉNEZ, 2007, p.201).

Quando o usuário necessita de formação anterior, ou certo, esforço para navegar na página Web, é sinal de que os resultados além de insatisfatórios podem não atingir os objetivos.

ß) A organização da Informação permite acesso a qualquer informação com somente três clicks ou, caso contrário, existem atalhos e/ou um mapa do site?

O usuário ao tentar o acesso a uma informação espera obter respostas rápidas, portanto, quando é obrigado a clicar mais de três vezes para chegar ao que busca normalmente abandona a pesquisa. A respeito da navegação afirmam que:

\begin{abstract}
Uma página Web com seu sistema de navegação bem definido e organizado, permite ao internauta ir de um ponto a outro pelo caminho desejado ou pelo menor caminho, possibilitando melhor aproveitamento do tempo de uso ou de acesso, evitando assim que o usuário tenha que passar por muitas páginas até chegar à informação desejada, ou que se depare com links inválidos, entre outros problemas (VIDOTTI; SANCHES, 2004).
\end{abstract}

Os atalhos e o mapa do site podem servir de ajuda para tornar mais simples o processo de busca quando se tem um conteúdo muito extenso ou muitos links, por exemplo. 
1) Na categoria Assistência ao usuário selecionamos o indicador: - Existe uma seção de ajuda on-line para o usuário?

Em uma página Web além do mapa do site, um link para proporcionar Ajuda on-line garante o correto uso do site, além de esclarecer dúvidas e responder a perguntas a respeito do mesmo. Apresenta normalmente diversas perguntas e respostas que podem ser consultadas em uma seção normalmente chamada "Perguntas frequentes".

A presença de um Serviço de Ajuda online transmite uma imagem de que o site está orientado para a satisfação do usuário, o que influencia diretamente na confiabilidade.

2) Na categoria Acessibilidade foi selecionado o seguinte indicador:

- Dispõe de texto alternativo para descrever a informação não textual (imagens fixas ou em movimento, áudio, etc.)?

O site deverá enfrentar o desafio da indexação das informações não textuais, tais como fórmulas, sons e imagens estáticas ou em movimento, por exemplo, ou seja, realizar a transposição do real/analógico para o virtual/digital sem perder sua habilidade de armazenamento e disseminação de informações de maneira rápida e precisa, ampliando constantemente as habilidades humanas de absorver e formar novas informações.

3) Na categoria Uso de normas aceitas foi selecionado o seguinte indicador:

- Utiliza linguagem de marcação normalizada, sem extensões proprietárias?

O desenvolvimento das linguagens de marcação mudou o panorama da estruturação de documentos, apesar de não ser seu objetivo inicial. Na década de 1980, a linguagem de marcação foi implantada como uma forma de assegurar a transferência dos dados mantendo aspectos da apresentação $(\mathrm{BOSCH}, 2001$, p.4). 
Com o uso das linguagens de marcação, os sistemas informáticos na WWW realizam tarefas de rotina e também outras mais especializadas, sempre e quando se trate de trabalhar dentro das páginas Web. Não se tem ainda, no entanto, um procedimento confiável para processar a semântica. Por esta razão se produzem avanços na Web semântica (BOSCH, 2001, p. 8).

Berners-Lee, Hendler e Lassila citados por Bosh (2001, p.4) afirmam que a Web semântica brinda conteúdo significativo às páginas da Rede, criando um ambiente onde agentes de software, movendo-se de uma página a outra, possam facilmente efetuar tarefas sofisticadas para usuários, trata-se de uma extensão para que a informação tenha um significado definido, permitindo que máquinas e pessoas possam trabalhar em cooperação.

A seleção desta categoria se deve ao fato da autora deste trabalho estar de acordo com a afirmação de Jiménez Piano e Ortiz-repiso Jiménez (2007, p. 201) de que a ausência de compatibilidade entre os sistemas se deve ao descumprimento das normas ou sua inexistência que se torna um dos problemas básicos dos sistemas automatizados.

Sempre que aplicável e possível, as normalizações devem ser construídas tendo como base outras pré-existentes, e não depender de tecnologias proprietárias de um provedor em particular.

Segundo Bia e S'anchez-Quero (2010?), as extensões proprietárias são difíceis de manejar, são modificadas de acordo com as caprichosas decisões corporativas dos fabricantes e não são fáceis de se converterem a outros formatos quando a opção não é proporcionada pelo fabricante. Este critério de seleção do formato deve ser parte de um plano global de preservação que deve abarcar aspectos como os procedimentos de preservação. Portanto um dos aspectos mais importantes na decisão de escolher a extensão proprietária é a preservação de documentos.

Nenhuma normalização deve depender de um sistema operacional, ambiente ou aplicação específica. Independência de aplicação e implementação são as mais importantes propriedades de qualquer modelo normalizado. 
É importante que o formato escolhido seja amplamente usado e possa ser suportado pelos navegadores da Internet além de ter a capacidade de converterse facilmente a novos formatos que a tecnologia do futuro possa produzir.

4) Na categoria Estilo ou aspectos estéticos, foi selecionado o indicador:

a) Existe um equilíbrio entre o texto, imagens e espaços em branco?

A estética da página Web torna a navegação mais ou menos agradável, o que pode influenciar nos resultados ou mesmo na decisão de navegar ou não na mesma.

A respeito do uso de imagens, Jiménez Piano e Ortiz-Repiso Jiménez (2007, p. 203) chamam a atenção para que a inserção de imagens fixas ou em movimento não distraia o usuário do conteúdo do site considerando seus fins práticos e estéticos com as cores utilizadas.

Para Hassan Montero (2002), existem algumas técnicas para destacar objetos de informação (links, parágrafos, dados) relevantes em uma página Web, para defini-las hierarquicamente: as informações mais importantes devem ser colocadas em áreas de interface mais destacadas; enfatizá-las através de efeitos tipográficos; o tamanho dos textos mais relevantes deve ser aumentado; usar contraste de cor para distribuir e discriminar objetos de informação e, agrupar e relacionar objetos de informação. Porém, o uso de intermitentes, deslocamentos ou deslizamentos, pode ser percebido pelo usuário apenas como publicidade e não como informação relevante.

O equilíbrio entre o texto, as imagens e o correto uso dos espaços em branco pode definir que uma página Web tem um desenho excelente e harmonioso, não produzindo poluição visual.

b) Os menus são consistentes tela a tela? 
Ao realizar uma busca o usuário deve contar com menus em cada tela apresentada no site para que possa retroceder ou avançar sem perder a linha de seguimento da navegação, resguardando assim seus resultados.

\subsection{USABILIDADE E VISIBILIDADE}

Embora muitos dos critérios e indicadores anteriormante expostos também tenham relação com a Usabilidade e Visibilidade, nesta seção estes critéiros serão abordados mais detidamente, como critérios fundamentais para a avaliação de páginas Web. No caso deste estudo, estes critérios subsidiarão a análise pretendida dos sites de Arquivos espanhóis.

\subsubsection{Usabilidade}

O termo Usabilidade tem origem latina (usum), mas trata-se de um neologismo do castelhano atual, e deriva diretamente do inglês usability. A aceitação inglesa é mais ampla que a castelhana e se refere à facilidade ou nível de uso em que o desenho de um objeto facilita ou dificulta seu manejo. De maneira geral, é a capacidade de utilização que tem um sistema. Segundo a ISO 9241-11 (1998), Usabilidade "é a medida na qual um produto pode ser usado por usuários específicos para alcançar objetivos específicos com efetividade, eficiência e satisfação num contexto de uso específico"

A usabilidade, em termos ainda mais gerais, descreve as interações entre o homem e a máquina (Man-Machine Interaction). Em castelhano, era usual também outra expressão para definir a facilidade de utilização de um aparelho mecânico: "amigável", termo que já caiu no esquecimento e lembra a perífrase do inglês user friendly, ou seja "amigável para o usuário". 
Relacionadas à usabilidade, usam-se: simplificar, rentabilizar, otimizar, facilitar, melhorar, acelerar são expressões que giram em torno do conceito de usabilidade." Maior usabilidade consiste em maior flexibilidade e maior interação.

A Usabilidade é uma característica daquilo que é utilizável, funcional. É tornar óbvio o óbvio, levando em conta as necessidades do utilizador/usuário e o contexto em que este está inserido.

$\mathrm{Na}$ era da eletrônica e dos computadores, a usabilidade é um componente essencial das páginas de internet, da televisão interativa, dos dispositivos móveis como telefones, controles a distancia, etc. e no caso de um programa de computador ou uma página Web poderíamos definir a usabilidade dizendo que é a capacidade de um software de ser compreendido, aprendido, usado e ser atrativo para o usuário.

Em sua definição mais abrangente, usabilidade diz respeito a "um conjunto de propriedades que fazem com que algo seja fácil de ser utilizado". Está atrelada com a facilidade com que um usuário alcança o seu objetivo ao usar um determinado produto ou serviço. ${ }^{97}$

A Usabilidade é bem definida por Dillon e Morris (1999) citado por Hassan Montero e Ortega Santamaria (2009, p. 10): "a usabilidade representa o grau em que o usuário pode explorar a utilidade". Mais completa ainda é a seguinte definição citada por Koohang (2009, p.130):

In general, usability is the extent to which a product or a system enables users to achieve speci-fied goals. Usability is the ability of a product or system to effectively and efficiently fulfill the needs and specifications of users. Usability is essential to user satisfaction and user acceptance of a product or system. It is the measure of the quality of the user's experience when interacting with a product or system (Dumas \& Redish, 1993; Guillemette, 1989; Nielsen 1993, 2000; Rosenbaum, 1989; Rubin, 1994; Shackel 1991) ${ }^{98}$.

Tendo em vista as considerações anteriores, conclui-se que os autores em geral estão de acordo quanto à usabilidade estar diretamente associada ao

\footnotetext{
97 Neste estudo, consideramos o produto como uma página de Internet com o qual o usuário interage com um objetivo específico.

$98 \mathrm{Em}$ geral, a usabilidade é a medida que um produto ou um sistema permite aos usuários alcançar os objetivos especificados. A usabilidade é a capacidade de um produto ou sistema de maneira eficaz e eficiente estar em conformidade com os requisitos e especificações dos usuários. A usabilidade é essencial para a satisfação do usuário e a aceitação do usuário de um produto ou sistema. É a medida da qualidade da experiência do usuário ao interatuar com um produto ou sistema (DUMAS \& REDISH, 1993; GUILLEMETTE, 1989; NIELSEN,1993, 2000; ROSENBAUM, 1989; RUBIN, 1994; SHACKEL 1991). (Tradução nossa).
} 
usuário: Nielsen; Dillon e Morris; Hassan Montero, Martín Fernández e Lazza entre outros. Estando de acordo com a constatação destes autores, deve-se confrontar o usuário e o sistema, pois como afirmam Hassan Montero e Ortega Santamaria (2009): "uma das melhores maneiras de avaliar a usabilidade de um site é colocando-o à prova com o teste de usuários ${ }^{99,}$

Isso representa também uma das maiores dificuldades na hora de desenvolver sistemas informáticos eficientes e eficazes devido à grande variedade de usuários. O que é importante para uns não é tanto para outros, como por exemplo, ter ajuda on-line permanente, segundo sugere, por exemplo, o próprio Nielsen (1993) em seus princípios heurísticos.

Os princípios básicos para avaliar o nível de usabilidade de um produto, da perspectiva do usuário, são muitos, e ao se tratar de um conceito empírico, que varia constantemente com a evolução das novas tecnologias, há que se considerar os princípios listados a seguir como linhas de orientação em contínuo desenvolvimento. Com foco nas páginas Web, pode-se avaliar a usabilidade de um portal destacando Nielsen (2003):

1) a Facilidade de aprendizagem (learnability), que no caso de um arquivo digital se refere à facilidade e rapidez com que novos usuários podem ter uma interação efetiva com os conteúdos oferecidos pela Web;

2) a Eficiência (efficiency), que é o nível da rapidez do programa na execução das tarefas selecionadas pelo usuário;

3) a Memorização (Memorability), que indica se para o usuário facilmente recorda e pode repetir as tarefas, se necessário;

4) os Erros (Errors) se referem às falhas que os usuários cometem ao utilizar o sistema e à facilidade com que podem se recuperar dessas falhas. Aqui se mede a Eficácia do sistema;

5) a Satisfação do usuário ao realizar as tarefas oferecidas pelo site.

Pode-se somar a esses cinco componentes que indicam a qualidade de um site, a flexibilidade, neste caso o número de possibilidades que o usuário e o

99 MONTERO Y SANTAMARÍA (2009). Informe APEI sobre Usabilidad, n.3 - 2009. Gijón: Asociación Profesional de Especialistas en Información, 2009. 
sistema dispõem para intercambiar informação e a multiplicidade de vias para realizar uma tarefa.

No caso das Bibliotecas Digitais e dos Arquivos que tem suas páginas disponíveis na rede essas características se resumem à facilidade e rapidez com que os usuários interatuam efetivamente com os conteúdos da página Web e se sentem satisfeitos com os resultados obtidos.

É evidente que estas variáveis que determinam o grau de usabilidade de uma página Web dependem sempre do usuário final. O nível de instrução, a idade, o conhecimento de idiomas etc, influenciam na capacidade de interação com os conteúdos oferecidos pela rede, e por tanto uma das melhores formas de avaliar a usabilidade é realizar testes com pessoas reais através de tarefas ou questionários que permitam medir e quantificar, através de um critério mais objetivo, se o resultado final do produto se ajusta às expectativas dos idealizadores da página Web.

No desenvolvimento de uma página Web é possível identificar outras características ainda mais específicas que as cinco anteriores. De acordo com Nielsen (2000) existem as regras básicas para boa Usabilidade, que consistem em: Clareza na arquitetura da informação, facilidade de navegação, simplicidade, relevância do conteúdo, coerência, rapidez e atenção voltada aos utilizadores. 1) Clareza na arquitetura da informação, 2) Facilidade de navegação, 3) Simplicidade, 4) Relevância do conteúdo, 5) Coerência (Manter a consistência), 6) Rapidez (Tempo suportável), 7) Atenção voltada aos utilizadores (Foco nos usuários).

De acordo com os preceitos de Rosenfeld e Morville ${ }^{100}$ (citado por Reis, 2006, p. 3), é necessário conhecer os usuários, suas necessidades, hábitos, comportamentos e experiências para elaborar a arquitetura de informação de um Website. Além disso, é importante compreender as características do conteúdo, quanto ao formato, estrutura, volume, etc., bem como as características específicas do contexto de uso: objetivo do Website, cultura e política da empresa, ambiente de uso, restrições tecnológicas, etc. Na visão usuárioconteúdo-contexto e suas interdependências de cada Website o arquiteto da

\footnotetext{
${ }^{100}$ Cf. ROSENFELD, L. \& MORVILLE, P. Information Architecture for the Word Wide Web. 2ed. Sebastopol: O'Reilly, 2002.
} 
informação necessita balanceá-las, para que a informação certa venha a ser acessada pela pessoa certa no momento certo.

Há uma diversidade de estudos que abordam o processo que envolve a arquitetura da informação de Websites (MCGEE e PRUSAK, 1994; ROSENFELD e MORVILLE, 1998; STRAIOTO, 2002; GARRET, 2003; DONATI, CARVALHO e PRADO, 1998, entre outros).

McGee e Prusak (1994 citados por Camargo, 2004, p. 21) consideram como objetivo de uma arquitetura da informação a elaboração de "um mapa" que envolvam os dados organizacionais, a fim de se construir um sistema tomando como parâmetro esse mapa. Eles desenvolveram estudos sobre os processos para gerenciar a informação.

Para cada tipo de Website, faz-se necessária a implantação de serviços e recursos específicos, cabendo à arquitetura da informação viabilizar o processo de desenvolvimento, facilitando assim a estruturação das informações.

Os cientistas da informação, a exemplo de Rosenfeld e Morville (1998) tratam de categorias de elementos e expõem opções para o desenvolvedor fazer suas escolhas conforme as suas necessidades, envolvendo os processos de organização, recuperação, apresentação, disseminação da informação e interfaces. A arquitetura da informação, visualizada por Garret (2003) apresenta elementos que podem ser percebidos em top-down e bottom-up, que agem como elementos que dividem a estruturação do Website. Cada qual implica um processo a ser realizado e, como outros, apresenta elementos contidos nos processos de organização, recuperação, apresentação, disseminação da informação e interfaces, além de abranger o processo de personalização da informação (CAMARGO, 2004, p.33).

Outros cientistas da informação, a exemplo de Donati; Carvalho e Prado(1998), focam seus estudos somente em elementos para interfaces.

Entre tantas definições para arquitetura da informação, há que se considerar um denominador comum entre elas: sua utilidade na estruturação de dados, ou seja, de estrutura informacional consistente. Os autores tratam da organização dos dados com o fim precípuo de viabilizar ao usuário a informação. Dessa forma, pode-se dizer que a expressão "arquitetura da informação" tem por 
foco o usuário. Portanto, relevam-se as tecnologias para subsidiar 0 armazenamento, a recuperação de informação e sua disseminação.

Há uma carência de estudos sobre a arquitetura da informação em bibliotecas digitais e sites de Arquivos. Normalmente os elementos dessas áreas são muito específicos envolvendo processos próprios de temas inseridos na área de Ciência da Informação.

É cabível de destaque que os prejuízos de algumas instituições muitas vezes estão relacionados à falta de uma arquitetura da informação consistente, portanto torna-se imprescindível ter "clareza" na Arquitetura da Informação, para que o sistema de recuperação de um site seja satisfatório para o usuário na busca de informações.

Uma página Web não deveria aparecer ao navegador virtual de forma confusa, em que todos os conteúdos se apresentam de forma desordenada em uma tela inicial. Chamamos arquitetura da informação, portanto, a atividade que leva a organizar, classificar e definir os vários conteúdos de um Website. O desenho da página tem que suportar adequadamente a oferta de conteúdos e permitir sua busca (findability).

Outro aspecto importante a se considerar é a informação a ser disponibilizada, a respeito disso, Hassan Montero (2002) esclarece que um objeto de informação é considerado importante quando pode satisfazer as necessidades dos usuários, portanto o desenho de informação do site deve ter uma linguagem e um esquema compreensível para o usuário.

Já não é possível pensar a Internet como uma série de hipertextos entrelaçados. Quando se realiza uma operação específica, normalmente esperase que fazendo click com o mouse sobre um ícone, a gráfica de algum modo altere, favorecendo a interação com a página (é típico o exemplo do mouse que se transforma numa ampulheta). É o que Nielsen, em seu Heuristic evaluation of user interfaces chama "visibilidade do status do sistema". Ao lado deste desenho chamado "de interação", existe um "desenho gráfico" que não constitui apenas o componente meramente estético da página Web. Vários estudos têm demonstrado que uma agradável combinação das cores e das formas são 
percebidas pelos usuários como mais fáceis de usar ${ }^{101}$. Entre uma tela em preto e negro e uma tela colorida com um ou outro adorno gráfico, a tela colorida parece mais atrativa e, em última análise, mais user friendly; o primeiro impacto de um usuário com a página de início de uma Web é visual.

Simplicidade versus Complexidade. Qualquer usuário de internet desfruta da simplicidade de uma página Web; um desenho simples e sóbrio, que ofereça apenas os elementos funcionais e estéticos necessários, diminui a carga visual e cognitiva que pode constituir uma barreira para o navegador com pouca experiência $^{102}$. A simplicidade, além disso, reduz as frustrações do usuário que terá menos probabilidades de equivocar-se. Ao contrário da simplicidade, joga o fator da complexidade inerente a cada página Web. A quantidade de informação oferecida ou o elevado número de operações que se podem executar através do portal de uma Web, às vezes, não permitem que a tela inicial tenha apenas poucos pulsantes evidentes, porque se requer uma organização mais hierárquica dos conteúdos ou das funções, que implica diferentes passagens.

Tendo em vista a exposição anterior, podemos identificar quatro componentes principais em qualquer situação de utilização de um sistema: o utilizador, a tarefa, a ferramenta e o meio ambiente. Os usuários são muito diferentes entre si: mais ou menos capazes a respeito do uso de computadores, com reduzida ou vasta experiência no uso dos sistemas informáticos e/ou buscas de informações ou navegação na Web, por esta razão as características da interface são muito decisivas. ${ }^{103}$

Alguns autores concordam que para aumentar a aceitação e satisfação do usuário os designers examinam a interface do usuário e suas características com o objetivo de e melhorar a usabilidade geral dos sistemas informáticos, quer dizer,

101 KUROSU, M. y KASHIMURA, K. Determinants of the Apparent Usability. Proceedings of IEEE SMC, 1995, pp. 1509-1513. TRACTINSKY, N.; KATZ, A. S.; IKAR, D. What is beautiful is usable. Interacting with Computers, 13, 2000, pp. 127-145. LAVIEA, T.; TRACTINSKY, N. Assessing dimensions of perceived visual a esthetics of Web sites. International Journal of Human-Computer Studies, vol. 60, n. 3, 2004, pp. 269-298.

102 Sobre a importância da simplicidade no desenvolvimento de uma página de internet cf.: MAEDA, J.; As leis da simplicidade, Barcelona, Gesida, 2006. TANENN, R.; "Clarity en complexity». Appliance Design, vol. 56, n. 9, set. 2008.

${ }^{103}$ Shackel, B. (1991). Usability - context, framework, design and evaluation. In Shackel, B. and Richardson, S. (eds.). Human Factors for Informatics Usability. Cambridge University Press, Cambridge, 21-38. 
melhorar a usabilidade para os usuários e segundo a perspectiva deles (CALDEIRA, 1994, 1999; CALDEIRA \& OTERO, 1997, 2003).

A boa usabilidade de um Website, portanto, pode estar relacionada principalmente a fatores que de alguma forma estejam relacionados às regras básicas de Usabilidade de Nielsen (2000) e um site deve ter:

1) Navegação clara e objetiva;

2) Senso de orientação ("onde está", "de onde veio" e "para onde vai”);

3) Localização da informação desejada;

4) Design da interface;

Compreender a usabilidade, portanto, implica em se posicionar como os usuários e pensar como eles se comportariam frente ao seu produto. Segundo Nielsen (2000), estudioso do assunto e "guru" da usabilidade, o modo como se alcançam conceitos de design apropriados consiste em observar os usuários e perceber o que eles gostam, o que eles consideram fácil e onde eles encontram empecilhos (RIBEIRO, 2006, p.10).

5) Diagramação do texto;

6) Tempo de resposta.

Muitos desses fatores são subjetivos. Isso porque estão atrelados às preferências do usuário e prerrogativas de interconexão, o que inviabiliza uma medida precisa do grau de usabilidade. Dessa forma, é judicioso notar como a usabilidade é determinada, fundamentalmente, pelo design das páginas e pela arquitetura da informação. Portanto, segundo Ribeiro (2006), dificilmente os usuários alcançarão os resultados desejados se a página não estiver bem estruturada conforme suas necessidades e com um esquema de navegação facilitador.

Incrementar a usabilidade na Web abrange o uso de táticas para aprimorar a eficácia das páginas, viabilizando-as em um ambiente apropriado que respalde os objetivos do usuário. O Web designer deve focar-se no design da interação e buscar adequá-lo ao comportamento humano. A experiência do usuário que navega no site consiste em um aspecto essencial da usabilidade. A usabilidade deve ser levada em conta em todo o processo de desenvolvimento de sites para assegurar a adequação aos usuários e a facilidade de uso. De acordo com Michael Beckley, autor do programa Appian Web Personalization Report (AWPR), 
é possível estabelecer regras cruciais para avaliar a usabilidade de um site, a saber: aprender com as reações do usuário; não colocar resistência à personalização; não negligenciar qualquer fonte de informação; conquistar o usuário pelo visual; observar os aspectos que os usuários aprovam ou desaprovam; criar eficientes mecanismos para "facilitar a vida do usuário"; construir uma arquitetura de informação em que rapidamente os usuários atinjam seus objetivos (fazer com que o usuário chegue à informação desejada com apenas três cliques, como sugere Jacob Nielsen); minimizar o código HTML revisando-o a cada três meses, ter cuidado com os links deixando o site livre de links inexistentes e, por fim, rapidez no carregamento do site (RODRIGUES; BECHER, 2009, p. 8-10).

Desenvolver um site com boa qualidade não corresponde a uma atividade fácil, tanto que muitos dos sites disponíveis na Internet, não seguem os princípios de acessibilidade e usabilidade (RODRIGUES; BECHER, 2009, p.6).

Dessa forma, fica evidente porque a usabilidade consiste no mais relevante propósito para o Web designer. Na concepção de Holmes (2002), considerando que um site com boa usabilidade diz respeito àquele que pode ser usado com efetividade pelo usuário, existem variados fatores que colaboram para o fracasso dos sites em termos de usabilidade, porém, o principal deles é a diferença entre o modelo mental do designer e do usuário. A internet, nesse sentido, destaca-se por ser o maior meio de obtenção de informação e por sua capacidade de supressão de barreiras físicas, geográficas e espaciais, o que permite a circulação universal da informação. $O$ uso da Internet trouxe para os deficientes em geral uma nova forma de se integrarem e interagirem com a sociedade, cumprindo sua cidadania com mais autonomia e independência, considerando que a internet thes permite $o$ acesso às informações minuto a minuto e de forma muito mais rápida e satisfatória.

Em todo o mundo podemos encontrar pessoas com algum tipo de deficiência e segundo o Censo 2000 realizado pelo Instituto Brasileiro de Geografia e Estatística (IBGE), estima-se que no Brasil existam aproximadamente 24.600 .256 pessoas com alguma limitação o que representa $14,5 \%$ da população brasileira, isso significa que um número significativo de pessoas podem ser excluídas da participação na nova sociedade caso não tenham acesso aos recursos necessários para obtenção de informação (RODRIGUES; BECHER, 2009, p.3). 
Um bom exemplo dessa tecnologia são os leitores de tela, os quais permitem o acesso do deficiente visual ao computador. Além das Tecnologias Assistivas $(\mathrm{TAs})^{104}$, utilizadas para que os deficientes visuais consigam interagir com os sites da internet é necessário que esses sites sejam acessíveis aos leitores de tela, pois isto possibilita a interpretação e a leitura do que é apresentado na tela do computador, por softwares que englobam a TA. Uma maneira de garantir a acessibilidade nos sites é a implementação de princípios que visam melhorar o acesso à Internet, levando-a ao seu potencial máximo: usabilidade, design universal e acessibilidade, a observação desses princípios torna o site acessível e usável.

O World Wide Web vem desenvolvendo, desde a sua fundação, em 1994, algumas recomendações a respeito das novas tecnologias a fim de que sejam utilizadas da melhor maneira possível. Lançou, em 1999, o guia de recomendação para acessibilidade no conteúdo Web para que os desenvolvedores de sites tivessem um guia para a implementação da acessibilidade nos sites.

\begin{abstract}
O Brasil também apresentou algumas iniciativas a fim de garantir a acessibilidade nos sites, o Decreto-lei no. 5.296/2004, que regulamenta as leis da acessibilidade, tornou obrigatória a acessibilidade nos sites da administração publica e outra iniciativa foi o lançamento em 2005 de uma cartilha de recomendações para acessibilidade nos sites, elaborada pelo Departamento de Governo eletrônico em parceira com a ONG acessibilidade Brasil. O poder da Web está em sua universalidade." (RODRIGUES; BECHER, 2009, p.3).
\end{abstract}

As novas tecnologias que emergiram nessa sociedade da informação apresentaram uma grande relevância para os deficientes visuais por lhes possibilitar o acesso ao grande número de informações circulantes no mundo, de forma mais autônoma e independente, talvez essa fosse a principal razão pela qual ela tem se tornado tão disseminada e buscada pelos PNE, considerando que a informação e o conhecimento podem ser adquiridos e forma independente. Com o acesso à informação que a Internet disponibiliza, o deficiente visual passa a ter condições de exercer uma participação mais expressiva nessa nova sociedade (RODRIGUES; BECHER, 2009, p.4).

\footnotetext{
${ }^{104}$ Entende-se por TA todo recurso ou serviço que visa ampliar alguma habilidade funcional do indivíduo com alguma deficiência, para facilitar a execução de alguma tarefa ou funções do cotidiano com maior independência, podendo ser aplicada também a softwares ou hardwares.
} 
Por outro lado, encontram-se usuários dispostos a instituir esse relacionamento. De forma cada vez mais crescente, as pessoas ganham acesso à rede, seja em casa, no trabalho ou nas instituições de ensino. O público torna-se diversificado, assim como também seus interesses e demandas.

Quanto aos entraves à usabilidade na Web, Jacob Nielsen (2000), 0 grande especialista da usabilidade, apresenta sete barreiras. O primeiro entrave sinalizado é a Irrelevância no uso de termos: tais como Website, on-line e homepage, no título dessa última, quando o utilizador certamente sabe que está em todos esses contextos. O mesmo se passa com títulos de página iniciados por artigo (exemplo: os nossos produtos, o carrinho de compras, as suas dúvidas em vez de: produtos, carrinho de compras, dúvidas) o que não possibilita desenvolver marcadores (bookmarks) na ordem alfabética mais lógica para 0 usuário/utilizador. Também são irrelevantes os links iniciados por expressões repetidas, geralmente o nome da própria empresa em cujo Website o internauta já se encontra.

O segundo entrave diz respeito à redundância, ou seja, trata-se de várias ocorrências de um mesmo elemento em áreas diversas, especialmente alternativas de navegação e até links ativos para a homepage na própria homepage. A informação a respeito de assuntos similares deve estar toda no mesmo local os nomes nos menus não devem levar a mal-entendidos.

O terceiro entrave consiste na ausência de conteúdos informativos satisfatórios e realmente relevantes. A informação não se pode embaralhar com 0 marketing de uma forma pouco rigorosa. Títulos e cabeçalhos excessivamente vagos, pouco específicos devem ser impedidos.

O quarto entrave relaciona-se à inadequação discursiva que se pode observar em cabeçalhos de notícia muito longos e difíceis de ler on-line; opções de menu com expressões demasiadamente técnicas para o público em geral, nomes fantasia que nada dizem utilizados como itens de menu (exemplo "grande casa" em vez de "homepage"), abreviaturas utilizadas sem prévia apresentação da expressão completa.

O quinto entrave trata da inconsistência, a inexistência de coesão como, por exemplo, a utilização aleatória de letras maiúsculas e minúsculas entre as 
opções de um mesmo menu de navegação ou uso aleatório de sinais de pontuação. A posição, a ordem, o espaçamento deve ser consistente na interface de forma a auxiliar o utilizador/usuário a dominar o processo.

O sexto entrave atém-se ao "mau posicionamento e má organização" de palavras-chave e com a categorização e subcategorização de menus. É extremamente importante subcategorizar consistentemente os assuntos.

Segundo Moraes (2002) um sistema deve oferecer sua funcionalidade de tal maneira que o usuário seja capaz de controlá-lo e utilizá-lo sem demasiados constrangimentos sobre suas capacidades e habilidades, Krug (2001) concorda e acrescenta que um produto só pode ter boa usabilidade se funcionar bem. Eason (1984) destaca a utilidade percebida do produto: "O maior indicador da usabilidade de um produto é se ele é usado".

Nielsen (1993) ainda ressalta cinco atributos que integram a natureza multidimensional da usabilidade. Para o sistema apresentar boa usabilidade, é imprescindível satisfazer a estes requisitos: fácil aprendizado, eficiência no uso, facilidade de lembrança, poucos erros e satisfação subjetiva.

De forma parecida, veja-se como foram catalogados os principais aspectos que englobam o termo "usabilidade":

Fatores relacionados à abrangência do termo usabilidade: facilidade de aprendizagem; efetividade; atitude; flexibilidade; utilidade percebida do produto; adequação à tarefa; características da tarefa; características dos usuários (MORAES, 1999 citado por SANTOS, 2000, p. 2)

A adequação às características dos usuários e suas capacidades físicas, cognitivas e emocionais relacionam-se com métodos e técnicas de ergonomia.

São vários os autores que corroboram essa questão da facilidade de uso como aspecto fundamental da usabilidade: Shackel (citado por SANTOS, 2008, p.2), afirma que a usabilidade consiste na capacidade de um sistema ser facilmente utilizado e com eficiência pelo usuário. Nielsen (1990) e Santos (2000) classificam a usabilidade de forma parecida, também baseando seus conceitos em elementos como a eficiência somada à facilidade de uso. Santos (2000, p. 2), apresenta o conceito de usabilidade de Bastien e Scapin (1993), os autores a concebem como o diálogo na interface, ou seja, a capacidade do software em possibilitar que o usuário atinja suas metas através da interação com o sistema. 
Para se conhecer a usabilidade é preciso que ela seja testada muitas vezes em um ambiente realista, desempenhando atividades típicas, pois do contrário, não é possível observar se existe dificuldade ou facilidade na realização de tarefas durante a utilização da Interface. Conforme Badre $(2002)^{105}$, a facilidade de utilização está atrelada à execução de uma tarefa com sucesso por meio de um número mínimo de ações.

Norman ${ }^{106}$ (1988 citado por VECHIATO, 2010, p.106-107) concebe alguns princípios para um design de interação, a partir de um bom modelo conceitual: consistência das informações, visibilidade dos recursos, mecanismos de feedback para o utilizador/usuário, compatibilidade com os modelos conhecidos pelos usuários, Affordance (incentivos e pistas para incentivar o usuário a realizar alguma tarefa) e restrições (oportunamente o sistema deverá restrigir o tipo de interação com o usuário). Tais premissas também estão presentes nas heurísticas de Nielsen. $O$ autor além destas premissas, considera que questões como a concordância entre o sistema e o mundo real, controle do usuário, padrões, flexibilidade e design minimalista, auxiliam a usabilidade.

Quanto aos métodos experimentais ou empíricos de avaliação de Usabilidade, estes sempre devem utilizar técnicas observacionais de questionamento e estar focados no usuário. Tais conceitos nos remetem à ideia de Interface "amigável" para o usuário, e, nesse sentido, os sistemas operativos definem sua capacidade de interação e, consequentemente, sua usabilidade.

De acordo com Pinto (2008), na concepção de Norman ${ }^{107}$, considerado um dos pais da moderna ciência cognitiva, o usuário não deve focalizar excessivamente sua atenção na Interface e sim no trabalho que deseja executar, pois para todos os efeitos, a melhor Interface é aquela que não se faz notar. Isso quer dizer que, se a todo momento o usuário tiver que interromper suas ações, para entender, por exemplo, a continuidade do processo, significa que a Interface não tem boa interatividade.

105 Cf. BADRE, A. N. Shaping Web usability: interaction design in context. Boston: Pearson Education, 2002.

${ }^{106}$ Norman, Donald A. (1998). The Design of Every Things. London: The Mit Press.

107 Cf. NORMAN, D. A. Design Emocional: por que adoramos (ou detestamos) os objetos do diaadia. Rio de Janeiro: Rocco, 2008. 
Quanto ao esforço cognitivo do usuário, Krug $^{108}$ (2000, citado por HACK; SANTOS, 2010, p.414), retoma a primeira lei de usabilidade: "não me faça pensar", pois segundo o autor, uma página Web deve ser evidente por si só e autoexplicativa sem depender do esforço do usuário, pois alguns detalhes em uma página Web podem fazer o usuário parar e pensar desnecessariamente.

As pesquisas de Norman (2008), na área de psicologia do design, demonstraram que o fator emocional é fundamental nos processos que envolvem a concepção, interação e tomada de decisões, segundo o autor, as emoções são capazes de mudar a maneira de pensar, servindo constantemente para guiar as pessoas para o comportamento adequado, pois as complexas condições do organismo que envolvem variações no corpo, impactam tanto na saúde, quanto na criatividade e até mesmo na resolução de problemas. Portanto, uma das abordagens do chamado design emocional, portanto, é desenvolver produtos que diminuam as frustrações e os efeitos negativos na capacidade cognitiva dos indivíduos (HACK; SANTOS, 2010, p. 413 ).

De acordo com Pinto (2008, p. 6), Levy ${ }^{109}$, ao propor um entendimento da interface enquanto rede cognitiva de interacções, cuja função é criar uma interdependência com os indivíduos através de técnicas de comunicação e representação que estruturam a rede cognitiva coletiva e contribuem para a definição de suas propriedades, concluindo que "as tecnologias intelectuais estão também nos sujeitos através da imaginação e da aprendizagem."

Nesse contexto, a avaliação, objetiva solucionar os problemas de usabilidade numa interface, que podem ser confirmados e receber recomendações precisas, por meio de avaliadores, através de inspeções ou examinando aspectos de usabilidade de uma interface, os quais podem ser especialistas em usabilidade ou especialistas em determinado padrão de interface, bem como construtores e consultores de softwares. Estas avaliações podem ser aplicadas em fases iniciais e/ou finais do desenvolvimento do projeto ou mesmo quando os sites já estão disponíveis em rede, bem como podem ser

\footnotetext{
${ }_{108}^{108}$ Autor da obra Não me faça pensar.

109 Para maiores informações, ver: Levy, Pierre (1992). As Tecnologias da Inteligência: o futuro do pensamento na era Informática. Tradução: Carlos Irineu da Costa. São Paulo, Ed. 34, 2004.

Disponível em: http://www.scribd.com/doc/17394163/As-Tecnologias-da-Inteligencia. Acesso em: 17 fev. 2011.
} 
realizados testes de usuários através dos quais, usuários reais ou potenciais avaliam a interface geralmente realizando tarefas simples.

A vasta literatura que envolve a Usabilidade, sugere vários métodos de avaliação da Usabilidade dos sites, conforme dispostos a seguir:

- Avaliação Heurística: uso de lista de heurísticas;

- Revisão de Guidelines: consiste em verificar se o site está em conformidade com algumas guidelines;

- Inspeção de Consistência: consistência dentro de uma família de interfaces (terminologia, cores, layout, formatos entrada/saída);

- Percurso Cognitivo : Walkthrough Cognitivo; (predição de uso): consiste na análise do "caminho" percorrido na execução de uma tarefa (modelagem psicológica) onde especialistas revisam o sistema para predizer problemas que usuários podem encontrar;

- Walkthrough Pluralístico: É um método de avaliação sistemático que reúne um grupo de avaliadores, usuários finais, projetistas, desenvolvedores e especialistas em fatores humanos. A avaliação é baseada em protótipos construídos em papel ou acetato com várias peças, cada uma representando elementos da interface e suas possíveis variações;

- Teste com usuários: métodos empíricos ou experimentais, que se baseiam em testes realizados com usuários, geralmente um grupo de usuários reais que utilizam o Website anotando os problemas de uso que encontram para poder solucionar-los posteriormente ou realizando tarefas. Trata-se de uma prova controlada em 'laboratório' ou realizada no mundo real. Nesta categoria temos o chamado "Teste de Usabilidade" ou simplesmente "Avaliação com o Usuário".

Com relação à avaliação heurística, deve-se estabelecer algumas heurísticas para avaliar a interface e apresentar a especialistas para que encontrem os problemas de usabilidade. Nielsen (2000) apresenta uma escala de 0 a 4 para determinar a gravidade desses problemas de usabilidade: 
0 - indica o grau de severidade mais baixo, ao qual se atribui pouca importância, por não afetar a operação da interface, normalmente são problemas estéticos

1 - indica os problemas de usabilidade que não têm necessidade de solução imediata, são os chamados "problemas cosméticos";

2 - indica problemas simples, de baixa prioridade, de fácil reparação;

3 - envolve problemas graves, que devem ser reparados com alta prioridade;

4 - indica problemas catastróficos de usabilidade que devem ser reparados imediatamente.

Normalmente, após realizar uma avaliação heurística, pode-se comprovar o efeito desses problemas sobre os usuários através dos "testes de usuários". Quando se pretende elaborar um teste com usuários, devem-se, de preferência, considerar os perfis dos usuários, quer dizer, a que segmentação ou categoria pertencem, para estabelecer posteriormente que tarefas vão realizar no teste e, por último, desenhar os formulários onde serão recolhidos os resultados da experiência.

Anteriormente ao teste com usuários recomenda-se fazer uma avaliação prévia do site em questão para que se descubram os problemas gerais de Usabilidade, uma vez que quase todos os sites em sua concepção passam por avaliações para atender a alguns princípios para garantir sua qualidade. Assim sendo, identificamos os principais problemas de Usabilidade antes mesmo de pôr à prova um site pelos usuários.

Diante do exposto anteriormente, pode-se questionar qual seria o método mais adequado para se utilizar na avaliação de um site. Recomenda-se pois, misturar e adaptar métodos para conseguir resultados mais seguros. Porém, segundo Krug (2006, p. 14), a usabilidade "It's not a rocket surgery"110", apenas significa que qualquer pessoa com interesse, experiência e habilidades comuns somados ao bom senso pode utilizar o site sem dificuldades.

110 "Não é um bicho de sete cabeças" (Tradução e interpretação nossa). 
De acordo com Santos (2000, p. 3), a "avaliação heurística" usada na Interação Humano-Computador foi introduzida por Jakob Nielsen e Rolf Molich no início da década de 1990, quando propuseram um método através do qual o criador da página aplica um determinado número de princípios, ou heurísticas, ao projeto. Nielsen e Molich descreveram um método no qual um pequeno grupo de avaliadores examina uma dada interface e procura por problemas que violem alguns princípios gerais do bom projeto de interface.

Os autores destacam ainda que, em contrapartida, a avaliação heurística apresenta como desvantagens o fato de ser um método altamente subjetivo e não estruturado. Devido à sua natureza não estruturada, pode levar a resultados pobres ao se considerar a confiabilidade e validade preditiva ${ }^{111}$.

É importante considerar que, duas ferramentas juntas, melhor que a utilização de apenas uma, possibilitam determinar a usabilidade real de um site. As mais recomendáveis são justamente a avaliação de especialistas e o teste de usuários. A primeira preferencialmente deve ser feita antes que o site esteja disponível para os usuários, porque será mais fácil corrigir os erros ou adaptá-lo às necessidades reais de seus usuários e a segunda geralmente é feita após a avaliação dos especialistas para validar ou confrontar os resultados verificando o grau de conformidade com os princípios da usabilidade. A avaliação, porém, deve ocorrer durante todo o ciclo de vida do sistema, pois os resultados podem servir para melhorar gradativamente a interface, podendo-se identificar dificuldades do usuário e melhorar o produto.

Para a avaliação dos especialistas, as heurísticas consistem em dos métodos mais práticos e mais baratos para se avaliar um site. Segundo Nielsen (2000), a avaliação heurística dispensa a opinião dos usuários, porém existem discordâncias:

[...] aunque técnicas de evaluación como la heurística son muy útiles para detectar errores de diseño ampliamente conocidos y reiterativos, las características y peculiaridades de cada diseño, así como de cada audiencia, harán necesaria una evaluación "específica" que asegure la usabilidad del sitio (HASSAN MONTERO e MARTÍN FERNÁNDEZ, 2003) ${ }^{112}$

\footnotetext{
111 Idem.

112 [...] ainda que técnicas de avaliação como a heurística sejam muito úteis para detectar erros de desenho amplamente conhecidos e repetitivos, as características e peculiaridades de cada desenho bem como de cada audiência, exigirão uma avaliação "específica" para garantir a usabilidade do site (Tradução nossa).
} 
Portanto os testes envolvendo usuários podem vir a complementar a visão dos avaliadores. Para realizar o teste de usuários ou as chamadas provas informais, na medida do possível devem-se convidar participantes com perfis e características que estejam de acordo com a audiência "potencial" do site.

Os testes com usuários podem ser realizados através de Cheklists, Registro de interação mediante vídeo, áudio e ferramentas de interação log, como descritos a seguir:

1. Cheklists: técnica de anotação de dados, através de listas de observações.

2. Vídeo: utilização de câmeras para gravar a interação do usuário com o site durante o teste. Pode-se reduzir o impacto da presença da câmera instalandoas antes do início dos testes.

3. Ferramenta log: consiste na coleta automática de dados e não interfere no trabalho do usuário: utilizando ferramentas logging disponíveis para softwares.

Técnicas mais simples também podem ser utilizadas nos testes de usuário como, por exemplo, a utilização de questionários semiestruturados, destinados à observação de características específicas que se deseje comprovar no site a ser avaliado.

\subsubsection{Visibilidade}

A importância da Visibilidade, na Web, reside na ideia de que as pessoas possam facilmente encontrar a informação disponibilizada no ciberespaço.

Essa Visibilidade pode ser garantida levando-se em consideração três características básicas que são: a acessibilidade, a otimização dos serviços de busca e o design da página Web.

A questão da acessibilidade está relacionada tanto com as limitações físicas dos indivíduos quanto à funcionalidade de um site, ou seja, um site que apresente dificuldades em sua navegação também afeta diretamente a sua Visibilidade. 
As deficiências físicas podem ser amenizadas com a inclusão de alguns recursos como, por exemplo: aumento da fonte e "ouvir" o texto, que são os mais usuais atualmente.

As recomendações do W3C com relação à acessibilidade colaboram para que os sites se tornem usáveis também para aquelas pessoas que têm quaisquer limitações visuais. Estas questões, no entanto, ultrapassam a deficiência visual, pois a acessibilidade envolve também aspectos de outra natureza.

O Web designer responsável pela criação dos sites trata da construção de páginas, logo determina as condicionantes de acessibilidade e influencia as posições nos resultados dos serviços de pesquisa. Uma página bem desenhada deverá ser facilmente interpretada por pessoas e máquinas. Este é o fundamento do bom design.

O aspecto gráfico, a criatividade ou sentido de gratificação do designer nunca se devem sobrepor aos requisitos de visibilidade da página.

A Web foi criada para divulgar informação e este é o fator chave do seu sucesso, portanto é fundamental que o maior número de pessoas possível tenha acesso a ela.

É possível distinguir entre uma modalidade própria do "espaço público dos gregos", centrado na ideia de polis, e uma modalidade própria do "espaço público burguês", centrado na categoria de "publicidade" (SERRA, 2002, p.2).

Um dos fatores que podem conferir a Visibilidade de um site é o posicionamento Web.

O posicionamento de alguns sites culturais na internet nem sempre refletem a realidade do mesmo, por vezes não encontramos estes sites entre os dez primeiros resultados através de buscadores como o Google, por exemplo, e estes resultados não correspondem à sua real atividade presencial cotidiana.

El posicionamiento en Internet ha sido definido como la posición que ocupa un portal, desde el punto de vista de los usuarios, en relación con su competencia ${ }^{113}$ (SOTOMAYOR et al., 2005, p. 16).

\footnotetext{
${ }^{113} \mathrm{O}$ posicionamento na internet tem sido definido como a posição que um site ocupa desde o ponto de vista dos usuários, em relação à concorrência. (Tradução nossa)
} 
Os autores explicam que o Posicionamento não se resume apenas ao campo de ação dos buscadores, porém está relacionado também a outros canais da navegação pela rede (como o email ou os links estabelecidos entre as páginas Web que apesar de ter um menor peso quantitativo podem chegar a adquirir um valor qualitativo bem maior).

Ainda de acordo com os supracitados autores, diversos pesquisadores e especialistas pretendem chegar a um método global de análise e critérios de interpretação para o posicionamento Web e para tanto, estão unindo seus conhecimentos e suas experiências. A partir de então, sugerem cinco diferentes tipos de análises para se conseguir um melhor posicionamento de um site:

1. Análise dos objetivos estratégicos: Se definem os objetivos estratégicos do site para ter seu reflexo na internet. Para isso se analisam o âmbito temático (descritores por campos de atividade), os sócios ou colaboradores, os termos ou palavras-chave que definem as atividades ou serviços do site e se estabelece o público-alvo.

2. Análise do conteúdo do site: se estuda um estudo dos materiais, dos serviços e informações que são publicadas: volume dos conteúdos, estrutura, funcionalidade, glossário de termos usados, prestações multilíngües e links recomendados. Para analisar o conteúdo se mede: a qualidade do site estudando se são cumpridas as normas relacionadas à usabilidade e a acessibilidade do mesmo, através da manutenção periódica das páginas, se analisam os possíveis links falhos, que por algum motivo não são alcançáveis através da Web e que convém repetir; se mede o volume dos conteúdos, das páginas bem como os serviços que o site oferece, verificando se o formato das mesmas é o adequado para sua indexação nos diferentes buscadores; a variedade de idiomas utilizados e os serviços personalizados.

3. Análise do uso do site: Recomenda-se fazer uso de um programa de analise de tráfico Web e de uma enquete assim como conhecer as limitações dos analisadores e as margens de erro das entrevistas na hora de interpretar e avaliar. Analisam-se as tendências dos usuários: volume de páginas mais visitadas, o número de visitas, sua duração e procedência 
e seu efeito sobre a atividade presencial em cada site, através do ficheiro $\log$.

4. Análise da popularidade do site: Seria útil que o conteúdo tenha qualidade e desenho acessível e "utilizável". Em geral os usuários estão muito mais interessados no conteúdo dos sites e se pode ajustar por meio de uma exaustiva análise os que são mais importantes para os visitantes. O estudo das páginas mediante as quais os usuários têm acesso à página Web ou a abandonam é também muito útil para otimizar sua arquitetura. A popularidade na verdade corresponde à sua posição no ranking de páginas do buscador (Google). Aqui entra o controle da visibilidade através de um segmento das posições que ocupam os acessos a uma determinada página Web nas listas dos buscadores.

5. Análise da eficiência e da rentabilidade: Se recomenda situar o site na vizinhança adequada, incluir conteúdos de qualidade relacionados aos setores estratégicos do site, incluir palavras-chave e palavras ou frases pelas quais os usuários buscam o site, o intercâmbio de links e banners com outros portais e o posicionamento adequado nos buscadores mediante ferramentas adequadas para isso.

$\mathrm{Na}$ verdade, a análise da popularidade do site sugerida por Sotomayor et al. $(2005)^{114}$ reflete bem o que se deve verificar em uma página Web quando se deseja conhecer o fator Visibilidade: analisar as páginas mais visitadas, conhecer a frequência com que são visitadas e o tempo médio que os usuários passam nela (utilizando-se ferramentas estatísticas para medir o tráfico das páginas); definir um grupo de palavras-chave de referência e realizar busca através dos buscadores (verificar o posicionamento Web utilizando ferramentas específicas e realizando um controle da eficácia da visibilidade); conhecer o tipo de sites que os usuários que utilizam o site analisado costuma visitar (graças à ferramenta TouchGraph do Google se pode analisar uma análise dos links que uma determinada página dispõe e que o motor de busca tem em conta, ou seja, perfil temático); controle da sociabilidade através de links externos realizados desde outros sites (se mede o número de links relacionados a um site mediante possibilidades que alguns buscadores apresentam como o Google e o AltheWeb 
e de ferramentas estatísticas como Webtrends); verificar a integração do site na Rede verificando sua visibilidade em comunidades virtuais de usuários, listas de distribuição, boletins, etc; controle da difusão em meios através da própria atividade presencial do site e mediante o uso das News do Google e outros meios digitais.

Codina (2004, p.2) apresentou uma tabela com definições sobre posicionamento Web utilizando os seguintes termos: Posicionar (Colocar alguma coisa no seu lugar); Posicionamento Web (Conjunto de procedimento e técnicas que estudam as características que proporcionam a um site ou página Web a máxima visibilidade na Internet); Posicionamento planificado (O posicionamento que uma página Web consegue devido a uma campanha consciente e planejada, que pode ser natural ou fraudulenta); Posicionamento natural ( $\mathrm{O}$ posicionamento que uma página Web consegue de maneira espontânea); Posicionamento planificado fraudulento ( $O$ posicionamento é conseqüência de atividades direcionadas conscientemente a forçar os resultados. Termo relacionado com spam); Posicionamento Planificado ético (Consiste em conseguir os mesmos resultados em que se obteria com um posicionamento natural em uma situação "ideal" em que são utilizados exaustivamente os motores de busca e os responsáveis pelo site desenharam espontaneamente sites com visibilidade ótima para os motores de busca).

O autor apresenta ainda conceitos sobre Palavra-chave, Metadados, Popularidade, Pagerank, Google bombing, Relevância, TrafficRank e Spam, uma vez que todos estes itens refletem diretamente no posicionamento Web.

Ainda segundo o supracitado autor, os motores de busca utilizam critérios externos e internos para calcular a relevância relativa de uma página Web na rede de acordo com a maneira que se busca a informação, porém afirma que:

(...) Los motores de búsqueda mantienen en secreto el detalle último de sus procedimientos, ya que se trata de una información susceptible de conferirles ventaja competitiva y, por tanto, la, consideran un secreto industrial. Por este motivo, todo aquello que los estudiosos y profesionales afirman sobre el tema, en realidad es, o bien simple especulación, o bien resultado de inferencias indirectas. Es decir, a partir de la observación y del análisis de los resultados, existe un cierto consenso entre los analistas 
sobre qué clase de criterios usan los motores de búsqueda para ordenar los resultados ${ }^{115}$.

De acordo com os critérios para avaliar a visibilidade de sites que a maior parte dos analistas utilizam e a partir de suas próprias observações, Codina (2004, p.5) reúne em uma tabela os quatro maiores motores de busca da atualidade: Google, Yahoo, HotBot e Msn, e chama a atenção para o fato de que não se sabe como se combinam em cada momento a importância de cada um deles e que no decorrer do tempo eles podem variar assim como o peso relativo de cada critério pode variar, por isso mesmo chama de especulação sólida e bem fundamentada sua classificação dos critérios internos e externos. Alguns desses critérios externos, no entanto, são os que medem claramente a visibilidade da página, portanto apresentamos os mesmos no quadro a seguir:

\begin{tabular}{|l|l|}
\hline \multicolumn{2}{|c|}{ Critérios externos em links (visibilidade) } \\
\hline 1. Número de links recebidos pela página & $\begin{array}{l}\text { Um site será mais relevante quanto mais links } \\
\text { recebe de outras páginas. }\end{array}$ \\
\hline 2. Qualidade dos links recebidos pela página & $\begin{array}{l}\text { Um link que procede de uma página pessoal, } \\
\text { outorga menos valor que um link que procede do } \\
\text { Yahoo, por exemplo, isso determina a qualidade. }\end{array}$ \\
\hline 3. Texto dos links recebidos pela página & $\begin{array}{l}\text { Alguns buscadores, mas principalmente o Google, } \\
\text { consideram que o texto que serve de ancoradouro } \\
\text { ao link externo até outra página como uma pista ou } \\
\text { uma inferência válida para calcular a relevância da } \\
\text { página que o link remete. }\end{array}$ \\
\hline
\end{tabular}

\section{Quadro 27: Critérios externos em links}

Fonte: Informações retiradas da Tabela: Critérios externos a La página Web (CODINA, 2004, p.6).

\footnotetext{
115 ...os motores de busca mantém em segredo o detalhe final dos seus procedimentos, já que se trata de uma informação suscetível de lhes conferirem vantagem competitiva e, portanto, a consideram um segredo industrial. Por este motivo, tudo aquilo que os estudiosos e profissionais afirmam sobre o tema é, ou apenas simples especulação, ou resultado de inferências indiretas. Ou seja, a partir da observação e da análise dos resultados, existe um certo consenso entre os analistas sobre que classe de critérios usam os motores de busca para ordenar os resultados ${ }^{\urcorner}$. (Tradução nossa)
} 


\section{Capítulo 5 TRILHANDO OS CAMINHOS DA METODOLOGIA}

Neste capítulo, apresentam-se etalhadamente os procedimentos metodológicos utilizados para a coleta de dados tanto da avaliação preliminar quanto da avaliação propriamente dita. 


\subsection{INTRODUÇÃO À METODOLOGIA}

Todo o método consiste na ordem e na disposição das coisas para as quais devemos voltar o olhar do espírito, para descobrir alguma verdade.

Descartes

Para atender à motivação inicial do estudo em questão, considerou-se pertinente uma revisão literária, para fundamentar os pontos a serem explorados no estudo em questão. Assim, foram utilizadas fontes oriundas de materiais concretamente já elaborados disponíveis, em livros, e artigos de periódicos, a respeito dos critérios de avaliação de sites de um modo geral.

Foram também realizadas buscas on-line para levantar informações relevantes sobre o tema já que, segundo Codina (2000, p. 10), "Es ya un tópico afirmar que Internet es la mejor fuente de información sobre Internet..."116

Com o propósito de desenvolver uma pesquisa de abordagem quantiqualitativa, por considerar as interpretações de dados estatísticos e também o olhar do observador-participante sobre avaliação de sites de Arquivos, tomou-se como apoio os pressupostos teórico-metodológicos de Jiménez Piano e OrtizRepiso Jiménez (2007) e Nielsen (2002), este último, internacionalmente conhecido como o "papa da usabilidade", que norteou inúmeras pesquisas na área de avaliação de sites. Além desses autores, também recorreu-se a outros autores de referência na área de usabilidade de sites a exemplo de Hassan Montero e Martín Fernández através do site Nosousabilidad ${ }^{17}$. Posteriormente, com a necessidade de ampliar e diversificar o universo da pesquisa, em uma nova avaliação chamada de "Avaliação propriamente dita" tomou-se como base também os pressupostos teóricos de Nielsen (1993; 2000); Aitta, Kaleva e

\footnotetext{
116 "Já é lugar-comum afirmar que "Internet é a melhor fonte de informação sobre internet...". (Tradução nossa)

${ }_{17}$ Revista Multidisciplinar sobre desenho, pessoas e tecnologia. Para mais informações consultar: http://www.nosolousabilidad.com/acercade.htm
} 
Kortelainen (2007); Hassan Montero (2000); Hassan Montero e Ortega Santamaría (2009); Hassan Montero e Martín Fernández (2002; 2003).

Esta pesquisa assumiu inicialmente um caráter exploratório, com o intuito de coletar maiores informações sobre páginas Web de Arquivos e sobre os critérios de avaliação de sites. Para facilitar a delimitação do tema, focou-se nos Arquivos espanhóis. ${ }^{118}$

Depois de registrar dados desde a origem dos Arquivos, sua transformação ao longo dos anos, passando pela análise de sua evolução, buscou-se aprofundar o conhecimento de sua realidade atual, identificando as causas do processo de evolução e o porquê das transformações - o que configura o caso de pesquisa explicativa, quanto aos objetivos pretendidos.

Quanto à escolha do objeto de estudo, no primeiro momento, foi utilizada a lista de arquivos estatais dirigidos pelo ministério da cultura da Espanha disponibilizado no site do $\mathrm{MCU}^{119}$ para realização da avaliação geral das páginas Web de Arquivos.

Quanto à natureza da pesquisa, ela pode ser identificada como um trabalho científico original, pois ao que consta nos registros publicados, ainda não foi realizado outro que trate com profundidade da avaliação de sites de Arquivos espanhóis. Dessa forma, este estudo vem contribuir, ainda que timidamente, ao progresso da ciência, conhecida como pura ou fundamental.

De início, foram levados em consideração diversos critérios de avaliação e seus indicadores de qualidade. Tais avaliações são realizadas normalmente no momento da criação do site quando se deseja que ele cumpra as exigências quanto aos conceitos técnicos de qualidade. São, porém, esses mesmos conceitos que norteiam as avaliações posteriores focadas, sobretudo na sua Usabilidade, ou seja, verificando através dos critérios avaliados a facilidade de uso desses sites e a visão dos usuários - reais e/ou potenciais - sobre eles.

Tanto a Visibilidade quanto a Usabilidade formam parte essencial do conjunto de critérios para a avaliação de recursos digitais e o controle desses

\footnotetext{
118 A escolha temática teve influência direta dos orientadores da Tese, que levaram em consideração a localidade onde estava sendo desenvolvida, a qual seria apresentada ao Programa de Doutorado em Biblioteconomia e Documentação da Universidade de Salamanca, na Espanha.

${ }^{119}$ Disponível em: http://www.mcu.es/archivos/CE/archivoscentros.html
} 
critérios pode ser considerado a mais forte ferramenta para os gestores do recurso avaliado, dado que envolve praticamente todos os demais. Portanto, na avaliação posterior ou "Avaliação propriamente dita", o estudo dos sites foi direcionado a esses dois critérios. Para tanto, foram considerados especificamente a bibliografia referente à usabilidade e a visibilidade de sites, sobretudo os de bibliotecas e Arquivos.

Vale salientar que a apresentação desta investigação seguiu as normas da Associação Brasileira de Normas Técnicas (ABNT) para apresentação de trabalhos científicos, portanto, toda a redação do texto e disposição dos elementos está em conformidade com essas normas. Para a apresentação dos dados estatíticos utilizou-se o programa SPSS.

Para avaliar a visibilidade dos Arquivos nesta investigação, em primeiro lugar, foram considerados os metatados, uma vez que, corroborando Codina (2004), um dos recursos para avaliar a visibilidade é a posição natural, o que significa que os sites têm visibilidade autêntica, sem a utilização de recursos para forçar os resultados ou mesmo o posicionamento Web que significa uma planificação ética que acontece quando os criadores do site direcionam os metadados para que os motores de busca encontrem facilmente a página resultando em uma visibilidade ótima por ocupar as primeiras posições nos resultados. Piano Jiménez e Ortiz-Repiso Jiménez (2007) também apresentam no Critério Busca e Recuperação a Categoria Metadados, dentro do qual foi selecionado o indicador: Apresenta metadados padronizados?

A busca através dos buscadores utilizando palavras-chave coincide com uma das sugestões de Sotomayor et al. (2005) para analisar o fator Visibilidade de um site. Quanto ao posicionamento Web, o mesmo incide também sobre o sexto entrave de Usabilidade de Nielsen: "mau posicionamento e má organização" de palavras-chave.

Dos pressupostos teóricos de Piano Jiménez e Ortiz-Repiso Jiménez (2007), utilizou-se também os seguintes critérios, categorias e indicadores:- Do Critério Autoridade, Categoria Identificação e Reputação utilizou-se o indicador: Traz informação sobre a Instituição que hospeda ou cria a página Web do Arquivo? 
- Do Critério Administração:

- . Categoria Administração do sistema utilizou-se o indicador: Existe alguma garantia de autenticidade, como certificações, etc?

- .Categoria Atualização utilizou-se: data da última modificação

Dos pressupostos teóricos de Gutierrez, extraíram-se alguns indicadores que em parte coincidem com os de Piano Jiménez e Ortiz-Repiso Jiménez (2007):

- Do critério Conteúdo utilizou-se o indicador: A informação está numa linguagem apropriada e com uma profundidade acessível para o público a que se dirige?

- Do Critério Autoria, utilizaram-se os seguintes indicadores:

- Contém indicações claras e explícitas sobre a autoria e/ou responsabilidade intelectual do recurso?

- Existem indícios que de o recurso está criado, produzido ou editado por uma instituição ou organismo de reconhecido prestígio em seu campo?

- Do critério Atualização, utilizou-se o indicador: A informação é atualizada regulamente?

- Do Critério facilidade de Uso utilizaram-se os seguintes critérios:

- O site está acessível para usuários com necessidades especiais?

- Está claro como navegar através das páginas do recurso?

. Apresenta um mapa do site?

. Existe ajudas e sistemas de recuperação de informação adicionais?

- Do Critério Apresentação, utilizaram-se os seguintes critérios:

- A interface é clara e fácil de usar?

- Os links a outras páginas são fáceis de encontrar?

- Os usuários com necessidades especiais teriam dificuldade para usar o site? (Problemas potenciais: letra pequena, pouco uso de espaço em branco, "frames", falta de cor de contraste entre elementos, etc).

- Do Critério Interatividade, utilzou-se o critério: 
. Se pode perguntar, sugerir ou enviar mensagens ao administrador do site? (que corresponde à ajuda ao usuário).

Para a avaliação da Usabilidade na Avaliação propriamente dita tomou-se como base os pressupostos teóricos de Nielsen (1993; 2000); Aitta, Kaleva e Kortelainen (2007); Hassan Montero (2000); Hassan Montero e Ortega Santamaría (2009); Hassan Montero e Martín Fernández (2002; 2003). As heurísticas de Nielsen (2000) serviram de base para criar as heurísticas juntamente com a proposta de heurísticas para bibliotecas de Astle e Muir (2002) e de Aitta e Kaleva (2007) que se trata de uma combinação das avaliações propostas por Aitta (2004) e Kaleva (2004), também baseadas em heurísticas de Nielsen e, no caso da segunda avaliação, também em testes de usabilidade.

Foi utilizado ainda, para a construção do Questionário dos avaliadores da avaliação propriamente dita, através da Revista Eletrônica sobre Usabilidade No Solo Usabilidad, a proposta de avaliação de usabilidade de Travieso Rodríguez, Alonso arévalo e Vivancos Secilla (2007). Do Modelo para avaliação de Especialistas (Para analisar a Usabilidade e a acessibilidade de um site) foram extraídas algumas questões dentro das Categorias apresentadas, são estas:

- Categoria Aspectos gerais:

. Mantém consistência tanto no funcionamento como na aparência geral do site?

- Categoria Redação:

. O site utiliza uma linguagem familiar aos usuários?

- Categoria Navegação:

. Existe um controle para que os links não caiam no vazio?

.O site tem um mapa do site ou um buscador para o acesso aos conteúdos sem a necessidade de navegação?

- Categoria Interface:

.O espaço visual é devidamente aproveitado? Apresenta equilíbrio entre texto e espaços em branco?

- Categoria Visibilidade Hipertextual: Posicionamento segundo Google

- Categoria Controle e Retroalimentação. Se o sistema prevê respostas ao usuário, ou seja, sua interação com o usuário em suas ações 
- Categoria Ajudas ao usuário. Existe um link com a seção "Ajuda" em destaque na página de início ?

- Categoria Controle e Retroalimentação:. O Usuário tem controle sobre a interface? Possui liberdade para atuar?

Algumas das questões apresentadas dos pressupostos teóricos dos diferentes autores coincidem ou se complementam e as questões utilizadas nos questionários tanto dos avaliadores quanto dos usuários também foram baseadas em experiências descritas nestes pressupostos somadas às decisões tomadas conjuntamente com um especialista em construção e avaliação de sites para que resultasse em uma proposta que não causasse exaustão nos atores envolvidos sem perder seu caráter funcional no que diz respeito à análise dos sites aqui descritas.

\subsection{PROCEDIMENTOS PARA A COLETA DE DADOS}

Preliminarmente foi feita uma avaliação geral dos sites de Arquivos estatais espanhóis, os quais se encontram hospedados no site oficial no Ministério da Cultura da Espanha $(\mathrm{MCU})^{120}$. Com os dados obtidos, através do levantamento bibliográfico e online, decidiu-se criar um quadro com critérios de avaliação de sites, conforme exposto no capítulo 4 , os quais refletem a qualidade dos sites e sua interação com o usuário. Para tanto, foram verificadas as diversas listas apresentadas pelos autores e determinados os indicadores que seriam mais adequados considerar em cada critério selecionado. Ao final, foram incluídas no quadro, as categorias desses critérios e alguns de seus indicadores cuidadosamente selecionados (Cf. Apêndice E).

Foram convidados avaliadores para opinar sobre os sites dos Arquivos espanhóis, objeto deste estudo, nas duas propostas de avaliação.

Faz-se uma ressalva a respeito dos resultados das avaliações: uma vez que a pesquisa não tem fins lucrativos, não se pode garantir em 100\% o

\footnotetext{
${ }^{120}$ Ministerio de Cultura da Espanha. Disponível em : www.mcu.es. Acesso em 22 jun. 2011
} 
comprometimento dos avaliadores. Dessa feita, considerando, pois, a hipótese da desistência e a necessidade de confirmar as impressões dos avaliadores a respeito dos sites, fez-se pertinente reforçar o olhar sobre o objeto de estudo por meio da observação de usuários da Internet, os ciberusuários, cuja contribuição possibilitou uma margem de segurança às avaliações, adquirindo uma visão multidiciplinar dos sites.

Para que os resultados tivessem a máxima aproximação da realidade, em relação à leitura das informações solicitadas, decidiu-se que todos os participantes envolvidos - usuários e avaliadores - atendessem ao pré-requisito da familiaridade com a língua espanhola e, no caso dos usuários, também conhecimento básico de buscas através da rede.

\subsection{DESCRIÇÃO DA AVALIAÇÃO PRELIMINAR}

Para esta fase da avaliação, selecionaram-se como corpus, páginas Web de 11 Arquivos Estatais Espanhóis. Foram convidados para exercer o papel de avaliadores: dois bibliotecários e dois Webdesigners, sendo a própria autora uma das avaliadoras (avaliador participante).

Justifica-se a escolha de dois especialistas em informática e dois profissionais da área de Biblioteconomia e Documentação por se tratar de gestores de duas áreas complementares no que se refere ao domínio de conhecimento de sites de Arquivos.

A análise preliminar foi baseada nos pressupostos teóricos de Jiménez Piano e Ortiz-repiso Jiménez (2007), a primeira Doutora em Biblioteconomia e Documentação e a segunda, Doutora em Filologia espanhola, cujas atividades docentes e de investigação estão centradas principalmente nas tecnologias de informação e Hassan Montero e Martínez Fernandez, o primeiro designer interativo e pesquisador sobre visibilidade e interação humano-computador, o segundo, pesquisador sobre usabilidade e acessibilidade no meio virtual, que fazem parte da direção editoral da Revista Eletrônica No solo Usabilidad, que 
serve como ferramenta para a divulgação e intercâmbio de conhecimentos entre pesquisadores e desenvolvedores $W e b^{121}$.

Conforme a versão reduzida do modelo Bracad $^{122}$ das autoras Jiménez Piano e Ortiz-repiso Jiménez (2007), que mantêm os critérios e as categorias consideradas mais importantes e de maior peso, e consta de 5 critérios de avaliação com 21 categorias e 48 indicadores ${ }^{123}$, utilizou-se a escala da segunda edição da obra de Vilar Barrío de 1998 para se obter o peso total de cada critério subdividido entre seus indicadores, conforme se visualiza a seguir:

Tabela 1 - Peso dos critérios ${ }^{124}$

\begin{tabular}{|c|c|c|c|c|c|c|c|}
\hline CRITÉRIOS & $\begin{array}{c}\text { BUSCA } \\
\text { E } \\
\text { RECUP } \\
\text { ERAÇ̃̃ } \\
0\end{array}$ & $\begin{array}{l}\text { CONT } \\
\text { EÚDO }\end{array}$ & $\begin{array}{c}\text { AUTOR } \\
\text { IDADE }\end{array}$ & $\begin{array}{c}\text { DESENH } \\
0\end{array}$ & $\begin{array}{c}\text { ADMIN } \\
\text { ISTRAÇ } \\
\tilde{\text { AOO }}\end{array}$ & $\begin{array}{c}\text { To } \\
\text { TAL }\end{array}$ & $\begin{array}{c}\text { PERCE } \\
\text { NTUAL } \\
(\%)\end{array}$ \\
\hline BUSCA E RECUPERAÇÃO & & 2 & 5 & 2 & 2 & 11 & 23,91 \\
\hline $\begin{array}{l}\text { CONTEÚDO } \\
\end{array}$ & 2 & & 2 & 5 & 2 & 11 & 23,91 \\
\hline AUTORIDADE & 2 & 1 & & 2 & 2 & 07 & 15,22 \\
\hline DESENHO & 2 & 1 & 2 & & 5 & 10 & 21,74 \\
\hline ADMINISTRAÇ̃̃̃O & 2 & 2 & 2 & 1 & & 07 & 15,22 \\
\hline & 46 & 100,00 \\
\hline
\end{tabular}

Legenda: 1 - MENOS IMPORTANTE 2 - IMPORTANTE IGUAL 3 -SIGNIFICATIVAMENTE MAIS IMPORTANTE

Como se pode observar na Tabela 1 , o peso dos critérios foi definido comparando-os entre si. Assim, atribuiu-se peso 1 ao critério considerado de menor importância em relação ao que está sendo comparado; peso 2, quando os dois critérios comparados são considerados de igual importância e peso 5 , quando o critério é considerado significativamente mais importante do que aquele com o qual está sendo comparado. Essa pontuação serviu apenas para delimitar a pontuação máxima dentro de cada um dos critérios e subdividi-la posteriormente de forma adequada entre os indicadores apresentados para cada um deles. Dessa forma, obteve-se um modelo padrão de questionário, disposto em um quadro (Cf. Apêndice E), no qual se verifica que o peso máximo, atribuído

\footnotetext{
121 Sobretudo na Espanha esta Revista tem um peso relevante com relação ao tema "Usabilidade". 122 Bracad é um acrônimo dos critérios de avaliação de sites definidos por Piano e Jimenez (Cf. lista de siglas, nas pré-textuais desta investigação)

${ }^{123}$ Cf. Piano e Jimenez (2007, p. 239).

${ }^{124}$ Elaboração da própria autora.
} 
a cada um dos indicadores, é 3, haja vista a possibilidade de alguns elementos terem um caráter mais importante do que outros, justificando o peso 3 . O peso 5 , porém, estaria muito distante da realidade já que não foram utilizados todos os indicadores sugeridos por Jiménez Piano e Ortiz-Repiso Jieménez (2007), mas selecionados os de maior "relevância" como justificado anteriormente. Tanto a escolha dos indicadores mais relevantes, quanto a decisão de atribuir peso máximo 3 a cada elemento foi tomada conjuntamente com o Webdesigner $^{125}$,

A partir desse modelo padrão, foi elaborado um questionário similar, destinado aos avaliadores, sem o preenchimento da respectiva pontuação, para avaliar as páginas Web dos Arquivos, objeto deste estudo (Cf. Apêndice F). Tal questionário deveria ser preenchido com base na pontuação pré-existente no questionário-modelo que apresentava o total de pontos destinado a cada indicador.

Para cada Arquivo, foi preenchido pelos avaliadores um questionário em que pontuavam cada um dos indicadores dos critérios dispostos na tabela, conforme sua visão a respeito do dito Arquivo. A soma total dos pontos revelaria a boa ou má qualidade do site avaliado.

Também foi realizado, em novembro de 2009, em um laboratório de Informática da Universidade Federal de Pernambuco (UFPE), um teste de usabilidade com usuários potenciais dos sites dos Arquivos selecionados. Vale salientar que os participantes eram todos alunos do curso de Biblioteconomia da referida universidade, perfazendo um total de vinte entrevistados. Essa atividade contou com a colaboração do Professor Doutor Marcos Galindo, que mui gentilmente cedeu o espaço de suas aulas. O tempo de execução do teste foi de duas horas de duração.

O teste se constituía de um questionário com questões iniciais cuja finalidade era compor o perfil do "usuário potencial", bem como medir o seu nível de conhecimento em informática. Pedia-se nas demais questões, a realização de tarefas simples (Cf. Apêndice G), explorando basicamente a homepage de cada Arquivo, utilizando a URL do Ministério da Cultura (MCU) para localizá-los, uma

${ }^{125}$ O Web designer convidado a opinar sobre o modelo adaptado teve participação impornte como colaborador, durante a primeira etapa da avaliação, conferindo credibilidade ao processo, haja vista sua formação técnica e grande experiência em criação, desenvolvimento e manuteção de sites. 
vez que os onze Arquivos estudados se encontram hospedados dentro desse site, tornando possível o seu acesso através de sua página principal.

Para se chegar às páginas Web dos Arquivos hospedados no site do MCU, primeiramente deve-se acessar sua homepage, anteriormente citada.

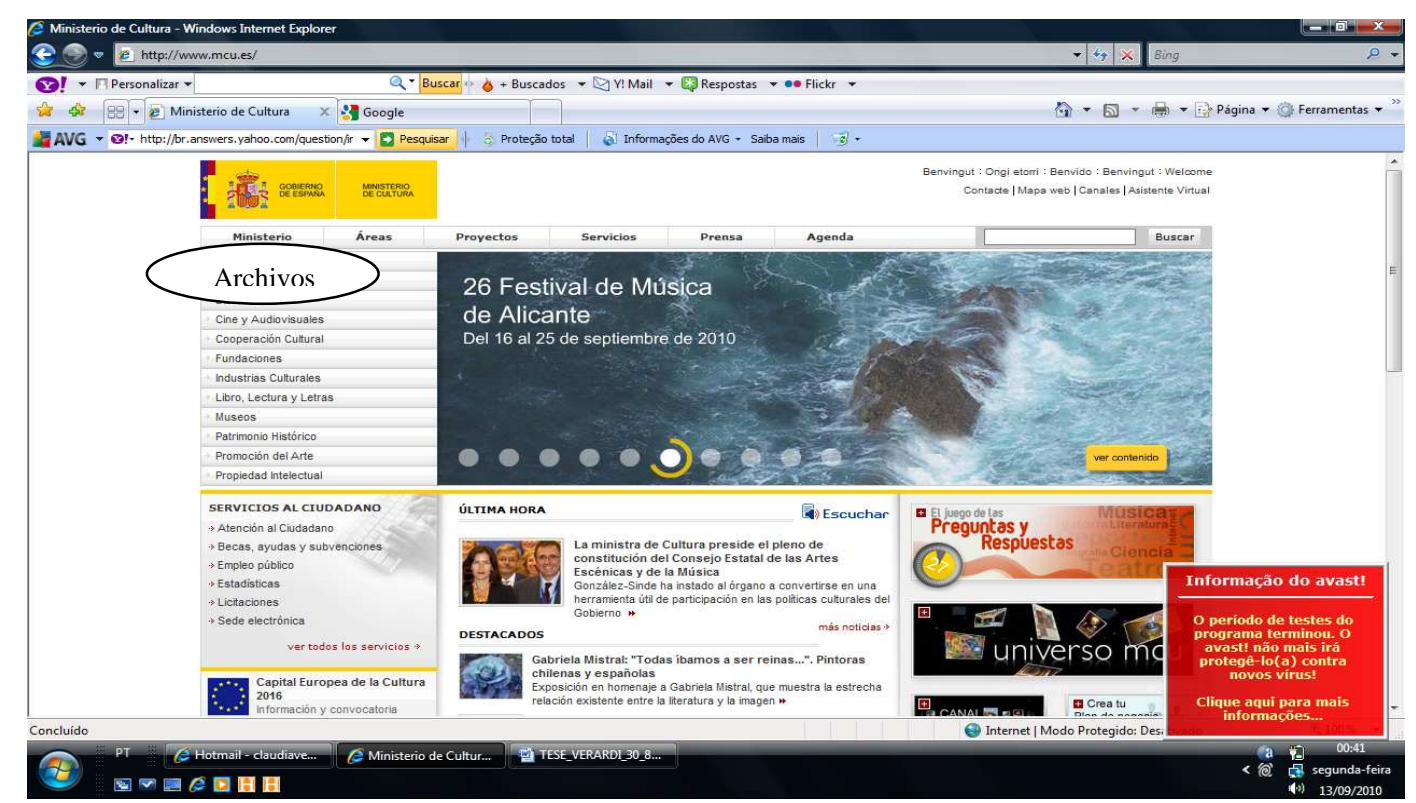

Figura 5- Homepage do site do MCU

Assim, na Homepage do MCU, clica-se em "Arquivos" (Figura 2), que aparece no menu do lado esquerodo da tela. Em seguida clica-se em "Archivos e Centros", surgindo a lista dos Arquivos estatais espanhóis, como se observa na figura a seguir. 


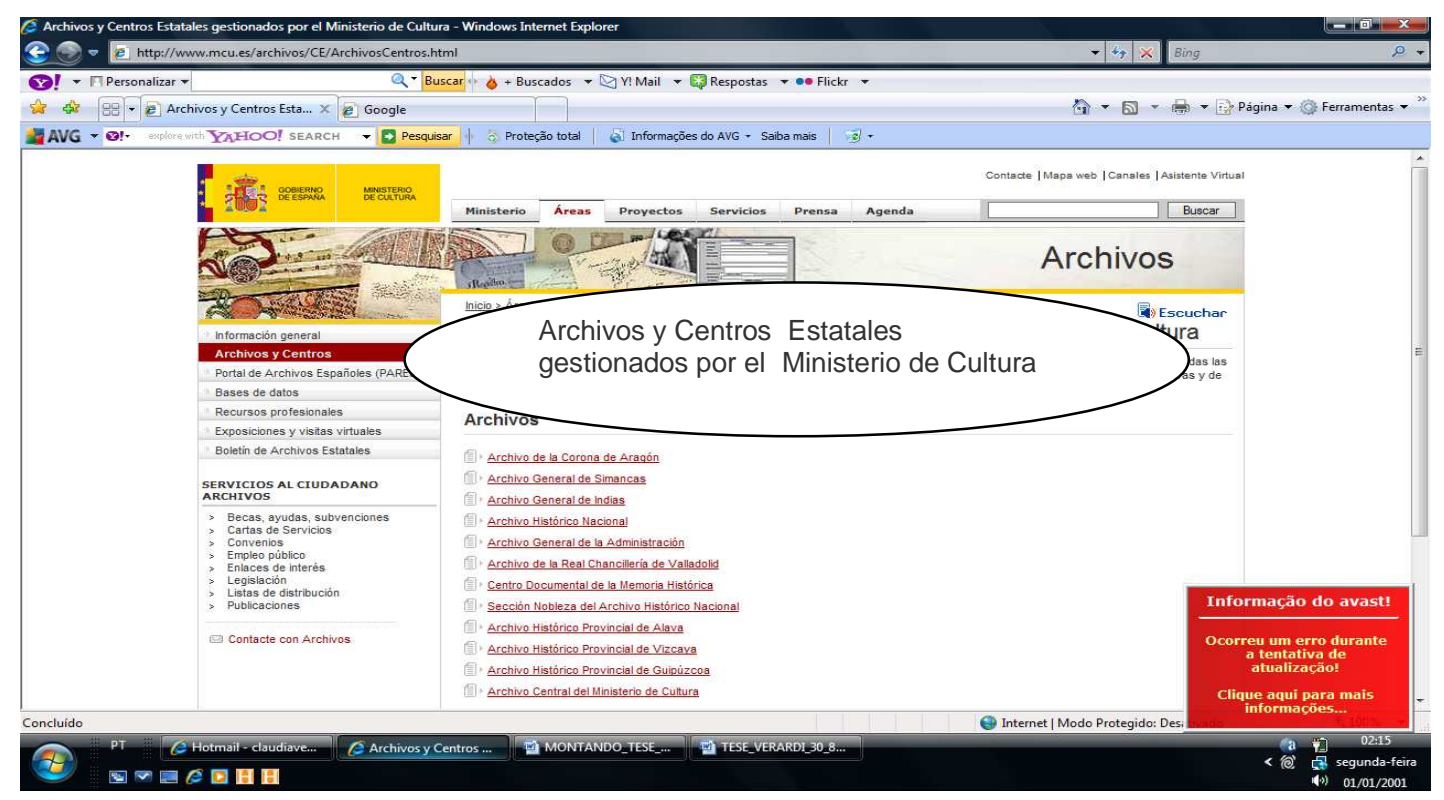

Figura 6 - Arquivos e Centros Estatais dirigidos pelo MCU

A partir daí se pode chegar à homepage de cada um dos Arquivos. Também é possível ir diretamente ao Arquivo, utilizando a URL de cada um deles.

Esta investigação inicial pôde constatar que todos os sites dos Arquivos Estatais espanhóis mantinham aparentemente o mesmo nível de qualidade, no que se refere à apresentação e consistência de informações, uma vez que possuem uma padronização de disponibilização de dados na Internet, conforme os critérios do site do MCU onde estão hospedados.

\subsection{DESCRIÇÃO DA AVALIAÇÃO PROPRIAMENTE DITA}

Para a avaliação propriamente dita, decidiu-se investigar outras páginas Web de Arquivos espanhóis, por considerar os resultados da avaliação preliminar de pouca representatividade, como se pode constatar nos resultados dessa avaliação (Cf. Cap. 6). Como toda pesquisa em sua fase exploratória, após levar em consideração os valores e os interesses dos avaliadores, a autora, que está diretamente envolvida com a ação, decidiu não participar da prática da avaliação, reservando-se à análise geral dos resultados. 
A proposta da Avaliação propriamente dita se baseou principalmente nos pressupostos teóricos de Nielsen, além dos estudos empíricos de Aitta, Kaleva e Kortelainen, Hassan Montero, Martín Fernández e Ortega Santamaría, conforme apresentado no início deste capítulo. Utilizou-se ainda, para compor o questionário dos avaliadores da avaliação propriamente dita, parte do "Modelo para avaliação de especialistas" para avaliar a usabilidade e a acessibilidade dos sites (CríspuloTraviesso Rodríguez, Julio Alonso Arévalo e José María Vivancos Secilla).

Primeiramente foram feitas buscas na Internet a fim de tomar conhecimento de outras URLs de Arquivos públicos na Espanha. Uma vez encontradas as páginas e tendo em vista a necessidade de redirecionar a proposta de avaliação testada inicialmente, que se baseava, sobretudo, na proposta de Jiménez Piano e Ortiz-Repiso Jiménez (2007) e se tratava de critérios de avaliação em geral, foram estudadas outras formas de avaliação. Consequentemente, como nova proposta de avaliação de sites de Arquivos, decidiu-se utilizar os critérios de usabilidade e visibilidade.

\subsubsection{Da escolha dos critérios de avaliação}

A escolha do critério de usabilidade se deve ao fato de que uma boa usabilidade determina se um site será mais ou menos utilizado pelos usuários já que é o fator mais importante na relação usuário-interface.

No caso das páginas Web (sites) de Arquivo, a usabilidade influi também na disseminação dos mesmos e de seus fundos, uma vez que os usuários não perdem tempo em sites que ofereçam dificuldade de serem utilizados (usados).

A escolha do critério visibilidade se deve ao fato de que um site poderá ter mais relevância e credibilidade quanto mais ocupe as primeiras posições nos resultados obtidos em pesquisas realizadas através dos motores de busca ou ainda recebendo links de páginas Web de boa reputação que remetam o usuário até ele (site). 
Devido à pretensão inicial de dissertar em espanhol, os questionários da avaliação preliminar foram redigidos nessa língua. Por questões de clareza, contudo, e, para evitar qualquer inadequação semântica e uso incorreto de expressões e termos técnicos, na transferência para a língua "de chegada", decidiu-se, redigir em português.

Para analisar a Usabilidade e Visibilidade dos sites de Arquivos estudados nesta pesquisa considerou-se um grupo de avaliadores que foram convidados a contribuir espontaneamente com a pesquisa. Para uma visão complementar, optou-se fazer o teste com usuários potenciais para avaliar os sites dos Arquivos também segundo sua perspectiva.

Observou-se que muitos estudos exitosos sobre usabilidade de bibliotecas digitais tomam como base as heurísticas de Nielsen para suas avaliações e alcançam resultados satisfatórios com um grande índice de acertabilidade.

\subsubsection{Aplicação de Heurísticas para Sites de Arquivos}

Baseando-se, sobretudo, em heurísticas direcionadas a sites de bibliotecas sugeridas por Aitta, Kaleva e Kortelainen (2007) bem como nas anteriormente sugeridas pelo próprio Nielsen, criou-se uma nova proposta de avaliação de Usabilidade devidamente adaptada para a avaliação de sites de Arquivos.

No presente estudo, as heurísticas de Nielsen foram aplicadas considerando tais experiências, pode-se destacar além do anteriormente citado, o estudo de Astle e Muir (2002) que por sua vez está baseado na combinação das avaliações de sites sugeridas por Aitta (2004) - embora adaptada em muitos aspectos - e Kaleva (2004), que se complementam. A primeira se baseou apenas em avaliação heurística e a segunda também utilizou teste de usabilidade. Os autores apresentam uma combinação de heurísticas desenvolvidas nestes dois estudos, que são parcialmente sobrepostas.

Essas heurísticas para páginas Web de bibliotecas estão baseadas em estudos anteriores que incidem sobre os fatores que afetam a capacidade de 
utilização dos sites de bibliotecas bem como em estudos de usabilidade em geral além dos estudos empíricos de Aitta (2004) e Kaleva (2004). Tais heurísticas são coincidentes em parte com as heurísticas de Nielsen, porém com algumas adaptações ao tipo de organização em questão: a biblioteca.

Nessa perspectiva, para a avaliação de sites de Arquivos, propostos nesta investigação, utilizou-se esse modelo direcionado a bibliotecas, com uma pequena supressão (4⿳亠口冋 heurística) ${ }^{126}$. Os avaliadores primeiramente percorreram livremente os sites dos Arquivos em estudo verificando se os mesmos cumprem ou ferem alguma das oito heurísticas apresentadas a seguir:

1. Linguagem natural: observar se o site utiliza uma linguagem familiar ao usuário e desprovida de termos técnicos da área de arquivos e documentação e as informações se apresentam de forma lógica e natural. (Correlação com a $2^{2}$ - Heurística de Nielsen)

2. Liberdade de circulação e controle de ações: observar se o site oferece liberdade de uso com mecanismos compreensíveis e facilmente localizáveis de navegação. (Correlação com a 3ª Heurística de Nielsen)

3. Consistência nas convenções adotadas: observar se o site fornece consistência, ou seja, se ele cumpre com as definições convencionadas previamente, ou seja, verificar a uniformidade do site. (Correlação com a $4^{\mathrm{a}}$ Heurística de Nielsen)

4. Disponibilização, clareza e precisão dos links: observar principalmente se o site apresenta links destacados do texto normal quando visitados e se o link levará o usuário ao ponto exato que o mesmo sugere, ou seja, se o link indica claramente o que o usuário encontrará ao clicar sobre o mesmo. (correlação com a $7^{\mathfrak{a}}$ Heurística de Nielsen)

5. Natureza estética e Simplicidade da interface: os comandos do site devem estar visíveis, facilitando a identificação e redução dos riscos do usuário se perder no processo de suas pesquisas. Recorrendo ao princípio "menos é mais", o site deve apresentar apenas informações relevantes para o momento exato da pesquisa, ou seja, oferecer ao usuário apenas

${ }^{126}$ Sugestão nossa. 
informações que ele realmente necessite naquele exato momento. Evitando informações irrelevantes ou desnecessárias, a interface exigirá menos esforço por parte do usuário para "aprender" a utilizá-la. Ele deve reconhecer em vez de memorizar as funções do site. (correlação com a $6^{\mathbf{a}}$ e $8^{\text {a }}$ Heurística de Nielsen)

6. Visibilidade: Levar em conta um grupo especial de usuários como, por exemplo: pessoas com deficiência, idosos, crianças, etc. e observar se existem opções para esse grupo. (correlação com a Heurística 1).

7. Instruções e documentação: As instruções contidas no site devem ser fáceis de encontrar e estarem relacionadas às tarefas que 0 usuário executa, contendo os passos para a realização de um determinado objetivo, porém não devem ser demasiado extensas. (correlação com a 10aㅗ Heurística de Nielsen).

A partir dessas heurísticas, formularam-se questões através das quais o avaliador deveria responder baseando-se em informações colhidas da própria página Web de cada Arquivo estudado.

Para compor o questionário dedicado aos avaliadores dos sites em estudo, foram consideradas questões que pudessem avaliar a visibilidade e a usabilidade dos mesmos.

Para a avaliação da Visibilidade decidiu-se atribuir uma pontuação para cada elemento que varia de 0 a 2, considerando-se que 0 : não atende às expectativas, 1: atende parcialmente às expectativas; 2: atende às expectativas. Foram apresentadas quatro questões:

1. Apresenta metadados padronizados? - Os metadados quando bem definidos, bem elaborados, auxiliam os motores de busca a recuperar o site, colocando-o em evidência.

2. Traz informações sobre a instituição que hospeda ou cria a página Web do Arquivo? - Uma vez que o site é recuperado, as informações sobre a Instituição contribuem para que ela se torne mais conhecida, aumentando a visibilidade do próprio centro. 
3. Existe alguma garantia de autenticidade, como certificações, etc.? - os selos de autenticidade garantem a veracidade do site, que ele é oficial e original e não clonado. Os usuários podem acessar seu conteúdo com segurança, isso faz com que eles se mantenham na página Web, e permite também que ele seja recomendado por páginas confiáveis.

4. A página Web do Arquivo está em posição orgânica nos resultados das buscas através do motor Google? A chamada posição orgânica ou natural é o nome dado aos resultados encontrados pelo buscador que não são pagos e sim, filtrados pelo buscador de acordo com a relevância do site para o termo que o usuário está pesquisando. Revela que o site está em evidência naturalmente, sem precisar de artifícios para que apareça entre os primeiros resultados da pesquisa através dos motores de busca. Assim sendo, se a página do Arquivo aparece nos primeiros resultados da busca representa um forte indício de que é visível em rede.

Para a avaliação da Usabilidade de sites de arquivos, propostos nesta investigação, utilizou-se o modelo de Astler e Muir (2006) direcionado a bibliotecas, com uma pequena supressão (4- heurística) ${ }^{127}$. Essas heurísticas para páginas Web de bibliotecas estão baseadas em estudos anteriores que incidem sobre os fatores que afetam a capacidade de utilização dos sites de bibliotecas bem como em estudos de usabilidade em geral além dos estudos empíricos de Aitta (2004) e Kaleva (2004). Tais heurísticas são coincidentes em parte com as heurísticas de Nielsen, porém com algumas adaptações ao tipo de organização em questão: a biblioteca.

Foram escolhidas sete heurísticas apresentadas para a avaliação dos sites objeto deste estudo.

A partir dessas heurísticas, formularam-se questões através das quais 0 avaliador deveria responder baseando-se em informações colhidas da própria página Web de cada arquivo estudado. Apresenta-se a seguir os indicadores utilizados para cada heurística.

${ }^{127}$ Sugestão nossa. 
$\checkmark$ Heurística 1: Linguagem natural: observar se o site utiliza uma linguagem familiar ao usuário e desprovida de termos técnicos da área de arquivos e documentação e as informações se apresentam de forma lógica e natural. (Correlação com a $2^{\underline{a}}$ Heurística de Nielsen):

1. Os ícones são familiares e correspondem à realidade (são reais)? - A familiaridade do usuário com os ícones utilizados facilita a navegação e cada ícone deve realmente corresponder ao que sugere para que não haja desperdício de tempo com informações que não interessam no momento.

2. As escolhas de menu existentes, estão ordenadas de maneira lógica e com seqüência natural (apresenta os nomes dos itens e as possíveis variáveis das tarefas)? - Um menu organizado de forma lógica auxilia o processo de busca.

3. A linguagem usada é familiar, clara e simples a cada tela? - O usuário deve sentir que pode interagir com o site sem dificuldade, entendendo a linguagem para que não pareça difícil encontrar o que busca.

4. Utiliza linguajar ou jargão próprio da área e, caso utilize, explica o significado desses termos para os leigos? - Às vezes é necessário o uso de algum termo técnico ou jargão, porém deve-se oferecer ao usuário uma explicação clara sobre o sentido dele.

$\checkmark$ Heurística 2: Liberdade de circulação e controle de ações: observar se o site oferece liberdade de uso com mecanismos compreensíveis e facilmente localizáveis de navegação. (Correlação com a $3^{\text {a }}$ Heurística de Nielsen):

1. O site apresenta janelas sobrepostas e é fácil para os usuários reorganizarem as janelas na tela e navegarem entre elas? - Quando se está realizando tarefas no site é interessante não perder de vista cada passo e poder voltar à atividade anterior com facilidade.

2. Se o sistema tiver múltiplos níveis de menu, o mesmo permite que os usuários voltem aos menus anteriores e alterem a escolha anterior? - 0 
menu deve permitir que o usuário mude a busca de onde está sem precisar refazer todo o percurso inicial.

$\checkmark$ Heurística 3: Consistência nas convenções adotadas: observar se o site fornece consistência, ou seja, se ele cumpre com as definições convencionadas previamente, ou seja, verificar a uniformidade do site. (Correlação com a 4⿳亠丷a Heurística de Nielsen):

1. O site segue padrões de formatação consistentes no design de menus, teclas e funções em todas as páginas do site? - A consistência nos padrões permite que a visualização dos dados seja facilitada,e que se navegue mais facilmente.

2. O uso freqüente de todas as letras maiúsculas em uma tela é inibido? Demasiadas letras maiúsculas não são indicadas por chamar atenção do usuário sem necessidade.

3. A lista de menus está presente verticalmente com seus títulos centralizados e justificados do lado esquerdo? - A eficácia de um site esta diretamente relacionada â sua navegabilidade e portanto, o desenho de um site deve garantir que todos os elementos de navegação estejam ligados por meio dos menus. A lista de menus disponibilizada na lateral esquerda é uma das três posições em que normalmente aparecem para facilitar as pesquisas. De acordo com Haguenauer, Cordeiro Filho e Mota (2008) a navegabilidade significa que o portal depende de sistemas de navegação adequados, como menus, buscas, barras laterais, links e outros; devendo ser apresentados de forma clara e harmoniosa, de maneira a orientar o cibersusuário durante a navegaçao, para que não haja interrupções ou caminhos sem volta e garantindo uma estrutura sólida e consciente das informações.

4. As instruções on-line aparecem num local consistente nas telas? - As instruções devem aparecer sempre num mesmo local para que seja identificadas facilmente se necessário, evitando que o usuário perca tempo buscando-as. 
Heurística 4: Disponibilização, clareza e precisão dos links: observar principalmente se o link indica claramente o que o usuário encontrará ao clicar sobre o mesmo. (Correlação com a $7^{7}$ Heurística de Nielsen):

1. A disposição dos dados começa no canto superior esquerdo da tela? - Os dados no canto superior da tela são melhor visualizados.

2. Os itens selecionados aparecem destacados em outra cor ou sombreados? - Esse destaque é importante para lembrar ao usuário onde ele se encontra.

3. Ao clicar em um item, o que aparece em seguida corresponde exatamente ao que foi proposto, ou seja, o usuário é levado ao lugar que o link sugere? - É muito importante que o usuário ao clicar em um link encontre exatamente o que deseja sem desperdiçar tempo com o que não lhe é útil.

Heurística 5: Natureza estética e Simplicidade da interface: os comandos do site devem estar visíveis, facilitando a identificação e redução dos riscos do usuário se perder no processo de suas pesquisas. Recorrendo ao princípio "menos é mais", o site deve apresentar apenas informações relevantes para o momento exato da pesquisa, ou seja, oferecer ao usuário apenas informações que ele realmente necessite naquele exato momento. Evitando informações irrelevantes ou desnecessárias, a interface exigirá menos esforço por parte do usuário para "aprender" a utilizá-la. Ele deve reconhecer ao invés de memorizar as funções do site. (Correlação com a 6ª e 8aㅡ Heurística de Nielsen):

1. Todos os dados que usuário precisa para disponibilizar em cada etapa aparecem numa sequência lógica de seguimento? - Se os dados aparecem em uma sequência lógica o usuário não precisa "adivinhar" onde estão as informações.

2. Os recursos visuais e espaços em branco são usados para distinguir perguntas, instruções, e input de usuários? - Uma boa utilização das cores ajuda a identificar claramente os elementos que estão sendo utilizados durante a navegação. 
3. As mensagens estão posicionadas de modo visível na tela? - Se o usuário tem de esforçar-se para tomar conhecimento de alguma informaçao, pode desistir daquele site.

4. As áreas de texto têm um espaço livre em volta? - O Texto que não apresenta áreas em branco ao redor torna-se confuso e cansativo.

5. Espaços em branco são usados para criar simetria? - Os espaços em branco também servem para harmonizar visualmente a página Web e descansar a vista do usuário.

6. O uso de cores é consistente em todo o sistema? - As cores utilizadas devem ser mantidas até o final para que se possa caracterizar aquele site porque ao se manter o padrão este se torna a "cara" do site.

7. As ações e comunicações do sistema são constantes fazendo com que o usuário não necessite esforçar-se para atingir seus objetivos? - Todas as ações do usuário devem contar com respostas muito claras em todo o sistema auxiliando o mesmo para que atinja o resultado que deseja.

$\checkmark$ Heurística 6: Visibilidade: O sistema deve manter os usuários informados sobre o que eles estão fazendo, com feedback imediato e levar em conta um grupo especial de usuários como por exemplo:deficientes visuais, idosos, crianças, etc. e observar se existem opções para esse grupo (Correlação com a $1^{1}{ }^{a}$ Heurística de Nielsen):

1. O sistema dispõe de algum tipo de guia navegacional ou mapa para identificar as várias opções da página e indicar sua relação com as outras? - Normalmente os mapas podem ser muito úteis especialmente para aqueles que visitam o site pela primeira vez.

2. Existe um sistema consistente de feedback para cada ação realizada? -As respostas do sistema são importantes pois o usuário se certifica de que está avançando em cada tarefa.

3. Todas as páginas contêm um título ou um cabeçalho que descrevem o seu conteúdo? - A importância do título está em que o usuário não se perderá durante a navegação pois identifica com facilidade onde está. 
4. Há um esquema consistente e estético no design de ícones em todo o site? - Os ícones devem ser facilmente identificados durante todo o tempo e toda ação realizada pelo usuário.

5. Oferece funções opcionais para os deficientes visuais "ouvirem" e a opção de aumento da fonte para pessoas com dificuldade visual? - Os recursos de acessibilidade cada vez estão sendo mais exigidos e asseguram também que não haja "exclusão digital".

$\checkmark$ Heurística 7: Instruções e documentação: As instruções contidas no site devem ser fáceis de encontrar e estarem relacionadas às tarefas que 0 usuário executa, contendo os passos para a realização de um determinado objetivo, porém não devem ser demasiado extensas. (Correlação com a 10ํㅡㄹ Heurística de Nielsen).

1. Existe a função "ajuda" e ela é facilmente encontrada, em uma tecla etiquetada com o nome AJUDA ou em um menu especial? - A função ajuda se torna fundamental quando se chega a um impasse durante a navegação porém deve estar em uma posição visível para que seja facilmente identificada.

2. A navegação oferece respostas rápidas e precisas ao usuário? Normalmente o sucesso de um site depende do quão preciso e rápido ele possa ser para garantir a satisfação de quem o está utilizando.

\subsubsection{Visibilidade de Sites de Arquivos}

Outro critério de avaliação considerado nessa pesquisa foi a Visibilidade ${ }^{128}$, uma vez que mede a facilidade com que os usuários tomam conhecimento da existência das páginas Web de Arquivos, ou seja, o quanto um site é visto pelo usuário. O caráter quase "sagrado" dos Arquivos vem gerando, ao longo da

\footnotetext{
${ }^{128}$ Embora uma das heurísticas sugeridas para avaliar a Usabilidade trate do aspecto visibilidade do status do sistema a Visibilidade escolhida como critério de avaliação aqui se refere à qualidade de ser perceptível aos usuários.
} 
história, certa dissimetria entre eles e os indivíduos, por conta disso despertou-se o interesse de verificar a Visibilidade dos sites dos Arquivos, objeto desse estudo.

As ferramentas disponíveis para verificação da Visibilidade em sua maioria dependem da decisão do criador da página, para oferecer ao usuário, por exemplo, a disponibilização do Ranking da página na Internet. Para avaliar a Visibilidade, portanto, decidiu-se incluir antes das questões referentes à avaliação heurística de usabilidade, questões objetivas referentes a esse critério dentro do questionário direcionado aos avaliadores, a fim de detectar indícios de que a página possua ou não uma boa visibilidade. A escolha dessas questões foi baseada nas considerações de Jiménez Piano e Ortiz Repiso Jiménez (2007) que incluem, no questionário de avaliação de sites, três indicadores que se referem à visibilidade, dentro do critério "autoridade" e da categoria "controle de qualidade," a saber: 1. Recepção de links a partir de páginas de qualidade; 2. Existência de assessores externos revisando os documentos e, 3. A presença de diretórios com políticas de controle de qualidade garantindo evidentemente a qualidade do site.

Conforme as autoras, ${ }^{129}$ quando se busca informações na Web, geralmente se escreve um endereço na barra do navegador ou se encontra a página Web através de um motor de busca. No primeiro caso, quando o usuário já conhece a URL da página, por ter tomado conhecimento da existência do site através de um link em algum outro site de qualidade, ou através de alguma fonte segura, normalmente ele tem certa garantia da qualidade desse site, porém, quando se trata do segundo caso, ou seja, quando encontra o site através de um motor de busca, faz-se necessário a examinar alguns elementos para comprovar essa qualidade.

Quanto à existência de assessores externos que revisem os documentos, decidiu-se não utilizar tal indicador haja vista a dificuldade de localizar, no site, a informação a esse respeito, que fica geralmente no plano do responsável pela criação e manutenção do mesmo, pois ainda que uma página Web conte com essa assessoria constante, o usuário não toma conhecimento desse fato, tornando-se difícil para o avaliador responder a essa questão com segurança.

${ }^{129}$ Op.Cit, p. 148. 
O último indicador mostra que se um site está incluído em um diretório, cujos documentos sejam rigorosamente selecionados, a exemplo da inclusão em diretórios de prestígio, pode-se garantir a sua qualidade, porém essa inclusão deve aparecer em um ponto bem visível do site.

A partir das questões baseadas no critério da Visibilidade bem como das questões a respeito da Usabilidade, criou-se um modelo de questionário (Cf. Apêndice $\mathrm{H}$ ) através do qual o avaliador deveria basear-se para analisar os sites preenchendo um questionário (Cf. Apêndice I) para cada um dos Arquivos estudados.

A partir de então, para analisar a Usabilidade e Visibilidade dos sites de Arquivos estudados nesta pesquisa considerou-se um grupo de avaliadores que foram convidados a contribuir espontaneamente com a pesquisa. Posteriormente, a fim de obter uma visão complementar, a exemplo da Avaliação preliminar, decidiu-se fazer teste com usuários potenciais para avaliar os sites dos Arquivos também segundo sua perspectiva.

\subsubsection{Universo de Pesquisa}

No mundo globalizado em que se vive em plena era da comunicação informatizada, qualquer indivíduo que seja capaz de acessar a Internet em busca de informação é usuário potencial de sites de arquiv4os, sendo portanto capaz de analisar a qualidade de um site, independentemente de ser ele codificado em sua linguagem de origem.

Nessa perspectiva, pelo fato de se encontrar a autora no Brasil, como justificado na introdução deste estudo, por ocasião das avaliações, considerou-se pertinente selecionar, para compor a amostra da pesquisa, pessoas localizadas em seu país de origem. Por uma questão de prevenir qualquer incoerência nos resultados por conta de desvio semântico, uma das exigências era que todos os 
participantes envolvidos - usuários e avaliadores - tivessem familiaridade com a língua espanhola ${ }^{130}$.

Decidiu-se selecionar 4 avaliadores, com formação na área de informática e domínio em construção, avaliação e manutenção de sites. Sendo um Mestre em Ciência da computação, um Mestre em Ciência da Linguagem, um Programador Web e um Consultor em Acessibilidade e mestrando em Informática da Universidade Federal do Estado do Rio de Janeiro (UNIRIO).

Para comparar posteriormente com a visão dos avaliadores, a exemplo da avaliação preliminar, convidaram-se 15 novos usuários potenciais para realizar algumas tarefas, a fim de verificar o nível de satisfação dos mesmos em relação aos sites, todos com certo conhecimento de informática. Conforme Nielsen (2000), 15 usuários é um quantitativo suficiente para uma amostra representativa em termos de usabilidade. Tais usuários eram alunos de graduação da área de Biblioteconomia, alunos de mestrado em Ciência da Informação e funcionários da Fundação Joaquim Nabuco com formações diversas, com domínio de Informática, esse cuidado deve-se ao fato de que estamos tratando de um tema que abrange essas áreas de interesse.

O teste com usuários da Avaliação propriamente dita consistia em um questionário (Cf. Apêndice J) com tarefas práticas onde os usuários deveriam preencher baseando-se em informações encontradas nos sites dos Arquivos. Posteriormente avaliamos os resultados obtidos nos testes de usuário e dispomos os resultados em tabelas.

\footnotetext{
${ }^{130}$ Esse critério de seleção não foi muito difícil de ser atendido, haja vista que a língua espanhola vem sendo muito difundida no mundo e, no que diz respeito ao Brasil, tem grande receptividade, sobretudo após o acordo entre o então presidente Luis Inácio Lula da Silva
} 


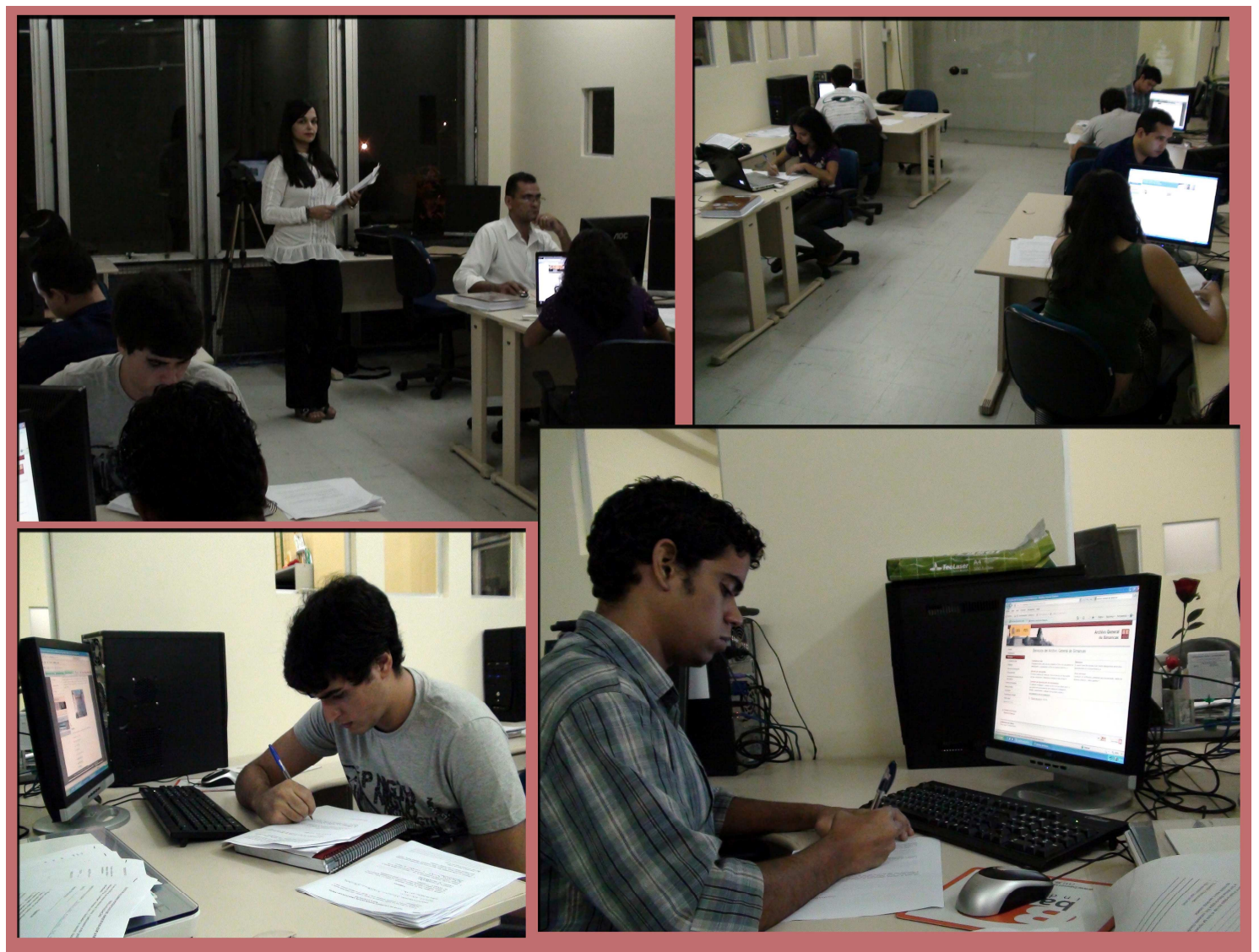

Figura 7 - Foto do Teste com usuários da UFPE, turma de Mestrado do professor Marcos Galindo

\subsubsection{Processo da escolha dos Arquivos Espanhóis}

Para a avaliação propriamente dita, relativa à Usabilidade e à Visibilidade, também foi considerado o site do $\mathrm{MCU}$, contudo foi realizada uma varredura na própria Internet para encontrar outras URLs de sites de Arquivos espanhóis. Essa investigação resultou numa lista de Arquivos por tipologia, cujas URLs foram confirmadas, ou seja, puderam ser devidamente acessadas confirmando, assim, os seus endereços eletrônicos.

A técnica utilizada para encontrar páginas Web de arquivos espanhóis foi acessar os motores de busca (Google e Yahoo).

A fim de encontrar URLs de sites de Arquivos espanhóis, inicialmente foi feita uma busca na Internet através do Google usando a expressão "Arquivos espanhóis" e "Arquivos estatais espanhóis". Entre os cinco primeiros resultados 
dessas duas buscas, porém, não se encontrou nenhuma resposta relevante. Por esse motivo, decidiu-se refazer a pesquisa, dessa vez, utilizando-se a língua espanhola. A pesquisa com a expressão "Archivos Estatales Españoles" apresentou, logo no primeiro resultado, o Portal de Archivos Españoles (PARES) $^{131}$ que se trata de um Projeto do Ministério da Cultura da Espanha com o objetivo de difundir o Patrimônio Histórico Documental Espanhol, por meio da Internet, Tal patrimônio foi conservado em sua rede de centros, oportunizando ao usuário o livre acesso de forma gratuita. O portal PARES oferece um catálogo dinâmico do Centro Documental da Memória Histórica e de 11 Arquivos estatais, a saber: Archivo de la Corona de Aragón; Archivo General de Simancas; Archivo General de Indias; Archivo Histórico Nacional; Archivo General de la Administración; Archivo de la Real Chancillería de Valladolid; Sección Nobleza del Archivo Histórico Nacional; Archivo Histórico Provincial de Álava; Archivo Histórico Provincial de Vizcaya; Archivo Histórico Provincial de Guipúzcoa; Archivo Central del Ministerio de Cultura. ${ }^{132}$

O segundo resultado apresenta um link para a página oficial do MCU justamente na parte em que mostra os Arquivos ${ }^{133}$ e no terceiro resultado aparece outra subpágina do MCU "Archivos y Centros Estatales"134. Isso significa que, os três primeiros resultados, ou seja, aqueles que estão em maior evidência, remetem o usuário ao site do Ministério de Cultura da Espanha. Quando se busca por "Archivos de España", encontra-se como primeiro resultado a subpágina "Archivos" do site do Ministério de Cultura (Cf. Nota explicativa de número 9). Em segundo lugar, aparece a página oficial do Projeto PARES.

Realizando-se a busca através do Yahoo, utilizando a expressão "Archivos estatales españoles", o portal PARES aparece como primeiro resultado e a página dos Arquivos e Centros do Ministério da Cultura ${ }^{135}$ aparece como quarto resultado. No quinto resultado encontra-se um diretório de Arquivos da Comunidade Valenciana ${ }^{136}$, onde aparece uma lista de Arquivos espanhóis.

\footnotetext{
${ }^{131}$ Portal PARES. Disponível em: http://pares.mcu.es. Acessado em: 22 jun. 2011

132 Os citados Arquivos e o Centro Documental da Memória Histórica coincidem com a lista de Arquivos contida no site do MCU. (Op. Cit)

$133 \mathrm{http}: / /$ www.mcu.es/archivos

134 http://www.mcu.es/archivos/CE/ArchivosCentros.html

135 http://www.mcu.es/archivos/CE/ArchivosCentros.html

$136 \mathrm{http}: / /$ dglab.cult.gva.es/Archivos/archivos_espanoles_e.htm
} 
Através de nova busca no Yahoo utilizando-se, dessa vez, a expressão "Archivos de España", o portal PARES aparece apenas no quinto resultado da busca. Como segundo resultado, aparece o site da Associação Latinoamericana de Arquivos (Asociación Latinoamericana de archivos). ${ }^{137}$ Nessa página, aparecem diversos links a respeito de temas relacionados a arquivos, entre outros:

\begin{tabular}{|l|l|}
\hline \multicolumn{1}{|c|}{ LINKS DE ARQUIVOS ESPANHÓIS } & \\
\hline Consejo Internacional de Archivos & http://www.ica.org/ \\
\hline Comité de normas de descripción archivístico (ICA) & http://www.hmc.gov.uk/icacds/icacds.htm \\
\hline $\begin{array}{l}\text { INFOLAC (Programa de la sociedad de la información para América Latina } \\
\text { y el Caribe) }\end{array}$ & http://infolac.ucol.mx/ \\
\hline $\begin{array}{l}\text { Ayudas a entidades privadas sin ánimo de lucro para realizar proyectos } \\
\text { archivísticos sobre patrimonio Documental Español }\end{array}$ & http://www.mcu.es/jsp/plantilla_wai.jsp?id=9\&area=archivos \\
\hline Archivos Españoles en RED (PARES) & http://pares.mcu.es/ \\
\hline Bibliografía de Archivos & http://www.mcu.es/ccbae/es/consulta/busqueda.cmd \\
\hline Portal de Archivos Unesco & http://www.unesco.org/webworld/portal_archives/ \\
\hline Censo Guía de Archivos Iberoamericanos & http://www.aer.mcu.es/sgae/index_censo_guia.jsp \\
\hline Agencia Española de Cooperación Internacional & http://www.aeci.es/ \\
\hline Guía de Fuentes Documentales de Archivos & $\begin{array}{l}\text { http://www.mcu.es/guiafuentesdoc/cargarFiltro.do?layout=guia } \\
\text { fuentesdoc\&cache=init\&language=es }\end{array}$ \\
\hline
\end{tabular}

\section{Quadro 28 - Links de Arquivos espanhóis}

Continuando as buscas através do Google, dentro da mesma temática, em um desses desdobramentos, pôde-se chegar à página da Associação dos Arquivistas de Castela e Leão na Espanha ${ }^{138}$. Nesse site, os arquivos aparecem listados por tipologia dentro das regiões a que pertencem cujos nomes estão "linkados" às suas respectivas URL. Ao conferir esses endereços eletrônicos, na tentativa de acessar os sites, observou-se que muitos deles não abriam. Dessa forma, este estudo apresenta uma contribuição aos pesquisadores, em termos de fornecer os seus endereços eletrônicos dos sites devidamente conferidos os quais foram inseridos no Anexo 4.

A Acal é uma organização de pessoas que trabalham com documentos e arquivos. Foi fundada, em 1991, por um grupo de estudantes de Arquivística da Escola de Biblioteconomia da Universidade de Salamanca. É constituída por profissionais de arquivos que trabalham em diferentes áreas e em diferentes tipos de centros de todas as comunidades autônomas do Estado. Também faz parte de Acal um grande número de instituições arquivísticas, pois a associação pretende

\footnotetext{
${ }^{137} \mathrm{http}: / / \mathrm{www}$. ala.or.cr/enlaces.htm

${ }^{138}$ Disponível em: http://www.acal.es/Recursos/Archivos/tabid/176/Default.aspx . Acesso em: 22 jun.2011.
} 
representar os interesses dos arquivos e dos profissionais da área além disseminar informações. Essa organização promove também o intercâmbio com profissionais de áreas afins como bibliotecários e documentalistas que, juntamente aos profissionais de arquivo, formam os "profisssionais da informação". Entre outras informações, a homepage da Acal disponibiliza um link chamado Recursos dentro do qual existe um "sublink" chamado "Arquivos", onde se pode conferir por cada comunidade autônoma a lista de Arquivos de cada cidade (Cf. Anexo 4). Os tipos de Arquivos encontrados são: da administração local, da prefeitura, das universidades, de fundações, da Administração autonômica, estatais, religiosos, musicais, militares, políticos e até mesmo arquivos pessoais.

Para melhor visualização das comunidades da Espanha, apresenta-se a seguir um quadro com suas respectivas capitais.

\begin{tabular}{||l|l|}
\hline \multicolumn{1}{|c|}{ COMUNIDADES DA ESPANHA } & \multicolumn{1}{c|}{ CAPITAIS } \\
\hline Andaluzia (Andalucía) & Sevilha \\
\hline Principado das Astúrias & Oviedo \\
\hline País Basco & Vitória-Gasteiz \\
\hline Castela-La Mancha & Toledo \\
\hline Catalunha & Barcelona \\
\hline Galiza & Santiago de Compostela \\
\hline Comunidade Foral de Navarra & Pamplona \\
\hline Comunidade Valenciana & Valência \\
\hline Aragão (Aragón) & Saragoça \\
\hline Ilhas Baleares & Palma de Maiorca \\
\hline Cantábria & Santander \\
\hline Castela e Leão & Valladolid \\
\hline Extremadura & Mérida \\
\hline Região de Múrcia & Múrcia \\
\hline La Rioja & Logronho \\
\hline Comunidade autônoma de Madrid & Madrid \\
\hline Comunidade autônoma das Ilhas Canárias & Las Palmas de Gran Canária \\
\hline
\end{tabular}

\section{Quadro 29 - Comunidades da Espanha versus capitais}

Durante as investigações, verificou-se a existência de várias outras listas de arquivos e diretórios de arquivos, contudo dada a imensa quantidade de páginas Web de Arquivos encontradas, considerou-se pertinente realizar uma 
escolha aleatória de uma parcela suficientemente representativa para uma análise quanti-qualitativa.

Os Arquivos analisados pelos avaliadores foram:

- Archivo Histórico Nacional

- Archivo de la Diputación de Sevilla

- Archivo Vasco de La Música Eresbil

- Histórico Provincial de Huesca

- Archivo Histórico Eclesiástico de Bizcaya

- Archivo Histórico de Asturias

- Archivo General Militar de Ávila

- Archivo de La Universidad de Salamanca

- Archivo General de Simancas

- Arquivo Municipal de Santander

- Arquivo da Emigração Galega

- Archivo Histórico de protocolos de Gipuskoa

- Archivode Hullera Vasco-Leonesa

- Archivo Histórico Provincial de Granada

Para a escolha dos arquivos que foram avaliados, tomou-se por base informações recolhidas junto ao Diretório de Arquivos da Comunidade Valenciana, a lista de Arquivos da Acal, bem como Portal de Arquivos da Unesco. ${ }^{139}$ Buscouse conferir primeiramente cada URL dos arquivos listados nesses sites, comprovando se as páginas correspondiam ao endereço fornecido e se estavam ativas. Decidiu-se avaliar, dentro da tipologia coincidente nas listas anteriormente citadas, através das buscas online, um site de cada tipo existente. Desse modo foram selecionados 14 arquivos para esta avaliação. Para melhor visualização, os dados referentes aos Arquivos foram devidamente dispostos em um quadro (Cf.

139 Cf.: Texto Disponível em:

http://www.unescoci.org/cgibin/portals/archives/search.cgi?d=1\&type=phrase\&query=Spain 
Apêndice L). Antes de adentrar na discussão propriamente dita, considerou-se pertinente um breve relato sobre os Arquivos espanhóis que foram selecionados para que se tome conhecimento de suas peculiaridades e seu valor histórico ${ }^{140}$.

\subsubsection{Apresentação dos Arquivos cujos sites são avaliados nesta investigação}

Aqui apresenta-se um brevíssimo histórico dos 14 Arquivos da Espanha, selecionados para análise, com especificações sobre cada um, desde sua origem, função, estrutura dos fundos e serviços.

\subsubsection{Archivo Histórico Nacional (AHN)}

Esse Arquivo foi selecionado por ser considerado de grande representação nacional. Ele conserva a documentação produzida e recebida pelo aparelho administrativo do Estado desde a idade moderna de arquivos públicos e privados desde a idade média.

O Arquivo Histórico Nacional desde a sua fundação se constituiu como "Archivo Histórico do Reino de Espana", com caráter de arquivo público. Foi criado para recolher a documentação produzida pelos órgãos da Administração do Estado que já não tem valor administrativo, porém tem valor histórico. Atualmente aos seus depósitos se devem transferir os documentos qualificados como históricos, porque superaram previamente as eliminações racionais que estabelecem a Lei de Patrimônio Histórico Espanhol em seu artigo 58.

As funções deste Arquivo são: conservar e proteger o patrimônio histórico documental que possui; descrever os conteúdos informativos dos documentos, e tornar acessível, tanto ao investigador como ao cidadão os fundos documentais,

\footnotetext{
140 Informações recolhidas dos próprios sites dos referidos Arquivos, traduzidas e adaptadas pela autora.
} 
assim como potencializar a difusão cultural dos mesmos. O Archivo Histórico Nacional é a instituição que guarda e conserva a documentação produzida e recebida pelos órgãos que conformam o aparelho administrativo do Estado espanhol desde a Idade Moderna, assim como outros fundos documentais de instituições públicas e privadas desde a Idade Média.

Os fundos documentais do Archivo Histórico Nacional estão estruturados em um quadro de classificação que, dada a sua diversidade, divide-se em cinco grandes seções: Instituições do Antigo Regime, Instituições contemporâneas, Instituições eclesiásticas, Arquivos privados e Coleções

Quanto aos seus serviços, o Arquivo disponibiliza: consulta em sala: livre e gratuito, com as exceções contempladas na Lei 30/92 do Regime Jurídico das administrações públicas e do procedimento Adminstrativo Comum e Lei 16/85do Patrimônio Histórico Nacional; serviço de Reprografia: com as restrições previstas nas normas; serviço de reserva de documentos por telefone; Biblioteca; Convênio de reprodução de documentos, entre outros.

Para acessar a página do referido centro, o endereço eletrônico disponível é: $\quad$ www.mcu.es/archivos/MC/AHN/index.html.

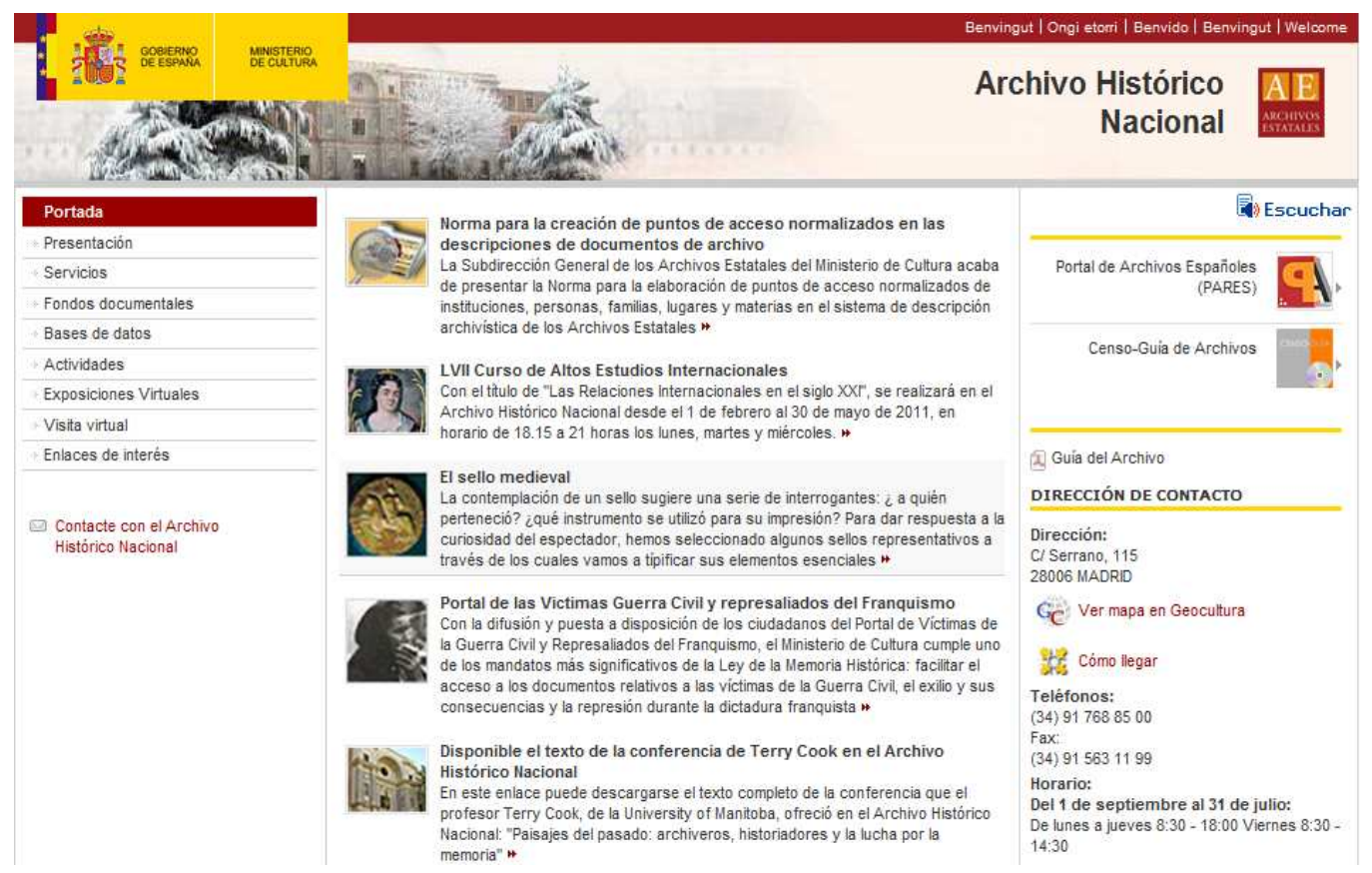

Figura 8: Homepage do Archivo Historico Nacional 
Como se pode observar na figura 8, em sua Homepage, o site do Arquivo apresenta um menu com as seguintes opções de navegação: Apresentação pequena apresentação sobre o Arquivo e suas funções. Clicando nesta opção aparece os seguintes sublinks: História (pequena história do Arquivo); Edifício: Fala da estrutura arquitetônica do Edifício onde funciona Arquivo; Estrutura Admisnistrativa: está subdividida em: Direção, Subdireção, Departamento de Ingresso de Fundos, Departamento de Referências; Departamento de Coordenação e Normalização; Serviços: Clicando neste link, aparecem os seguintes sublinks: Consulta em sala, reserva de documentos por telefone, Biblioteca, Outros Serviços, Convênios de reprodução de documentos; Fundos Documentais: Clicando neste link, aparecem os seguintes sublinks: Introdução, Quadro de Classificação, Bibliografia, Instrumentos de referência; Bases de dados: apresenta as bases de dados do Arquivo Histórico Nacional; Atividades: parte dedicada a divulgar exposições, conferências, cursos, jornadas, bem como oferecer visitas guiadas. Neste link também encontra-se o Ciclo da "Peça do Mês", que se trata da exposição periódica de alguns dos documentos mais representativos do Arquivo com a finalidade de difundir seus fundos documentais.

\subsubsection{Archivo de la Diputación de Sevilla (ADS)}

Os Conselhos provinciais nasceram como uma criação legislativa da Constituição de Cádiz, em 1812, que estipula que "em cada província deve haver um Conselho Provincial para promover a sua prosperidade, presidido pelo Chefe superior ou governador político". Eram fortemente dependentes do poder estatal centralizado.

A Constituição de 1869 autoriza os Conselhos Provinciais a ter autonomia própria e poder político para atingir seus objetivos, sendo estabelecido como órgão administrativo a partir do Estatuto de 1925. Este é o conceito de Governo Provincial que chegou aos nossos dias, adaptado a nossa legislação vigente.

O Archivo de La Diputación de Sevilla, formado num processo natural ao longo do tempo, está constituído pelo conjunto orgânico de documentos produzidos ou recebidos pelo município para ser um verdadeiro reflexo de suas 
funções e atividades no serviço de gestão administrativa, informação, investigação e cultura.

O Arquivo é composto por diversos fundos. O primeiro é o do próprio Conselho provincial, formado pela documentação produzida pela Corporação ao longo de sua história, de meados do século XIX, até o presente momento. É, portanto, um fundo aberto a novos documentos.

Infelizmente, devido a vários acidentes, especialmente ao incêndio ocorrido em 1906, foi perdida a maioria da documentação do século XIX. No entanto, os livros de registro da Companhia se conservaram ininterruptas desde 1880.

Os fundos restantes correspondem aos Arquivos de hospitais e centros filantrópicos de Sevilha, que passaram a depender da Câmara Municipal para assumir esta função pública através da Lei Orgânica de 21 de outubro de 1868.

O centro possui os seguintes serviços: sala de consulta, com capacidade para dez usuários; informação documental e bibliográfica; serviço de fotocópias; certificados e cópia certificada da documentação; biblioteca auxiliar, especializada em arquivística, administração e história local; assesoramento técnico aos Arquivos Municipais da província, além do serviço de difusão mediante o Website da Província, cujo endereço eletrônico disponível ao acesso é: http://www.dipusevilla.es/dipusevilla/opencms/site/Web/areas/cultura/menu_sec/ar chivo_y_publicaciones/temas/archivo_de_la_diputacion.

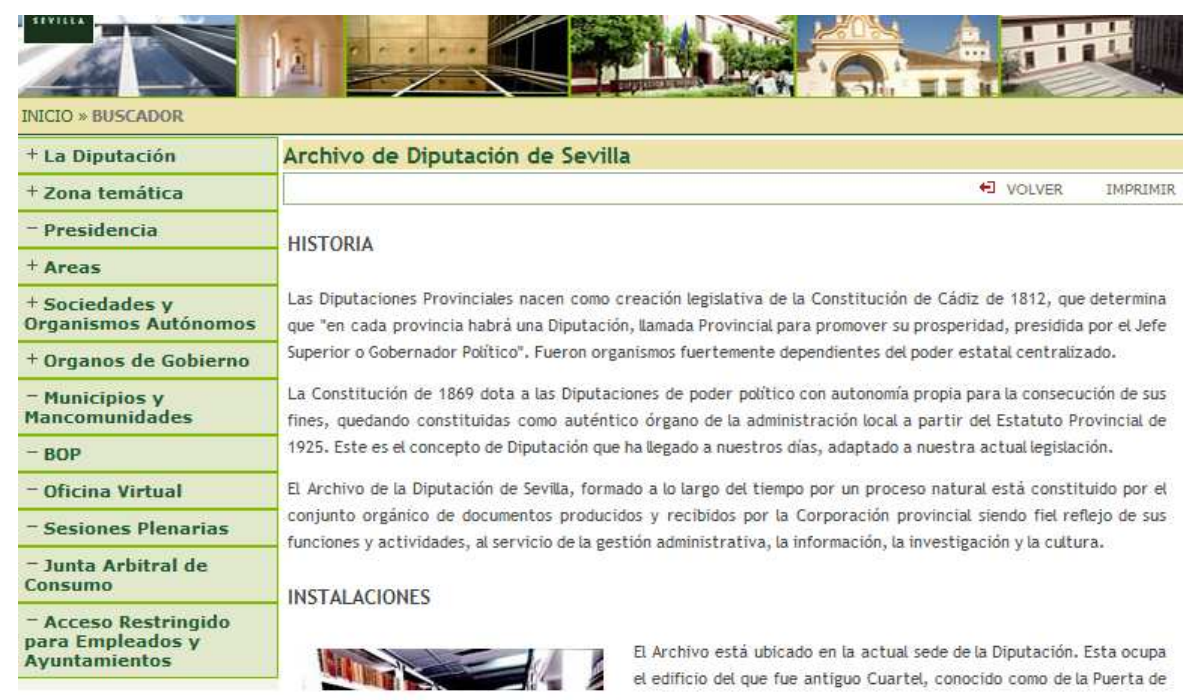

Figura 9: Homepage do Archivo de Diputación de Sevilla 
Como se pode observar na figura 9 acima, na sua homepage encontram-se as seguintes opções de navegação: História (pequena história do Arquivo), Instalações, Acesso, Horário, Fundos (pequena descrição e links para os fundos: Fundo da Deputação Provincial de Sevilha (corresponde ao Quadro de classificação em formato PDF), Fundos dos Hospitais e Centros benéficos (em PDF) e Arquivo da Deputação provincial de Sevilha (em PDF) e, um Aviso legal (a respeito do caráter pessoal do uso dos dados e reprodução de documentos).

O acesso às informações de seus fundos é livre, porém exige-se o prévio cadastramento do pesquisador ou simplesmente a apresentação do documento de identidade. Vale salientar que as informações sobre os Fundos do Arquivo estão disponibilizadas em formato PDF, não sendo possível a visualização dos documentos em tela.

\subsubsection{Archivo Vasco de la Música Eresbil (AVME)}

A iniciativa de se criar um centro para recolher os trabalhos para o festival Musikaste, uma semana dedicada à divulgação de compositores bascos, em 1974, originou o Arquivo. Localizado em Errentería, Comunidade Autônoma do País Basco, Província de Guipuzcoa. No ano de 1980, foi iniciado um ciclo de concertos de câmara com o nome "Eresbil EresiaK", para apoiar jovens intérpretes. Para muitos destes concertos, foi realizado um importante trabalho de transcrição e cópia de partituras, principalmente antigas.

No ano de 1986, foi emitido um Decreto-Lei do Governo Vasco que criava o atual Conselho de Eresbil. A principal preocupação desse acervo é que a música, além de preservada, seja difundida. O mesmo é regido por um Patronato integrado por: Governo Vasco, Prefeitura de Gipuzkoa; Cidade de Errentería Coral Andra Errenteria; Coral Andra Mari, de Errenteria.

O centro está dividido em cinco seções: Compositores vascos, Fundos de Arquivo, Arquivo sonoro, Biblioteca musical e Documentação. 
A seção Compositores bascos se dedica a recolher ao depósito legal, desde o ano 2000, uma cópia das partituras de compositores da comunidade autônoma do País Basco. Inicialmente a recompilação das partituras foi realizada tanto em buscas como colaboração dos próprios autores.

A seção Fundos de Arquivos consta de fundos documentais, acervos e bibliotecas pessoais, assim como fundos institucionais e doações ou concessões em depósito que começaram a chegar, a partir de 1978. De acordo com informação do próprio site ${ }^{141}$ do Arquivo, em 2008, o Arquivo dispunha de 146 fundos.

A seção Arquivo Sonoro recolhe os registros das obras sonoras criadas pelos autores vascos. $\mathrm{Na}$ atualidade, a ideia foi ampliada a toda a produção musical editada no País Vasco, assim como a produção relativa a intérpretes vascos. Desde o ano 2000, recolhe-se uma cópia do Depósito Legal em discos da Comunidade Autônoma Vasca.

A seção Biblioteca Musical, na qual se recolhem as principais fontes impressas para o fomento de pesquisas na área de música, constituindo uma importante fonte de obras de referência. Reúne também coleções europeias de partituras como apoio aos músicos na busca e estudo de repertório.

A seção Documentação se dedica a recolher todo material informativo relativo aos compositores e intérpretes bascos, a exemplo de: artigos de periódico, recortes de jornal, relatórios, fotografias, entrevistas, etc.

Os serviços oferecidos pelo Arquivo são: consulta em sala - acesso direto à consulta de referência e bibliografias atualizadas, coleção de partituras de autores vascos e revistas do ano em curso; orientação e informação bibliográfica sobre diversos temas através de correio, email ou fax; reprodução de documentos textuais ou sonoros com as limitações que atendem à Lei de Propriedade intelectual e ao princípio de preservação do documento; empréstimo interbibliotecário: dirigido principalmente às Bibliotecas Musicais do País basco, e em casos particulares a outras bibliotecas; serviços Bibliográficos - ERESBIL cataloga os documentos musicais que entram no acervo através de depósito legal e fornece esses registros à Biblioteca do governo basco em Lakua. Também se

${ }^{141}$ Disponível em: http://www.eresbil.com/seccionesEresbil.asp. Acesso em : 25 novembro 2010. 
realizam catálogos bibliográficos e ou discográficos com pedido prévio. Reprografia: fotocópias para uso de investigação; reproduções sonoras e audiovisuais.

O endereço eletrônico do Arquivo é: http://www.eresbil.com/.

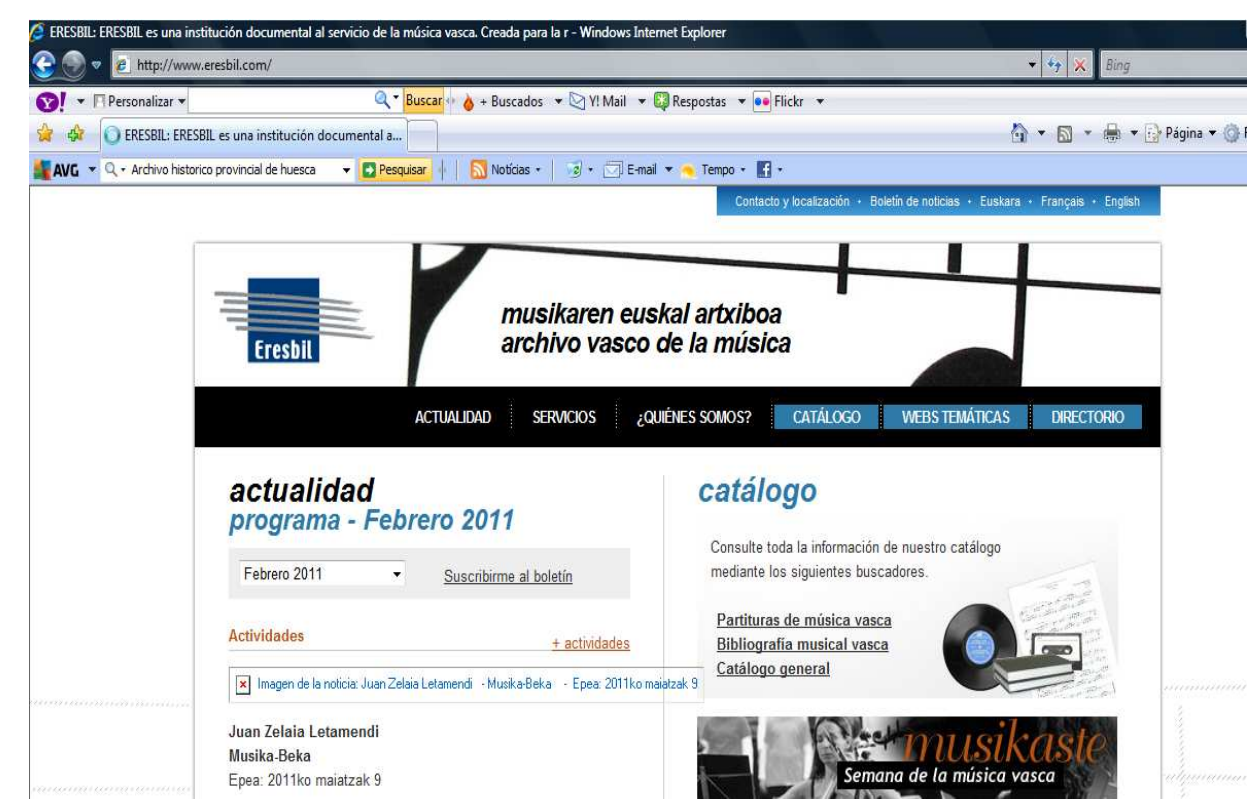

Figura 10 - Homepage do Archivo Vasco de la Música Eresbil

A homepage desse Arquivo possui um menu com as seguintes opções de navegação: Atualidade (Corresponde às notícias e novidades); Serviços: abre sublinks para Relação de serviços, Publicações para venda e Instalações; Quem somos - abre sublinks para: Origem do Arquivo, objetivo do Arquivo, Seções,Relações institucionais e Memórias; Catálogo: Abre sublinks para: Partituras de Música Basca, Bibliografia Musical Basca e Catálogo Geral; Webs temáticas: Sublinks para Editoriasi Musicais de Euskal Herria (séc. XV - 1950), Casas e Selos discográficos Euskaul Herria e Luis de Arámburu (1905-1999); Diretório: Sublinks para Diretório P. Basco-Navarra e outros links.

Através do Catálogo se pode tomar conhecimento da documentação que existe em cada coleção, porém não se pode vizualizar os documentos em tela. 


\subsubsection{Arquivo Histórico Provincial de Huesca (AHPH)}

A Província de Huesca está localizada no Norte da Comunidade de Aragão, entre as províncias de Navarra e de Gerona. A capital Huesca, foi o coração do reino de Aragão.

Dentre vários acontecimentos importantes, apresentamos um resumo dos mais marcantes na História do Arquivo Histórico Provincial de Huesca:

- Em 1931: Foi aprovado o decreto de 12 de noviembre de 1931 pelo qual se dispõe a formação dos Arquivos Históricos Provinciais em todas as capitais de província. Em 12 de dezembro se constituiu em Huesca a Junta do Patronato do Arquivo Histórico Provincial.

- Em 1988: Inclusão da documentação histórica da Prefeitura de Huesca.

- Em 2005: Os fundos documentais ocupam sete Kilômetros de prateleiras e abarcam um amplo período cronológico, desde o final do século XIl até 2004.

O acesso aos documentos, é livre e grátis, no entanto, exige-se apresentação do documento de identidade, o passaporte ou algum documento de identificação equivalente. Excetuam-se da livre consulta os documentos com restrições legais ao acesso. Existem algumas normas para a sala de consulta.

Quanto aos fundos, com o objetivo de reunir, preservar e difundir os documentos, seu acervo é formado por documentação histórica e protocolos notariais de mais de cem anos de antiguidade (Decreto de 12 de novembro de 1931 dos Ministérios de Instrução Pública e Belas Artes e de Justiça); documentação produzida pelos órgãos da Administração Periférica do Estado (Decreto 914/1969, de 8 de maio, de criação do Arquivo Geral da Administração Civil) e documentação produzida pela Delegação Territorial e os Serviços Provinciais do Governo de Aragão (Decreto 12/1993, de 9 de fevereiro, da Diputación General de Aragón, por el que se cria o Arquivo da Administração da Comunidade Autônoma de Aragão).

Os serviços deste Arquivo são os relacionados a seguir: Acesso e informação geral sobre os fundos documentais e os Arquivos onde estão conservados, sobre os fundos de Arquivo e seus instrumentos de descrição: se 
atende via fax, email, telefone ou correios. A Consulta de originais na sala de investigadores (considerando as restrições legais e as normas de consulta); A Reprodução, que pode ser feita nos seguintes suportes: cds, diapositivos, fotográficos, microfilmes. Biblioteca auxiliar: coleção bibliográfica com mais de 4.500 volumes, especializada em Arquivística, Ciências auxiliares e instrumentos de descrição de outros acervos, obras de referência de caráter geral, obras sobre a história de Aragão e história de Huesca. Difusão: Visitas guiadas, exposições e Jornada de Portas Abertas (uma vez por ano o Arquivo abre suas portas aos que desejam conhecer melhor o centro e os fundos que ele possui).

O endereço eletrônico do Arquivo é:

<http://www.aragon.es/DepartamentosOrganismosPublicos/Departamentos/ EducacionCulturaDeporte/AreasTematicas/Archivos/ArchivosGestionados/Archivo sHistoricosProvinciales/ArchivoHistorioProvincialHuesca>

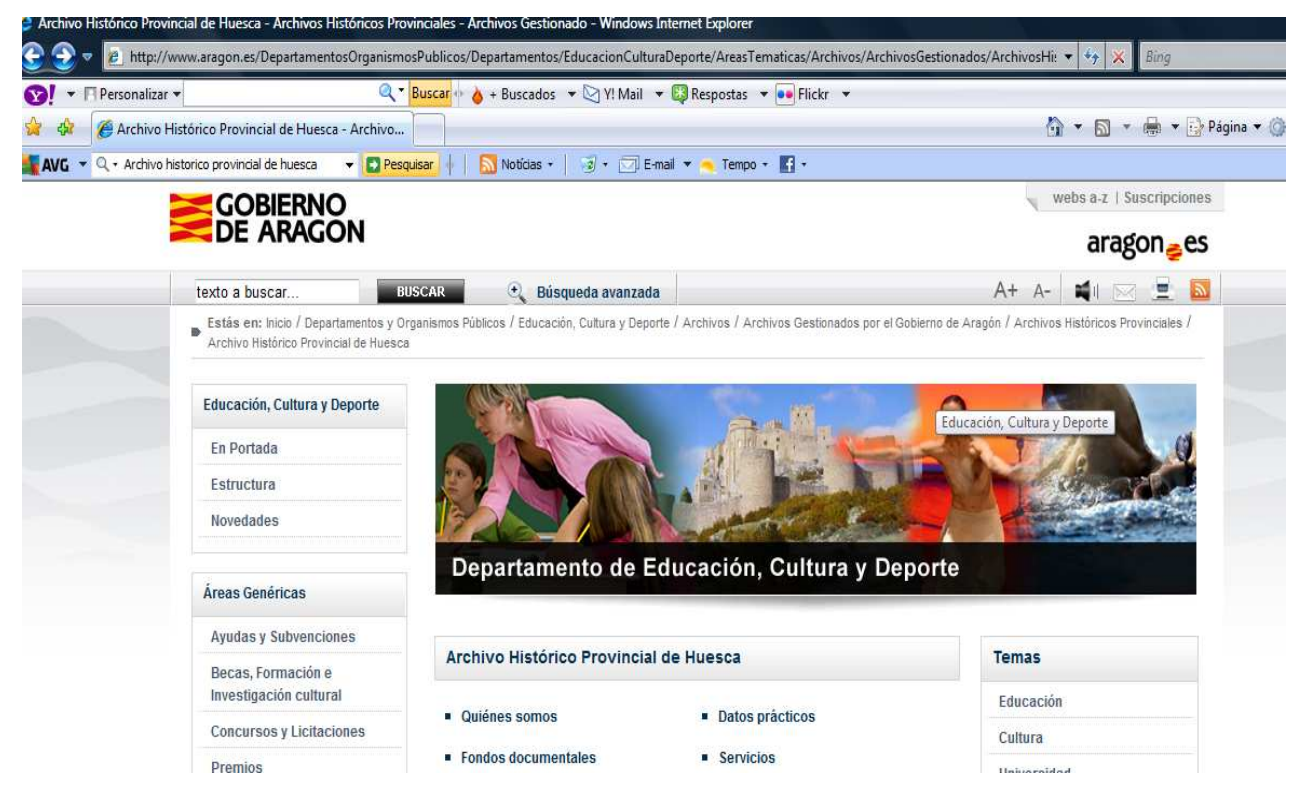

Figura 11 - Homepage do Archivo Histórico Provincial de Huesca

A homepage deste Arquivo oferece as seguintes opções de navegação: Quem somos, Dados práticos, Fundos documentais, Serviços, Publicações sobre o Arquivo, Notícias e Projetos, Perguntas freqüentes do pesquisador, Exposições.

Clicando-se em Quem somos, aparecem outros links com as seguintes informações: História do centro, Edifício, Funções, Recursos, Pessoal, 
Estatísticas, Dossiê de imprensa (notícias a respeito do Arquivo que saíram em periódicos).

Ao acessar o link Fundos documentais aparece a lista de fundos e o Quadro de classificação destes. A classificação é meramente descritiva, não se pode acessar o próprio documento em tela.

\subsubsection{Archivo Histórico Eclesiástico de Vizcaya (AHEV)}

Este impressionante edifício foi planejado nos anos 1930 para abrigar um manicômio. As obras estavam muito avançadas, o projeto elaborado por Diego de Basterra morreu definitivamente com a guerra civil. Depois foi reutilizado para usos diversos como workshops, secador de rapé e inclusive leiteria. Em 1951, o arquiteto Vega o readaptou para Seminário Diocesano, terminando as obras do Seminário Maior em 1960. O arquivo, desde a sua criação, ultrapassou a segunda a terceira planta e, desde o ano 2000 , situa-se na quinta planta do antigo Seminário Maior e que agora é conhecido como edifício A de Arteaga Centrum.

No Arquivo Histórico Eclesiástico de Vizcaya estão depositados os fundos dos arquivos de 190 paróquias de Vizcaya com documentação anterior a 1900. O livro mais antigo que chegou ao centro corresponde a registros originais de batismo da paróquia de Santiago de Zeanuri-Ipiñaburu, que começa em 1501. Entre os vários documentos se encontra documentação do século XIV, sendo o pergaminho mais antigo do ano de 1346, contando ainda com alguns fragmentos litúrgico-musicais do século XII e XIII, catalogados com a ISAD (G). Além disso, o Seminário Diocesano, o Instituto Diocesano de Teologia e Pastoral, Ação Católica de Homens, Ação Católica de Mulheres, ASCEA, Apostolado Seglar, Conselho Diocesano de Laicos, Secretariado da Juventude, Cáritas e diversas delegações curiais pediram pareceres ao Serviço Diocesano de Arquivos ou depositaram imediatamente seus fundos no Arquivo.

Quanto aos serviços, o pessoal de Arquivo assessora e orienta os usuários presenciais e virtuais fornecendo dados fundos, história diocesana,etc. O Arquivo 
conta ainda com uma biblioteca auxiliar à disposição dos usuários e incentiva a difusão cultural através de visitas guiadas, exposições e organização de jornadas.

Os usuários presenciais poderão consultar os instrumentos de descrição disponíveis na sala e na rede, consultar a documentação microfilmada e digitalizada, e solicitar serviços de reprografia.

Os usuários virtuais podem consultar os catálogos e registros sacramentais, e solicitar serviços de reprografia.

Existem na sala instrumentos de descrição a disposição dos usuários, que podem consultar todos os fundos que por suas características estejam acessíveis ao público. Preferivelmente a consulta é feita através de microfilme ou suporte digital.

$O$ arquivo oferece um serviço de reprografia e um serviço de transcrição elaborando extratos e cópias literais, segundo as tarifas vigentes. Os funcionários do arquivo não realizam buscas genealógicas nem investigação alguma. Sua função é assessorar e orientar aos usuários presenciais e virtuais na busca e localização de documentos.

Através do serviço de informação e referência, facilita dados sobre fundos, história diocesana ou dados sobre outras instituições diocesanas ou, em caso de não ser documentação própria do arquivo, procura indicar ao solicitante onde ele pode encontrar a informação solicitada.

O endereço eletrônico do Arquivo é: <http://www.aheb-beha.org/> 


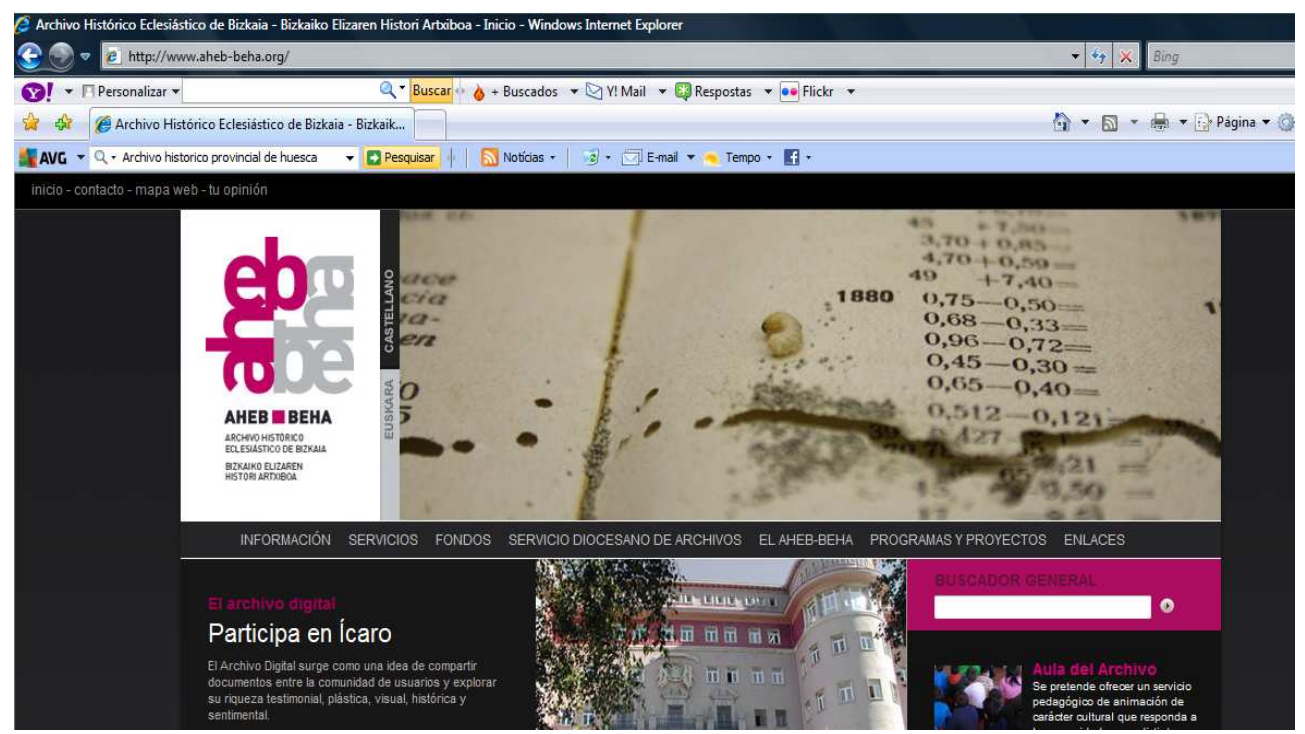

Figura 12 - Homepage do Archivo Histórico Eclesiástico de Vizcaya

Na homepage do Arquivo encontra-se as seguintes opções de navegação: Informação - informação sobre o Edifício onde funciona o Arquivo; Serviços informações sobre os serviços do Arquivo e apresenta links para o formulário de consulta de registros sacramentais e o Formulário de solicitação; Fundos Informações sobre os fundos dos Arquivos e um quadro de classificação Serviço Diocesano de Arquivos - Serviço que tem a finalidade de unificar a política arquivística da Diocese e implantar um sistema de gestão integral de todos os arquivos diocesanos; O Archivo Histórico Eclesiástico de Biscaya informações sobre o Arquivo; Programas e Projetos - Informa sobre os programas e projetos do Arquivo em relação ao seu acervo e mudanças na descrição dos fundos, etc; Links - apresenta diversos links de interesse.

Também apresenta as notícias e novidades e informações de contato em sua página inicial.

\subsubsection{Archivo Histórico de Asturias (AHA)}

A criação do Archivo Histórico de Asturias completa o sistema de arquivos da Administração do Principado de Asturias, regulado já em sua fase 
administrativa mediante o Decreto 21/1996, de 6 de junho, pelo qual se regula a organização e funcionamento do sistema de arquivos administrativos do Principado de Asturias.

O Archivo Histórico de Asturias compartilha a sede e os meios materiais e pessoais com o Arquivo Histórico Provincial de Asturias. O Arquivo Histórico Provincial de Oviedo, em 1983, passou a se chamar Archivo Histórico Provincial de Asturias como consequência do câmbio de denominação da província; foi criado pela Ordem Ministerial de 11 de janeiro de 1956, um quarto de século depois de que sua promulgação o Decreto de 12 de novembro de 1931 sobre Regime e denominação dos Arquivos Históricos de Protocolos e Históricos Provinciais. Em virtude disso, se estabeleceu a criação destas instituições nas capitais de província com a principal finalidade de recolher e guardar os protocolos notariais de mais de cem anos de antiguidade. Contudo, sucessivos decretos e ordens ministeriais propiciaram sua conversão em Arquivos gerais de âmbito provincial com o caráter duplo de histórico e intermediário.

Podemos estabelecer três etapas na vida do Arquivo. A primeira etapa entre sua criação, em 1956, e o ano de 1972, quando se desloca para instalações mais adequadas. A segunda etapa vai de de 1972 a 1999, e está marcada por dois feitos: a inauguração no dia 12 de maio de 1972 de uma nova sede na ala oeste do Monastério de San Pelayo e a assinatura do contrato em 1988, sobre Gestão do Arquivo de Titularidade Estatal entre o Principado de Asturias e o Ministério de Cultura.

A terceira etapa começa no ano de 2000, quando se experimenta um extraordinário incremento dos fundos documentais em todas as seções do Arquivo, e, portanto, um incremento de usuários. Foram efetuadas novas transferências de protocolos notariais; houve uma incorporação massiva de documentação procedente das delegações da Administração Central e dos órgãos da Administração de Justiça; houve o ingresso de um interessante e variado bloco de arquivos privados, nobiliários e de empresa, sim esquecer as transferências desde o Arquivo Geral da Administração do Principado de Asturias dos fundos da extinta Diputación Provincial, do Hospício e da histórica Junta Geral do Principado. O Archivo Histórico de Asturias também gerencia a entrada 
dos fundos documentais dos Hospitais Psiquiátricos, Provincial e Geral de Asturias.

Essa fase termina, em março de 2010, com o translado do Arquivo a sua nova sede na antiga Carceragem Modelo de Oviedo, donde se conservam mais de 140 fundos documentais diferentes, tanto públicos como privados.

O Arquivo é destinado a acolher os inventários de Fundos Documentais de procedências diversas, resultado dos programas de cooperação promovidos pelo Principado de Asturias para garantir a conservação e difusão dos Arquivos das distintas entidades públicas e privadas.

O Arquivo dispõe de um Buscador de Fundos Documentais com Invent'rios na rede, e, este instrumento permite localizar nos inventários os registros descritivos que contêm os nomes, expressões ou períodos cronológicos solicitados, com referência a origem orgânica ou funcional dos documentos e seguindo a estrutura dos quadros de classificação dos fundos arquivísticos.

Os serviços disponibilizados no Arquivo são: Reprografia de contato, leitora de microfilmes; lâmpada de luz de quartzo; informação documental e bibliográfica, empréstimo de documentação aos organismos produtores, expedição de certificados; expedição da carteira nacional de pesquisador; consulta bibliográfica online; biblioteca especializada; empréstimo interbibliotecário; visitas guiadas concertadas para grupos.

O endereço eletrônico do Arquivo é: http://www.archivosdeasturias.info/

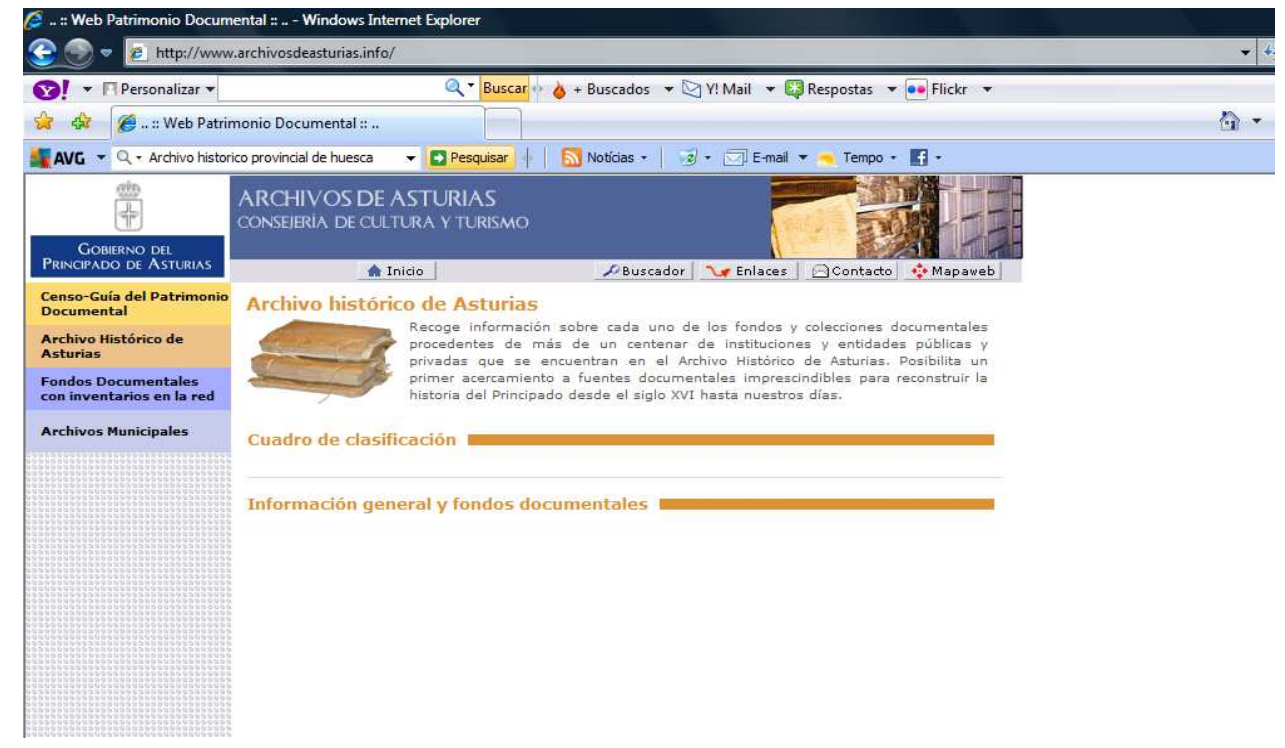


Figura 13 - Homepage do Archivo Histórico de Asturias

A homepage deste Arquivo possui uma estrutura bem simples onde se encontra informações gerais sobre o mesmo e as seguintes opções de navegação: Quadro de classificação - Classificação dos fundos documentais(Informação Geral e fundos Documentais: apresenta informações sobre o Arquivo como: endereço, telefone e fax, correio eletrônico e página Web, diretor ou responsável, História do Arquivo), Extensão e suporte da documentação - informações sobre o acesso aos fundos, informações sobre os serviços oferecidos pelo Arquivo, informações sobre os Guias do Arquivo, informa que o Arquivo é de titularidade pública e apresenta uma lista dos Fundos dos Arquivos em que clicando-se em cada um dos fundos abre o sublink com as informações sobre os mesmos (Identificação, contexto,conteúdo e estrutura, acesso e utilização,documentação associada, notas e observações e controle da descrição).

\subsubsection{Archivo General Militar de Avila (AGMA)}

O Arquivo Geral Militar de Ávila é um Arquivo Histórico, subsidiado pelo Ministério da defesa (Exército de Terra). Através da Instrução Geral 1/93 de Adaptações Orgânicas do Estado Maior do Exército (Divisão de Planos e Organização), foi criado o Archivo General Militar de Ávila em 1994 para descongestionar os arquivos históricos do Exército de Terra, já que tanto o Arquivo Central do Serviço Histórico Militar como o Arquivo Geral Militar de Segovia se encontravam saturados. Portanto ele é um dos Arquivos mais jovens da Espanha. Seu núcleo inicial se constituiu com o antigo "Archivo Histórico de la Campaña", que em 1939 unificou em apenas um Arquivo as documentações militares do exército franquista e do republicano.

O Archivo General Militar é normalmente consultado por investigadores e pessoas particulares que pretendem saber o que aconteceu com os familiares que desapareceram durante a Guerra Civil. 
Os Fundos do Arquivo são: Administração Republicana Anterior à Guerra; Civil. Ministério da Guerra; Guerra Civil. Zona Nacional; Guerra Civil. Zona; Republicana; Milícias Nacionais; Divisão Azul; Hospitais; Ministério do Exército; Fábrica de Armas de Toledo; Coleções (Documentação gráfica);

Entre outros, os fundos desse Arquivo se articulavam nos seções "as Unidades da Zona Nacional e Republicana durante a Guerra Civil Espanhola", no período compreendido entre os anos 1936 y 1939 e à gerada pelo extinto Ministério do Exército, entre 1939 e 1977.

Inicialmente seus Fundos são constituídos pelas documentações transferidas pela Central do S.H.M. (Arquivo da Guerra e Arquivo da Milicia Nacional), documentos da antiga Quarta Seção do Arquivo Geral Militar de Madri. Em especial, os documentos do Arquivo da Guerra Civil Espanhola e do Arquivo da Milícia Nacional. Fundos das Brigadas Internacionais, as Brigadas Mixtas, Milícias nacionais (Falange e Requetés), Divisão Azul... Ao núcleo documental do centro se incorporaram também os fundos do Hospital Militar de Zaragoza e da Subsecretaria do Ministério do Exército (1939-1977) e posteriormente, outros novos documentos.

Com relação à documentação da chamada "Zona Nacional": reúne a documentação do Quartel General de Franco e de seus diferentes Corpos de Exército, divisões, etc, assim como das Unidades de Falange Espanhola e de Requetés. Trata-se de documentação administrativa e de caráter militar gerada, principalmente, pelos Quartéis Generais das distintas Unidades que participaram na guerra. A documentação referente aos prisioneiros e batalhões de trabalhadores se encontra na 1a Seção (organização). Seu estado atual, não permite a identificação das vítimas, porém existem bases de dados de caráter onomástico em que se encontram informatizados um volume de 317 metros lineares de documentação diversa e de expedientes. A consulta é livre, sem restrições, de acordo com a legislação geral.

Com relação à documentação das Unidades da Zona Republicana: se conservam documentos do Ministério de Defesa Nacional e do Ministério de Propaganda, das Direções Gerais de Segurança e de polícia, bem como documentos da Generalidad de Cataluña e do Governo basco. Ainda conta com documentação militar gerada pelos Estados Maiores das distintas Unidades que 
participaram na Guerra Civil referentes aos inventários de prisioneiros e dos batalhões de trabalhadores. Seu atual estado também não permite a identificação das vítimas, ainda que existem bases de dados de caráter onomástico, com um volume total de 187 metros lineares de documentação e expedientes. A consulta é em regime de acesso com restrições.

Os Fundos do Ministério do Exército: contêm a documentação administrativa gerada pela extinta Subsecretaria do Ministério do Exército e pela Segunda Seção do Estado Maior Central durante o período de tempo compreendido entre os anos de 1939 e 1977 e faz referência às relações de entrega de prisioneiros campos de concentração batalhões de trabalhadores. Seu atual estado não permite a identificação das vítimas por causa do insuficiente nível de descrição, conta apenas com deficientes relações e inventários de entrega destas, embora existam bases de dados de caráter onomástico, com um total 1.068 de metros lineares de documentação. Sua consulta é em regime de acesso com restrições, uma vez que a documentação da Segunda Seção do Estado Maior Central se encontra afetada pela Lei de Segredos Oficiais. Finalmente, deve-se ressaltar a escassez de recursos humanos e materiais existentes, fato que dificulta a classificação e revisão da documentação depositada nestes Arquivos. Os serviços oferecidos disponibilizados neste Arquivo são: Fotocópias certificadas de documentação ou Certificado de dados concretos de alguma documentação,

através do preenchimento de formulários contidos no site. Para isso há um formulário para pedidos específicos de informação.

O endereço eletrônico do Arquivo está subsidiado à página do Instituto de Historia e Cultura Militar, Órgão de nível de Direção integrado organicamente ao Quartel Geral do Exército, responsável pela proteção, conservação, investigação e divulgação do patrimônio histórico, cultural, móvel, documental e bibliográfico do Exército de Terra espanhol.

Desde 1969, o Arquivo da Real Chancelaria vinha exercendo as funções de Arquivo Histórico Provincial, motivo pelo qual se iniciou o processo de coleta e inclusão dos fundos documentais gerados pelas vários escritórios provinciais e outros órgãos dependentes do Estado na Província. No ano de 1991, o Arquivo Provincial começou a funcionar como Unidade independente do Archivo de la 
Real Chancillería de Granada, gerido pelo Ministério da Cultura do Governo de Andaluzia, em virtude do Real Decreto 864/1984, de 29 de fevereiro. Começou assim o processo de constituição, até o ano de 1994 quando foi incorporado ficou incorporado ao Sistema de Arquivos do Estado, formando parte da rede de Arquivos Históricos Provinciais.

$\mathrm{Na}$ atualidade é regido pelo acordo de colaboração entre o Ministério de Cultura e a Junta de Andaluzia, de 21 de maio de 1994. Nesse mesmo ano os Arquivos Históricos Provinciais foram integrados plenamente ao Sistema Andaluz de Arquivos.

Quanto aos fundos, o Archivo Histórico Provincial de Granada acolhe entre seus fundos informação sobre os povoadores mouros e os processos da Inquisição.

Seus muitos kilômetros de estantes acolhem uma série de exclusivas jóias documentais procedentes em sua maioria dos fundos do Tesouro que se cederam ao Archivo Histórico de Granada e seu Reino por volta de 1922.

Um dos grupos documentais mais valiosos deste centro é o formado pelos 'Libros de población del antiguo Reino de Granada', do século XVI. Com a expulsão dos mouros, muitas terras ficaram despovoadas e Felipe II firmou uma ordem chamada "suertes de terra" aos critãos velhos, tanto do reino de Granada como do resto das províncias espanholas, que quisessem repovoar aquelas terras. Aos novos proprietários se exigia que explorassem as terras e que não a vendessem ao menos durante 0 período de dois anos. Para controlar esta mudança de proprietários bem como para fosse cumpridas as exigências para a posse, foram anotados os detlahes das transações através dos livros de povoação. Nestes documentos, fechados desde o ano de 1572, aparecem o nome do mouro a quem pertenciam as terras e do novo povoador.

As perseguições aos mouros e judeus, inclusive no século XVIII, se pode investigar neste Arquivo através do Fisco da Inquisição, um bloco documental de grande importância, já que são os únicos testemunhos escritos existentes das ações do Santo Ofício no Reino de Granada.

Outro importante bloco documental está formado pelo Cadastro do Marqués de la Ensenada no Antigo Reino de Granada. Em meados do século 
XVIII, ordenou-se a elaboração de um cadastro dos bens imóveis dos cidadãos para a consequente imposição fiscal dos bens rurais e urbanos. Junto aos dados econômicos, os manuscritos mostram toda uma cartografía das povoações espanholas, uma vez que os funcionários que registravam os bens faziam desenhos de toda a cidade, incluindo até mesmo as pontes e os principais monumentos. O Relatório do Marqués da Ensenada é, portanto, uma importante prova da evolução urbana das cidades.

Aberta à sociedade em geral, como um serviço público. Oferece Informação primária, necessária para a investigação, o estudo, a cultura e a própria atividade da administração. Os visitantes da página Web do Archivo Histórico Provincial de Granada podem consultar várias bases de dados de seus fundos. Será possível descarregar as bases de dados a partir do Quadro de Classificação, em que se busca primeiramente o fundo de interesse do usuário. Já estão disponíveis a consulta das descrições dos "Livros da Povoação do antigo Reino de Granada" e da "Real Sociedade Econômica de Amigos do País de Granada".

O endereço eletrônico do Arquivo é:

http://www.ejercito.mde.es/unidades/Madrid/ihycm/Archivos/agm-avila index.html

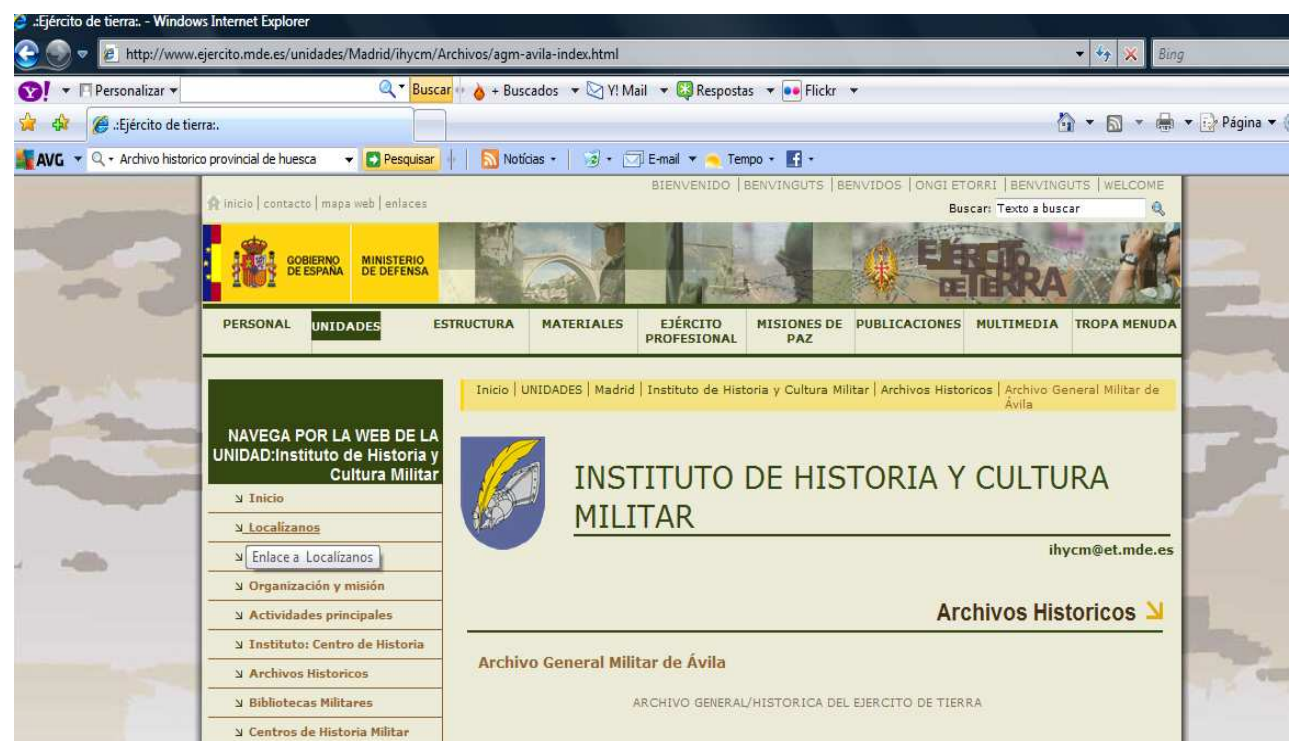

Figura 14 - Homepage do Archivo General Militar de Ávila 
Na homepage, encontram-se informações gerais sobre o Arquivo, dois links para petição de dados específicos do Arquivo, em que um é apresentado em formato Word e o outro em formato PDF e encontra-se também o email do Arquivo.

Apesar de a homepage apresentar o Arquivo de maneira concisa, existem diversas opções de navegação no site do Instituto de História e Cultura Militar ao que administra o Arquivo.

\subsubsection{Archivo de la Universidad de Salamanca (AUS)}

Salamanca é uma cidade situada na província do mesmo nome, na região de Castilla León, no centro da Península Ibérica. É uma cidade conhecida pela sua cultura, pelo seu Rio Tomes, pela sua gastronomia e pelos seus aromas castelhanos.

A cidade de Salamanca ostenta o título de "LA DORADA", admitida pela Unesco como patrimônio histórico da humanidade. Terra de clima ameno e topografia variada. Sendo a cidade situada em local mais plano mas com montanhas ao norte e ao sul. Dona da penúltima catedral gótica construída na Espanha. Como seus maiores tesouros encontraremos a Universidade de Salamanca (a segunda universidade mais antiga da Europa, fundada no ano 1218 por Alfonso IX de Leão).

O serviço de arquivos da Universidade de Salamanca é a unidade técnica de apoio à administração, ao ensino e à pesquisa, responsável pela gestão do Arquivo da referida Universidade.

O Arquivo universitário é a unidade responsável pela organização, conservação e serviço do Patrimônio Documental da Universidade de Salamanca; assim como o conjunto orgânico de documentos produzidos ou reunidos pela Universidade de Salamanca, ou pelos membros de sua comunidade, no exercício de suas funções, ao serviço de sua utilização para a gestão administrativa, a informação, a cultura e a investigação. 
O sistema de arquivo da Universidade de Salamanca consiste de todos os arquivos de gerenciamento (arquivos de Escritório), os arquivos centrais, 0 arquivo intermediário e o arquivo histórico da universidade. Esta estrutura corresponde às diferentes fases do ciclo de vida de documentos, desde que se produzem no arquivo de gestão, passando por sua transferência ao arquivo central e intermediário, até que sejam descartados, ou mantidos permanentemente no arquivo histórico.

O Arquivo Central do Reitorado reúne e gerir os documentos transferidos pelos órgãos da direção da Universidade e os serviços administrativos da gestão central.

O Arquivo Intermediário é responsável pela gestão dos documentos transferidos dos diferentes centros arquivísticos e da administração de diversos centros acadêmicos sendo sua consulta pelos órgãos produtores, esporádicas. A gestão de documentos oriundos dos diversos centros de arquivos de diferentes centros acadêmicos administrativos quando a consulta pelos órgãos de fomento é esporádica. Os documentos permanecem arquivados até a sua remoção definitiva ou transferência ao Arquivo Histórico.

O Arquivo Histórico conserva a documentação histórica produzida pela Universidade. Além dessa documentação, formam parte deste Arquivo, o Archivo de D. Miguel de Unamuno, o Archivo de D. Pedro Dorado Montero, o Archivo de D. Ricardo Espinosa Maeso e os demais fundos e coleções documentais vinculados à Universidade que têm natureza histórica.

O Arquivo Central do Reitorado e o Arquivo Intermediário somente emprestam os documentos aos órgãos produtores para fins de trâmite, busca de antecedentes e informação administrativa. A consulta da documentação com a finalidade de pesquisa é realizada na Sala de Pesquisa do Arquivo Histórico ou na Casa-Museu "Miguel de Unamuno".

O acesso dos investigadores e cidadãos em geral aos fundos do Arquivo da Universidade de Salamanca está submetido á restrições estabelecidas pela Lei 30/1992, de 26 de novembro, de Regime Jurídico das Administrações Públicas do Procedimento Administrativo Comum, e a Lei 16/1985, de 25 de junho, do Patrimônio Histórico Espanhol. 
De acordo com o estabelecido na legislação sobre proteção do direito à honra, a intimidade pessoal e familiar e à própria imagem, a Secretaria-Geral da universidade de Salamanca pode permitir a consulta de documentos sujeitos a restrições de acesso nos casos em que se justifiquem o interesse histórico, científico cultural relevante do trabalho de pesquisa que se pretende desenvolver, desde que o investigador concorde por escrito em respeitar a lei vigente.

Os serviços prestados pelos arquivos e o resto dos centros do Serviço de Arquivos e Bibliotecas são regidos por tarifas de preços públicos aprovadas pela Administração da Universidade de Salamanca.

Uma observação a ser feita é que quando buscamos por "Arquivo da Universidade de Salamanca" nos motores de busca, nos primeiros resultados encontramos a página http://sabus.usal.es/ que nos remete ao Sabus = Serviço de Arquivos e Bibliotecas da Universidade de Salamanca, na homepage deste site, encontramos o link: Arquivos, clicando nele encontramos enfim a homepage deste Arquivo:

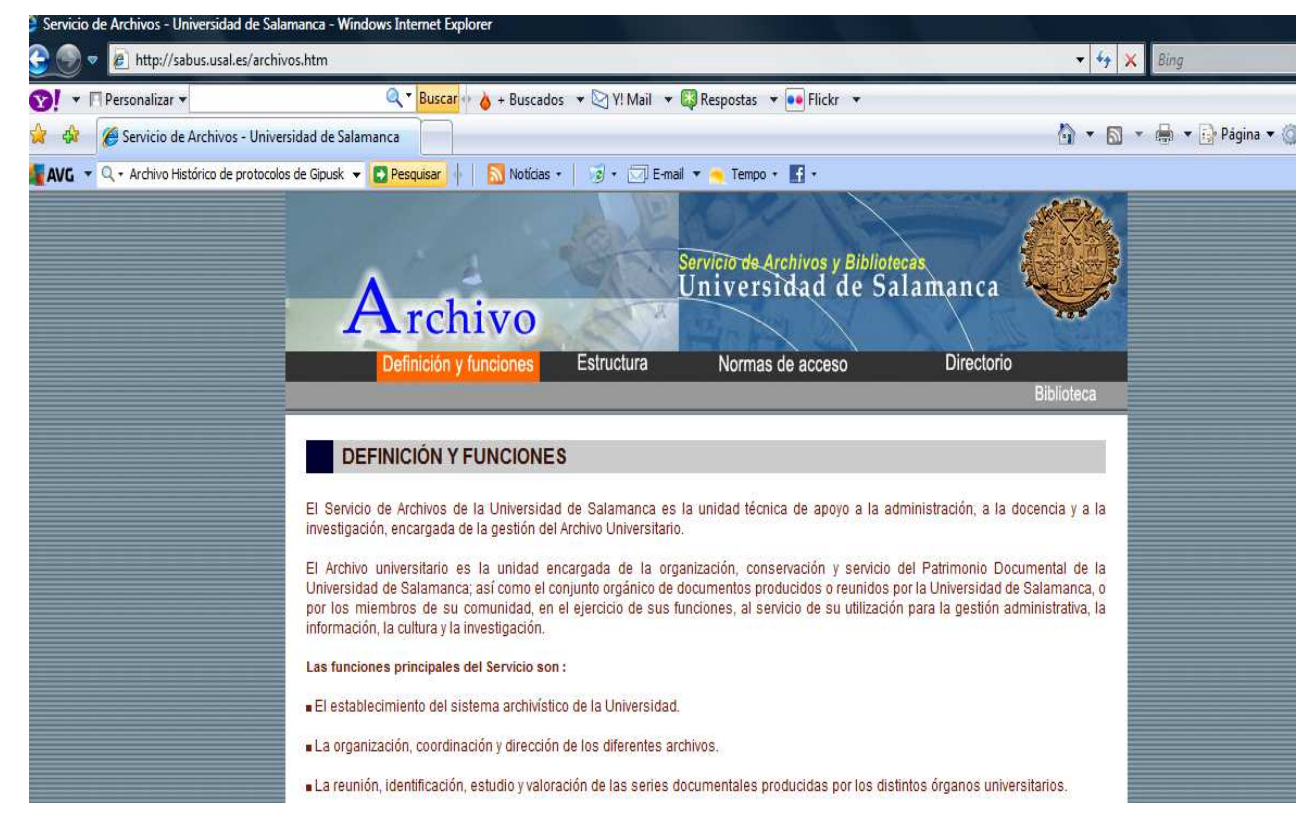

Figura 15 - Homepage do Archivo de la Universidad de Salamanca

Conforme demonstra a figura 15, a homepage do Arquivo possui informações sobre a definição e funções do Arquivo, oferecendo as seguintes opções de navegação: Estrutura - informações sobre como está estruturado os 
Arquivos da USAL e as funções de cada um deles: Archivo Central Del Rectorado, Archivo Intermédio e Archivo Histórico; Normas de Acesso informações sobre o acesso dos cidadãos e pesquisadores aos fundos do Arquivo; Diretório - informações gerais sobre os Arquivos:endereço, email. Telefone, fax e nome do responsável.

A homepage não apresenta Quadro de classificação ou lista dos fundos dos Arquivos para os usuários do Site.

\subsubsection{Archivo General de Simancas (AGS)}

No último terço do século $X V$, em plena época de lutas nobres de facções de famílias poderosas, os Almirante de Castela, construíram um castelo na aldeia histórica de Simancas, perto de Valladolid. Os reis católicos, de acordo com sua política de controle da nobreza, exigiram aos Enrg hquez que fosse entregue a Fortaleza que passou às mãos da Coroa. Após sufocado o movimento plebeu, fortalecido o poder real e desenvolvido o aparelho administrativo da monarquia, Carlos V ordena, em 16 de setembro de 1540, guardar em uma das torres, devidamente acondicionados para isso, um importante conjunto de documentos.

O Archivo General de Simancas, iniciado por Carlos V e concluído por seu filho Felipe II, guarda toda a documentação produzida pelos Orgãos do Governo da monarquia hispânica desde a época dos Reis Católicos (1475) até a entrada do Regime Liberal (1834). Constitui, portanto, o fundo documental mais homogêneo e completo da memória histórica da Espanha dos séculos XVI até o XVIII.

Em 1844 termina a etapa do Arquivo a serviço da Administração, com a chegada do regime liberal, Simancas a partir daí se abre à investigação histórica. O Arquivo passa a ser então Histórico.

Este importante conjunto documental está guardado desde o século XVI em um edifício construído, exclusivamente para o Arquivo, por Juan de Herrera. Desde então as gerações de arquivistas o mantêm a fim de evitar sua perda ou 
deterioração. Eles o estudam, o descrevem e o difundem para que se torne conhecido e apreciado. Qualquer cidadão pode ter acesso com facilidade ao estudo de uma das épocas que mais merecem destaque do passado histórico da Espanha.

Este caminho verdadeiramente excepcional do Arquivo de Simancas o converte em um dos arquivos mais importantes para o estudo da época moderna.

No século $X X$, se realizam novas obras para adaptar o Arquivo às modernas técnicas que surgem, sobretudo no campo da reprografia e da restauração.

A partir do ano de 2000 , foi realizada outra reforma para habilitar novos espaços e adaptá-los às metas para os avanços tecnológicos do novo milênio.

Em 1844, os arquivos são abertos à investigação e Simancas deve adaptar-se a este novo rol franqueando o acesso a historiadores nacionais e estrangeiros.

Os fundos do Arquivo de Simancas refletem a estrutura administrativa desde o reinado dos Reis Católicos (fins do século XV) até a caída do Antigo Regime (princípios do século $X I X)$. Neste longo período se distinguem duas épocas: Austria (XVI-XVII) e Bourbons (XVIII). Consequentemente os fundos de Simancas tem dois grandes blocos: os pertencentes à era austríaca e os da era Bourbon.

$\mathrm{Na}$ era Austríaca existiram tantos Conselhos quantos territórios que constituíam a monarquia hispânica (Conselho e Câmara de Castela, de Aragão, de Indías, de Italía, de Flandres e Portugal) e todas as questões gerais relacionados a eles (Conselho de Estado, de Guerra, do Tesouro, de Inquisição, das Ordens e das Cruzadas). Treze Conselhos ou órgãos em cujas mãos passavam todos os assuntos tocantes aos territórios e questões já mencionadas. Em Simancas, portanto, para os séculos XVI e XVII existem tantas seções quantos Conselhos houveram, com quatro exceções: os conselhos das Ordens, Indias, Aragão e Inquisição.

Os órgãos do governo da época Bourbon foram as Secretarias de Despacho, de Guerra, do Tesouro, de Graça e da Justiça, e da Marinha e das Índias. 
Em Simancas, portanto, para o século XVIII existem tantas seções quantas Secretarias existem. Além dessas existem seções factícias, não derivadas de um determinado órgão administrativo produtor: Patronato Real, Mapas, Planos e Desenhos.

Os serviços oferecidos pelo Arquivo são: consulta em sala: o acesso é livre, porém, o usuário deve apresentar um documento de identificação e preencher uma ficha para usuários externos. Serviço de Reprografia: este serviço obedece normas que estabelecem suas condições e limitações; Convênio de Reprodução de documentos: se qualquer usuário ou investigador deseje utilizar os documentos do Arquivo para fins de exposição, trabalhos científicos, etc. deverá firmar um acordo com o Ministério da Cultura seguindo as condições exigidas para o acordo. Biblioteca: a biblioteca não realiza empréstimos porém qualquer usuário tem livre acesso aos fundos do Arquivo especializado na Época Moderna. Outros: empréstimos para exposição, visitas guiadas, entre outros.

O endereço eletrônico do Arquivo é:

http://www.mcu.es/archivos/MC/AGS/index.html

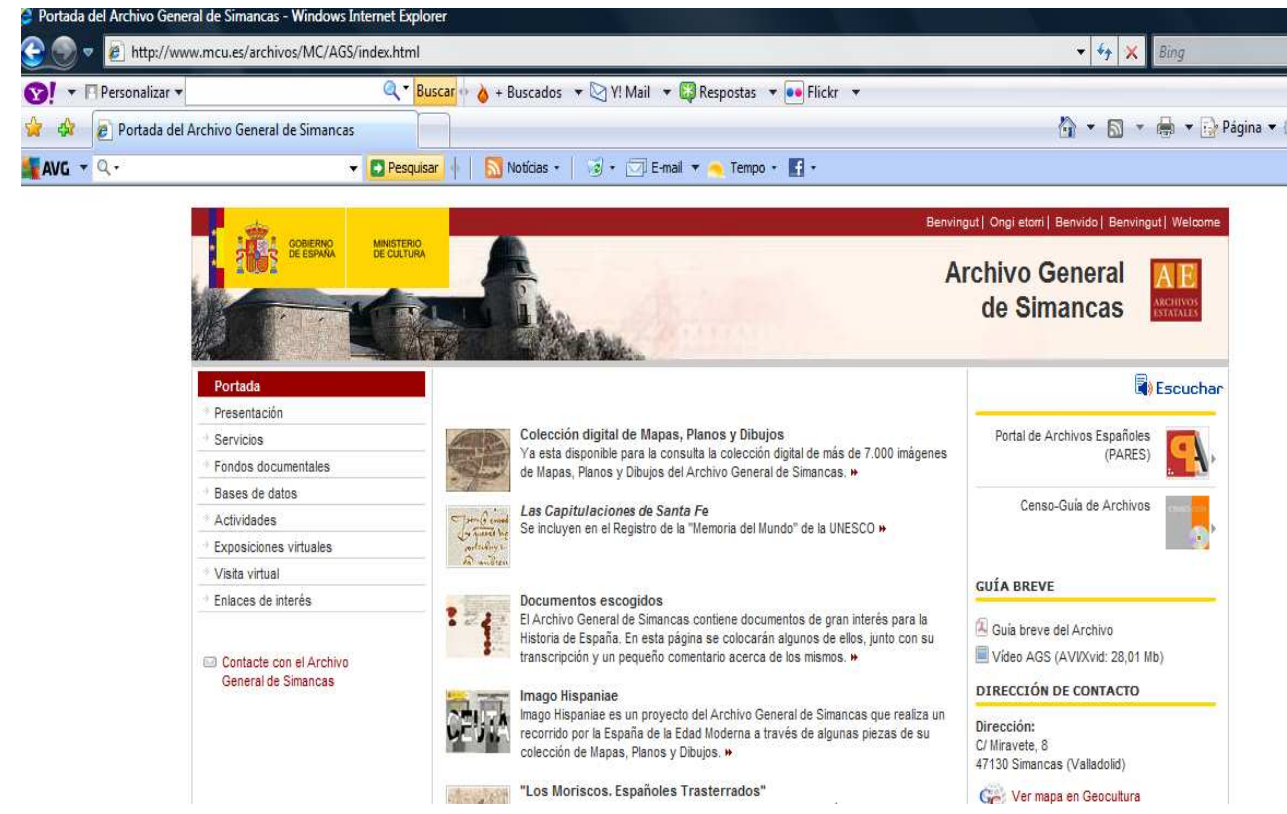

Figura 16 - Homepage do Archivo General de Simancas

Em sua Homepage, o site deste Arquivo apresenta um menu com as seguintes opções de navegação: Apresentação - pequena apresentação sobre o 
Arquivo e suas funções. Clicando nesta opção aparece os seguints sublinks: História (pequena história do Arquivo); Edifício: Fala da estrutura arquitetônica do Edifício onde funciona Arquivo; Estrutura Admisnistrativa: está subdividida em: Direção, Subdireção, Departamento de Ingresso de Fundos, Departamento de Referências; Departamento de Coordenação e Normalização; Serviços Clicando neste link, aparecem os seguintes sublinks: Consulta em sala, reserva de documentos por telefone, Biblioteca, Outros Serviços, Convênios de reprodução de documentos; Fundos Documentais - Clicando neste link, aparecem os seguintes sublinks: Introdução, Quadro de Classificação, Bibliografia, Instrumentos de referência; Bases de dados - apresenta as bases de dados do Arquivo Histórico Nacional; Atividades - parte dedicada a divulgar exposições, conferências, cursos, jornadas, bem como oferecer visitas guiadas. Neste link também encontra-se o Ciclo da "Peça do Mês", que se trata da exposição periódica de alguns dos documentos mais representativos do Arquivo com a finalidade de difundir seus fundos documentais; Exposições Virtuais Acesso a exposições em rede; Visita Virtual - Relativa às exposições virtuais e a quaisquer serviços que eventualmente se disponibilize através da Web; Links de interesse - Links de páginas Web relacionadas com as atividades do Arquivo.

\subsubsection{Archivo Municipal de Santander (AMS)}

O Archivo Municipal de Santander é a memória da Instituição que o criou e por sua própria natureza a memória da cidade. É definido como o conjunto de documentos de qualquer data, acumulados em um processo natural, que foram gerados e recebidos pela prefeitura no cumprimento de suas funções.

A prefeitura de Santander conserva um patrimônio documental de valor extraordinário pela quantidade, variedade e amplitude temática. O patrimônio documental municipal vem sendo formado desde a ldade Média e segue crescendo continuamente na atualidade.

O objetivo perseguido pelo acúmulo de documentos é o testemunho e servir de referência para a resolução do trabalho cotidiano da prefeitura e 
preservar testemunhos jurídicos e legais para assegurar os direitos dos cidadãos e da Corporação.

O Arquivo constitui um serviço básico dentro da organização da prefeitura e ainda um serviço público, cuja missão é conservar e facilitar o acesso ao patrimônio documental do município.

O Quadro de Classificação do Archivo Municipal de Santander é único para todos os documentos, desde o mais antigo, do ano 1295, até as últimas transferências recebidas. Está baseada na Proposta do Quadro de Classificação de Fundos da prefeitura elaborado pela Mesa de Trabalho sobre Organização de Arquivos Municipais. Esse quadro visa a contribuir para o desenvolvimento de uma metodologia arquivística cada vez mais normalizada na Espanha.

A estrutura funcional do Quadro de Classificação reflete a continuidade das competências que a prefeitura assumiu através do tempo As funções

são permanentes, foram mantidos ao longo dos séculos, seja qual for o nome dos escritórios que tenham exercido. A estrutura da organização do fundo da prefeitura, refletida no quadro, se repete nas sucessivas Seções, Subseções, Séries e Subséries. Está dividido em quatro Seções: Governo,

Administração, Serviços e Serviço de Finanças.

Esse Arquivo mantém, juntamente com a prefeitura de Santander, convênio com algumas universidades: Universidad de Cantabria e com a Universidade de Educação à Distância (U.N.E.D.), para que alunos universitários realizem sua formação prática em Arquivística no Archivo Municipal de Santander. Na universidade de Cantábria, a disciplina Patrimônio Documental, da Área de Ciências e Técnicas Historiográficas na Faculdade de Filosofia e Letras e o curso de Mestrado em Patrimônio Histórico e Territorial na Faculdade de Filosofia e Letras. Na U.N.E.D, o Curso de Especialização Universitária em Arquivística.

A homepage do Arquivo pode ser acessada através do seguinte endereço eletrônico:

http://portal.aytosantander.es/portal/page/portal/inet_santander/ficha/ficha_ayto?it emld=2079049 


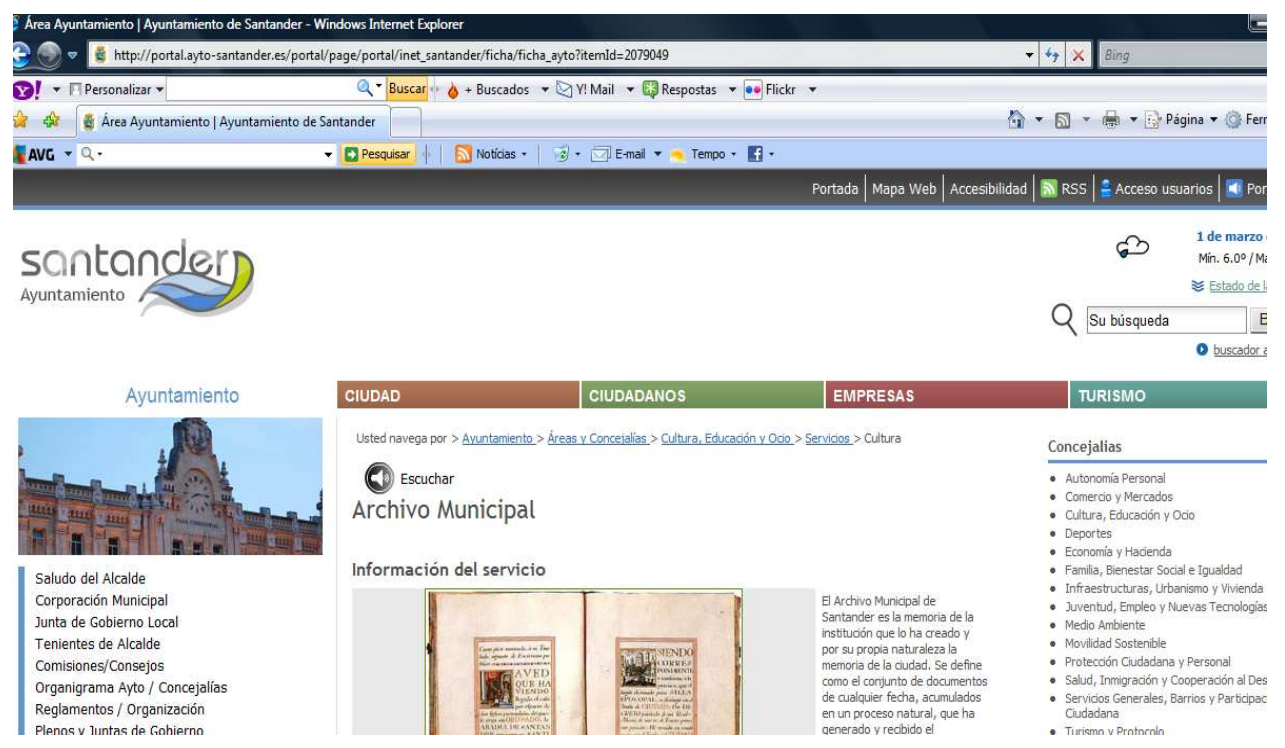

Figura 17 - Homepage do Archivo Municipal de Santander

A homepage do Arquivo apresenta as seguintes informações: sobre os serviços do Arquivo, endereço, telefone, email e horário de funcionamento. Também apresenta três anexos em formato PDF: Resumo do Quadro de Classificação, Quadro de Classificação e Convênios de Colaboração com Universidades.

\subsubsection{Arquivo da Emigración Galega (AEG)}

O arquivo da emigração galega fica em santiago de compostela que é a capital da Galiza, na província da corunha, é uma cidade mundialmente famosa pela sua catedral de fachada barroca onde acorrem os peregrinos que perfazem os caminhos de Santiago de maneira a depararem-se com o manto de Santiago (santiago maior, muito raramente chamado santiago, o grande, porém mais conhecido como santiago de compostela) um dos apóstolos de Jesus Cristo, cujo corpo se diz que foi trasladado para aquele lugar.

Os objetivos gerais do AEG são: Conservar a memória viva da emigração galega através da recuperação do seu patrimônio cultural; constitui-se como um centro de documentação, investigação e difusão referencial que amplia e mantém as suas distintas modalidades de acesso e disposição de materiais de interesse 
para os investigadores; difundir e promover estudos e investigações de caráter científico que sirvam para um melhor conhecimento dos distintos aspectos relacionados co fenômeno da nossa emigração.

Desde 1995, o arquivo da emigração galega publica semestralmente a revista Estudios Migratorios que tem como objetivo servir de ponto de encontro e reflexão para os pesquisadores sobre os movimentos migratórios em geral, e sobre os galegos em particular, acolhendo nas suas páginas diversas investigações sobre esta temática sob diferentes perspectivas científicas.

Os fundos documentais do AEG estão classificados em: bibliográficos, documentais, estatísticos, audiovisuais, orais e fundos das sociedades galegas.

O Arquivo oferece os seguintes serviços: o arquivo da emigração galega, como centro documental e de referência informativa; possui uma biblioteca especializada em temas migratórios composta por monografias e publicações periódicas de caráter científico. Esse fundo bibliográfico integra-se na biblioteca do conselho da cultura galega e como fundo de especial interesse para Galícia, na rede de bibliotecas de Galícia, o que permitirá o seu posterior acesso mediante um catálogo automatizado.

O arquivo da emigração galega realiza tarefas de reprodução, catalogação para possíveis buscas avançadas e conservação das gravações digitalizadas, com a finalidade de pôr à disposição de cientistas sociais, pesquisadores e acadêmicos este patrimônio documental. Através do endereço eletrônico: http://www.consellodacultura.org/arquivos/aeg/ se pode acessar sua homepage. 


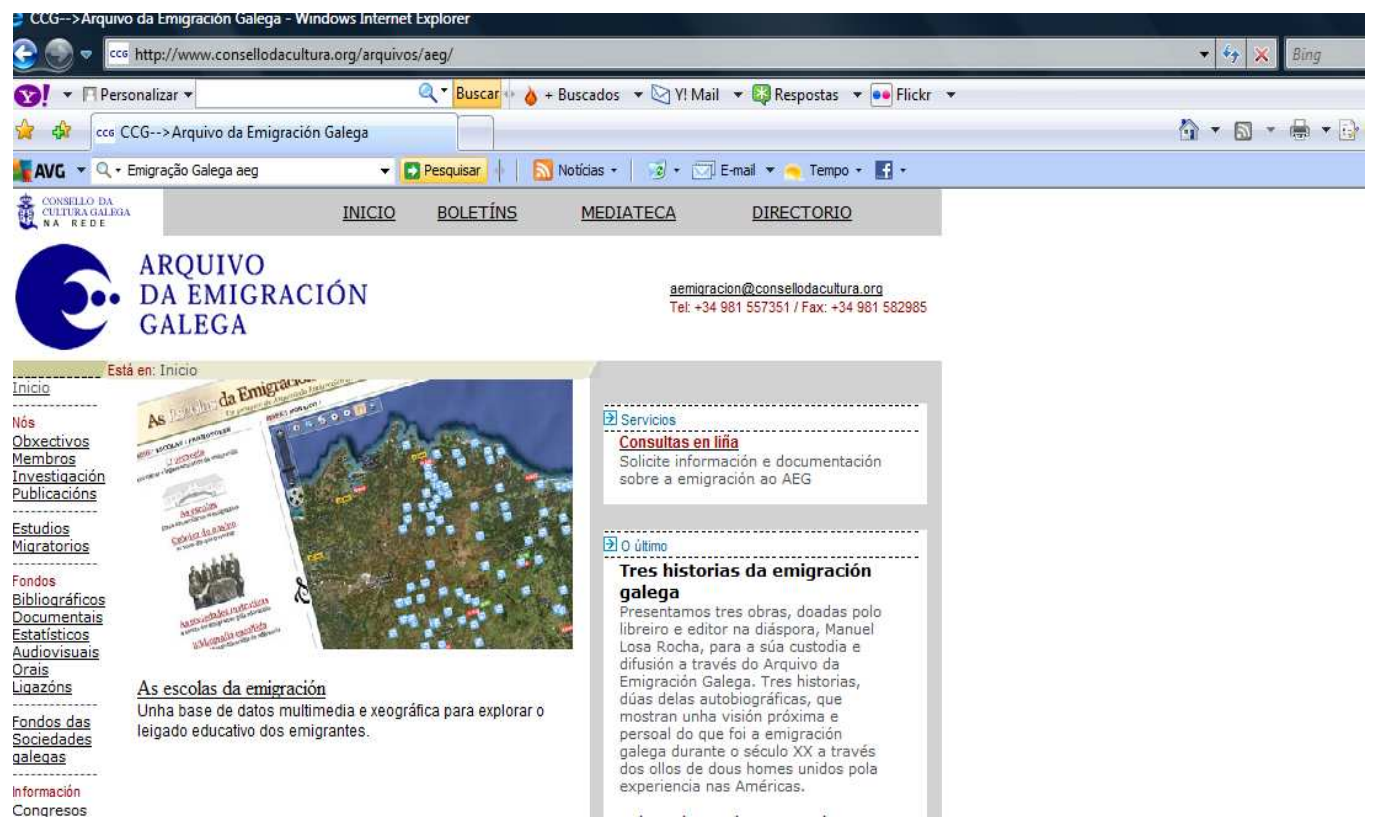

Figura 18 - Homepage do Arquivo da Emigración Galega

$\mathrm{Na}$ homepage desse Arquivo encontramos as seguintes opções de navegação: Nós - Informações sobre o Arquivo subdivididas em Objetivos, Membros, Investigação, Publicações e Estudos Migratórios; Fundos Informações sobre os fundos do Arquivo que estão subdivididos em Bibliográficos, Documentais, Estatísticos, Audiovisuais e Orais, com link para Fundos das Sociedades Galegas e Links de interesse; Informação - onde se apresentam informações gerais e também os eventos do Arquivo; Contato - Subdividido em Consultas, Sugestões e Endereço.

\subsubsection{Archivo Histórico de Protocolos de Gipuzkoa (AHPG)}

Gipuzkoa (Guipúzcoa em espanhol) é uma província da comunidade autônoma do País Basco, na Espanha, cuja capital é São Sebastião. É limitada com o Departamento francês dos Pirineus Atlânticos pelo nordeste, Navarra ao leste, Vizcaya ao oeste, Álava ao sudoeste e o Golfo de Bizcaia ao norte.

O Arquivo histórico de Protocolos de Gipuzcoa foi criado por um despacho do Ministério da Educação Nacional de 10 de julho de 1942 e está sediado na antiga Universidade de Oñati. Guarda os protocolos notariais de mais de cem 
anos de antiguidade e os fundos documentais relativos às Contadurias de Hipotecas (1768-1862). O Arquivo Histórico de Protocolos de Gipuzkoa, desde a sua criação, é gerido pelo Conselho Provincial de Gipuzkoa. Juntamente com o Arquivo Geral de Gipuzkoa integra a área de Arquivos da Direção-Geral da Cultura, dentro do Serviço de Patrimônio Histórico e Artístico, Arquivos e Museus.

No que se refere aos fundos documentais e instrumentos descritivos, 0 Arquivo é constituído pelos fundos de protocolos notariais e de Livros de Contas Hipotecárias. Ambos os fundos têm ferramentas descritivas mecanizadas.

Esta coleção é composta por protocolos notariais de mais de cem anos de antiguidade dos distritos de Azpeitia, Bergara e Donostia- San Sebastian. Os protocolos do distrito de Toulouse estão no Arquivo Geral de Gipuzkoa. A maioria dos protocolos notariais preservados neste arquivo tem seu início no século XVI, porém se conservam escrituras mais antigas que remontam ao ano de 1445. $O$ fundo notarial conceitualmente é um fundo aberto a novos membros através de transferências adequadas. Encontram-se nestes fundos de Arquivo disponíveis ao público os protocolos notariais de Azpeitia até 1905, os do partido notarial de Bergara, até 1905, e, igualmente, os do partido notarial de San Sebastian até 1905.

O Fundo Livros de Créditos Hipotecários é composto de registros onde estão os instrumentos notariais relativos a censos, feitos da justiça e hipotecas, e posteriormente transmissões e impostos sobre bens imóveis, pode-se dizer que se trata do precursor do que hoje é o Registro Predial. O registro de hipotecas foi criado em 1768 por Carlos III, sendo abolido em 1862. Durante esse período, sofreu várias modificações, mas o marco mais importante veio através do decreto de Junho de 1845, já que alterava, entre outras coisas, a estrutura do livro e a extensão do mesmo. Embora tenha sido lançada em 1768, você pode encontrar registros de atos anteriores a esta data, tendo em conta a exigência de registro de todos os documentos mesmo que fossem de data mais antiga.

Grande parte do interesse deste fundo para os usuários de Arquivo se baseia no fato de que cada localidade deveria registrar as escrituras que tinham como objeto um imóvel (casas, Quintas ou terrenos) localizados na mesma, embora a escritura tivesse sido assinada em outro lugar. 
Conforme o site desse Arquivo ${ }^{142}$, este fundo é composto por 713 lotes, envolvendo um total de 24 metros lineares. Eles são classificados em quatro secções que correspondem aos quatro partidos notariais e dentro destes, por sua vez, estão agrupadas em livros de registro e livros índice, que são classificadas por local, data e tipo de registro ou de propriedades inscritas.

Os Instrumentos descritivos correspondem a duas obras de PEREZ e GOMEZ, sendo uma delas intitulada: As Contadorias de Hipotecas em Guipúzcoa $^{143}$ e a outra se trata de um inventário dos fundos desse arquivo ${ }^{144}$ Além dessas duas obras existe um inventário elaborado com base no que foi publicado no 3ํㅡㄴ número da Revista Bilduma, que se pode consultar tanto em suporte de papel como na base de dados, porém apenas na sala de leitura do próprio arquivo, onde além dos dados que constavam no inventario original, foram acrescentados os seguintes aspectos: se estão microfilmados e sua localização.

A Coleção factícia é composta por pergaminhos musicais. É constituída por todos os pergaminhos com textos musicais que constituem as capas de certos protocolos. O Inventário foi feito em colaboração com ERESBIL ${ }^{145}$. Foram identificadas 219 capas com inscrições musicais neste inventário.

Para consultar qualquer documento desses fundos é necessário que o usuário se desloque até o local e torne-se usuário apresentando um documento de identidade e fazendo um cartão de usuário. As informações digitalizadas somente podem ser consultadas pelos usuários na Sala de Leitura do Arquivo.

O Arquivo oferece também os seguintes serviços: consultas sobre informações gerais e cópias de documentação que podem ser realizadas por usuários que vêm para o centro, por telefone, carta ou Internet (através de email); biblioteca auxiliar, com acesso restrito aos usuários do arquivo, é composta de volumes de monografias e de publicações periódicas. O fundo se concentra principalmente em obras da história local, arquivística, fontes documentais, paleografia, ferramentas descritivas de arquivos. Seu catálogo está informatizado

\footnotetext{
${ }^{142}$ Disponível em: http://www.oinati.gipuzkoakultura.net/oinati/. Acesso em: 27 novembro 2010.

${ }^{143}$ PEREZ, C.M. Aparicio; GÓMEZ, I. González: Las Contadurías de Hipotecas en Guipúzcoa. In: Décimo Congreso de Estudios Vascos. Archivos, Bibliotecas y museos. Artxiboak, Liburutegiak, Museoak (Pamplona,1987). San Sebastian: Eusko Ikaskuntza,1988.

${ }^{144}$ Idem. Inventario de los fondos pertenecientes a las Contadurías de Hipotecas en Guipúzcoa. In: Bilduma, no 3, pp. 99-119

${ }^{145}$ ERESBIL é uma instituição documental a serviço da música basca. Pode ser consultada através do site: http://www.eresbil.com/
} 
e acessível através de computadores localizados na Sala de Leitura; Serviço de Reprografia: se pode obter fotocópias da documentação sempre e quando seu estado de conservação o permita e quando as próprias características do documento não corra risco de deteriorização ao ser manipulado (Por exemplo: se forem muito espessos ou não estejam encadernados ou já estejam deteriorados).

O Arquivo pode ser consultado através da Internet através da seguinte URL: http://oinati.gipuzkoakultura.net/oinati/

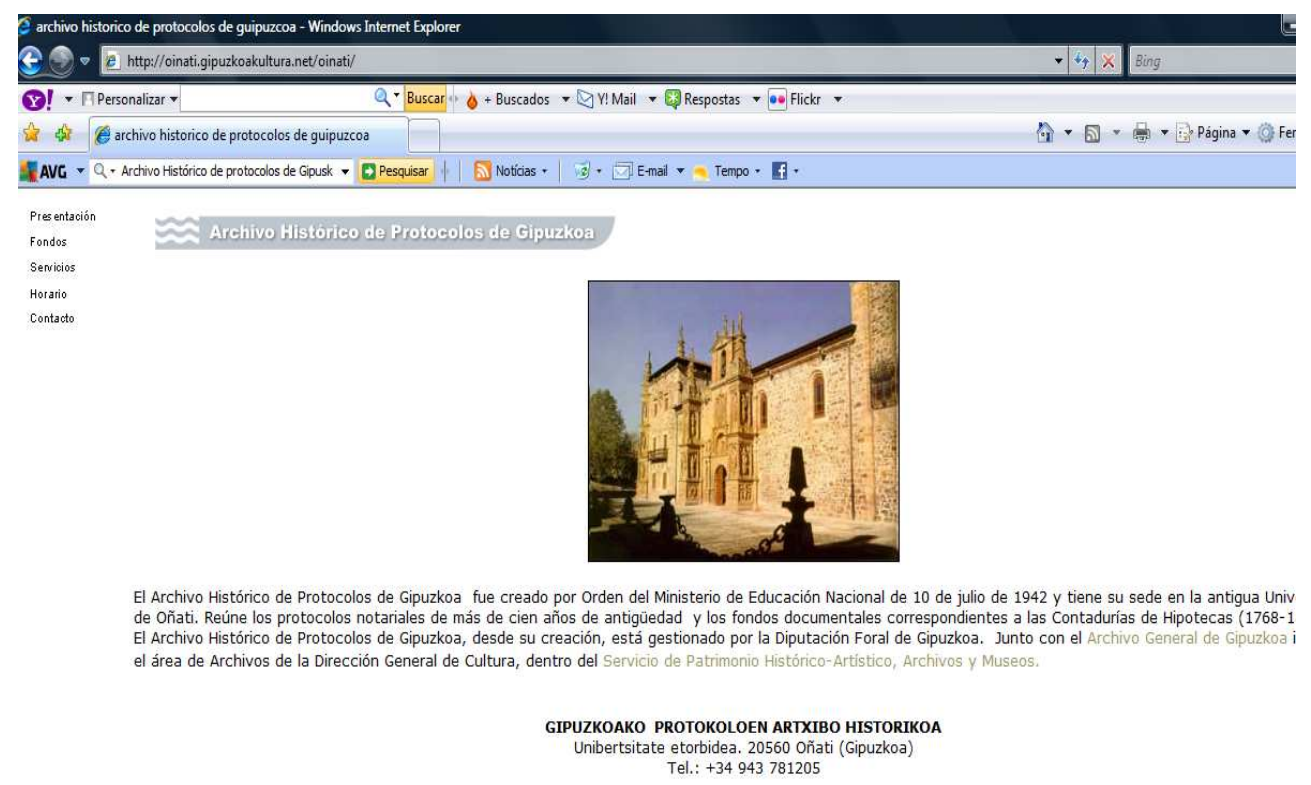

Figura 19 - Homepage do Archivo Histórico de Protocolos de Gipuzcoa

$\mathrm{Na}$ Homepage do Arquivo encontram-se as seguintes opções de navegação: Apresentação - Informações gerais sobre o Arquivo; Fundos Informações sobre os fundos documentais e instrumentos descritivos; Serviços informações gerais sobre o acesso, consultas e outros serviços oferecidos pelo Arquivo; Horário - Informações sobre o horário de funcionamento; Contato neste link aparece um formulário de email para obter informações adicionais sobre o Arquivo e seus serviços, o telefone e o fax para contato. 


\subsubsection{Archivo de Hullera Vasco-Leonesa (AHVL)}

A Fundação Hullera Vasco-Leonesa é uma instituição cultural privada, sem fins lucrativos, que desenvolve suas atividades no âmbito da Comunidade Autônoma de Castela e Leão.

No dia 15 de abril de 1988, o Conselho de Administração de Hullera VascoLeonesa aprova os projetos de Biblioteca e Arquivo da Sociedade, como resultado da necessidade crescente de melhorar os sistemas informativos e o tratamento dos documentos. O Serviço de Arquivo nasce vinculado à Direção Administrativa com dois objetivos: ajudar na gestão diária dos serviços administrativos e de coletar, organizar e divulgar o patrimônio documental preservado como uma história centenária.

Desde 1995, a custódia, conservação, organização e gestão do Arquivo é da responsabilidade da Fundação Hullera Vasco-Leonesa, mediante convênio suscrito con Hullera Vasco-Leonesa, S.A. Os distintos fundos documentais procedem de distintas empresas que estiveram relacionadas com Hullera VascoLeonesa ao longo de sua história. As datas dos documentos abarcam desde meados do século XIX até a atualidade.

O Arquivo de Hullera Vasco-Leonesa realiza um esforço permanente para oferecer um serviço eficiente e eficaz na organização e difusão dos documentos e o acesso a à informação que contém, assim como para dar a conhecer a importância dos Arquivos de Empresas como centros de gestão documental e como centros de conservação do patrimônio empresarial.

Segue a lista dos fundos do Arquivo: Sociedade Anônima Hullera VascoLeonesa (1889-); Indústrias do Fenar S.A. (IFSA) (1962-); Centro de investigação e Desenvolvimento S.A. (CIDSA) (1963-); Minas de Barruelo S.A. (1844-1995); Minero Dominicana El Yujo C. Por A. (1984-1995); Sociedade Regular Coletiva Valle y Díez (1935-1943); Agrupación de Productores de Carbón y otros Combustibles S.A. (APROCAR)(1976-1988); Cerâmica del Duero S.A. (19691986); Compañía de Inversiones Inmobiliarias S.A. (CINVASA) (1973-1980); Compañía de Inversiones Inmobiliarias S.A. (CINVASA) (1973-1980); Financiera Benamariel S.A. (1970-1983); Uranios de Trastamara S.A. (1963-1986); 
Cementos La Robla S.A. (1957-1968); Promotora de Minas de Carbón S.A. (PMC) (1976-1994); Magnesitas de Rubián S.A. (1986-1991); Vidriera Leonesa S.A. (VILESA) (1958-1995); Carboastur S.A. (1986-1990); Banco Industrial de León (BANILE) (1963-1977);Anglo-Hispana de Minas (1911-1928); Hulleras de Sabero y Anexas S.A. (1892-).

Os serviços oferecidos pelo Arquivo são os seguintes: Recepção da documentação procedente da gestão administrativa nos distintos departamentos de Sociedade Anônima Hullera Vasco-Leonesa; Asesoramento aos departamentos sobre as técnicas de organização e transferência dos documentos ao Arquivo; seleção e organização dos documentos de acordo com o Quadro de Classificação; serviço rápido e eficaz de empréstimo e de informação aos departamentos; conservação e custódia do patrimônio histórico documental; abertura aos cidadãos e serviços personalizados aos investigadores, com as limitações estabelecidas; difusão do conteúdo do Arquivo através de publicações, exposições, cursos, conferências, entre outros meios.

A homepage do Arquivo pode ser acessada através do endereço eletrônico: http://www.fhvl.es/fhvl/content.asp?Contentld=610

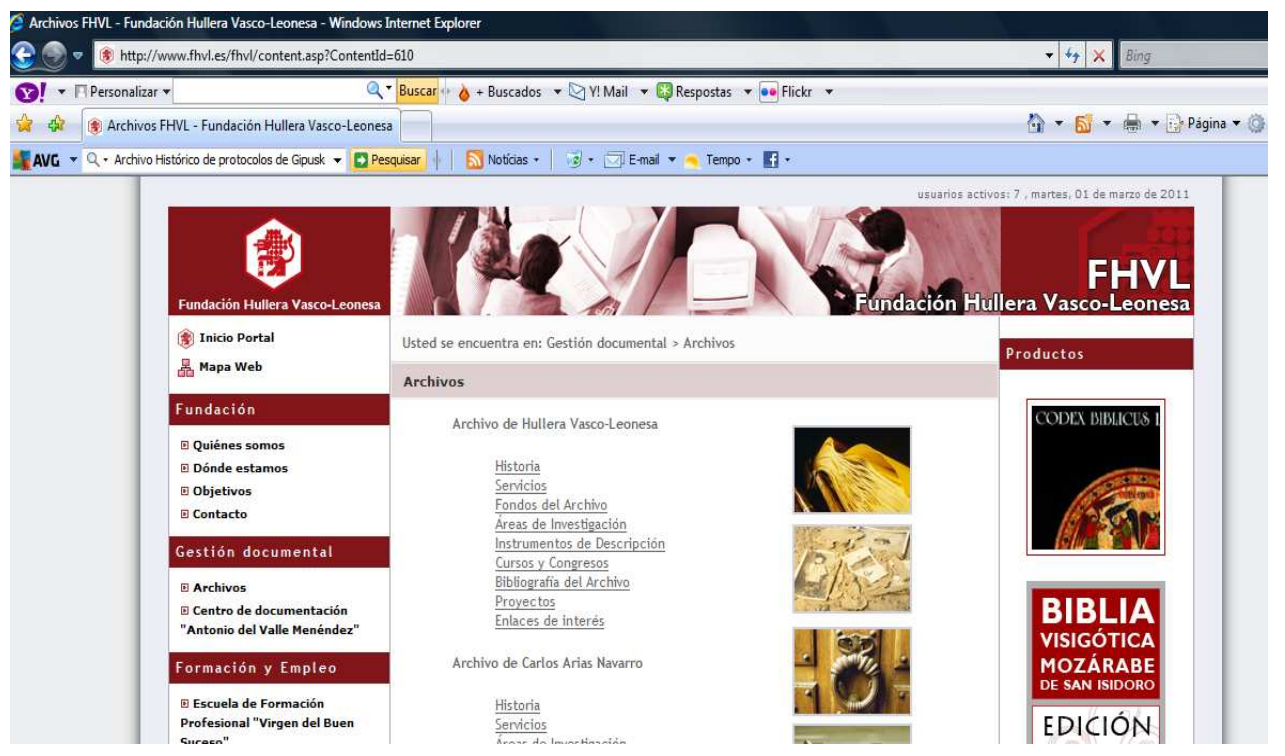

Figura 20 - Homepage do Archivo de Hullera Vasco-Leonesa 
Como se pode observar na Figura 20, a Homepage do Arquivo oferece as seguintes opções de navegação: História - pequena história do Arquivo; Serviços: informações a respeito dos serviços oferecidos pelo Arquivo; Fundos do Arquivo - Listagem dos fundos do Arquivo; Áreas de pesquisa - Informações sobre as áreas de investigação do Arquivo; Instrumentos de Descrição apresenta em formato PDF o Quadro de Classificação, o Catálogo digital da série "Registros de pessoal" do fundo Sociedade Anônima Hullera Vasco-Leonesa, Catálogo digital da série "Expedientes de concessões mineiras" dos fundos Minas de Barruelo S.A., Sociedade Anônima Hullera Vasco-Leonesa e Hulleras de Sabero e Anexas, Arquivo de Sociedade Anônima Hullera Vasco-Leonesa: "Tríptico-Guía del investigador" León, 1997, Guia do Arquivo de Sociedade Anônima Hullera Vasco-Leonesa. León, 2001, Descrição do Archivo International Standard for Describing Institutions with Archival Holdings (ISDIAH); Cursos e Congressos: Informações sobre Cursos, Congressos, Jornadas e Conferências, do ano de 1996 a 2010; Bibliografia do Arquivo - apresenta calendário organizado por ano, a partir de 1996 de bibliografias a respeito do Arquivo; Informações sobre os projetos do Arquivo - encontram-se informações gerais sobre os projetos: nome do projeto, financiamento, data de início e de final e objetivos; Links de interesse - links de interesse dos usuários do Arquivo, como por exemplo do Projeto PARES do Ministério de Cultura da Espanha.

\subsubsection{Archivo Histórico Provincial de Granada (AHPGR)}

Desde 1969, o Arquivo da Real Chancelaria vinha exercendo as funções de Arquivo Histórico Provincial, motivo pelo qual se iniciou o processo de coleta e inclusão dos fundos documentais gerados pelas vários escritórios provinciais e outros órgãos dependentes do Estado na Província. No ano de 1991, o Arquivo Provincial começou a funcionar como Unidade independente do Archivo de la Real Chancillería de Granada, gerido pelo Ministério da Cultura do Governo de Andaluzia, em virtude do Real Decreto 864/1984, de 29 de fevereiro. Começou assim o processo de constituição, até o ano de 1994 quando foi incorporado foi 
incorporado ao Sistema de Arquivos do Estado, formando parte da rede de Arquivos Históricos Provinciais.

$\mathrm{Na}$ atualidade é regido pelo acordo de colaboração entre o Ministério de Cultura e a Junta de Andaluzia, de 21 de maio de 1994. Nesse mesmo ano os Arquivos Históricos Provinciais foram integrados plenamente ao Sistema Andaluz de Arquivos. O Archivo Histórico Provincial de Granada acolhe entre seus fundos informação sobre os povoadores mouros e os processos da Inquisição. Seus muitos kilômetros de estantes acolhem uma série de exclusivas jóias documentais procedentes em sua maioria dos fundos do Tesouro que se cederam ao Archivo Histórico de Granada e seu Reino por volta de 1922.

Um dos grupos documentais mais valiosos deste centro é o formado pelos "Libros de población del antiguo Reino de Granada", do século XVI. Com a expulsão dos mouros, muitas terras ficaram despovoadas e Felipe II firmou uma ordem chamada "suertes de terra" aos cristãos velhos, tanto do reino de Granada como do resto das províncias espanholas, que quisessem repovoar aquelas terras. Aos novos proprietários se exigia que explorassem as terras e que não a vendessem ao menos durante 0 período de dois anos. Para controlar esta mudança de proprietários bem como para fosse cumpridas as exigências para a posse, foram anotados os detalhes das transações através dos livros de povoação. Nestes documentos, fechados desde o ano de 1572, aparecem o nome do mouro a quem pertenciam as terras e do novo povoador.

As perseguições aos mouros e judeus, inclusive no século XVIII, se pode investigar neste Arquivo através do 'Fisco da Inquisição', um bloco documental de grande importância, já que são os únicos testemunhos escritos existentes das ações do Santo Ofício no Reino de Granada.

Outro importante bloco documental está formado pelo 'Cadastro do Marqués de la Ensenada no Antigo Reino de Granada'. Em meados do século XVIII, ordenou-se a elaboração de um cadastro dos bens imóveis dos cidadãos para a consequente imposição fiscal dos bens rurais e urbanos. Junto aos dados econômicos, os manuscritos mostram toda uma cartografia das povoações espanholas, uma vez que os funcionários que registravam os bens faziam desenhos de toda a cidade, incluindo até mesmo as pontes e os principais 
monumentos. O Relatório do Marqués da Ensenada é, portanto, uma importante prova da evolução urbana das cidades.

Aberta à sociedade em geral, como um serviço público, oferece informação primária, necessária para a investigação, o estudo, a cultura e a própria atividade da administração.

A Homepage do Arquivo pode ser acessada através do seguinte endereço eletrônico:

http://www.juntadeandalucia.es/cultura/archivos/Web_es/contenido?id=0754eda058a4-11dd-b44b-31450f5b9dd5\&idArchivo=0754eda0-58a4-11dd-b44b31450f5b9dd5\&idContArch=02cd09d5-57e2-11dd-ba1f31450f5b9dd5\&idTipo=02cd09d5-57e2-11dd-ba1f-31450f5b9dd5

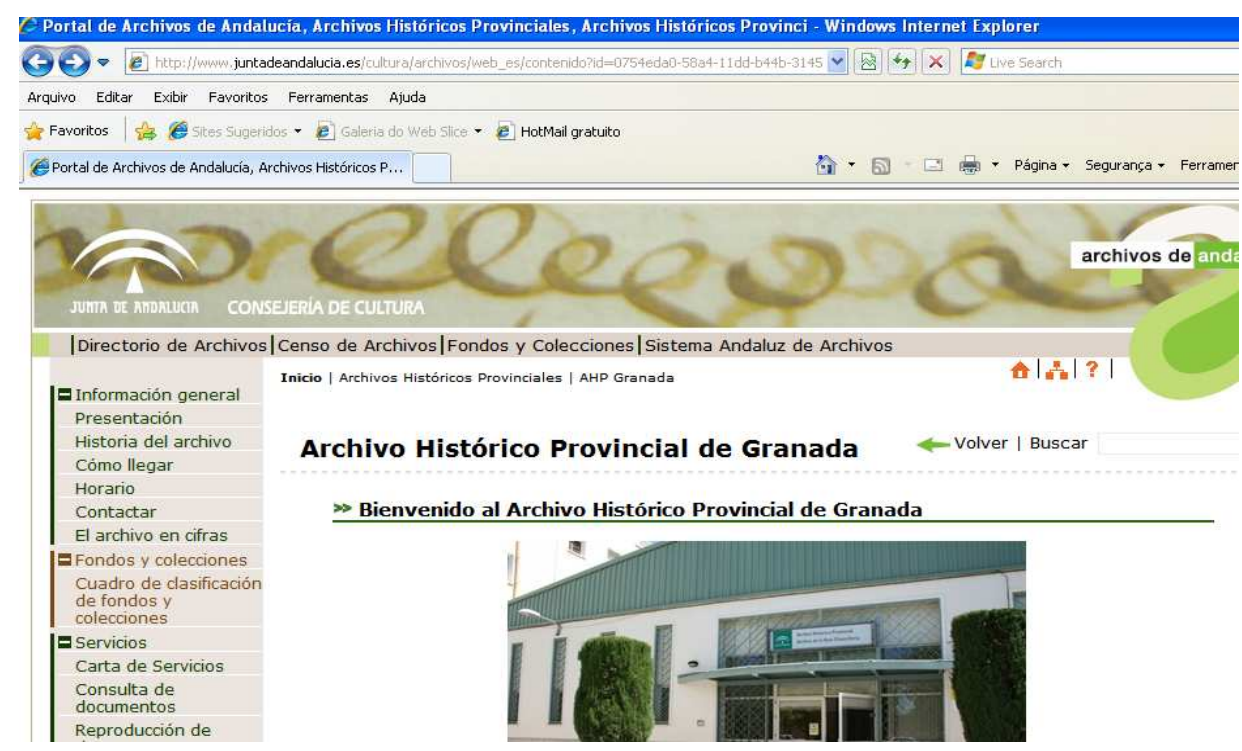

Figura 21 - Homepage do Archivo Histórico Provincial de Granada

Sua Homepage oferece ao usuário uma apresentação on-line com informações gerais sobre o Arquivo, acesso à base de dados de seus fundos e acesso à informações através do facebook.

Desde setembro do ano de 2010, o usuário conta com as bases de dados disponíveis on-line, podendo acessar o Quadro de Classificação e consultar a descrição dos fundos "Os Livros do Reino da Cidade Velha de Granada" e da "Real Sociedade Econômica de amigos do País de Granada". 


\title{
Capítulo 6
}

\section{ANÁLISE E INTERPRETAÇÃO DOS DADOS}

\author{
Neste capítulo, discutem-se primeiramente os \\ resultados dos dados coletados por ocasião da \\ formação do corpus da avaliação preliminar e, em outra \\ seção, os resultados da avaliação propriamente dita dos \\ sites dos Arquivos espanhóis aqui estudados.
}




\title{
6.1 APRESENTAÇÃO DOS RESULTADOS DO TESTE DE USUÁRIOS NA UFPE - AVALIAÇÃO PRELIMINAR
}

\begin{abstract}
Os resultados provêm do aproveitamento das oportunidades e não da solução dos problemas. A solução de problemas só restaura a normalidade. As oportunidades significam explorar novos caminhos.
\end{abstract}

Peter Drucker

O teste de usuários da Avaliação preliminar contou com a participação de vinte estudantes do curso de Biblioteconomia da Universidade Federal de Pernambuco e foi realizado no Laboratório de Informática da UFPE, no dia 17 do mês de setembro de 2009, com duas horas de duração. Os participantes do teste já haviam sido contactados anteriormente e concordado em colaborar. $\mathrm{Na}$ ocasião, todos tiveram uma explicação sobre procedimento do teste, bem como tomado ciência do seu motivo e objetivo. Antes do início das tarefas foram explicadas as questões e a forma de acesso às páginas a serem avaliadas.

Inicialmente o teste constava de questões que visavam traçar o perfil dos participantes. Em seguida, apresentava questões a respeito da qualidade das páginas Web de cada Arquivo, mediante realização de duas tarefas para cada critério de avaliação, a exceção do critério "Autoridade", que apresentava apenas uma questão. Cada um dos usuários potenciais deveria escolher dois Arquivos estatais espanhóis dentro do site do MCU e responder um questionário para cada um dos Arquivos por eles escolhidos. Para fins metodológicos utilizou-se análise de frequência dos dados a partir de diferentes variáveis: Sexo, Faixa etária, Escolaridade, Experiência em buscas pela Internet, Motores de busca mais utilizados pelos usuários, Posição dos sites nos resultados das buscas através de buscadores da Internet, Identificação do ícone de busca na homepage do site, Sites com conteúdo semelhante aos do MCU, Linguagem do site, Área de acesso restrito nos sites avaliados, Visualização das atualizações e novidades dos sites avaliados, Navegação nas páginas Web avaliadas, Navegação nas páginas Web avaliadas, Erro ou confusão visual nos sites avaliados. 
Durante todo o teste, o mediador (a autora) esteve esclarecendo dúvidas e auxiliando os participantes quando solicitavam. Alguns usuários hesitavam quando desconheciam alguma palavra em espanhol, contudo o teste correu tranquilamente e os usuários verbalizaram que o consideraram fácil.

A partir da leitura dos dados recolhidos mediante a aplicação das tarefas, foi possível validar as informações, analisando os dados de forma quantiqualitativa.

Os dados quantitativos foram analisados com recursos estatísticos do Programa SPSS e dispostos em tabelas. A análise qualitativa permitiu uma compreensão de como o usuário interage com o sistema, obtendo-se uma visão geral do objeto de estudo proposto: as páginas Web dos Arquivos Estatais espanhóis dentro do site do MCU.

A seguir demonstramos através de tabelas a Avaliação dos Resultados:

Observa-se, no primeiro momento, que a participação no teste de usuários teve número equilibrado de homens e mulheres dispostos a colaborar com a avaliação.

Tabela 2. Distribuição dos participantes por sexo

\begin{tabular}{c|c|c} 
Sexo & N & $\%$ \\
\hline Feminino & 11 & 55,00 \\
\hline Masculino & 09 & 45,00 \\
\hline Total & $\mathbf{2 0}$ & $\mathbf{1 0 0 , 0 0}$ \\
\hline
\end{tabular}

Fonte: Pesquisa direta/2009

Como se observa na Tabela 2, os entrevistados do sexo feminino compreendiam $55 \%$ dos entrevistados e os do sexo masculino $45 \%$. Esse fato reduz a probabilidade de um eventual viés nos resultados.

Em relação à idade, a maioria dos participantes tinha menos de trinta anos, como se pode observar na Tabela 4 a seguir. 
Tabela 3. Faixa etária dos participantes do teste

\begin{tabular}{l|l|l}
\hline Faixa etária & $\mathbf{N}$ & $\%$ \\
\hline 20 a 25 anos & 12 & 60,00 \\
\hline $\mathbf{2 6}$ a $\mathbf{3 0}$ anos & $\mathbf{6}$ & $\mathbf{3 0 , 0 0}$ \\
\hline Mais de 30 anos & 2 & 10,00 \\
\hline Total & $\mathbf{2 0}$ & $\mathbf{1 0 0 , 0 0}$ \\
\hline
\end{tabular}

Fonte: Pesquisa direta/2009

De forma mais específica, 12 usuários (60\%) estavam na faixa etária mais jovem, compreendida entre os 20 e 25 anos. Em contrapartida apenas dois usuários (10\%) tinham mais de trinta anos.

Em relação à formação acadêmica dos participantes, somente dois tinham graduação completa anterior em outra área: um em Geografia e outro em Belas Artes. Apresenta-se seguir o resumo dessas informações.

Tabela 4 - Nível de formação dos usuários

\begin{tabular}{c|c|c} 
Escolaridade & N & $\%$ \\
\hline Superior incompleto & 18 & 90,00 \\
\hline Superior completo & 02 & 10,00 \\
\hline Total & $\mathbf{2 0}$ & $\mathbf{1 0 0 , 0 0}$ \\
\hline
\end{tabular}

Fonte: Pesquisa direta/2009

Como demostrado na Tabela 4, a maioria dos entrevistados (90\%) possuía nível superior incompleto. Todos eram alunos do Curso de Biblioteconomia da Universidade Federal de Pernambuco.

Em relação à experiência de buscas na Internet, apenas um participante admitiu não ter experiência, como se observa a seguir. 
Tabela 5 - Experiência em buscas pela Internet

\begin{tabular}{c|c|c} 
Experiência & \multicolumn{1}{c}{$\mathbf{N}$} & $\%$ \\
\hline Sim & 19 & 95,00 \\
\hline Não & 01 & 5,00 \\
\hline Total & $\mathbf{2 0}$ & $\mathbf{1 0 0 , 0 0}$ \\
\hline
\end{tabular}

Fonte: Pesquisa direta/2009

Como se pode conferir na Tabela 5 acima, a grande maioria dos entrevistados (95\%) tem familiaridade com pesquisas através da Internet.

Os computadores utilizados no teste foram similares, uma vez que as tarefas foram realizadas no laboratório de informática da Biblioteca Central da Universidade Federal de Pernambuco, e os computadores disponibilizados para esse fim possuíam as mesmas características técnicas e o mesmo provedor de Internet, conforme especificações a seguir: Windows XP, AMD Athlon Processor, $1 \mathrm{~GB}$ de memória, rede compartilhada (extensão de endereço físico) - banda larga.

Essas características são consideradas razoáveis para uma boa navegação em sites que não necessitem descarregar grandes arquivos, como é o caso dos sites de Arquivos. ${ }^{146}$

Quanto às tarefas referentes ao critério "Busca e Recuperação", seguem algumas considerações.

Na primeira tarefa, "Motores de busca", os usuários deveriam entrar na página Web do Ministério de Cultura da Espanha e realizar esta tarefa (até 3 Arquivos escolhidos por eles mesmos), uma vez que as páginas Web dos Arquivos estatais espanhóis se encontram subsidiados pela página Web do MCU. A atividade consistia em escolher dois buscadores e realizar pesquisa através deles, apontando a posição em que o Arquivo se encontrava nos resultados. Para responder a essa questão, basearam-se nos buscadores que normalmente utilizam em suas pesquisas.

${ }^{146}$ Verificar explicação semântica da palavra Arquivo (Cf. Capítulo 1). 
Tabela 6. Motores de busca mais utilizados pelos usuários

\begin{tabular}{c|c|c} 
Motor de busca & \multicolumn{1}{c}{ N } & \multicolumn{1}{c}{$\%$} \\
\hline Google & 17 & 85,00 \\
\hline Yahoo & 11 & 55,00 \\
\hline Cadê & 07 & 35,00 \\
\hline Altavista & 04 & 20,00 \\
\hline Bing & 01 & 5,00 \\
\hline Total & $\mathbf{2 0}$ & $\mathbf{1 0 0 , 0 0}$ \\
\hline
\end{tabular}

Fonte: Pesquisa direta/2009*147

Como demonstra a Tabela 6 , os usuários escolheram, em sua maioria, o Google (85\%) e em segundo lugar o Yahoo (55\%) para realizarem suas pesquisas. Percebe-se que o motor de busca Bing aparece, porém foi citado apenas uma vez, o que sugere sua baixa utilização.

Em relação à posição em que os Arquivos aparecem nas buscas através dos motores de busca citados anteriormente, em primeiro lugar, devemos esclarecer que os vinte usuários que participaram do teste estavam divididos em dois grupos, sendo que, no primeiro grupo, cada participante trabalharia dois ou três dos seis primeiros Arquivos estatais subsidiados pelo site do MCU, escolhidos aleatoriamente por eles próprios e, no segundo grupo, cada participante trabalharia dois ou três dos seis Arquivos restantes também escolhidos aleatoriamente por eles próprios. Assim que alguns Arquivos foram analisados mais vezes que outros, entretanto, nos centramos nas três primeiras posições obtidas nos resultados das buscas realizadas através dos três motores de busca mais utilizados e que foram coincidentes para cada um desses Arquivos:

\footnotetext{
${ }^{147}$ os usuários poderiam escolher mais de um motor de busca.
} 
Tabela 7 - Posição dos sites nos buscadores da Internet

\begin{tabular}{c|c|c|c}
\hline Arquivos & \multicolumn{3}{|c}{ Posição nos buscadores } \\
\hline Archivo de la Corona de Aragón & Google & Yahoo & Altavista \\
\hline Archivo General de Simancas & $1^{\underline{a}}$ & $1^{\underline{a}}$ & \\
\hline Archivo General de Indias & $1^{\underline{a}}$ & $3^{\underline{a}}$ & \\
\hline Archivo Histórico Nacional & $1^{\underline{a}}$ & & \\
\hline Archivo General de la Administración & $1^{\underline{a}}$ & $4^{\underline{a}}$ & \\
\hline Archivo de la Real Chancillería de Valladolid & $1^{\underline{a}}$ & & \\
\hline Centro Documental de la Memoria Histórica & & & \\
\hline Sección Nobleza del Archivo Histórico Nacional & & & $1^{\underline{a}}$ \\
\hline Archivo Histórico Provincial de Alava & & & \\
\hline Archivo Histórico Provincial de Vizcaya & $1^{\underline{a}}$ & & \\
\hline Archivo Histórico Provincial de Guipúzcoa & $1^{\underline{a}}$ & & \\
\hline Archivo Central del Ministerio de Cultura & $1^{\underline{a}}$ & & \\
\hline
\end{tabular}

Fonte: Pesquisa direta/2009

No que se refere à posição em que o site do Arquivo ocupa nos resultados através dos motores de busca, nota-se que, em alguns casos, houve três coincidências nas respostas através da busca pelo nome do Arquivo em um ou mais buscadores. Considerando que a maioria dos entrevistados se concentrou no buscador Google, observa-se neste motor de busca, que os sites dos Arquivos avaliados geralmente apareceram na $1^{\underline{a}}$ posição nos resultados, havendo bastante variação nos resultados encontrados através dos motores de busca Yahoo e Altavista.

Na segunda tarefa, "Visualização dos resultados", a atividade consistia em identificar, na homepage de cada página Web de Arquivo, uma opção como um ícone ou "lupa" para realizar uma busca. Todos os usuários responderam que não a encontraram afetando diretamente à tarefa 2 do mesmo seguimento que consistia em realizar uma busca simples e outra avançada que por essa razão não foi realizada. As respostas estão demonstradas na Tabela a seguir: 
Tabela 8 - Identificação do ícone de busca na homepage do site

\begin{tabular}{l|c|c}
\hline \multicolumn{1}{c|}{ Respostas } & N & $\%$ \\
\hline Não Encontrado & 16 & 80,00 \\
\hline Encontrado apenas na homepage do & 3 & 15,00 \\
\hline Sem resposta & 1 & 5,00 \\
\hline Total & $\mathbf{2 0}$ & $\mathbf{1 0 0 , 0 0}$ \\
\hline
\end{tabular}

Fonte: Pesquisa direta/2009

Verifica-se na Tabela 8 que 16 usuários (80\%) afirmaram não encontrar o ícone de busca nos sites avaliados. Três usuários ou seja $15 \%$ dos entrevistados encontraram a ferramenta de busca na homepage do MCU e não nas páginas Web dos Arquivos. Apenas um usuário não respondeu à questão, isso pode significar que o mesmo não encontrou a ferramenta. Em virtude desses resultados a tarefa seguinte, que consistia em realizar uma pesquisa através desse buscador, não foi realizada.

No Critério "Autoridade", o usuário potencial deveria observar se a página principal de cada Arquivo avaliado continha informações a respeito da Instituição que abriga ou cria o site, no caso desse estudo, informações a respeito do site do MCU.

Tabela 9 - Informações sobre o MCU nos sites avaliados

\begin{tabular}{c|c|c}
\hline RESPOSTA & N & $\%$ \\
\hline Sim (Sem dificuldade) & 14 & 70,00 \\
\hline Sim (com dificuldade) & 6 & 30,00 \\
\hline Total & $\mathbf{2 0}$ & $\mathbf{1 0 0 , 0 0}$ \\
\hline
\end{tabular}

Fonte: Pesquisa direta/2009

Entre os participantes, 30\% afirmaram ter dificuldade em chegar às informações a respeito do $\mathrm{MCU}$, porém $70 \%$ não tiveram nenhuma dificuldade em acessar as informações. Isso significa que as informações a respeito do MCU estão nos sites, porém exigem um pouco mais de atenção dos usuários para que sejam localizadas. 
O Critério "Conteúdo" apresentava duas tarefas. A primeira tarefa a respeito da originalidade consistia em buscar na Internet, através dos motores de busca com os quais estavam acostumados a fazer suas pesquisas, os sites dos Arquivos objeto desse estudo.

O objetivo dessa tarefa era verificar se existiam outras URls dos sites dos Arquivos objeto desse estudo, ou seja, se os usuários encontravam sites com conteúdo semelhante ao das páginas Web dos Arquivos avaliados com endereço Web não vinculado ao MCU. A seguir apresentamos os resultados:

Tabela 10 - Sites com conteúdo semelhante ${ }^{148}$ *

\begin{tabular}{l|c|c}
\hline \multicolumn{1}{c|}{ RESPOSTAS } & N & $\%$ \\
\hline Nenhuma página é tão completa como a Url vinculada ao MCU & 2 & 10,00 \\
\hline Não encontrei & 7 & 35,00 \\
\hline Não encontrei no Google e no Yahoo & 3 & 15,00 \\
\hline Possui outros sites & 2 & 10,00 \\
\hline Sim & 4 & 20,00 \\
\hline Sim: www.pares.mcu.es & 1 & 5,00 \\
\hline Sim: www.bne.es & 2 & 10,00 \\
\hline Sim: www.paisvasco.notariado.org & 1 & 5,00 \\
\hline Total & $\mathbf{2 0}$ & $\mathbf{1 0 0 , 0 0}$ \\
\hline
\end{tabular}

Fonte: Pesquisa direta/2009

Metade dos participantes (50\%) não encontraram site com conteúdo similar ao dos Arquivos subsidiados pelo MCU, enquanto $30 \%$ deles, apesar de afirmarem existir sites com conteúdo similar, não apontaram no teste suas respectivas URLs. Apenas 20\% apresentaram endereços Web dos sites que consideraram semelhantes aos subsidiados pelo MCU.

Ao analisar os sites sugeridos pelos participantes, percebe-se que o do PARES realmente apresenta conteúdo similar ao encontrado no site MCU, a respeito dos Arquivos Estatais espanhóis. Há que se considerar, porém, que

${ }^{148}$ Questão com possibilidade de mais de uma resposta - múltipla 
PARES é um projeto do Ministério da cultura da Espanha, ou seja, também está diretamente relacionado ao MCU.

O segundo site sugerido nos remete à página da Biblioteca Nacional da Espanha que apresenta em sua homepage um link para o site do MCU, significando que se tratam das mesmas informações. Aqui se faz um parênteses pois o site de uma Instituição séria e confiável oferece link para o site do MCU, revelando um indício de boa Visibilidade. O terceiro site sugerido nos resultados, diz respeito a arquivos do País Vasco, apresentando links para alguns arquivos: Archivo Histórico Provincial de Álava, Archivo Histórico Provincial de Vizcaya e Archivo Histórico Provincial de Guipúzcoa.

A segunda tarefa a respeito da "Redação e Organização dos sites" consistia em observar se a linguagem dos sites dos Arquivos avaliados era clara e simples ou, ao contrário, complexa e difícil.

Tabela 11 - Linguagem do site

\begin{tabular}{c|c|c}
\hline Linguagem do site & $\mathbf{N}$ & $\%$ \\
\hline Clara e Simples & 17 & 85,00 \\
\hline Complexa & 0 & 0,00 \\
\hline Sem resposta & 3 & 15,00 \\
\hline Total & $\mathbf{2 0}$ & $\mathbf{1 0 0 , 0}$ \\
\hline
\end{tabular}

Fonte: Pesquisa direta/2009

Na tabela 11, observa-se que três dos participantes não responderam a essa questão, em contrapartida a maioria considerou que a linguagem utilizada nos sites dos Arquivos avaliados é clara e simples. Isso indica que para os usuários desses sites não existe dificuldade de compreensão do conteúdo dado que apenas $15 \%$ não se manifestou a respeito. A omissão da resposta pode ser entendida como desconhecimento do tema "arquivos".

No critério "Administração", os usuários tinham que responder a duas questões. A primeira consistia em observar se o site apresentava alguma restrição de uso, demonstra-se a seguir os resultados: 
Tabela 12 - Área de acesso restrito nos sites avaliados

\begin{tabular}{l|l|l} 
Respostas & \multicolumn{1}{l}{ N } & \multicolumn{1}{l}{} \\
\hline Não & 18 & 90,00 \\
\hline Sim & 1 & 5,00 \\
\hline Sem resposta & 1 & 5,00 \\
\hline Total & $\mathbf{2 0}$ & $\mathbf{1 0 0 , 0 0}$ \\
\hline
\end{tabular}

Fonte: Pesquisa direta/2009

A maioria dos participantes do teste predominantemente (90\%) afirmaram que os sites não tinham restrição de uso e apenas 5\% respondeu haver encontrado restrições, porém sem maiores explicações. Isso significa que os sites não contêm áreas restritas apenas a algum tipo especial de usuário.

A segunda tarefa consistia em observar se os sites contêm uma política de atualização, ou seja, se as novidades e atualizações dos referidos sites podem ser visualizadas com facilidade, devendo o participante responder objetivamente com um sim ou não.

\section{Tabela 13 - Visualização das atualizações e Novidades dos sites avaliados}

\begin{tabular}{c|c|c} 
Respostas & \multicolumn{1}{c}{$\mathbf{N}$} & $\%$ \\
\hline Sim & 17 & 85,00 \\
\hline Não & 3 & 15,00 \\
\hline Total & $\mathbf{2 0}$ & $\mathbf{1 0 0 , 0 0}$ \\
\hline
\end{tabular}

Fonte: Pesquisa direta/2009

A maioria dos usuários (85\%) considerou que se pode visualizar com facilidade as informações referentes a atualizações e novidades dos sites. Apenas 3 usuários (15\%), afirmaram o contrário. Isso demonstra que em matéria de atualização, os sites correspondem ao esperado.

Quanto ao quinto critério referente ao "Desenho" do site, o teste de usuários apresentava duas tarefas práticas, a primeira consistia em verificar se o usuário "potencial" apresentava dificuldade em navegar no site ou sentia 
necessidade de algum treinamento ou desprender maiores esforços para utilizálo. Os vinte usuários participantes (100\%) responderam que navegam intuitivamente, não necessitando de treinamento anterior para utilizar a página Web.

Tabela 14 - Navegação nas páginas Web avaliadas

\begin{tabular}{l|c|c}
\multicolumn{1}{c}{ Respostas } & N & $\%$ \\
\hline Navegam intuitivamente & 20 & 100,00 \\
\hline $\begin{array}{l}\text { Necessitam treinamento para } \\
\text { navegar nas páginas }\end{array}$ & 0 & 0,00 \\
\hline Total & $\mathbf{2 0}$ & $\mathbf{1 0 0 , 0 0}$ \\
\hline
\end{tabular}

Fonte: Pesquisa direta/2009

Como se pode conferir na tabela 14, a tarefa teve unanimidade nos resultados, pois todos os participantes do teste afirmaram que navegam intuitivamente pelo site. Isso sinaliza, portanto, que o site do MCU oferece uma boa interface com opções claras em que o usuário consegue navegar com facilidade, sem necessitar conhecimento prévio de seu mecanismo de funcionamento.

A segunda tarefa desse critério consistia em verificar se ocorria algum erro ou confusão visual na forma como as informações são apresentadas ao navegar no site.

Tabela 15 - Erro ou confusão visual nos sites avaliados

\begin{tabular}{|c|c|c|}
\hline Respostas & $\mathbf{N}$ & $\%$ \\
\hline $\begin{array}{l}\text { O site não apresenta erros ao acessar a } \\
\text { página Web e/ou confusão visual na } \\
\text { apresentação das informações }\end{array}$ & 20 & 100,00 \\
\hline $\begin{array}{l}\text { O site apresenta erros ao acessar a página } \\
\text { Web e/ou confusão visual na apresentação } \\
\text { das informações }\end{array}$ & 0 & 0,00 \\
\hline Total & 20 & 100,00 \\
\hline
\end{tabular}

Fonte: Pesquisa direta/2009 
As respostas apresentadas na tabela 15 demonstram que, a exemplo da questão anterior, $100 \%$ dos participantes não detectaram nenhuma falha ou erro ao navegar nas páginas Web dos Arquivos avaliados, ou seja, os usuários normalmente não encontram erro ou confusão visual nas páginas Web avaliadas durante todo o processo de navegação.

A análise dos resultados fornecidos pelos usuários potenciais dos sites, indica que estes atendem aos pré-requisitos essenciais a um site de qualidade, uma vez que correspondem às expectativas dos usuários, oferecendo atualização, clareza e consistência.

\subsection{APRESENTAÇÃO DOS RESULTADOS FORNECIDOS PELOS AVALIADORES - AVALIAÇÃO PRELIMINAR}

A avaliação preliminar das páginas Web de Arquivos estatais espanhóis, subsidiados pelo site do MCU, contou com a participação de cinco avaliadores.

Quanto à formação dos avaliadores, informa-se que o primeiro avaliador, a própria autora, tem formação em Biblioteconomia com especialização em Arquivos; o segundo avaliador é Mestre em Ciência da Computação; o terceiro avaliador tem formação em Biblioteconomia, com especialização em literatura infantil; o quarto avaliador é graduado em Física, com Mestrado, Doutorado e pósdoutorado em Biofísica e o quinto e último avaliador é Técnico em Desenvolvimento Web. Os dois avaliadores com formação em Biblioteconomia, apesar da experiência em utilização da Internet, por não serem da área de informática, foram devidamente treinados por um Webdesigner especialista em construção de sites, estando, por conseguinte, aptos para responderem o questionário da avaliação.

Para cada Arquivo selecionado, os avaliadores preencheram um questionário com cinco critérios de avaliação, com indicadores dentro de cada critério, cuja soma da pontuação dada a esses indicadores gerava a pontuação total do critério. Os avaliadores deveriam observar a pontuação no modelo de questionário a eles disponibilizado que serviu de base para as avaliações. (Cf. Apêndice C). 
Posteriormente, para melhor classificar os resultados da avaliação dos sites feita pelos avaliadores, optou-se por utilizar uma escala quanti-qualitativa. Utilizou-se o modelo de escala de "critérios qualitativos" de Nieto Caraveo e Díaz Villa (2005). De acordo com a escala desses autores, o site pode ser classificado como deficiente, insuficiente, regular, suficiente ou sobressalente, decidiu-se utilizar essa escala desconsiderando-se o item "insuficiente" por ter um significado muito próximo a "deficiente", podendo acarretar problemas de interpretação, foram utilizadas portanto apenas as demais características para classificar os sites deste estudo, conforme observa-se a seguir:

Tabela 16 - Escala de pontuação de Nieto Caraveo e Díaz Villa (2005)

\begin{tabular}{c|c} 
ESCALA DE PONTUAÇÃO & CLASSIFICAÇÃO \\
\hline 0 a 2,5 & Deficiente \\
\hline 2,6 a 5 & Regular \\
\hline 5,1 a 7,5 & Suficiente \\
\hline 7,6 a 10 & Sobressalente \\
\hline
\end{tabular}

Fonte: adaptação da autora

Analisa-se a seguir os resultados obtidos através dos questionários respondidos pelos avaliadores.

Tabela 17 - Síntese das notas atribuídas pelos avaliadores

\begin{tabular}{c|c|c|c}
\hline Mínimo & máximo & média & desvio \\
\hline 0 & 10 & 5,21 & 2,79 \\
\hline
\end{tabular}

Como pode ser observado, a média geral atribuída pelos cinco avaliadores em todos os cinco critérios utilizados durante a análise preliminar foi de 5,21, com um desvio padrão de 2,79. De acordo com a escala proposta, isso quer dizer que em média os avaliadores classificaram os sites como "suficientes". Além disso, é possível observar que houve grande variação na atribuição das notas, já que encontra-se um mínimo de zero e um máximo de 10. A seguir serão 
desagregados esses dados para analisar a distribuição da nota por avaliador. A tabela 17 sumariza essas informações.

Tabela 18 - Pontuação por avaliador da Avaliação Preliminar

\begin{tabular}{c|c|c|c|c|c} 
Avaliador & \multicolumn{1}{c}{ mínimo } & \multicolumn{1}{c}{ máximo } & \multicolumn{1}{c}{ média } & \multicolumn{1}{c}{ desvio padrão } & coeficiente de variação $^{149}$ \\
\hline 1 & 1 & 9 & 5,79 & 2,64 & 0,46 \\
\hline 2 & 0 & 6 & 3 & 2,55 & 0,85 \\
\hline 3 & 1 & 9 & 5,77 & 2,63 & 0,46 \\
\hline 4 & 4 & 10 & 7,48 & 2,17 & 0,29 \\
\hline 5 & 2 & 6 & 4 & 1,43 & 0,36 \\
\hline
\end{tabular}

De acordo com os dados, observa-se que o avaliador 2 foi aquele que atribuiu, em média, as notas mais baixas, com uma média de 3 , um desvio padrão de 2,64 e um coeficiente de variação de 0,46, indicando de acordo com a escala que esse avaliador em particular classifica os sites como "regulares". No outro oposto, tem-se o avaliador 4 com uma média de 7,48, um desvio em relação à média de 2,17 e um coeficiente de variação de 0,29, sugerindo a classificação dos sites como "sobressalentes". Adicionalmente, é possível afirmar que enquanto o avaliador 2 é o mais heterogêneo já que apresenta um coeficiente de variação de 0,85, o avaliador 4 foi aquele que atribuiu notas mais parecidas, seu coeficiente de variação foi 0,29 .

O gráfico, abaixo, ilustra melhor as médias por avaliador disponibilizadas em ordem decrescente.

\footnotetext{
149 O coeficiente de variação é uma medida de dispersão para comparar médias de distribuições diferentes. Isso porque o desvio padrão é relativo à média e como em duas distribuições as médias podem ser diferentes, o desvio dessas duas distribuições pode não ser diretamente comparável. Uma solução é utilizar o coeficiente de variação: basta dividir o valor do desviopadrão pela média.
} 


\section{Gráfico 1 - Média por avaliador da Avaliação Preliminar- Pontuação (decrescente)}

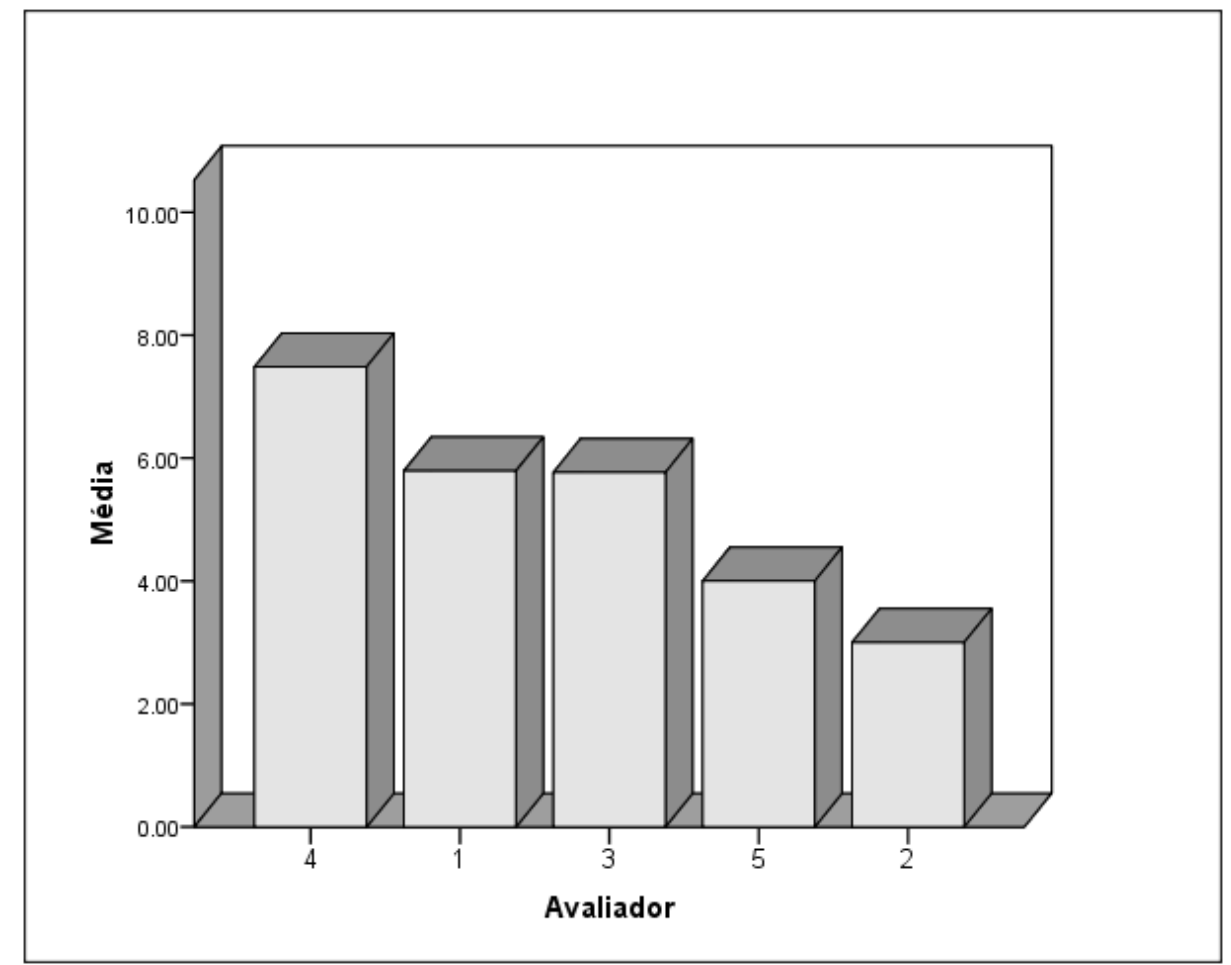

Uma possibilidade analítica adicional é examinar a distribuição das notas de acordo com os diferentes atributos, ou seja, de acordo com os critérios utilizados pelos avaliadores. A tabela, a seguir, sintetiza essas informações.

Tabela 19 - Pontuação por critérios

\begin{tabular}{c|c|c|c|c|c} 
Critério & \multicolumn{1}{c}{ mín. } & \multicolumn{1}{c}{ max. } & \multicolumn{1}{c}{ média } & \multicolumn{1}{c}{ desvio padrão } & Cof. de variação \\
\hline Busca e recuperação & 0 & 9 & 4,60 & 2,83 & 0,62 \\
\hline Conteúdo & 5 & 10 & 7,53 & 1,80 & 0,24 \\
\hline Autoridade & 1 & 8 & 2,42 & 1,99 & 0,82 \\
\hline Desenho & 6 & 10 & 7,17 & 1,43 & 0,20 \\
\hline Administração & 1 & 7 & 4,32 & 1,94 & 0,45
\end{tabular}

De acordo com os dados, observa-se que o critério Autoridade apresentou a menor média $(2,42)$, com um desvio padrão de 1,99 e um coeficiente de variação de 0,82 , fato que classifica o Critério como deficiente. Por outro lado, o critério Conteúdo apresentou, comparativamente, a maior média $(7,53)$, com um 
desvio padrão de 1,80 e um coeficiente de variação de 0,24 , podendo ser considerado suficiente tendendo para sobressalente.

\section{Gráfico 2 - Média por critério Avaliação Preliminar - Pontuação (decrescente)}

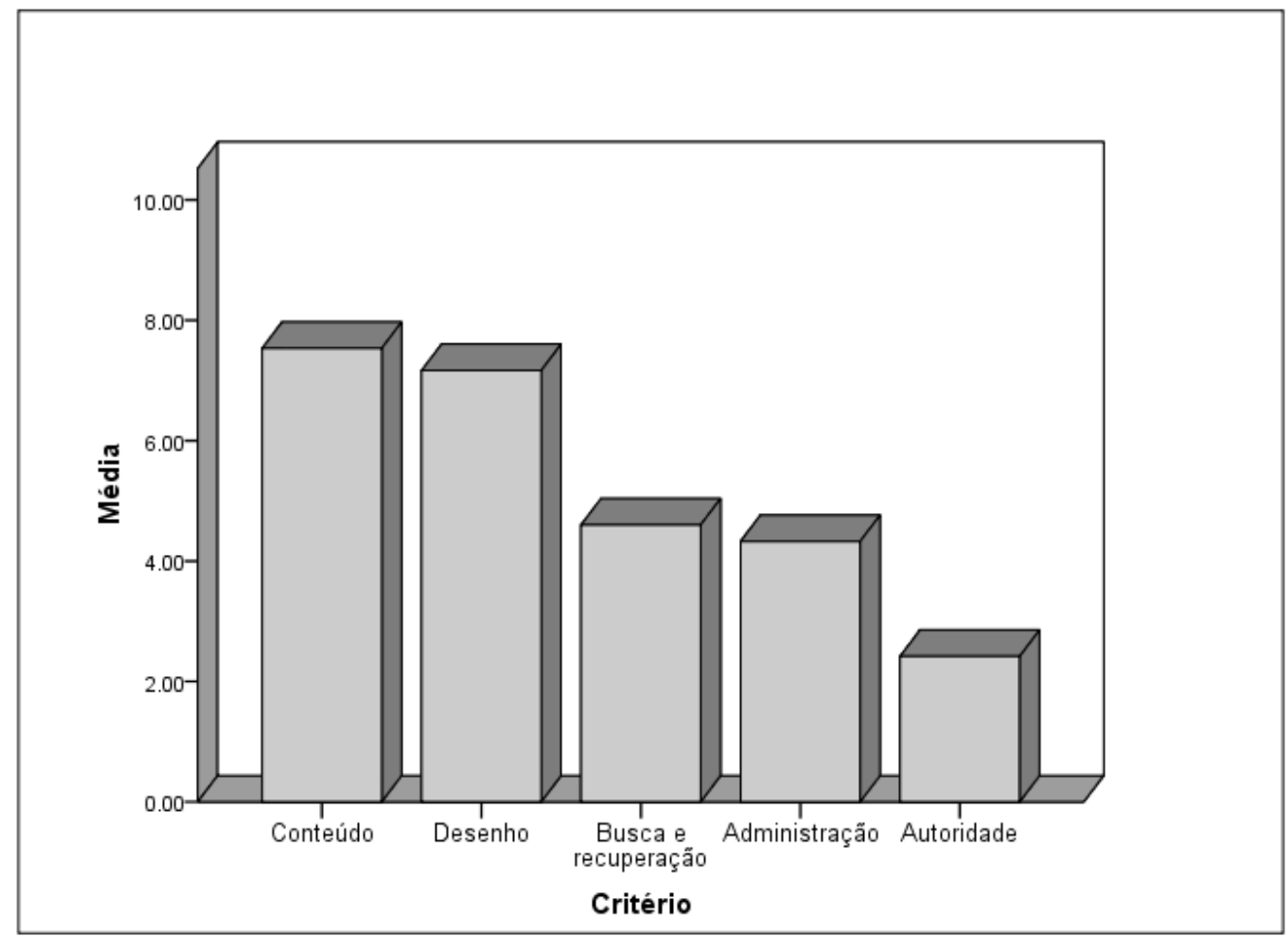

Como observa-se no Gráfico anterior, os critérios Conteúdo $(7,53)$ e Desenho $(7,17)$ apresentaram médias próximas que os classifica como "suficientes". Os Critérios Busca e Recuperação $(4,60)$ e Administração $(4,32)$ também apresentaram médias semelhantes, podendo ambos serem classificados como "regulares". O Critério Autoridade apresentou média 2,42, destoando dos demais, pois sua classificação é "deficiente", fato que influencia negativamente a pontuação média geral dos sites.

Por fim, para os propósitos do presente trabalho, é importante analisar a média por Arquivo. A tabela sumariza a média, o desvio padrão e o coeficiente de variação por arquivo. 
Tabela 20 - Variação de pontuação por Arquivo - Avaliação Preliminar

\begin{tabular}{|c|c|c|c|}
\hline Arquivo & média & desvio padrão & coeficiente de variação \\
\hline ACA & 5,06 & 2,58 & 0,51 \\
\hline ACMC & 5,16 & 2,84 & 0,55 \\
\hline AGA & 5,32 & 2,90 & 0,55 \\
\hline AGI & 5,36 & 2,97 & 0,55 \\
\hline AGS & 5,40 & 2,94 & 0,54 \\
\hline $\mathrm{AHN}$ & 5,24 & 2,86 & 0,55 \\
\hline AHPA & 5,20 & 2,89 & 0,56 \\
\hline AHPG & 5,16 & 2,84 & 0,55 \\
\hline AHPV & 5,16 & 2,84 & 0,55 \\
\hline ARCV & 5,12 & 2,77 & 0,54 \\
\hline $\mathrm{CDMH}$ & 5,16 & 2,84 & 0,55 \\
\hline SNAHN & 5,16 & 2,84 & 0,55 \\
\hline
\end{tabular}

Comparativamente, os dados revelam uma forte semelhança na média dos diferentes arquivos analisados. Isso porque todos eles se aproximam da mesma magnitude, no caso, valor cinco. Em relação à heterogeneidade da distribuição, a análise do coeficiente de variação sugere que o Archivo de la Corona de Aragón (ACA) é aquele que apresentou notas mais similares. No outro oposto, tem-se o Archivo Histórico Provincial de Álava (AHPA) com um coeficiente de variação de 0,56 , sugerindo maior heterogeneidade nas notas recebidas.

De acordo com o modelo de avaliação (Cf. Apêndice C), a soma total dos pontos prevista para o Critério Busca e Recuperação é 11, perfazendo um percentual de $23,91 \%$.

Observou-se que existe coincidência entre os resultados dos avaliadores 1 e 3, com 6 pontos, que equivalem a um percentual de 13,04\%, e discrepância entre os resultados dos demais avaliadores. $O$ resultado do avaliador 4 é o que mais se aproxima dos resultados dos avaliadores anteriormente comentados, com 8 pontos, que equivalem a 17,38\%. Os avaliadores 2 e 5 apresentaram resultados mais aproximados ( 0 e 3 ), que equivale a $2,17 \%$ e $6,52 \%$ respectivamente. Isso significa que para as pessoas que não tem formação ligada à área informática avaliaram de maneira positiva a busca e recuperação de informações neste site, já os especialistas foram mais exigentes possivelmente pela visão mais acurada. 
Para o critério Conteúdo, a soma total dos pontos de acordo com o modelo da avaliação é 11 , perfazendo um percentual de $23,91 \%$. Com relação a esse critério, os avaliadores tiveram maior uniformidade nos resultados. Para 9 dos Arquivos avaliados a pontuação foi 9 , que corresponde a 19,56\%, porém os avaliadores 2 e 5, com formação na área de informática apresentam pontuação menor que os demais e aproximadas, porém não idênticas: pontuação 6 e 5, que equivale a 13,04 \% e 10,86\% respectivamente. Esses resultados indicaram que os profissionais que não são da área de informática avaliaram positivamente esse critério, porém os avaliadores ligados à área de informática consideram que, nesse critério, os Arquivos atingem em média 50\% do resultado esperado.

No Critério Autoridade, a soma total dos pontos prevista de acordo com o modelo da avaliação é 7, perfazendo um percentual de 15,22\%. Nesse Critério, os avaliadores apresentam resultado similar para todos os Arquivos. Os avaliadores 1 e 3, da área de Biblioteconomia coincidem os resultados, com pontuação 1 que correspondem a 2,17\%, bem como os avaliadores 2 e 5, da área de informática, com pontuação 2 que corresponde a 4,34\%. Apenas o avaliador número 4 apresenta pontuação mais elevada que os demais, variando as respostas em cada Arquivo, porém coincide em 7 Arquivos com pontuação 5 que equivale a $10,87 \%$. Nesse critério, a maioria dos avaliadores considera que as páginas Web não atingem ao objetivo, pois a média dos resultados é inferior a 2 pontos que equivale a apenas $4,34 \%$. O resultado do avaliador 4 tão divergente dos demais pode indicar que sua formação em Biofísica talvez o faça interpretar de maneira diferente os dados, possivelmente por ser muito distante de Arquivos e Informática.

No critério Desenho, a soma total dos pontos prevista para esse critério, de acordo com o modelo da avaliação, é 10 , perfazendo um percentual de $21,74 \%$. Nesse critério, os resultados dos dois profissionais de Biblioteconomia são coincidentes bem como dos dois avaliadores da área de Informática. Os avaliadores 1 e 3 apresentam resultados com pontuação 7 que equivale a $15,21 \%$. Os avaliadores 2 e 5 apresentam resultados com pontuação 6 que equivale a $13,04 \%$. O avaliador 4 , porém, apresenta um resultado com uma pontuação mais elevada que os demais, para 10 Arquivos apresenta pontuação 10 que equivale a $21,74 \%$. Em relação a esse critério o avaliador 4 sugere que os 
Arquivos cumprem 100\% com o objetivo proposto, em detrimento das respostas dos outros avaliadores cujos resultados giram em torno de 6,5 pontos com um percentual de $14,13 \%$.

No critério Administração, a soma total dos pontos prevista para esse critério, de acordo com o modelo da avaliação é 10, perfazendo um percentual de $21,74 \%$. Nesse critério, os resultados dos dois profissionais de Biblioteconomia voltam a ser coincidentes, em 10 dos Arquivos avaliadores seus resultados indicaram pontuação 6 que equivale a 13,04\%. Os avaliadores 2 e 5, da área de Informática, diferem nos resultados desse critério, apresentando pontuação 1 e 4, que corresponde a 2,17\% e 8,69\% respectivamente. O profissional 4 apresenta resultado coincidente com um dos profissionais da área de informática, em 9 dos Arquivos avaliados, com pontuação 4 que equivale a 8,69\%. Nesse critério, os profissionais da área de Biblioteconomia avaliaram as páginas Web de maneira positiva, porém um dos profissionais da área de informática considerou as páginas Web deficientes neste aspecto, porém, o profissional da área de Biofísica bem como um dos profissionais da área de informática consideraram que o critério corresponde em parte ao esperado com média abaixo dos 50\%.

Para melhor representar os resultados, utilizou-se o programa estatístico SPSS, cujos resultados foram disponibilizados em gráficos. Em primeiro lugar, para cada critério em cada site, considerou-se a média e o desvio padrão a fim de conhecer a classificação individual de cada critério.

Posteriormente, para se conhecer a pontuação média geral de cada site, a média de cada critério foi multiplicada pela porcentagem total equivalente ao critério (segundo o modelo de avaliação proposto aos avaliadores). Em seguida, somam-se todas as pontuações médias e o resultado é dividido por cinco (número de critérios) para se conhecer o peso total dado ao site. Para tanto, utiliza-se a seguinte fórmula:

M.B\&Rx23,91\%+M.C $\times 23,91 \%+M \cdot A \cdot \times 15,22 \%+M \cdot D \cdot \times 21,74+M \cdot A d \cdot \times 15,22=P . G$. 
Para a leitura da fórmula apresentada, lê-se:

M.B\&R = Média do critério Busca e Recuperação

$23,91 \%$ = Porcentagem geral de pontos do critério Busca e Recuperação

M.C = Média do critério Conteúdo

$23,91 \%$ = Porcentagem geral de pontos do critério Conteúdo

M.A. = Média do critério Autoridade

$15,22 \%=$ Porcentagem geral de pontos do critério Autoridade

M. D. = Média do critério Desenho

$21,74 \%=$ Porcentagem geral de pontos do critério Desenho

M. Ad. = Média do critério Administração

$15,22 \%=$ Porcentagem geral de pontos do critério Administração

P.G. = Pontuação Geral do site.

Na sequência, apresentam-se os resultados da avaliação dos critérios em cada site.

\section{Archivo Central del Ministério de Cultura}

Tabela 21 - Pontuação dos resultados dos critérios - ACMC

\begin{tabular}{c|c|c} 
Critério & média & desvio padrão \\
\hline Busca e recuperação & 4,60 & 3,13 \\
\hline Contéudo & 7,60 & 1,95 \\
\hline Autoridade & 2,20 & 1,64 \\
\hline Desenho & 7,20 & 1,64 \\
\hline Administração & 4,20 & 2,05 \\
\hline
\end{tabular}

Como se pode observar na Tabela 21, no site do Archivo Central del Ministério de Cultura, todos os itens tem alto desvio padrão, mostrando a divergência dos avaliadores nos resultados deste site.

O Critério Busca e Recuperação, com a média 4,6 classificado como "regular", apesar do alto desvio padrão $(3,13)$.

No site deste Arquivo, o critério Conteúdo é o melhor avaliado, com média 7,6, portanto classificado como "sobressalente". 
Em relação ao critério Autoridade, a média de pontuação dada pelos avaliadores foi 2,2, o que o classificou como "deficiente".

O critério Desenho é avaliado como "suficiente", com média 7,2 e por fim, o critério Administração, com média 4,2, foi avaliado como "regular".

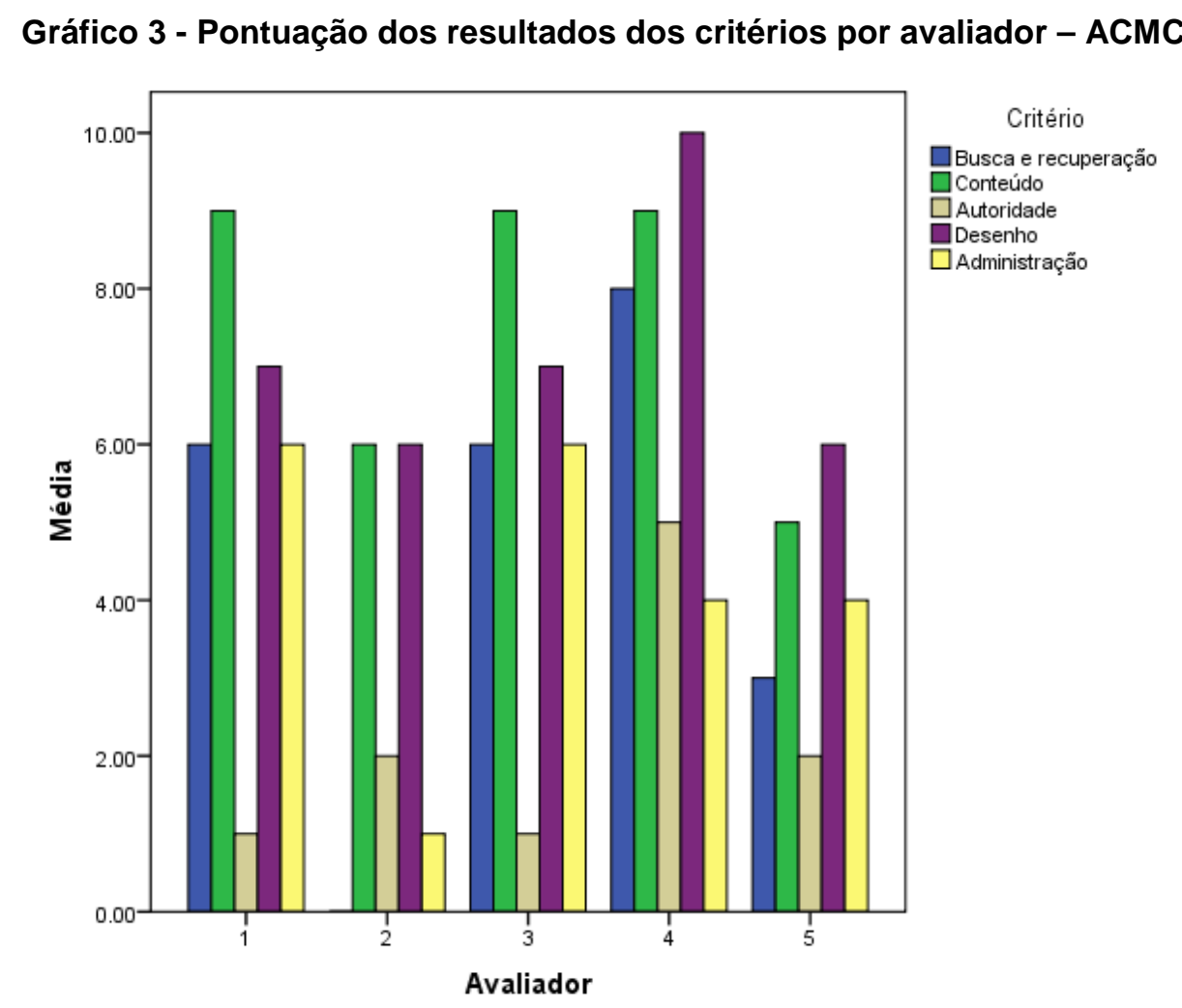

O Gráfico 3 ilustra com clareza que em relação ao critério Desenho o resultado do avaliador 4 se desctacou dos demais. Com relação ao critério Conteúdo, os avaliadores 1,3 e 4 coincidiram nos resultados. Percebe-se também que o critério Autoridade, tendo resultados coincidentes para os avaliadores 1 e 3 , foi o pior avaliado.

Utilizando-se a fórmula para calcular a média geral dos critérios de avaliação dos sites, verifica-se que a média geral do site do Archivo Central del Ministerio de Cultura foi de 5,45:

$4,6 \times 23,91 \%+7,6 \times 23,91 \%+2,2 \times 15,22 \%+7,2 \times 21,74+4,2 \times 15,22=5,45$ 
De acordo com a média geral $(5,45)$, pode-se afirmar que este site é considerado "suficiente".

\section{Archivo de la Corona de Aragon}

Tabela 22 - Pontuação dos resultados dos critérios - ACA

\begin{tabular}{c|c|c}
\hline critério & média & desvio padrão \\
\hline Busca e recuperação & 4,40 & 2,88 \\
\hline Contéudo & 6,40 & 1,52 \\
\hline Autoridade & 2,80 & 2,95 \\
\hline Desenho & 7,00 & 1,22 \\
\hline Administração & 4,70 & 2,28 \\
\hline
\end{tabular}

Com relação ao site do Archivo de la Corona de Aragon, todos os itens tem alto desvio padrão, mostrando a divergência dos avaliadores neste site.o critério Autoridade foi o pior avaliado, com média 2,80 e classificado como "regular", em posição oposta está o critério Desenho com média 7 e portanto classifcado como "suficiente". O critério Busca e Recuperação e o critério Administração, com médias 4,4 e 4,7 respectivamente, foram classificados como "regulares". O critério Conteúdo, com média 6,4 foi classificado como "suficiente". 
Gráfico 4 - Pontuação dos resultados dos critérios por avaliador - ACA

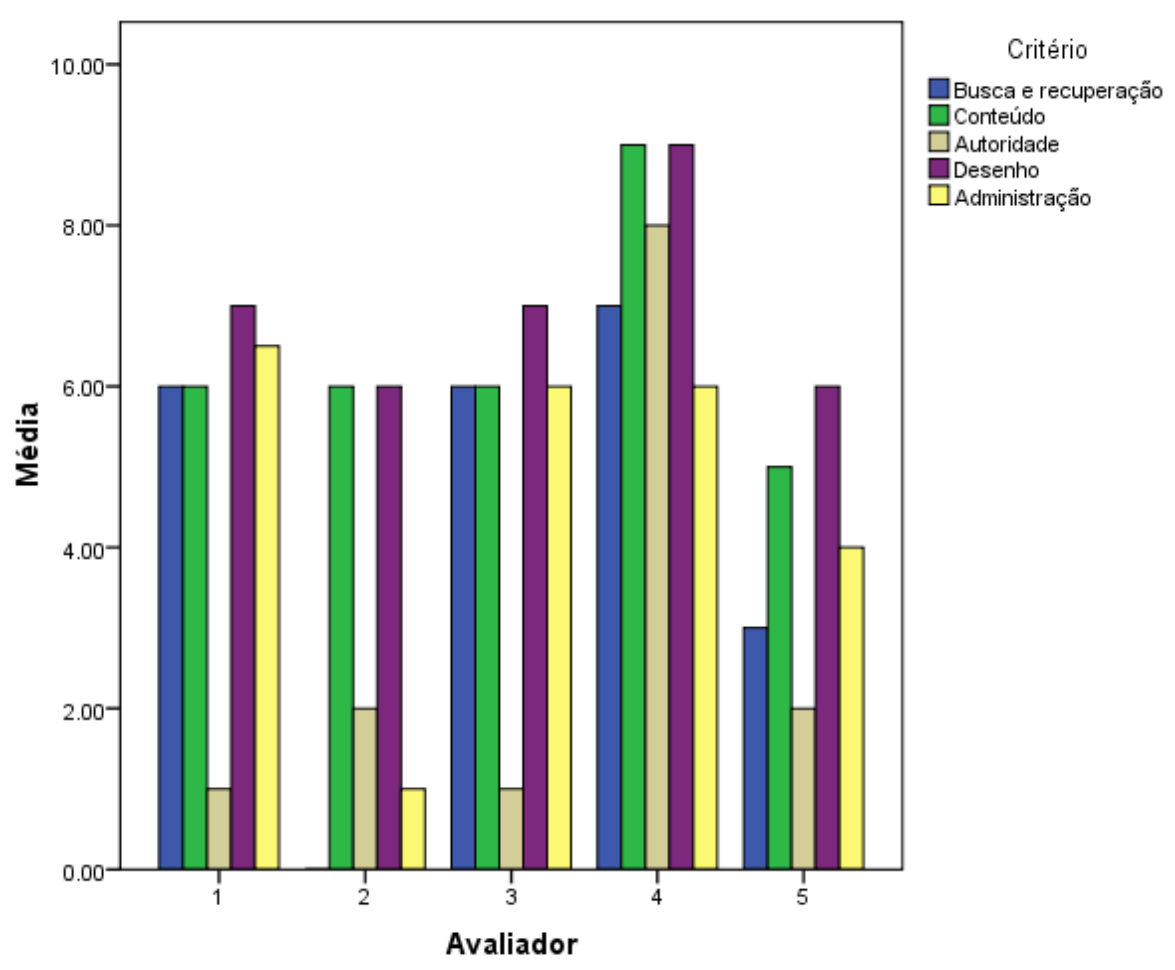

Como demonstra o gráfico 4, houve coincidências nos resultados de alguns avaliadores. Quanto ao critério Busca e Recuperação, os avaliadores 1 e 3 apresentaram resultados similares. Os avaliadores 1, 2 e 3 apresentaram resultados similares para o Critério Conteúdo, porém o avaliador 4 destaca-se dos demais. $O$ avaliador 4 se destacou no critério Autoridade com maior média, em oposição aos avaliadores 1 e 3 que apresentaram as menores médias similares. Com relação ao Critério Desenho, o avaliador 4 apresentou maior média, seguido dos avaliadores 1 e 3 com resultados similares. O avaliador 1 apresentou maior média para o critério Administração seguido dos avaliadores 3 e 4 com médias similares, em situação oposta se encontra o avaliador 2 com menor média.

Utilizando-se a fórmula para calcular a média geral dos critérios de avaliação dos sites, verifica-se que a média geral do site do Archivo de la Corona de Aragón foi de 5,22: 
De acordo com a média geral do site $(5,2)$, pode-se afirmar que ele é considerado "suficiente".

\section{Archivo de la Real Chancillería de Valladolid}

Tabela 23 - Pontuação dos resultados dos critérios - ARCV

\begin{tabular}{c|c|c}
\hline Critério & média & desvio padrão \\
\hline Busca e recuperação & 4,60 & 3,13 \\
\hline Contéudo & 7,60 & 1,95 \\
\hline Autoridade & 2,20 & 1,64 \\
\hline Desenho & 7,00 & 1,22 \\
\hline Administração & 4,20 & 2,05 \\
\hline
\end{tabular}

Como se pode observar na Tabela 23, o site do Archivo de la Real Chancillería de Valladolid houve divergência dos avaliadores neste site, sobretudo para o critério Busca e Recuperação, com desvio padrão 3,13. O critério Conteúdo neste Arquivo foi o melhor avaliado, com média 7,6 e classificado portanto, como "sobressalente".

O critério Autoridade, com média 2,2, foi avaliado como "deficiente".

Com média 7, o critério Desenho foi avaliado como "suficiente", E os critérios Busca e Recuperação $(4,6)$ e Administração $(4,2)$, foram classificados como "regulares". 


\section{Gráfico 5 - Pontuação dos resultados dos critérios por avaliador - ARCV}

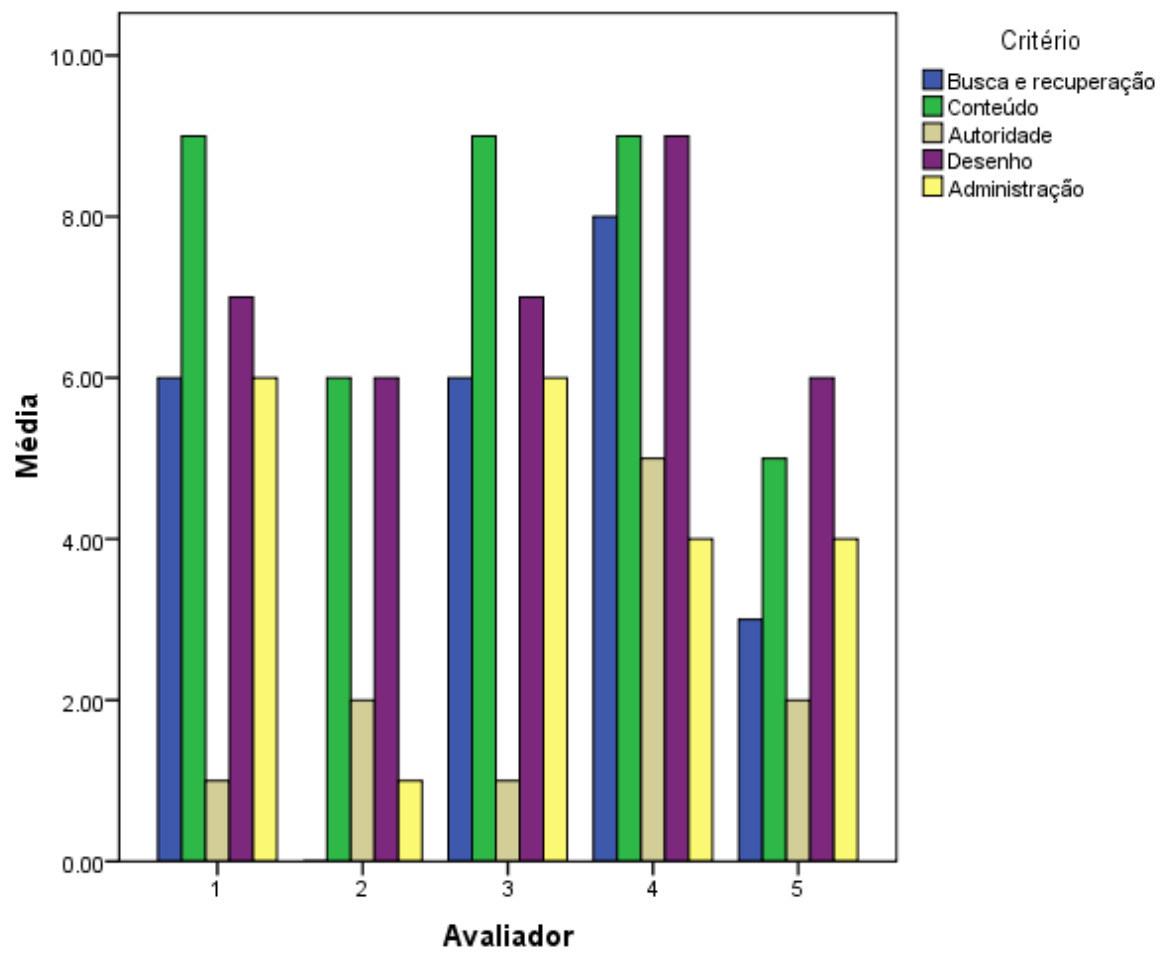

Observa-se no Gráfico 5 que na avaliação deste site, houve coincidência nos resultados dos avaliadores 1, 3 e 4 para o critério Conteúdo. Os avaliadores 1 e 3 apresentaram também resultados similares para o critério Administração. Percebe-se ainda, que o critério Desenho foi melhor avaliado pelo avaliador 4. 0 critério Autoridade obteve resultados similares dos avaliadores 1 e 3 , obtendo a pior pontuação em relação aos demais critérios.

Utilizando-se a fórmula para calcular a média geral dos critérios de avaliação dos sites, verifica-se a média geral do site do Archivo de la Real Chancillería de Valladolid:

De acordo com o média geral do site $(5,41)$, ele é classificado como "suficiente". 


\section{Archivo General de Índias}

Tabela 24 - Pontuação dos resultados dos critérios - AGI

\begin{tabular}{c|c|c}
\hline Critério & Média & desvio padrão \\
\hline Busca e recuperação & 4,60 & 3,13 \\
\hline Contéudo & 7,80 & 2,17 \\
\hline Autoridade & 2,80 & 2,95 \\
\hline Desenho & 7,20 & 1,64 \\
\hline Administração & 4,40 & 2,30 \\
\hline
\end{tabular}

Quanto ao site do Archivo General de Indias, todos os itens tem alto desvio padrão, mostrando a divergência dos avaliadores neste site. O critério Busca e Recuperação, com alto desvio padrão $(3,13)$, indica que foi o critério que obteve opiniões mais divergentes dos avaliadores, porém sua média de 4,6, o classificou como "regular". O critério Conteúdo foi avaliado como "sobressalente", com média 7,8. O critério Autoridade desse site, com média 2,8, foi avaliado como "deficiente". O critério desenho foi avaliado como "suficiente", com média 7,2.

E por fim o critério Administração, com média de 4,4 foi classificado como "regular". 
Gráfico 6 - Pontuação dos resultados dos critérios por avaliador - AGI

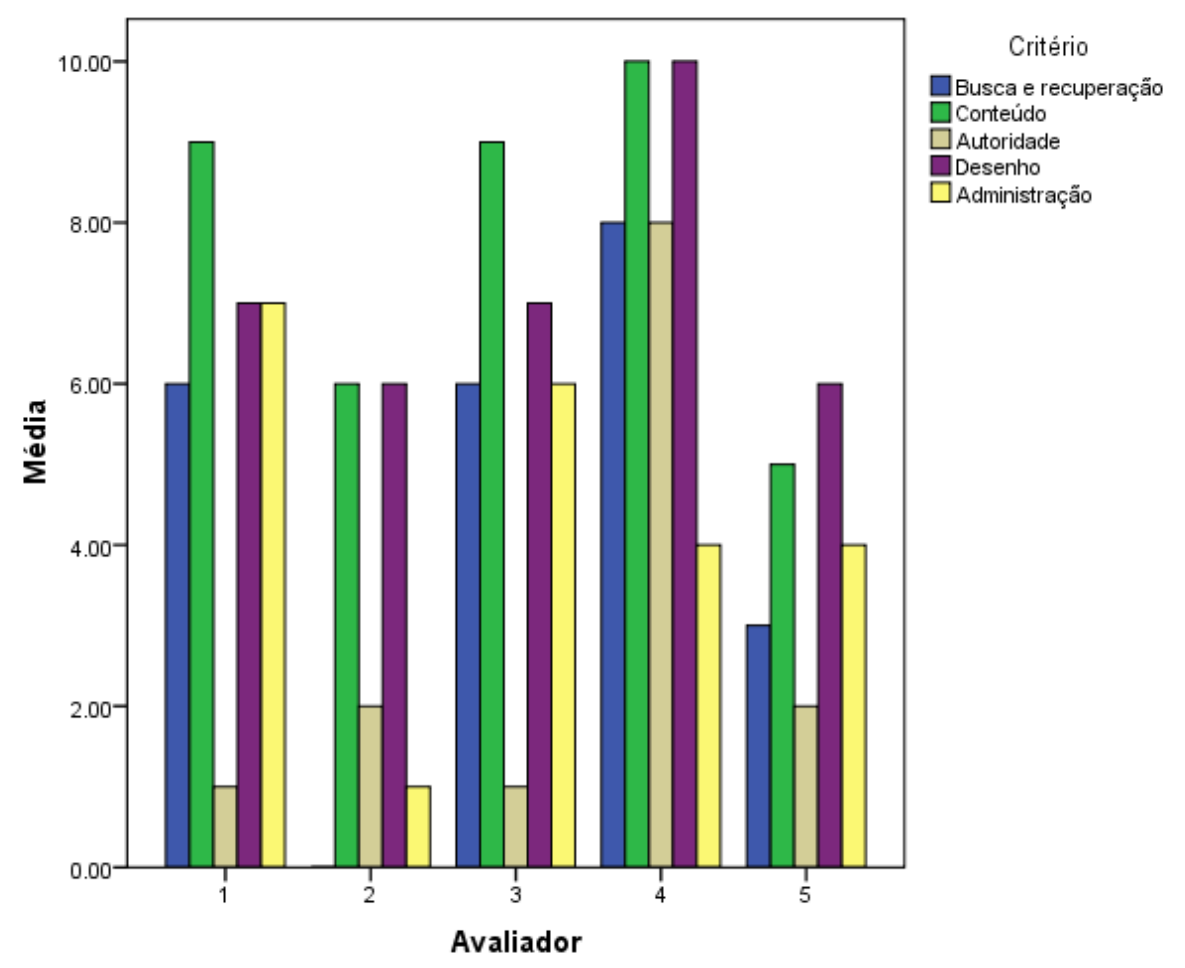

Como demonstra o Gráfico 6 , houve coincidência nos resultados dos avaliadores 1 e 3 para os seguintes critérios: Busca e Recuperação, Conteúdo, Autoridade e Desenho. Percebe-se claramente que o avaliador 4 foi quem melhor avaliou os critérios Conteúdo e Desenho. Os avaliadores 4 e 5 coincidiram nos resultados do critério Administração. O critério Autoridade recebeu maior pontuação do avaliador 4 .

Utilizando-se a fórmula para calcular a média geral dos critérios de avaliação dos sites, verifica-se que a média geral do site do Archivo General de Indias foi de 5,62:

$4,6 \times 23,91 \%+7,8 \times 23,91 \%+2,8 \times 15,22 \%+7,2 \times 21,74+4,4 \times 15,22=5,62$

5

De acordo com o Peso Total do site, pode-se afirmar que em geral ele é considerado de boa qualidade, pois sua pontuação o classifica como "suficiente". 


\section{Archivo General de la Administración}

Tabela 25 - Pontuação dos resultados dos critérios - AGA

\begin{tabular}{c|c|c}
\hline Critério & média & desvio padrão \\
\hline Busca e recuperação & 4,60 & 3,13 \\
\hline Contéudo & 7,60 & 1,95 \\
\hline Autoridade & 2,60 & 2,51 \\
\hline Desenho & 7,20 & 1,64 \\
\hline Administração & 4,60 & 2,51 \\
\hline
\end{tabular}

Quanto ao site do Archivo General de la Administración, o critério Busca e Recuperação, apresentou maior desvio padrão $(3,13)$, porém com média 4,6 , foi classificado como "regular". O critério Conteúdo foi o melhor avaliado $(7,6)$ e classificado como "sobressalente", já no critério Autoridade esse site foi avaliado como "deficiente", com média 2,6. Seguido do critério Desenho, avaliado como "suficiente" com média 7,2. Por fim, o critério Administração, em que a média foi de 4,6, foi classificado como "regular".

Gráfico 7 - Pontuação dos resultados dos critérios por avaliador - AGA

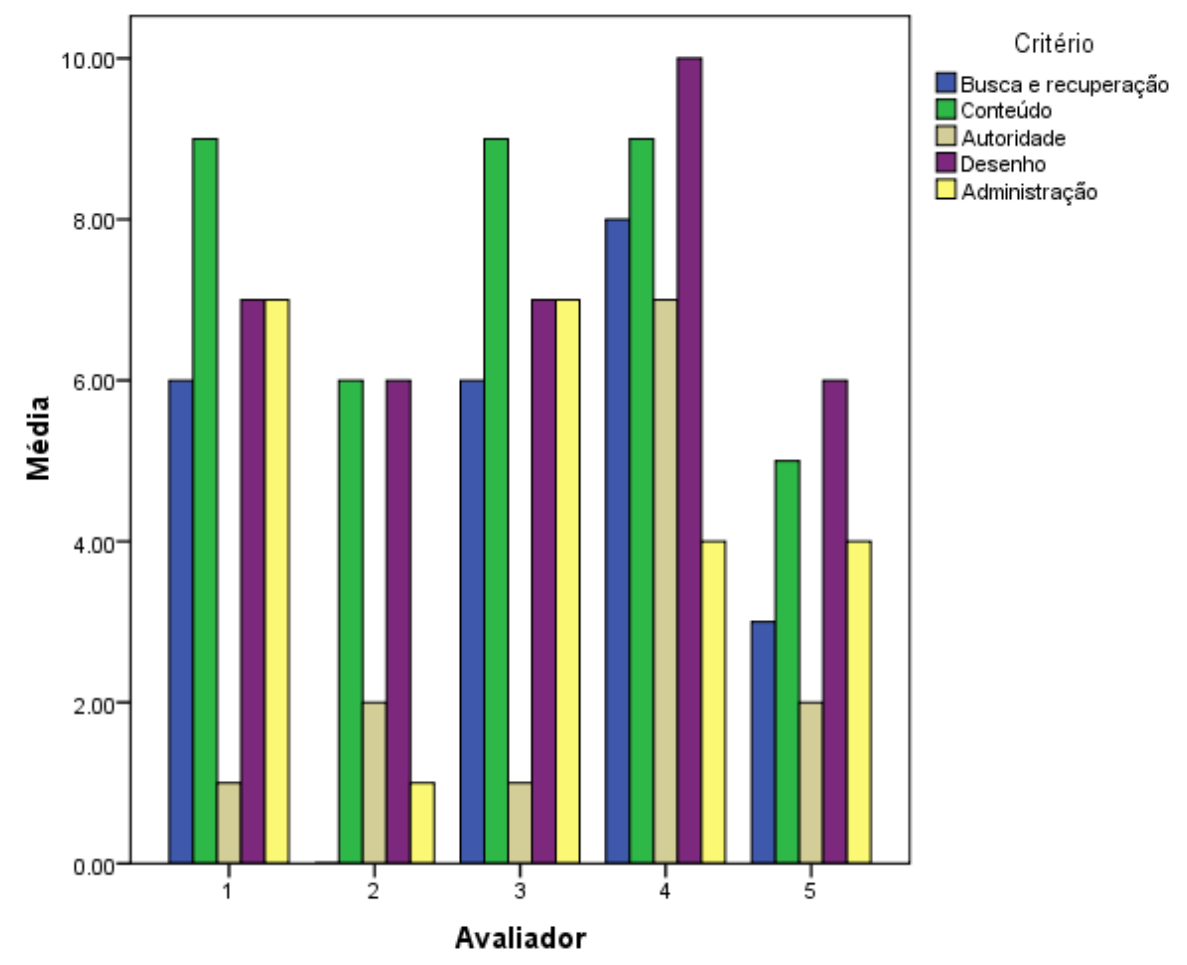


O Gráfico 7 demonstra claramente que o critério Desenho obteve maior pontuação do avaliador 4. Houve coincidência nos resultados dos avaliadores $1 \mathrm{e}$ 3 para todos os critérios. Percebe-se também que o critério Administração obteve menor pontuação do avaliador 2 e obteve resultados similares dos avaliadores $4 \mathrm{e}$ 5. Também houve coincidência nos resultados dos avaliadores 2 e 5 para o critério Desenho.

Utilizando-se a fórmula para calcular a média geral dos critérios de avaliação dos sites, verifica-se que a média geral do site do Archivo General de la Administración foi de 5,57:

$\underline{4,6 \times 23,91 \%+7,6 \times 23,91 \%+2,6 \times 15,22 \%+7,2 \times 21,74+4,6 \times 15,22}=5,57$

\section{5}

De acordo com a média total do site $(5,57)$, ele foi classificado como "suficiente".

\section{Archivo General de Simancas}

Tabela 26 - Pontuação dos resultados dos critérios - AGS

\begin{tabular}{c|c|c}
\hline Critério & média & desvio padrão \\
\hline Busca e recuperação & 4,60 & 3,13 \\
\hline Contéudo & 7,80 & 2,17 \\
\hline Autoridade & 2,80 & 2,95 \\
\hline Desenho & 7,20 & 1,64 \\
\hline Administração & 4,60 & 2,19 \\
\hline
\end{tabular}

Quanto ao site do Archivo General de Simancas, todos os itens tem alto desvio padrão, mostrando a divergência dos avaliadores neste site. O Critério Conteúdo, foi o melhor avaliado, com média 7,8, foi classificado portanto, como "sobressalente". O critério Autoridade, em sentido oposto, obteve a média mais baixa $(2,8)$, sendo ainda classificado como "regular". Os critérios Busca e Recuperação e Administração (ambos com média 4,6) foram avaliados como 
"regulares". Com média 7,20, o critério Desenho foi classificado como "suficiente".

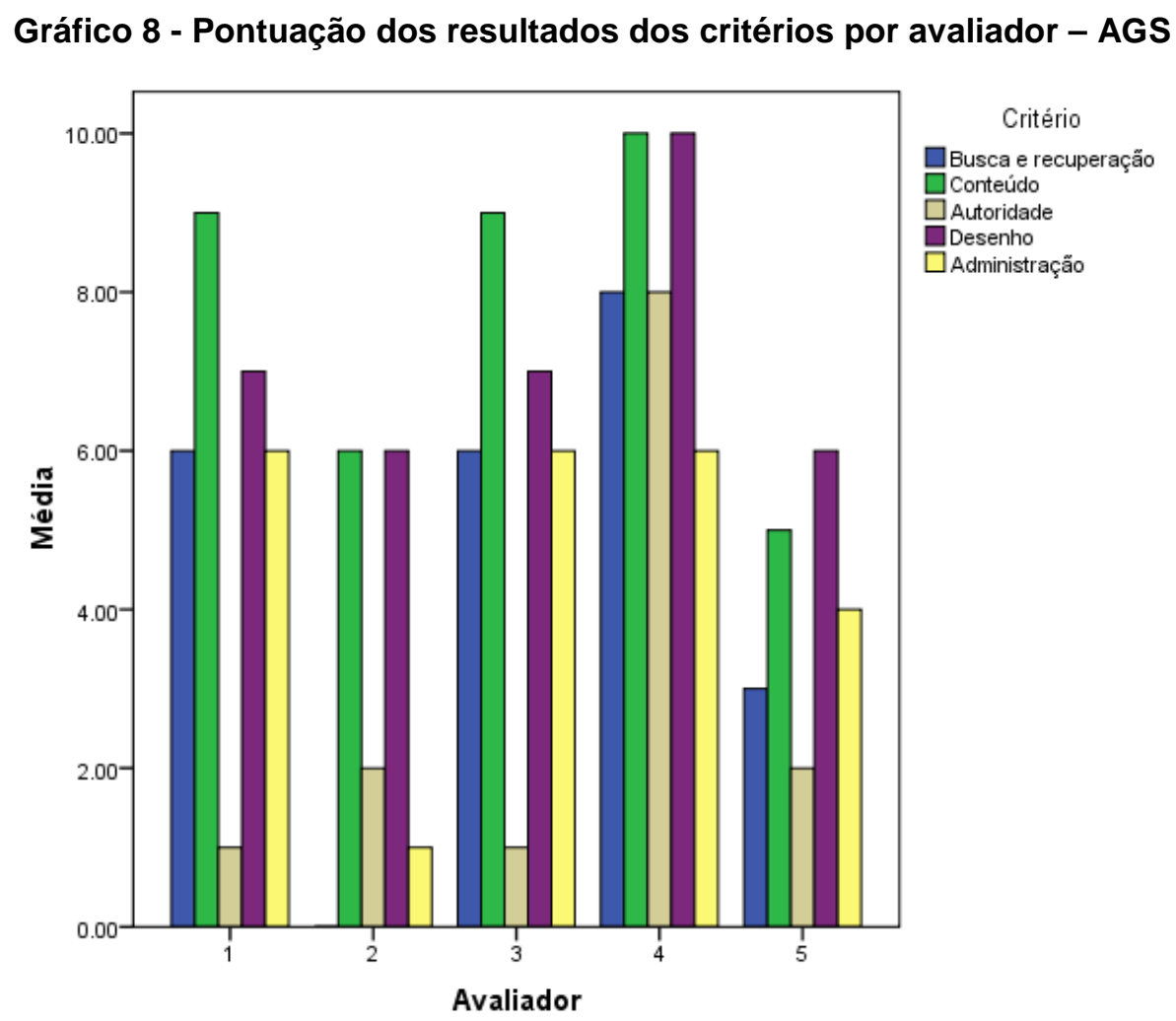

Como se pode observar no Gráfico 8 , houve coincidência nos resultados dos avaliadores 1 e 3 para todos os critérios. Claramente percebe-se que 0 avaliador 4 foi quem melhor avaliou os critérios Conteúdo e Desenho. Os avaliadores 2 e 5 coincidiram nos resultados dos critérios Autoridade e Desenho.

Utilizando-se a fórmula para calcular a média geral dos critérios de avaliação dos sites, verifica-se que a média geral do site do Archivo General de Simancas foi de 5,65 :

De acordo com o média geral do site, pode-se afirmar que em geral ele é considerado de boa qualidade tendo em vista que sua pontuação total o classifica como "suficiente". 


\section{Archivo Histórico Nacional}

Tabela 27 - Pontuação dos resultados dos critérios - AHN

\begin{tabular}{c|c|c} 
Critério & média & desvio padrão \\
\hline Busca e recuperação & 4,60 & 3,13 \\
\hline Contéudo & 7,60 & 1,95 \\
\hline Autoridade & 2,60 & 2,51 \\
\hline Desenho & 7,20 & 1,64 \\
\hline Administração & 4,20 & 2,05 \\
\hline
\end{tabular}

Quanto ao Archivo Historico Nacional, todos os itens tem alto desvio padrão, mostrando a divergência dos avaliadores neste site. O critério Busca e Recuperação que possui o maior desvio padrão $(3,13)$, com média 4,6 , foi classifcado como "regular".

O critério Conteúdo desse site foi o melhor avaliado com média 7,6, como "sobressalente".

Com a menor média $(2,6)$, o critério Autoridade foi avaliado como "regular".

O critério Desenho foi avaliado como "suficiente", com média 7,2. E no que refere ao critério Administração, em que a média foi de 4,2, o site tende a ser avaliado como "regular".

Gráfico 9 - Pontuação dos resultados dos critérios por avaliador - AHN 


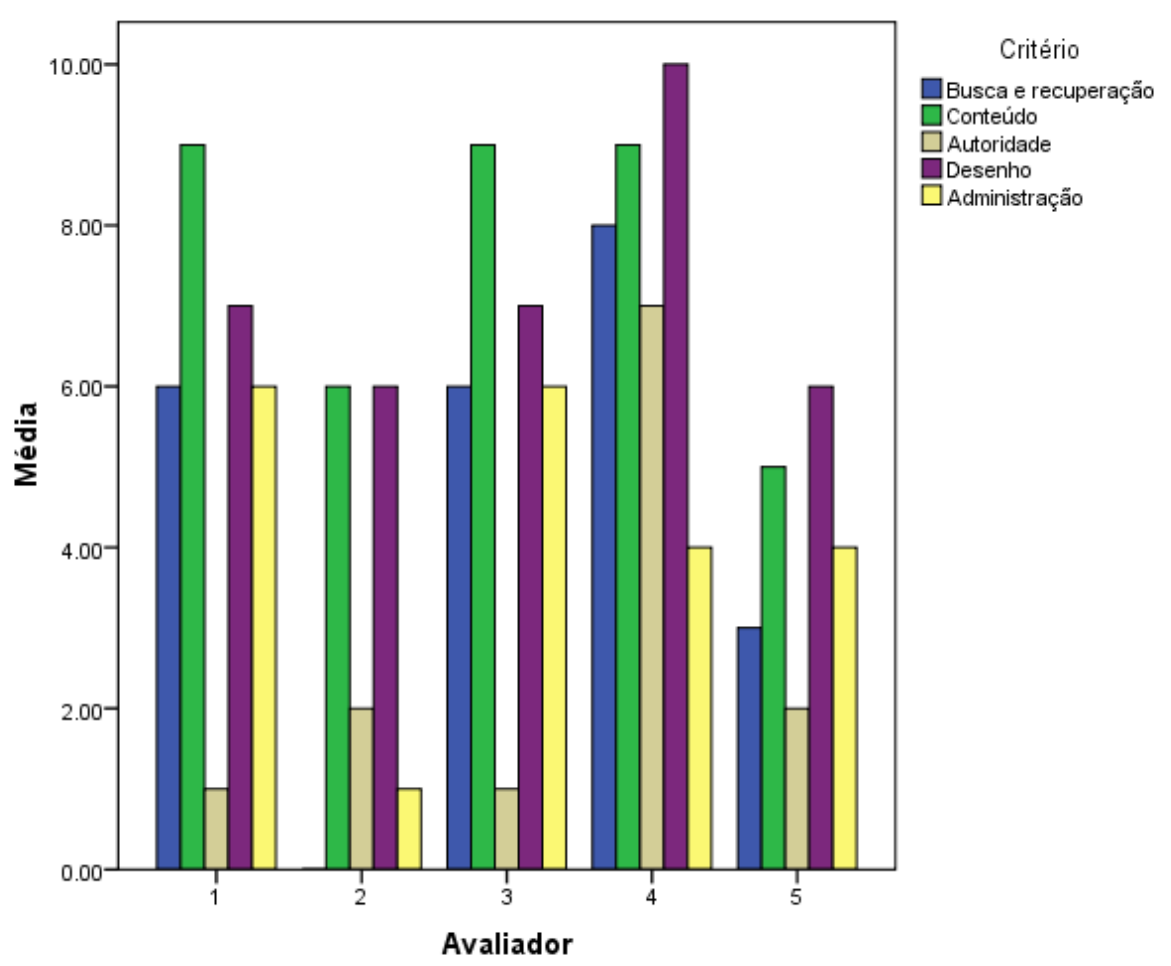

O Gráfico 9 demonstra que houve coincidência nos resultados dos avaliadores 1 e 3 para todos os critérios. Os avaliadores 2 e 5 coincidiram nos resultados dos critérios Autoridade e Desenho. O critério Desenho recebeu maior pontuação do avaliador 4. Os resultados dos avaliadores 1, 3 e 5 foram coincidentes para o critério Conteúdo. O critério Administração também obteve resultados similares dos avaliadores 4 e 5 .

Utilizando-se a fórmula para calcular a média geral dos critérios de avaliação dos sites, verifica-se que a média geral do site do Archivo Historico Nacional foi de 5,51 .

\section{$4,6 \times 23,91 \%+7,6 \times 23,91 \%+2,6 \times 15,22 \%+7,2 \times 21,74+4,2 \times 15,22=5,51$}

5

De acordo com a média geral do site, ele pode ser classificado como "suficiente". 


\section{Archivo Histórico Provincial de Álava}

Tabela 28 - Pontuação dos resultados dos critérios - AHPA

\begin{tabular}{c|c|c}
\hline Critério & média & desvio padrão \\
\hline Busca e recuperação & 4,80 & 3,42 \\
\hline Contéudo & 7,60 & 1,95 \\
\hline Autoridade & 2,20 & 1,64 \\
\hline Desenho & 7,20 & 1,64 \\
\hline Administração & 4,20 & 2,05 \\
\hline
\end{tabular}

Quanto ao Archivo Histórico provincial de Álava, todos os itens tem alto desvio padrão, mostrando a divergência dos avaliadores neste site. O critério Busca e Recuperação, com a média 4,8, foi avaliado como "regular", bem com o o critério Administração, com média 4,2. O critério Conteúdo neste site foi avaliado como "sobressalente", com média 7,6, sendo acompanhado do critério Desenho, classificado como "suficiente", com média 7,2. Já o critério Autoridade nesse site foi avaliado como "deficiente", com média 2,2.

Gráfico 10 - Pontuação dos resultados dos critérios por avaliador - AHPA

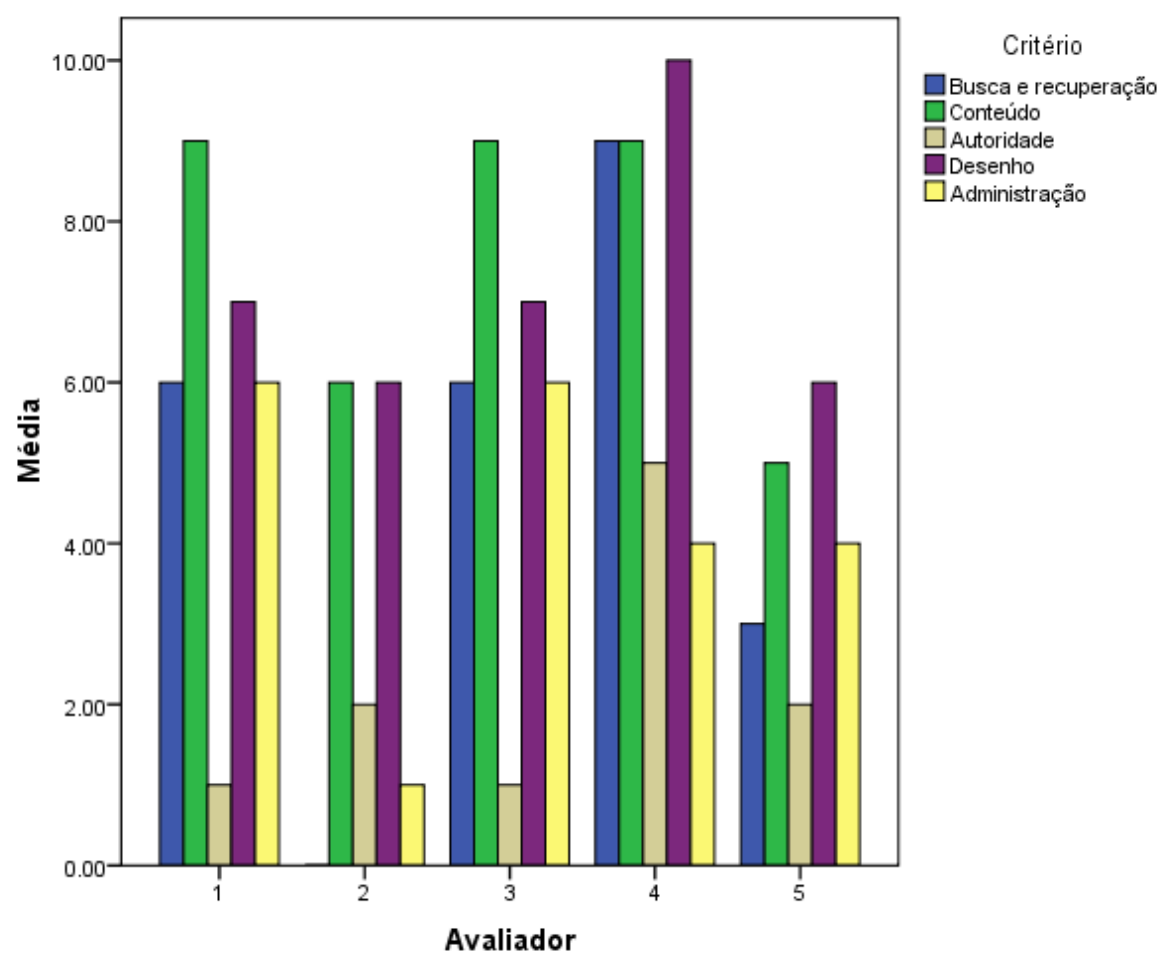


Os resultados dos avaliadores 1 e 3 foram coincidentes para todos os critérios como se pode observar no Gráfico 10. Os avaliadores 2 e 5 coincidiram nos resultados dos critérios Autoridade e Desenho. O critério Desenho recebeu maior pontuação do avaliador 4 . Os resultados dos avaliadores 1,3 e 4 foram coincidentes para o critério Conteúdo. $O$ critério Administração também obteve resultados similares dos avaliadores 4 e 5 .

Utilizando-se a fórmula para calcular a média geral dos critérios de avaliação dos sites, verifica-se que a média geral do site do Archivo Historico Provincial de Álava foi de 5,50:

De acordo com a média geral do site, pode-se afirmar que ele é considerado de boa qualidade sendo então classificado como "suficiente".

\section{Archivo Histórico Provincial de Guipúzcoa}

Tabela 29 - Pontuação dos resultados dos critérios - AHPG

\begin{tabular}{c|c|c} 
Critério & média & desvio padrão \\
\hline Busca e recuperação & 4,60 & 3,13 \\
\hline Contéudo & 7,60 & 1,95 \\
\hline Autoridade & 2,20 & 1,64 \\
\hline Desenho & 7,20 & 1,64 \\
\hline Administração & 4,20 & 2,05 \\
\hline
\end{tabular}

Quanto ao Archivo Histórico Provincial de Guipúzcoa, todos os critérios tem alto desvio padrão, mostrando a divergência dos avaliadores neste site. $\mathrm{O}$ critério Busca e Recuperação, com a média 4,6, indicam uma tendência a ser avaliado como suficiente. O conteúdo é avaliado como suficiente, com média 7,6 .

O Critério Autoridade desse site é avaliado como deficiente, com média 2,2 . 
O Critério desenho é avaliado como suficiente, com média 7,2. E o critério administração, em que a média é de 4,2 , tende para deficiente apesar de ser classificado como regular.

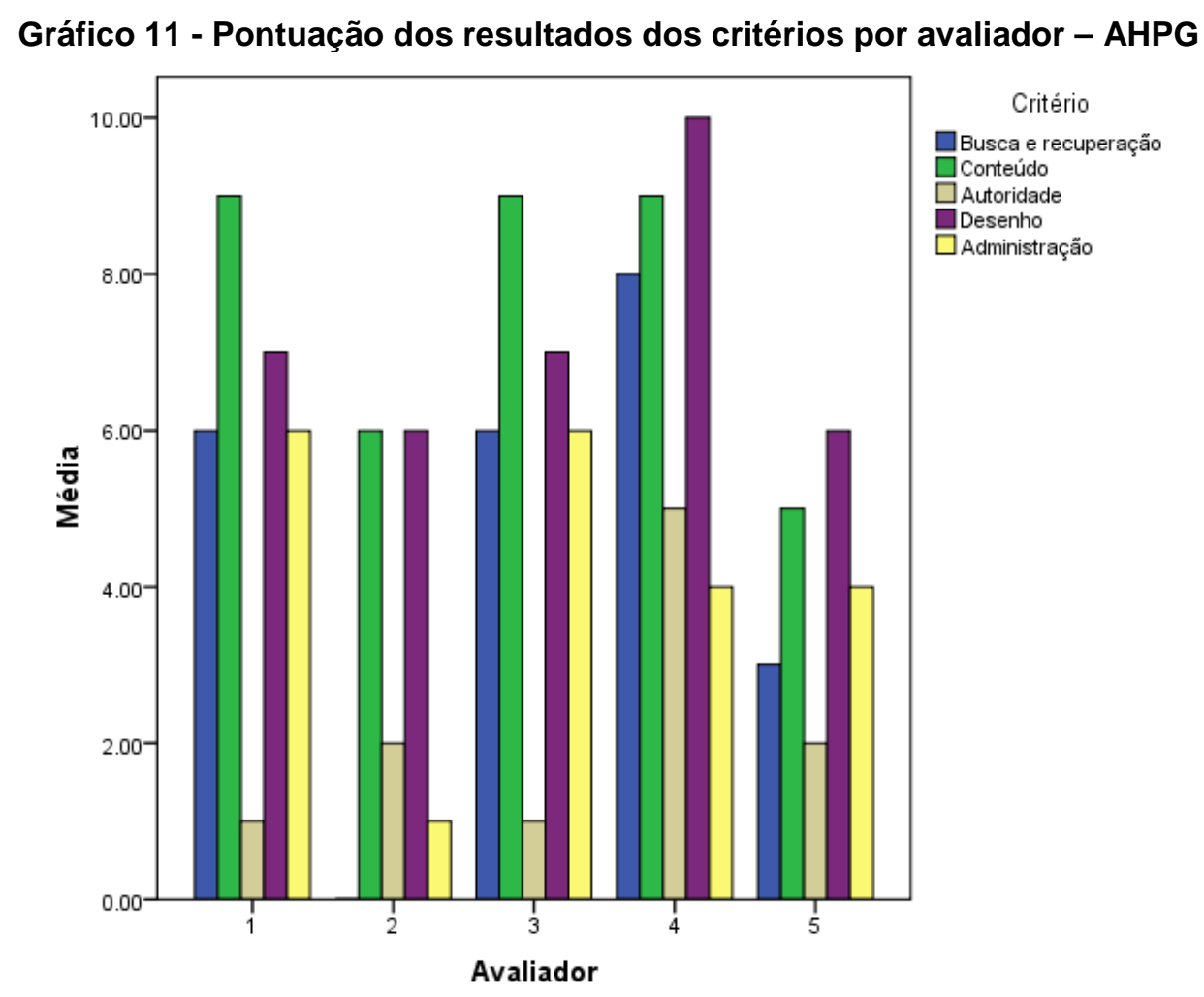

O Gráfico 11 demonstra que houve coincidência nos resultados dos avaliadores 1 e 3 para todos os critérios. Os avaliadores 2 e 5 coincidiram nos resultados dos critérios Autoridade e Desenho. O critério Desenho recebeu maior pontuação do avaliador 4. Os resultados dos avaliadores 1, 3 e 4 foram coincidentes para o critério Conteúdo. O critério Administração também obteve resultados similares dos avaliadores 4 e 5 .

Utilizando-se a fórmula para calcular a média geral dos critérios de avaliação dos sites, verifica-se que a média geral do site do Archivo Historico Provincial de Guipúzcoa foi de 5,45:

$4,6 \times 23,91 \%+7,6 \times 23,91 \%+2,2 \times 15,22 \%+7,2 \times 21,74+4,2 \times 15,22=5,45$ 
De acordo com a média geral do site, ele é classificado como "suficiente".

\section{Archivo Histórico Provincial de Vizcaya}

\begin{tabular}{c}
\multicolumn{3}{c}{ Tabela 30 - Pontuação dos resultados dos critérios - AHPV } \\
\begin{tabular}{c|c|c} 
Critério & média & desvio padrão \\
\hline Busca e recuperação & 4,60 & 3,13 \\
\hline Contéudo & 7,60 & 1,95 \\
\hline Autoridade & 2,20 & 1,64 \\
\hline Desenho & 7,20 & 1,64 \\
\hline Administração & 4,20 & 2,05 \\
\hline
\end{tabular}
\end{tabular}

Quanto ao Archivo Histórico Provincial de Vizcaya, todos os itens tem alto desvio padrão, mostrando a divergência dos avaliadores neste site. O critério Busca e Recuperação, com a média 4,6, indicam uma tendência a ser avaliado como suficiente. O conteúdo é avaliado como suficiente, com média 7,6.

O Critério Autoridade desse site é avaliado como deficiente, com média 2,2 .

O Critério desenho é avaliado como suficiente, com média 7,2. E o critério administração possui média de 4,2, que o classifica como regular.

Gráfico 12 - Pontuação dos resultados dos critérios por avaliador - AHPV 


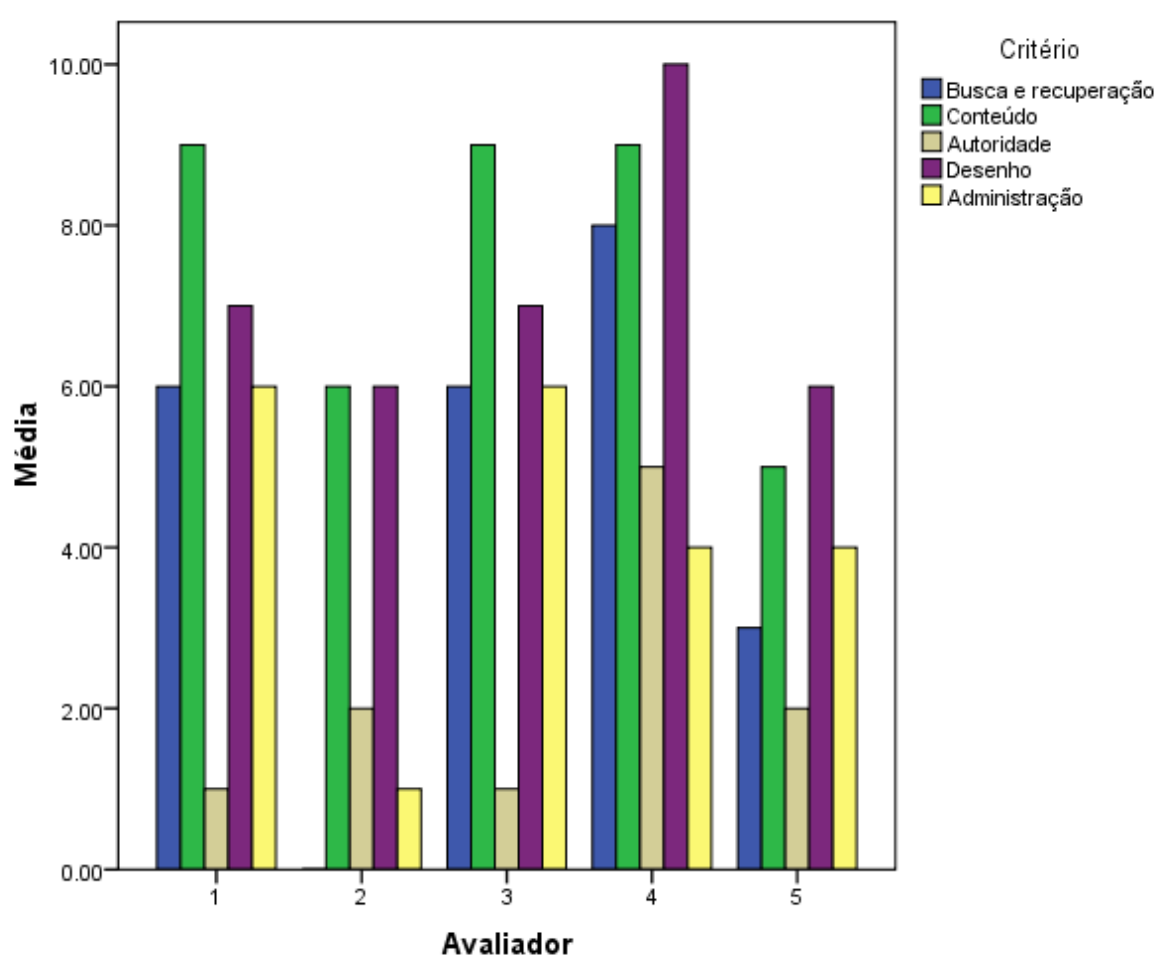

O Gráfico 12 demonstra que houve coincidência nos resultados dos avaliadores 1 e 3 para todos os critérios. Os avaliadores 2 e 5 coincidiram nos resultados dos critérios Autoridade e Desenho. $O$ critério Desenho recebeu maior pontuação do avaliador 4. Os resultados dos avaliadores 1,3 e 4 foram coincidentes para o critério Conteúdo. $O$ critério Administração também obteve resultados similares dos avaliadores 4 e 5 .

Utilizando-se a fórmula para calcular a média geral dos critérios de avaliação dos sites, verifica-se que a média geral do site do Archivo Historico Provincial de Vizcaya foi de 5,45:

$4,6 \times 23,91 \%+7,6 \times 23,91 \%+2,2 \times 15,22 \%+7,2 \times 21,74+4,2 \times 15,22=5,45$

5

De acordo com a média geral do site, pode-se afirmar que em geral ele é considerado de boa qualidade, pois é classificado como "suficiente". 


\section{Centro Documental de la Memoria Histórica}

Tabela 31 - Pontuação dos resultados dos critérios - CDMH

\begin{tabular}{c|c|c} 
Critério & média & desvio padrão \\
\hline Busca e recuperação & 4,60 & 3,13 \\
\hline Contéudo & 7,60 & 1,95 \\
\hline Autoridade & 2,20 & 1,64 \\
\hline Desenho & 7,20 & 1,64 \\
\hline Administração & 4,20 & 2,05 \\
\hline
\end{tabular}

Quanto ao Centro Documental de la Memoria Histórica, todos os itens tem alto desvio padrão, mostrando a divergência dos avaliadores neste site. O critério Busca e Recuperação, com a média 4,6, com um desvio padrão 3,13 indicam uma tendência a ser avaliado como suficiente. O conteúdo é avaliado como sobressalente, com média 7,6. O critério autoridade desse site é avaliado como deficiente, com média 2,2. O critério desenho é avaliado como suficiente, com média 7,2. O critério administração, com média de 4,2 é classificado como regular.

Gráfico 13 - Pontuação dos resultados dos critérios por avaliador - CDMH 


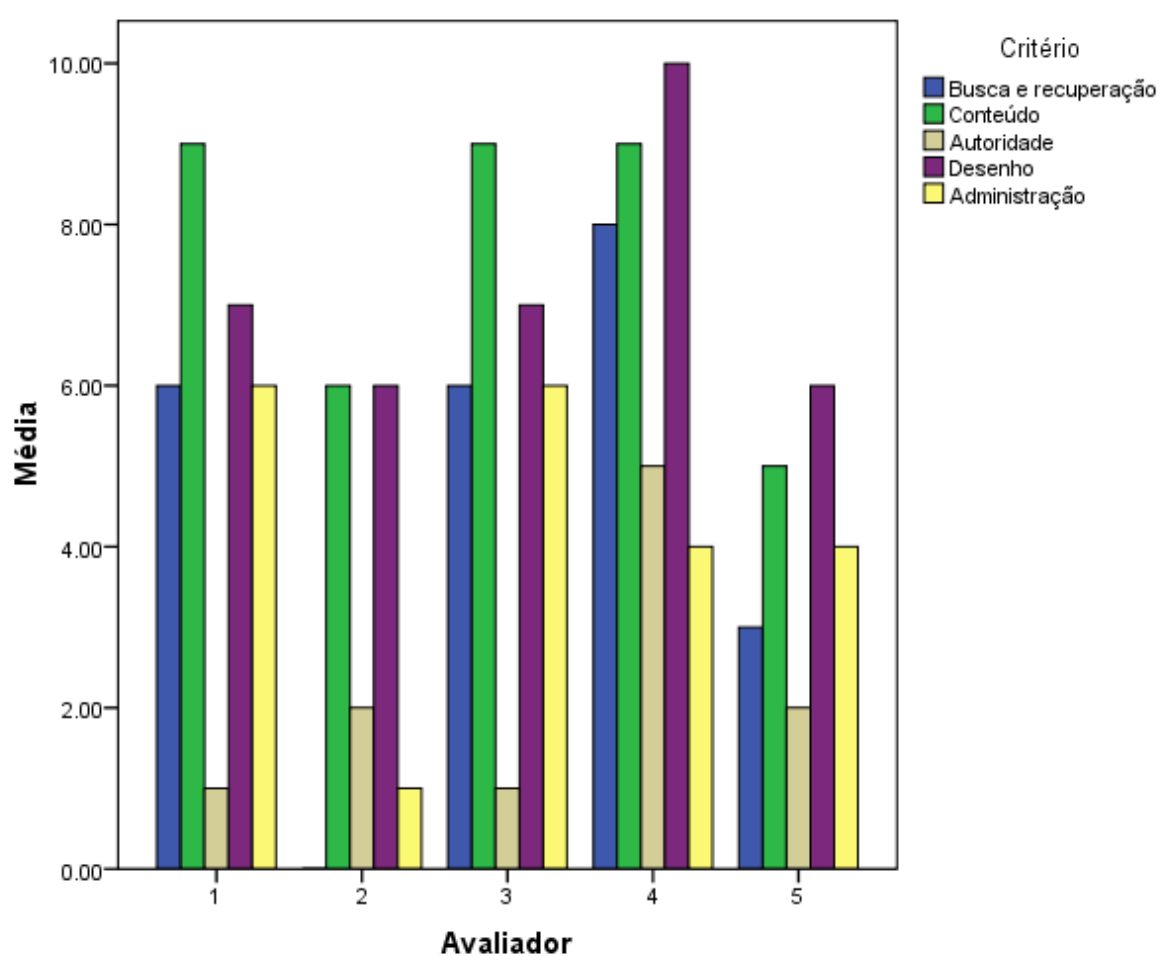

Utilizando-se a fórmula para calcular a média geral dos critérios de avaliação dos sites, verifica-se que a média geral do site do Centro Documental da Memoria Historica foi de 5,45:

$4,6 \times 23,91 \%+7,6 \times 23,91 \%+2,2 \times 15,22 \%+7,2 \times 21,74+4,2 \times 15,22=5,45$

5

De acordo com o Peso Total do site, ele é classificado como "suficiente".

12. Sección Nobleza Archivo Histórico Nacional

Tabela 32 - Pontuação dos resultados dos critérios - SNAHN

\begin{tabular}{c|c|c} 
Critério & Média & desvio padrão \\
\hline Busca e recuperação & 4,60 & 3,13 \\
\hline Contéudo & 7,60 & 1,95 \\
\hline Autoridade & 2,20 & 1,64 \\
\hline Desenho & 7,20 & 1,64 \\
\hline Administração & 4,20 & 2,05 \\
\hline
\end{tabular}


Quanto ao Sección Nobleza Archivo Histórico Nacional, todos os itens tem alto desvio padrão, mostrando a divergência dos avaliadores neste site. $O$ critério Busca e Recuperação, com a média 4,6 e moda 6, com um desvio padrão 3,13 indicam uma tendência a ser avaliado como suficiente. O Conteúdo é avaliado como sobressalente, com média 7,6 e moda 9. O Critério desenho é avaliado como suficiente, com média 7,2 e moda 6 . E o critério administração, em que a média é de 4,2 e moda 4, é classificado como regular com tendência se classificado como deficiente por causa do desvio padrão alto (2). Já o Critério Autoridade desse site é avaliado como deficiente, com média 2,2 e moda 1.

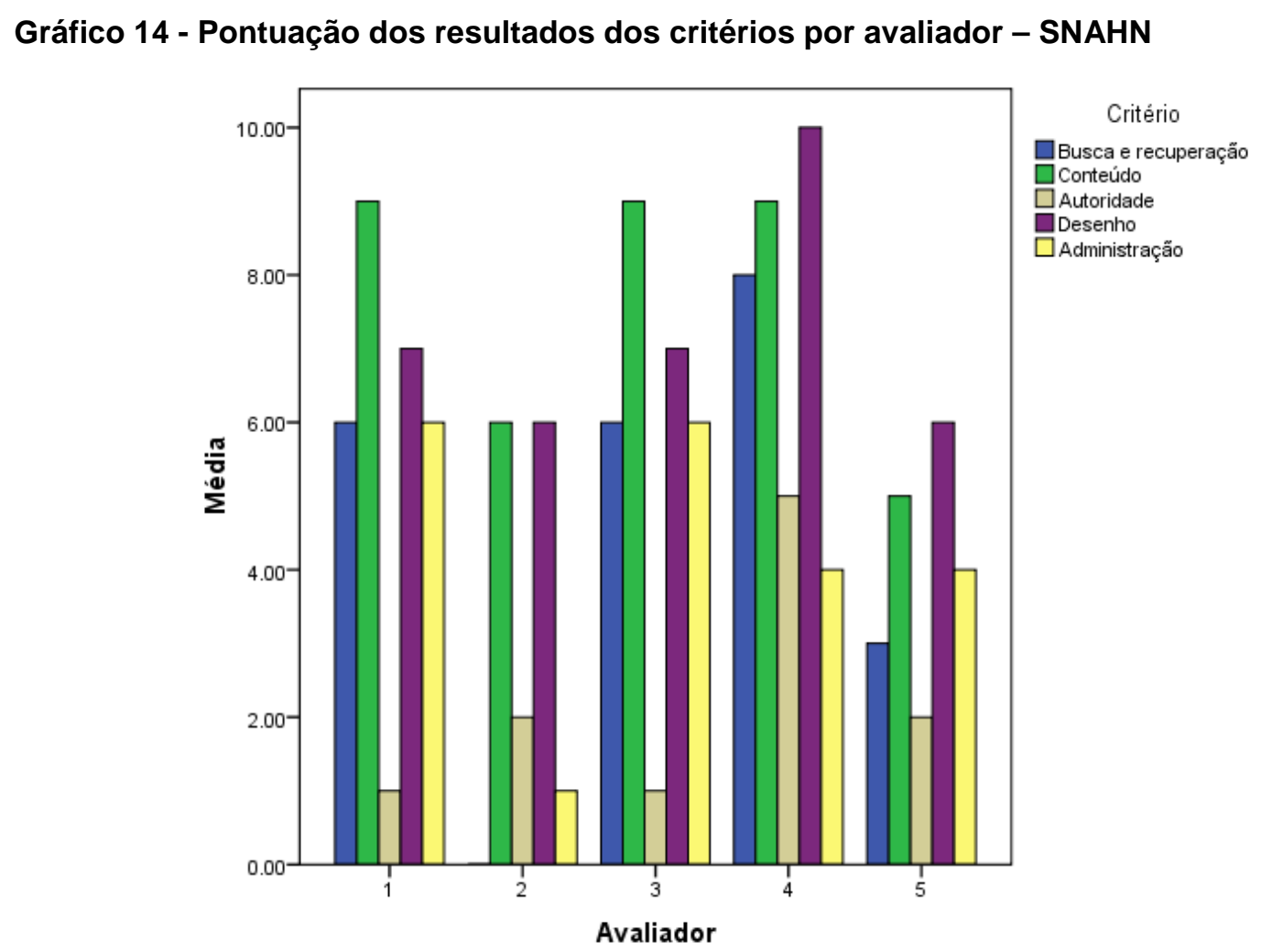

Utilizando-se a fórmula para calcular a média geral dos critérios de avaliação dos sites, verifica-se que a média geral do site da Sección Nobleza Archivo Histórico Nacional foi de 5,45: 
De acordo com a média geral do site, pode-se afirmar que ele é "suficiente".

Tendo em vista os resultados apresentados, conclui-se que todos os sites dos Arquivos estatais espanhóis avaliados possuem boa qualidade, isto significa que o site do MCU é considerado de boa qualidade, mantendo-se regular em todos os aspectos que o compõem, com consistência e coerência.

Apesar de os sites avaliados terem apresentado, nessa primeira análise, um resultado positivo, em termos de qualidade, considerou-se prudente realizar uma nova investigação uma vez que houve uniformidade nos resultados pelo fato de as páginas Web dos 11 arquivos avaliados se encontrarem hospedados no site do Ministério da Cultura da Espanha e, portanto, seguirem o mesmo padrão de apresentação, o que restringiu a análise, configurando caso de limitação do instrumento de avaliação, justificando assim a necessidade de ampliar a investigação para outras páginas Web de arquivos. Para a avaliação posterior, aqui chamada Avaliação propriamente dita, considerou-se a orientação de um Mestre em Usabilidade, segundo o qual a autora não deveria participar como avaliadora como ocorreu na avaliação preliminar, pois esse fato pode comprometer os resultados, uma vez que o autor normalmente tende a interferir com uma visão particularizada dos fatos podendo distorcer as informações. A autora, portanto, deveria concentrar-se apenas em analisar os resultados da coleta de dados.

Com o aprofundamento no estudo a respeito dos critérios de avaliação de sites, e, na tentativa de encontrar outras páginas Web de arquivos espanhóis, considerou-se a importância do critério da Visibilidade para o caso específico dos Arquivos, já que os mesmos não são percebidos como centros modernos de informação, ou seja, ainda há uma dissimetria entre Arquivo e informatização. Possivelmente, isso ocorre pela carga semântica arcaica que a palavra Arquivo suscita.

Nessa perspectiva, além de tomar conhecimento de outros arquivos que possuem páginas na Internet, ao investigar a Usabilidade, outro critério de fundamental importância de um site, resgata-se a sua real situação e facilidade de uso. 
Essas questões foram consideradas uma vez que, para enfrentar o processo evolutivo tecnológico atual e aproximar a informação de Arquivo da perspectiva do mundo globalizado, faz-se necessário tornar os Arquivos mais visíveis para a sociedade. Essa necessidade, advinda do fato de o espaço virtual coexistir com o espaço real, e, ambas complementarem-se mutuamente, sugere uma ideia de universalidade e, portanto, a democratização dessa realidade vem através da Visibilidade.

Acredita-se que existam dois aspectos da Visibilidade: um que é a visibilidade da informação dentro da própria página de internet e a Visibilidade do site dentro da Web.

Assim, a partir dessa nova compreensão, considerou-se apropriado, a utilização de novas ferramentas de avaliação com novo universo de pesquisa.

\subsection{DISCUSSÃO INICIAL DA AVALIAÇÃO PROPRIAMENTE DITA}

A Avaliação propriamente dita teve a coleta de dados realizada em outubro de 2010, quando foi realizado o teste de usuários na Universidade Federal de Pernambuco, com alunos de mestrado em Ciência da Informação, no laboratório de informática. A segunda etapa do teste de usuários foi realizada com estagiários da Fundação Joaquim Nabuco, perfazendo um total de 15 usuários.

A decisão de convidar dois públicos distintos de usuários para o teste se justifica pelo fato de que se pretendia ampliar as possibilidades de divergência nas respostas, constituindo assim uma maneira de certificar se de fato o site apresenta falha em algum aspecto ou apresenta algum ponto positivo, uma vez que os usuários se encontravam em um ambiente distinto, com estímulos externos distintos e nível de escolaridade também distintos, pois os estagiários ainda cursam a Universidade e todos os alunos do Mestrado já concluíram os estudos de nível superior. Assim sendo, as coincidências nas respostas revelam de fato os erros e acertos, ou melhor dito, os pontos positivos e negativos dos sites. 
Os usuários deveriam entrar nos sites e responder ao questionário do teste com questões objetivas, como as de ordem pessoal, bem como em questões que dependiam da realização de pequenas tarefas relativas ao site, preenchendo um questionário para cada site.

Com relação aos avaliadores dos sites, convidou-se 4 especialistas em criação, desenvolvimento e manutenção de sites, os quais receberam a devida orientação para o preenchimento do questionário com questões a respeito da visibilidade e da usabilidade. Eles deveriam preencher um questionário para cada um dos quatorze sites e trabalhar separadamente, sem colaboração mútua, manifestando sua impressão pessoal a respeito do site para posteriormente comentarem entre si os resultados e decidir sobre alguns aspectos em que gostariam de ouvir opinião dos colegas.

Para os testes de usuário, as variáveis selecionadas para avaliar essas Websites foram:

1. Tempo de avaliação

2. Posição dos sites nos motores de busca Google e Yahoo

3. Primeira impressão causada pelo site

4. Ferramenta de busca

5. Coerência dos links e necessidade de treinamento

6. Linguagem do site.

7. Impressão geral do site.

Já o questionário dos avaliadores estava dividido em duas partes, a primeira chamada "Avaliação a respeito da Visibilidade" e a segunda, "Avaliação Heurística de Usabilidade". A primeira, composta por quatro questões, em que os avaliadores deveriam pontuar de 0 a 2 os indicadores, apresentava as seguintes variáveis:

1. Metadados padronizados

2. Informações a respeito da Instituição

3. Garantia de autenticidade

4. Posição natural (aqui chamada orgânica) nos resultados das buscas 
A segunda parte do questionário dos avaliadores era composta por 25 questões, que correspondiam aos indicadores das heurísticas, em que os avaliadores deveriam indicar o grau de severidade, de acordo com Nielsen (2000), dos problemas encontrados nos sites, numa escala de 0 a 4.

Esta pontuação de severidade serviu para classificar os maiores e menores problemas de usabilidade de acordo com as heurísticas propostas para este estudo. (Cap. 5, seção 5.2.1.1).

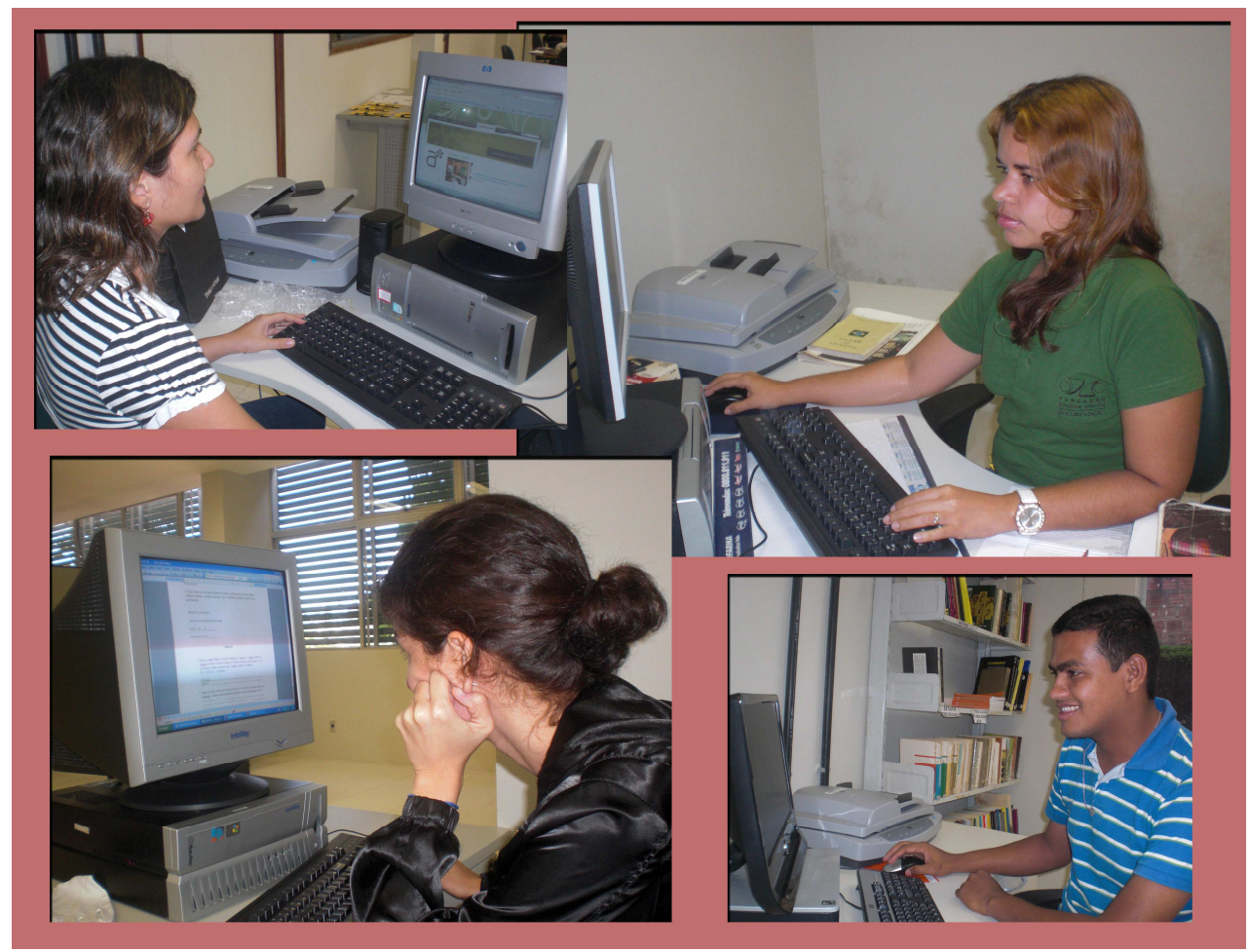

Figura 22 - Foto do Teste com usuários da Fundaj (estagiários)

\subsection{Análise dos resultados do teste de usuários}

Para a análise dos resultados dos testes de usuário, consideramos as duas experiências como apenas um "corpo", ou seja, reunimos os resultados dos testes com os mestrandos da UFPE e os resultados dos testes com os estagiários da Fundaj. Ao todo foram entrevistados 15 usuários, sendo 8 alunos de Mestrado e 7 estagiários da Fundaj. 
Para compor o questionário destinado ao teste com usuários da Avaliação Propriamente dita, foram utilizadas questões gerais para avaliar os sites em estudo, sendo a primeira questão destinada a avaliar a Visibilidade e as demais para avaliar a Usabilidade destes, uma vez que o objetivo do teste de usuários é justamente conhecer a interação do mesmo com o sistema. O questionário apresentava seis questões as quais estão listadas a seguir:

1. O usuário deveria buscar a URL do Arquivo, utilizando o Google e o Yahoo e anotar a posição em que a página Web do Arquivo aparece nos resultados. A posição do site nos resultados, como visto anteriormente, revela boa visibilidade em rede.

2. Uma vez encontrado o site do Arquivo, deveria clicar no link do mesmo e observar se a página demorava a carregar. Comentar qual a primeira impressão que teve da homepage do site. A primeira impressão pode garantir que o usuário permaneça no site ou imediatamente busque a outro comprometendo a usabilidade do mesmo.

3. O usuário deveria observar se existe na página Web uma lupa ou um ícone que represente a possibilidade de fazer pesquisas dentro dela. Depois deveriam marcar com um $X$ se haviam encontrado ou não a lupa $e$ comentar o grau de dificuldade. A lupa favorece encontrar mais rapidamente o que se deseja e é uma ferramenta que favorece a usabilidade.

4. Ao navegar livremente pelo site, o usuário deveria comentar se os links clicados correspondiam ao que se imaginava ou seja, se havia coerência entre o link e o conteúdo que aparece. O usuário deveria observar se ele navega intuitivamente, ou seja, sem necessitar de treinamento anterior nem exigir esforço de sua parte.

5. O usuário deveria observar se o conteúdo do site utiliza uma linguagem clara e simples, em seguida marcar com um X em simples ou complexa e justificar resposta. De acordo com Morkens e Nielsen (1997), os estudos sobre como os usuários lêem na Web revelaram que na verdade eles não lêem e sim fazem uma varredura no texto, e os sites que utilizam uma linguagem concisa, pesquisável (entendível) e objetiva ao mesmo tempo podem aumentar até $124 \%$ sua usabilidade. A utilização dos termos simples ou complexa para a linguagem do site

6. Nesta última questão, o usuário deveria descrever, em termos gerais, a sensação que teve ao navegar no site, ou seja, quais foram suas 
impressões pessoais a respeito da estética e do conteúdo do site em geral. As características observadas pelo usuário depois de realizar as tarefas podem confirmar ou modificar sua pimeira impressão ou acrescentar alguma opinião que reflita verdadeiramente a sua interação com o sistema.

Analisa-se a seguir os resultados obtidos no teste de usuários de acordo com cada variável:

\section{Variável 1 - Tempo de avaliação do site}

A variável Tempo de avaliação do site corresponde ao tempo que os usuários levaram para concluir as tarefas referentes a cada Arquivo. Essa variável é relativa, pois depende da habilidade do usuário em navegar na Web. Pensou-se inicialmente que durante o teste com os usuários, tanto com os usuários da UFPE quanto com os da Fundaj, que à medida que se familiarizavam com as tarefas, concluíam mais rapidamente as avaliações seguintes. Isso, porém, não foi comprovado, como observa-se no gráfico a seguir.

Para análise dos dados dessa variável, desconsiderou-se os resultados com pontuação zero, ou seja, somente foram consideradas as situações válidas e não aquelas não encontradas.

Tabela 33 - Estatística descritiva - Tempo de Avaliação

\begin{tabular}{c|c|c|c}
\hline Mínimo & máximo & média & desvio \\
\hline 2 & 50 & 10,13 & 7,48 \\
\hline
\end{tabular}

A estatística descritiva do tempo de avaliação dos usuários revela que, em média, cada usuário demorou 10,13 minutos para realizar as atividades avaliativas. Além disso, como o valor do desvio padrão $(7,48)$ se aproxima do valor da média, é possível afirmar que a distribuição é bastante heterogênea. Ou seja, existem valores muito abaixo da média e valores bem acima do termo médio. Uma forma de visualizar esse fenômeno diz respeito aos tempos mínimo e máximo. A avaliação mais rápida foi realizada em 2 minutos. No outro oposto tem- 
se a duração de 50 minutos referente à avaliação mais demorada. A tabela abaixo desagrega esses dados por usuário.

Tabela 34 - Estatística descritiva - Tempo de avaliação por Usuário

\begin{tabular}{c|c|c|c}
\hline Usuário & média & desvio padrão & coeficiente de variação \\
\hline 1 & 7,43 & 2,95 & 0,40 \\
\hline 2 & 4,85 & 2,15 & 0,44 \\
\hline 3 & 4,79 & 2,61 & 0,54 \\
\hline 4 & 2,64 & 0,84 & 0,32 \\
\hline 5 & 12,46 & 3,02 & 0,24 \\
\hline 6 & 12,71 & 6,59 & 0,52 \\
\hline 7 & 15,83 & 4,69 & 0,30 \\
\hline 8 & 8,00 & 3,62 & 0,45 \\
\hline 9 & 8,75 & 3,41 & 0,39 \\
\hline 10 & 7,79 & 2,69 & 0,35 \\
\hline 11 & 9,86 & 3,68 & 0,37 \\
\hline 12 & 8,21 & 4,21 & 0,51 \\
\hline 13 & 6,71 & 2,52 & 0,38 \\
\hline 14 & 15,21 & 6,07 & 0,40 \\
\hline 15 & 28,15 & 11,24 & 0,40 \\
\hline & & &
\end{tabular}

O gráfico a seguir replica essas informações. 
Gráfico 15 - Tempo de avaliação por Usuário (decrescente) - em minutos

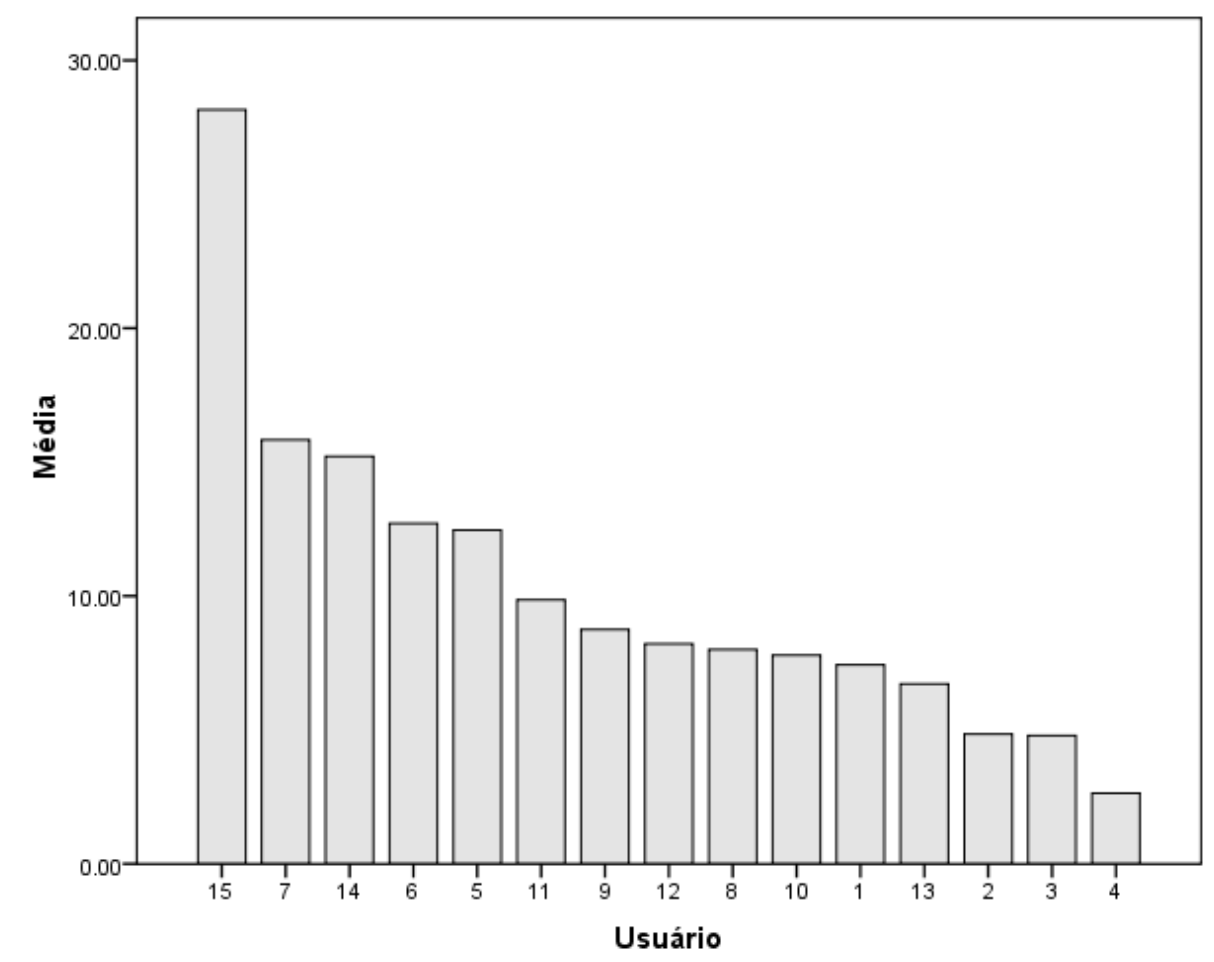

No gráfico acima, o eixo $X$ (linha horizontal) representa o número de cada usuário. Já o eixo Y (linha vertical) representa a média de tempo despendido por usuário para avaliar os diferentes arquivos. Como pode ser observado, o usuário 15 apresentou, em média, o maior tempo $(28,15)$, com um desvio padrão de 11,24 e um coeficiente de variação de 0,40 . Em segundo lugar, aparece o usuário $7 \mathrm{com}$ uma média de 15,83, com um desvio padrão de 4,69 e um coeficiente de variação de 0,30. Tem-se, ainda, o usuário 14 que apresentou uma média de 15,21, um desvio padrão de 6,07 e um coeficiente de variação de 0,40. No outro oposto da distribuição, tem-se os usuários 4,3 e 2, respectivamente. O usuário 4 apresentou a menor média $(2,64)$, com um desvio padrão de 0,84 e um coeficiente de variação de 0,32 . Por sua vez, o usuário 3 apresentou uma média de 4,79, com um desvio padrão de 2,61 e um coeficiente de variação de 0,54 . Já o usuário 2 apresentou uma média de 4,85, com um desvio padrão de 2,15 e um coeficiente de variação de 0,44. Em termos substanciais, esses dados sugerem que existe muita variabilidade no que diz respeito ao tempo de avaliação dos arquivos pelos usuários.

A tabela, a seguir, apresenta a distribuição do tempo de avaliação por Arquivo. 
Tabela 35 - Estatística descritiva - Tempo de avaliação por Arquivo - em minutos

\begin{tabular}{c|c|c|c} 
Arquivo & \multicolumn{1}{c}{ média } & \multicolumn{1}{c}{ desvio padrão } & coeficiente de variação \\
\hline ADS & 13,54 & 10,47 & 0,77 \\
\hline AEG & 9,93 & 5,96 & 0,60 \\
\hline AGMA & 7,60 & 4,19 & 0,55 \\
\hline AGS & 9,40 & 5,54 & 0,59 \\
\hline AHA & 9,60 & 7,99 & 0,83 \\
\hline AHEV & 11,87 & 9,94 & 0,84 \\
\hline AHN & 12,93 & 5,97 & 0,46 \\
\hline AHPG & 10,40 & 9,11 & 0,88 \\
\hline AHPGR & 9,57 & 7,22 & 0,75 \\
\hline AHPH & 10,27 & 6,53 & 0,64 \\
\hline AHVL & 8,43 & 6,63 & 0,79 \\
\hline AMS & 6,30 & 2,31 & 0,37 \\
\hline AUS & 9,33 & 5,65 & 0,61 \\
\hline AVME & 11,73 & 11,22 & 0,96
\end{tabular}

Gráfico 16 - Tempo de avaliação por Arquivo (decrescente) - em minutos

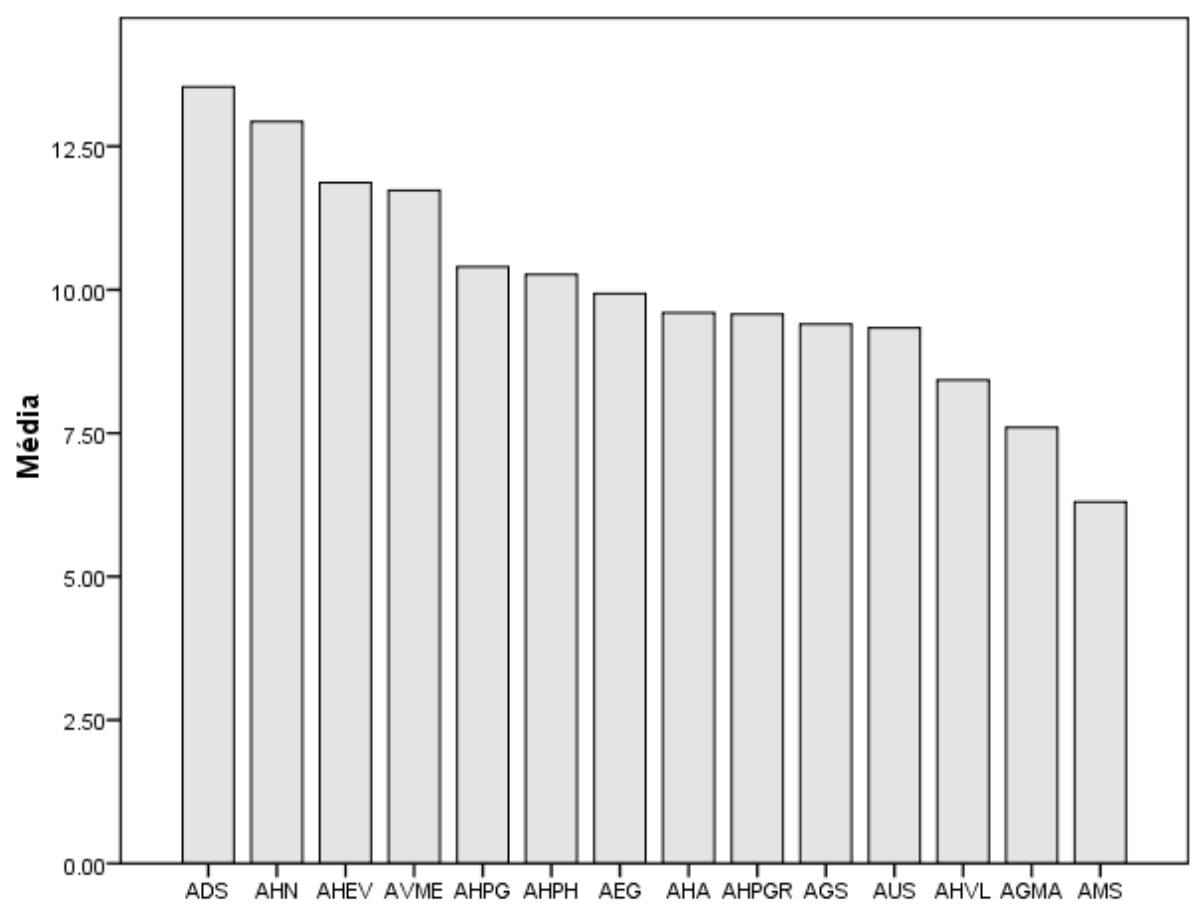


Em comparação aos demais Arquivos, o Archivo de la Diputación de Sevilla (ADS) foi aquele que os usuários, em média, consumiram mais tempo para avaliar (13,54). Em segundo lugar, aparece o Archivo Histórico Nacional (AHN) com um tempo médio de 12,93, com um desvio padrão de 5,97 e um coeficiente de variação de 0,46. Tem-se, em terceiro lugar, o Archivo Histórico Eclesiástico de Vizcaya (AHEV) com uma média de 11,87, um desvio padrão de 9,94 e um coeficiente de variação de 0,84 . No outro oposto da distribuição, tem-se o Archivo Municipal de Santander com uma média de 6,30, um desvio padrão de 2,31 e um coeficiente de variação de 0,37. Importante destacar, também, o Archivo General Militar de Avila (AGMA) e o Archivo de Hullera Vasco-Leonesa (AHVL). Enquanto o primeiro apresentou média de 7,60, com um desvio padrão de 4,19 e um coeficiente de variação de 0,55 , o segundo demonstrou uma média de 8,43, com um desvio padrão de 6,63 e um coeficiente de variação de 0,79. Esses dados sugerem que existe muita variabilidade no que diz respeito ao tempo de avaliação por arquivo.

\section{Variável 2 - Posição dos sites nos Motores de Busca Google e Yahoo}

Nessa variável medem-se os resultados da busca, utilizando os dois grandes motores de busca Google e Yahoo. Os usuários deveriam buscar os Arquivos pelo nome através desses dois motores de busca. Exemplo: "Archivo Histórico Nacional", verificar em que posição dos resultados da busca aparece o site do Arquivo. 
Gráfico 17 - Posição do site nos buscadores

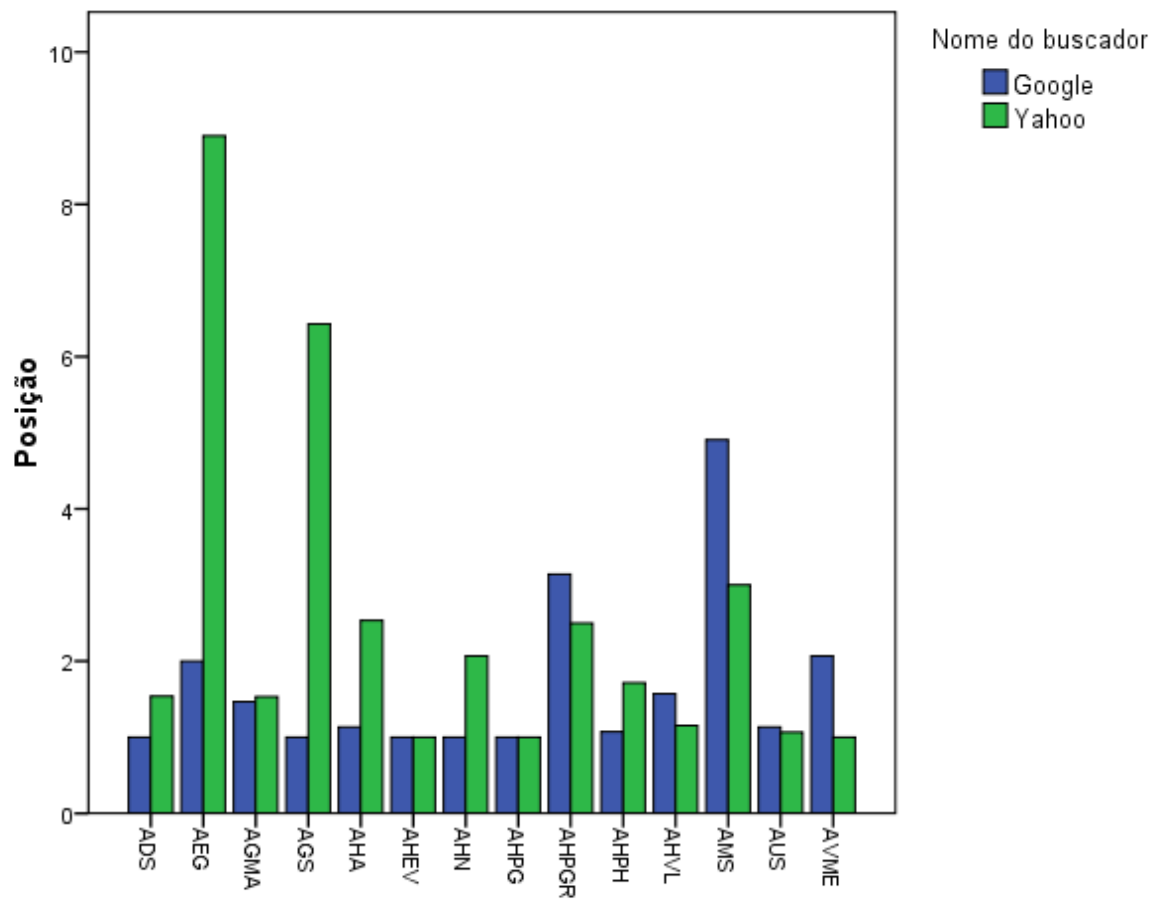

Decidiu-se agrupar os sites pela facilidade de localização em três grupos: sites fáceis de serem localizados pelos dois motores de buscas; sites fáceis de serem localizados por um dos motores e os sites difíceis de serem localizados através dos dois motores.

\begin{tabular}{|c|c|c|}
\hline $\begin{array}{c}\text { Sites fáceis de serem } \\
\text { localizados pelos dois } \\
\text { motores }\end{array}$ & $\begin{array}{c}\text { Sites fáceis de serem } \\
\text { localizados por um dos } \\
\text { motores }\end{array}$ & $\begin{array}{c}\text { Sites difíceis de serem } \\
\text { localizados pelos dois } \\
\text { motores }\end{array}$ \\
\hline AHN & AHA & AMS \\
\hline ADS & AGS & \\
\hline AVME & AEG & \\
\hline AHPH & & \\
\hline AGMA & & \\
\hline AUS & & \\
\hline AHPG & & \\
\hline AHVL & & \\
\hline Quadro 30 & & \\
\hline
\end{tabular}

Quadro 30 - Agrupamento dos sites pela facilidade de localização 
Essa variável é significativa para a análise da Visibilidade dos sites. É importante dizer, no entanto, que algumas diferenças encontradas com relação à posição dos sites nos Motores de Buscas, possivelmente estejam relacionadas com a habilidade do usuário para encontrar rapidamente a página. Depende, por exemplo, da utilização de operadores boleanos, como por exemplo, a utilização de aspas: colocar o nome do Arquivo entre aspas especificar o site desejado no momento da busca.

No entanto, no caso do Archivo Municipal de Santander e do Archivo Histórico Provincial de Granada, os resultados indicaram que eles tiveram, em geral, problemas para ser encontrados através das buscas, isso significa provavelmente que os metadados destes sites não estão suficientemente adequados, pois as páginas não são visualizadas facilmente.

\section{Variável 3 - Primeira impressão causada pelo site}

\section{Archivo Histórico Nacional (AHN)}

A maioria dos usuários considerou que o site desse Arquivo não demora a carregar, ou seja, tem um rápido carregamento da página, apresenta layout organizado e agradável, com informações claras e que é bem estruturado. Somente uma minoria considerou o tamanho da fonte pequena. Isso significa que o site desse Arquivo causou inicialmente uma boa impressão nos usuários. A tabela a seguir sumariza essas informações.

Tabela 36 - Primeira Impressão - AHN

\begin{tabular}{c|c|c} 
Caracteristicas & \multicolumn{1}{c}{ N } & $\%$ \\
\hline Rapidez ao carregar & 12 & 80,00 \\
\hline Bom layout & 7 & 46,67 \\
\hline Bom conteúdo & 9 & 60,00 \\
\hline Bom uso de cores & 1 & 6,67 \\
\hline
\end{tabular}




\section{Archivo Del La Diputación de Sevilla}

Esse site teve um consenso entre os usuários, que o consideraram acessível, rápido na transferência de dados, agradável, interface simples, design agradável. Somente uma minoria considerou que o site possuía muitos espaços em branco e apenas um usuário teve uma má impressão da interface, provavelmente por uma questão de preferência pessoal. Pode-se inferir, a partir dessas colocações, que a primeira impressão sobre o site é que ele é acessível e agrada à maioria dos usuários, precisando, porém, reestruturar seu layout.

Tabela 37 - Primeira Impressão - ADS

\begin{tabular}{c|c|c} 
Caracteristicas & N & $\%$ \\
\hline Rapidez ao carregar & 7 & 46,67 \\
\hline Bom layout & 3 & 20,00 \\
\hline Bom conteúdo & 5 & 33,33 \\
\hline Bom uso de cores & 1 & 6,67 \\
\hline Interface amigável & 2 & 13,33 \\
\hline
\end{tabular}

\section{Archivo Vasco de La Música Eresbil}

A maioria dos usuários avaliou positivamente este site, afirmando que o carregamento era rápido, considerou o visual agradável, a interface amigável e bom uso de cores. Um usuário afirmou que o site "hão carregava". Alguns se queixaram de que algumas imagens demoraram para abrir. Apenas um usuário afirmou que o layout era "malfeito". 
Isso significa que apesar de o site, à primeira impressão, agradar à maioria, desagrada em alguns aspectos particulares, principalmente no que se refere ao carregamento das imagens.

Tabela 38 - Primeira Impressão - AVME

\begin{tabular}{c|c|c} 
Caracteristicas & N & $\%$ \\
\hline Rapidez ao carregar & 5 & 33,33 \\
\hline Bom layout & 3 & 20,00 \\
\hline Bom conteúdo & 1 & 6,67 \\
\hline Bom uso de cores & 3 & 20,00 \\
\hline Interface amigável & 2 & 13,33 \\
\hline
\end{tabular}

Archivo Histórico Provincial de Huesca

Esse site foi avaliado positivamente pela maioria dos usuários, que o consideraram de fácil carregamento, interface "amigável", links organizados, e consideraram a homepage "limpa" e "agradável". Somente um usuário a considerou confusa.

Tabela 39 - Primeira Impressão - AHPH

\begin{tabular}{c|c|c} 
Caracteristicas & 7 & 46,67 \\
\hline Rapidez ao carregar & 4 & 26,67 \\
\hline Bom layout & 1 & 6,67 \\
\hline Bom conteúdo & $\cdot$ & $\cdot$ \\
\hline Bom uso de cores & & \\
\hline Interface amigável & 4 & 26,67 \\
\hline
\end{tabular}


A maioria dos usuários considerou que a página tem bom carregamento, bom formato, bom design, boa estética e bom uso de cores. Alguns usuários, porém, queixaram-se da demora no carregamento. Isso indica que o site causou uma primeira impressão positiva para a maioria dos entrevistados e apenas para alguns o tempo de carregamento da página foi considerado um problema. Esta demora no carregamento provavelmente foi consequência de algum problema momentâneo de conexão.

\begin{tabular}{c|c|c}
\multicolumn{2}{c}{ Tabela 40 - Primeira Impressão - AHEV } \\
Caracteristicas & N & $\%$ \\
\hline Rapidez ao carregar & 4 & 26,67 \\
\hline Bom layout & 9 & 60,00 \\
\hline Bom conteúdo & 1 & 6,67 \\
\hline Bom uso de cores & 3 & 20,00 \\
\hline Interface amigável & 2 & 13,33 \\
\hline
\end{tabular}

Archivo Histórico de Astúrias (AHA)

Para a maioria dos usuários, a primeira impressão é que o site carrega rápido, é de fácil navegação e tem bom uso de cores. Uma minoria considera o carregamento lento e apenas um usuário considera a página confusa visualmente. 
Tabela 41 - Primeira Impressão - AHA

\begin{tabular}{c|c|c}
\hline Caracteristicas & N & $\%$ \\
\hline Rapidez ao carregar & 9 & 60,00 \\
\hline Bom layout & 2 & 13,33 \\
\hline Bom conteúdo & 2 & 13,33 \\
\hline Bom uso de cores & 1 & 6,67 \\
\hline Interface amigável & 4 & 26,67 \\
\hline
\end{tabular}

Archivo General Militar de Ávila (AGMA)

Os usuários classificaram positivamente o site, com carregamento rápido, interface neutra, bom uso de cores, bom design e layout agradável, com apenas uma opinião divergente.

Tabela 42 - Primeira Impressão - AGMA

\begin{tabular}{c|c|c} 
Caracteristicas & N & $\%$ \\
\hline Rapidez ao carregar & 5 & 33,33 \\
\hline Bom layout & 3 & 20,00 \\
\hline Bom conteúdo & 3 & 20,00 \\
\hline Bom uso de cores & 3 & 20,00 \\
\hline Interface amigável & 3 & 20,00 \\
\hline
\end{tabular}


Embora este site tenha sido considerado de rápido carregamento, a maioria dos usuários o considera pouco interativo, pouco atrativo e muito carregado de informações. Essa opinião pode ser avaliada pelo seguinte ponto de vista: um site muito carregado de informação pode significar que as informações importantes estão ofuscadas, podendo dificultar a navegação no site.

Tabela 43 - Primeira Impressão - AUS

\begin{tabular}{c|c|c}
\hline Caracteristicas & N & $\%$ \\
\hline Rapidez ao carregar & 7 & 46,67 \\
\hline Bom layout & 1 & 6,67 \\
\hline Bom conteúdo & 2 & 13,33 \\
\hline Bom uso de cores & $\cdot$ & $\cdot$ \\
\hline Interface amigável & $\cdot$ & $\cdot$ \\
\hline
\end{tabular}

Archivo General de Simancas (AGS)

Este site foi avaliado positivamente pela maioria dos usuários em todos os aspectos: carregamento rápido, interface "amigável", agradável, possui layout organizado, bom uso de imagens, informações diversificadas na homepage. Consideraram o site em geral simples e objetivo. 
Tabela 44 - Primeira Impressão - AGS

\begin{tabular}{c|c|c}
\hline Caracteristicas & N & $\%$ \\
\hline Rapidez ao carregar & 8 & 53,33 \\
\hline Bom layout & 6 & 40,00 \\
\hline Bom conteúdo & 3 & 20,00 \\
\hline Bom uso de cores & $\cdot$ & $\cdot$ \\
\hline Interface amigável & 7 & 46,67 \\
\hline
\end{tabular}

Archivo Municipal de Santander (AMS)

Houve diferenças de opinião entre os usuários. A maioria, porém, o considerou, "funcional", bem construído, atrativo, rápido carregamento das páginas e layout agradável. Três dos usuários não opinaram a respeito desse site. O fato de uma minoria não responder está atrelado ao fato de estes usuários não haverem conseguido acessar os sites, possivelmente por problemas momentâneos de conexão.

Tabela 45 - Primeira Impressão - AMS

\begin{tabular}{c|c|c}
\hline Caracteristicas & N & $\%$ \\
\hline Rapidez ao carregar & 5 & 33,33 \\
\hline Bom layout & 4 & 26,67 \\
\hline Bom conteúdo & 4 & 26,67 \\
\hline Bom uso de cores &. & $\cdot$ \\
\hline Interface amigável & 4 & 26,67 \\
\hline
\end{tabular}


As opiniões sobre este site foram díspares, entretanto a maioria o considerou de carregamento rápido e interessante. Alguns o acusaram de possuir má disposição das informações, considerando-as confusas e carregadas. Entende-se por informações carregadas, que o site apresenta muitas informações que não são do interesse do pesquisador, a exemplo do excesso de merchandising (propagandas), como mencionou um dos usuários. Dessa forma, pode-se concluir que apesar de possuir potencial para ser um excelente site, necessita talvez de uma reestruturação das informações através de uma seleção do que realmente importa para o usuário.

Tabela 46 - Primeira Impressão - AEG

\begin{tabular}{c|c|c}
\hline Caracteristicas & N & $\%$ \\
\hline Rapidez ao carregar & 8 & 53,33 \\
\hline Bom layout & 2 & 13,33 \\
\hline Bom conteúdo & 3 & 20,00 \\
\hline Bom uso de cores & 1 & 6,67 \\
\hline Interface amigável & 1 & 6,67 \\
\hline
\end{tabular}

D Archivo Histórico de Protocolos de Gipuskoa (AHPG)

A opinião geral foi de que o site tem um bom carregamento, mas é pobre de conteúdo, carente de informação. A homepage tem layout muito simples e faz mal uso de cores. Enfim, na primeira impressão, o site não agradou à maioria dos usuários. 
Tabela 47 - Primeira Impressão - AHPG

\begin{tabular}{c|c|c}
\hline Caracteristicas & N & $\%$ \\
\hline Rapidez ao carregar & 8 & 53,33 \\
\hline Bom layout & 1 & 6,67 \\
\hline Bom conteúdo & $\cdot$ & $\cdot$ \\
\hline Bom uso de cores & $\cdot$ & $\cdot$ \\
\hline Interface amigável & 3 & 20,00 \\
\hline
\end{tabular}

Archivo de Hullera Vasco-Leonesa (AHVL)

As opiniões foram divididas, enquanto alguns consideraram interessante, bom uso de cores, equilíbrio entre texto e imagem, outros não se agradaram do seu design, consideraram o site simples e pouco atrativo. A maioria, porém concordou que tem rápido carregamento das páginas.

Tabela 48 - Primeira Impressão - AHVL

\begin{tabular}{c|c|c}
\hline Caracteristicas & N & $\%$ \\
\hline Rapidez ao carregar & 7 & 46,67 \\
\hline Bom layout & 5 & 33,33 \\
\hline Bom conteúdo & 2 & 13,33 \\
\hline Bom uso de cores & 2 & 13,33 \\
\hline Interface amigável & 5 & 33,33 \\
\hline
\end{tabular}


Archivo Histórico Provincial de Granada (AHPGR)

Considerando o site de carregamento rápido, a maioria opinou favoravelmente, ressaltando o design moderno e interessante, interface "amigável", bom uso de cores, organizado. Apenas dois usuários, consideraram que o site era muito carregado de informações. Para esses usuários possivelmente o design arrojado fugiu aos padrões de sites nos quais estavam acostumados a navegar.

\begin{tabular}{c|c|c}
\multicolumn{3}{c}{ Tabela 49 - Primeira Impressão - AHPGR } \\
\hline Caracteristicas & N & $\%$ \\
\hline Rapidez ao carregar & 6 & 40,00 \\
\hline Bom layout & 6 & 40,00 \\
\hline Bom conteúdo & 3 & 20,00 \\
\hline Bom uso de cores & 1 & 6,67 \\
\hline Interface amigável & 4 & 26,67 \\
\hline
\end{tabular}

\section{Variável 4 - Ferramenta de Busca}

Essa variável corresponde à ferramenta de busca de informações existentes dentro do próprio site, a exemplo, de uma lupa pela qual se pode ir diretamente à informação desejada. O usuário deverá indicar se encontra ou não essa ferramenta no site avaliado. 
Tabela 50 - Ferramenta de busca - Usuários

\begin{tabular}{c|c|c}
\multicolumn{1}{c}{ Sigla } & \multicolumn{1}{c}{$\mathbf{N}$} & $\%$ \\
\hline AHEV & 15,00 & 100,00 \\
\hline AHA & 13,00 & 86,67 \\
\hline AHPGR & 13,00 & 86,67 \\
\hline ADS & 11,00 & 73,33 \\
\hline AMS & 9,00 & 60,00 \\
\hline AHVL & 4,00 & 26,67 \\
\hline AVME & 2,00 & 13,33 \\
\hline AUS & 2,00 & 13,33 \\
\hline AHN & 0,00 & 0,00 \\
\hline AHPH & 0,00 & 0,00 \\
\hline AGMA & 0,00 & 0,00 \\
\hline AGS & 0,00 & 0,00 \\
\hline AEG & 0,00 & 0,00 \\
\hline AHPG & 0,00 & 0,00 \\
\hline
\end{tabular}

Como se pode observar na Tabela 50 , os quinze usuários entrevistados (100\%), encontraram a ferramenta de busca no Archivo Histórico Eclesiástico de Vizcaya. Em segundo lugar aparecem os sites dos Arquivos: Archivo Histórico de Astúrias e Archivo de la Diputación de Sevilla, em que treze usuários encontraram a ferramenta (86,67\%). Em seguida, está o site do Archivo Municipal de Santander, onde nove usuários $(60 \%)$ encontraram a ferramenta. No site do Archivo de Hullera Vasco-Leonesa, quatro usuários (26,67\%) identificaram a ferramenta. Apenas dois usuários (13,33\%) encontraram a ferramenta de busca nos sites do Archivo Vasco de la Música Eresbil e do Archivo de la Universidad de Salamanca. Nos demais Arquivos, os usuários não encontraram a ferramenta de busca. 
Gráfico 18 - Ferramenta de busca - Usuários (decrescente)

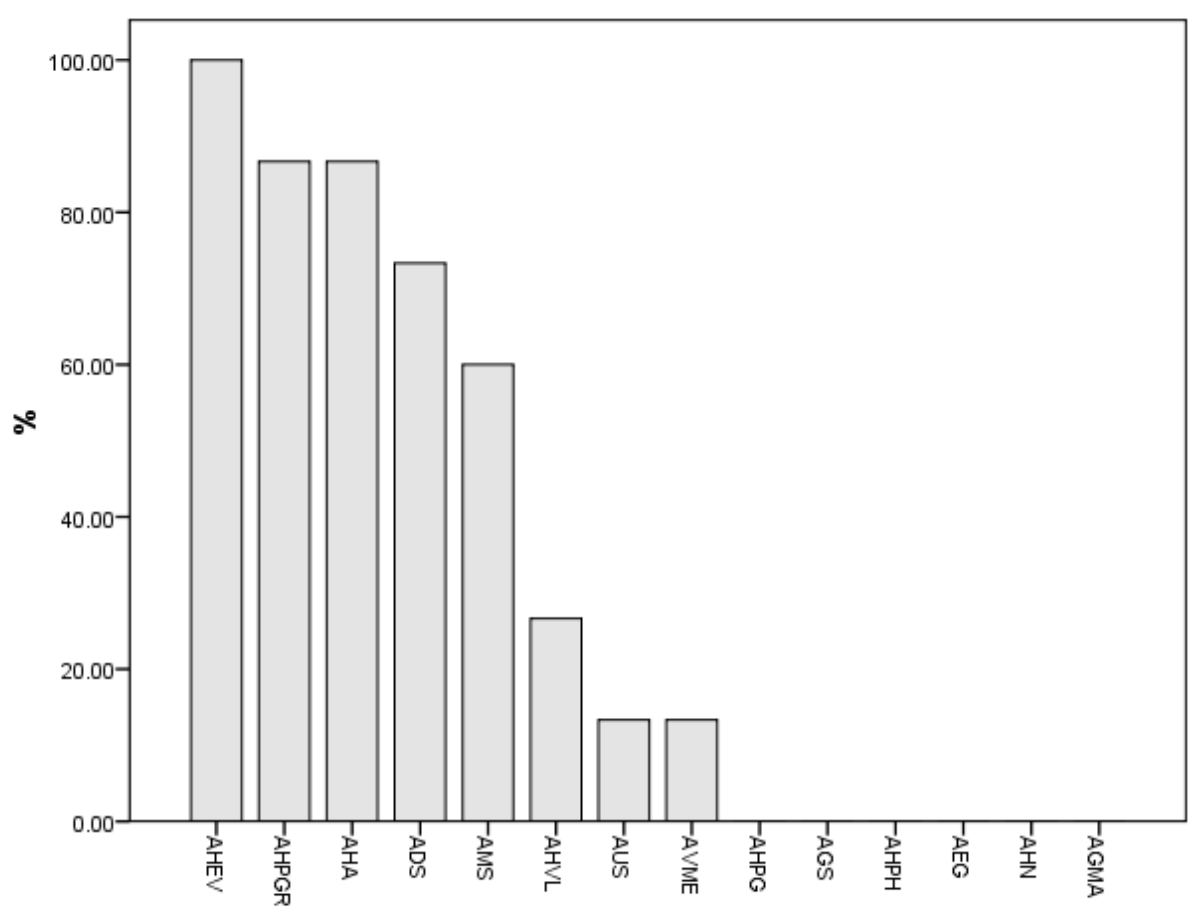

No gráfico 18, percebe-se nitidamente que o site do Archivo Histórico Eclesiástico de Vizcaya destaca-se dos demais, pois 100\% dos usuários encontraram a ferramenta de busca. Percebe-se também a equivalência dos resultados nos sites dos Arquivos: Archivo Histórico Provincial de Granada e Archivo Histórico de Astúrias e dos sites do Archivo de la Universidad de Salamanca e do Archivo Vasco de la Musica Eresbil.

\section{Variável 5 - Coerência dos links e necessidade de treinamento}

Quanto à variável Coerência dos links e necessidade de treinamento, a primeira resposta diz respeito ao fato de os links possuírem coerência, ou seja, remeterem o usuário à informação a que se propõem. A segunda resposta que se refere à necessidade ou não de treinamento, diz respeito à facilidade que o usuário encontra para navegar no site. Nestes dois pontos, a resposta foi 
compactada com um sim ou não, sendo o sim representado na análise pelo número 1 e a resposta não, representado na análise pelo número 2 .

\section{Tabela 51 - Coerência dos Links}

\begin{tabular}{c|c|c|c}
\hline Mínimo & máximo & média & desvio \\
\hline 10 & 15 & 12,93 & 1,44 \\
\hline
\end{tabular}

No que diz respeito à coerência dos links, observa-se que a média de respostas positivas foi de $12,93 \mathrm{com}$ um desvio padrão de 1,44. Isso quer dizer que a grande maioria dos usuários encontrou uma correspondência entre as informações teoricamente ofertadas pelo link e o seu real conteúdo. A tabela, a seguir, sintetiza a frequencia do número de respostas positivas em relação aos links por arquivo.

Tabela 52 - Coerência dos Links por arquivo

\begin{tabular}{l|c|c}
\hline Arquivo & $\mathbf{N}$ & $\%$ \\
\hline ADS & 11 & 73,33 \\
\hline AEG & 14 & 93,33 \\
\hline AGMA & 13 & 86,67 \\
\hline AGS & 13 & 86,67 \\
\hline AHA & 13 & 86,67 \\
\hline AHEV & 14 & 93,33 \\
\hline AHN & 15 & 100,0 \\
\hline AHPG & 13 & 86,67 \\
\hline AHPGR & 14 & 93,33 \\
\hline AHPH & 14 & 93,33 \\
\hline AHVL & 14 & 93,33 \\
\hline AMS & 10 & 66,66 \\
\hline AUS & 11 & 73,33 \\
\hline AVME & 12 & 80,0 \\
\hline
\end{tabular}

Os usuários consideram que os sites dos Arquivos têm coerência nos links. Os sites dos Arquivos que mais se destacaram foram: Archivo Histórico Nacional (AHN) com 100\% das respostas e os seguintes: Arquivo Histórico EV (AHEV), 
Archivo Histórico Provincial de Granada (AHPGR), Archivo Histórico Provincial de Huesca (AHPH), Archivo de Hullera Vasco-Leonesa (AHVL) com 93,33\%.

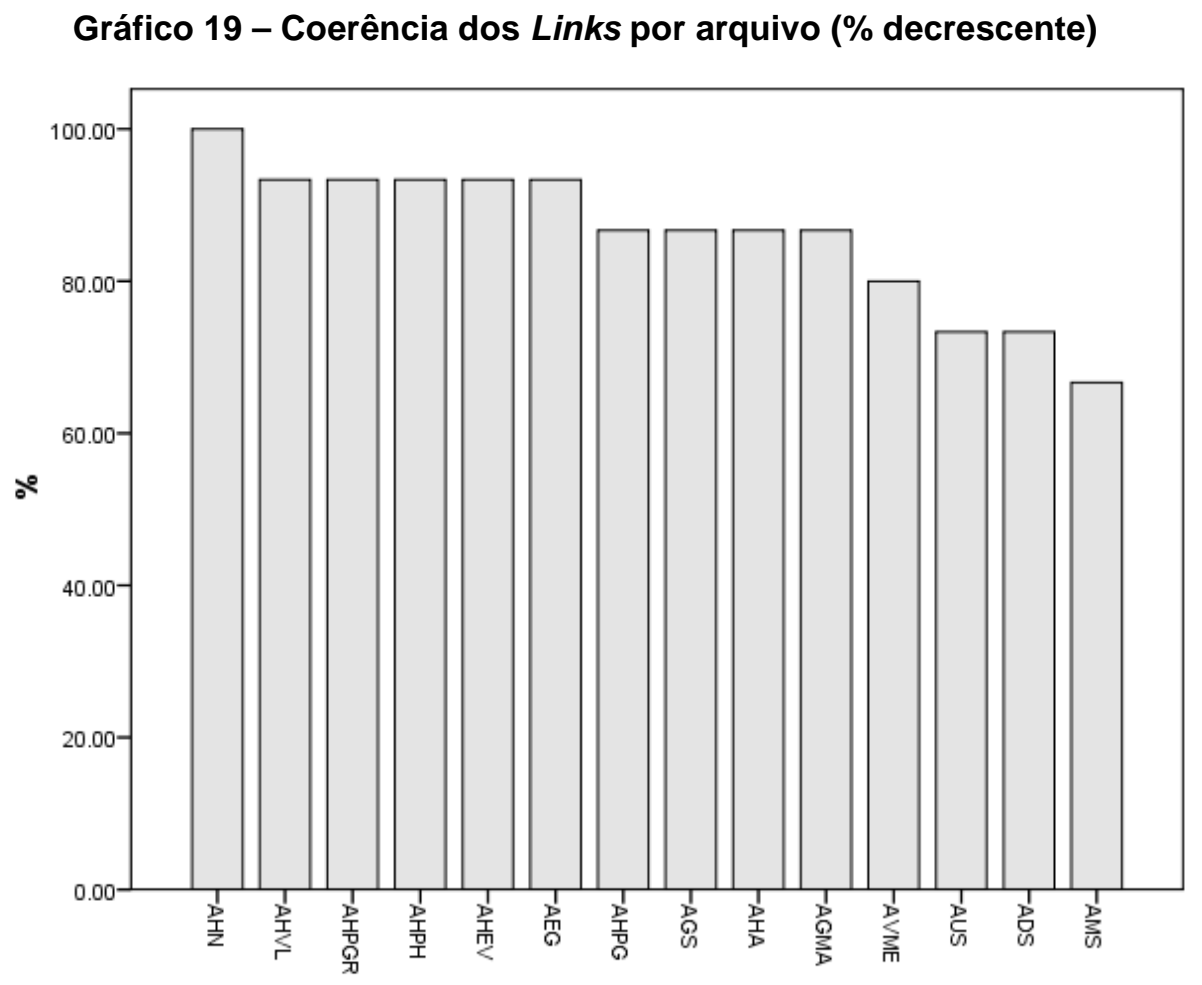

Como pode ser observado, o Archivo Histórico Nacional (AHN) foi aquele que apresentou o maior percentual de respostas positivas no que diz respeito à coerência dos links (100,0\%). No outro oposto, o Archivo Municipal de Santander (AMS) apresentou a menor proporção de respostas positivas, registre-se: $(66,66 \%)$.

A tabela, a seguir, apresenta a estatística descritiva referente à necessidade de treinamento.

Tabela 53 - Necessidade de treinamento

\begin{tabular}{c|c|c|c}
\hline Mínimo & máximo & média & desvio \\
\hline 0 & 3 & 0,79 & 0,89 \\
\hline
\end{tabular}

No quesito necessidade de treinamento, tem-se o seguinte: mínimo de zero e máximo de três. Em média, 0,79 usuários responderam positivamente ao serem 
indagados a respeito da necessidade de treinamento para navegar nos respectivos sites, sendo o desvio padrão de 0,89 . A tabela, a seguir, sumariza a frequencia do número de respostas positivas em relação à necessidade de treinamento por arquivo.

Tabela 54 - Necessidade de treinamento por arquivo

\begin{tabular}{c|c|c}
\hline Arquivo & $\mathbf{N}$ & $\%$ \\
\hline ADS & 1 & 6,67 \\
\hline AEG & 1 & 6,67 \\
\hline AGMA & 3 & 20,0 \\
\hline AGS & 0 & 0 \\
\hline AHA & 1 & 6,67 \\
\hline AHEV & 0 & 0 \\
\hline AHN & 0 & 0 \\
\hline AHPG & 1 & 6,67 \\
\hline AHPGR & 0 & 0 \\
\hline AHPH & 0 & 0 \\
\hline AHVL & 0 & 0 \\
\hline AMS & 1 & 6,67 \\
\hline AUS & 2 & 13,34 \\
\hline AVME & 1 & 6,67 \\
\hline & &
\end{tabular}

Em relação à essa variável, $20 \%$ dos usuários considera que o site do Archivo General Militar de Ávila (AGMA) necessita de treinamento e 13,34\% considera o site Archivo de la Universidad de Salamanca (AUS). Os usuários consideram que os sites dos seguintes Arquivos não necessitam de treinamento pata navegar em suas páginas: Archivo General de Simancas (AGS), Archivo Histórico Eclesiástico de Vizcaya (AHEV), Archivo Histórico Nacional (AHN), Archivo Histórico Provincial de Granada (AHPGR), Archivo Histórico Provincial de Huesca (AHPH), Archivo de Hullera Vasco-Leonesa (AHVL). 
Gráfico 20 - Necessidade de treinamento por arquivo

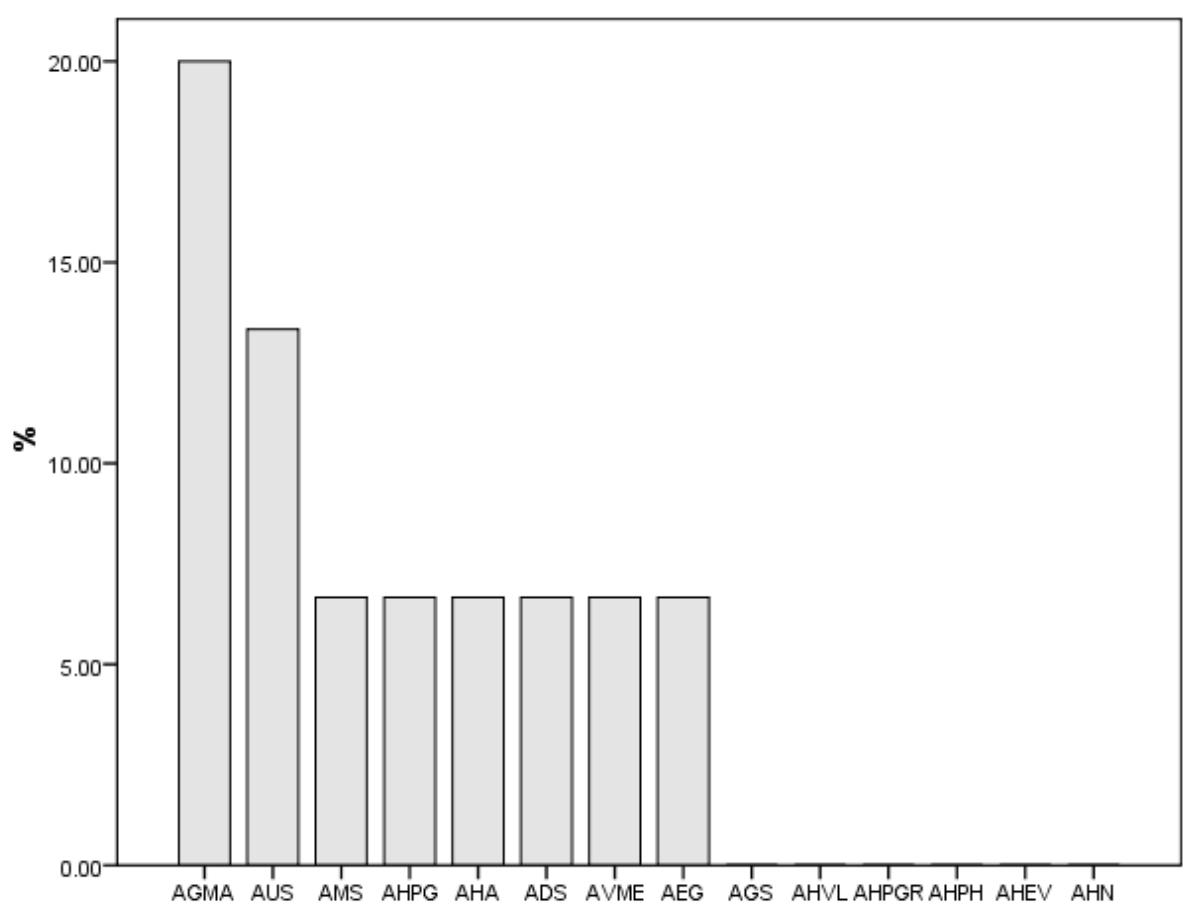

$\mathrm{Na}$ opinião dos usuários, o Archivo General Militar de Avila (AGMA) foi aquele que apresentou a maior proporção de respostas positivas em relação à necessidade de treinamento (20\%). Por outro lado, para seis diferentes arquivos não se registrou uma única resposta positiva em relação à necessidade de treinamento, o que sugere que esses arquivos são mais amigáveis, são eles: Archivo General de Simancas (AGS), Archivo de Hullera Vasco-Leonesa (AHVL), Archivo Histórico Provincial de Granada (AHPG), Archivo Histórico Provincial de Huesca (AHPH), Archivo Histórico de Eclesiásticos de Vizcaya (AHEV) e Archivo Histórico Nacional (AHN).

\section{Variável 6 - Linguagem do site}

A avaliação dessa variável corresponde à classificação do usuário em simples ou complexa. Nessa variável, foram considerados pela maioria simples. Somente alguns foram considerados pelos analistas como de linguagem 
complexa: Archivo de La Diputación de Sevilla, Archivo Vasco de La Musica Eresbil, Archivo de la Universidad de Salamanca e Arquivo da Emigración Galega.

Tabela 55 - Linguagem do site

\begin{tabular}{|c|c|c|c|}
\hline Sigla & simples & complexa & Não respondeu \\
\hline $\mathrm{AHN}$ & $\begin{array}{c}15 \\
(100)\end{array}$ & $\begin{array}{c}0 \\
(0)\end{array}$ & $\begin{array}{c}0 \\
(0)\end{array}$ \\
\hline ADS & $\begin{array}{c}11 \\
(73,33)\end{array}$ & $\begin{array}{c}2 \\
(13,33)\end{array}$ & $\begin{array}{c}2 \\
(13,33)\end{array}$ \\
\hline AVME & $\begin{array}{c}11 \\
(73,33)\end{array}$ & $\begin{array}{c}3 \\
(20)\end{array}$ & $\begin{array}{c}1 \\
(6,67)\end{array}$ \\
\hline $\mathrm{AHPH}$ & $\begin{array}{c}14 \\
(93,33)\end{array}$ & $\begin{array}{c}1 \\
(6,67)\end{array}$ & $\begin{array}{c}0 \\
(0)\end{array}$ \\
\hline AHEV & $\begin{array}{c}15 \\
(100)\end{array}$ & $\begin{array}{c}0 \\
(0)\end{array}$ & $\begin{array}{c}0 \\
(0)\end{array}$ \\
\hline $\mathrm{AHA}$ & $\begin{array}{c}14 \\
(93,33)\end{array}$ & $\begin{array}{c}1 \\
(6,67)\end{array}$ & $\begin{array}{c}0 \\
(0)\end{array}$ \\
\hline AGMA & $\begin{array}{c}14 \\
(93,33)\end{array}$ & $\begin{array}{c}1 \\
(6,67)\end{array}$ & $\begin{array}{c}0 \\
(0)\end{array}$ \\
\hline AUS & $\begin{array}{c}13 \\
(86,67)\end{array}$ & $\begin{array}{c}2 \\
(13,33)\end{array}$ & $\begin{array}{c}0 \\
(0)\end{array}$ \\
\hline AGS & $\begin{array}{c}15 \\
(100)\end{array}$ & $\begin{array}{c}0 \\
(0)\end{array}$ & $\begin{array}{c}0 \\
(0)\end{array}$ \\
\hline AMS & $\begin{array}{c}10 \\
(66,67)\end{array}$ & $\begin{array}{c}1 \\
(6,67)\end{array}$ & $\begin{array}{c}4 \\
(26,67)\end{array}$ \\
\hline$A E G$ & $\begin{array}{c}10 \\
(66,67)\end{array}$ & $\begin{array}{c}5 \\
(33,33)\end{array}$ & $\begin{array}{c}0 \\
(0)\end{array}$ \\
\hline $\mathrm{AHPH}$ & $\begin{array}{c}14 \\
(93,33)\end{array}$ & $\begin{array}{c}1 \\
(6,67)\end{array}$ & $\begin{array}{c}0 \\
(0)\end{array}$ \\
\hline AHVL & $\begin{array}{c}15 \\
(100)\end{array}$ & $\begin{array}{c}0 \\
(0)\end{array}$ & $\begin{array}{c}0 \\
(0)\end{array}$ \\
\hline AHPGR & $\begin{array}{c}15 \\
(100)\end{array}$ & $\begin{array}{c}0 \\
(0)\end{array}$ & $\begin{array}{c}0 \\
(0)\end{array}$ \\
\hline
\end{tabular}


Como pode ser observado, a proporção de não respondentes é bastante residual. Em particular, apenas para três arquivos não apresentaram respostas, são eles: Archivo de la Diputación de Sevilla (ADS) com 13,33\%, Archivo Vasco de La Musica Eresbil (AVME) com 6,67\% e o Archivo Municipal de Santander (AMS) com $26,67 \%$. No que diz respeito à avaliação da linguagem do site, registra-se que a maioria dos usuários classificou a linguagem como simples. $E$ essa tendência se mantém consistente entre os diferentes arquivos. Em particular, em quatro arquivos observou-se unanimidade dos usuários em relação ao tipo de linguagem, registre-se: Archivo Histórico Nacional (AHN), Archivo Histórico Eclesiástico de Vizcaya (AHEV), Archivo de Hullera Vasco-Leonesa (AHVL) e Archivo Histórico Provincial de Granada (AHPGR). Comparativamente, o arquivo com a linguagem mais complexa é o Arquivo da Emigración Galega com $33,3 \%$. Em termos substanciais, isso significa dizer que a linguagem dos sites avaliados foram considerados de fácil compreensão.

\section{Variável 7 - Impressão geral do site}

Essa última variável corresponde a uma resposta subjetiva referente à opinião geral em relação a cada site.

\section{Archivo Histórico Nacional (AHN)}

A impressão geral que este site causou nos usuários foi positiva: Design agradável, fácil navegação, possui recursos acessibilidade, coerência, carregamento rápido, layout organizado. Desconsiderou-se uma opinião de um único usuário por te-lo considerado simples, sem grandes atrativos. 
Tabela 56 - Impressão Geral- AHN

\begin{tabular}{c|c|c}
\hline Caracteristicas & N & $\%$ \\
\hline Rapidez ao carregar & 1 & 6,67 \\
\hline Bom layout & 6 & 40,00 \\
\hline Bom conteúdo & 4 & 26,67 \\
\hline Bom uso de cores & 1 & 6,67 \\
\hline Interface amigável & 5 & 33,33 \\
\hline Apresenta recursos de acessibilidade & 8 & 53,33 \\
\hline
\end{tabular}

Archivo Del La Diputación de Sevilla (ADS)

Os usuários fizeram uma avaliação ressaltando possíveis defeitos no site. Um dos problemas mencionados foi em relação ao não aproveitamento dos espaços em branco. Segundo suas respostas, consideraram o site: carregado, navegação regular, possui mapa explicativo do site, conteúdo disperso, sem organização, sem recursos de acessibilidade, muito espaço em branco.

Tabela 57 - Impressão Geral - ADS

\begin{tabular}{c|c|c}
\hline Caracteristicas & N & $\%$ \\
\hline Rapidez ao carregar & 0 & 0,00 \\
\hline Bom layout & 1 & 6,67 \\
\hline Bom conteúdo & 2 & 13,33 \\
\hline Bom uso de cores & 1 & 6,67 \\
\hline Interface amigável & 4 & 26,67 \\
\hline Apresenta recursos de acessibilidade & 2 & 13,33 \\
\hline
\end{tabular}


As opiniões sobre a impressão geral a respeito desse site foram favoráveis, com algumas restrições: complicado para os leigos e a fonte poderia ser melhorada, porém um usuário afirma que apesar disso, existe um recurso para aumento da letra. A Estética também não agradou muito. Enfim, opiniões gereralizadas, imprecisas e até contraditórias, pois enquanto alguns o consideram interessante e de amplo conteúdo, afirmam também que não encontraram recursos de acessibilidade. Assim, podemos observar que as opiniões divergiam quanto à acessibilidade, entretanto isso se pode se justificar pela dificuldade de se encontrar a ferramenta, como confirmado por um dos usuários segundo o qual a encontrou com muita dificuldade.

Tabela 58 - Impressão Geral- AVME

\begin{tabular}{c|c|c}
\hline Caracteristicas & N & $\%$ \\
\hline Rapidez ao carregar & 0 & 0,00 \\
\hline Bom layout & 1 & 6,67 \\
\hline Bom conteúdo & 2 & 13,33 \\
\hline Bom uso de cores & 0 & 0,00 \\
\hline Interface amigável & 1 & 6,67 \\
\hline Apresenta recursos de acessibilidade & 3 & 20,00 \\
\hline
\end{tabular}

Archivo Histórico Provincial de Huesca (AHPH)

A maioria dos usuários considera o site "suave", simples, organizado, de fácil navegação, possui ferramentas de acessibilidade como aumento de fonte e áudio (um deles afirmou que a ferramenta de aumento de fonte não funciona). Alguns, no entanto, consideram que o site poderia ser melhorado em termos de organização dos espaços. 
Tabela 59 - Impressão Geral - AHPH

\begin{tabular}{c|c|c}
\hline Caracteristicas & N & $\%$ \\
\hline Rapidez ao carregar & 0 & 0,00 \\
\hline Bom layout & 2 & 13,33 \\
\hline Bom conteúdo & 2 & 13,33 \\
\hline Bom uso de cores & 0 & 0,00 \\
\hline Interface amigável & 2 & $13 ., 33$ \\
\hline Apresenta recursos de acessibilidade & 10 & 66,67 \\
\hline
\end{tabular}

Archivo Histórico Eclesiástico de Vizcaya (AHEV)

De maneira geral o site foi considerado agradável pelos usuários, objetivo e bem estruturado, esteticamente simples, porém sem recursos de acessibilidade. Algumas opiniões destoavam das demais que o consideraram funcional e interessante do ponto de vista informacional, de bom conteúdo, considerando o layout confuso. No geral, concordaram que possui um visual atraente e hierarquias informacionais bem definidas.

Tabela 60 - Impressão Geral - AHEV

\begin{tabular}{c|c|c}
\hline Caracteristicas & N & $\%$ \\
\hline Rapidez ao carregar & 0 & 0,00 \\
\hline Bom layout & 10 & 66,67 \\
\hline Bom conteúdo & 2 & 13,33 \\
\hline Bom uso de cores & 0 & 0,00 \\
\hline Interface amigável & 1 & 6,67 \\
\hline Apresenta recursos de acessibilidade & 1 & 6,67 \\
\hline
\end{tabular}


Apesar de algumas opiniões divergentes, para a maioria dos usuários o site carrega rápido, possui interface "amigável”, conteúdo coerente e estética agradável, porém não se encontram recursos de acessibilidade.

\begin{tabular}{c|c|c} 
Tabela 61 - Impressão Geral - AHA \\
\hline Caracteristicas & N & $\%$ \\
\hline Rapidez ao carregar & 1 & 6,67 \\
\hline Bom layout & 3 & 20,00 \\
\hline Bom conteúdo & 2 & 13,33 \\
\hline Bom uso de cores & 0 & 0,00 \\
\hline Interface amigável & 3 & 20,00 \\
\hline Apresenta recursos de acessibilidade & 0 & 0,00 \\
\hline
\end{tabular}

Archivo General Militar de Ávila (AGMA)

Com apenas uma opinião divergente, os usuários classificaram positivamente o site: navegação fácil e tranquila, interface neutra, bom uso de cores, bom design e layout agradável, coerência nos links, equilíbrio entre texto e imagem, consistência nas informações. O único ponto negativo apontado foi a ausência de ferramentas de acessibilidade.

Tabela 62 - Impressão Geral - AGMA

\begin{tabular}{c|c|c}
\hline Caracteristicas & $\mathbf{N}$ & $\%$ \\
\hline Rapidez ao carregar & 1 & 6,67 \\
\hline Bom layout & 2 & 13,33 \\
\hline Bom conteúdo & 2 & 13,33 \\
\hline
\end{tabular}




\begin{tabular}{c|c|c}
\hline Bom uso de cores & 1 & 6,67 \\
\hline Interface amigável & 1 & 6,67 \\
\hline Apresenta recursos de acessibilidade & 4 & 26,67 \\
\hline
\end{tabular}

Quanto à impressão geral a respeito do site uma parcela considerável $(13,33)$ apontou bom layout e bom conteúdo. As demais características dos sites consideradas foram: rapidez ao carregar a página, bom uso de cores e interface amigável (6,67 das respostas).

Archivo de La Universidad de Salamanca (AUS)

Os usuários consideraram que o site exagera na utilização da cor azul, é esteticamente pobre, sem recursos de acessibilidade, mal elaborado, e deorganizado, além de possuir carregamento lento das páginas.

\begin{tabular}{c|c|c} 
Tabela 63 - Impressão Geral - AUS \\
\hline Caracteristicas & N & $\%$ \\
\hline Rapidez ao carregar & 0 & 0,00 \\
\hline Bom layout & 1 & 6,67 \\
\hline Bom conteúdo & 0 & 0,00 \\
\hline Bom uso de cores & 0 & 0,00 \\
\hline Interface amigável & 0 & 0,00 \\
\hline Apresenta recursos de acessibilidade & 0 & 0,00 \\
\hline
\end{tabular}

Archivo General de Simancas (AGS)

$\mathrm{Na}$ opinião geral, o site apresenta estética regular, recurso de acessibilidade, fácil navegação, layout organizado e bom uso de cores. Um ponto 
negativo é que apresenta uma única ferramenta de acessibilidade: escutar. No âmbito geral o site foi aprovado.

Tabela 64 - Impressão Geral - AGS

\begin{tabular}{c|c|c}
\hline Caracteristicas & N & $\%$ \\
\hline Rapidez ao carregar & 0 & 0,00 \\
\hline Bom layout & 6 & 40,00 \\
\hline Bom conteúdo & 4 & 26,67 \\
\hline Bom uso de cores & 1 & 6,67 \\
\hline Interface amigável & 3 & 20,00 \\
\hline Apresenta recursos de acessibilidade & 11 & 73,33 \\
\hline
\end{tabular}

Archivo Municipal de Santander (AMS)

Houve divergência de opinião entre os usuários. Enquanto alguns consideraram o site bem construído, atrativo, com carregamento rápido das páginas e layout agradável, três dos usuários não responderam às questões relativas a este Arquivo, justificando que o fato ocorreu devido à problemas com o carregamento da página. A maioria considerou o site funcional, objetivo, esteticamente agradável, com bom conteúdo disponível e recurso de acessibilidade (Escutar).

Tabela 65 - Impressão Geral - AMS

\begin{tabular}{c|c|c}
\hline Caracteristicas & N & $\%$ \\
\hline Rapidez ao carregar & 1 & 6,67 \\
\hline Bom layout & 6 & 40,00 \\
\hline Bom conteúdo & 3 & 20,00 \\
\hline Bom uso de cores & 0 & 0,00 \\
\hline Interface amigável & 1 & 6,67 \\
\hline Apresenta recursos de acessibilidade & 5 & 33,33 \\
\hline
\end{tabular}


As opiniões a respeito desse site foram divergentes, alguns afirmaram que o mesmo não apresenta ferramenta de acessibilidade e outros que possui a ferramenta "escutar". Certamente os primeiros usuários, por algum motivo, não se deram conta da existência da ferramenta. Alguns usuários recomendaram que se deveria reestruturar o layout da página, chamando a atenção para o equilíbrio entre a imagem e o texto, apontando para a má utilização do espaço, além de sugerir melhor seleção de informações. Alguns opinaram que o site é interessante e tem rápido carregamento das páginas.

Tabela 66 - Impressão Geral - AEG

\begin{tabular}{c|c|c}
\hline Caracteristicas & $\mathbf{N}$ & $\%$ \\
\hline Rapidez ao carregar & 0 & 0,00 \\
\hline Bom layout & 2 & 13,33 \\
\hline Bom conteúdo & 1 & 6,67 \\
\hline Bom uso de cores & 0 & 0,00 \\
\hline Apresenta recursos de acessibilidade & 0 & 0,00 \\
\hline
\end{tabular}

Archivo Histórico de Protocolos de Gipuskoa (AHPG)

A maioria dos usuários considerou que o site tem um bom carregamento, porém faz mal uso de cores e é pobre de conteúdo, ou seja, carente de informação, tornando a homepage muito simples. Enfim, na visão geral, este site não agradou aos usuários. 
Tabela 67 - Impressão Geral - AHPG

\begin{tabular}{c|c|c}
\hline Caracteristicas & N & $\%$ \\
\hline Rapidez ao carregar & 1 & 6,67 \\
\hline Bom layout & 2 & 13,33 \\
\hline Bom conteúdo & 0 & 0,00 \\
\hline Bom uso de cores & 0 & 0,00 \\
\hline Interface amigável & 1 & 6,67 \\
\hline Apresenta recursos de acessibilidade & 0 & 0,00 \\
\hline
\end{tabular}

Archivo de Hullera Vasco-Leonesa (AHVL)

As opiniões continuaram divergentes tal qual na primeira impressão, enquanto alguns consideraram o site interessante, com bom uso de cores, equilíbrio entre texto e imagem, outros não se agradaram do seu design, considerando-o simples e pouco atrativo. A maioria, porém concordou que o site tem rápido carregamento de páginas.

Tabela 68 - Impressão Geral - AHVL

\begin{tabular}{c|c|c}
\hline Caracteristicas & N & $\%$ \\
\hline Rapidez ao carregar & 1 & 6,67 \\
\hline Bom layout & 6 & 40,00 \\
\hline Bom conteúdo & 1 & 6,67 \\
\hline Bom uso de cores & 0 & 0,00 \\
\hline Interface amigável & 3 & 20,00 \\
\hline Apresenta recursos de acessibilidade & 3 & 20,00 \\
\hline
\end{tabular}


Archivo Histórico Provincial de Granada (AHPGR)

As opiniões em sua maioria foram favoráveis, considerando o site de carregamento rápido, de fácil navegação, design moderno e interessante, interface "amigável", bom conteúdo e organizado. Não foram, porém, encontradas ferramentas de acessibilidade. Uma minoria considerou que o site era muito carregado de informações, provavelmente para estes usuários o site poderia ser mais prático, ou seja, apresentar as informações de forma mais objetiva.

Tabela 69 - Impressão Geral - AHPGR

\begin{tabular}{c|c|c}
\hline Caracteristicas & N & $\%$ \\
\hline Rapidez ao carregar & 0 & 0,00 \\
\hline Bom layout & 8 & 53,33 \\
\hline Bom conteúdo & 3 & 20,00 \\
\hline Bom uso de cores & 2 & 13,33 \\
\hline Interface amigável & 3 & 20,00 \\
\hline Apresenta recursos de acessibilidade & 1 & 6,67 \\
\hline
\end{tabular}

\subsubsection{Análise dos Resultados dos Avaliadores}

\subsubsection{Resultados da Avaliação de Visibilidade}

Para avaliar a Visibilidade dos sites aqui estudados, foram apresentadas quatro questões aos avaliadores onde estes teriam que pontuar o site utilizando a escala de 0 a 2 onde:

- 0 (zero) significava que o site não atendia às expectativas,

- 1: atendia parcialmente às expectativas e

- 2: atendia às expectativas.

As questões apresentadas dizem respeito a Metadados padronizados, Informações sobre a instituição, Garantia de autenticidade, como certificações do 
site e posição natural da página Web do Arquivo nos resultados das buscas através do motor de busca Google.

Tabela 70 - Estatística descritiva - Visibilidade
\begin{tabular}{c|c|c|c}
\hline Mínimo & máximo & média & desvio \\
\hline 0 & 2 & 1,50 & 0,70 \\
\hline
\end{tabular}

Em relação à visibilidade, tem-se uma média de 1,50, com um desvio padrão de 0,70 . De acordo com a codificação adotada, a visibilidade varia entre 0 e 2, em que valores próximos ao zero sugerem baixa visibilidade e escores próximos ao 2 denotam alta visibilidade. A tabela, a seguir, sumariza a visibilidade por tipo de informação analisada.

Tabela 71 - Média da Visibilidade por variável

\begin{tabular}{c|c|c|c}
\hline Tipo & média & desvio padrão & coeficiente de variação \\
\hline Metadados padronizados & 1,50 & 0,69 & 0,46 \\
\hline Informações sobre a instituição & 1,52 & 0,71 & 0,47 \\
\hline Autenticidade & 1,36 & 0,80 & 0,59 \\
\hline Posição no Google & 1,61 & 0,56 & 0,35 \\
\hline
\end{tabular}

Comparativamente, observa-se que a posição no motor de busca apresentou a maior média no quesito visibilidade $(1,61)$. No outro oposto, tem-se a autenticidade com a menor média, registre-se: 1,36. No que diz respeito à variabilidade das médias, observa-se que a distribuição mais homogênea referese exatamente a posição nos motores de busca, com um desvio padrão de 0,56 e um coeficiente de variação de 0,35. No outro extremo, tem-se novamente a dimensão da autenticidade, com um desvio padrão de 0,80 e um coeficiente de variação de 0,59. Em termos menos técnicos, esses dados sugerem que os avaliadores atribuíram notas mais diferenciadas entre si em relação à autenticidade dos arquivos analisados, e foram mais semelhantes ao julgarem a posição nos motores de busca. A próxima tabela sintetiza a estatística descritiva por avaliador. 
Tabela 72 - Estatística descritiva - Visibilidade por Avaliador

\begin{tabular}{c|c|c|c}
\hline Avaliador & média & desvio padrão & coeficiente de variação \\
\hline 1 & 1,79 & 0,56 & 0,31 \\
\hline 2 & 1,25 & 0,74 & 0,59 \\
\hline 3 & 1,52 & 0,63 & 0,41 \\
\hline 4 & 1,43 & 0,74 & 0,52 \\
\hline
\end{tabular}

Como pode ser observado, o avaliador 1 atribuiu, em média, as notas mais elevadas $(1,79)$. No outro oposto tem-se o avaliador 2 com uma média de 1,25. No que diz respeito à variabilidade dos escores, registra-se que os avaliadores 2 e 4 atribuíram, em média, notas mais diferentes quando comparados com os avaliadores 1 e 3 . Substantivamente, esses resultados sugerem que a experiênia laboral dos dois coincidem neste aspecto.

O gráfico, a seguir, ilustra a dispersão da média da visibilidade por arquivo.

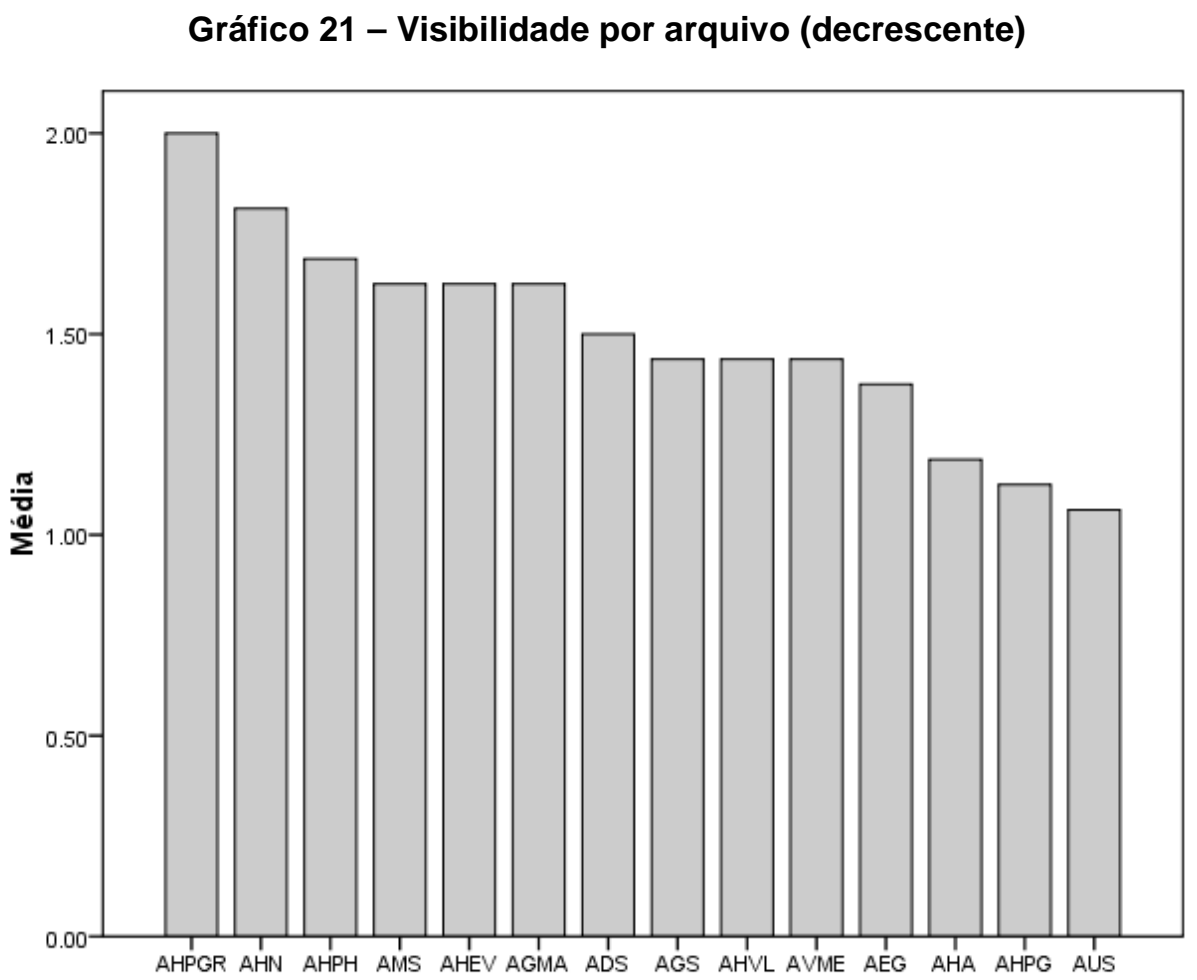

Como pode ser observado, as três maiores médias foram atribuídas aos arquivos AHPGR (2), AHN $(1,82)$ e AHPH $(1,69)$. No outro oposto, tem-se o AHA, AHPG e AUS como os arquivos que apresentaram, comparativamente, as 
menores médias de visibilidade. Ou seja, esses resultados sugerem que os três primeiros atendem parcialmente às expectativas comtendência a atender totalmente.

Ao analisar a distribuição da visibilidade de acordo com as seguintes variáveis: metadados padronizados, informações sobre a instituição, autenticidade e a posição natural nos motores de busca observa-se os resultados apresentados nas tabelas e gráficos a seguir.

Tabela 73 - Metadados padronizados por Arquivo

\begin{tabular}{c|c|c} 
Arquivo & \multicolumn{1}{c}{ média } & desvio padrão \\
\hline ADS & 1,50 & 0,58 \\
\hline AEG & 1,25 & 0,96 \\
\hline AGMA & 1,50 & 058 \\
\hline AGS & 1,25 & 0,96 \\
\hline AHA & 1,50 & 1,00 \\
\hline AHEV & 1,75 & 0,50 \\
\hline AHN & 1,50 & 0,58 \\
\hline AHPG & 1,50 & 0,58 \\
\hline AHPGR & 2,00 & 0,00 \\
\hline AHPH & 1,75 & 0,50 \\
\hline AHVL & 1,50 & 1,00 \\
\hline MAS & 1,50 & 1,00 \\
\hline AUS & 1,25 & 096 \\
\hline AVME & 1,25 & 0,50
\end{tabular}

No que se refere à variável presença de metadados padronizados o Archivo Histórico provincial de Granada (AHPGR) obteve a maior média (2), seguido do Archivo Histórico Provincial de Huesca (AHPH) e do Archivo Histórico Eclesiástico de Vizcaya, ambos com média 1,75.

como se pode visualizar melhor no gráfico a seguir. 


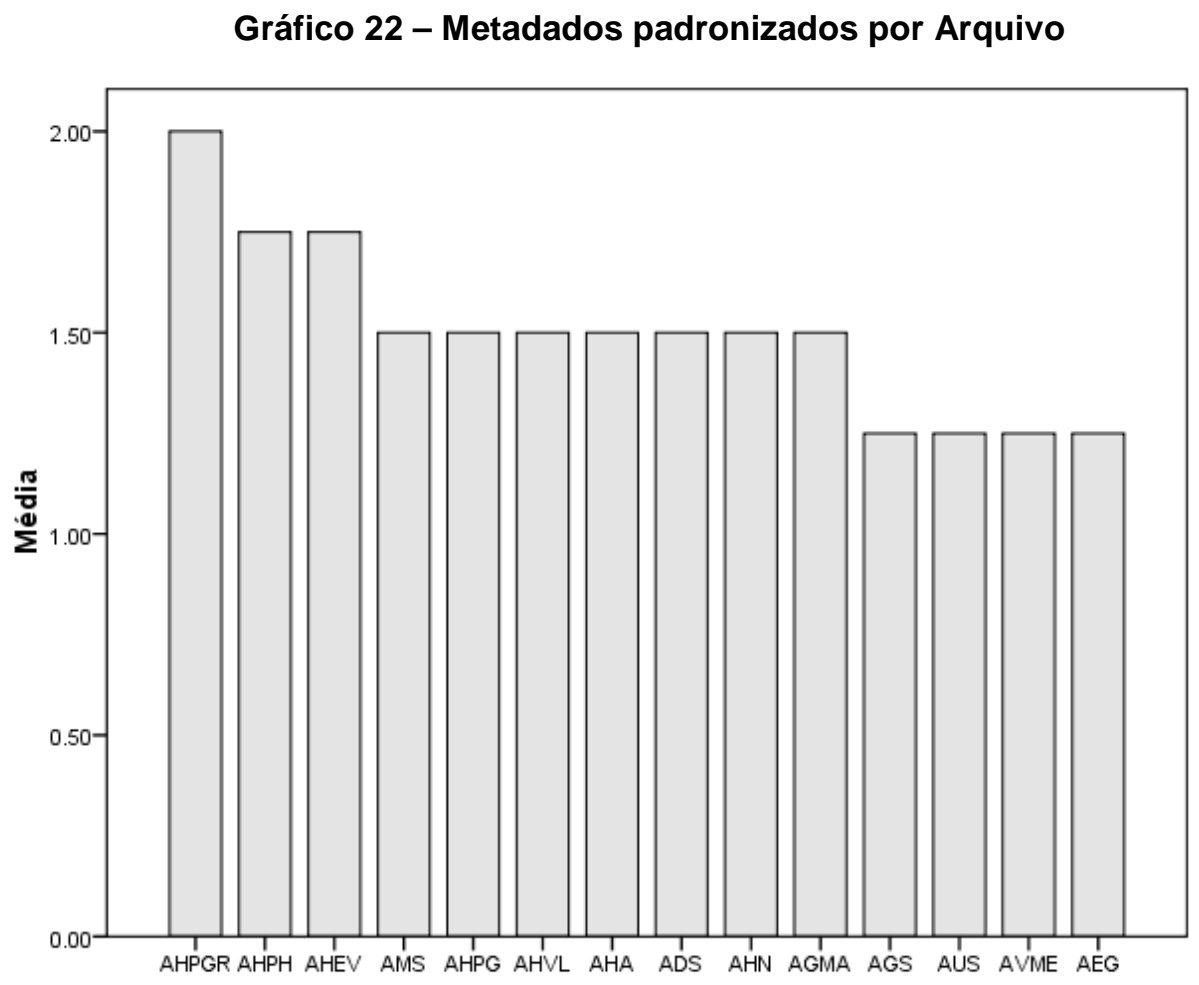

Tabela 74 - Informações sobre a instituição por Arquivo

\begin{tabular}{c|c|c} 
Arquivo & média & desvio padrão \\
\hline ADS & 1,75 & 0,50 \\
\hline AEG & 1,75 & 0,50 \\
\hline AGMA & 1,25 & 0,96 \\
\hline AGS & 1,50 & 1,00 \\
\hline AHA & 1,50 & 0,58 \\
\hline AHEV & 1,75 & 0,50 \\
\hline AHN & 2,00 & 0,00 \\
\hline AHPG & 0,25 & 0,50 \\
\hline AHPGR & 2,00 & 0,00 \\
\hline AHPH & 1,75 & 0,50 \\
\hline AHVL & 1,50 & 1,00 \\
\hline MAS & 1,75 & 0,50 \\
\hline AUS & 1,00 & 0,82 \\
\hline AVME & 1,50 & 0,58
\end{tabular}


Com relação às informações sobre a Instituição que abriga o Arquivo, destacaram-se o Archivo Histórico Nacional (AHN) e o Archivo Histórico Provincial de Granada (AHPGR), ambos com média 2, seguido pelos seguintes archivos: Archivo de Diputación de Sevilla (ADS), Arquivo da Emigración Galega (AEG), Archivo Eclesiástico de Vizcaya (AHEV) e Archivo Histórico Provincial de Huesca (AHPH), todos com média 1,75. Os arquivos: Archivo General de Simancas (AGS), Archivo Histórico de Astúrias (AHA), Archivo de Hullera Vasco-Leonesa (AHVL) e o Archivo Vasco de La Musica Eresbil (AVME) obtiveram média 1,50. O Archivo General Militar de Ávila (AGMA) obteve média 1,25 e o Archivo de La universidad de Salamanca obteve média 1.

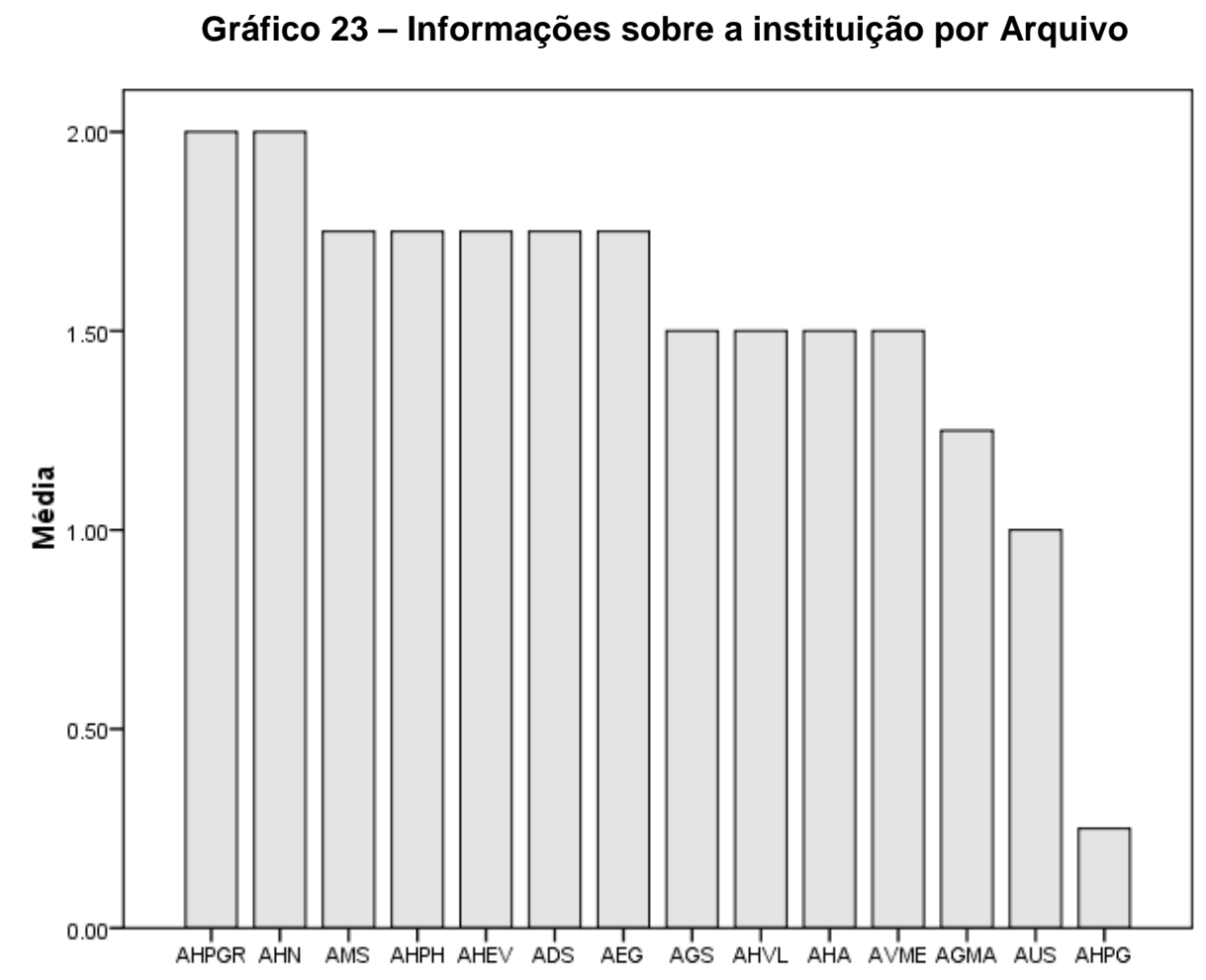

Observando-se 0 Gráfico 23, percebe-se claramente que o Archivo Histórico provincial de Granada (AHPGR) e o Archivo Histórico Nacional (AHN) coincidiram na média de pontuação dada a essa variável. Observa-se que apenas - Archivo Histórico Provincial de Gipúzcoa (AHPG) apresenta média baixa $(0,25)$ e bastante destoante dos demais Arquivos. 
Tabela 75 - Autenticidade por Arquivo

\begin{tabular}{c|c|c}
\hline Arquivo & média & desvio padrão \\
\hline ADS & 1,25 & 0,96 \\
\hline AEG & 1,50 & 0,58 \\
\hline AGMA & 1,75 & 0,50 \\
\hline AGS & 1,25 & 0,96 \\
\hline AHA & 0,25 & 0,50 \\
\hline AHEV & 1,50 & 0,58 \\
\hline AHN & 2,00 & 0,00 \\
\hline AHPG & 1,00 & 1,15 \\
\hline AHPGR & 2,00 & 0,00 \\
\hline AHPH & 1,75 & 0,50 \\
\hline AHVL & 1,00 & 0,82 \\
\hline AMS & 1,50 & 1,00 \\
\hline AUS & 1,00 & 1,15 \\
\hline AVME & 1,25 & 0,50
\end{tabular}

Percebe-se que o Archivo Histórico Provincial de Granada (AHPGR) e o Archivo Histórico Nacional (AHN) se destacam com a maior média (2), seguidos do Archivo Histórico Provincial de Huesca (AHPH) e Archivo General Militar de Ávila (AGMA) com média 1,75. O Archivo Municipal de Santander (AMS), o Archivo Histórico Eclesiástico de Vizcaya (AHEV) e o Archivo da Emigración Galega (AEG) obtiveram média 1,50. O Archivo General de Simancas (AGS), o Archivo de Diputación de Sevilla (ADS) e o Archivo Vasco de la Música Eresbil (AVME) obtiveram média 1,25. O Archivo Histórico de Protocolos de Gipúzcoa (AHPG), o Archivo de Hullera Vasco-Leonesa (AHVL), Archivo de la Universidad de salamanca (AUS) obtiveram média 1.O Archivo Histórico de Astúrias obteve média 0,25. 


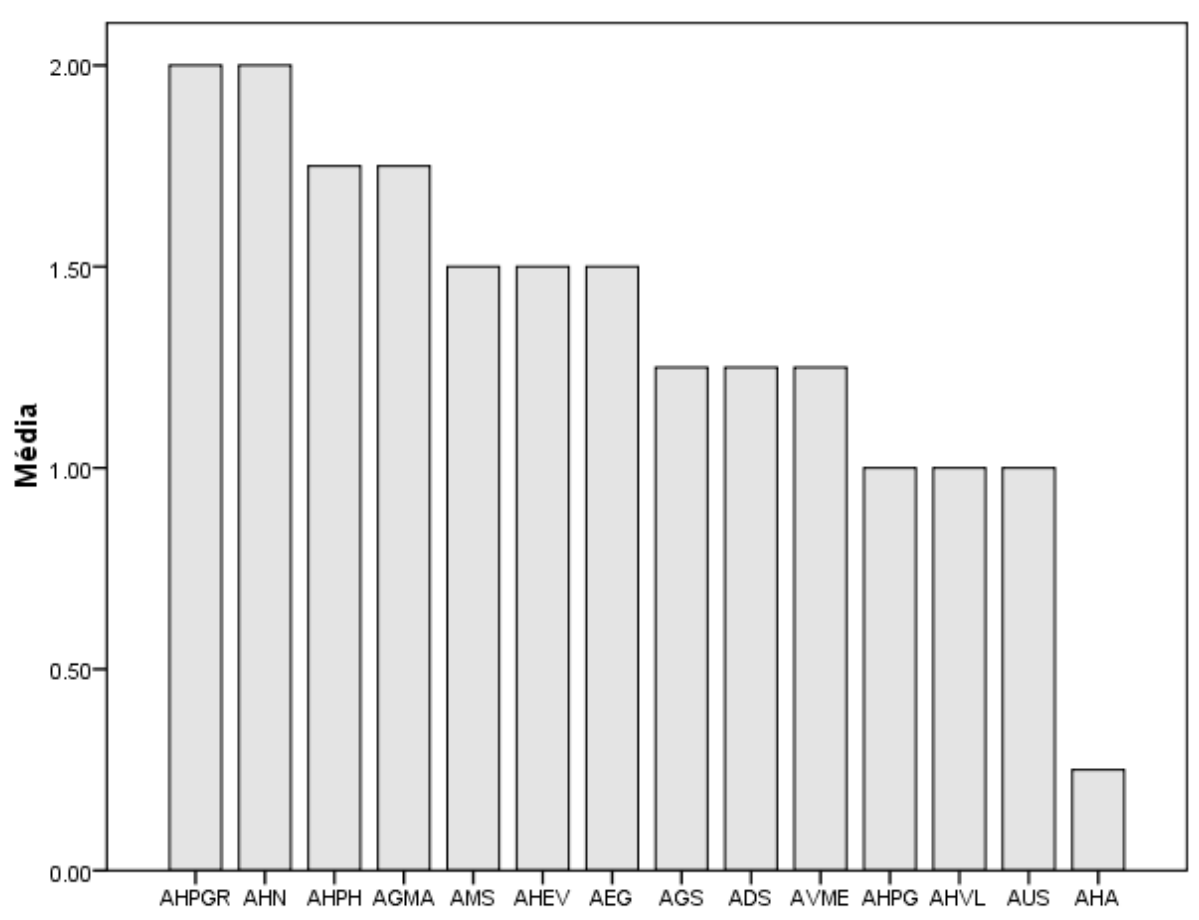

O Gráfico 24 mostra que, em relação à variável Autenticidade, o Archivo Histórico Nacional (AHN) e o Archivo Histórico provincial de Granada (AHPGR) se destacaram (ambos com média 2). Observa-se que houve coincidência também na média de resultados dos demais Arquivos e que apenas o Archivo Histórico de Asturias (AHA) destoou dos demais, obtendo média bastante inferior $(0,25)$, significando que os avaliadores não avaliaram bem essa variável em relação ao site deste Arquivo.

Tabela 76 - Posição natural nos motores de busca por Arquivo

\begin{tabular}{c|c|c}
\multicolumn{1}{c}{ Arquivo } & \multicolumn{1}{c}{ média } & desvio padrão \\
\hline ADS & 1,50 & 0,58 \\
\hline AEG & 1,00 & 0,82 \\
\hline AGMA & 2,00 & 0,00 \\
\hline AGS & 1,75 & 0,50 \\
\hline AHA & 1,50 & 0,58 \\
\hline AHEV & 1,50 & 0,58 \\
\hline AHN & 1,75 & 0,50
\end{tabular}




\begin{tabular}{c|c|c}
\hline AHPG & 1,75 & 0,50 \\
\hline AHPGR & 2,00 & 0,00 \\
\hline AHPH & 1,50 & 0,58 \\
\hline AHVL & 1,75 & 0,50 \\
\hline AMS & 1,75 & 0,50 \\
\hline AUS & 1,00 & 0,82 \\
\hline AVME & 1,75 & 0,50 \\
\hline
\end{tabular}

A tabela 76 demonstra que o Archivo General Militar de Ávila (AGMA) e o Archivo Histórico Provincial de Granada (AHPGR) se destacaram em relação a essa variável com média 2 . Em seguida, com média 1,75, seguem os seguintes arquivos: Archivo Municipal de Santander (AMS), O Archivo Histórico de Protocolos de Gipúzcoa (AHPG), Archivo General de Simancas (AGS), Archivo de Hullera Vasco-Leonesa (AHVL), Archivo Vasco de la Música Eresbil (AVME) e o Archivo Histórico Nacional (AHN). Em terceiro lugar, com média 1,50, os arquivos: Archivo Histórico de Astúrias (AHA), Archivo Histórico Provincial de Huesca (AHPH) Archivo Histórico Eclesiástico de Vizcaya (AHEV) e o Archivo de Diputación de Sevilla (ADS). Por fim o Archivo de la Universidad de salamanca (AUS) Archivo da Emigración Galega (AEG) com média 1. 
Gráfico 25 - Posição natural nos motores de busca por Arquivo

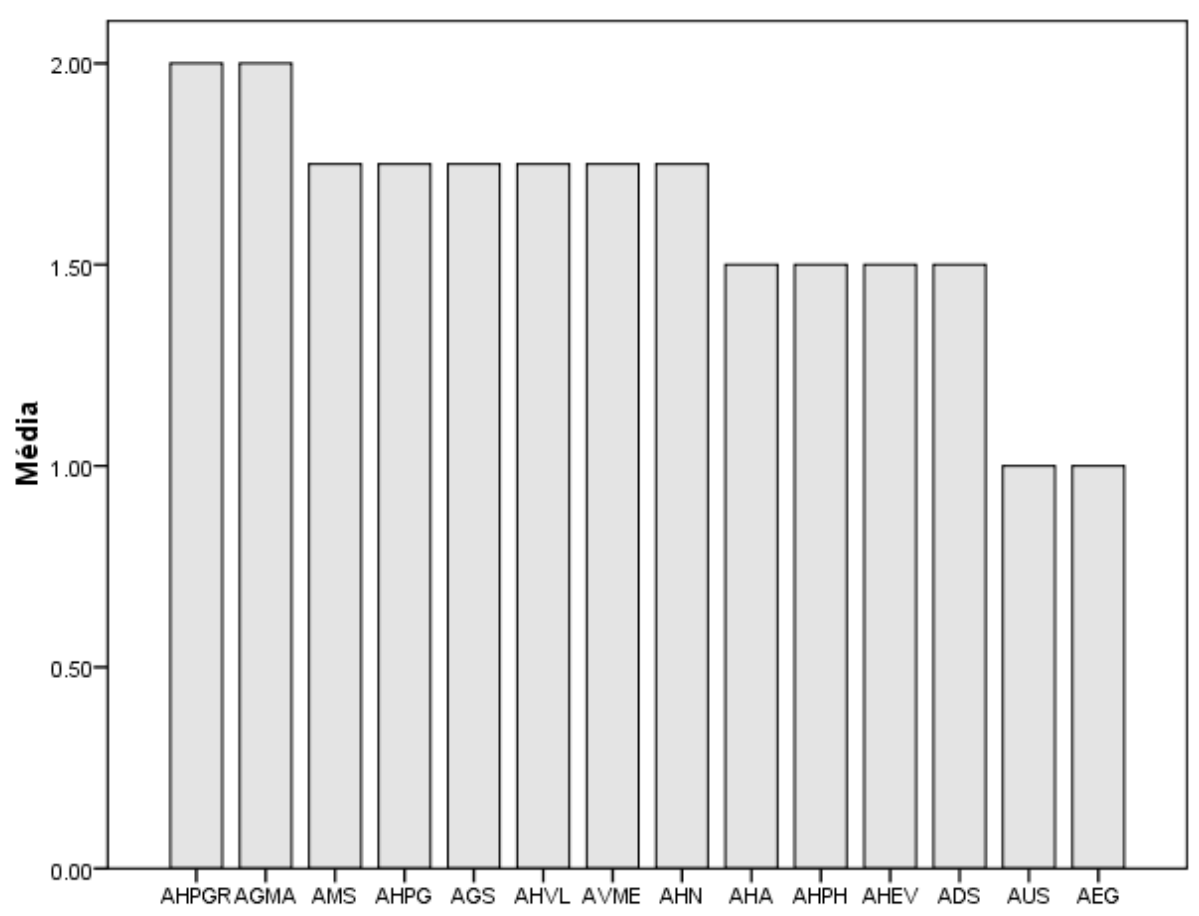

O Gráfico 25 mostra que em relação à variável Posição natural, se destacaram o Archivo General Militar de Ávila (AGMA) e o Archivo Histórico Provincial de Granada (AHPGR), ambos com média 2. Observa-se ainda que houve coincidência também na média de resultados dos demais Arquivos.

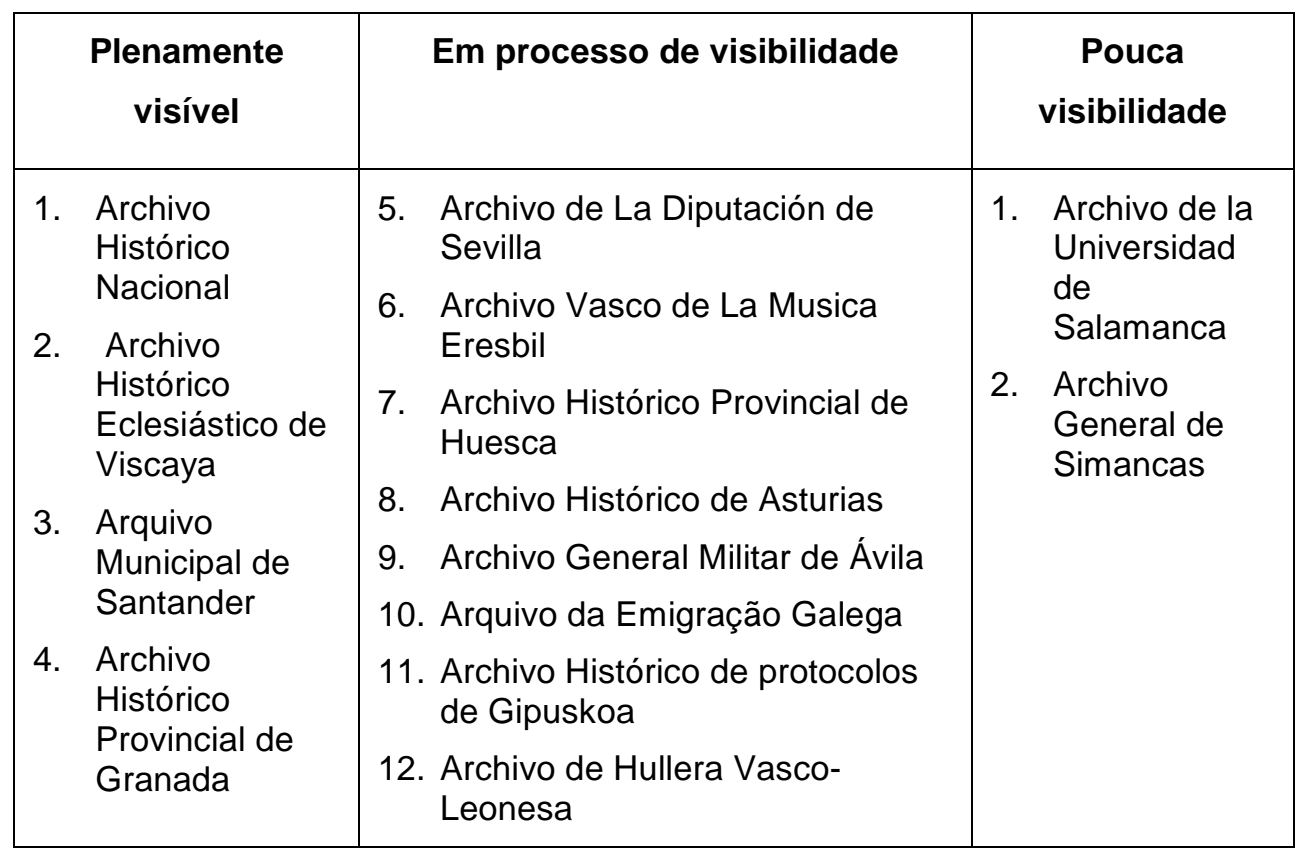

Quadro 31 - síntese da classificação dos sites avaliados 
Dos Arquivos analisados, quatro atendem a todos os critérios avaliados, oferecendo aos usuários um site de excelente visibilidade: Archivo Histórico Nacional, Archivo Histórico Eclesiástico de Viscaya, Arquivo Municipal de Santander e Archivo Histórico Provincial de Granada.

\subsubsection{Resultados da Avaliação Heurística}

Para avaliar a Usabilidade dos sites aqui estudados, foram apresentadas questões baseadas em sete heurísticas voltadas a sites de Arquivo em que os avaliadores teriam que pontuar o site utilizando a escala de gravidade de Nielsen (2000) cuja pontuação varia de 0 a 4, para determinar o grau de gravidade de problemas de usabilidade de cada indicador das heurísticas.

Com relação à escolha dos indicadores em cada heurística, vale salientar que inicialmente foi elaborada pela autora e posteriormente estudada conjuntamente com um especialista que ajustou o questionário de maneira a se tornar mais objetivo e menos fastidioso para os avaliadores sem que perdesse, no entanto, seu caráter abrangente. Desse modo, foi reduzido, ao máximo, o número de questões representando os indicadores para cada heurística, deixando apenas os que são realmente pertinentes e fundamentais em cada caso.

Desse modo, obtivemos o questionário estruturado com 29 questões, sendo as quatro primeiras a respeito de Visibilidade e as 25 questões seguintes correspondem às heurísticas. As heurísticas possuiam de 2 a 5 indicadores, conforme demosntra-se no quadro a seguir.

\begin{tabular}{|c|c|c|}
\hline \multicolumn{2}{|c|}{ HEURÍsTICAS } & INDICADORES \\
\hline $\mathbf{1}$ & Linguagem natural & 4 \\
\hline $\mathbf{2}$ & Liberdade de circulação e controle de ações & 2 \\
\hline $\mathbf{3}$ & Consistência nas convenções adotadas & 4 \\
\hline $\mathbf{4}$ & Disponibilização, clareza e precisão dos links & 3 \\
\hline
\end{tabular}




\begin{tabular}{|c|c|c|}
\hline 5 & Natureza estética e Simplicidade da interface & 5 \\
\hline 6 & Visibilidade & 5 \\
\hline 7 & Instruções e documentação & 2 \\
\hline
\end{tabular}

Quadro 32 - Heurísticas e indicadores

Os resultados obtidos através da pontuação dada pelos avaliadores serão analisados a seguir.

Tabela 77 - Pontuação das Heurísticas

\begin{tabular}{c|c|c|c}
\hline Mínimo & máximo & média & desvio \\
\hline 0 & 4 & 1,04 & 0,93 \\
\hline
\end{tabular}

Os dados sugerem que a média de avaliação das questões heurísticas foi de 1,04, com um desvio padrão de 0,93. Dada a magnitude da variabilidade em relação à média, é possível afirmar que a distribuição é bastante heterogênea. Além disso, como a média está mais próxima do zero do que do quatro é possível afirmar que em geral os sites apresentam baixos problemas de usabilidade. A tabela, a seguir, sumariza essas informações por avaliador.

Tabela 78 - Heurísticas por avaliador

\begin{tabular}{c|c|c|c}
\hline avaliador & média & desvio padrão & coeficiente de variação \\
\hline 1 & 0,76 & 0,76 & 1,00 \\
\hline 2 & 0,57 & 0,47 & 0,82 \\
\hline 3 & 1,29 & 0,50 & 0,39 \\
\hline 4 & 1,55 & 1,34 & 0,86 \\
\hline
\end{tabular}

Como observado, existe uma nítida diferença entre as médias atribuídas por cada avaliador. Em particular, é possível identificar duas principais tendências. A primeira agrupa os avaliadores 1 e 2 com médias de 0,76 e 0,57, respectivamente. A segunda tendência refere-se aos avaliadores 3 e $4 \mathrm{com}$ médias de 1,29 e 1,55, respectivamente. Em termos substanciais, esses dados sugerem que os dois primeiros avaliadores foram os que melhor classificaram os sites porque encontraram menores problemas de usabilidade, aproximando-se de 
zero que é a menor escala. No que diz respeito à variabilidade das médias, o avaliador 3 pode ser considerado o mais homogêneo. Em termos menos técnicos, isso quer dizer que as suas notas foram mais parecidas. No outro oposto, é possível afirmar que o avaliador 1 demonstrou comportamento mais heterogêneo. Isso significa dizer que ele atribuiu notas bastante diferentes em seu processo avaliativo.

O gráfico, abaixo, replica essas informações.

Gráfico 26 - Avaliação Heurística por avaliador (decrescente)

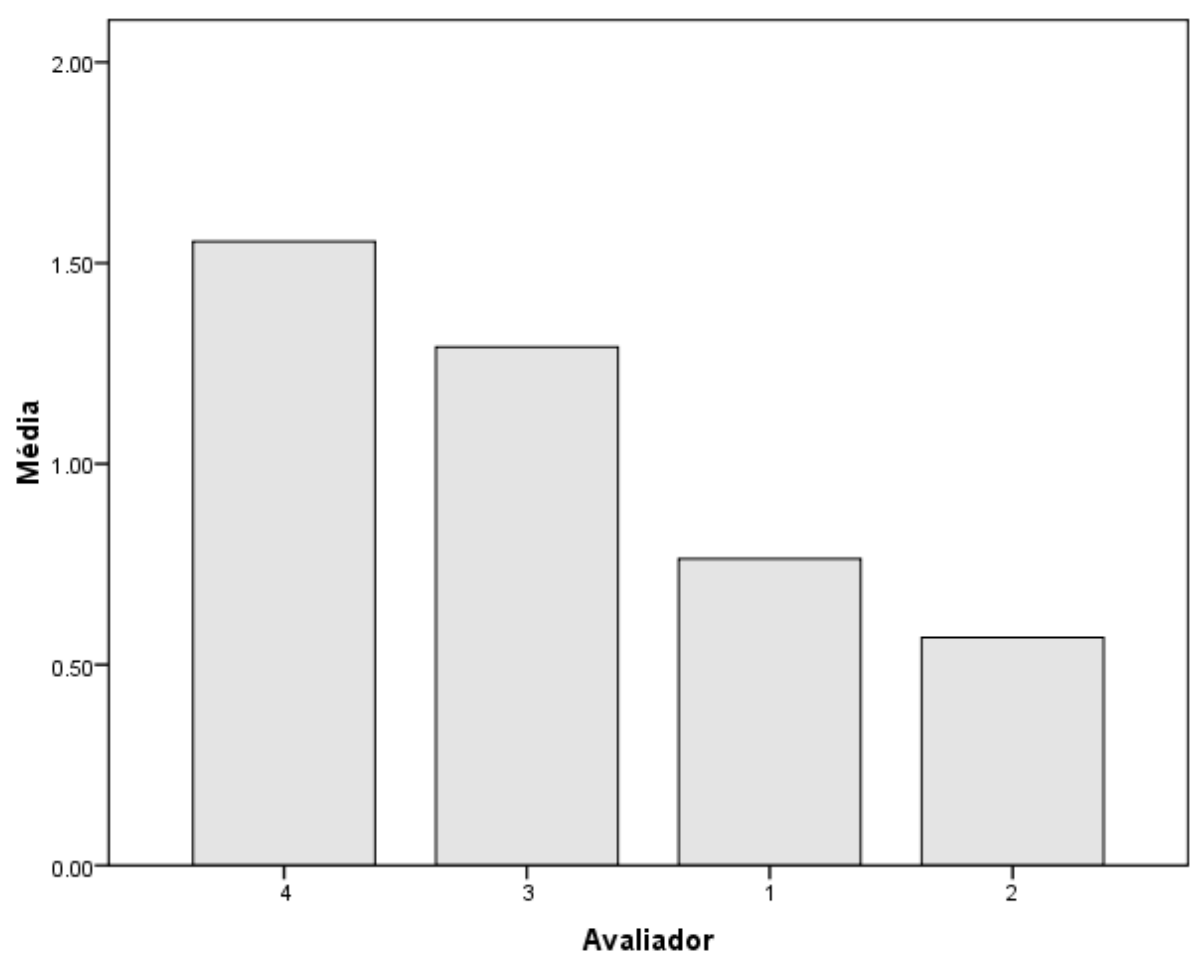

Tabela 79 - Média das Heurísticas

\begin{tabular}{c|c|c|c}
\hline heurística & média & desvio padrão & coeficiente de variação \\
\hline 1 & 0,78 & 0,80 & 1,03 \\
\hline 2 & 1,07 & 0,81 & 076 \\
\hline 3 & 0,73 & 0,65 & 0,89 \\
\hline 4 & 0,91 & 0,80 & 0,88 \\
\hline 5 & 0,83 & 0,72 & 0,87 \\
\hline 6 & 1,17 & 0,87 & 0,74 \\
\hline 7 & 1,82 & 1,29 & 0,71 \\
\hline
\end{tabular}


Ao desagregar a análise por heurística, observa-se que a de número 7 apresentou a maior média $(1,82)$. No outro oposto, a heurística 3 apresentou a menor média $(0,73)$. No quesito variabilidade, a distribuição mais heterogênea refere-se à heurística 1, com um desvio padrão de 0,80 e um coeficiente de variação de 1,03 . Por outro lado, a heurística 7 foi aquela com a distribuição mais homogênea em relação à média, com um desvio padrão de 1,29 e um coeficiente de variação de 0,71 . O gráfico a seguir ilustra esses dados.

Gráfico 27 - Pontuação das Heurísticas (ordem decrescente)

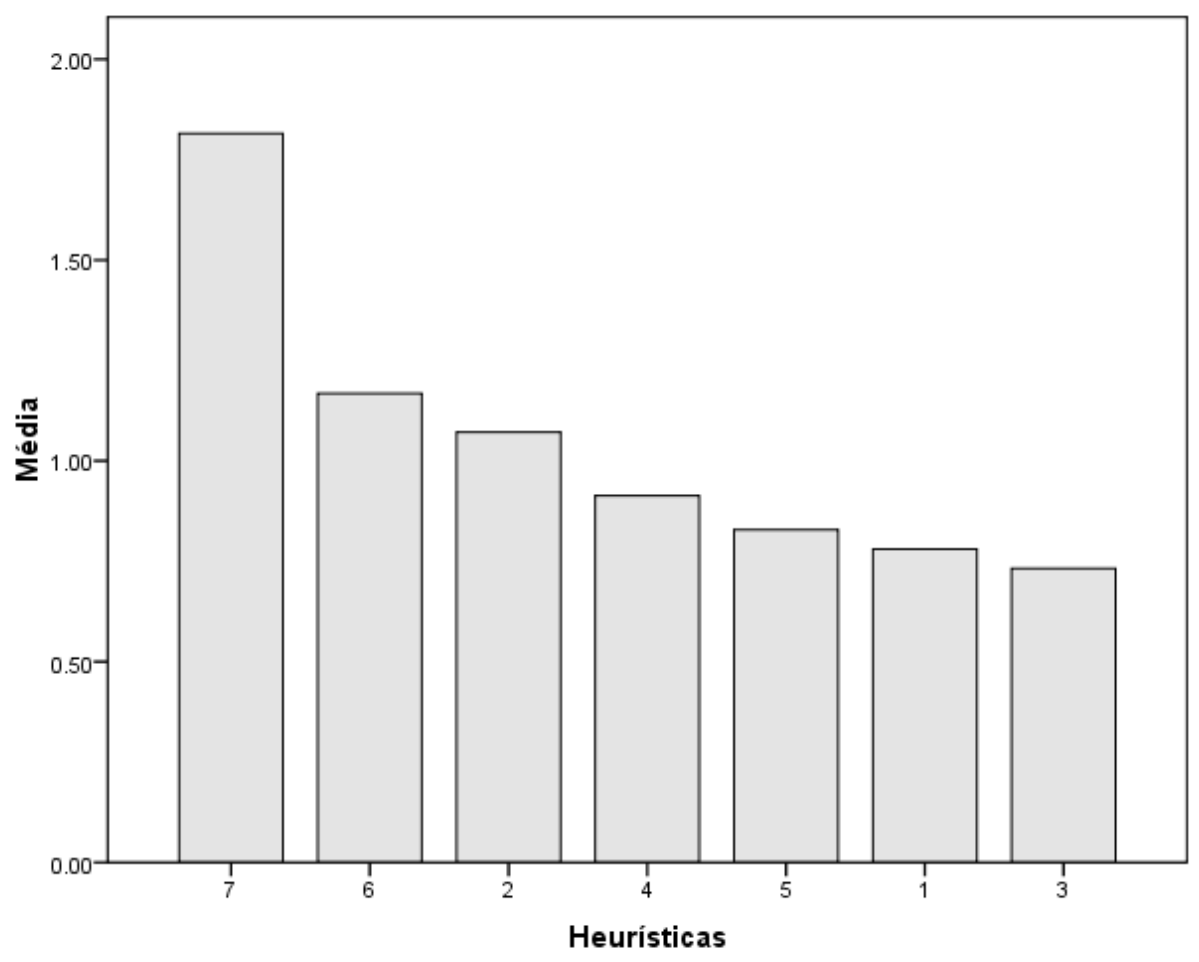

Como observado no Gráfico 27, a heurística 3 foi a melhor avaliada, seguida da heurística 1 e 5 . A heurística 7 foi a pior classificada uma vez que apresentou segundo problemas mais graves de usabilidade.

As diferentes heurísticas obviamente possuem características distintas e cada indicador das mesmas terão graus de gravidade distintos na avaliação de um site. Muitos autores, como Robert Bailey, citado por Santinho (2001), refletem sobre o que Nielsen (2000) considera como problemas menores de usabilidade, e preferem considerar como problemas não existentes ou "não- problemas". No caso desse estudo, considerou-se a gravidade sugerida por Nielsen pela questão 
da subjetividade resultante de opiniões de avaliadores, que normalmente pode ocorrer, ou seja, se um avaliador considera um problema mínimo como problema, seria útil registrar e não prudente registrar como não problema pela pouca importância, uma vez que ao término da avaliação, estes descartes, ou seja, os "não problemas" reais serão evidenciados e excluídos do rol nos resultados finais quando da computação final dos resultados se for concluído que aquele item é, de fato, irrelevante.

Para se obter uma média da gravidade encontrada pelos avaliadores em cada heurística, dado que elas possuem mais de um indicador, decidiu-se fazer uma regra aritmética simples, de modo a considerar o resultado dessa operação como o índice final da gravidade da heurística. Para tanto, considerou-se que os indicadores como um conjunto constituem a heurística, dando peso relativo à heurística e não ao indicador. Desse modo, a $1^{\underline{a}}$ heurística, por exemplo: Linguagem natural, que possui 4 indicadores, encontrará sua gravidade relativa ao site nesta razão:

$$
\mathrm{GTH}=\mathrm{Gl}+\mathrm{Gl} 2+\mathrm{Gl} 3+\mathrm{Gl} 4
$$

Onde:

GTH = Gravidade Total da Heurística

Gl1 = Gravidade do Indicador 1

$\mathrm{Gl} 2=$ Gravidade do indicador 2

$\mathrm{GI} 3=$ Gravidade do indicador 3

GI4= Gravidade do indicador 4

Assim, sucessivamente, utilizou-se esta fórmula, modificando-se apenas o número de indicadores, para calcular os níveis de gravidade de cada heurística que correspondem aos problemas encontrados nos sites pelos avaliadores através das sete heurísticas.

A seguir, demonstra-se a pontuação média de cada heurística por Arquivo e por avaliador. O objetivo deste procedimento é elevar a tranparência da análise de dados conferindo eventual replicabilidade dos resultados obtidos. 
Heurística 1 - Linguagem Natural:

Tabela 80 - Pontuação de cada avaliador por arquivo - Linguagem Natural

\begin{tabular}{c|c|c|c|c}
\multicolumn{5}{c}{ Avaliador } \\
\hline Arquivo & $\mathbf{1}$ & $\mathbf{2}$ & $\mathbf{3}$ & $\mathbf{4}$ \\
\hline ADS & 0 & 0 & 1,25 & 2,25 \\
\hline AEG & 0,25 & 0 & 1,25 & 2,5 \\
\hline AGMA & 0 & 0,2 & 1,5 & 2,25 \\
\hline AGS & 0 & 0 & 1,25 & 1 \\
\hline AHA & 0 & 0,5 & 1 & 1 \\
\hline AHEV & 0 & 1 & 1,5 & 0,75 \\
\hline AHN & 0,5 & 0 & 0,5 & 0,75 \\
\hline AHPG & 2 & 0 & 1 & 1 \\
\hline AHPGR & 0 & 0 & 1,25 & 2 \\
\hline AHPH & 0,5 & 0,75 & 1,25 & 3,5 \\
\hline AHVL & 0 & 0 & 1,75 & 0 \\
\hline AMS & 0 & 0 & 2 & 0 \\
\hline AUS & 0,75 & 0,25 & 1 & 0,75 \\
\hline AVME & 0,5 & 0,5 & 1,25 & 0,5 \\
\hline
\end{tabular}

Como se pode observar na Tabela 80, o Archivo Histórico Nacional (AHN), o Archivo de Hullera Vasco Leonesa (AHVL) e o Archivo Municipal de Santander (AMS) se destacam pois neste aspecto apresentaram problemas menores de usabilidade. Em contrapartida, o Archivo Historico Provincial de Granada (AHPGR) apresenta problemas cosméticos de usabilidade. 
Gráfico 28 - Linguagem Natural - pontuação de cada Arquivo

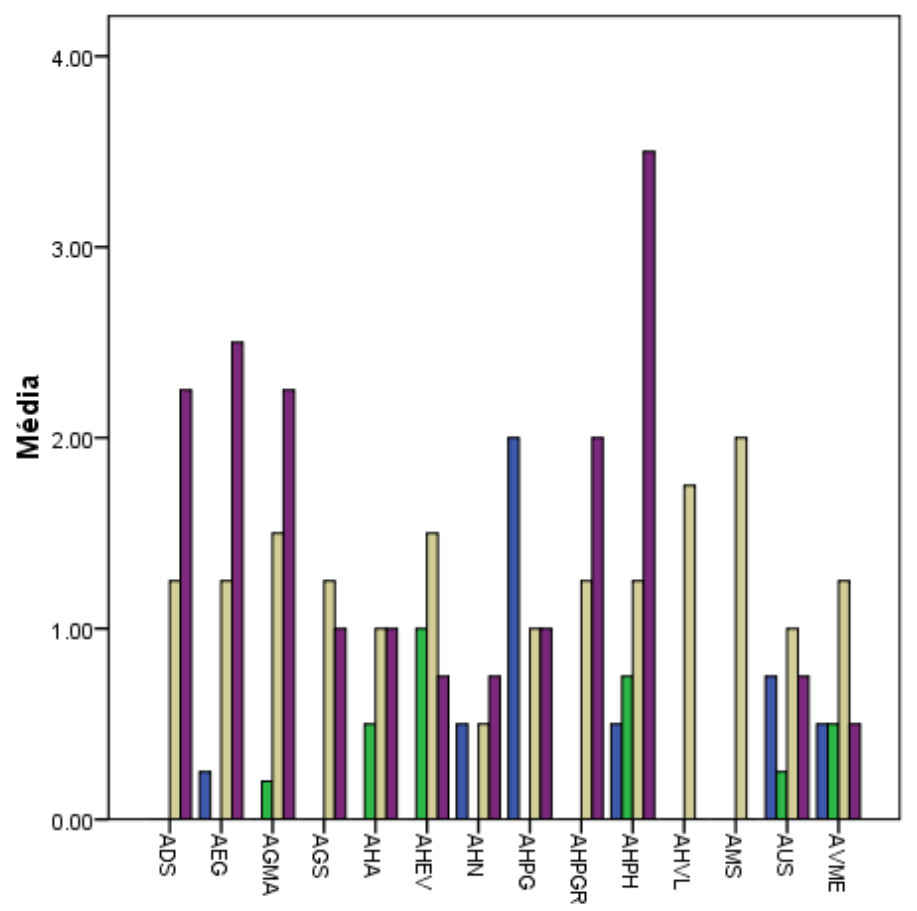

Avaliador

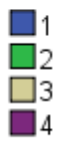

Todos os sites possuem um baixo impacto na usabilidade no que se refere à Heurística Linguagem natural. Os problemas de usabilidade encontrados podem ser considerados de pouca importância e poderão ser corrigidos posteriormente, se os criadores e/ou técnicos de manutenção dos sites assim julgarem necessário. O site do Archivo Histórico Provincial de Huesca é o que apresenta tendência a problemas maiores nessa heurística (média 1,5).

Heurística 2 - Liberdade de circulação e controle de ações: 
Tabela 81 - Liberdade de circulação e controle de ações - Pontuação de cada avaliador por arquivo

\begin{tabular}{c|c|c|c|c} 
Arquivo & \multicolumn{4}{c}{ Avaliador } \\
\hline & $\mathbf{1}$ & $\mathbf{2}$ & $\mathbf{3}$ & $\mathbf{4}$ \\
\hline ADS & 0,5 & 2 & 1,5 & 0 \\
\hline AEG & 0 & 0 & 2 & 3 \\
\hline AGMA & 1,5 & 1,5 & 2 & 2,5 \\
\hline AGS & 1 & 0,5 & 1,5 & 0 \\
\hline AHA & 1 & 1,5 & 1 & 2,5 \\
\hline AHEV & 0,5 & 1 & 2 & 1 \\
\hline AHN & 1 & 0 & 0,5 & 0 \\
\hline AHPG & 1,5 & 1 & 0,5 & 0 \\
\hline AHPGR & 0,5 & 0,5 & 1,5 & 0 \\
\hline AHPH & 1,5 & 1,5 & 0,5 & 3 \\
\hline AHVL & 1 & 0,5 & 1,5 & 0 \\
\hline AMS & 0 & 1 & 1,5 & 1 \\
\hline AUS & 2,5 & 0,5 & 1 & 0 \\
\hline AVME & 1,5 & 1 & 2 & 1,5 \\
\hline & & &
\end{tabular}

Quanto à Heurística Liberdade de circulação e controle de ações os sites dos Arquivos em geral apresentaram problemas mínimos de usabilidade, destacando-se o Archivo Historico Nacional (AHN) com média 0,37 . Alguns Arquivos apresentaram problemas "cosméticos" de usabilidade: Archivo de Diputación de Sevilla (ADS) e Archivo de la Universidad de Salamanca (AUS) ambos com média 1, Archivo Historico Eclesiástico de Vizcaya (AHEV) com média 1,1, Arquivo da Emigración Galega (AEG) com média 1,25, Archivo Vasco de la Musica Eresbil (AVME) com média 1,5, Archivo Historico Provincial de Huesca (AHPH) com média 1,62 e por fim, Archivo General Militar de Ávila (AGMA) com média 1,87. 


\section{Gráfico 29 - Liberdade de circulação e controle de ações - Pontuação de cada avaliador por arquivo}
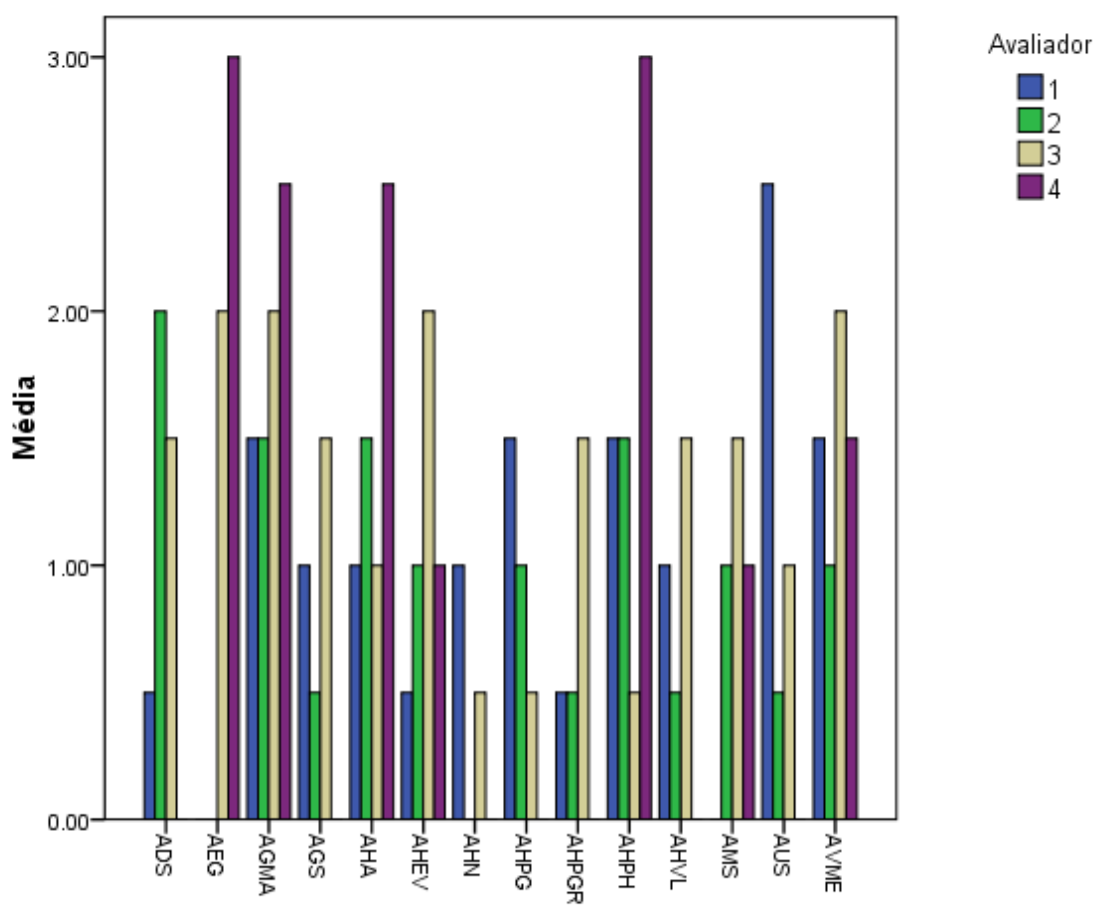

Como se observa no Gráfico 29, há uma grande variação na análise feita pelos avaliadores no que diz respeito às médias dessa heurística. O site do Archivo General Militar de Ávila (AGMA) apresentou maiores problemas nesse aspecto. Também merecem atenção, os sites dos Arquivos Archivo Histórico Provincial de Huesca (AHPH), Archivo de la Universidad de Salamanca(AUS) e Arquivo da Emigración Galega (AEG) porém suas médias indicam que apresentam problemas extremamente simples de usabilidade que não necessitam de solução urgente.

Heurística 3 - Consistência nas convenções: 
Tabela 82 - Consistência nas convenções adotadas -

Pontuação de cada avaliador por arquivo

\begin{tabular}{c|c|c|c|c} 
Arquivo & \multicolumn{4}{c}{ Avaliador } \\
\hline & $\mathbf{1}$ & $\mathbf{2}$ & $\mathbf{3}$ & $\mathbf{4}$ \\
\hline ADS & 1,5 & 0 & 1,25 & 0,5 \\
\hline AEG & 0,25 & 0,5 & 1 & 2,5 \\
\hline AGMA & 0,5 & 0,25 & 1,5 & 2 \\
\hline AGS & 0 & 0 & 1,25 & 1 \\
\hline AHA & 0,5 & 0,5 & 1 & 0,75 \\
\hline AHEV & 1,25 & 0,25 & 1,5 & 0,75 \\
\hline AHN & 0 & 0 & 0,5 & 1 \\
\hline AHPG & 0,25 & 0,25 & 1,25 & 0,75 \\
\hline AHPGR & 0,5 & 0,25 & 1,25 & 0,5 \\
\hline AHPH & 0,25 & 0,25 & 1,25 & 2,75 \\
\hline AHVL & 0 & 0 & 1,5 & 0,25 \\
\hline AMS & 0,25 & 0,5 & 1,75 & 0,25 \\
\hline AUS & 2 & 0,5 & 0,75 & 0,25 \\
\hline AVME & 0,25 & 0,75 & 0,25 & 0,25 \\
\hline
\end{tabular}

Quanto à Heurística Consistência nas convenções adotadas, os sites melhor avaliados foram: Archivo Vasco de la Musica Eresbil (AVME) e Archivo Historico Nacional (AHN) ambos com média 0,37, Archivo de Hullera VascoLeonesa (AHVL) com média 0,43, Archivo General de Simancas (AGS) com média 0,56, Archivo Historico Provincial de Guipúzcoa (AHPG) e Archivo Historico Provincial de Granada (AHPGR) com média 0,62, Archivo Municipal de santander (AMS) e Archivo Historico de Asturias (AHA) ambos com média 0,68. Foram detectados problemas cosméticos de usabilidade nos Arquivos: AHPH $(1,12)$, AGMA e AEG $(1,06)$. 
Gráfico 30 - Consistência nas convenções adotadas - Pontuação de cada avaliador por arquivo

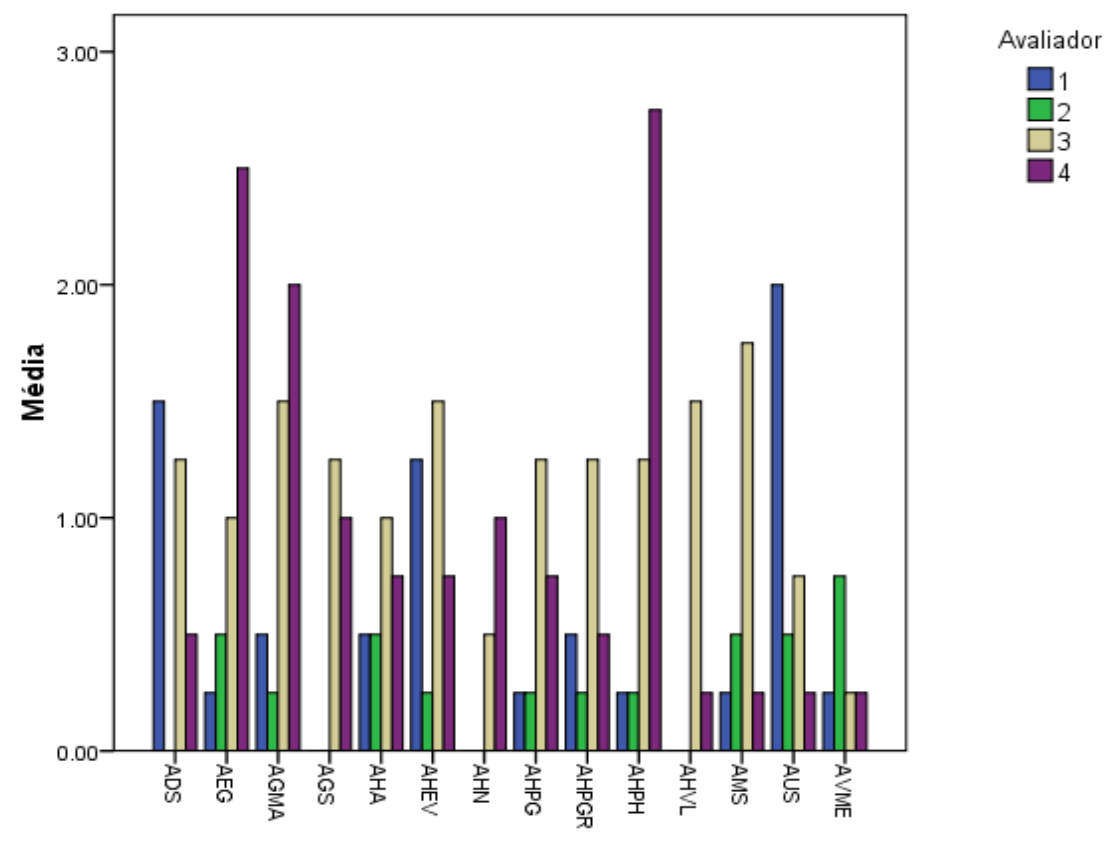

$\mathrm{Na}$ heurística Consistência nas convenções adotadas, observa-se em alguns momentos uma variação muito grande nas avaliações, tendo um desvio padrão de mais de 1 do Archivo Histórico Provincial de Huesca (AHPH) e do Arquivo da Emigração Galega (AEG), indicando avaliações bem diferentes em relação a estes sites, sendo por alguns avaliadores, considerados problemas mais complexos. No geral, a média indica um baixo nível de problemas.

Tabela 83 - Disponibilização, clareza e precisão dos links Pontuação de cada avaliador por arquivo

\begin{tabular}{c|c|c|c|c}
\hline Arquivo & \multicolumn{4}{|c}{ Avaliador } \\
\hline & $\mathbf{1}$ & $\mathbf{2}$ & $\mathbf{3}$ & $\mathbf{4}$ \\
\hline ADS & 1 & 0,5 & 1,33 & 0,33 \\
\hline AEG & 0,33 & 1,25 & 0,66 & 2,33 \\
\hline AGMA & 1 & 0,66 & 2 & 2,66 \\
\hline AGS & 0 & 0,25 & 2 & 0 \\
\hline AHA & 0,6 & 0,75 & 1,33 & 2,66 \\
\hline AHEV & 0,25 & 0 & 2 & 1,33 \\
\hline AHN & 0 & 0,25 & 1,33 & 0 \\
\hline & & &
\end{tabular}




\begin{tabular}{c|c|c|c|c}
\hline AHPG & 1,66 & 0,5 & 0,33 & 2,66 \\
\hline AHPGR & 0,66 & 0,33 & 2 & 0 \\
\hline AHPH & 1 & 0,33 & 1,66 & 1,66 \\
\hline AHVL & 0 & 0,5 & 2 & 1,33 \\
\hline AMS & 0 & 1 & 1,66 & 0,33 \\
\hline AUS & 1,66 & 0 & 0,66 & 0,33 \\
\hline AVME & 0 & 0,75 & 1,33 & 0 \\
\hline
\end{tabular}

A Heurística Disponibilização, clareza e precisão dos links apresenta problemas menores de usabilidade para os seguintes Arquivos: Archivo Histórico Nacional (AHN) com média 0,39, Archivo Vasco de la Musica Eresbil (AVME) com média 0,52, Achivo General de Simancas (AGS) com média 0,53, Archivo dela Universidad de Salamanca (AUS) com média 0,66, Archivo Histórico Provincial de Granada (AHPGR) e Archivo Municipal de Santander (AMS) com média 0,74. Os Arquivos: Arquivo da Emigración Galega (AEG) com média 1,14, Archivo Histórico Provincial de Huesca (AHPH) com média 1,16, Archivo Histórico Provincial de Guipúzcoa (AHPG) com média 1,28 e Archivo General Militar de Ávila (AGMA) com média 1,58 apresentaram problemas "cosméticos" de usabilidade. 
Gráfico 31 -Disponibilização, clareza e precisão dos links - Pontuação de cada avaliador por arquivo

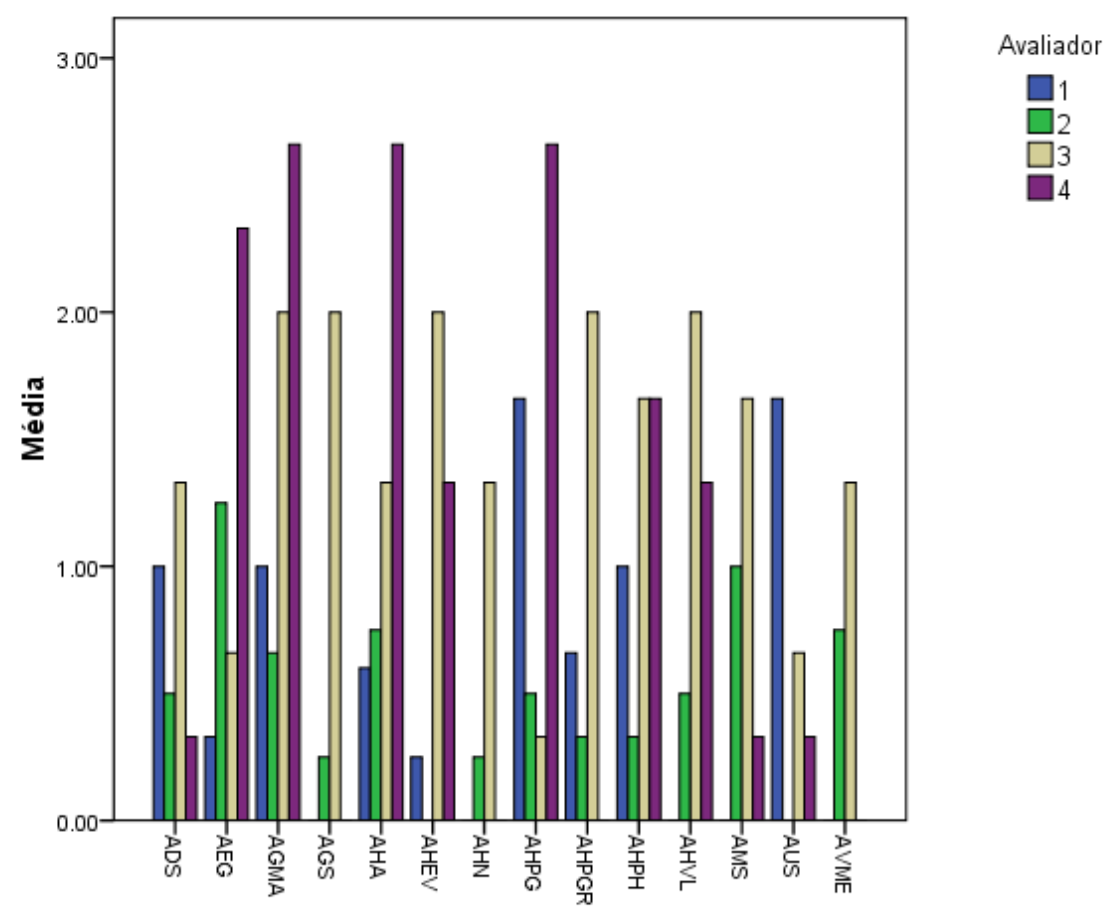

$\mathrm{Na}$ Heurística Disponibilização, clareza e precisão dos links, há uma grande dispersão entre as avaliações, mas os que apresentaram tendência a problemas maiores de usabilidade foram o Archivo General Militar de Ávila e Archivo Histórico de Asturias e do Archivo Histórico Provincial de Gipuzcoa (os três com média 2,66).

Tabela 84 - Natureza estética e simplicidade da interface -

Pontuação de cada avaliador por arquivo

\begin{tabular}{c|c|c|c|c}
\hline Arquivo & \multicolumn{4}{|c}{ Avaliador } \\
\hline & $\mathbf{1}$ & $\mathbf{2}$ & $\mathbf{3}$ & $\mathbf{4}$ \\
\hline ADS & 2,8 & 0,4 & 1,4 & 0,4 \\
\hline AEG & 0 & 0,6 & 0,8 & 2,6 \\
\hline AGMA & 0,2 & 0,6 & 0,8 & 2,6 \\
\hline AGS & 0 & 0 & 1,2 & 0,6 \\
\hline AHA & 0,6 & 0,6 & 1,2 & 1,6 \\
\hline AHEV & 0,8 & 0 & 1,6 & 0 \\
\hline AHN & 0,4 & 0 & 1 & 0,6 \\
\hline
\end{tabular}




\begin{tabular}{c|c|c|c|c}
\hline AHPG & 1,2 & 0 & 0,6 & 1 \\
\hline AHPGR & 0 & 0,2 & 1,8 & 0,8 \\
\hline AHPH & 0,4 & 0,2 & 1,4 & 1,4 \\
\hline AHVL & 0,6 & 0,2 & 2 & 0 \\
\hline AMS & 0 & 0,8 & 1,8 & 0,8 \\
\hline AUS & 2,2 & 0,2 & 0,6 & 1 \\
\hline AVME & 0,6 & 0,6 & 1,8 & 0,6 \\
\hline
\end{tabular}

A heurística Natureza estética e simplicidade da interface revelou problemas menores de usabilidade para os sites do seguintes Aquivos: Archivo General de Simancas (AGS) com média 0,45, Archivo Histórico Nacional (AHN) com média 0,5, Archivo Histórico Provincial de Guipúzcoa (AHPG), Archivo Histórico Provincial de Granada (AHPGR), Archivo de Hullera Vasco-Leonesa (AHVL) e Archivo de La Universidad de Salamanca (AUS) todos com média 0,7. Os seguintes Arquivos apresentaram problemas "cosméticos" de usabilidade: Arquivo da Emigración Galega (AEG) e Archivo Histórico de Astúrias (AHA) ambos com média 1, Archivo General Militar de Ávila (AGMA) com média 1,05 e por fim, Archivo de Diputación de Sevilla (ADS) com média 1,25. 
Gráfico 32 - Natureza estética e simplicidade da interface - Pontuação de cada avaliador por arquivo

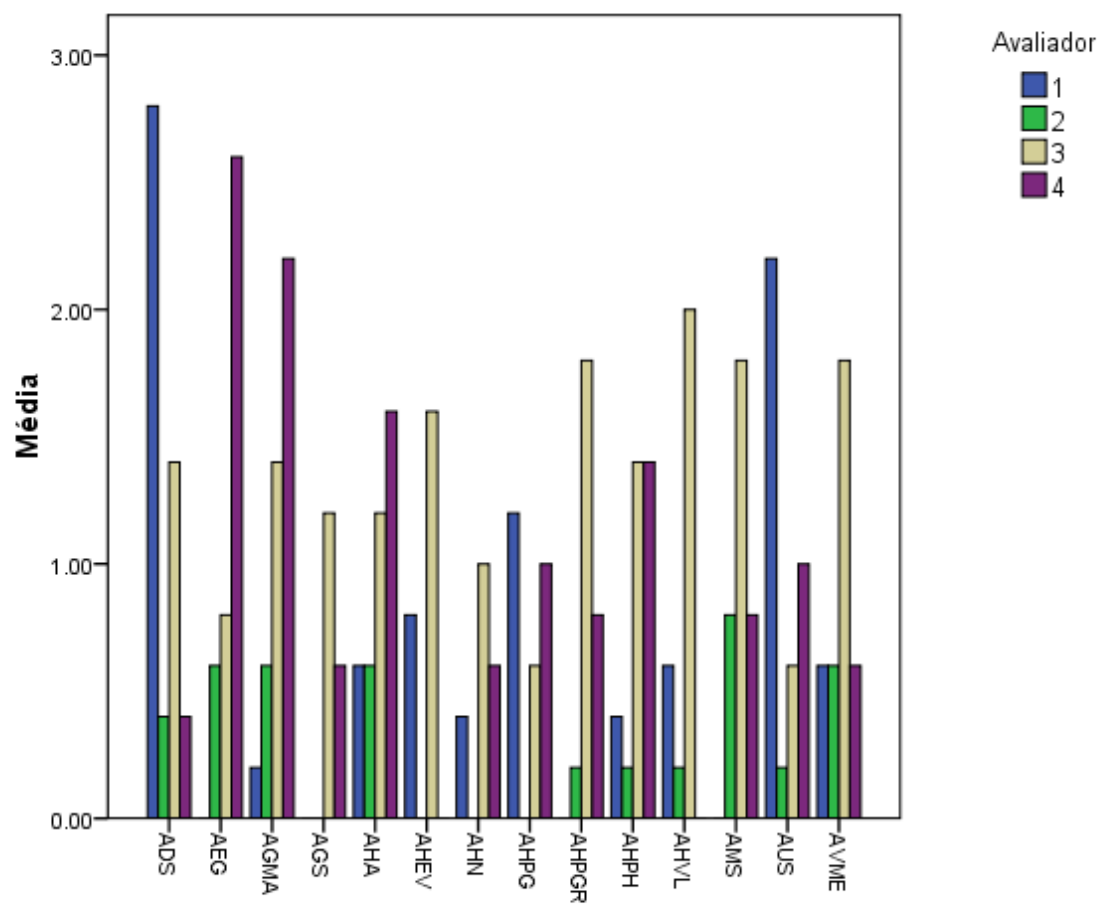

Fonte: Pesquisa Direta/2010

$\mathrm{Na}$ avaliação da heurística Natureza estética e Simplicidade da interface, há uma grande dispersão entre as avaliações, mas somente o Archivo de La Diputación de Sevilla (ADS) e o Arquivo da Emigração Galega têm desvio padrão maior que 1. Levando em consideração a média, todos os sites tem baixo problemas, sendo os que apresentaram tendência a problemas maiores o da ADS e da Archivo General Militar de Ávila.

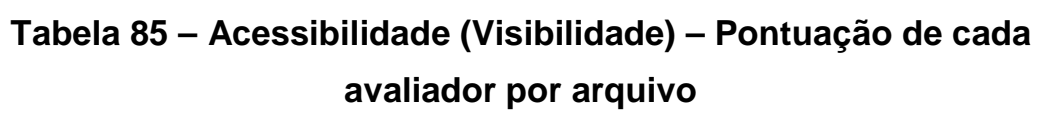

\begin{tabular}{c|c|c|c|c}
\hline Arquivo & \multicolumn{4}{|c}{ Avaliador } \\
\hline & $\mathbf{1}$ & $\mathbf{2}$ & $\mathbf{3}$ & $\mathbf{4}$ \\
\hline & & & & \\
\hline ADS & 1,4 & 0,6 & 1 & 0,4 \\
\hline AEG & 0,4 & 1,8 & 0,4 & 3,6 \\
\hline AGMA & 1 & 0,8 & 1,6 & 2,8 \\
\hline AGS & 0,4 & 0,2 & 1,2 & 1 \\
\hline
\end{tabular}




\begin{tabular}{c|c|c|c|c}
\hline AHA & 1,2 & 0,8 & 0,6 & 3,4 \\
\hline AHEV & 2 & 1 & 1,2 & 2 \\
\hline AHN & 0,6 & 1 & 0,6 & 0,8 \\
\hline AHPG & 2,2 & 0,4 & 0,8 & 4 \\
\hline AHPGR & 1,4 & 0,8 & 1,2 & 0,8 \\
\hline AHPH & 0,2 & 1 & 1,4 & 2,4 \\
\hline AHVL & 0,2 & 0,4 & 2 & 1 \\
\hline AMS & 0,4 & 0,8 & 1,8 & 0,2 \\
\hline AUS & 2,4 & 0,6 & 0,6 & 1,8 \\
\hline AVME & 0,6 & 0,6 & 1 & 0,6 \\
\hline
\end{tabular}

Os sites dos seguintes Arquivos apresentam problemas "cosméticos" de usabilidade em relação à heurística Acessibilidade: Arquivo da Emigración Galega (AEG) e Archivo Histórico Eclesiástico de Vizcaya (AHEV) ambos com média 1,55, Archivo General Militar de Ávila (AGMA) com média 1,55, Archivo Histórico de Astúrias (AHA) com média 1,5, Archivo Histórico Provincial de Granada (AHPG) com média 1,85, Archivo Histórico Provincial de Granada (AHPGR) com média 1,05, Archivo Histórico Provincial de Huesca (AHPH) com média 1,6 e Archivo de la Universidad de Salamanca (AUS) com média 1,35. Os demais sites apresentam problemas menores de usabilidade. 


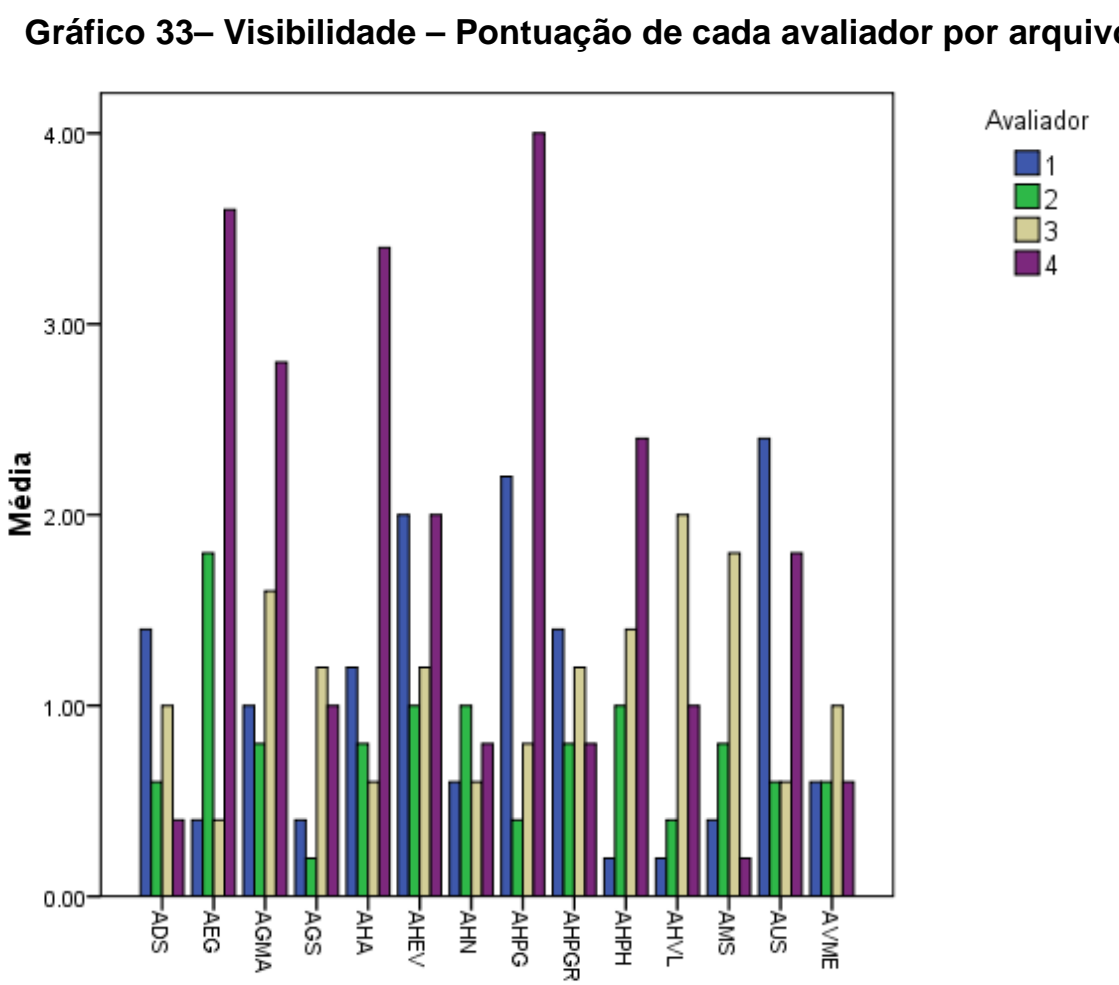

Fonte: Pesquisa Direta/2010

Na heurística Visibilidade, a dispersão maior é dada por um avaliador, com desvio padrão maior que 1 nos sites Archivo Histórico de Asturias, Arquivo da Emigração Galega e Archivo Histórico de protocolos de Gipuskoa, tendo os dois últimos uma média que tende para problemas mais graves em relação a essa heurística.

Tabela 86 - Instruções e documentação Pontuação de cada avaliador por arquivo

\begin{tabular}{c|c|c|c|c}
\hline Arquivo & \multicolumn{4}{|c}{ Avaliador } \\
\hline & $\mathbf{1}$ & $\mathbf{2}$ & $\mathbf{3}$ & $\mathbf{4}$ \\
\hline ADS & 0,5 & 1,5 & 1 & 4 \\
\hline AEG & 1,5 & 1,5 & 0,5 & 4 \\
\hline AGMA & 1,5 & 0,5 & 2 & 4 \\
\hline AGS & 1 & 0,5 & 2 & 4 \\
\hline AHA & 2 & 1 & 1,5 & 4 \\
\hline AHEV & 1,5 & 1 & 2 & 3 \\
\hline
\end{tabular}




\begin{tabular}{c|c|c|c|c}
\hline AHN & 0,5 & 1,5 & 2 & 4 \\
\hline AHPG & 3 & 1 & 0,5 & 4 \\
\hline AHPGR & 0,5 & 0,66 & 1 & 4 \\
\hline AHPH & 0 & 1 & 0,5 & 4 \\
\hline AHVL & 0 & 1 & 1,5 & 4 \\
\hline AMS & 0 & 1 & 2 & 3 \\
\hline AUS & 2,5 & 0,5 & 1,5 & 4 \\
\hline AVME & 2 & 1 & 1 & 2 \\
\hline
\end{tabular}

A heurística Instruções e documentação revelou problemas "cosméticos" de usabilidade para os sites do seguintes Aquivos: Archivo Histórico Provincial de Huesca (AHPH) com média 1,37, Archivo Municipal de Santander (AMS) e Archivo Histórico Eclesiástico de Vizcaya Archivo Vasco de La Musica Eresbil (AVME) ambos com média 1,5, Archivo Histórico Provincial de Granada (AHPGR) com média 1,54, AHVL com média 1,62, Archivo de Diputación de Sevilla (ADS) com média 1,75, Arquivo da Emigración Galega (AEG), Archivo General de Santander (AGS) e Archivo Histórico Eclesiástico de Vizcaya (AHEV) todos com média 1,87. Outros sites apresentaram pequenos problemas de usabilidade (nível 2) de de fácil reparação: Archivo General Militar de Ávila (AGMA) e Archivo Histórico Nacional (AHN) ambos com média 2 e, Archivo Histórico Provincial de Guipúzcoa (AHPG) e Archivo de La Universidad de Salamanca (AUS) ambos com média 2,12. 
Gráfico 34 - Instruções e documentação — Pontuação de cada avaliador por
arquivo

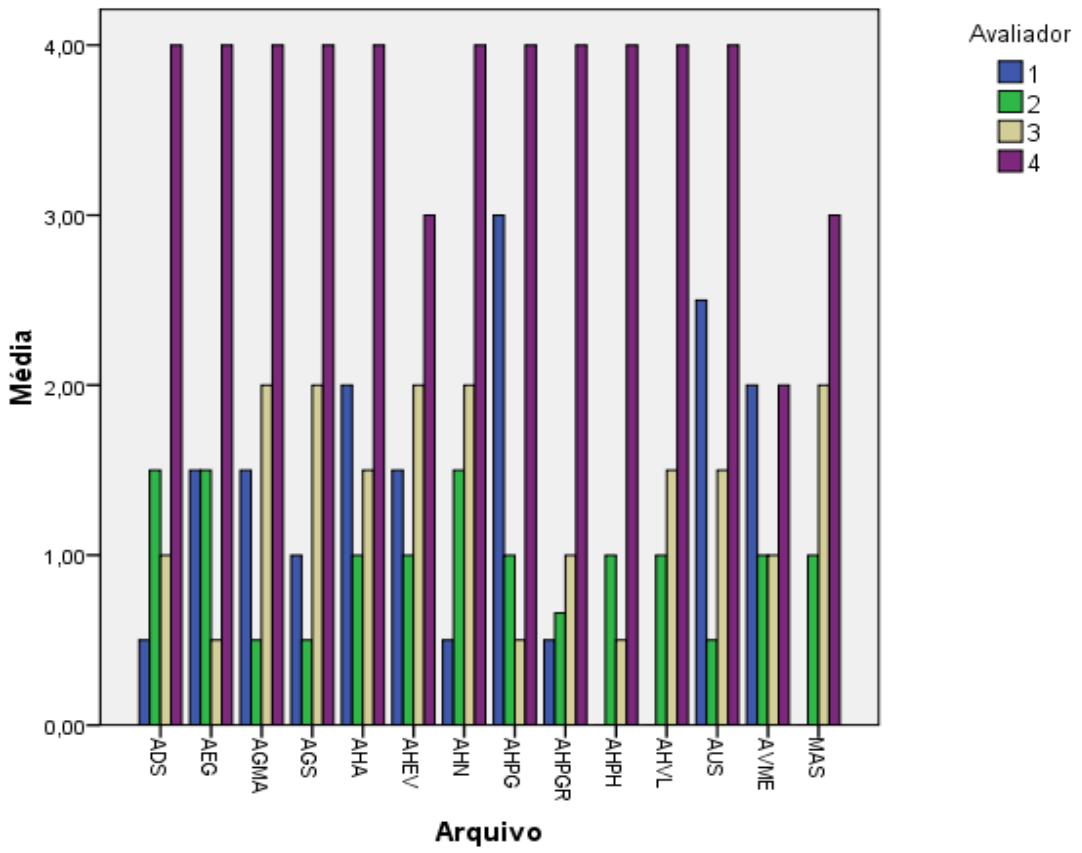

Fonte: Pesquisa Direta/2010

Na heurística Instruções e documentação, os sites Archivo Histórico de Asturias (2,12), Archivo Histórico de Protocolos de Guipuzkoa (média 2,12) e Arquivo da Emigração Galega (média 1,87), têm maior dispersão, tendo os dois últimos uma tendência para problemas mais graves de usabilidade em relação a essa heurística.

Considerando a média dos pontos atribuídos pelos avaliadores, observa-se uma constância entre as médias, com três delas tendendo para problemas menos graves e um para problemas maiores. É possível que o grau de dificuldade sentido pelo avaiador 4 tenha sido maior que os demais, considerando sua experiência e domínio das ferramentas de internet. Apresenta-se a seguir a visão dos avaliadores a respeito das heurísticas para cada Arquivo. 
Tabela 87 - Pontuação Heurísticas por Avaliador - ADS

\begin{tabular}{c|c|c} 
Avaliador & \multicolumn{1}{c}{ Média } & desvio padrão \\
\hline $\mathbf{1}$ & 1,10 & 0,92 \\
\hline $\mathbf{2}$ & 0,71 & 0,76 \\
\hline $\mathbf{3}$ & 1,25 & 0,19 \\
\hline $\mathbf{4}$ & 1,13 & 1,46 \\
\hline
\end{tabular}

Observa-se na Tabela 87 que o avaliador 3 foi quem encontrou maiores problemas de usabilidade no site do Archivo de Diputación de Sevilla, com média 1,25 e o avaliador 2 foi quem melhor classificou o site através das heurísticas com média 0,71 .

O avaliador 3 apresentou menor desvio padrão $(0,19)$ sugerindo que sua análise foi mais homogênea em relação a cada heurística. Em contrapartida o avaliador 4 apresentou maior desvio padrão $(1,46)$ significando que sua análise foi a mais heterogênea, quer dizer, suas respostas variaram bastante de uma heurística para outra.

Gráfico 35 - Avaliação Heurísticas por Avaliador - ADS

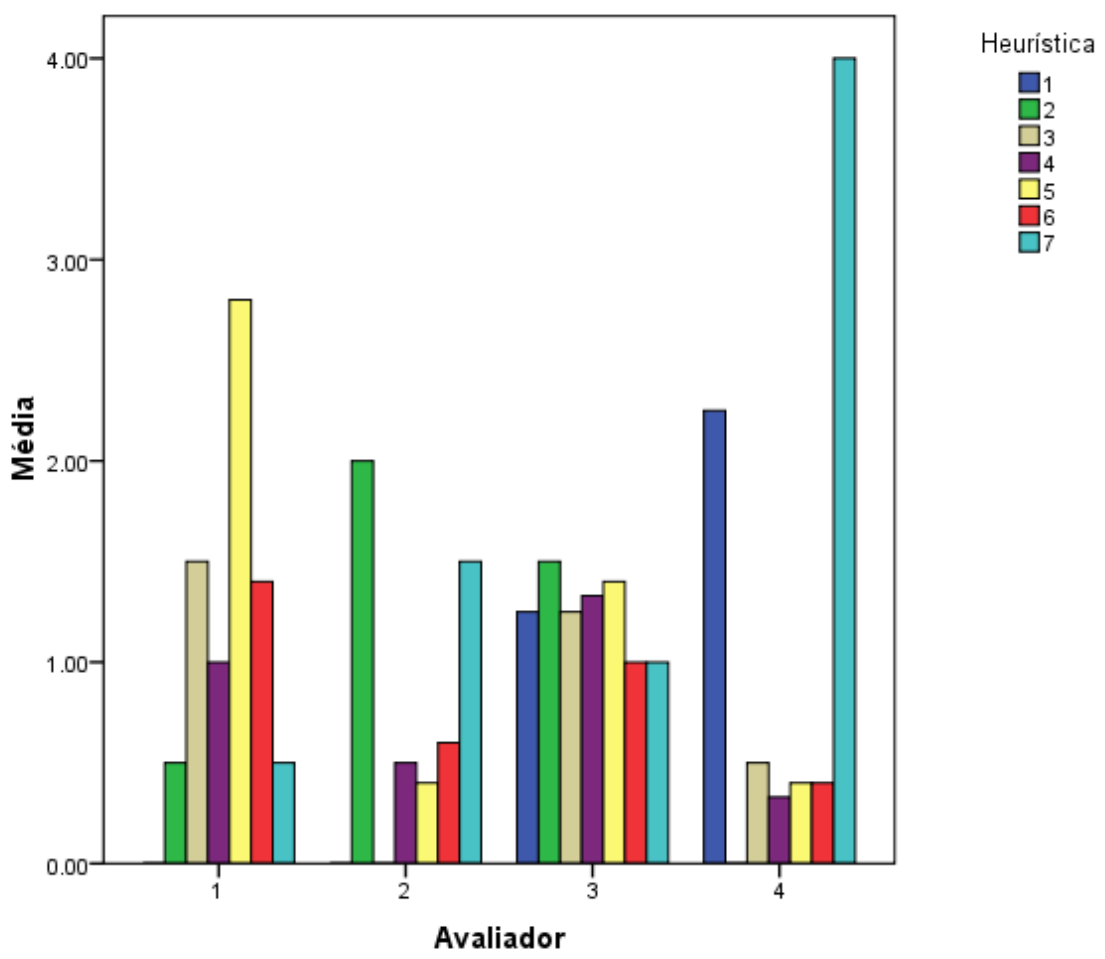


O Gráfico acima demonstra claramente a disparidade de resultados dos avaliadores em relação a algumas heurísticas. O avaliador 1 apresentou resultado bastante díspare para a heurística 5, o avaliador 2 para a heurística 2 e o avaliador 4 para a heurística 7.

Tabela 88 - Pontuação Heurísticas por Avaliador
\begin{tabular}{c|c|c} 
Avaliador & Média & desvio padrão \\
\hline $\mathbf{1}$ & 0,39 & 0,51 \\
\hline $\mathbf{2}$ & 0,81 & 0,72 \\
\hline $\mathbf{3}$ & 0,94 & 0,55 \\
\hline $\mathbf{4}$ & 2,93 & 0,64 \\
\hline
\end{tabular}

Observa-se na Tabela 88 que o avaliador 4 com média das heurísticas de 2,93, foi quem encontrou problemas de usabilidade de fácil reparação no site do Archivo da Emigración Galega.

$O$ avaliador 1 foi quem melhor classificou o site atavés das heurísticas, pois apresentou menor média $(0,39)$, bem como apresentou menor desvio padrão sugerindo que sua análise foi a mais homogênea em relação a cada heurística, isso significa que considerou que o site possui baixos problemas de usabilidade.

Os avaliadores 2 e 3 tiveram médias aproximadas $(0,81$ e 0,94 respectivamente), significando que opinam de forma semelhante e positiva a respeito da usabilidade do site. 
Gráfico 36 - Avaliação Heurísticas por Avaliador - AEG

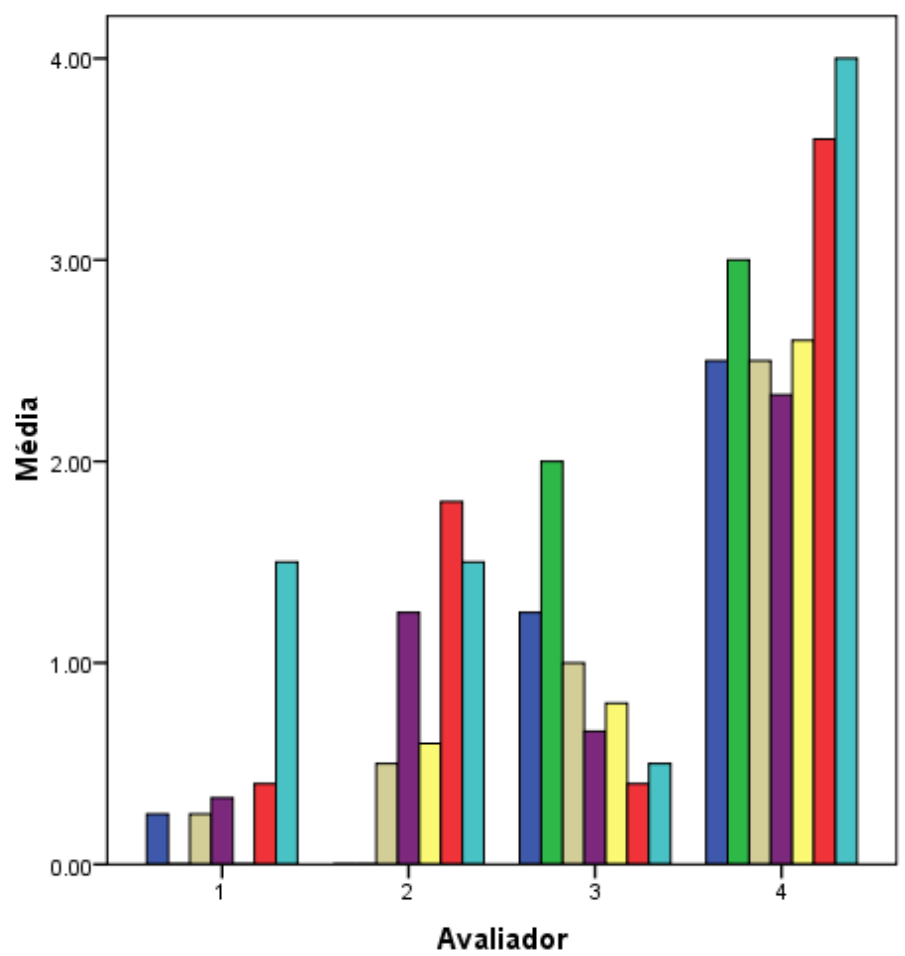

Heurística

$\square 1$
$\square 2$
$\square 3$
$\square 4$
$\square 5$
$\square 6$
$\square 7$

O Gráfico 36 acima demonstra claramente a disparidade de resultados dos avaliadores em relação a algumas heurísticas. Os avaliadores 1 e 4, apresentaram resultados bastante díspares para a heurística 7 referente a instruções e documentação.

Tabela 89 - Pontuação Heurísticas por Avaliador - AGMA

\begin{tabular}{c|c|c}
\hline Avaliador & média & desvio padrão \\
\hline $\mathbf{1}$ & 0,81 & 0,60 \\
\hline $\mathbf{2}$ & 0,64 & 0,43 \\
\hline $\mathbf{3}$ & 1,71 & 0,27 \\
\hline $\mathbf{4}$ & 2,63 & 0,66 \\
\hline
\end{tabular}

Observa-se na Tabela 89 que o avaliador 4 com média das heurísticas de 2,93, foi quem encontrou problemas de usabilidade de fácil reparação no site do Archivo da Emigración Galega.

O avaliador 1 foi quem melhor classificou o site através das heurísticas, pois apresentou menor média $(0,39)$, bem como apresentou menor desvio padrão 
sugerindo que sua análise foi a mais homogênea em relação a cada heurística, isso significa que considerou que o site possui baixos problemas de usabilidade.

Os avaliadores 2 e 3 tiveram médias aproximadas $(0,81$ e 0,94 respectivamente), significando que opinam de forma semelhante e positiva a respeito da usabilidade do site.

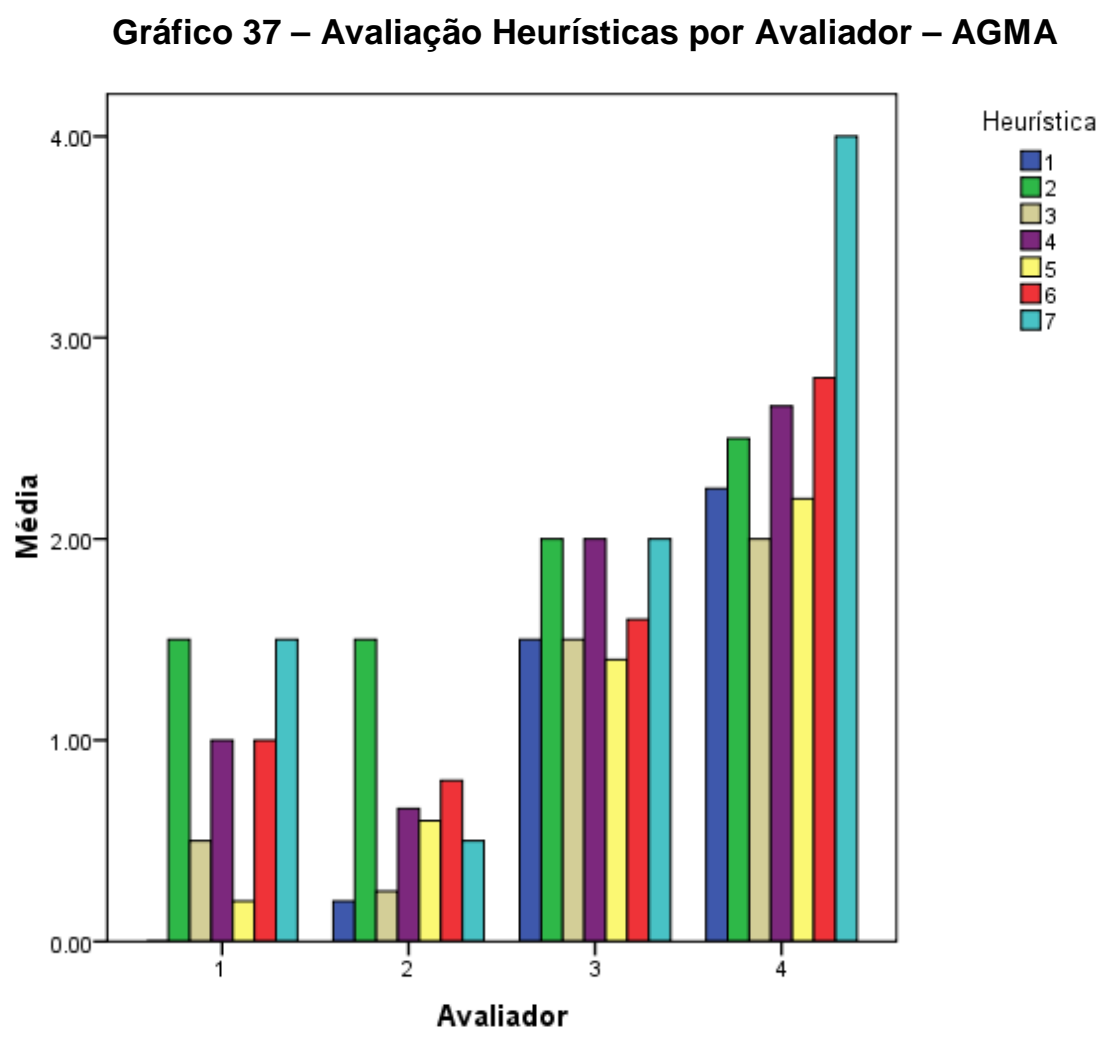

O Gráfico 37 demonstra claramente a disparidade de resultados dos avaliadores em relação a algumas heurísticas. Os avaliadores 2 e 4, apresentaram resultados bastante díspares para a heurística 2: Liberdade de circulação e controle de ações e 7: Instruções e documentação respectivamente. 
Tabela 90 - Pontuação Heurísticas por Avaliador - AGS

\begin{tabular}{c|c|c}
\hline Avaliador & média & desvio padrão \\
\hline $\mathbf{1}$ & 0,34 & 0,47 \\
\hline $\mathbf{2}$ & 0,21 & 0,22 \\
\hline $\mathbf{3}$ & 1,49 & 0,37 \\
\hline $\mathbf{4}$ & 1,09 & 1,36 \\
\hline
\end{tabular}

Observa-se na Tabela 90 que o avaliador $3 \mathrm{com}$ média 1,49, foi quem encontrou maiores problemas de usabilidade no site do Archivo General de Simancas, e o avaliador 2 foi quem melhor classificou o site através das heurísticas com média 0,21.

O avaliador 2 apresentou menor desvio padrão $(0,22)$ sugerindo que sua análise foi mais homogênea em relação a cada heurística. Em contrapartida o avaliador 4 apresentou maior desvio padrão $(1,36)$ significando que sua análise foi a mais heterogênea, quer dizer, suas respostas variaram bastante de uma heurística para outra.

Gráfico 38 - Avaliação Heurísticas por Avaliador - AGS

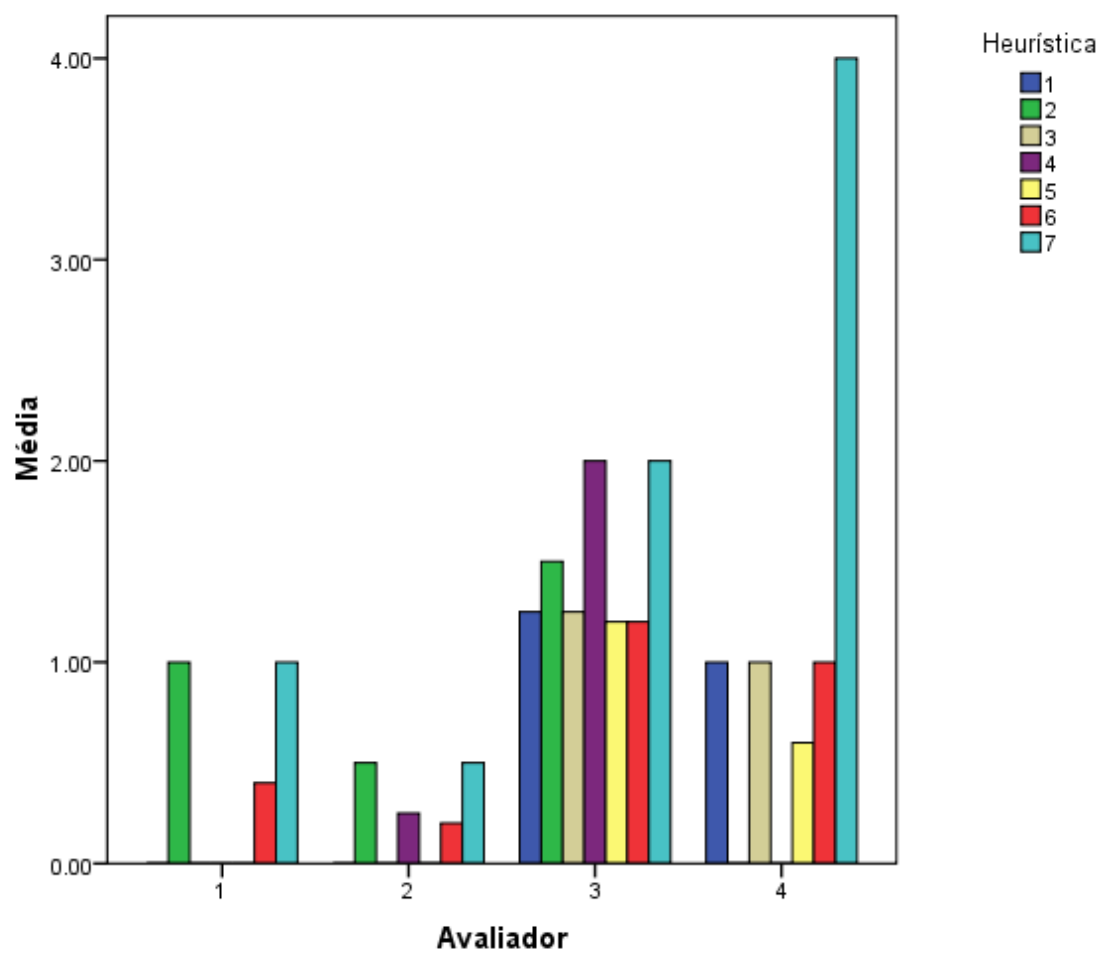


Como demonstrado no Gráfico 38, o avaliador 4 apresentou grande disparidade no resultado da heurística 7 (Instrução e Documentação) em relação aos outros avaliadores. $\mathrm{O}$ avaliador 2 apresentou resultados mais uniformes em todas as heurísticas em relação a este Arquivo.

Tabela 91 - Pontuação Heurísticas por Avaliador - AHA

\begin{tabular}{c|c|c} 
Avaliador & \multicolumn{1}{c}{ média } & desvio padrão \\
\hline $\mathbf{1}$ & 0,84 & 0,64 \\
\hline $\mathbf{2}$ & 0,81 & 0,35 \\
\hline $\mathbf{3}$ & 1,09 & 0,29 \\
\hline $\mathbf{4}$ & 2,27 & 1,21 \\
\hline
\end{tabular}

Observa-se na Tabela 91 que o avaliador 2 com média 0,81, foi quem encontrou menores problemas de usabilidade no site do Archivo Histórico de Asturias, e o avaliador 4 encontrou maiores problemas de usabilidade através das heurísticas com média 2,27.

O avaliador 3 apresentou menor desvio padrão $(0,29)$ sugerindo que sua análise foi mais homogênea em relação a cada heurística. $O$ avaliador 4 apresentou maior desvio padrão $(1,21)$ significando que sua análise foi a mais heterogênea, quer dizer, suas respostas variaram bastante de uma heurística para outra. 


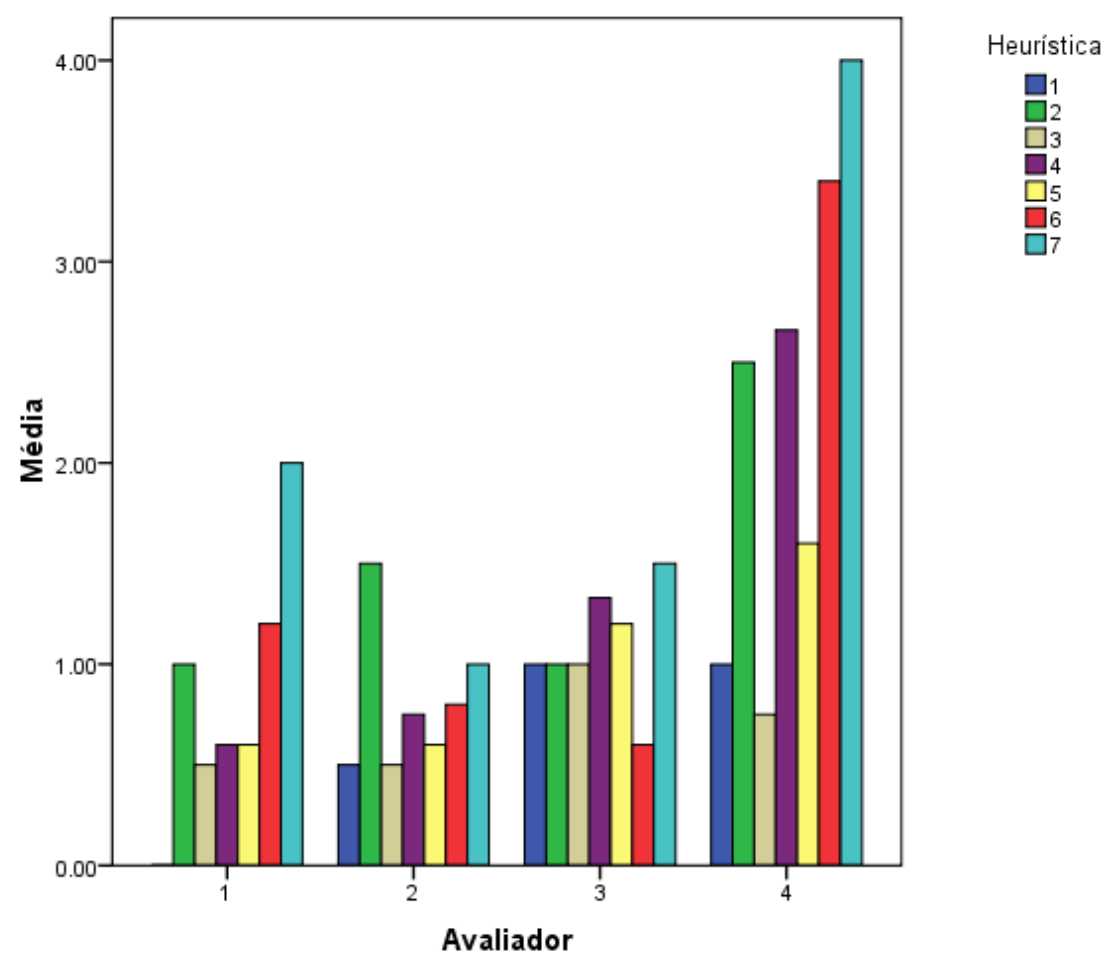

O Gráfico 39 acima demonstra claramente a disparidade de resultados dos avaliadores em relação a algumas heurísticas. Os avaliadores 1 e 4 apresentaram resultados bastante díspares para a heurística 7 (Instrução e Documentação), o avaliador 2 para a heurística 2 (consistência nas convenções adotadas). 0 avaliador 3 apresentou mais homegeneidade nos resultados, não apresentando nenhuma disparidade.

Tabela 92 - Pontuação Heurísticas por Avaliador - AHEV

\begin{tabular}{c|c|c}
\hline Avaliador & Média & desvio padrão \\
\hline $\mathbf{1}$ & 0,90 & 0,72 \\
\hline $\mathbf{2}$ & 0,61 & 0,50 \\
\hline $\mathbf{3}$ & 1,69 & 0,32 \\
\hline $\mathbf{4}$ & 1,26 & 0,98 \\
\hline
\end{tabular}

$\mathrm{Na}$ Tabela 92, verifica-se que o avaliador 2 com média 0,61 , foi quem encontrou menores problemas de usabilidade no site do Archivo Histórico Eclesiástico de Vizcaya, e o avaliador 3 encontrou maiores problemas de usabilidade através das heurísticas com média 1,69. 
O avaliador 3 apresentou menor desvio padrão $(0,32)$, sugerindo que sua análise foi mais homogênea em relação a cada heurística. $O$ avaliador 4 apresentou maior desvio padrão $(0,98)$, significando que sua análise foi a mais heterogênea, ou seja, suas respostas variaram bastante de uma heurística para outra.

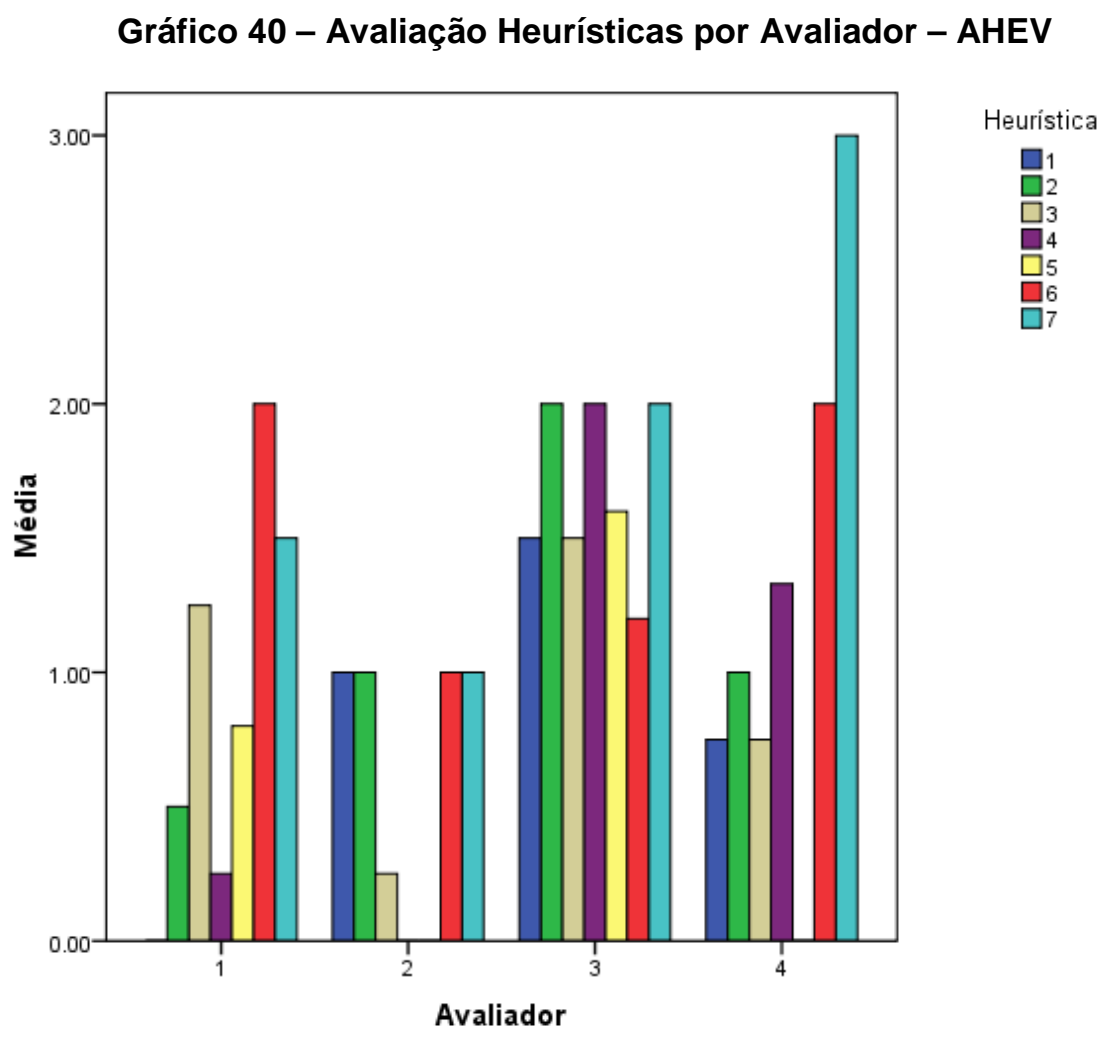

O Gráfico acima demonstra claramente a disparidade de resultados dos avaliadores em relação a algumas heurísticas. O avaliador 1 apresentou disparidade no resultado da heurística 6 (Visibilidade) e o avaliador 4 apresentou disparidade na heurística 7 (Instrução e Documentação). Os avaliadores 2 e 3 apresentaram mais homegeneidade nos resultados.

Tabela 93 - Pontuação Heurísticas por Avaliador - AHN

\begin{tabular}{c|c|c} 
Avaliador & média & desvio padrão \\
\hline $\mathbf{1}$ & 0,43 & 0,35 \\
\hline $\mathbf{2}$ & 0,39 & 0,61 \\
\hline $\mathbf{3}$ & 0,92 & 0,57 \\
\hline $\mathbf{4}$ & 1,02 & 1,37 \\
\hline
\end{tabular}


Na avaliação do site do Archivo Histórico Nacional, conforme se observa na Tabela 93, verifica-se que o avaliador 2 com média 0,39, foi quem encontrou menores problemas de usabilidade, e o avaliador 4, com média 1,02 encontrou maiores problemas de usabilidade através das heurísticas.

O avaliador 1 apresentou menor desvio padrão $(0,35)$, sugerindo que sua análise foi mais homogênea em relação a cada heurística. O avaliador 4 apresentou maior desvio padrão $(1,37)$, significando que sua análise foi a mais heterogênea, ou seja, suas respostas variaram bastante de uma heurística para outra.

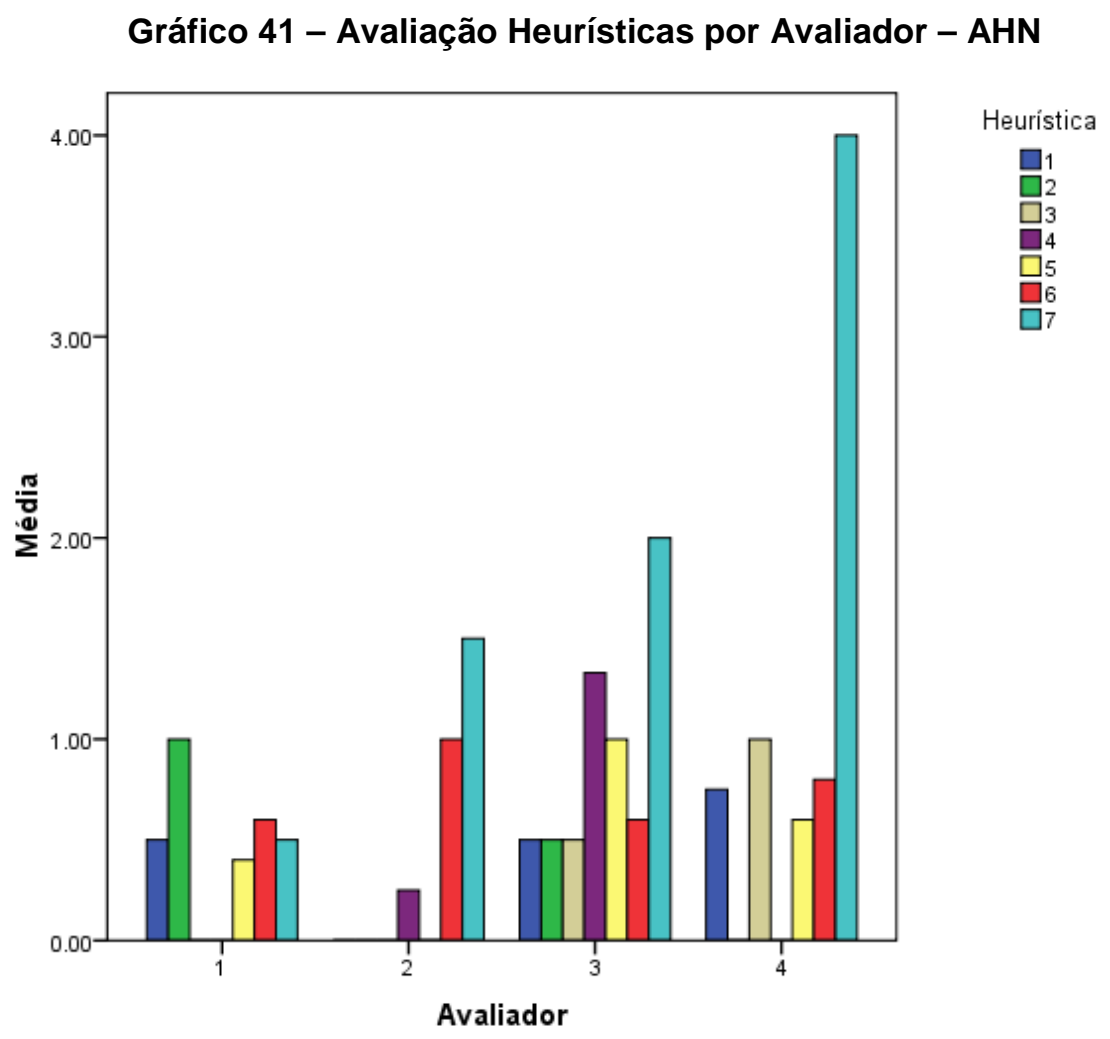

O Gráfico 41 acima demonstra claramente a disparidade de resultados dos avaliadores em relação a algumas heurísticas. Os avaliadores 2, 3 e 4 apresentaram disparidade na heurística 7 (Instrução e Documentação). 0 avaliador 1 apresentou mais homegeneidade nos resultados. 
Tabela 94 - Pontuação Heurísticas por Avaliador - AHPG

\begin{tabular}{c|c|c} 
Avaliador & \multicolumn{1}{c}{ média } & desvio padrão \\
\hline $\mathbf{1}$ & 1,69 & 0,86 \\
\hline $\mathbf{2}$ & 0,45 & 0,42 \\
\hline $\mathbf{3}$ & 0,71 & 0,32 \\
\hline $\mathbf{4}$ & 1,92 & 1,63 \\
\hline
\end{tabular}

Na avaliação do site do Archivo Histórico Provincial de Gipúzcoa conforme observa-se na Tabela 94 verifica-se que o avaliador 2 com média 0,45 , foi quem encontrou menores problemas de usabilidade, e o avaliador 4, com média 1,92 encontrou maiores problemas de usabilidade através das heurísticas.

O avaliador 3 apresentou menor desvio padrão $(0,32)$, sugerindo que sua análise foi mais homogênea em relação a cada heurística. $O$ avaliador 4 apresentou maior desvio padrão $(1,63)$, significando que sua análise foi a mais heterogênea, significando que suas respostas variaram bastante de uma heurística para outra.

\section{Gráfico 42 - Avaliação Heurísticas por Avaliador - AHPG}

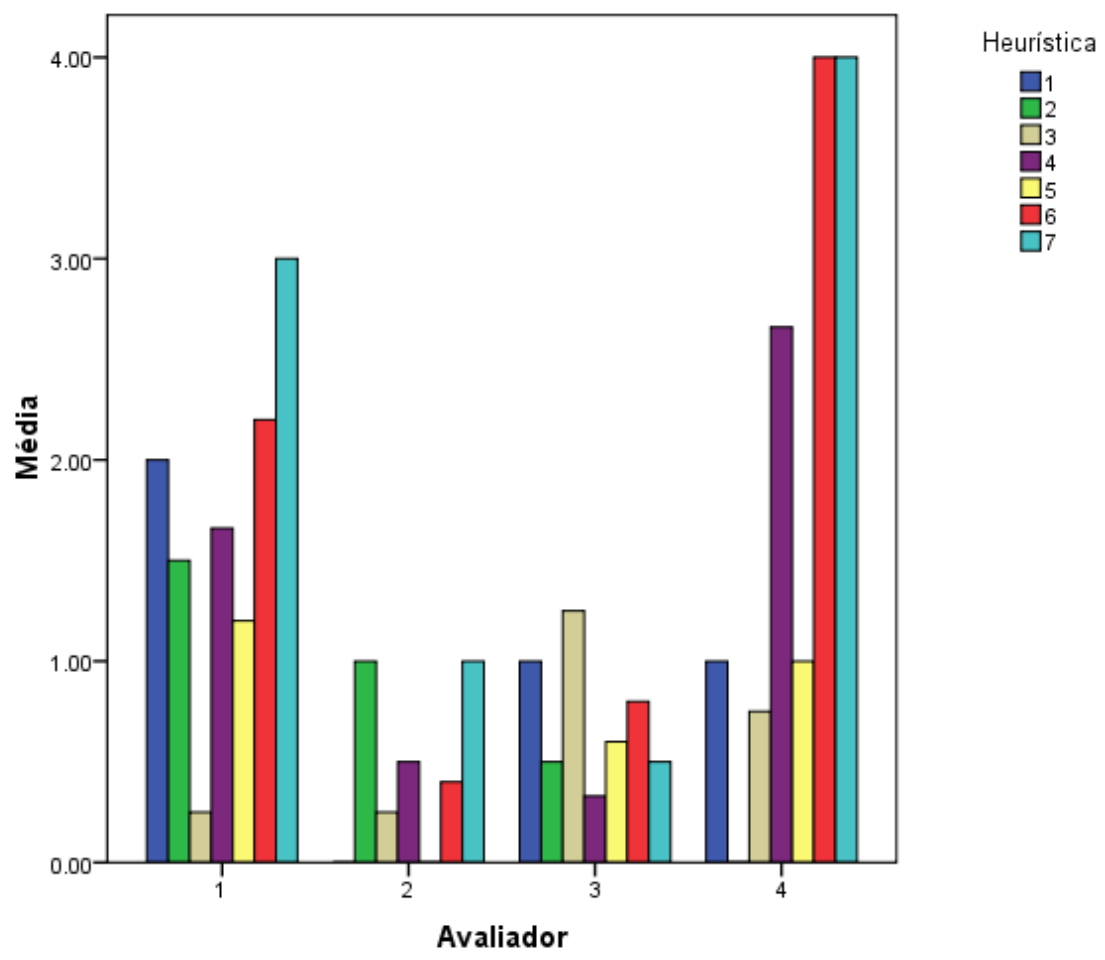


O Gráfico 96 demonstra claramente a disparidade no resultado do avaliador 1 para a heurística 7 (Instrução e Documentação). O avaliador 1 apresentou mais homegeneidade nos resultados.

Tabela 95 - Pontuação Heurísticas por Avaliador - AHPGR

\begin{tabular}{c|c|c}
\hline Avaliador & média & desvio padrão \\
\hline $\mathbf{1}$ & 0,51 & 0,47 \\
\hline $\mathbf{2}$ & 0,39 & 0,28 \\
\hline $\mathbf{3}$ & 1,50 & 0,30 \\
\hline $\mathbf{4}$ & 1,16 & 1,42 \\
\hline
\end{tabular}

Na avaliação do site do Archivo Histórico Provincial de Granada, conforme observa-se na Tabela 95, verifica-se que o avaliador 2 com média 0,39, foi quem encontrou menores problemas de usabilidade, e o avaliador 3, com média 1,50 encontrou maiores problemas de usabilidade através das heurísticas.

O avaliador 2 apresentou menor desvio padrão $(0,28)$ sugerindo que sua análise foi mais homogênea em relação a cada heurística. O avaliador 4 apresentou maior desvio padrão $(1,42)$ significando que sua análise foi a mais heterogênea, quer dizer, suas respostas variaram bastante de uma heurística para outra. 
Gráfico 43 - Avaliação Heurísticas por Avaliador - AHPGR

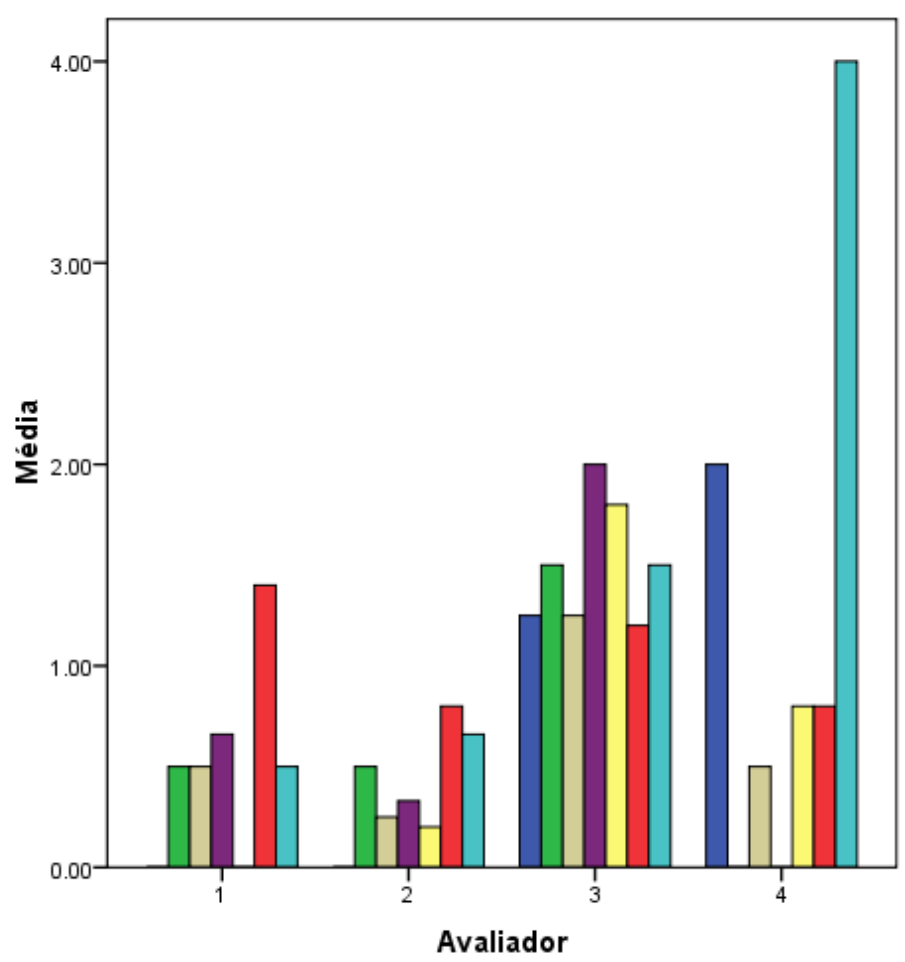

Heurística

$\square 1$
$\square 2$
$\square 3$
$\square 4$
$\square 5$
$\square 6$
$\square 7$

O Gráfico 43 demonstra claramente a disparidade de resultados do avaliador 1 no resultado da heurística 6 (Visibilidade) e do avaliador 4 no resultado da heurística 7 (Instrução e Documentação). Os avaliadores 2 e 3 apresentaram mais homegeneidade nos resultados, isso significa que a formação e experiência profissional de ambos os levaram a coincidir na visão a respeito dos sites.

Tabela 96 - Pontuação Heurísticas por Avaliador - AHPH

\begin{tabular}{c|c|c}
\hline Avaliador & média & desvio padrão \\
\hline $\mathbf{1}$ & 0,55 & 0,52 \\
\hline $\mathbf{2}$ & 0,72 & 0,48 \\
\hline $\mathbf{3}$ & 1,14 & 0,46 \\
\hline $\mathbf{4}$ & 2,67 & 0,94 \\
\hline
\end{tabular}

Conforme observa-se na Tabela 96 verifica-se que o avaliador 3 com média 0,46 , foi quem encontrou menores problemas de usabilidade, e 0 avaliador 4, com média 0,94 encontrou maiores problemas de usabilidade através das heurísticas. 
O avaliador 3 apresentou menor desvio padrão $(0,46)$ sugerindo que sua análise foi mais homogênea em relação a cada heurística. $O$ avaliador 4 apresentou maior desvio padrão $(0,94)$, significando que sua análise foi a mais heterogênea, quer dizer, suas respostas variaram bastante de uma heurística para outra.

Gráfico 44 - Avaliação Heurísticas por Avaliador - AHPH

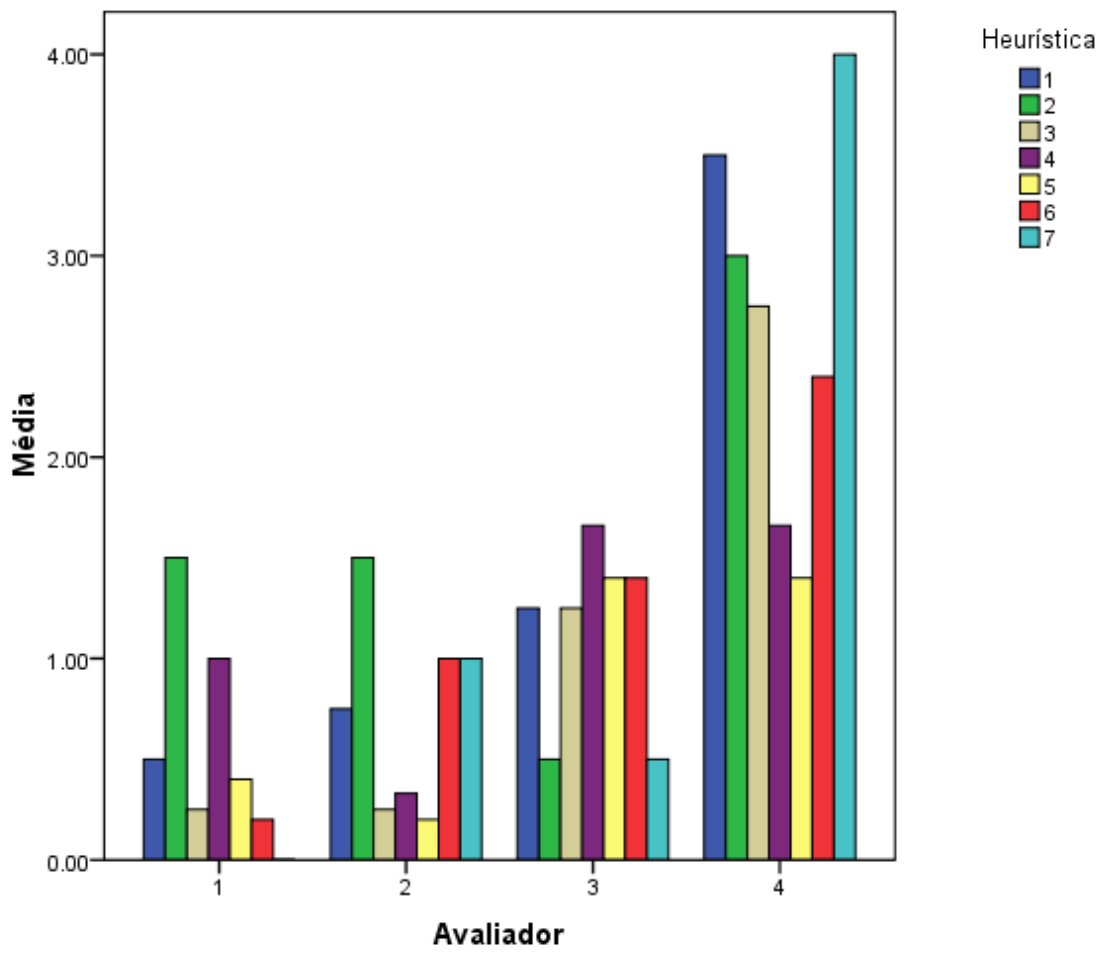

O Gráfico 44 acima demonstra claramente a disparidade de resultados dos avaliadores em relação a algumas heurísticas. Os avaliadores 1 e 2 apresentaram disparidade no resultado da heurística 2 (Liberdade de circulação e controle de ações) e o avaliador 4 apresentou mais heterogeneidade nos resultados.

Tabela 97 - Pontuação Heurísticas por Avaliador - AHVL

\begin{tabular}{c|c|c}
\hline Avaliador & média & desvio padrão \\
\hline $\mathbf{1}$ & 0,26 & 0,40 \\
\hline $\mathbf{2}$ & 0,37 & 0,35 \\
\hline $\mathbf{3}$ & 1,75 & 0,25 \\
\hline $\mathbf{4}$ & 0,94 & 1,45 \\
\hline
\end{tabular}


Conforme observa-se na Tabela 97 verifica-se que o avaliador $1 \mathrm{com}$ média 0,26 , foi quem encontrou menores problemas de usabilidade, e o avaliador 4, com média 0,94 encontrou maiores problemas de usabilidade através das heurísticas.

O avaliador 3 apresentou menor desvio padrão $(0,25)$, sugerindo que sua análise foi mais homogênea em relação a cada heurística. $O$ avaliador 4 apresentou maior desvio padrão $(1,45)$ significando que sua análise foi a mais heterogênea, ou seja, suas respostas variaram bastante de uma heurística para outra.

\section{Gráfico 45 - Avaliação Heurísticas por Avaliador - AHVL}

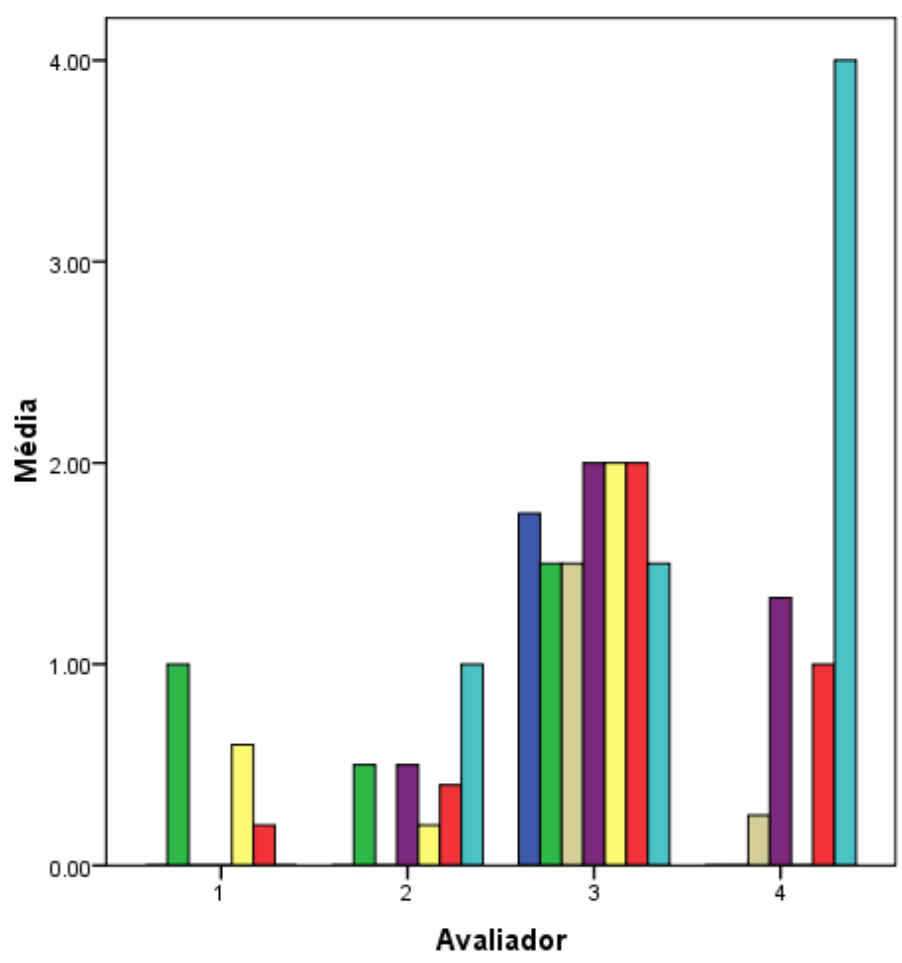

Heurística
$\square 1$
$\square 2$
$\square 3$
$\square 4$
$\square 5$
$\square 6$
$\square 7$

O Gráfico acima demonstra claramente que o avaliador 4 apresentou mais heterogeneidade nos resultados. $O$ avaliador 4 apresentou resultado maior disparidade no resultado da heurística 7 (Instrução e Documentação). 


\begin{tabular}{|c|c|c|}
\hline Avaliador & média & desvio padrão \\
\hline 1 & 0,09 & 0,16 \\
\hline 2 & 0,73 & 0,37 \\
\hline 3 & 1,79 & 0,18 \\
\hline 4 & 0,80 & 1,03 \\
\hline
\end{tabular}

A avaliação do Archivo Municipal de Santander, conforme observa-se na Tabela 98, demosntra que o avaliador $1 \mathrm{com}$ média 0,09 , foi quem encontrou menores problemas de usabilidade, chegando quase ao resultado 0 e $o$ avaliador 3 , com média 1,79 encontrou maiores problemas de usabilidade através das heurísticas.

O avaliador 1 apresentou menor desvio padrão $(0,16)$, sugerindo que sua análise foi mais homogênea em relação a cada heurística. $O$ avaliador 4 apresentou maior desvio padrão $(1,03)$ significando que sua análise foi a mais heterogênea, quer dizer, suas respostas variaram bastante de uma heurística para outra.

Gráfico 46 - Avaliação Heurísticas por Avaliador - AMS

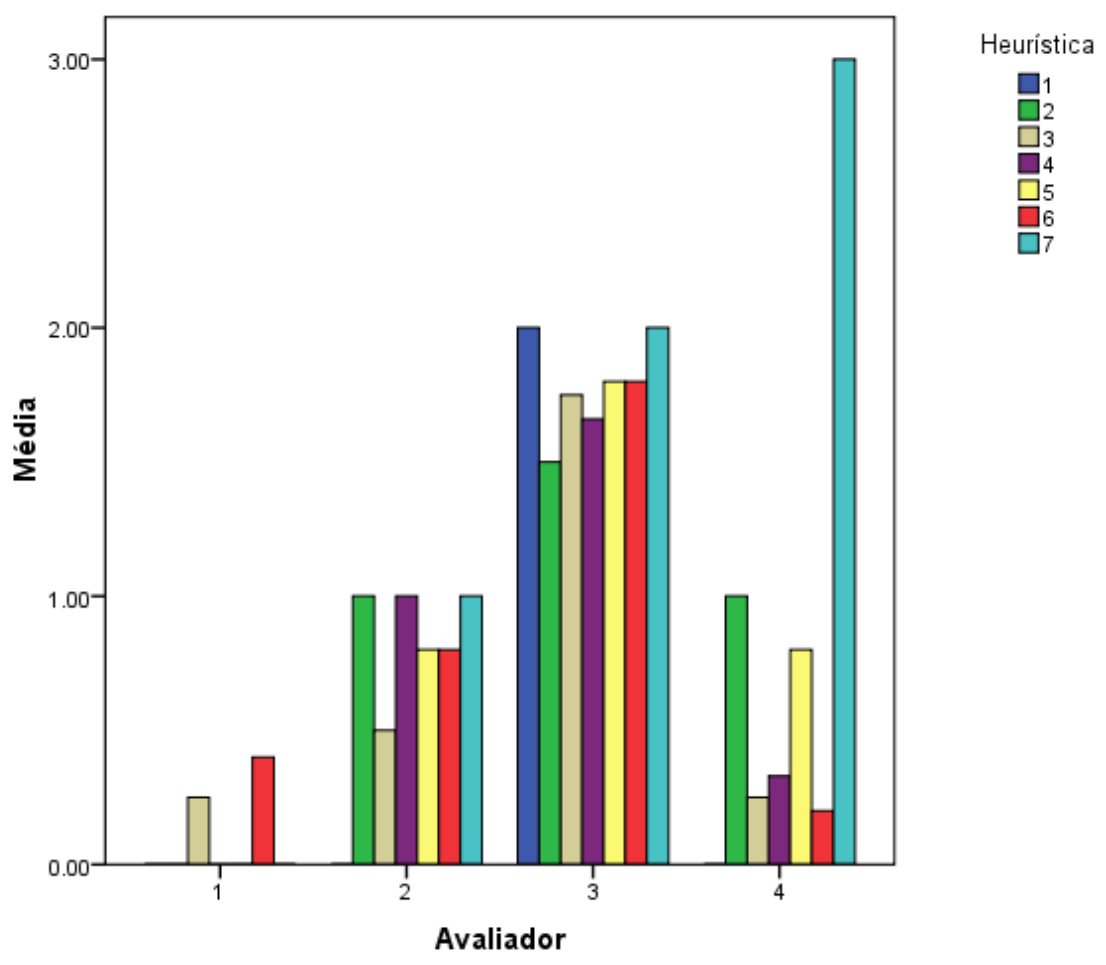


O Gráfico 46 demonstra claramente a disparidade de resultados do avaliador 4 no resultado da heurística 7 (Instrução e Documentação). Os demais avaliadores apresentaram mais homegeneidade nos resultados.

Tabela 99 - Pontuação Heurísticas por Avaliador - AUS

\begin{tabular}{c|c|c}
\hline Avaliador & média & desvio padrão \\
\hline $\mathbf{1}$ & 2,00 & 0,63 \\
\hline $\mathbf{2}$ & 0,36 & 0,22 \\
\hline $\mathbf{3}$ & 0,87 & 0,33 \\
\hline $\mathbf{4}$ & 1,16 & 1,39 \\
\hline
\end{tabular}

$\mathrm{Na}$ avaliação do site do Archivo de La Universidad de Salamanca conforme se verifica na Tabela 99 que 0 avaliador 2 com média 0,36 , foi quem encontrou menores problemas de usabilidade, e o avaliador 1, com média 2,0 encontrou maiores problemas de usabilidade através das heurísticas.

O avaliador 2 apresentou menor desvio padrão $(0,22)$, sugerindo que sua análise foi mais homogênea em relação a cada heurística. $O$ avaliador 4 apresentou maior desvio padrão $(1,39)$ significando que sua análise foi a mais heterogênea, quer dizer, suas respostas variaram bastante de uma heurística para outra. 


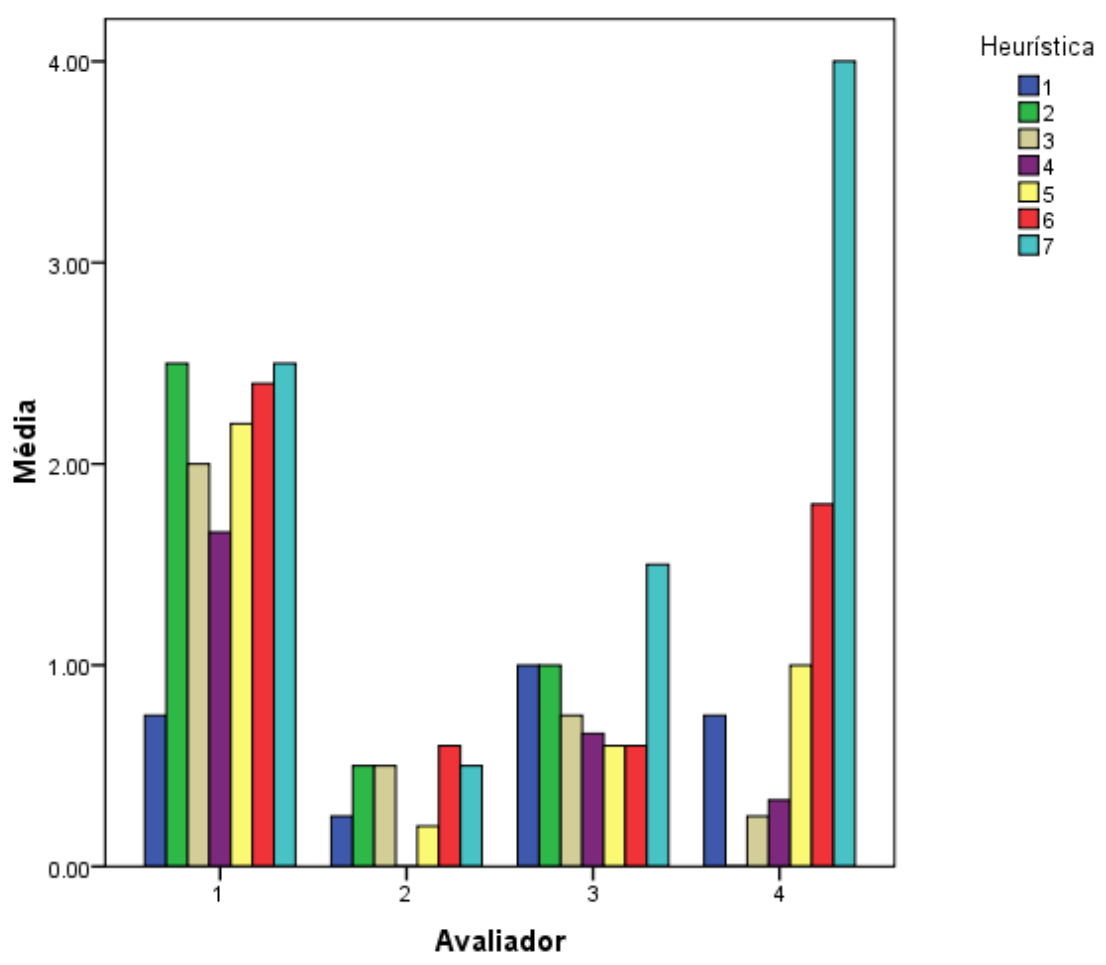

O Gráfico 47 demonstra claramente a disparidade de resultados do avaliadores 3 e 4 no resultado da heurística 7 (Instrução e Documentação). 0 avaliador 1 apresentou mais homogeneidade nos resultados.

Tabela $\mathbf{1 0 0}$ - Pontuação Heurísticas por Avaliador - AVM
\begin{tabular}{c|c|c} 
Avaliador & média & desvio padrão \\
\hline $\mathbf{1}$ & 0,78 & 0,71 \\
\hline $\mathbf{2}$ & 0,74 & 0,20 \\
\hline $\mathbf{3}$ & 1,23 & 0,58 \\
\hline $\mathbf{4}$ & 0,78 & 0,71 \\
\hline
\end{tabular}

Conforme observa-se na Tabela 100, o avaliador 2 com média 0,74 , foi quem encontrou menores problemas de usabilidade, e o avaliador 3 , com média 1,23 encontrou maiores problemas de usabilidade através das heurísticas.

O avaliador 2 apresentou menor desvio padrão $(0,20)$ sugerindo que sua análise foi mais homogênea em relação a cada heurística. Os avaliadores 1 e 4 apresentaram a mesma resposta de maior desvio padrão $(0,71)$, significando que as respostas de ambos variaram bastante de uma heurística para outra. 
Gráfico 48 - Avaliação Heurísticas por Avaliador - AVME

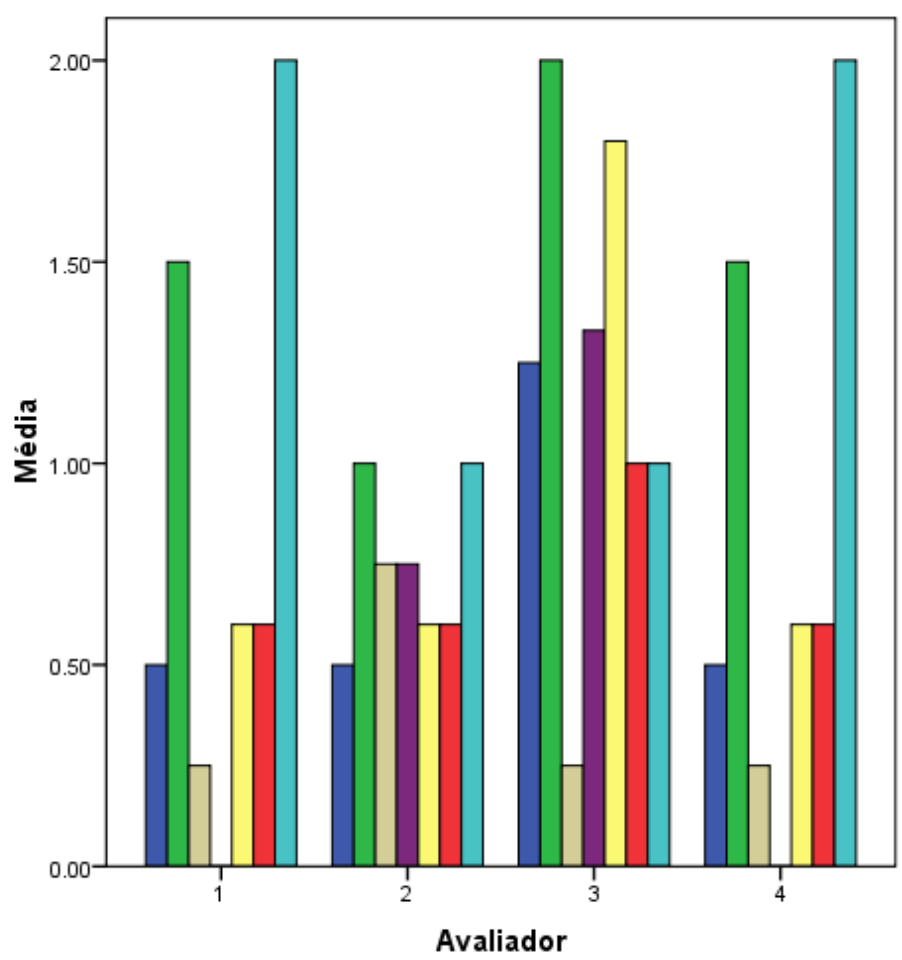

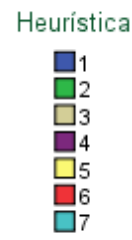

O Gráfico 48 demonstra claramente a disparidade de resultados dos avaliadores 1 e 4 nos resultados da heurística 7 (Instrução e Documentação). $O$ avaliador 2 apresentou mais homogeneidade nos resultados.

No geral, todos os sites não apresentaram problemas muito graves, havendo alguns com maior tendência a problemas maiores, sistematizado no quadro a seguir:

\begin{tabular}{|l|l|}
\hline Heurísticas & $\begin{array}{l}\text { Sites com heurísticas que tendem a problemas } \\
\text { maiores }\end{array}$ \\
\hline $\begin{array}{l}1 \text { Linguagem natural por } \\
\text { site }\end{array}$ & Archivo Histórico Provincial de Huesca \\
\hline $\begin{array}{l}2 \text { Liberdade de circulação e } \\
\text { controle de ações }\end{array}$ & Archivo General Militar de Ávila \\
\hline $\begin{array}{l}\text { 99Consistência nas } \\
\text { convenções adotadas }\end{array}$ & Nenhum \\
\hline
\end{tabular}




\begin{tabular}{|l|l|}
\hline $\begin{array}{l}4 \text { Disponibilização, clareza e } \\
\text { precisão }\end{array}$ & $\begin{array}{l}\text { Archivo General Militar de Ávila e do Archivo Histórico } \\
\text { Provincial de Huesca }\end{array}$ \\
\hline $\begin{array}{l}\text { Simplicidade da interface } \\
\text { Natureza estética e }\end{array}$ & $\begin{array}{l}\text { Archivo de La Diputación de Sevilla e da Archivo General } \\
\text { Militar de Ávila }\end{array}$ \\
\hline 6 Visibilidade & $\begin{array}{l}\text { Arquivo da Emigração Galega e Archivo Histórico de } \\
\text { protocolos de Gipuskoa }\end{array}$ \\
\hline 7 & e \\
documentação & $\begin{array}{l}\text { Arquivo da Emigração Galega e Archivo Histórico de } \\
\text { protocolos de Gipuskoa }\end{array}$ \\
\hline
\end{tabular}

Quadro 33 - Síntese das heurísticas que tendem a problemas maiores

O quadro acima relacionou os sites às heurísticas, ou seja, demonstrando com isso as dificuldades apresentadas por esses arquivos, a exemplo do Archivo General Militar de Ávila, que apresentou dificuldades em duas heurísticas 4 e 7. Praticamente todos os sites apresentam problemas em, no mínimo, uma heurística. Na heurística Visibilidade dois Arquivos apresentam dificuldade (Emigração Galega e Bipuskoa), os quais também apresentam dificuldade na heurística Instruções e documentação.

\subsection{Discussão geral dos resultados}

De maneira geral, a opinião dos usuários em relação à primeira impressão sobre os sites avaliados foi favorável, com exceção de alguns. Ocorreram, entretanto, algumas mudanças de opinião, entre a primeira impressão, e a impressão geral, levando em consideração todas as variáveis. À medida que se familiarizavam com o site, ao responder à última variável, a impressão geral manifestava muitas restrições.

Em muitos aspectos, as suas observações corroboravam as respostas que deram à variável Primeira impressão.

Embora os resultados das avaliações indiquem que nenhum dos sites possui problemas mais graves, com necessidades urgentes de aprimoramento, alguns apresentaram heurísticas que podem ser revistas. 
Confrontaram-se finalmente os resultados obtidos pelos avaliadores e pelos usuários, os quais culminaram em uma pontuação para cada site que permitia uma análise geral da situação deles em matéria de Usabilidade e Visibilidade.

Essas observações poderão servir de base para futuras avaliações se os responsáveis pelos sites aqui avaliados assim o desejarem, para obter maior êxito nos objetivos definidos no momento da criação dos mesmos. Bem como, se desejam melhorar sua usabilidade, uma vez que o usuário final é sempre o motivo da permanência de um site na $W e b$.

Pôde-se assim contribuir de alguma forma para uma crescente melhoria na disseminação dos Arquivos Espanhóis e das informações neles contidas. 


\section{Capítulo 7 CONSIDERAÇÕES FINAIS}

Este capítulo é dedicado às conclusões a que se chegou a partir da análise dos dados recolhidos, cuja reflexão sobre a situação dos Arquivos espanhóis estudados permitiu apresentar as possibilidades de melhoria da usabilidade e visibilidade de seus sites. Ademais ratificam-se informações de utilidade para os usuários, pesquisadores ou amantes de Arquivos espanhóis tanto do Brasil e da Espanha como de qualquer outra parte do mundo. 


\title{
7.1 OBSERVAÇÕES, CONCLUSÕES E RECOMENDAÇÕES
}

\author{
O conhecimento não está vinculado a país algum. É transnacional, é portátil. \\ Pode ser criado em qualquer lugar, de forma rápida e barata. Ele é, por \\ definição, mutável.
}

Peter Drucker

Este estudo discorreu sobre avaliação de sites de Arquivos espanhóis, por meio da qual se buscou identificar a interação homem/computador. Conforme proposta inicial de analisar os referidos sites, objeto deste estudo, os usuários e os avaliadores responderam os questionários que tinham a finalidade de identificar os elementos que demonstrem a visibilidade e a usabilidade dos sites estudados, porém com diferenças consideráveis no que tange à profundidade e ao conhecimento técnico no caso do questionário dos avaliadores.

As pesquisas bibliográficas constataram que os novos meios de comunicação sobretudo a Internet propiciaram a disseminação galopante de informações. As propriedades da informação digital têm características distintas que formam um novo perfil de usuários, sem limitações espaciais ou temporais. Os centros de informação, tais como Bibliotecas e Arquivos devem ser constantemente adaptados a esse universo dinâmico dos meios digitais e proporcionar aos seus usuários a melhor disponibilização possível dos seus serviços. No caso específico dos Arquivos, promove-se também através de seus Websites a divulgação de seus fundos documentais e da própria Instituição em si mesma.

A informação disponível em rede, ou seja, aquela que pode ser acessada por meio da Internet, tem sido objeto de muitos estudos, sobretudo de pesquisas a respeito da necessidade de avaliação de qualidade e critérios utilizados para este fim. O elevado número de páginas disponíveis na rede requer o respaldo 
desses critérios para que se possa distinguir informação de qualidade daquela que não é útil.

A presente proposta de avaliação pretendeu oferecer uma visão sobre os Arquivos espanhóis, a partir da avaliação de suas bases de dados. Este trabalho constituiu em um meio de promover ações de avaliação desses sites ao buscar identificar fatores que podem prejudicar o seu desempenho e direcionar propostas para melhoria dos aspectos que prejudicam sua visibilidade e usabilidade além de divulgar os Arquivos espanhóis em nível nacional e internacional.

Para a construção das questões da avaliação preliminar, foi utilizada a versão abreviada do questionário BRACAD de Jimenez Piano e Ortiz-Repiso Jimènez (2007) dado que as próprias autoras reconhecem a complexidade da aplicação do questionário em sua versão integral. Porém, para tornar viável a avaliação dos sites aqui estudados, uma vez que o objetivo apontava para uma visão global dos sites sem aprofundamento em nenhum aspecto, ou seja, trata-se de um modelo resumido dessa versão abreviada. Para que não houvesse, porém, prejuízo da essência do questionário em sua versão abreviada, os valores foram repensados e analisados à luz da interpretação dos indicadores e sua respectiva importância dentro dos critérios. Neste aspecto, contou-se com a parceria de um especialista da área de informática e construção e manutenção de sites.

Foi utilizada como modelo, para a construção das questões da avaliação propriamente dita, além de considerar os pressupostos teóricos de Hassan Montero; Martín Fernández e Ortega Santamaría, através da Revista Eletrônica sobre Usabilidade No Solo Usabilidad, a proposta de avaliação de usabilidade de Travieso Rodríguez, Alonso arévalo e Vivancos Secilla (2007).

O principal instrumento de coleta de dados foi composto por questionários com variáveis qualitativas e quantitativas, respondidos pelos atores primários (avaliadores) envolvidos na pesquisa. Utilizou-se, também como instrumento de coleta de dados, os testes com usuários, que consistiram em uma entrevista semiestruturada, também em forma de questionário, onde os usuários deveriam responder algumas questões e realizar tarefas a respeito dos sites. 
Quanto às questões apresentadas na avaliação, estavam todas direcionadas para a visibilidade e usabilidade dos sites objeto desse estudo. A temática de cada questão, portanto, girava em torno desses aspectos.

A aplicação da presente proposta de avaliação ofereceu uma análise dos sites espanhóis de Arquivos através da visão de pessoas de um país que trabalha em parceria técnico-científica, como é o caso do Brasil, o qual pretende manter o elo de colaboração e cooperação científica, a partir da pesquisa de campo e disponibilização dos dados obtidos. Consiste também em um meio de promover ações de experiências de parceria, buscando identificar fatores que promovem melhorias dos sites dos Arquivos e gerar aprendizado em ambos os países envolvidos no processo.

Após a compilação dos resultados, pôde-se chegar a algumas conclusões que se pontuarão a seguir.

Algumas informações inesperadas foram obtidas como, por exemplo, o fato de alguns usuários terem considerado certos sites como "pouco atrativo", "carregado de informações", "simples" entre outras opiniões pessoais utilizando palavras ou expressões pouco técnicas sobretudo para descrever características negativas dos sites.

Por outro lado, alguns sites tiveram avaliação clara e positiva, como por exemplo: bom uso de cores, bom layout, bom conteúdo, equilíbrio entre texto e imagem, fácil navegação.

Dos quatorze sites analisados na Avaliação propriamente dita, os seguintes foram considerados pelos usuários com boa usabilidade e visibilidade: Archivo HIstórico Nacional, Archivo Histórico Provincial de Huesca, Archivo Histórico Eclesiástico de Viscaya, Archivo Histórico de Astúrias, Archivo General Militar de Ávila, Archivo General de Simancas, Archivo Municipal de Santander, Archivo da Emigração Galega, Archivo de Hullera Vasco-Leonesa, Archivo Histórico Provincial de Granada.

Foi verificado que os visitantes da página Web do Archivo Histórico Provincial de Granada já podem consultar vários dados de seus fundos. Será possível, por exemplo, descarregar as bases de dados a partir do Quadro de Classificação, onde se busca primeiramente o fundo de interesse do usuário. Já 
estão disponíveis a consulta das descrições dos "Livros da Povoação do antigo Reino de Granada" e da "Real Sociedade Econômica de Amigos do País de Granada."

Quanto ao Archivo General de Simancas, verificou-se que, ao acessar o link que se refere à sua apresentação, aparece um folheto que pode ser descarregado na página com informação ampliada sobre a história e os fundos do Arquivo Geral de Simancas. Seguindo as instruções do vídeo, a folha toma a mesma forma de uma carta da Idade Moderna.

Em relação ao site do Archivo Vasco de la Música Eresbil, os usuários tiveram opiniões muito divergentes, porém pode-se considerar que no geral a avaliação foi negativa. Interpreta-se este entendimento a respeito do site como uma reação à maneira como as informações são disponibilizadas.

Verificou-se também, a partir dos usuários, que os seguintes sites deixam a desejar em matéria de acessibilidade: Archivo Histórico de Astúrias, Archivo General Militar de Ávila, Archivo Histórico Provincial de Granada. O site do Archivo de La Universidad de Salamanca tem a usabilidade comprometida. $O$ do Archivo Histórico de Protocolos de Gipuskoa não agradou à maioria dos usuários, fato que compromete a usabilidade.

Com relação aos resultados apresentados pelos avaliadores, constatou-se que nenhum dos sites apresentou problemas catastróficos de usabilidade. Entre os problemas graves de usabilidade encontrados, destacam-se alguns sites em relação à Liberdade de circulação e controle de ações: Archivo General Militar de Ávila, Archivo Histórico Provincial de Huesca, Archivo de la Universidad de Salamanca e Arquivo da Emigração Galega com dificuldade de navegação ou pouco clara.

Em relação à Heurística Disponibilização, clareza e precisão dos links os sites que apresentaram problemas medianos de usabilidade foram o do Archivo General Militar de Ávila e do Archivo Histórico Provincial de Guipúzcoa, com inconsistência entre alguns links e cabeçalhos de páginas e inconsistência entre elementos da interface. 
Quanto à heurística Natureza estética e Simplicidade da interface, os seguintes sites apresentaram baixo problema de usabilidade: do Archivo de Diputación de Sevilla e do Archivo General Militar de Ávila.

$\mathrm{Na}$ heurística Visibilidade os sites dos Arquivos: Archivo Histórico de Asturias, Arquivo da Emigração Galega e Archivo Histórico de protocolos de Guipúskoa tendem a apresentar problemas graves de usabilidade.

Ao confrontar finalmente os resultados obtidos pelos avaliadores e usuários, chegou-se a algumas conclusões após análise geral da situação de cada site em matéria de Usabilidade e Visibilidade. As visões dos avaliadores e usuários tiveram pontos coincidentes apesar de o questionário preenchido pelos avaliadores ser mais minucioso do que o dos usuários.

O ponto mais coincidente entre as duas avaliações (avaliadores e usuários) diz respeito ao problema de usabilidade dos sites do Archivo de la Universidad de Salamanca e do Archivo de Diputación de Sevilla. Com relação à visibilidade, os avaliadores consideram que o site do Archivo Histórico de Protocolos de Guipúskoa tem má visibilidade enquanto que os usuários apontam neste site problemas de usabilidade, esta divergência demonstra que o site chama a atenção de forma negativa nos dois critérios envolvidos por algum aspecto observado pelos atores envolvidos.

Ao análisar os resultados, concluiu-se que os sites avaliados em geral têm boa usabilidade, podendo ser melhorados em alguns aspectos e que apresentam boa visibilidade na Web, com exceção do já mencionado Archivo Histórico de Protocolos de Guipúskoa.

Os questionamentos iniciais sobre a liberdade expressiva dos sites que levam os usuários a necessitar de indicadores que lhe dêem suporte à otimização da informação suscitaram indagações sobre se de fato os sites de arquivos cumpriam as condições mínimas para uma boa usabilidade e sobre se possuíam boa visibilidade e tais questões levaram a se construir algumas hipóteses gerais que foram testadas neste estudo, a saber: que a maioria dos arquivos espanhóis possuem páginas Web e isso é um elemento facilitador para o usuário; que os sites do Ministério da Cultura da Espanha possuem também melhor visibilidade e 
que a maioria não permite a visualização dos documentos em tela, podendo comprometer assim a sua usabilidade.

Com relação a essas hipóteses inicialmente levantadas, pôde-se constatar que a maioria dos Arquivos públicos espanhóis possui página Web e esse fato constitui um elemento facilitador para o usuário no momento da pesquisa; que os sites dos Arquivos subsidiados pelo MCU têm boa qualidade, porém, outros sites de Arquivos espanhóis também cumprem bem seu objetivo, necessitando apenas, a exemplo dos primeiros, disponibilizarem o documento em tela. $O$ fato do documento poder ser visualizado através do site na tela do computador, não compromete a usabilidade porém representa maior conforto sobretudo para usuários que se encontram fisicamente distantes do Arquivo e o consulta apenas através da rede.

Quanto às Hipóteses específicas, pôde-se confirmar que:

1. No que se refere à variável presença de metadados padronizados puderam comprovar esta hipótese o Archivo Histórico provincial de Granada (AHPGR), que se destacou com média (2), seguido do Archivo Histórico Provincial de Huesca (AHPH) e do Archivo Histórico Eclesiástico de Vizcaya, ambos com média 1,75 indicando que esses Arquivos possuem metadados que contribuem para a visibilidade em rede;

2. Com relação às informações sobre a Instituição que abriga o Arquivo, destacaram-se o Archivo Histórico Nacional (AHN) e o Archivo Histórico Provincial de Granada (AHPGR), ambos com média 2, que comprovaram essa hipótese. No entanto, os arquivos: Archivo General Militar de Ávila (AGMA) e o Archivo de La universidad de Salamanca (AUS) obtiveram as menores médias: 1,25 e 1 respectivamente, significando que neste aspecto foram os que mais comprometeram a hipótese;

3. Quanto às Certificações de autenticidade; o Archivo Histórico Provincial de Granada (AHPGR) e o Archivo Histórico Nacional (AHN) se destacam com média (2) significando que ambos comprovaram a hipótese. No sentido oposto encontra-se o Archivo Histórico de Astúrias que com média 0,25 indica que não apresenta claramente as certificações de autenticidade; 
4. O Archivo General Militar de Ávila (AGMA) e o Archivo Histórico Provincial de Granada (AHPGR) comprovaram a hipótese Posição natural nos resultados das buscas através do motor de busca Google, destacando-se dos demais com média 2. O Archivo de la Universidad de salamanca (AUS) e o Archivo da Emigración Galega (AEG) no entanto, os que tiveram menor média (1) significando que foram os que comprovaram a hipótese em parte;

5. Quanto ao uso de Linguagem natural, o Archivo Histórico Nacional (AHN), o Archivo de Hullera Vasco Leonesa (AHVL) e o Archivo Municipal de Santander (AMS) comprovaram essa hipótese com destaque pois neste aspecto apresentaram problemas menores de usabilidade. Em contrapartida, o Archivo Historico Provincial de Granada (AHPGR) apresenta problemas cosméticos de usabilidade, comprovando em parte essa heurística.

6. Em relação aos mecanismos compreensíveis e facilmente localizáveis de navegação os sites comprovaram essa heurística, porém alguns necessitam rever este aspecto: Archivo General Militar de Ávila com média 1,87, que apresentou maiores problemas nesse aspecto, Archivo Histórico Provincial de Huesca (média 1,62), Archivo de la Universidad de Salamanca (média 1) e Arquivo da Emigración Galega (média 1,25), cujas médias indicam que apresentam problemas "cosméticos" de usabilidade;

7. Quanto à Consistência nas convenções adotadas, os sites comprovaram esta hipótese e os melhor avaliados foram: Archivo Vasco de la Musica Eresbil (AVME) e Archivo Historico Nacional (AHN) ambos com média 0,37, Archivo de Hullera Vasco-Leonesa (AHVL) com média 0,43, Archivo General de Simancas (AGS) com média 0,56, Archivo Historico Provincial de Guipúzcoa (AHPG) e Archivo Historico Provincial de Granada (AHPGR) com média 0,62, Archivo Municipal de santander (AMS) e Archivo Historico de Asturias (AHA) ambos com média 0,68. Foram detectados problemas cosméticos de usabilidade nos Arquivos: Archivo Histórico Provincial de Huesca (1,12), Archivo General Militar de Ávila (AGMA) e Arquivo da Emigración Galega $(1,06)$; 
8. No que se refere à clareza e precisão dos links os sites comprovaram a hipótese apresentando problemas menores de usabilidade para os seguintes Arquivos: Archivo Histórico Nacional (AHN) com média 0,39, Archivo Vasco de la Musica Eresbil (AVME) com média 0,52, Achivo General de Simancas (AGS) com média 0,53, Archivo dela Universidad de Salamanca (AUS) com média 0,66, Archivo Histórico Provincial de Granada (AHPGR) e Archivo Municipal de Santander (AMS) com média 0,74. Os Arquivos: Arquivo da Emigración Galega (AEG) com média 1,14, Archivo Histórico Provincial de Huesca (AHPH) com média 1,16, Archivo Histórico Provincial de Guipúzcoa (AHPG) com média 1,28 e Archivo General Militar de Ávila (AGMA) com média 1,58 apresentaram problemas "cosméticos" de usabilidade;

9. Os sites do seguintes Aquivos Oferecem ao usuário apenas informações relevantes ou necessárias, comprovando essa heurística: Archivo General de Simancas (AGS) com média 0,45, Archivo Histórico Nacional (AHN) com média 0,5, Archivo Histórico Provincial de Guipúzcoa (AHPG), Archivo Histórico Provincial de Granada (AHPGR), Archivo de Hullera Vasco-Leonesa (AHVL) e Archivo de La Universidad de Salamanca (AUS) todos com média 0,7 . Os seguintes sites apresentaram problemas "cosméticos" de usabilidade: Arquivo da Emigración Galega (AEG) e Archivo Histórico de Astúrias (AHA) ambos com média 1, Archivo General Militar de Ávila (AGMA) com média 1,05 e por fim, Archivo de Diputación de Sevilla (ADS) com média 1,25;

10. Quanto aos Recursos de acessibilidade disponíveis todos os sites estudados comprovaram esta hipótese apresentando problemas menores de usabilidade à excessao dos seguintes: Arquivo da Emigración Galega (AEG) e Archivo Histórico Eclesiástico de Vizcaya (AHEV) ambos com média 1,55, Archivo General Militar de Ávila (AGMA) com média 1,55, Archivo Histórico de Astúrias (AHA) com média 1,5, Archivo Histórico Provincial de Granada (AHPG) com média 1,85, Archivo Histórico Provincial de Granada (AHPGR) com média 1,05, Archivo Histórico Provincial de Huesca (AHPH) com média 1,6 e Archivo de la Universidad 
de Salamanca (AUS) com média 1,35 que apresentaram problemas "cosméticos" de usabilidade

11. O sites estudados com relação às Instruções fáceis de encontrar e relacionadas às tarefas que o usuário executa comprovaram a heurística porém alguns apresentaram problemas "cosméticos" de usabilidade: Archivo Histórico Provincial de Huesca (AHPH) com média 1,37, Archivo Municipal de Santander (AMS) e Archivo Histórico Eclesiástico de Vizcaya Archivo Vasco de La Musica Eresbil (AVME) ambos com média 1,5, Archivo Histórico Provincial de Granada (AHPGR) com média 1,54, AHVL com média 1,62, Archivo de Diputación de Sevilla (ADS) com média 1,75, Arquivo da Emigración Galega (AEG), Archivo General de Santander (AGS) e Archivo Histórico Eclesiástico de Vizcaya (AHEV) todos com média 1,87. Outros sites apresentaram problemas de nível 2, que são de fácil reparação e não exigem providências imediatas: Archivo General Militar de Ávila (AGMA) e Archivo Histórico Nacional (AHN) ambos com média 2 e, Archivo Histórico Provincial de Guipúzcoa (AHPG) e Archivo de La Universidad de Salamanca (AUS) ambos com média 2,12.

A efeito de conclusão, confirmou-se que as recomendações dos usuários pesam construtivamente, pelo fato de chamar a atenção para pontos que podem ser melhorados em um futuro próximo em benefício não apenas dos usuários bem como em razão, sobretudo, da visibilidade desses sites.

Ademais, esse estudo poderá servir de base para futuras avaliações se os responsáveis pelos sites aqui avaliados assim o desejarem, a fim de obter maior êxito nos objetivos definidos no momento da criação dos mesmos. Bem como, se desejam melhorar sua usabilidade, uma vez que o usuário final é sempre o motivo da permanência de um site na Web, podendo ainda contribuir de alguma forma para uma crescente melhoria na disseminação dos Arquivos Espanhóis e das informações neles contidas, ao tempo em que contribuem também para aumentar sua visibilidade. 


\section{REFERÊNCIAS}

ABREU, Leonardo. Performances de celulares com diferentes modelos de navegação. Applied Erginomics, [S.I.], v. 29, n. 1, p. 25-33, 1998.

ACIOLI, Sonia. Redes sociais e teoria social: revendo os fundamentos do conceito. Inf., v. 12, n. esp. 2007. Disponível em: <http://www.brapci.ufpr.br/download.php?dd0=11334>. Acesso em: 11 fev. 2011

AGUILLO, Isidro F. Indicadores hacia una evaluación no objetiva (cuantitativa) de sedes Web. In: JORNADAS ESPAÑOLAS DE DOCUMENTACIÓN, 7., 2000, Bilbao. Anais eletrônico ... Bilbao: FESABID, 2000. v. 7, p. 233-248. Disponível em: <http://dialnet.unirioja.es/servlet/libro?codigo=738>. Acesso em: 5 fev. 2010.

AGUILLO, Isidro F. Indicadores hacia una evaluación no objetiva (cuantitativa) de sedes Web. In: JORNADAS ESPAÑOLAS DE DOCUMENTACIÓN, 7., 2000, Bilbao. Anais eletrônico ... Bilbao: FESABID, 2000. v. 7, p. 233-248. Disponível em: <http://dialnet.unirioja.es/servlet/libro?codigo=738>. Acesso em: 5 fev. 2010.

AITTA, Marjo-Riitta; KALEVA, Saana; KORTELAINEN, Terttu. Heuristic evaluation applied to library Web services. New Library World, v. 109, n. 1/2, p. 25-45, 2008. Disponível em: $<$ http://www.emeraldinsight.com/Insight/viewPDF.jsp?Filename=html/Output/Publi shed/EmeraldFullTextArticle/Pdf/0721090102.pdf>. Acesso em: 8 jul 2010

ALFARO, Luis Correa. No sólo de usabilidad vive el hombre. Disponível em: $<$ http://www.chilepd.cl/content/view/3484/No-solo-de-Usabilidad-vive-elHombre.html>. Acesso em: 16 jun.. 2010. 7 p.

ALFONSO ALONSO-MOÑOYERRO, Belén de. Evolución histórica del acceso a la sala de lectura en los archivos estatales. Boletín de la $A N A B A D$, v. 49, n. 3-4, p. 391-400, jul./dic. 1999.

ÁLVAREZ GARCIA, Belén; GONZÁLEZ SECO, Beatriz; VELASCO SUÁREZ, Ana. La relación entre el administrado y su administración, viejas limitaciones y nuevos retos ante el marco de la e-adminsitración: del receptor pasivo al ciudadano interactivo. procedimientos, procesos, servicios, trámites...que pinta aqui um documentalista! Zaragoza: FESABID, 2009. p. 29-38. Disponível em: $<$ http://www.fesabid.org/zaragoza2009/actas-fesabid-2009/29-37.pdf>. Acesso em: 25 nov. 2010.

ALVES, Fernanda Maria Melo; QUIROA HERRERA, Maria Lourdes. Análisis y evaluación de sitios Web de bibliotecas nacionales: los casos de Brasil y de 
Portugal. Revista Española de Documentación Científica, Madrid, v. 30, n. 2, p. 199-217, 2007. Disponível em:

$<$ http://redc.revistas.csic.es/index.php/redc/issue/view/45>. Acesso em: 26 jan. 2011.

ALVES JÚNIOR, Nilton. Caracterização de redes complexas: aplicação à modelagem relacional entre sistemas autônomos da Internet. 2007. 114 fls. Tese (Doutorado em Modelagem Computacional) - Instituto Politécnico do Estado do Rio de Janeiro, Nova Friburgo (RJ), 2007. Disponível em: <http://www..rederio.br/dowloads/tese>. Acesso em: 29 abr. 2010.

AMÂNDIO, Maria José. Avaliação das bibliotecas digitais Perseus e Virgínia Tech: análise comparativa de sistemas de pesquisa e recuperação de informação. 2007. [em linha] Disponível em: <http://pesquisarpdf.net/preview/aHR0cDovL2JhZGluZm8uYXBiYWQucHQvQ29u Z3Jlc3NvOS9DT001NC5wZGY= >. Acesso em: 2 jan. 2011.

ARMS, William Y. Automated digital libraries: how effectively can computers be used for the skilled tasks of professional librarianship? D-Lib Magazine, v. 6, n. 7/8, jul./ago. 2000.2 Disponível em: <http://www.dlib.org/dlib/july00/arms/07arms.html>. Acesso em: 6 jul. 2010.

ARMS, William Y. Digital Libraries. 2. ed. Massachusetts: Institute of Tecnology, 2001. $308 \mathrm{p}$.

ASSOCIAÇÃO BRASILEIRA DE NORMAS TÉCNICAS (ABNT). NBR 6023: Informação e documentação - Referências - Elaboração. Rio de Janeiro, 2002.

NBR 14724: Informação e documentação - Trabalhos Acadêmicos apresentação. Rio de Janeiro, 2005.

ASTLE, Peter J.; MUIR, Adrienne. Digitization and preservation in public libraries and archives. Journal of Librarianship and Information Science, v. 34, n. 2, p. 6779, 2002. Disponível em: <http://lis.sagepub.com/cgi/content/abstract/34/2/67>. Acesso em: 16 jun. 2010.

ATIKINS, Dan. Vision for digital libraries. In: AN INTERNATIONAL RESEARCH AGENDA FOR DIGITAL LIBRARIES, 1998, Bruxelas. [Anais...]. Bruxelas: [s.n.], out. 1998. p.11-14.

AUSTIN, Brice. Mooer's law: in and out of context. Journal of the American Society for Information Science and Technology, v. 52, n. 8, p. 607-609, 2001. 
BAEZA-YATES, Ricardo; RIVERA LOAIZA, Cuauhtémoc; VELASCO MARTÍN, Javier. Arquitectura de la informação y usabilidad en la Web. El Profesional de la Informação, v. 13, n. 3, p. 168-178, maio/jun. 2004. <Disponível em: $<$ http://www.elprofesionaldelainformacion.com/contenidos/2004/mayo/1.pdf>. Acesso em: 2 fev. 2010.

BANHOS, Vângela Tatiana Madalena. Usabilidade na recuperação de informação: um enfoque no Catálogo Athena. 2008. 120 f. Dissertação (Mestrado em Ciência da informação) - Faculdade de Filosofia e Ciências da Universidade Estadual Paulista, Marília, 2008.

BARROS, Maria Teresa Morais de Gouveia Osório Antas de. Del códice medieval al código digital: evaluación de la visibilidad de proyectos de fondo antiguo de las bibliotecas públicas y universitarias ibéricas. Granada, 2007. Tesis Doctoral. Departamento de Biblioteconomía y Documentación, Universidad de Granada, Granada, 2007. Disponível em: http://hera.ugr.es/tesisugr/16827260.pdf Acesso em: $1^{\circ}$ abr. 2011.

BECANA SANAHUJA, Carlos. El papel de los archivos en la nueva Ley de Administración Electrónica: El caso de la Diputación Provincial de Huesca. Jornadas de Archivos Aragoneses, 8., 2008, Huesca. [Anais...]. Huesca: Gobierno de Aragon; Diputación Provincial, 2008. t. 2, p. 49-73.

BELLOTTO, Heloísa Liberalli. Arquivos permanentes: tratamento documental. 2. ed. rev. e ampl. Rio de janeiro: FGV, 2004. 320 p.

BENBUNAN-FICH, Raquel. Using protocol analysis to evaluate the usability of a commercial Web site. Information \& Management, v. 39, n. 2, p. 151-163, dez. 2001.

BERNERS-LEE, Tim; HENDLER, James; LASSILA, Ora. The semantic Web: a new form of Web content that is meaningful to computers will unleash a revolution of new possibilities. Scientific American, mayo 2001. Disponível em: <http://www.scientificamerican.com/2001/0501issue/0501berners-lee.html>. Acesso em: 23 set. 2009.

BETTIOL, Eugênia Maranhão. Necessidades de informação: uma revisão. Revista de Biblioteconomia, Brasília, v. 18, n. 1, p. 59-69, jan./jun. 1990.

BETTIOL, Eugênia Maranhão. Necessidades de informação: uma revisão. Revista de Biblioteconomia, v. 18, n. 1, p. 59-69, jan./jun. 1990. 
BINS ELY, Vera Helena Moro et al. Jardim Universal - espaço livre para todos. Albergo, 2006. In: CONGRESSO BRASILEIRO DE ERGONOMIA, 14., Curitiba, PR. 29 out.-2 nov., 2006. Disponível em: <http://arq.ufsc.br/petarq/wpcontent/uploads/2008/02/abergo-25.pdf>. Acesso em: 15 fev. 2011.

BONAL ZAZO, José Luis; ORTEGO DE LORENZO-CACÉRES, Maria Del Pilar. Archivos en línea: formatos de información archivística en Internet. In: JORNADAS ESPAÑOLAS DE DOCUMENTACIÓN, 4., 1998, Bilbao. Anais eletrônicos... Bilbao: FESABID, 1998. v. 1. Disponível em: <http://www.floridauni.es/ fesabid98/Comunicaciones/j_bonal/j_bonal.htm>. Acesso em: $1^{\circ} \stackrel{0}{m a r}$. 2010.

BORDONS, Maria; FELIPE, Alice; GOMÉZ, Isabel. Revistas Científicas españolas con factor de impacto en el año 2000. Revista Española de Documentación Científica, v. 25, n. 1, p. 49-71, 2002.

BORRÁS GÓMEZ, Joaquín. La formación de usuarios como vía eficaz para la implantación de un programa de gestión de documentos y archivos en las universidades. Ponencia presentada en el Seminario de ICA/SUV de Córdoba, celebrado el 20-21 de septiembre de 2000. Disponível em: <http://www.upf.edu/arxiu/_pdf/ponicasuv.pdf>. Acesso em: 13 fev. 2011.

BORRUEL LÓPEZ, Enrique; OCAÑA LACAL, Daniel de. El control administrativo de la documentación generada por la Administración General del Estado: criterios para la informatización de las entradas y salidas de documentos en los archivos. Boletín de la ANABAD, Madrid, v. 45, n. 3, p. 205-218, 1995. Disponível em: $<$ http://www.anabad.org/boletinpdf/pdf/XLV(1995)_3_205.pdf>. Acesso em: 25 jan. 2011.

$\mathrm{BOSCH}$, Mela. Documentos y lenguaje de marcado: conceptos, problemas y tendencias. El profesional de la información, v. 10, n. 11, p. 8, nov. 2001.

BOTON-MUÑOZ, María P. M. et al. Encuesta de evaluación de la "usabilidad" de la sede Web de la Biblioteca Universitaria de Córdoba. In: JORNADAS BIBLIOTECARIAS DE ANDALUCÍA, 15., 2009, Córdoba. Anais...: Bibliotecas, rompiendo barreras, tejiendo redes. Córdoba: Asociación Andaluza de Bibliotecarios, 2009. p. 1-10.

BREVE história dos mecanismos de busca. Página Uno.com. 2010. Disponível em: <http://www.pagina-uno.com/tutoriais/historia-mecanismos-de-busca.php $>$. Acesso em: 29 abr. 2010. 
BÜLTMANN, Barbara et al. Digitized content in the UK research library and archives sector. Journal of Librarianship and Information Science, v. 38, n. 2, p. 105-122, 2006. Disponível em: <http://lis.sagepub.com>. Acesso em: 31 ago. 2007.

BUSTELO RUESTA, Carlota. Los sistemas de gestión electrónica de la documentación y la teoría del ciclo vital de los documentos en las organizaciones. Scire: Representación y Organización del Conocimiento, v. 3, n. 2, jul p. 45-53, dic. 1997.

CABALLERO-CORTÉS, Laura; FABA-PÉREZ, Cristina. Ranking de accesibilidad Web de las bibliotecas universitarias virtuales en España: el caso particular de Andalucía. In: JORNADAS BIBLIOTECARIAS DE ANDALUCÍA, 15., 2009, Badajoz. [Anais...]. Badajoz: Universidad de Extremadura, Facultad de Biblioteconomía y Documentación, 2009. Disponivel em: <http://74.125.155.132/scholar?q=cache:conuRzK7zTMJ:scholar.google.com/+Ra nking+de+accesibilidad+Web+de+las+bibliotecas+universitarias+virtuales+en+Es pa\%C3\%B1a:\&hl=pt-BR\&as_sdt=2000 >. Acesso em: 11 jul. 2010.

CABRERA FACUNDO, Ana Margarita; COUTíN DOMÍNGUEZ, Adrián. Las bibliotecas digitales: Parte II. Acimed: revista cubana de los profesionales de la información y la comunicación en salud, v. 13, n. 5, 2005. Disponível em: <http://eprints.rclis.org/bitstream/10760/6673/1/aci06305.pdf> Acesso em 27 jun.2011.

CABRERA MORALES, Asunción et al. Encuesta de evaluación de la "Usabilidad" de la sede Web de la Biblioteca Universitaria de Córdoba. 10 p. XV JORNADAS BIBLIOTECARIAS DE ANDALUCÍA, 15., 2009, Córdoba. [Anais...]. Córdoba: Asociación Andaluza de Bibliotecarios, Universidad de Extremadura, Facultad de Biblioteconomía y Documentación, 2009.

CALDEIRA, Pedro Zany. O computador (não) tem sempre razão. Análise Psicológica, n. 12, p. 117-128, 1994.

A usabilidade das Bibliotecas Digitais: a perspectiva dos leitores/utilizadores. Cadernos de Biblioteconomia, Arquivística e Documentalistas (Cadernos BAD), n. 2, p. 18-35, 2003. Disponível em: <http://redalyc.uaemex.mx/pdf/385/38505003.pdf>. Acesso em: 6 jul. 2010.

; OTERO, N. Avaliação ergonômica de sistema 3D E de realidade virtual. Lusíada. Psicologia, n. 11, p. 54-64, 2003. 
Virtual reality usability evaluation techniques: RECMUV and TILE VIZ. Human factors and ergonomics society. Europe Chapter 1997 annual Conference, 1997. Bochum: HFES Europe Chapter, 1997. p. 343-453.

CAMARGO, L. S. de A. de. Arquitetura da informação para biblioteca digital personalizável. 2004. Dissertação (Mestrado em Ciência da Informação) Universidade Estadual Paulista-Unesp, Marília, 2004. Disponível em: $<$ http://www.marilia.unesp.br/Home/PosGraduacao/Cienciadalnformacao/Disserta coes/camargo_lsa_me_mar.pdf>. Acesso em: 15 fev. 2011.

; VIDOTTI, S. A. B. G.; CAMARGO, V. Arquitetura da informação para Bibliotecas Digitais: uma abordagem centrada no usuário. In: SIMPÓSIO INTERNACIONAL DE BIBLIOTECAS DIGITAIS, 2., 2004, Campinas, SP. [Anais...]. Campinas, SP:, 2004. p. 1-6.

CANALES BECERRA, Haymee. Visibilidad de la producción documentaria del complejo agropecuario de la provincia Habana. In: INFO: CONGRESO INTERNACIONAL DE INFORMACIÓN, 2004, Habana, Cuba. Anais eletrônicos. Habana, Cuba, 2004. v. 5. Disponível em: <http://www.congresoinfo.cu/UserFiles/File/Info/Info2004/Ponencias/167.pdf>. Acesso em: 1ํabr. 2010.

CARDOSO, J. C. ILIB, uma proposta de interface de consulta personalizável para Bibliotecas Digitais. 2000. 112 f. Dissertação (Mestrado em Ciência da Computação) - Faculdade de Informática, Pontifícia Universidade Católica do Rio Grande do Sul, Porto Alegre, 2000. Disponível em: $<$ http://www.wawrwt.iar.unicamp.br/entrada_textos01.html>. Acesso em: 3 mar. 2004.

CARNIELLO, Monica Franchi; ZULIETTI, Luis Fernando. Ferramentas de comunicação organizacional na era das mídias digitais. In: ABRAPCORP 2007: CONGRESSO BRASILEIRO CIENTÍFICO DE COMUNICAÇÃO, GT ABRAPCORP $3, \quad 1^{\circ}$ maio 2007. Disponível em: <http://www.vertent.net/abrapcorp/www/trabalhos/gt3/gt3_carniello.pdf>. Acesso em: 13 fev. 2011.

CARUCCI, Paola et al. Genesis del documento: redacción, clasificación y valor jurídico. In: Documento y archivo de gestión: diplomática de ahora mismo. Carmona: Universidad Internacional Menéndez Pelayo, 1994. p. 61-78.

CASARES, Javier. História de los buscadores: de 1993 a 2008. [S. I.], 2009. Disponível em: <http://javiercasares.com/seo/historia-de-los-buscadores/>. Acesso em: 29 abr. 2010. 
CASTELLS, Manuel. A galáxia Internet: reflexões sobre Internet, negócios e sociedade. Minho, Portugal: Universidade do Minho, Mestrado em Tecnologia Educativa, 2008. (Tese de Mestrado). Recensão de: BESSA, Fátima. Disponível em: <http://www.e-profe.net/tecnologia/galaxia_internet.pdf>. Acesso em: $11 \mathrm{fev}$. 2010.

Internet y la sociedad red. In: Lección inaugural del programa de doctorado sobre la Sociedad de la Información y el Conocimiento. Catalunya: Universitat Oberta de Catalunya, 2000. Disponível em: <http://www.mvdenred.edu.uy/download/destacados/castells.pdf>.

Acesso em: 13 fev. 2011.

CAYETANO MARTÍN, M.C. ¿La información en los archivos históricos: derecho o disciplina? Boletín de la ANABAD, v. 49, n. 3-4, p. 295-304, jul./dic. 1999.

CEDOC. Conservação/Preservação de documentos. Brasília: Centro de Documentação da Universidade de Brasília; UnB. Disponível em: <http://vsites.unb.br/cedoc/conservacao.htm>. Acesso em: 1ํ dez. 2010.

CERDÁ DÍAZ, Julio. Archivos locales en la Web. El futuro en la red. In: JORNADAS DE ARCHIVOS ARAGONESES, 8., 2008, Huesca. Actas... Huesca: Gobierno de Aragon, Diputación Provincial, 2008. T. II, p. 151-172. Disponível em: $<$ http://portal.aragon.es/portal/page/portal/CULTURA/PUBLIELECTRONICAS/PAT RIMONIOCULTURAL/ARCHIVOS/Actas\%20VIII\%20Jornadas\%202/26\%20Archiv os\%20locales\%20en\%20la\%20Web.pdf>. Acesso em: 18 jan. 2011.

. Desarrollo de sistemas de acceso on line a fondos de archivo. Propuesta metodológica, 2002. In: CONGRESO INTERNACIONAL DE INFORMACIÓN INFO 2002, Habana, Cuba, feb. 2002. Disponível em: <http://www.bibliociencias.cu/gsdl/collect/eventos/index/assoc/HASH3820.dir/doc. pdf>. Acesso em: 18 jan. 2011.

CHEN, Qimei; RODGERS, Shelly; Yi He. A critical review of the E-satisfaction literature. American Behavioral Scientist, v. 52, n. 1, p. 38-59, set. 2008. Disponível em: <http://abs.sagepub.com/cgi/content/abstract/52/1/38>. Acesso em: 20 mar. 2010.

CODINA, Lluís. Evaluación de recursos digitales en línea: conceptos, indicadores y métodos. Revista Española de Documentación científica, v. 23, n. 1, p. 9-44, 2000.

Parámetros e indicadores de calidad para la evaluación de recursos digitales. In: JORNADAS ESPAÑOLAS DE DOCUMENTACIÓN, 7., 2000, Bilbao. 
Anais ... Bilbao: Servicio Editorial de la Universidad del País Vasco, 2000a. p. $135-44$.

. Posicionamiento Web: conceptos y ciclo de vida. Hipertext. net, n. 2,
Disponível <http://eprints.rclis.org/bitstream/10760/9008/1/Posicionamiento_Web_Conceptos _y_Ciclo_de_Vida.pdf>. Acesso em: 14 abr. 2010.

COHEN, Laura. How to choose a search engine or research database. [S. I.: s. n.], 1999. Disponível em: <http://www.albany.edu/library/internet/choose.html>. Acesso em: $21 \mathrm{fev} .2011$.

CONARQ. Carta para a preservação do patrimônio arquivístico digital: preservar para garantir o acesso. Disponível em: <http://www.conarq.arquivonacional.gov.br/Media/publicacoes/cartapreservpatrim arqdigitalconarq2004.pdf >. Acesso em: 5 fev. 2010.

\begin{abstract}
Arquivísticas. dez./2000. Disponível em: <http://www.conarq.arquivonacional.gov.br/Media/publicacoes/diretrizes_para_a_c onstruo_de_Websites.pdf>. Acesso em: 5 fev. 2010.
\end{abstract}

CONFORTO, Débora; SANTAROSA, Lucila M. C. Acessibilidade à Web: Internet para todos. Revista de Informática na Educação: Teoria, Prática. v. 5, n. 2, p. 87102, nov. 2002.2 Disponível em: <http://pan.nied.unicamp.br/ proinesp/material/arquivos/Semana\%203\%20\%20Int ernet\%202/Leituras/Leitura\%20Complementar\%20\%20Acessibilidade/acessibilida de.pdf>. Acesso em: 6 ago. 2009.

CONGRESSO INTERNACIONAL DE ERGONOMIA E USABILIDADE, DESIGN DE INTERFACES E INTERAÇÃO HUMANO COMPUTADOR, 5., 2005, Rio de Janeiro. Anais... Rio de Janeiro: Laboratório de Ergonomia e Usabilidade de Interfaces em Sistemas Humano Tecnologia - PUC-Rio, 2005.

CONGRESO NACIONAL DE ANABAD, 7., 1999, Toledo. Actas... Toledo: ANABAD; Federación Española de Asociaciones de Archiveros, Bibliotecários, Arqueólogos, Museólogos y Documentalistas, 1999.

CUADRADO FERNÁNDEZ, Olga; GÓMEZ DOMíNGUEZ, David. Los archivos municipales españoles en línea: evaluación del contenido de sus Webs. In: JORNADAS ANDALUZAS DE ARCHIVOS MUNICIPALES: Archivos Electrónicos, empresa y ciberespacio, 4., 2001, p. 64-71. Disponível em: <http://www.ugr.es/ vjarchiv/images/David.doc>. Acesso em: 1ํabr. 2011. 
CUNHA, Murilo Bastos. Desafios na construção de uma biblioteca digital. Ciência da Informação, v. 28, n. 3, p. 255-266, set./dez. 1999.

Construindo o futuro: a biblioteca universitária brasileira em 2010. Ciência da Informação, v. 29, n. 1, p. 71-89, jan./abr. 2000. Disponível em: <http://www.ibict.br/cienciadainformacaos. Acesso em: 8 jun. 2004.

CURTY, Renata Gonçalves; ARAUJO, Nelma Camelô de. Análise da usabilidade de interface de repositório institucional: enfoque nos princípios ergonômicos. In: ENANCIB, 9., 2008, São Paulo,SP. Anais eletrônicos... São Paulo, SP: USP, 2008. v.9. Disponível em: <http://www.enancib2008.com.br/cd/6\%20\%20Trabalhos\%20em\%20PDF/GT8/1\%20-\%200ral/1985\%20-

$\% 20$ An\%C3\%A1lise\%20da\%20usabilidade\%20de\%20interface\%20de\%20reposit \%E2\%80\%A6.pdf>. Acesso em: 16 jun. 2010.

DANNEMANN, Fernando Kitzinger. Internet: significado de suas siglas. Disponível em:

$<$ http://www.fernandodannemann.recantodasletras.com.br/visualizar.php?idt=1336 665>. Acesso em: 14 abr. 2010.

DAVENPORT, Thomas H. Ecologia da informação: Por que só a tecnologia não basta para o sucesso na era da informação. São Paulo: Futura, 1998. 316 p.

DE LA RICA, Enrique. Marketing en Internet. Madrid: Anaya Multimedia , Esic Editorial, $2000 . \quad$ Disponível em: $<$ http://redgiga.com/documentacion/marketingeninternet.pdf > Acesso em: 30 mar. 2011

DIAGO, Gloria Gómez; PELLÓN, Daniel Martí, Método de una investigación en comunicación: fuentes primarias y card sorting para identificar y agrupar en niveles los criterios de evaluación más utilizados en festivales Web, Textos de la CiberSociedad, 7., 2005. Disponível em: <http://www.cibersociedad.net>. Acesso em: 16 set. 2010.

DIAS, Guilherme Ataíde. Periódicos científicos eletrônicos brasileiros na área de Ciência da Informação: análise das dinâmicas de acesso e uso. 2003. Tese (Doutorado em Ciências da Comunicação) - Universidade de São Paulo, São Paulo, 2003.

DONATI, L. P; CARVALHO, H.; PRADO, G. Sites na Web: considerações sobre o design gráfico e estrutura de navegação. Projeto Wawrwt, 1998. Disponível em: 
<http://www.wawrwt.iar.unicamp.br/entrada_textos01.html>. Acesso em: 3 mar. 2004.

DURANTI, Luciana. A ciência arquivística. Córdoba: [s. n.], 1994.

EDUTEKA. Evaluación crítica de una página Web. Disponível em: $<$ http://school.discoveryeducation.com/schrockguide/pdf/evaluacionWeb.pdf>. Acesso em: 20 jul. 2008.

- Modelo Gavilán 2.0 una propuesta para el desarrollo de la competencia para manejar información (CMI). Disponível em: <http://www.eduteka.org/pdfdir/ModeloGavilan.pdf>. Acesso em: 22 jul. 2008.

Módulo sobre competência para manejar información. Disponível em: <http://www.eduteka.org/pdfdir/CMIListaCriteriosEvaluarFuentes.pdf>. Acesso em: 2 mar. 2010.

Tecnologias de informação y comunicaciones para enseñanza básica y media. Evaluación Crítica de uma página Web para níveis de enseñanza primaria, media y secundaria: razones de peso para evaluar. Disponível em: <http://school.discoveryeducation.com/schrockguide/pdf/evaluacionWeb.pdf>. Acesso em: 5 fev. 2010.

EÍTO BRUN, Ricardo. Colecciones digitales: análisis de usabilidad. In: JORNADAS ESPAÑOLAS DE DOCUMENTACIÓN, 7., 2000, Bilbao. Anais Bilbao: FESABID, 2000. v. 7, p. 435-444.

ELIASEN, Karen et al. Navigating online menus: a quantitative experiment. College \& Research Libraries, v. 58, n. 6, p. 509-516, nov. 1997. Disponível em: <http://crl.acrl.org/content/58/6/509.abstract>. Acesso em: 16 jun. 2010.

ESPAÑA. Secretaría General para la Administración Pública. Direción Geeneral de Modernización Administrativa. Guia para la edición y publicación de lãs páginas Web de La Administración General del Estado. Disponível em: <http://www.chsegura.es/export/descargas/informaciongeneral/imageninstitucional /administracionelectronica/docsdescarga/guia_funciona.pdf>. Acesso em: 2 fev. 2010.

FERNÁNDEZ, Lissete (Trad.). Evaluando páginas Web: técnicas a aplicar y preguntas a formular. In: FÓRUM TELEMATIC DE DOCÊNCIA UNIVERSITÁRIA. Anais eletrônico ... Barcelona: Universidad de Barcelona. Disponível em: <http://www.ub.es/forum/Conferencias/evalua.htm>. Acesso em: 17 set. 2008. 
FERNÁNDEZ DEL TORCO ALONSO, Juan Manuel; PEDRO GARCÍA, Concepción de el acceso de los ciudadanos a los archivos. Boletín de la $A N A B A D$, [S. I.], v. 49, n. 3-4, p. 213-222, jul./dic. 1999.

FERNEDA, Edberto. Recuperação de informação: análise sobre a contribuição da Ciência da Computação para a Ciência da Informação. 2003. 147 f. Tese (Doutorado em Ciência da Informação) - Escola de Comunicação e Artes, Universidade de São Paulo, São Paulo, 2003.

FURQUIM, T. A. Fatores motivadores de uso de site Web: um estudo de caso. Ciência da Informação, v. 33, n. 1, p. 48-54, 2004. Disponível em: $<$ http://revista.ibict.br/index.php/ciinf/article/viewArticle/40/39>. Acesso em: $17 \mathrm{fev}$. 2011.

GALLEGO-LORENZO, Josefa; SANTOS DE PAZ, Lourdes. La presencia de las bibliotecas de Castilla y León en Internet. Boletín de la Asociación Andaluza de Bibliotecarios, v. 18, n. 72, 2003. Disponível em: <http://www.aab.es/pdfs/baab72/72a2.pdf>. Acesso em: 5 jan. 2011.

GARCÍA GONZÁLEZ, María; CHAÍN NAVARRO, Célia. Los contenidos de la Web de los archivos históricos estatales. El ciudadano más cerca de la información. Cuadernos de Documentación Multimedia, v. 20, p. 5-24, 2009. Disponível em: <http://multidoc.rediris.es/cdm2/index.php/revista/article/view/33/36>. Acesso em: 17 jan. 2011.

GARCIA RUIZ, Miguel Ángel el al. Análisis de usabilidad en bibliotecas digitales: el caso de El Dorado. Disponível em: $<$ http://docente.ucol.mx/ mgarcia/Analisis_Usabilidad_elDorado.pdf>. Acesso em: 12 ago. 2009.

GARFIELD, Eugene. A tribute to Calvin N. Mooers: a pioneer of information retrieval. The Scientist, v. 11, n. 4, mar. 1997. Disponível em: < http://www.thescientist.com/images/yr1997/mar/comm_970317.html> Acesso em: 1ํ abr. 2011.

GARRETT, Jesse James. The elements of user experience: user-centers design for the Web. $2^{\text {nd }}$. ed. Indianápolis (Indiana), 2003. 189 p. Disponível em: <http://www.jjg.net/ia/elements.pdf>. Acesso em: 20 maio 2004.

GIANNAKIS, Mihalis. Facilitating learning and knowledge transfer through supplier development. Supply chain management: an International Journal, v. 13, n. 1, p.62-72, 2008. 
GILBERT, Myrna; CORDEY-HAYES, Martyn. Understanding the process of knowledge transfer to achieve successful technological innovation, Technovation, v. 16, n. 6 , p. 301-312, 1996.

GOMES, Bianca Antonio; DINIZ, Eliane da Silva Alcoforado. Aplicação de técnicas de avaliação de Interface com o usuário: avaliando um software pedagógico. In: CONGRESSO DE INICIAÇÃO CIENTÍFICA, 17; ENCONTRO DE PÓS-GRADUAÇÃO, 10., 2008, Pelotas, RS. Anais eletrônico ... Pelotas, RS: UFPe, 2008.2 Disponível em: <http://www.ufpel.edu.br/cic/2008/cd/pages/pdf/CE/CE_01959.pdf>. Acesso em: 2 fev. 2010.

GOMES, Carolina Glayce. Avaliação da usabilidade do sistema Pergamum de gerenciamento de bibliotecas. Disponível em: <http://www.pergamum.pucpr.br/redepergamum/trabs/UsabilidadePergamum.pdf> Acesso em: 28 abr. 2010.

GÓMEZ, Joaquín. La formación de usuarios como vía eficaz para la implantación de un programa de gestión de documentos y archivos en las universidades. In: SEMINÁRIO ICA/SUV, 2000, Córdoba. Disponível em: <http://www.upf.edu/arxiu/_pdf/ponicasuv.pdf>. Acesso em: 11 jan. 2011.

GÓMEZ DIAGO, Gloria; MARTÍ PELLÓN, Daniel. Método de una investigación en comunicación: fuentes primarias y card sorting para identificar y agrupar en niveles los criterios de evaluación más utilizados en festivales Web. Revista Textos de la CiberSociedad, [S. I.], n. 7, 2005. Disponível em: $<$ http://www.cibersociedad.net/textos/articulo.php?art=64>. Acesso em: 30 mar. 2010.

GONÇALVES, Rose Mary. Atendimento via internet: utilidade e usabilidade. Disponível em: <http://www.ergopublic.net.br>. Acesso em: 12 abr. 2010.

Ergonomia do serviço de atendimento ao público via internet: utilidade e usabilidade de Web sites para os usuários. 2002. 123 f. Dissertação (Mestrado em Psicologia) - Universidade de Brasília, Brasília, 2002.

GRACIOSO, L. S. Análise da recuperação de livros digitais na Internet. 2001. Trabalho de Conclusão de Curso (Especialização em Filosofia e Ciências) Faculdade de Filosofia e Ciências, Universidade Estadual Paulista, Marília, 2001

GROSS, Clifford M. The right fit: The power of ergonomics as a competitive strategy. [S. I.]: Productivity Press, 1996. 
GROSS, Clifford M. The right fit: The power of ergonomics as a competitive strategy. [S. I.]: Productivity Press, 1996.

HACK, Josias Ricardo; SANTOS, Juliano Alves dos. Influência do design emocional na interação homem/computador. Liinc em Revista, v. 6, n. 2, p. 411421, set. 2010. Disponível em: <http://www.ibict.br/liinc>. Acesso em: 18 fev. 2011.

HACKOS, Jo Ann; REDISH, Ginny. User and task analysis for interface design. New York, NY: John Wiley and Sons, 1998.

HASSAN MONTERO, Yusef. Cómo leen los usuários em la Web. No solo Usabilidad, n.1, dec. 2002. Disponível em: $<$ http://www.nosolousabilidad.com/articulos/como leen usuarios.htm $>$. Acesso em: 26 jan. 2011.

HAGUENAUER, Cristina Jasbinschek; CORDEIRO FILHO, Francisco; MOTA, Rodrigo Amorim. Desenvolvimento de portais de informação para suporte a comunidades virtuais de aprendizagem.set. 2008. Disponível em: $<$ http://tecnologiasnaeducacao.pro.br/revista/a1n1/art5.pdf> Acesso em 25 jun. 2011.

HASSAN MONTERO, YUSEF. Cómo leen los usuarios en la Web. Nosolousabilidad, n.1, dec. 2002. Disponível em: <http://www.nosousabilidad.com/articulos/como_leen_usuarios.htm> Acesso em: 26 jan. 2011.

; MARTÍN FERNÁNDEZ, Francisco J. Método de test con usuarios. No Solo Usabilidad, n. 2, 2003. Disponível em: <http://www.hipertext.net/Web/pag206.htm\#5.3.2>. Acesso em: 13 fev. 2011.

; IAZZA, Ghzala. Diseño Web centrado en el usuario: usabilidad y arquitectura de la información. Hipertext.net, n. 2, 2004. Disponível em: <http://www.hipertext.net/Web/pag206.htm>. Acesso em: 22 set. 2009.

; ORTEGA SANTAMARÍA, Sergio. Informe APEI sobre usabilidad, n. 3. Gijón: Asociación Profesional de Especialistas en Información, 2009. Disponível em: <http://www.nosolousabilidad.com/manual/>. Acesso em: 10 fev. 2010.

HEREDIA HERRERA, Antonia. ¿Qué es un archivo? Gijón: Trea; 2007 p. 19 y siguientes. 
HOLMES, Marilyn; LOWE, Robyn. Web usability \& Navigation: a beginner's guide. Berkeley: McGraw-Hill, 2002.

HOUAISS, Antônio; VILLAR, Mauro de Salles. Rede. In: Dicionário Houaiss da língua portuguesa. Rio de Janeiro: Objetiva, 2009. p. 1627.

HYODO, Tatiana. A literatura sobre necessidades de informação: uma análise a partir de artigos publicados no periódico "Ciência da Informação". Enc. Bibli: $R$. Eletr. Bibliotecon. Ci. Inf., v. 14, n. 27, 2009. Disponível em: $<$ http://www.periodicos.ufsc.br/index.php/eb/article/viewFile/6872/10141>. Acesso em: 20 jul. 2010.

INTERNATIONAL Telecommunication Union (ITU). The world in 2010: ICT facts and figures. World Statistic Day: 20/10/2010. Geneva/Switzerland. Disponível em: $<$ http://www.itu.int/lTU-D/ict/material/FactsFigures2010.pdf $>$. Acesso em: $10 \mathrm{mar}$. 2011.

ISO (INTERNATIONAL ORGANIZATION FOR STANDARDIZATION). ISO 924111. International standards for $\mathrm{HCl}$ and usability. Geneva/Switzerland: ISO, 1998. Disponível

em: http://www.it.uu.se/edu/course/homepage/acsd/vt09/ISO9241part11.pdf Acesso em: 2 abr. 2011.

ISO (INTERNATIONAL ORGANIZATION FOR STANDARDIZATION). ISO 154891. Information and documentation - Records Management. Part 1: General. Geneva: ISO, 2001. Disponível em: <http://www.iso.org>. Acesso em: 13 fev. 2011.

ISO (INTERNATIONAL ORGANIZATION FOR STANDARDIZATION). ISO/TR 15489-2:2001: Information and documentation - records management: Part 2: Guidelines. Geneva: ISO, 2001b. Disponível em: <http://www.iso.org>. Acesso em: 13 fev. 2011

JARDIM, José Maria. A invenção da memória nos arquivos públicos. Ciência da Informação, v. 25, n. 2, p. 209-216, maio/ago. 1996.

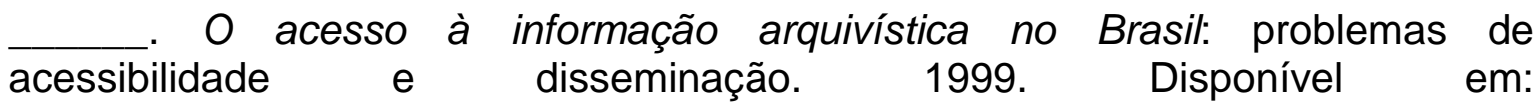
<http://www.conarq.arquivonacional.gov.br/Media/publicacoes/mesa/o_acesso_i nformao_arquivstica_no_brasil.pdf>. Acesso em: 12 abr. 2010.

$\begin{array}{ccrrr} & \text { Arquivos, transparência do } & \text { Estado e capacidade governativa na } \\ \text { sociedade } & \text { da } & \text { informação. } & 2001 . & \text { Disponível }\end{array}$ 
$<$ https://bvc.cgu.gov.br/bitstream/123456789/3350/1/Arquivos_transparencia_do_ estado_capacidade.pdf>. Acesso em: 4 dez. 2010.

JIMÉNEZ PIANO, Marina. Evaluación de sedes Web. Revista Española de Documentación Científica, v. 24, n. 4, p. 405-432, 2001. Disponível em: $<$ http://redc.revistas.csic.es/index.php/redc/article/viewFile/69/130>. Acesso em: 1ㅇa․ 2010.

ORTIZ-REPISO JIMÉNEZ, Virginia. Evaluación y calidad de sedes Web. Gijón: Ediciones TREA, 2007.

JORDAN, Patrick W. Human factors for pleasure in product use. Apllied Ergonomics, v. 29, n. 1, p. 25-33, 1998.

JORNADA PORTALES DE ARCHIVOS EN INTERNET - EXPERIENCIAS, 2008, Madri. Disponível em: $<$ http://www.mcu.es/archivos/CE/Portales_Archivos_Internet.html>. Acesso em: 16 jun. 2010

KEINONEN, Turkka. Usabilidad de los productos interactivos. Disponível em: <http://www2.uiah.fi/projects/metodi/258.htm>. Acesso em: 27 set. 2009.

KOOHANG, Alex. Expanding the concept of usability. Informing Science Journal, v. 7, 2004. Disponível em:<http://inform.nu/Articles/Vol7/v7p129-141-002.pdf>. Acesso em: 10 mar. 2011.

KRUG, Steve. Não me faça pensar! Uma abordagem de bom senso à usabilidade na Web. Second edition. Tradução do original Don't Make Me Think! Rio de Janeiro: Alta $\quad 2006 . \quad$ Dooks, Disponível em: <http://altabooks.tempsite.ws/capitulos_amostra/nfpensar.pdf>. Acesso em: 22 jan. 2011.

KUKLINSKI, Hugo Pardo. Um modelo de aplicación Web Institucional Universitaria. El caso de los Webcom: Webs de Facultates de Comunicación de Iberoamérica. 2005. 204 f. Tese (Doutorado em Comunicação Audiovisual e Publicidade) - Departamento de Comunicación Audiovisual y de Publicidad, Universidad Autonoma de Barcelona, Barcelona, 2005. Disponível em: http://www.tesisenxarxa.net/TDX/TDX_UAB/TESIS/AVAILABLE/TDX-0213106194137//hpk1de2.pdf > Acesso em: 31 mar. 2011. 
LARA FILHO, Durval de. O fio de Ariadne e a arquitetura da informação na www. DataGramaZero - Revista de Ciência da Informação, v. 4, n. 6, dez. 2003. Disponível em: <http://www.dgz.org.br>. Acesso em: 18 abr.2004

LEITE, J. C.; de Souza, C. S. Uma linguagem de especificação para a Engenharia Semiótica de Interfaces de usuário. In: WORKSHOP SOBRE FATORES HUMANOS EM SISTEMAS COMPUTACIONAIS, 1999, Campinas, SP. Proceedings... Campinas: Instituto de Computação da Unicamp, 1999.

LÉVY, Pierre. O que é o virtual? Tradução de Paulo Neves. Título original: Qu'estce lê virtuel? São Paulo: Ed. 34, 2007. 160 p. (Coleção TRANS).

As tecnologias da inteligência: o futuro do pensamento na era da informática. Tradução de Carlos Irineu da Costa. Título original: Les Technologies de l' intelligence. São Paulo: Ed. 34, 1999. 208 p. (Coleção TRANS).

LIMA, Clóvis Ricardo Montenegro; CARVALHO, Lidiane dos Santos; LIMA, José Rodolfo Tenório. Notas para uma administração discursiva das organizações. DataGramaZero - Revista de Ciência da Informação, artigo 3, dez. 2010. Diponível em: <http://www.datagramazero.org.br/dez10/Art_03.htm>. Acesso em: 13 fev. 2011.

LLANSÓ I. SANJUAN, Joaquim. Sistemas archivísticos y modelos de gestión de documentos en el ámbito internacional (parte II). Códice, v. 2, n. 2, p. 39-70, jul./dez. 2006. Disponível em: <redalyc.uaemex.mx/pdf/953/95320204.pdf>. Acesso em: 21 jan. 2011.

LÓPEZ CÍA, Iñigo. Sistema digital de archivo y recuperación de informação multimedia para centros de documentación. Disponível em: <http://www.rediris.es/difusion/publicaciones/boletin/38/ponencia3.html>. Acesso em: 2 fev. 2010.

LÓPEZ GÓMEZ, Pedro. El desarrollo técnico de la profesión: archivística. In: JORNADAS 150 ANIVERSARIO DEL CUERPO FACULTATIVO: El Cuerpo Facultativo de Archiveros y Bibliotecarios. Pasado, Presente ¿y futuro? (Algunas aportaciones del cuerpo facultativo). Madrid: Ministerio de Cultura. Dirección General del Libro, Archivos y Bibliotecas, 2008. Disponível em: <http://www.mcu.es/principal/docs/novedades/2008/150Aniversario_PedroLopez.p df>. Acesso em: 25 jan. 2011. da $A N A B A D$, v. 38, n. 1-2, p. 149-171, jan./jun. 1988. 
MANIEGA LEGARDA, David. Aplicación de un estudio de usabilidad en bibliotecas digitales: la Biblioteca Virtual de la UOC, 2002. In: CONTENIDOS Y ASPECTOS LEGALES EN LA SOCIEDAD DE LA INFORMACIÓN (CALSI), 2002, Valencia. Anais eletrônico ... Valencia: 2002. 15 f. Disponível em: $<$ http://eprints.rclis.org/504/>. Acesso em: 10 jun. 2010.

MANO GONZÁLEZ, Marta de La; MORO CABERO, Manuela. Los nuevos retos de la formación de usuarios: a la conquista del usuario virtual. In: JORNADAS ESPAÑOLAS DE DOCUMENTACIÓN, 6., 1998, Valencia. Anais. Valencia: FESABID, 1998, v. 6, p. 635-640.

MANZARI, Laura; TRINIDAD-CHRISTENSEN, Jeremiah. User-Centered Design of a Web site for library and information science students: heuristic evaluation and usability testing, information technology and libraries. [S. I.], p. 163-169, sep. 2006. Disponível em: <http://www.ala.org/ala/mgrps/divs/lita/ital/252006/number3september/manzari. pdf >. Acesso em: 16 jun. 2010.

MARIEL DOMÍNGUEZ, Lorena. Los usuarios, internet y el bibliotecário: estudio de usuarios sobre los recursos en línea. Inf. cult. soc., n. 18, ene.jjun. 2008. Disponível em: <http://www.scielo.org.ar/scielo.php?pid=S185117402008000100004\&script=sci_a rttext>. Acesso em: 11 jan. 2011.

MARIZ, Anna Carla Almeida. Arquivos públicos brasileiros: a transferência da informação na internet. 2005, 187 f. Tese (Doutorado em Ciência da Informação) - Escola de Comunicação, Universidade Federal do Rio de Janeiro. Disponível em: <http://tede-dep.ibict.br/tde_busca/arquivo.php?codArquivo=2>. Acesso em: 18 jan. 2011.

MARQUES, Amelia. Arquivos na ciência da informação. c.2007. Disponível em: <http://ameliamarques.Web.simplesnet.pt>. Acesso em: 3 mar.2010.

MARQUÉZ CORREA, Joaquín. Guía para evaluación experta. Disponível em: $<$ http://www.jmarquez.com/documentos/jm_checklist.pdf>. Acesso em: 7 maio 2010.

MARTINS, Neire do Rossio. Manual técnico organização de arquivos correntes e intermediários. Campinas, SP: Universidade Estadual de Campinas, 2005. Disponível em: <http://www.unicamp.br/siarq/publicacoes/organizacao_arquivos_correntes_interm ediarios.pdf>. Acesso em: 11 fev. 2011. 
MARTINS, Paulo Henrique. As redes sociais, o sistema da dádiva e o paradoxo sociológico. In: Redes Sociais e Saúde. Recife: UFPE, 2008. p. 8-23.

MARTINEZ, Antonio Lopo; OLIVEIRA, José Renato Sena. A contabilidade e o hipertexto: um estudo sobre o uso de Websites como meio de disseminação científica contábil por instituições de ensino superior brasileiras. Revista Contabilidade \& Finanças, v. 18, n. 43. p. 97-108, jan./abr. 2007.

MARTINEZ, Maria Laura. Usabilidade no design gráfico de Web sites. In: GRAPHICA'2000 - III INTERNATIONAL CONFERENCE ON GRAPHICS ENGINEERING FOR ARTS AND DESIGN, 3., E 140 SIMPÓSIO NACIONAL DE GEOMETRIA DESCRITIVA E DESENHO TÉCNICO, 14, 2000, Ouro Preto, Minas Gerais. $<$ http://www.faac.unesp.br/graduacao/di/downloads/Webdesign/USABILIDADE.pdf >. Acesso em: 16 out. 2010.

MARTÍNEZ BRAVO, Indira. Que es Internet y como surgió. Disponível em: $<$ http://indira-informatica.blogspot.com/2007/09/que-es-internet-y-comosurgi.html>. Acesso em: 16 ago. 2009. (Blog)

MARTÍNEZ GARCIA, Luis. El sistema español de archivos em la Costitución: la Confrontación entre Teoría y Realidad. Boletín de la $A N A B A D, 49$, n. 3-4, p. 89172, 1999.

MARTÍNEZ RADUÀ, Betlem. Paseo por el mapa español de archivos em Internet: el pergamino cibernético. Anuari SOCADI de documentació i informació. 1998, p. $55-64$. <http://www.raco.cat/indez.php/Bibliodoc/article/viewFile/6522/66044>. Acesso em: 9 jan. 2011.

McGEE, James; PRUSAK, Laurence. Gerenciamento estratégico da informação. Trad. Astrid Beatriz de Figueiredo. Rio de Janeiro: Campus, 1994.

MERLO VEGA, José Antonio. La evaluación de la calidad de la información Web: aportaciones teóricas y experiencias prácticas. Disponível em: <http://exlibris.usal.es/merlo/escritos/calidad.htm>. Acesso em: 20 jul. 2008.

MIRANDA, M. K. F. O.; SÁ, R. C. B.; LIMA, M. G. Desenvolvimento e usabilidade da biblioteca digital visão holandesa do Laboratório Liber-UFPE. Disponível em: <http://bibliotecas-cruesp.usp.br/3sibd/docs/miranda644.pdf>. Acesso em: 28 abr. 2010. 
MONISTROL, Ricard. Pàgines Web de museus a Europa: tendències em estructures i models. In: JORNADA EN DIFUSIÓN CULTURAL I WWW, 1., Barcelona, Espanha. Disponível em: <www.ricardmonistrol.cat/Ricard.Monistrol.ppt>. Acesso em: 16 jun. 2010.

MINISTERIO DE ADMINISTRACIONES PÚBLICAS. Secretaría General para La Administración Pública. Direción Geeneral de Modernización Administrativa. Guia para la edición y publicación de lãs páginas Web de La Administración General del Estado. Disponível em: <http://www.chsegura.es/export/descargas/informaciongeneral/imageninstitucional /administracionelectronica/docsdescarga/guia_funciona.pdf>. Acesso em: 2 fev. 2010.

MONTEIRO, Luis. A internet como meio de comunicação: possibilidades e limitações. In: CONGRESSO BRASILEIRO DE CIÊNCIA DA COMUNICAÇÃO, 24., 2001, Campo Grande-MS. [Anais...]. Campo Grande-MS: [s.n.], 2001. p. 2737. <http://galaxy.intercom.org.br:8180/dspace/bitstream/1904/4714/1/NP8MONTEIR O.pdf>. Acesso em: 23 mar. 2011.

MOOERS, Calvin N. Zatocoding applied to mechanical organization of knowledge. American Documentation, v. 2, n. 1, p. 20-32, 1951.

Mooers' law or, why some retrieval systems are used and others are not. American Documentation, v.11, n.3, July, 1960.

MORAES, Edson Andrade de; WERNECK, Vera Maria Benjamim. Uma abordagem de avaliação de qualidade de aplicações Web. Disponível em: $<$ http://magnum.ime.uerj.br/cadernos/cadinf/vol14/6-vera.pdf>. Acesso em: 6 ago. 2009.

MORAES, Anamaria de. Design e avaliação de interface: ergodesign e interação humano-computador. Rio de Janeiro: [s. n.], 2002. 148 p.

Usabilidade de interfaces e interação humano-computador: o papel da ergonomia. In: MORAES, Anamaria de; AMADAO, Giuseppe (Org.). Coletânea de palestras de convidados internacionais e nacionais Ergodesign e USIHC, Rio de Janeiro: FAPERJ; iUsEr, 2004. 174 p.

MORO CABERO, Manuela. Metodologia para la planificación y diseño de uma página Web em um archivo. El Archivo en la red: curso de formación continuada- 
Diputación Provincial de Salamanca. Salamanca: Universidad de Salamanca, nov. 2001. Trabalho não publicado.

MOURA, Gevilacio Aguiar Coêlho de. Sistemas de busca da Web: diretórios e mecanismos de busca. Disponível em: <http://www.quatrocantos.com/ tec_Web/sist_busca/index.htm>. Acesso em: 25 abr. 2010.

NEGRETE GUTIÉRREZ, María del Calmen. Criterios de selección para recursos digitales. México: Universidad Autônoma de México. Scire, v. 8, n. 2, p. 53-60, jul./dez. $2002 . \quad$ Disponível em: $<$ http://ibersid.eu/ojs/index.php/scire/article/view/1171/1153>. Acesso em: 13 fev. 2011.

NIELSEN, Jakob. How to conduct a heuristic evaluation. 2000. Disponível em: <http://www.ehow.com/how_2049727_conduct-heuristic-evaluation.html>. Acesso em: 20 set. 2009.

. Reports February 2010 U.S. Search Rankings. Disponível em: $<$ http://blog.nielsen.com/nielsenwire/online_mobile/nielsen-reports-february 2010u-s-search-rankings >. Acesso em: 5 set. 2010.

Ten usability heuristics. useit.com. Disponível em: <http://www.useit.com/papers/heuristic/heuristic_list.html>. Acesso em: 16 ago. 2002.

. Usabilty. Disponível em: <http://www.useit.com/alertbox/20030825.html>. Acesso em: 23 set. 2009.

. Usability Engineering. Cambridge, MA: Academic Pressional, 1993.

; LORANGER, Hoa. Usabilidade na Web: projetando Websites com qualidade. Rio de Janeiro: Elsevier, 2007. 406 p.

Sons, 1994.

; MACK, R.L. Usability inspection methods. New York, NY: John Wiley and

NORMAN, D. Cognitive Engineering. In: NRMAN, D.; DRAPER, S. (Ed.). User centered system design. Hillsdale, NJ: Lawrence Erlbaum, 1986. p..31-61. 
. Psychology of everyday things. [S. I.]: BasicBooks, HarperCollins Publishers, 1988.

Cognitive Artifacts. In: Carroll, J. M. (Ed.) Designing interaction: psychology ate the human-computer interface. New York: Cambridge University Press, 1991. p. 17-38.

Things that make us smart: defending human attributes in the age of the machine. Reading, MA: Addison-Wesley. 1993.

OCAÑA LACAL, Daniel de. Ignorancia, ilegalidad y otros males: panoramica del derecho de acceso a los archivos públicos en España. Boletín de la Anabad, v. 49 , n. 3-4, p. 173-211, jul./dic. 1999. Disponível em: <http://www.anabad.org/boletinpdf/pdf/XLIX(1999)_3-4_173.pdf> Acesso em: 19 jan. 2011.

- Los Archivos Históricos Provinciales en la legislación: Evolución y perspectivas en su setenta y cinco aniversario. Boletín de la $A N A B A D$, v. 57 , n. 1 , p. 261-282,2007. (Exemplar dedicado a: Jornadas "1931-2006. 75o Aniversario de la Creación de los Archivos Históricos Provinciales. Pasado, presente y futuro"). Disponível em: <http://dialnet.unirioja.es/servlet/articulo?codigo=2491240>. Acesso em: 8 jul. 2010.

OHIRA, Maria Lourdes Blatt; SCHENKEL, Marília Beatriz de Castro; SILVEIRA, Celoi da. Critérios para avaliação de conteúdo dos sites dos Arquivos Públicos Estaduais do Brasil. In: CIBERĖTICA: Simpósio Internacional de Propriedade Intelectual, INFORMAÇÃO E ÉTICA, 2.; ENCONTRO NACIONAL DE INFORMAÇÃO E DOCUMENTAÇÃO JURÍDICA, 8.; PAINEL BIBLIOTECONOMIA EM SANTA CATARINA, 22., 2003, Florianópolis. Anais eletrônico... Florianópolis, SC: $\quad$ UDESC, $2003 . \quad$ Disponível em:<http://www.udesc.br/arquivos/secao/cdoc/Artigo_Simposio_Internacional.pdf> . Acesso em: 2 fev. 2010.

OHIRA, Maria Lourdes Blatt; PRADO, N. S; CUNHA, L. S. Bibliotecas virtuais e digitais: análise comparativa dos artigos e periódicos e comunicações em eventos (1995/2000). In: SEMINÁRIO NACIONAL DE BIBLIOTECAS UNIVERSITÁRIAS, 11., 2002, Recife. Anais eletrônicos... Recife: UFPE, 2002 SNBU, 2002.

PÁDUA, Elisabeth Matallo M. Metodologia da pesquisa: abordagem teóricoprática. 6. ed. São Paulo: Papirus, 2000.

PAYNE, Hugh W. L. Education and archives. In: INTERNATIONAL CONGRESS ON ARCHIVES, 9., 1980, London. Anais... London: [s. n.], 1980. 
PEARROW, Mark. Web site usability handbook. Rockland, MA: Charles River Media, 2000.

PEIS REDONDO, Eduardo; RUÍZ RODRÍGUEZ, Antonio Angel; MONEDA CORROCHANO, Mercedes de la. Propuesta metodológica para la aplicación de la EAD (Encoded Archival Description): hacia la información electrónica de archivos. In: ACTAS DE LAS JORNADAS ESPAÑOLAS DE DOCUMENTACIÓN, 6., 1998, Bilbao. Anais eletrônicos... Bilbao: FESABID, 1998. v. 2,p. 703-714. Disponível em: <http://dialnet.unirioja.es/servlet/articulo?codigo=2091801>. Acesso em: 20 fev. 2011.

PERPINYÀ MORERA, Mei. Estat de la qüestió de l'automatització als arxius catalans. Anuari SOCADI de documentació i informació. 1997. p. 113-120. Disponível

em: <http://www.raco.cat/index.php/Bibliodoc/article/viewFile/56351/65773>. Acesso em: 12 jan. 2011.

PETERSON, Kate. Academic Web Site Design and Academic Templates: where does the library fit in?. Information technology and libraries, p. 217-221, dec. 2006. Disponível em: $<$ http://www.ala.org/ala/mgrps/divs/lita/ital/252006/number4decembera/peterson.p df>. Acesso em: 16 jun. 2010.

PINHO, José Benedito. Publicidade e vendas na Internet: técnicas e estratégias. São Paulo: Sammus, 2000.

A Internet como veículo de comunicação publicitária. Revista FAMECOS, Porto Alegre, n. 10, p. 86-93, jun. 1999.

PINTO, Júlio Miguel Cabral da Costa. Contributos para a concepção de interfaces na Web: o utilizador no centro de uma constelação. Tékhne,: Revista de Estudos Politécnicos, Barcelos, Portugal, n. 9, p. 370-382, jun. 2008. Disponível em: < http://www.scielo.oces.mctes.pt/pdf/tek/n9/n9a18.pdf >. Acesso em: 14 fev. 2011.

PRATES, Raquel Oliveira; BARBOSA, Simone Diniz Junqueira. Avaliação de Interfaces de usuário: conceitos e métodos. Disponível em: <http://www.inf.pucrio.br/ inf1403/docs/JAl2003_PratesBarbosa_avaliacao.pdf>. Acesso em: 9 jul. 2009.

PRIMO, Alex Fernando Teixeira. Interação mediada por computador: a comunicação e a educação a distância segundo uma perspectiva sistêmicorelacional. 2003. Tese (Doutorado em Informáica na Educação) - Universidade Federal do Rio Grande do Sul, Porto Alegre, 2007. Disponível em: 
$<$ http://www.desafiopedagogico.com/documentos/TESE\%20PROF\%20ALEX\%20 PRIMO\%20SBR\%20TIC.pdf>. Acesso em: 14 abr. 2010.

. Interação mediada por computador: comunicação, cibercultura, cognição. Porto Alegre: Sulina, 2007. Resenha de: ALMEIDA, Cândida. Revista digital de tecnologias cognitivas, São Paulo, n. 4, 2010. Disponível em: $<$ http://www.pucsp.br/pos/tidd/teccogs/resenhas/interacao-mediada-porcomputador-alex-primo.html>. Acesso em: 14 abr. 2010.

PUBLICAÇÃO e divulgação na Web: Web design, usabilidade e optimização para motores de busca. Disponível em: <http://visibilidade.net/>. Acesso em: 12 abr. 2010.

O QUE é Ergonomia? Histórico e fases da Ergonomia: abrangência da Ergonomia. Disponível em: <http://www.ergonet.com.br/download/ergonomiaintrod.pdf>. Acesso em: 22 maio 2009.

QUE es Internet y como surgió. Disponível em: <http://indirainformatica.blogspot.com/2007/09/que-es-internet-y-como-surgi.html>. Acesso em: 12 abr. 2010.

RAMÍREZ CÉSPEDES, Zulia. Critérios e indicadores para evaluar las bibliotecas digitales. Acimed, v. 14, n. 6, 2006. Disponível em: <http://bvs.sld.cu/revistas/aci/vol14_6_06/aci04606.htm>. Acesso em: 8 jul. 2010.

RAMIRÉZ LÓPEZ, Celia. La Archivística: un viejo oficio, una nueva profesión. In: VILLANUEVA BAZÁN, Gustavo (Coord.). Teoría y práctica archivística. México: UNAM, 2000. v. 1. p. 13-20. (Cuadernos del Archivo histórico de la Universidad Nacional Autónoma de México - UNAM, 11).

MUÑOZ-CAÑAVATE, Antonio. Resenha de: RAMOS-SIMÓN, L. Fernando. Bases de datos de libre acceso difundidas por la Administración General del Estado. Madrid, Espanha: Editorial Complutense, 2009. El profesional de la información, v. 18, n. 4, jul./ago, p. 475-477, 2009.

RECUERO, Raquel. Considerações sobre a difusão de Informações em Redes Sociais na Internet. In: CONGRESSO BRASILEIRO DE CIÊNCIAS DA COMUNICAÇÃO DA REGIÃO SUL, 8., 2007, Passo Fundo (RS). Anais eletrônico ... Passo Fundo, RS: UPF, 2007. Disponível em: <http://www.intercom.org.br/papers/regionais/sul2007/resumos/R0464-1.pdf.>. Acesso em: $1^{\circ}$ abr. 2010. 
REIS, Luís. O arquivo e a arquivistica evolução histórica. Biblios:, ano 7, n. 24, abr./jun. $2006 . \quad$ Disponível em: <http://redalyc.uaemex.mx/redalyc/src/inicio/ArtPdfRed.jsp?iCve=16172402>. Acesso: 13 fev. 2011.

RIBEIRO, Daniel Melo. Vantagens corporativas da aplicação dos padrões Web voltados para acessibilidade e usabilidade. 2006. 54 f. Monografia (Especialização em Gestão Estratégica da Informação) - Escola de Ciência da Informação, Universidade Federal de Minas Gerais, Belo Horizonte, 2006. Disponível em: <http://www.danielmelo.net/padroesWeb.pdf>. Acesso em: 13 fev. 2011.

RIBEIRO, Fernanda. Novos caminhos da avaliação de informação. Arquivística.net, v. 1, n. 2, p. 53-74, jul./dez. 2005. Disponível em: <http://ler.letras.up.pt/uploads/ficheiros/artigo9821.PDF>. Acesso em: 24 jan. 2011.

RICHARDSON, Roberto Jarry et al. Pesquisa social: métodos e técnicas. 3. ed. São Paulo: Atlas, 1999. 287 p.

ROCHA, Heloísa Vieira da; BARANAUSKAS, Maria Cecília Calani. Design e avaliação de interfaces humano-computador. São Paulo: NIED, 2003.

RODRIGUES, Beatriz Russo. A abordagem ergonômica sobre a usabilidade e agradabilidade. 2003. 352 f. Dissertação (Mestrado em Design) - Pontifícia Universidade Católica do Rio de Janeiro, Rio de Janeiro, 2003.

RODRIGUES, Georgete Medleg. A representação da informação em arquivística: uma abordagem a partir da perspectiva da Norma Internacional de Descrição Arquivística. In: RODRIGUES, Georgete M.; LOPES, Iza L. (Org.). Organização e representação do conhecimento. Brasília: Thesaurus, 2003. p. 211-229. Disponível em: <http://repositorio.bce.unb.br/bitstream/10482/1442/1/CAPITULO_Representacaol nformacaoArquivistica.pdf>. Acesso em: 18 jan. 2011

RODRIGUES, Mayara Barbosa; BECHER, Anderson. Acessibilidade $e$ usabilidade na Web. Disponível em: $<$ http://www.sucesumt.org.br/mtdigital/anais/files/AcessibilidadeeUsabilidadenaWe b.pdf>. Acesso em: 13 fev. 2011.

RODRÍGUEZ, David. Crear páginas Web: guía básica para archiveros. Boletín de la Asociación Española de Archiveros, Bibliotecarios, Museólogos y Documentalistas, v. 48, n. 1, p. 93-115, ene./mar. 1998. 
ROSENFELD, L; MORVILLE, P. Information Architecture for the World Wide Web. Sebastopol, CA: O’Reilly, 1998. 202 p.

RUBIO LINIERS, María Cruz et al. Internet y la historia de España. Revista General de Información y documentació, Madrid, Espanha, v. 8, n. 2, p.149-163, 1998.

Disponível

em: <http://revistas.ucm.es/byd/11321873/articulos/RGID9898220149A.PDF>. Acesso em 13 fev. 2011.

SALTON, G. The SMART retrieval system: experiments in automatic document processing. Englewood Cliffs, N.J.: Prentice-Hall, 1971.

SANTAELLA, Lucia. Navegar no ciberespaço: o perfil cognitivo do leitor imersivo. São Paulo: Paulus, 2004. 191 p.

SANTAMARÍA GALLO, Abelardo. La Norma española de descripción archivística (NEDA): análisis y propuesta de desarrollo. Madri: Subdirección General de los Archivos Estatales, $2006.20 \mathrm{Disponível}$ <http://www.mcu.es/archivos/docs/NedaAnalisis.pdf>. Acesso em: 9 jan. 2011.

SANTINHO, Miguel. Avaliação heurística e testes com utilizadores: dois métodos, dois resultados - Análise comparada da usabilidade nos sítios das televisões portuguesas. Setembro 2001. Disponível em:

<http://banners.noticiasdot.com/termometro/boletines/docs/tv/varios/2001/set2001. pdf> Acesso em: 25 abr. 2011.

SANTOS, Robson L. G. dos. Usabilidade e métodos de avaliação de usabilidade de interfaces Web. In: ENCONTRO PAN-AMERICANO DE ERGONOMIA, CONGRESSO BRASILEIRO DE ERGONOMIA, 10., 2000, Rio de Janeiro. [Anais...]. Rio de Janeiro: Pontifícia Universidade Católica, 2000. Disponível em: <http://xa.yimg.com/kg/groups/20750039/2055696000/name/usab_metodos.pdf> Acesso em: 13 fev. 2011.

SAYÃO, Fernando. Base de dados: a metáfora da memória científica. Ciência da Informação, v. 25, n. 3, p. 314-318, set./dez. 1996.

SERRA, Joaquim Paulo. A Internet e o mito da visibilidade universal: Universidade da Beira Interior. Texto da Biblioteca Online de Ciências da Comunicação. 2002. Disponível em: <http://www.bocc.ubi.pt/pag/serra-paulo-internet-mito-visibilidadeuniversal.pdf>. Acesso em: 15 fev. 2011.

SERRALLER IBÁNEZ, Juan. Información y Derechos Humanos. Boletín de la ANABAD, Madrid, Espanha, t. 49, n. 3-4, p. 69-76, 1999. 
SHACKEL, B. Usability: context, framework, design and evaluation. In: RICHARDSON, S. (Ed.). Human factors for informatics usability. Cambridge: Cambridge University, 1991. p. 21-38.

SHELLENBERG, T. R. Arquivos modernos: princípios e técnicas. Rio de Janeiro: FGV, 1973.

. Padrões de avaliação. In: SCHELLENBERG, T. R. Manual de arquivos: evolução dos sistemas americanos de arquivamento. Rio de Janeiro: Arquivo Nacional, 1959.

SHNEIDERMAN, Ben. Designing the user interface: strategies for effective human-computer interaction..4th ed. Boston, MA, USA: Pearson Education, 2005. $624 \mathrm{p}$.

SILVA, Patrícia Maria; DIAS, Guilherme Ataíde. Teorias sobre aceitação de tecnologia: por que os usuários aceitam ou rejeitam as tecnologias de informação? In: Brazilian Journal of Information Science, v. 1, n. 2, p. 69-91, jul./dez. 2007. Disponível em: <http://www.bjis.unesp.br/pt/>. Acesso em: 20 jul. 2010.

; SENA JÚNIOR, Manoel Raimundo. A importância da cultura na adoção tecnológica, o caso do Tecnology Acceptance Model (TAM). Encontros Bibli, v. 13, n. 26, 2008. Disponível em: <http://redalyc.uaemex.mx/redalyc/pdf/147/14712794007.pdf>. Acesso em: 3 mar. 2011.

SOARES, Andréa et al. Avaliação de interface de programas educativos infantis audiovisuais para TV digital e interativa. Disponível em: <http://www.nuppead.unifacs.br/artigos/TVDI-ASoares_e_CCosta.pdf >. Acesso em: 16 ago. 2009.

SOTOMAYOR, Luis Cueto Álvarez de. Técnicas de análisis de posicionamiento. (Tradução nossa).

Disponível em: <http://www.elprofesionaldelainformacion.com/contenidos/2005/enero/2.pdf>. Acesso em: 14 abril 2010.

SOUZA, Clarisse Sieckenius et al. Projeto de interfaces de usuário: perspectivas cognitivas e semióticas. In: JORNADA DE ATUALIZAÇÃO EM INFORMÁTICA. CONGRESSO DA SOCIEDADE BRASILEIRA DE COMPUTAÇÃO, 9., 1999, Rio de Janeiro. Anais... Rio de Janeiro: [s. n.], 1999. Disponível em: <http://www.dimap.ufrn.br/ jair/piu/JAl_Apostila.pdf>. Acesso em: 8 jul. 2010. 
SPINELLI JUNIOR, Jayme. A Conservação de acervos bibliográficos \& documentais. Rio de Janeiro: Fundação Biblioteca Nacional, Dep. de Processos Técnicos, 1997. 90 p. (Documentos técnicos; 1). Disponível em: <http://www.bn.br/portal/arquivos/pdf/manualjame.pdf> Acesso em: 18 jan. 2011.

STEPHENSON, Neal. En el principio fue la línea de comandos. Madrid: Traficantes de sueños. Disponível em: <http://librodenotas.com/computacion/>. Acesso em: 13 abr. 2010.

STRAIOTO, Fabiana. A arquitetura da informação para a World Wide Web: um estudo exploratório. 2002. Dissertação (Mestrado em Ciência da Informação) Faculdade de Filosofia e Ciências, Universidade Estadual Paulista, Marília, 2002.

TAYLOR, Hugh A. Los servicios de archivo y el concepto de usuário; Estudio del RAMP/preparado por Hugh A. Taylor para el Programa General de Información y UNISIST.Paris: Unesco, 1984. 72 p.

TORRADO MORALES, Suzana. La página Web del Archivo Histórico del Instituto Luce: un instrumento de difusión cinematográfica. Revistas científicas de la universidad de Murcia: Anales de Documentación, Murcia, Espanha, n. 10, p. 413428, 2007. Disponível em: <http://revistas.um.es/analesdoc/article/view/1281>. Acesso em: 16 ago. 2009.

TRAMULLAS, Jesús. Diseño y arquitectura de la información para el Web, 20012004: un análisis bibliográfico selectivo. El profesional de La información, [S. I.], v. 13, n. 3, p. 202-209, mayo/jun. 2004.

.; GARRIDO, Piedad; NAVARRO, Diego. Evaluación de bibliotecas digitales de fondo antiguo. Apresentado na V JORNADA DE BIBLIOTECAS DIGITALES JBIDI, Granada, 2005.

TRAVIESO RODRíGUEZ, Críspulo; ALONSO ARÉVALO, Julio; VIVANCOS SEVILLA, José Maria. Usabilidad de los catálogos de las bibliotecas universitárias: propuesta metodológica de evaluación. Acimed, v. 16, n. 2, 2007. Disponível em: <http://bvs.sld.cu/revistas/aci/v.16_2_07/aci04807.htm>. Acesso em: 2 fev. 2010

TRINDADE, André. Os direitos fundamentais em uma perspectiva autopoética. Porto Alegre: Livraria dos Advogados. 2007. 154 p.

OS USUÁRIOS da internet estão cada vez mais egoístas, diz especialista. Estadão Online, São Paulo, 24 maio 2008. Caderno Economia/Tecnologia. Entrevista à BBC Brasil. Disponível em: 
<http://www.estadao.com.br/noticias/tecnologia,usuarios-da-internet-estao-maisegoistas-diz-especialista,177426,0.htm>. Acesso em: 6 ago. 2009.

VECHIATO, Fernando Luiz. Repositório digital como ambiente de inclusão digital e social para usuários idosos. 2010. Dissertação (Mestrado em Ciência da Informação) - Faculdade de Filosofia e Ciências, Universidade Estadual Paulista, Marília, 2010. Disponível em: <http://www.marilia.unesp.br/Home/PosGraduacao/Cienciadalnformacao/Dissertacoes/vechiato_fl_me_mar.pdf>. Acesso em: 15 fev. 2011.

VIDOTTI, S. A. B. G; SANCHES, S. A. S. Arquitetura da informação em Web sites. Disponível em: <http://libdigi.unicamp.br/document/?view=8302>. Acesso em: 7 ago 2009.

VILAR BARRIO, José Francisco. Las siete nuevas herramientas para la mejora de la calidad. 2. ed. rev. e ampl. Madrid: Fundación Confemental, 1998. 166 p.

VILLABUENA BAZÁN, Gustavo. La Norma Internacional General de Descripción necesidad de normalización archivística. In: (Coord.). Teoría y práctica archivística. México: UNAM, 2000. v. 1. p. 21-30. (Cuadernos del Archivo histórico de la Universidad Nacional Autónoma de México - UNAM, 11).

VISENTIN, Juan Ignacio. El papel de las Interfaces en la generación y transmisión de conocimientos dentro de una organización. 19 f. Trabalho Final (Graduação en Comunicación en Organizaciones Complejas) - Facultad Latinoamericana de Ciencias Sociales (FLACSO), Santiago (Chile), 2004. Disponível em: <http://www.reddircom.org/textos/visentin.pdf>. Acesso em: 2 fev. 2010.

WESTERA, G. Evaluating the documents you have found on the World Wide Web. Disponível em: <http://www. Webliminal.com/search/search-Web12.html>. Acesso em: 11 jul. 2010.

WURMAN, Richard Saul. Ansiedade de informação. Como transformar informação em compreensão. São Paulo: Cultura Editores Associados, 1991.

YAMAOKA, Eloi Juniti. Metadados para a Interoperabilidade do Governo. Revista Tema, ano 31, n. 192, jul./ago. 2007. Disponível em: <http://www.serpro.gov.br/imprensa/publicacoes/Tema/tema_192/materias/metad ados-para-a-interoperabilidade-do-governo>. Acesso em: 10 fev. 2011.

ZAMBRANO SILVA, Salvador; VILLANUEVA PLA, Enrique; RUS MOLINA, Lola La perspectiva de los usuarios: recuperación de información y usabilidad. Anales 
de Documentación, n. 10, p. 451-483, 2007. Disponível em: http://revistas.um.es/analesdoc/article/view/1281. Acesso em: 16 ago. 2009.

ZWEIZIG, D.; DERVIN, B. Public library use, users, use: advances in knowledge of the characteristics and needs of the adult clientele of American Public Libraries. Advances in Librarianship, n. 7, p. 231-255, 1977. Disponível em: $<$ http://www.tempusactas.unb.br/index.php/RBB/article/viewFile/616/614>. Acesso em: 20 jul.2010. 


\section{APÊNDICES}




\section{APÊNDICE A}

FICHA SOCIAL DO USUÁRIO

1. Sexo:

a) Masculino ( ) b) Feminino ( )

2. Faixa Etária:
a) de 18 a 30 (
b) de 31 a 45(
( ) c) de 46 a 60 ( ) d) Mais de 60 ( )

3. Nível de escolaridade:
a) Graduação
b) Especialização ( )
c) Mestrado
d) Doutorado ( )

Área de Conhecimento:

4. Área(s) em que atua e/ ou instituição(ções) em que trabalha:

5. Avalie sua experiência na utilização da Internet:
a) fraca
b) regular ( )
c) boa (
d) ótima ( )

6.Utiliza diversos métodos para realizar buscas online?

a) $\operatorname{sim}($ ) b) não ( )

6. Já participou de algum curso ou treinamento para o uso de catálogos e/ou base de dados online?
a) $\operatorname{sim}($ ) b) não ( ) 
8. Que tipo de sistema de busca de informação online costuma utilizar em pesquisas objetivas?

a) motores de busca da Internet (Google, Yahoo, Cadê, etc.) ( )

b) catálogo de bibliotecas digitais/virtuais e fundos digitais de Arquivos ( )

c) bases de dados da própria instituição na qual trabalha e/ou estuda ( )

d) outro(s)? Especifique.

Assinatura do participante: 


\section{APÊNDICE B}

\section{FICHA SOCIAL DO AVALIADOR}

Nome:

Faixa etária:

18 a 30 ( ) 31 a 45 ( ) 46 a 60 ( ) Mais de 60 ( )

Formação acadêmica:

Experiência em buscas de dados na Internet?

Regular ( ) Avançada ( )

Computador utilizado para realizar as avaliações (configuração):

Observação:

Para especificar o computador utilizado, informar o sistema operacional, o processador, a memória e o tipo de conexão à internet. Ex: Windows XP, Processador Dual Core, 1GB de memória, conexão de banda larga. 


\section{APÊNDICE C}

\section{TERMO DE RESPONSABILIDADE DOS USUÁRIOS}

A presente pesquisa tem como objetivo colher informações para compor a elaboração da tese de Doutorado intitulada: Uma proposta de avaliação em Usabilidade e Visibilidade de páginas Web de Arquivos Espanhóis, inserida no programa de Doutorado do Terceiro Ciclo da Universidade de Salamanca: Doctorado em Líneas de Investigación en Biblioteconomía y Documentación. A investigação propõe uma avaliação de sites de Arquivos espanhóis conforme os critérios de usabilidade e visibilidade a fim de apresentar a realidade dos Arquivos quanto a sua adequação às novas tecnologias e inserção no "mundo globalizado", e a interação do usuário com as páginas Web de Arquivo, em face da recuperação de informações disponibilizadas nos referidos sites.

Para ciência da responsabilidade da coleta de dados, seguem algumas observações:

1- Os dados pessoais do participante serão preservados.

2- O teste com "usuários potenciais" se efetuará em duas etapas:

Primeiro será aplicado um questionário com dados para identificar o sujeito e sua formação e segundo, serão aplicadas tarefas referentes ao uso dos sites dos Arquivos em questão.

3- Em qualquer fase do teste o participante tem o direito à desistência.

$\mathrm{Eu}$,

portador do $R G$

Declaro estar ciente do objetivo desta pesquisa, de que a participação é voluntária e de que fui devidamente esclarecido(a) quanto aos procedimentos da mesma e eventual divulgação da minha imagem sem ônus para as partes envolvidas.

Autorizo a utilização de informações resultantes do teste aplicado bem como de eventuais fotos tiradas durante as duas etapas do teste.

Data:

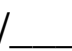

Assinatura do participante 


\section{APÊNDICE D}

\section{TERMO DE RESPONSABILIDADE DOS AVALIADORES}

A presente pesquisa tem como objetivo colher informações para compor a elaboração da tese de Doutorado intitulada: Visibilidade e Usabilidade de Arquivos Espanhóis em Rede, inserida no programa de Doutorado do Terceiro Ciclo da Universidade de Salamanca: Doctorado em Líneas de Investigación en Biblioteconomía y Documentación. A investigação propõe uma avaliação de sites de Arquivos espanhóis conforme os critérios de visibilidade e usabilidade a fim de apresentar a realidade dos Arquivos quanto a sua adequação às novas tecnologias e inserção no "mundo globalizado", e a interação do usuário com as páginas Web de Arquivo, em face da recuperação de informações disponibilizadas nos referidos sites.

Por uma questão de preservação de faces, convém informar que os dados pessoais dos participantes serão resguardados, sendo o presente termo apenas uma garantia de registro da coleta de dados para a pesquisa.

$\mathrm{Eu}$, , portador da identidade de número Declaro estar ciente do objetivo desta pesquisa, de que a participação é voluntária e de que fui devidamente esclarecido(a) quanto ao seu procedimento.

Autorizo a utilização de informações resultantes da avaliação.

Recife, de setembro de 2010 
APÊNDICE E - MODELO DEL CUESTIONARIO - EVALUADORES

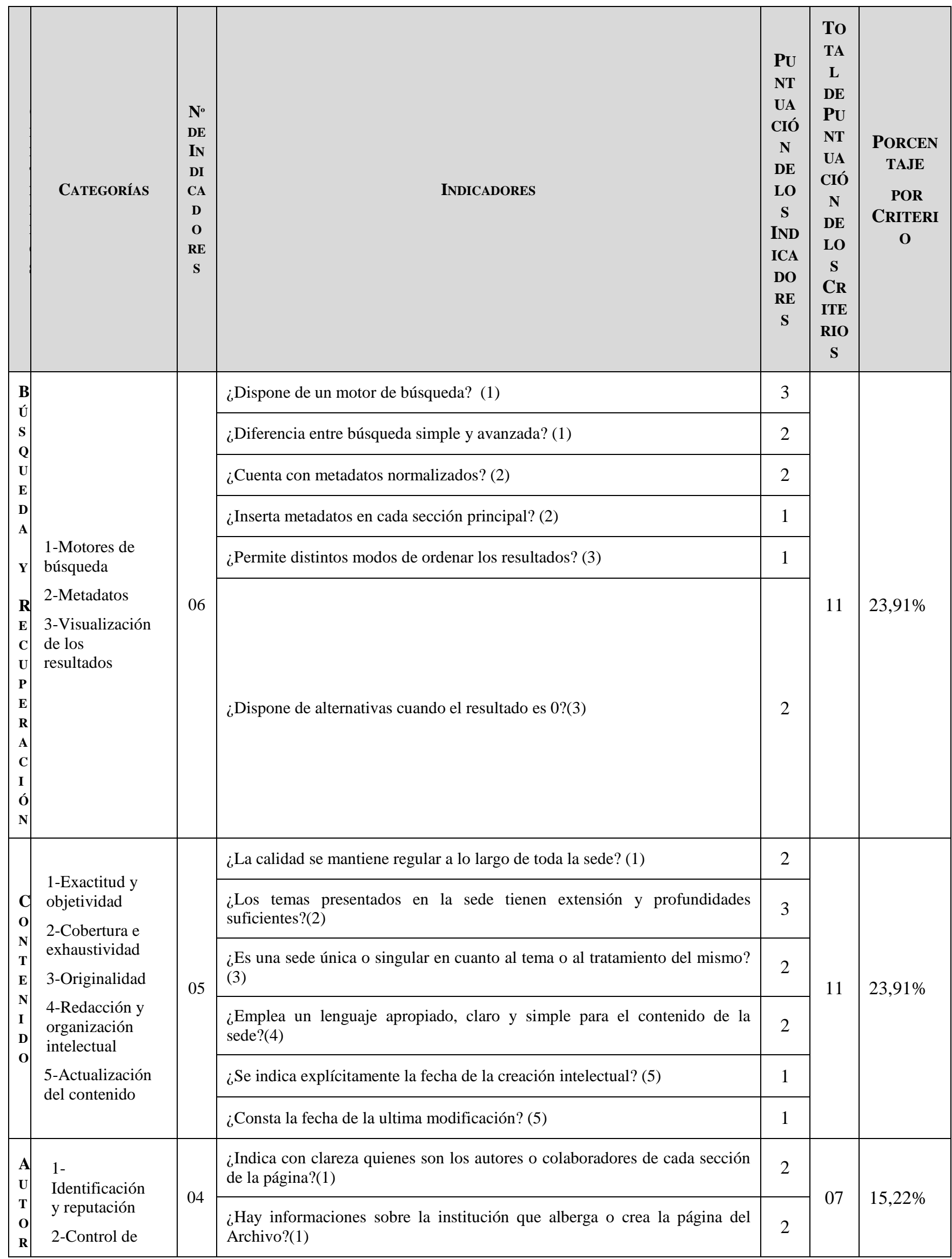




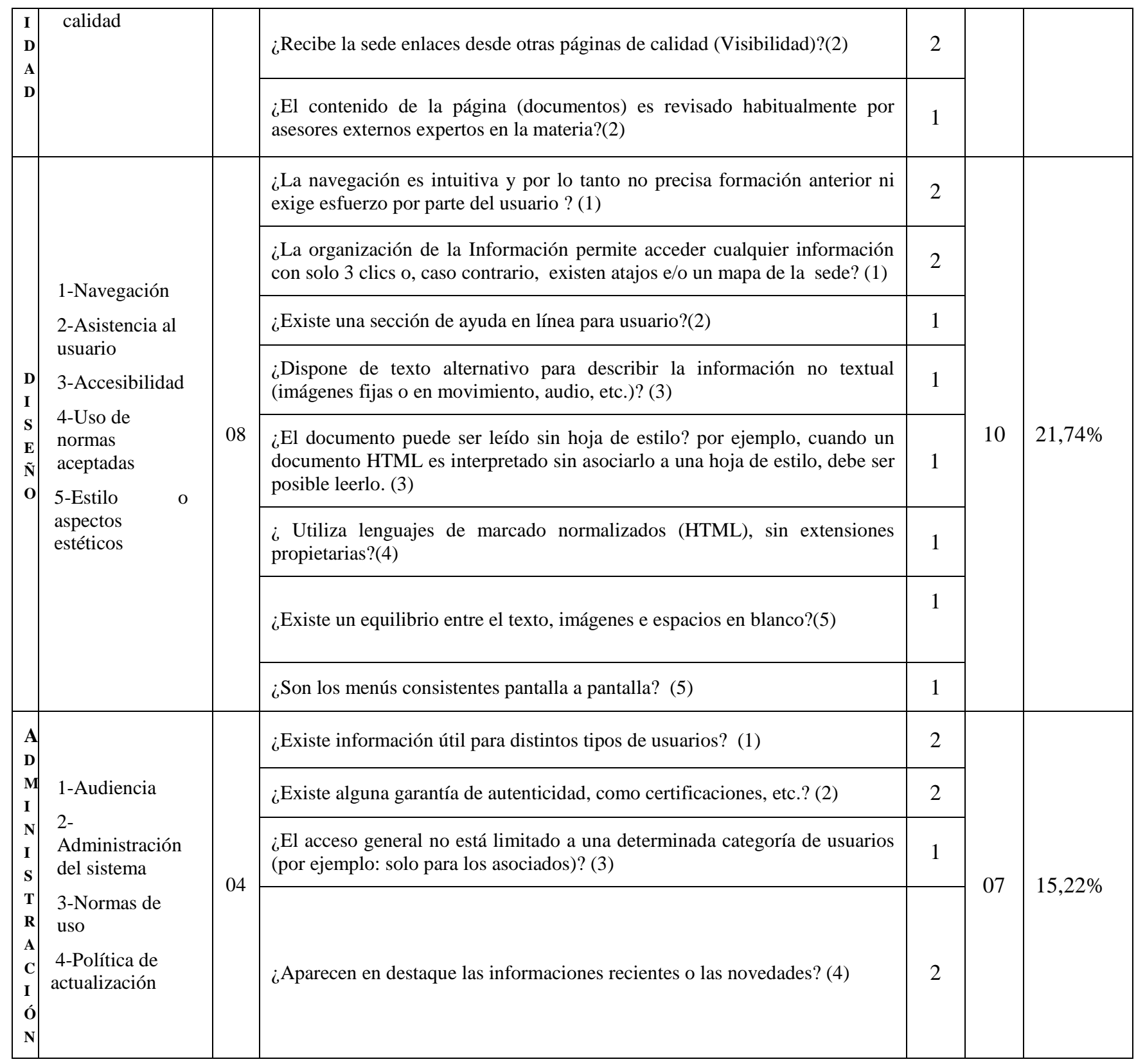




\section{ORIENTACIONES PARA RELLENAR EL CUESTIONARIO}

El cuestionario deberá ser rellenado por dos expertos en desarrollo de páginas Web y dos profesionales del área de Biblioteconomía y Documentación, la autora es uno de los evaluadores de las páginas.

La aplicación del cuestionario deberá ser realizada para cada página Web de Archivo Español que compone este estudio. Cada página web de Archivo estudiado a posteriori tendrá su evaluación basada en los resultados de las observaciones de cada uno de los evaluadores sumada a los resultados obtenidos en las tareas aplicadas a usuarios reales o potenciales de las páginas Web de los Archivos, además del confronto con las heurísticas de Nielsen para verificar si la página Web hiere a alguna de ellas.

\section{Puntuación del Cuestionario}

En el Modelo del cuestionario de la evaluación presentamos las puntuaciones a que corresponde cada Indicador dentro de las Categorías de los Criterios. A partir de esta puntuación los evaluadores deberán atribuir puntos a cada uno de los Indicadores según su entendimiento y conforme su opinión al respecto de cada Archivo estudiado.

\section{Ejemplo:}

Cuando el total de puntos de la pregunta (Indicador) es $\mathbf{2} \mathbf{2}$, la respuesta debe ser una de las tres opciones cuyos pesos son: 0, 102 , teniendo en cuenta que el valor máximo de la pregunta es 2. Abajo presentamos para este Indicador los posibles resultados:

a) No Cumplió totalmente el objetivo da pregunta $=\mathbf{0}$

b) Cumplió parcialmente el objetivo da pregunta $=\mathbf{1}$ (mitad del total de puntos que corresponde a pregunta dentro de cada Indicador)

c) Cumplió totalmente el objetivo de la pregunta $=\mathbf{2}$ (total de los puntos que corresponde a pregunta dentro de cada Indicador) 


\section{APÊNDICE F}

Cuestionario a ser rellenado por los Evaluadores

NOMBRE:

FORMACIÓN ACADEMICA:

¿EXPERIÊNCIA EN BUSQUEDAS EN INTERNET?

( )BÁSICA ( )MEDIANA ( )AVANZADA

ORDENADOR UTILIZADO PARA REALIZAR LAS TAREAS

(CONFIGURACIÓN):

ARCHIVO EVALUADO:

OBSERVACIÓN: PARA ESPECIFICAR EL ORDENADOR UTILIZADO INFORMAR: EL SISTEMA OPERACIONAL, PROCESADOR, MEMÓRIA Y TIPO DE CONEXIÓN A INTERNET.

EJ: WINDOWS XP, PROCESADOR DUAL CORE, 1GB DE MEMÓRIA, CONEXIÓN BANDA ANCHA. 


\begin{tabular}{|c|c|c|c|c|c|}
\hline $\begin{array}{l}\text { C } \\
\mathbf{R} \\
\mathbf{I} \\
\mathbf{T} \\
\mathbf{E} \\
\mathbf{R} \\
\mathrm{I} \\
\mathrm{O} \\
\mathrm{S}\end{array}$ & Categorías & INDICADORES & $\begin{array}{c}\text { PUNT } \\
\text { UACI } \\
\text { ÓN } \\
\text { DE } \\
\text { LOS } \\
\text { INDIC } \\
\text { ADOR } \\
\text { ES }\end{array}$ & $\begin{array}{l}\text { PUN } \\
\text { TUA } \\
\text { CIÓ } \\
\mathbf{N} \\
\text { DEL } \\
\text { EVA } \\
\text { LUA } \\
\text { DOR }\end{array}$ & $\begin{array}{c}\text { TOTA } \\
\text { L DE } \\
\text { PUNT } \\
\text { UACIÓ } \\
\text { N DE } \\
\text { LOS } \\
\text { CRITE } \\
\text { RIOS }\end{array}$ \\
\hline \multirow{6}{*}{$\begin{array}{c}\text { B } \\
\text { ÚS } \\
\mathbf{Q} \\
\text { UE } \\
\text { DA } \\
\mathbf{Y} \\
\mathbf{R} \\
\text { EC } \\
\text { UP } \\
\text { ER } \\
\text { AC } \\
\text { IÓ } \\
\mathbf{N}\end{array}$} & \multirow{6}{*}{$\begin{array}{l}\text { 1-Motores de } \\
\text { búsqueda } \\
\text { 2-Metadatos } \\
\text { 3-Visualización } \\
\text { de los resultados }\end{array}$} & ¿Dispone de un motor de búsqueda? (1) & 3 & & \\
\hline & & ¿Diferencia entre búsqueda simple y avanzada? (1) & 2 & & \\
\hline & & ¿Cuenta con metadatos normalizados? (2) & 2 & & \\
\hline & & ¿Inserta metadatos en cada sección principal? (2) & 1 & & \\
\hline & & ¿Permite distintos modos de ordenar los resultados? (3) & 1 & & \\
\hline & & ¿Dispone de alternativas cuando el resultado es 0?(3) & 2 & & \\
\hline \multirow{6}{*}{$\begin{array}{c}\text { C } \\
\text { O } \\
\text { NT } \\
\text { EN } \\
\text { ID } \\
\text { O }\end{array}$} & \multirow{6}{*}{$\begin{array}{l}\text { 1-Exactitud y } \\
\text { objetividad } \\
\text { 2-Cobertura e } \\
\text { exhaustividad } \\
\text { 3-Originalidad } \\
\text { 4-Redacción y } \\
\text { organización } \\
\text { intelectual } \\
\text { 5-Actualización } \\
\text { del contenido }\end{array}$} & ¿La calidad se mantiene regular a lo largo de toda la sede? (1) & 2 & & \\
\hline & & ¿Los temas presentados en la sede tienen extensión y profundidades suficientes?(2) & 3 & & \\
\hline & & ¿Es una sede única o singular en cuanto al tema o al tratamiento del mismo? (3) & 2 & & \\
\hline & & ¿Emplea un lenguaje apropiado, claro y simple para el contenido de la sede?(4) & 2 & & \\
\hline & & ¿Se indica explícitamente la fecha de la creación intelectual? (5) & 1 & & \\
\hline & & ¿Consta la fecha de la ultima modificación? (5) & 1 & & \\
\hline \multirow{4}{*}{$\begin{array}{c}\text { A } \\
\text { UT } \\
\text { O } \\
\text { RI } \\
\text { DA } \\
\text { D }\end{array}$} & \multirow{4}{*}{$\begin{array}{l}\text { 1-Identificación } \\
\text { y reputación } \\
\text { 2-Control de } \\
\text { calidad }\end{array}$} & $\begin{array}{l}\text { ¿Indica con clareza quienes son los autores o colaboradores de cada sección de la } \\
\text { página?(1) }\end{array}$ & 2 & & \\
\hline & & ¿Hay informaciones sobre la institución que alberga o crea la página del Archivo?(1) & 2 & & \\
\hline & & ¿Recibe la sede enlaces desde otras páginas de calidad (Visibilidad)?(2) & 2 & & \\
\hline & & $\begin{array}{l}\text { ¿El contenido de la página (documentos) es revisado habitualmente por asesores } \\
\text { externos expertos en la materia?(2) }\end{array}$ & 1 & & \\
\hline \multirow{5}{*}{$\begin{array}{l}\text { DI } \\
\text { SE } \\
\tilde{\mathbf{N}} \\
\mathbf{O}\end{array}$} & \multirow{5}{*}{$\begin{array}{l}\text { 1-Navegación } \\
\text { 2-Asistencia al } \\
\text { usuario } \\
\text { 3-Accesibilidad } \\
\text { 4-Uso de normas } \\
\text { aceptadas } \\
\text { 5-Estilo o } \\
\text { aspectos estéticos }\end{array}$} & $\begin{array}{l}\text { ¿La navegación es intuitiva y por lo tanto no precisa formación anterior ni exige } \\
\text { esfuerzo por parte del usuario ? (1) }\end{array}$ & 2 & & \\
\hline & & $\begin{array}{l}\text { ¿La organización de la Información permite acceder cualquier información con solo } 3 \\
\text { clics o, caso contrario, existen atajos e/o un mapa de la sede? (1) }\end{array}$ & 2 & & \\
\hline & & ¿Existe una sección de ayuda en línea para usuario?(2) & 1 & & \\
\hline & & $\begin{array}{l}\text { ¿Dispone de texto alternativo para describir la información no textual (imágenes fijas o } \\
\text { en movimiento, audio, etc.)? (3) }\end{array}$ & 1 & & \\
\hline & & $\begin{array}{l}\text { ¿El documento puede ser leído sin hoja de estilo? por ejemplo, cuando un documento } \\
\text { HTML es interpretado sin asociarlo a una hoja de estilo, debe ser posible leerlo. (3) }\end{array}$ & 1 & & \\
\hline
\end{tabular}




\begin{tabular}{|c|c|c|c|}
\hline & & ¿ Utiliza lenguajes de marcado normalizados (HTML), sin extensiones propietarias?(4) & 1 \\
\hline & & ¿Existe un equilibrio entre el texto, imágenes e espacios en blanco?(5) & 1 \\
\hline & & ¿Son los menús consistentes pantalla a pantalla? (5) & 1 \\
\hline A & & ¿Existe información útil para distintos tipos de usuarios? (1) & 2 \\
\hline $\begin{array}{l}\text { MI } \\
\text { NI }\end{array}$ & $\begin{array}{l}\text { 2-Administración } \\
\text { del sistema }\end{array}$ & ¿Existe alguna garantía de autenticidad, como certificaciones, etc.? (2) & 2 \\
\hline $\begin{array}{l}\text { ST } \\
\text { RA } \\
\text { CI }\end{array}$ & $\begin{array}{l}\text { 3-Normas de uso } \\
\text { 4-Política de }\end{array}$ & $\begin{array}{l}\text { ¿El acceso general no está limitado a una determinada categoría de usuarios (por } \\
\text { ejemplo: solo para los asociados)? (3) }\end{array}$ & 1 \\
\hline $\mathbf{N}$ & & ¿Aparecen en destaque las informaciones recientes o las novedades? (4) & 2 \\
\hline
\end{tabular}




\section{APÊNDICE G}

Tareas sugeridas a los usuarios de los Archivos evaluados

NOMBRE:

EDAD:

FORMACIÓN ACADEMICA:

() SUPERIOR INCOMPLETO () SUPERIOR COMPLETO

() MESTRADO/DOCTORADO () PÓS-DOCTORADO

¿EXPERIÊNCIA EN PESQUISAR POR INTERNET? ( )SIM ( )NÃO

ORDENADOR UTILIZADO PARA REALIZAR LAS TAREAS (CONFIGURACIÓN):

\section{OBSERVACIÓN:}

PARA ESPECIFICAR EL ORDENADOR UTILIZADO INFORMAR: EL SISTEMA OPERACIONAL, PROCESADOR, MEMÓRIA Y TIPO DE CONEXIÓN A INTERNET.

EJ: WINDOWS XP, PROCESADOR DUAL CORE, 1GB DE MEMÓRIA, CONEXIÓN BANDA ANCHA.

Criterio: Búsqueda e Recuperación.

Categorías:

1- Motores de busca (Visibilidad).

Sugerir que o usuario realice una búsqueda en dos motores de búsqueda (ej .g: Google, Yahoo, Ask, etc) e anote la posición en que el Archivo aparece en los resultados de acuerdo con cada motor de búsqueda utilizado.

2 - Visualización de los resultados:

Tarea 1: El usuario deberá identificar en la portada de cada página web de los Archivos estudiados, se existe una opción de búsqueda aun que sencilla (ej: caja de texto seguido de botón "procurar" o ícono ("lupa") que represente la posibilidad de realizar una investigación.

Tarea 2: Hacer uso de los mecanismos de búsqueda, caso existan, realizando una búsqueda simple y otra avanzada evaluando: a) se los resultados fueron satisfactorios, b) la precisión de los resultados obtenidos (se son compatibles con el objeto de la búsqueda).

Apoyo: El usuario deberá examinar antes de esta tarea los fondos documentales del Archivo e elegir un tema de su interés debiendo apuntar el mismo para posterior conferencia. 


\section{Criterio: Autoridad}

Categorías:

1-2: Identificación y Reputación/controle de calidad:

Tarea: El usuario deberá observar se cada página Web dos Archivos evaluados contiene informaciones al respecto de la institución que abriga o crea la página del Archivo.

\section{Criterio: Contenido}

Categorías:

1-Originalidade:

Tarea: El usuario deberá observar se existen otras sedes con contenido similar al de la página Web de los Archivos estudiados.

2- Redacción y organización:

Tarea: El usuario deberá observar se la sede utiliza un lenguaje claro y simple para el contenido de la sede. Expresar su opinión apuntando si la sede es simple o complejo (difícil).

\section{Criterio: Administración}

Categorías:

1-Normas de uso:

Tarea: El usuario deberá verificar se existen áreas de acceso restricto en las páginas Web de cada Archivo estudiado (algún dato que el mismo no pueda acceder por ser exclusivo para asociados por ejemplo)

2- Política de Actualización:

Tarea: ¿El usuario encuentra fácilmente las novedades de cada página Web de los Archivos estudiados? Apuntar si o no. 


\section{Criterio: Diseño}

Categorías:

1-Navegación:

Tarea: El usuario deberá observar se ele navega intuitivamente o sea, sin necesidad de formación previa ni esfuerzo por parte del mismo.

2-Accesibilidad

Tarea: Verificar se ocurre error al cargar las páginas Web de cada Archivo o confusión visual en la disposición de las informaciones. (Ej. las letras aparecen sobre imágenes o vice-versa). 


\section{APÊNDICE H}

\section{MODELO DE QUESTIONÁRIO PARA AVALIAÇÃO \\ DE SITES DE ARQUIVOS: \\ Esclarecimento sobre as tarefas dos avaliadores}

O objetivo geral destas tarefas é verificar os critérios de Visibilidade e Usabilidade de cada um dos sites que compõem o corpus da pesquisa. Os resultados de ambas as tarefas, no entanto, serão analisados separadamente tendo em vista que a pontuação de cada uma delas é inversamente variável.

\section{Avaliação a respeito da Visibilidade}

- Descrição da avaliação da Visibilidade: Questões objetivas para verificar a visibilidade dos sites dos Arquivos estudados nesta pesquisa, consideradas relevantes por alguns autores e utilizadas no método de avaliação de Piano e Jiménez (2007). Para pontuar essas questões, utiliza-se a pontuação de 0 a 2 , considerando-se que 0 : não atende às expectativas, 1 : atende parcialmente às expectativas; 2: atende às expectativas.

As Questões a respeito da Visibilidade de um site estão dispostas no quadro a seguir:

\begin{tabular}{|c|c|c|}
\hline Categorias & Questões & Pontuação \\
\hline Metadados & Apresenta metadados padronizados? & \\
\hline Identificação e reputação & $\begin{array}{l}\text { Traz informações sobre a instituição que } \\
\text { hospeda ou cria a página Web do Arquivo? }\end{array}$ & \\
\hline Administração do Sistema & $\begin{array}{l}\text { Existe alguma garantia de autenticidade, } \\
\text { como certificações, etc.? }\end{array}$ & \\
\hline Motores de busca & $\begin{array}{l}\text { A página Web do Arquivo está em posição } \\
\text { natural nos motores de buscas do Google? }\end{array}$ & \\
\hline
\end{tabular}




\section{Avaliação Heurística de Usabilidade}

- Descrição da avaliação Heurística: A Avaliação heurística, definida por Nielsen, é um método de avaliação de usabilidade na qual, um avaliador, durante a interação com um sistema, detecta problemas de usabilidade tendo como base um conjunto de princípios ou "heurísticas". O método baseia-se no julgamento de cada avaliador.

- Instrução para a avaliação: Neste estudo utilizamos heurísticas adaptadas à avaliação de usabilidade de sites de Arquivos (abaixo apresentadas) com questões diretas onde o avaliador atribuirá uma classificação a cada uma delas, de acordo com o grau de severidade do problema encontrado no site utilizando uma escala de 0 a 4 :

Nível 0: indica o grau de severidade mais baixo, ao qual se atribui pouca importância, por não afetar a operação da interface.

Nível 1: indica os problemas de usabilidade para os quais não há necessidade imediata de solução, são os chamados "problemas cosméticos".

Nível 2: indica problemas menores simples, de baixa prioridade, de fácil reparação.

Nível 3: envolve problemas graves, de alta prioridade, que devem ser reparados.

Nível 4 é denominado catastrófico, por indicar problemas muito graves de usabilidade,que devem ser reparados imediatamente. 


\section{QUESTIONÁRIO}

1. Heurística 1: Linguagem natural: observar se o site utiliza uma linguagem familiar ao usuário e desprovida de termos técnicos da área de arquivos e documentação e as informações se apresentam de forma lógica e natural. (Correlação com a $2^{\mathrm{a}}$ Heurística de Nielsen)

Quadro 1 - Questionário da heurística: Linguagem natural

\begin{tabular}{|c|c|c|c|}
\hline Item & Questão ou indicador & $\begin{array}{l}\text { Grau de } \\
\text { Severidade }\end{array}$ & Comentários \\
\hline 1.1 & $\begin{array}{l}\text { Os ícones são familiares e } \\
\text { correspondem à realidade (são } \\
\text { reais)? }\end{array}$ & & \\
\hline 1.2 & $\begin{array}{c}\text { As escolhas de menu existentes, } \\
\text { estão ordenadas de maneira lógica e } \\
\text { com sequiência natural (apresenta os } \\
\text { nomes dos itens e as possíveis } \\
\text { variáveis das tarefas)? }\end{array}$ & & \\
\hline 1.3 & $\begin{array}{c}\text { A linguagem usada é familiar, clara } \\
\text { e simples a cada tela? }\end{array}$ & & \\
\hline 1.4 & $\begin{array}{c}\text { Utiliza linguajar ou jargão próprio } \\
\text { da área e, caso utilize, explica o } \\
\text { significado desses termos para os } \\
\text { leigos? }\end{array}$ & & \\
\hline
\end{tabular}

2. Heurística 2: Liberdade de circulação e controle de ações: observar se o site oferece liberdade de uso com mecanismos compreensíveis e facilmente localizáveis de navegação. (Correlação com a $3^{\text {a }}$ Heurística de Nielsen) 
Quadro 2 - Questionário da heurística: Liberdade de circulação e controle de ações

\begin{tabular}{|c|c|c|c|}
\hline Item & Questão ou indicador & $\begin{array}{l}\text { Grau de } \\
\text { severidade }\end{array}$ & Comentários \\
\hline 2.1 & $\begin{array}{l}\text { O sistema apresenta janelas } \\
\text { sobrepostas e é fácil para os usuários } \\
\text { reorganizarem as janelas na tela e } \\
\text { navegarem entre elas? }\end{array}$ & & \\
\hline 2.2 & $\begin{array}{l}\text { Se o sistema tiver múltiplos níveis de } \\
\text { menu, o mesmo permite que os } \\
\text { usuários voltem aos menus anteriores e } \\
\text { alterem a escolha anterior? }\end{array}$ & & \\
\hline
\end{tabular}

3. Heurística 3: Consistência nas convenções adotadas: observar se o site fornece consistência, ou seja, se ele cumpre com as definições convencionadas previamente, ou seja, verificar a uniformidade do site. (Correlação com a 4ª Heurística de Nielsen)

Quadro 3 - Questionário da heurística: Consistência nas convenções adotadas

\begin{tabular}{|c|c|c|c|}
\hline Item & Questão ou indicador & $\begin{array}{l}\text { Grau de } \\
\text { Severidade }\end{array}$ & Comentários \\
\hline 3.1 & $\begin{array}{l}\text { O sistema segue padrões de } \\
\text { formatação consistentes no design } \\
\text { de menus, } \\
\text { teclas e funções em todas as } \\
\text { páginas do site? }\end{array}$ & & \\
\hline 3.2 & $\begin{array}{l}\text { O uso freqüente de todas as letras } \\
\text { maiúsculas em uma tela é inibido? }\end{array}$ & & \\
\hline 3.3 & $\begin{array}{l}\text { A lista de menus está presente } \\
\text { verticalmente com seus títulos } \\
\text { centralizados e justificados do lado } \\
\text { esquerdo? }\end{array}$ & & \\
\hline 3.4 & $\begin{array}{l}\text { As instruções on-line aparecem } \\
\text { num local consistente nas telas? }\end{array}$ & & \\
\hline
\end{tabular}


4. Heurística 4: Disponibilização, clareza e precisão dos links: observar principalmente se o link indica claramente o que o usuário encontrará ao clicar sobre o mesmo. (Correlação com a $7^{\mathrm{a}}$ Heurística de Nielsen)

Quadro 4 - Questionário da heurística: Disponibilização, clareza e precisão dos links

\begin{tabular}{|l|l|l|l|}
\hline Item & \multicolumn{1}{|c|}{ Questão ou indicador } & $\begin{array}{l}\text { Grau de } \\
\text { severidade }\end{array}$ & Comentários \\
\hline 4.1 & $\begin{array}{l}\text { A disposição dos dados começa no canto } \\
\text { superior esquerdo da tela? }\end{array}$ & & \\
\hline 4.2 & $\begin{array}{l}\text { Os itens selecionados aparecem destacados } \\
\text { em outra cor ou sombreados? }\end{array}$ & $\begin{array}{l}\text { Há uma distinção clara entre o item que } \\
\text { está em uso dos outros do menu disponível? }\end{array}$ & \\
\hline 4.3 & $\begin{array}{l}\text { Ao clicar em um item, o que aparece em } \\
\text { seguida corresponde exatamente ao que foi } \\
\text { proposto, ou seja, o usuário é levado ao } \\
\text { lugar que o link sugere? }\end{array}$ & & \\
\hline
\end{tabular}

5. Heurística 5: Natureza estética e Simplicidade da interface: os comandos do site devem estar visíveis, facilitando a identificação e redução dos riscos do usuário se perder no processo de suas pesquisas. Recorrendo ao princípio "menos é mais", o site deve apresentar apenas informações relevantes para o momento exato da pesquisa, ou seja, oferecer ao usuário apenas informações que ele realmente necessite naquele exato momento. Evitando informações irrelevantes ou desnecessárias, a interface exigirá menos esforço por parte do usuário para "aprender" a utilizá-la. Ele deve reconhecer ao invés de memorizar as funções do site. (Correlação com a $6^{\mathrm{a}}$ e $8^{\mathrm{a}}$ Heurística de Nielsen)

Quadro 5 - Questionário da heurística: Natureza estética e Simplicidade da interface

\begin{tabular}{|l|l|l|l|}
\hline \multicolumn{1}{|c|}{ Item } & \multicolumn{1}{|c|}{ Questão ou indicador } & $\begin{array}{c}\text { Grau de } \\
\text { severidade }\end{array}$ & Comentários \\
\hline 5.1 & $\begin{array}{l}\text { Os recursos visuais e espaços em branco são } \\
\text { usados para distinguir perguntas, instruções, e } \\
\text { input de usuários. }\end{array}$ & & \\
\hline 5.2 & $\begin{array}{l}\text { Todos os dados que usuário precisa para } \\
\text { disponibilizar em cada etapa aparecem numa }\end{array}$ & & \\
\hline
\end{tabular}




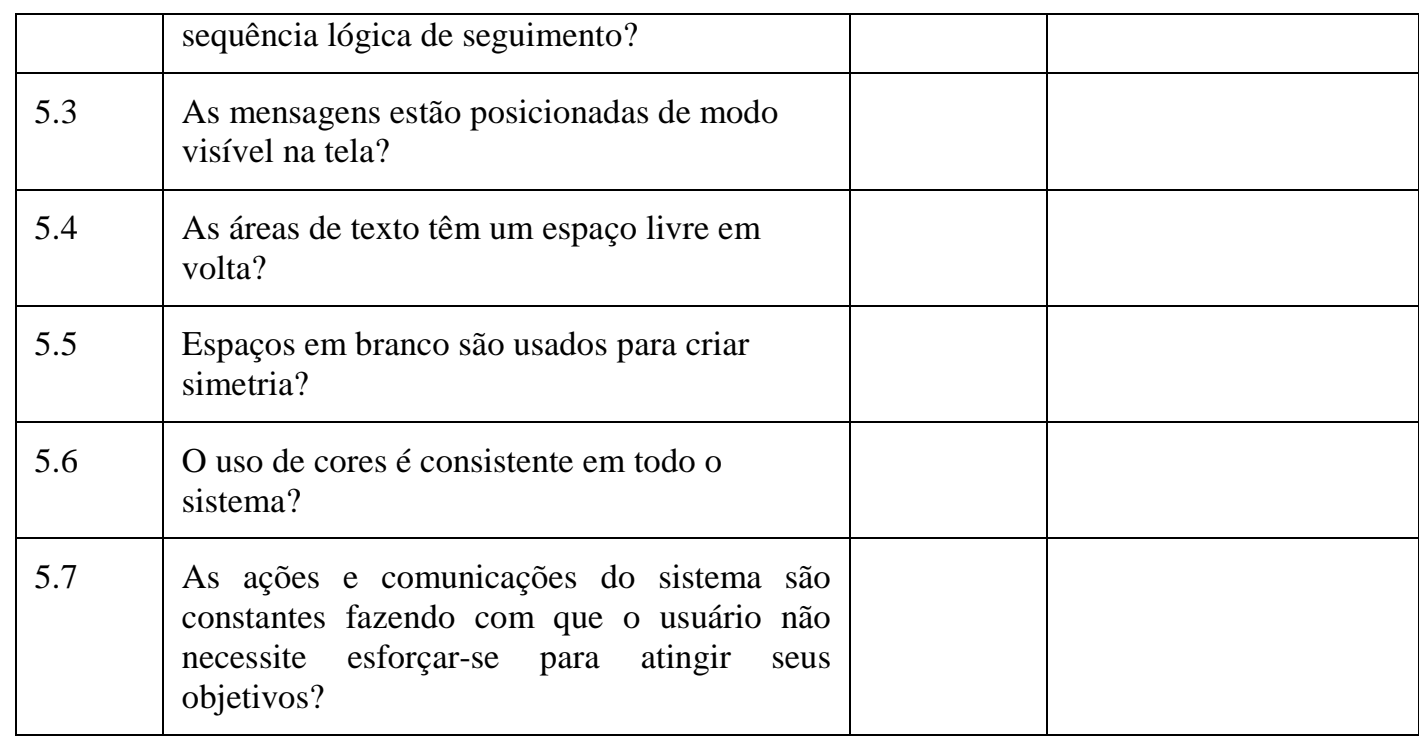

6. Heurística 6: Visibilidade: O site deve manter os usuários informados sobre o que eles estão fazendo, com feedback imediato e levar em conta um grupo especial de usuários como por exemplo:deficientes visuais, idosos, crianças, etc. e observar se existem opções para esse grupo (Correlação com a $1^{\text {a }}$ Heurística de Nielsen)

\section{Quadro 6 - Questionário da heurística: Visibilidade}

\begin{tabular}{|c|c|c|c|}
\hline Item & Questão ou indicador & $\begin{array}{l}\text { Grau de } \\
\text { Severidade }\end{array}$ & Comentários \\
\hline 6.1 & $\begin{array}{l}\text { A visualização de um único ícone selecionado } \\
\text { entre os outros não selecionados é clara? }\end{array}$ & & \\
\hline 6.2 & $\begin{array}{l}\text { O sistema dispõe de algum tipo de guia } \\
\text { navegacional ou mapa para identificar as várias } \\
\text { opções da página e indicar sua relação com as } \\
\text { outras? }\end{array}$ & & \\
\hline 6.3 & $\begin{array}{l}\text { Existe um sistema consistente de feedback para } \\
\text { cada ação realizada? }\end{array}$ & & \\
\hline 6.4 & $\begin{array}{l}\text { Todas as páginas contêm um título ou um } \\
\text { cabeçalho que descrevem o seu conteúdo? }\end{array}$ & & \\
\hline 6.5 & $\begin{array}{l}\text { Há um esquema consistente e estético no } \\
\text { design de ícones em todo o site? }\end{array}$ & & \\
\hline 6.6 & $\begin{array}{l}\text { Oferece funções opcionais para os deficientes } \\
\text { visuais "ouvirem" e a opção de aumento da } \\
\text { fonte para pessoas com dificuldade visual? }\end{array}$ & & \\
\hline
\end{tabular}


7. Heurística 7: Instruções e documentação: As instruções contidas no site devem ser fáceis de encontrar e estarem relacionadas às tarefas que o usuário executa, contendo os passos para a realização de um determinado objetivo, porém não devem ser demasiado extensas. (Correlação com a $10^{\mathrm{a}}$ Heurística de Nielsen)

Quadro 7 - Questionário da heurística: Instruções e documentação

\begin{tabular}{|c|c|c|c|}
\hline Item & Questão ou indicador & $\begin{array}{l}\text { Grau de } \\
\text { Severidade }\end{array}$ & Comentários \\
\hline 7.1 & $\begin{array}{l}\text { Existe a função "ajuda" e ela é facilmente } \\
\text { encontrada, em uma tecla etiquetada com } \\
\text { o nome AJUDA ou em um menu } \\
\text { especial? }\end{array}$ & & \\
\hline 7.2 & $\begin{array}{l}\text { A informação de ajuda é relevante e } \\
\text { objetiva, descrevendo fielmente o } \\
\text { mecanismo de navegação? }\end{array}$ & & \\
\hline 7.3 & $\begin{array}{l}\text { A navegação oferece respostas rápidas e } \\
\text { precisas ao usuário? }\end{array}$ & & \\
\hline
\end{tabular}




\section{APÊNDICE I}

\section{QUESTIONÁRIO PARA AVALIAÇÃO DE SITES DE ARQUIVOS - avaliação propriamente dita}

\section{AVALIADOR:}

\section{ARQUIVO:}

\section{DATA:}

\section{Avaliação a respeito da Visibilidade}

Utilizar a pontuação de 0 a 2, considerando-se que 0 : não atende às expectativas, 1 : atende parcialmente às expectativas; 2 : atende às expectativas.

\begin{tabular}{|l|l|l|}
\hline \multicolumn{1}{|c|}{ Questões } & Pontuação & Comentários \\
\hline 1. Apresenta metadados padronizados? & & \\
\hline $\begin{array}{l}\text { 2. Traz informações sobre a instituição } \\
\text { que hospeda ou cria a página Web do } \\
\text { Arquivo? }\end{array}$ & & \\
\hline $\begin{array}{l}\text { 3. Existe alguma garantia de } \\
\text { autenticidade, como certificações, etc.? }\end{array}$ & & \\
\hline $\begin{array}{l}\text { 4.A página Web do Arquivo está em } \\
\text { posição natural nos resultados das } \\
\text { buscas através dos motores Google e } \\
\text { Yahoo? }\end{array}$ & & \\
\hline
\end{tabular}

\section{Avaliação Heurística de Usabilidade}


Nível 0: indica o grau de severidade mais baixo, ao qual se atribui pouca importância, por não afetar a operação da interface.

Nível 1: indica os problemas de usabilidade para os quais não há necessidade imediata de solução, são os chamados "problemas cosméticos".

Nível 2: indica problemas menores simples, de baixa prioridade, de fácil reparação.

Nível 3: envolve problemas graves, de alta prioridade, que devem ser reparados.

Nível 4 é denominado catastrófico, por indicar problemas muito graves de usabilidade,que devem ser reparados imediatamente.

\begin{tabular}{|c|c|c|}
\hline Questões & $\begin{array}{l}\text { Grau de } \\
\text { Severidade }\end{array}$ & Comentários \\
\hline $\begin{array}{l}\text { 5. Os ícones são familiares e } \\
\text { correspondem à realidade (são reais)? }\end{array}$ & & \\
\hline $\begin{array}{l}\text { 6. As escolhas de menu existentes, estão } \\
\text { ordenadas de maneira lógica e com } \\
\text { seqüência natural (apresenta os nomes } \\
\text { dos itens e as possíveis variáveis das } \\
\text { tarefas)? }\end{array}$ & & \\
\hline $\begin{array}{l}\text { 7.A linguagem usada é familiar, clara e } \\
\text { simples a cada tela? }\end{array}$ & & \\
\hline $\begin{array}{l}\text { 8.Utiliza linguajar ou jargão próprio da } \\
\text { área e, caso utilize, explica o significado } \\
\text { desses termos para os leigos? }\end{array}$ & & \\
\hline $\begin{array}{l}\text { 9. O site apresenta janelas sobrepostas e } \\
\text { é fácil para os usuários reorganizarem as } \\
\text { janelas na tela e navegarem entre elas? }\end{array}$ & & \\
\hline $\begin{array}{l}\text { 10.Se o sistema tiver múltiplos níveis de } \\
\text { menu, o mesmo permite que os usuários } \\
\text { voltem aos menus anteriores e alterem a } \\
\text { escolha anterior? }\end{array}$ & & \\
\hline
\end{tabular}




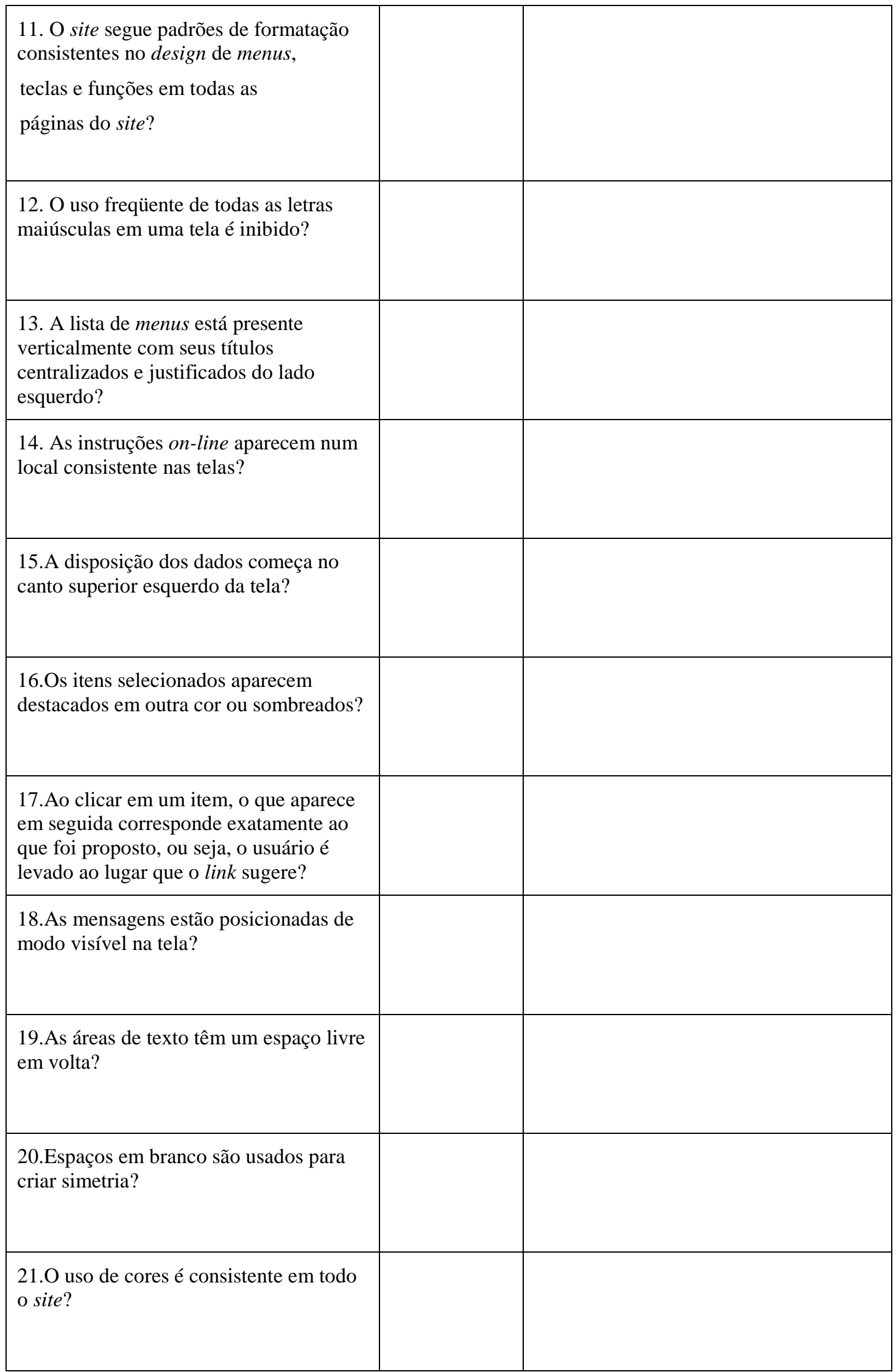




\begin{tabular}{|l|l|l|}
\hline $\begin{array}{l}\text { 22.As ações e comunicações do sistema } \\
\text { são constantes fazendo com que o } \\
\text { usuário não necessite esforçar-se para } \\
\text { atingir seus objetivos? }\end{array}$ & \\
\hline $\begin{array}{l}\text { 23.O site dispõe de algum tipo de guia } \\
\text { navegacional ou mapa para identificar as } \\
\text { várias } \\
\text { opções da página e indicar sua relação } \\
\text { com as outras? }\end{array}$ & & \\
\hline $\begin{array}{l}\text { 24.Existe um sistema consistente de } \\
\text { feedback para cada ação realizada? }\end{array}$ & \\
\hline $\begin{array}{l}\text { 25.Todas as páginas contêm um título ou } \\
\text { um cabeçalho que descrevem o seu } \\
\text { conteúdo? }\end{array}$ & \\
\hline $\begin{array}{l}\text { 26. Há um esquema consistente e } \\
\text { estético no design de ícones em todo o } \\
\text { site? }\end{array}$ & & \\
\hline $\begin{array}{l}\text { 27.Oferece funções opcionais para os } \\
\text { deficientes visuais "ouvirem" e a opção } \\
\text { de aumento da fonte para pessoas com } \\
\text { dificuldade visual? }\end{array}$ & \\
\hline $\begin{array}{l}\text { 28. Existe a função “ajuda" e ela é } \\
\text { facilmente encontrada, em uma tecla } \\
\text { etiquetada com o nome AJUDA ou em } \\
\text { um menu especial? Caso exista, ela é } \\
\text { relevante e objetiva? }\end{array}$ & \\
\hline $\begin{array}{l}\text { 29.A navegação oferece respostas } \\
\text { rápidas e precisas ao usuário? }\end{array}$ & \\
\hline
\end{tabular}

Assinatura do Avaliador: 


\section{APÊNDICE J}

\section{TESTE DE USUÁRIOS DE ARQUIVOS ESPANHÓIS - AVALIAÇÃO PROPRIAMENTE DITA}

O teste se dará em um tempo máximo de 2 horas, durante o qual o participante poderá pedir auxílio e esclarecer dúvidas a qualquer momento com o mediador (a autora) durante todo o procedimento.

ARQUIVO AVALIADO:

Data:

1

Hora de início:

\section{TAREFAS}

1. Buscar a URL do Arquivo, utilizando o Google e o Yahoo e anotar a posição em que ela aparece nos resultados. Anotar o resultado:

Google:

Yahoo:

2.Entrar na URL do site e observar se a página demora a carregar. Comentar qual a primeira impressão que tem da homepage do site.

3. Observar se existe na página Web uma lupa ou um ícone que represente a possibilidade de fazer pesquisas dentro dela. Marcar uma resposta abaixo e comentar o grau de dificuldade.

( ) Encontrei a lupa (ou ícone)

( ) Não encontrei a lupa (ou ícone) 
4. Navegar livremente pelo site e comentar se os links clicados correspondem ao que se imaginava (se há coerência entre o link e o que aparece ao ser clicado). O usuário deverá observar se ele navega intuitivamente, ou seja, sem necessitar de treinamento anterior nem exigir esforço de sua parte. Comentar e descrever seus passos.

5. Navegar livremente pelo site e comentar se os links clicados correspondem ao que se imaginava (se há coerência entre o link e o que aparece ao ser clicado). O usuário deverá observar se ele navega intuitivamente, ou seja, sem necessitar de treinamento anterior nem exigir esforço de sua parte. Comentar e descrever seus passos.

6. Observar se o conteúdo do site utiliza uma linguagem clara e simples. Opinar objetivamente classificando-a como simples ou complexa. Justificar resposta.

7. Descrever, em termos gerais, a sensação que se teve ao navegar no site, ou seja, as impressões pessoais a respeito da estética e do conteúdo do site. 
HORA DO TÉRMINO:

Assinatura do participante 


\section{APÊNDICE L}

Quadro dos Arquivos selecionados para a avaliação propriamente dita

\begin{tabular}{|c|c|c|}
\hline ARQUIVO & $\begin{array}{l}\text { TIPOLO } \\
\text { GIA }\end{array}$ & URL \\
\hline $\begin{array}{c}\text { Archivo Histórico } \\
\text { Nacional }\end{array}$ & $\begin{array}{c}\text { Estatal } \\
\text { histórico }\end{array}$ & http://www.mcu.es/archivos/MC/AHN/index.html \\
\hline $\begin{array}{l}\text { Archivo de la } \\
\text { Diputación de } \\
\text { Sevilla }\end{array}$ & $\begin{array}{l}\text { Diputaciones } \\
\text { Provinciales }\end{array}$ & $\frac{\frac{\text { http://www.dipusevilla.es/dipusevilla/opencms/site/web/are }}{\text { as/cultura/menu sec/archivo y publicaciones/temas/archiv }}}{\text { o de la diputacion }}$ \\
\hline $\begin{array}{l}\text { Archivo Vasco de } \\
\text { La Música Eresbil }\end{array}$ & $\begin{array}{l}\text { Archivos } \\
\text { Musicales }\end{array}$ & http://www.eresbil.com/ \\
\hline $\begin{array}{l}\text { Histórico } \\
\text { Provincial de } \\
\text { Huesca }\end{array}$ & $\begin{array}{l}\text { Administración } \\
\text { Autonómica- } \\
\text { Provinciales }\end{array}$ & $\frac{\text { http://portal.aragon.es/portal/page/portal/ARCHIVO/AHP H }}{\underline{\text { UESCA }}}$ \\
\hline $\begin{array}{l}\text { Archivo Histórico } \\
\text { Eclesiástico de } \\
\text { Bizcaya }\end{array}$ & Religioso & http://www.aheb-beha.org/ \\
\hline $\begin{array}{c}\text { Archivo Histórico } \\
\text { de Asturias }\end{array}$ & $\begin{array}{l}\text { Administración } \\
\text { Autonómica } \\
\text { Generales }\end{array}$ & http://www.archivosdeasturias.info/ \\
\hline $\begin{array}{l}\text { Archivo General } \\
\text { Militar de Ávila }\end{array}$ & $\begin{array}{l}\text { Estatales } \\
\text { Militares }\end{array}$ & $\frac{\text { http://www.ejercito.mde.es/Unidades/unidades/Madrid/ihyc }}{\underline{\text { m/Archivos/agm-avila-index.html }}}$ \\
\hline $\begin{array}{l}\text { Archivo de La } \\
\text { Universidad de } \\
\text { Salamanca }\end{array}$ & universitarios & http://sabus.usal.es/archivos.htm \\
\hline $\begin{array}{l}\text { Archivo General } \\
\text { de Simancas }\end{array}$ & $\begin{array}{l}\text { Estatales } \\
\text { Generales }\end{array}$ & http://www.mcu.es/archivos/MC/AGS/index.html \\
\hline $\begin{array}{l}\text { Arquivo } \\
\text { Municipal de } \\
\text { Santander }\end{array}$ & $\begin{array}{l}\text { Administración } \\
\quad \text { Local- } \\
\text { Ayuntamientos }\end{array}$ & $\frac{\text { http://portal.aytosantander.es/portal/page/portal/inet sant }}{\text { ander/ficha/ficha ayto?itemld }=2079049}$ \\
\hline $\begin{array}{c}\text { Arquivo da } \\
\text { Emigração Galega }\end{array}$ & Emigração & http://www.consellodacultura.org/arquivos/aeg/ \\
\hline $\begin{array}{l}\text { Archivo Histórico } \\
\text { de protocolos de } \\
\text { Gipuskoa }\end{array}$ & protocolos & http://www.gipuzkoakultura.net/oinati/ \\
\hline $\begin{array}{l}\text { Archivo de } \\
\text { Hullera Vasco- } \\
\text { Leonesa }\end{array}$ & Fundaciones & http://www.fhvl.es/fhvl/content.asp?Contentld=610 \\
\hline
\end{tabular}




\begin{tabular}{|c|c|c|}
$\begin{array}{c}\text { Archivo Histórico } \\
\text { Provincial de } \\
\text { Granada }\end{array}$ & $\begin{array}{c}\text { Administración } \\
\text { autonômica- } \\
\text { Provinciales }\end{array}$ & $\begin{array}{c}\text { http://www.juntadeandalucia.es/cultura/archivos/web es/c } \\
\text { ontenido?id=0754eda0-58a4-11dd-b44b- } \\
\frac{31450 f 5 b 9 d d 5 \& i d A r c h i v o=0754 e d a 0-58 a 4-11 d d-b 44 b-}{31450 f 5 b 9 d d 5 \& \text { idContArch=02cd09d5-57e2-11dd-ba1f- }} \\
\frac{31450 f 5 b 9 d d 5 \& i d T i p o=02 c d 09 d 5-57 e 2-11 d d-b a 1 f-}{\underline{31450 f 5 b 9 d d 5}}\end{array}$ \\
\hline
\end{tabular}


ANEXOS 
ANEXO 1

LEI 11.161/2005

BASE DA LEGISLAÇÃO FEDERAL DO BRASIL

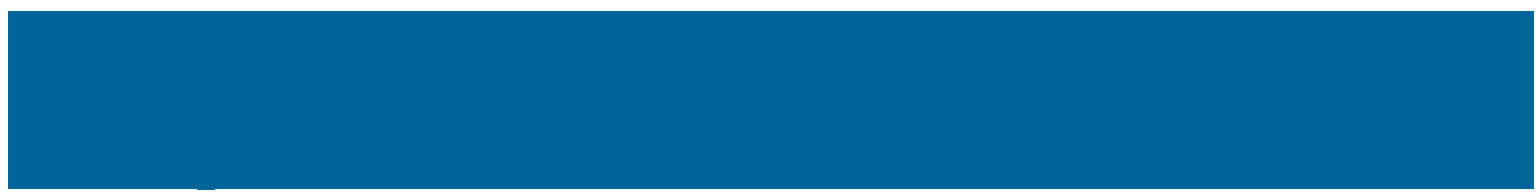

Situação: NÃO CONSTA REVOGAÇÃO EXPRESSA

Chefe de LUIZ INÁCIO LULA DA SILVA

Governo:

Origem: LEGISLATIVO

Fonte: D.O.U. DE 08/08/2005, P. 1

Link: Texto Integral

Ementa: DISPÕE SOBRE O ENSINO DA LÍNGUA ESPANHOLA.

Referenda: MINISTÉRIO DA EDUCAÇÃO - MEC

Alteração:

Correlação:

Interpretação: 
Assunto: OBRIGATORIEDADE, INCLUSÃO, DISCIPLINA, LINGUA ESPANHOLA, ESTABELECIMENTO DE ENSINO, ENSINO MEDIO

\section{Presidência da República}

Casa Civil

Subchefia para Assuntos Jurídicos

\section{LEI № 11.161, DE 5 DE AGOSTO DE 2005.}

Dispõe sobre o ensino da língua espanhola.

O PRESIDENTE DA REPÚBLICA Faço saber que o Congresso Nacional decreta e eu sanciono a seguinte Lei:

Art. $1^{\circ} \mathrm{O}$ ensino da língua espanhola, de oferta obrigatória pela escola e de matrícula facultativa para o aluno, será implantado, gradativamente, nos currículos plenos do ensino médio.

$\S 1^{\circ} \mathrm{O}$ processo de implantação deverá estar concluído no prazo de cinco anos, a partir da implantação desta Lei.

$\S 2^{2}$ É facultada a inclusão da língua espanhola nos currículos plenos do ensino fundamental de $5^{\mathrm{a}}$ a $8^{\mathrm{a}}$ séries.

Art. $2^{\circ} \mathrm{A}$ oferta da língua espanhola pelas redes públicas de ensino deverá ser feita no horário regular de aula dos alunos.

Art. $3^{\circ}$ Os sistemas públicos de ensino implantarão Centros de Ensino de Língua Estrangeira, cuja programação incluirá, necessariamente, a oferta de língua espanhola.

Art. 4ํํำ $\mathrm{A}$ rede privada poderá tornar disponível esta oferta por meio de diferentes estratégias que incluam desde aulas convencionais no horário normal dos alunos até a matrícula em cursos e Centro de Estudos de Língua Moderna.

Art. $5^{\circ}$ Os Conselhos Estaduais de Educação e do Distrito Federal emitirão as normas necessárias à execução desta Lei, de acordo com as condições e peculiaridades de cada unidade federada.

Art. 6ํํ A União, no âmbito da política nacional de educação, estimulará e apoiará os sistemas estaduais e do Distrito Federal na execução desta Lei.

Art. $7^{\circ}$ Esta Lei entra em vigor na data da sua publicação.

Brasília, 5 de agosto de $2005 ; 184^{\circ}$ da Independência e $117^{\circ}$ da República.

LUIZ INÁCIO LULA DA SILVA

Fernando Haddad

*Este texto não substitui o publicado no D.O.U. de 8.8.2005. 


\section{ANEXO 2}

\section{Constituição Espanhola de 1978, modificada pela Reforma de 27 de agosto de 1992 - Título VIII}

\section{De la Organización Territorial del Estado}

\section{CAPÍTULO TERCERO \\ De las Comunidades Autónomas}

\section{Artículo 143.}

1. En el ejercicio del derecho a la autonomía reconocido en el artículo 2 de la Constitución, las provincias limítrofes con características históricas culturales y económicas comunes, los territorios insulares y las provincias con entidad regional histórica podrán acceder a su autogobierno y constituirse en Comunidades Autónomas con arreglo a lo previsto en este Titulo y en los respectivos Estatutos .

2. La iniciativa del proceso autonómico corresponde a todas las Diputaciones interesadas o al órgano interinsular correspondiente y a las dos terceras partes de los municipios cuya población represente, al menos, la mayoría del censo electoral de cada provincia o isla. Estos requisitos deberán ser cumplidos en el plazo de seis meses desde el primer acuerdo adoptado al respecto por alguna de las Corporaciones locales interesadas.

3. La iniciativa, en caso de no prosperar, solamente podrá reiterarse pasados cinco años.

\section{Artículo 144.}

Las Cortes Generales, mediante ley orgánica, podrán, por motivos de interés nacional:

a) Autorizar la constitución de una comunidad autónoma cuando su ámbito territorial no supere el de una provincia y no reúna las condiciones del apartado 1 del artículo 143.

b) Autorizar o acordar. en su caso, un Estatuto de autonomía para territorios que no estén integrados en la organización provincial.

c) Sustituir la iniciativa de las Corporaciones locales a que se refiere al apartado 2 del artículo 143.

\section{Artículo 145.}

1. En ningún caso se admitirá la federación de Comunidades Autónomas.

2. Los Estatutos podrán prever los supuestos, requisitos y términos en que las Comunidades Autónomas podrán celebrar convenios entre sí para la gestión y prestación de servicios propios de las mismas, así como el carácter y efectos de la correspondiente comunicación a las Cortes Generales. En los demás supuestos, los acuerdos de cooperación entre las Comunidades Autónomas necesitarán la autorización de las Cortes Generales.

\section{Artículo 146.}

El proyecto de Estatuto será elaborado por una asamblea compuesta por los miembros de la Diputación u órgano interinsular de las provincias afectadas y por los Diputados y Senadores elegidos en ellas y será elevado a las Cortes Generales para su tramitación como ley. 


\section{Artículo 147.}

1. Dentro de los términos de la presente Constitución, los Estatutos serán la norma institucional básica de cada Comunidad Autónoma y el Estado los reconocerá y amparara como parte integrante de su ordenamiento jurídico.

2. Los Estatutos de autonomía deberán contener:

a) La denominación de la Comunidad que mejor corresponda a su identidad histórica.

b) La delimitación de su territorio.

c) La denominación, organización y sede de las instituciones autónomas propias.

d) Las competencias asumidas dentro del marco establecido en la Constitución y las bases para el traspaso de los servicios correspondientes a las mismas.

3. La reforma de los Estatutos se ajustará al procedimiento establecido en los mismos y requerirá, en todo caso, la aprobación por las Cortes Generales, mediante ley orgánica.

\section{Artículo 148.}

1. Las Comunidades Autónomas podrán asumir competencias en las siguientes materias:

1a) Organización de sus instituciones de autogobierno.

$2^{2}$ ) Las alteraciones de los términos municipales comprendidos en su territorio y, en general, las funciones que correspondan a la Administración del Estado sobre las Corporaciones locales y cuya transferencia autorice la legislación sobre Régimen Local.

$3^{\text {a })}$ Ordenación del territorio, urbanismo y vivienda.

4ª) Las obras públicas de interés de la Comunidad Autónoma en su propio territorio.

$5^{a}$ ) Los ferrocarriles y carreteras cuyo itinerario se desarrolle íntegramente en el territorio de la Comunidad Autónoma y en los mismos términos, el transporte desarrollado por estos medios o por cable.

$6^{\text {a }) ~ L o s ~ p u e r t o s ~ d e ~ r e f u g i o, ~ l o s ~ p u e r t o s ~ y ~ a e r o p u e r t o s ~ d e p o r t i v o s ~ y, ~ e n ~ g e n e r a l, ~ l o s ~ q u e ~ n o ~}$ desarrollen actividades comerciales.

$7^{a}$ ) La agricultura y ganadería, de acuerdo con la ordenación general de la economía.

$8^{\text {a) }) ~ L o s ~ m o n t e s ~ y ~ a p r o v e c h a m i e n t o s ~ f o r e s t a l e s . ~}$

$9^{2}$ ) La gestión en materia de protección del medio ambiente.

$10^{a}$ ) Los proyectos, construcción y explotación de los aprovechamientos hidráulicos, canales y regadíos de interés de la Comunidad Autónoma: las aguas minerales y termales.

$11^{\text {a) }}$ La pesca en aguas interiores, el marisqueo y la acuicultura, la caza y la pesca fluvial.

$\left.12^{\mathrm{a}}\right)$ Ferias interiores.

13ª $)$ El fomento del desarrollo económico de la Comunidad Autónoma dentro de los objetivos marcados por la política económica nacional .

14a) La artesanía.

15aㅡ) Museos, bibliotecas y conservatorios de música de interés para la Comunidad Autónoma.

16aㅗ) Patrimonio monumental de interés de la Comunidad Autónoma.

17ª) El fomento de la cultura, de la investigación y, en su caso, de la enseñanza de la lengua de la Comunidad Autónoma.

18a) Promoción y ordenación del turismo en su ámbito territorial.

19ª) Promoción del deporte y de la adecuada utilización del ocio.

$\left.20^{\mathrm{a}}\right)$ Asistencia social.

$21^{\text {a })}$ Sanidad e higiene.

22â) La vigilancia y protección de sus edificios e instalaciones. La coordinación y demás facultades en relación con las policías locales en los términos que establezca una ley orgánica. 
2. Transcurridos cinco años, y mediante la reforma de sus Estatutos, las Comunidades Autónomas podrán ampliar sucesivamente sus competencias dentro del marco establecido en el artículo 149.

Artículo 149.

1. El Estado tiene competencia exclusiva sobre las siguientes materias:

$1^{\text {a) }}$ La regulación de las condiciones básicas que garanticen la igualdad de todos los españoles en el ejercicio de los derechos y en el cumplimiento de los deberes constitucionales.

$2^{\text {a) }}$ Nacionalidad, inmigración, emigración, extranjería y derecho de asilo.

$3^{a}$ ) Relaciones internacionales.

$4^{a}$ ) Defensa y Fuerzas Armadas.

5a) Administración de Justicia.

6ª ) Legislación mercantil, penal y penitenciaria: legislación procesal, sin perjuicio de las necesarias especialidades que en este orden se deriven de las particularidades del derecho sustantivo de las Comunidades Autónomas.

$7^{\text {a }}$ ) Legislación laboral; sin perjuicio de su ejecución por los órganos de las Comunidades Autónomas.

$8^{a}$ ) Legislación civil, sin perjuicio de la conservación, modificación y desarrollo por las Comunidades autónomas de los derechos civiles, forales o especiales, allí donde existan. En todo caso, las reglas relativas a la aplicación y eficacia de las normas jurídicas, relaciones jurídico civiles relativas a las formas de matrimonio ordenación de los registros e instrumentos públicos, bases de las obligaciones contractuales, normas para resolver los conflictos de leyes y determinación de las fuentes del Derecho, con respeto, en este último caso, a las normas de derecho foral o especial.

$9^{a}$ ) Legislación sobre propiedad intelectual e industrial.

10ㄹ) Régimen aduanero y arancelario, comercio exterior.

11a) Sistema monetario: divisas, cambio y convertibilidad; bases de la ordenación del crédito, banca y seguros.

12ª) Legislación sobre pesas y medidas, determinación de la hora oficial.

13ª) Bases y coordinación de la planificación general de la actividad económica.

14ª) Hacienda general y Deuda del Estado.

$15^{\text {a) }}$ Fomento y coordinación general de la investigación científica y técnica.

$16^{a}$ ) Sanidad exterior. Bases y coordinación general de la sanidad. Legislación sobre productos farmacéuticos.

17ª) Legislación básica y régimen económico de la Seguridad Social, sin perjuicio de la ejecución de sus servicios por las Comunidades Autónomas.

18a ) Las bases del régimen jurídico de las Administraciones públicas y del régimen estatutario de sus funcionarios que, en todo caso, garantizarán a los administrados un tratamiento común ante ellas; el procedimiento administrativo común, sin perjuicio de las especialidades derivadas de la organización propia de las Comunidades Autónomas; legislación sobre expropiación forzosa; legislación básica sobre contratos y concesiones administrativas y el sistemas de responsabilidad de todas las Administraciones públicas.

19a) Pesca marítima, sin perjuicio de las competencias que en la ordenación del sector se atribuyan a las Comunidades Autónomas.

$20^{2}$ ) Marina Mercante y abanderamiento de buques: iluminación de costas y señales marítimas: puertos de interés general; aeropuertos de interés general: control del espacio aéreo, tránsito y transporte aéreo, servicio meteorológico y matriculación de aeronaves.

$21^{\text {a) }}$ Ferrocarriles y transportes terrestres que transcurran por el territorio de más de una Comunidad Autónoma; régimen general de comunicaciones: tráfico y circulación de vehículos a motor: correos y telecomunicaciones: cables aéreos, submarinos y radiocomunicación .

22ª) La legislación, ordenación y concesión de recursos y aprovechamientos hidráulicos cuando las aguas discurran por más de una Comunidad autónoma. y la autorización de las instalaciones 
eléctricas cuando su aprovechamiento afecte a otra Comunidad o el transporte de energía salga de su ámbito territorial.

23aㅡ) Legislación básica sobre protección del medio ambiente, sin perjuicio de las facultades de las Comunidades Autónomas de establecer normas adicionales de protección. La legislación básica sobre montes, aprovechamientos forestales y vías pecuarias.

24ª) ) Obras públicas de interés general o cuya realización afecte a más de una Comunidad Autónoma.

$25^{\text {a) }}$ Bases del régimen minero y energético.

26a) Régimen de producción, comercio, tenencia y uso de armas y explosivos.

27aㅗ) Normas básicas del régimen de prensa, radio y televisión y, en general, de todos los medios de comunicación social, sin perjuicio de las facultades que en su desarrollo y ejecución correspondan a las Comunidades Autónomas.

28a ) Defensa del patrimonio cultural, artístico y monumental español contra la exportación y la expoliación museos, bibliotecas y archivos de titularidad estatal, sin perjuicio de su gestión por parte de las Comunidades Autónomas.

29ạ) Seguridad pública, sin perjuicio de la posibilidad de creación de policías por las Comunidades Autónomas en la forma que se establezca en los respectivos Estatutos en el marco de lo que disponga una ley orgánica.

30a) Regulación de las condiciones de obtención, expedición y homologación de títulos académicos y profesionales y normas básicas para el desarrollo del artículo 27 de la Constitución a fin de garantizar el cumplimiento de las obligaciones de los poderes públicos en esta materia.

$\left.31^{\underline{a}}\right)$ Estadística para fines estatales.

32aㅡ) Autorización para la convocatoria de consultas populares por vía de referéndum.

2. Sin perjuicio de las competencias que podrán asumir las Comunidades Autónomas. el Estado considerará el servicio de la cultura como deber y atención esencial y facilitará la comunicación cultural entre las Comunidades Autónomas, de acuerdo con ellas.

3. Las materias no atribuidas expresamente al Estado por esta Constitución podrán corresponder a las Comunidades Autónomas, en virtud de sus respectivos Estatutos. La competencia sobre las materias que no se hayan asumido por los Estatutos de Autonomía corresponderá al Estado, cuyas normas prevalecerán, en caso de conflicto, sobre las de las Comunidades Autónomas en todo lo que no esté atribuido a la exclusiva competencia de éstas. El derecho estatal será, en todo caso. supletorio del derecho de las Comunidades Autónomas. 


\section{ANEXO 3}

\section{Constituição Espanhola de 1978, modificada pela Reforma de 27 de agosto de 1992 - Título IV}

\section{Del Gobierno y de la Administración}

\section{Artículo 97.}

El Gobierno dirige la política interior y exterior, la Administración civil y militar y la defensa del Estado. Ejerce la función ejecutiva y la potestad reglamentaria de acuerdo con la Constitución y las leyes.

\section{Artículo 98.}

1. El Gobierno se compone del Presidente, de los Vicepresidentes en su caso, de los Ministros y de los demás miembros que establezca la ley.

2. El Presidente dirige la acción del Gobierno y coordina las funciones de los demás miembros del mismo, sin perjuicio de la competencia y responsabilidad directa de éstos en su gestión.

3. Los miembros del Gobierno no podrán ejercer otras funciones representativas que las propias del mandato parlamentario, ni cualquier otra función pública que no derive de su cargo, ni actividad profesional o mercantil alguna.

4. La ley regulará el Estatuto e incompatibilidades de los miembros del Gobierno.

\section{Artículo 99.}

1. Después de cada renovación del Congreso de los Diputados, y en los demás supuestos constitucionales en que así proceda, el Rey, previa consulta con los representantes designados por los Grupos políticos con representación parlamentaria, y a través del Presidente del Congreso, propondrá un candidato a la Presidencia del Gobierno.

2. El candidato propuesto conforme a lo previsto en el apartado anterior expondrá ante el Congreso de los Diputados el programa político del Gobierno que pretenda formar y solicitará la confianza de la Cámara.

3. Si el Congreso de los Diputados, por el voto de la mayoría absoluta de sus miembros, otorgare su confianza a dicho candidato, el Rey le nombrará Presidente. De no alcanzarse dicha mayoría, se someterá la misma propuesta a nueva votación cuarenta y ocho horas después de la anterior, y la confianza se entenderá otorgada si obtuviere la mayoría simple.

4. Si efectuadas las citadas votaciones no se otorgase la confianza para la investidura, se tramitaran sucesivas propuestas en la forma prevista en los apartados anteriores.

5. Si transcurrido el plazo de dos meses, a partir de la primera votación de investidura, ningún candidato hubiere obtenido la confianza del Congreso, el Rey disolverá ambas Cámaras y convocará nuevas elecciones con el refrendo del Presidente del Congreso.

\section{Artículo 100.}

Los demás miembros del Gobierno serán nombrados y separados por el Rey, a propuesta de su Presidente.

Artículo 101. 
1. El Gobierno cesa tras la celebración de elecciones generales, en los casos de pérdida de la confianza parlamentaria previstos en la Constitución, o por dimisión o fallecimiento de su Presidente.

2. El Gobierno cesante continuará en funciones hasta la toma de posesión del nuevo Gobierno.

\section{Artículo 102.}

1. La responsabilidad criminal del Presidente y los demás miembros del Gobierno será exigible, en su caso, ante la Sala de lo Penal del Tribunal Supremo.

2. Si la acusación fuere por traición o por cualquier delito contra la seguridad del Estado en el ejercicio de sus funciones, sólo podrá ser planteada por iniciativa de la cuarta parte de los miembros del Congreso, y con la aprobación de la mayoría absoluta del mismo.

3. La prerrogativa real de gracia no será aplicable a ninguno de los supuestos del presente artículo.

\section{Artículo 103.}

1. La Administración Pública sirve con objetividad los intereses generales y actúa de acuerdo con los principios de eficacia, jerarquía, descentralización. desconcentración y coordinación, con sometimiento pleno a la ley y al Derecho.

2. Los órganos de la Administración del Estado son creados, regidos y coordinados de acuerdo con la ley.

3. La ley regulará el estatuto de los funcionarios públicos, el acceso a la función publica de acuerdo con los principios de mérito y capacidad, las peculiaridades del ejercicio de su derecho a sindicación, el sistema de incompatibilidades y las garantías para la imparcialidad en el ejercicio de sus funciones.

\section{Artículo 104.}

1. Las Fuerzas y Cuerpos de seguridad, bajo la dependencia del Gobierno, tendrán como misión proteger el libre ejercicio de los derechos y libertades y garantizar la seguridad ciudadana.

2. Una ley orgánica determinara las funciones, principios básicos de actuación y estatutos de las Fuerzas y Cuerpos de seguridad.

Artículo 105.

La ley regulará:

a) La audiencia de los ciudadanos, directamente o a través de las organizaciones y asociaciones reconocidas por la ley, en el procedimiento de elaboración de las disposiciones administrativas que les afecten.

b) El acceso de los ciudadanos a los archivos y registros administrativos, salvo en lo que afecte a la seguridad y defensa del Estado, la averiguación de los delitos y la intimidad de las personas.

c) El procedimiento a través del cual deben producirse los actos administrativos, garantizando, cuando proceda, la audiencia del interesado.

\section{Artículo 106.}

1. Los Tribunales controlan la potestad reglamentaria y la legalidad de la actuación administrativa, así como el sometimiento de ésta a los fines que la justifican.

2. Los particulares, en los términos establecidos por la ley, tendrán derecho a ser indemnizados por toda lesión que sufran en cualquiera de sus bienes y derechos, salvo en los casos de fuerza mayor, siempre que la lesión sea consecuencia del funcionamiento de los servicios públicos.

Artículo 107.

El Consejo de Estado es el supremo órgano consultivo del Gobierno. Una ley orgánica regulará su composición y competencia. 


\section{ANEXO 4}

\section{Lista de Arquivos da Associação de Arquivistas de Castela e Leão disponibilizada no site:}

http://www.acal.es/Recursos/Archivos/tabid/176/Default.aspx?PageContentl $\mathrm{D}=60$

\section{Archivos}

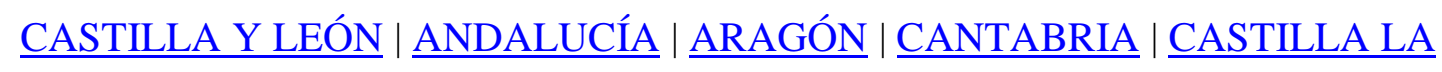

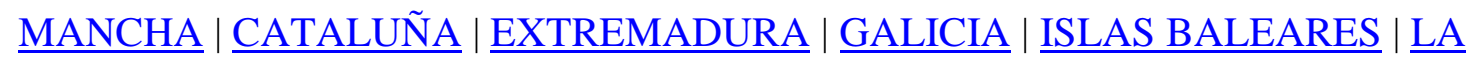

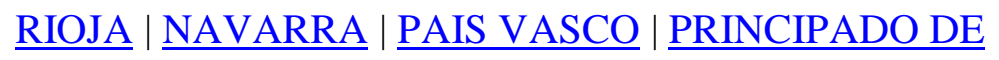

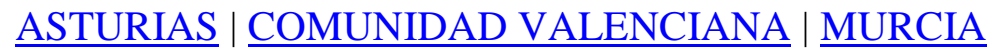

\section{CASTILLA Y LEÓN}

\section{ÁVILA}

Archivos Estatales

\section{Militares}

$\underline{\text { Archivo General Militar de Ávila }}$

http://www.ejercito.mde.es/Unidades/unidades/Madrid/ihycm/Archivos/agm-avilaindex.html

\section{BURGOS}


Archivos Administración Local

\section{Ayuntamientos}

$\underline{\text { Archivo Municipal de Burgos }}$

http://www.recbib.es/book/archivo-municipal-de-burgos

\section{Diputación}

$\underline{\text { Archivo de la Diputación Provincial de Burgos }}$

http://www.burgos.es/institucion/areas-de-actuacion/archivo-provincial

Archivos Universidades

$\underline{\text { Archivo de la Universidad de Burgos }}$

http://www2.ubu.es/archivo/

\section{LEÓN}

Archivos Administración Local

\section{Ayuntamientos}

\section{Archivo Municipal de León}

http://www.aytoleon.es/es/ayuntamiento/areasmunicipales/patrimonio/Paginas/ArchivoMu nicipal.aspx

$\underline{\text { Archivo Municipal de La Bañeza }}$

http://www.aytobaneza.es/index.php/mod.pags/mem.detalle/idpag.81/relcategoria.393/relc ategoriainicial.385/idmenu.114/chk.956212e7b8f38f541d60ec2b3974ac5f.html

\section{Diputación}

Archivo de la Diputación Provincial de León

http://www.aytobaneza.es/index.php/mod.pags/mem.detalle/idpag.81/relcategoria.393/relc ategoriainicial.385/idmenu.114/chk.956212e7b8f38f541d60ec2b3974ac5f.html

\section{Archivos Fundaciones}

$\underline{\text { Archivo de la Fundación Sierra - Pambley }}$

http://www.recbib.es/book/archivo-fundacion-sierra-pambley

Archivo de la Fundación Hullera Vasco-Leonesa

http://www.fhvl.es/fhvl/content.asp?ContentId=610 
Archivos Religiosos

\section{Catedral}

Archivo Catedralicio de León

http://www.catedraldeleon.org/archivo.htm

\section{SALAMANCA}

Archivos Administración Local

\section{Ayuntamientos}

$\underline{\text { Archivo Municipal de Ciudad Rodrigo }}$

http://www.ciudadrodrigo.net/archivomunicipal/

\section{Archivos Estatales}

Generales

Archivo General de la Guerra Civil Española

http://www.mcu.es/archivos/MC/AGC/index.html

\section{Archivos Religiosos}

\section{Catedral}

Archivo de la Catedral de Salamanca http://www.catedraldeleon.org/archivo.htm Archivos Universidades

$\underline{\text { Universidad de Salamanca }}$

http://sabus.usal.es/archivos.htm

\section{SEGOVIA}

\section{Archivos Administración Local}

\section{Ayuntamientos}

Archivo Histórico Municipal de Cuéllar

http://www.aytocuellar.es/index.php?pagina=contenido\&sec=culturaseis

\section{Archivos Estatales}

\section{Militares}

$\underline{\text { Archivo General Militar de Segovia }}$ 
http://www.ejercito.mde.es/Unidades/unidades/Madrid/ihycm/Archivos/agm-segoviaindex.html

Archivos Privados Archivo Histórico de la Casa Ducal de Alburquerque

http://www.aytocuellar.es/index.php?pagina $=$ contenido\&sec=culturasiete

\section{VALLADOLID}

Archivos Administración Autonómica

\section{Archivos centrales}

$\underline{\text { Consejería de Cultura y Turismo }}$

http://www.carm.es/neweb2/servlet/integra.servlets.ControlPublico?IDCONTENIDO=476 $\underline{6 \& \text { IDTIPO}=100 \& \text { RASTRO }=c \$ m 122,133}$

\section{Archivos Administración Local}

\section{Ayuntamientos}

\section{$\underline{\text { Archivo Municipal de Medina de Rioseco }}$}

http://www.medinaderioseco.com/cultura/index.shtml?idboletin=373\&idseccion=1861\&id $\underline{\text { articulo }=9859}$

$\underline{\text { Archivo Municipal de Valladolid }}$

http://www.ava.es/modules.php?name=Archivo

\section{Diputación}

$\underline{\text { Archivo de la Diputación Provincial de Valladolid }}$

http://www.diputaciondevalladolid.es/archivo/archivo.shtml

\section{Archivos Estatales}

\section{Generales}

Archivo General de Simancas

http://www.mcu.es/archivos/MC/AGS/index.html

$\underline{\text { Archivo de la Real Chancillería de Valladolid }}$

http://www.mcu.es/archivos/MC/ACV/index.html

\section{Archivos Universidades}

$\underline{\text { Archivo de la Universidad de Valladolid }}$ 
http://www.uva.es/cocoon_uva/impe/uva/navDirectorio?idSeccion=7666\&idMenuIzq=412 $\underline{3}$

$\underline{\text { ANDALUCÍA }}$

\section{ALMERÍA}

Archivos Administración Autonómica

\section{Provinciales}

Archivo Histórico Provincial de Almería

http://www.juntadeandalucia.es/cultura/archivos/impe/web_es/contenido?id=6fda16c0-

58a3-11dd-b44b-31450f5b9dd5\&idArchivo=6fda16c0-58a3-11dd-b44b-

$\underline{31450 \mathrm{f} 5 \mathrm{~b} 9 \mathrm{dd} 5 \& \mathrm{didCont} \text { Arch }=02 \mathrm{~cd} 09 \mathrm{~d} 5-57 \mathrm{e} 2-}$

\section{CÁDIZ}

\section{Archivos Administración Autonómica}

\section{Provinciales}

Archivo Histórico Provincial de Cádiz

http://www.juntadeandalucia.es/cultura/archivos/impe/web_es/contenido?id=dd732ff4-

58a3-11dd-b44b-31450f5b9dd5\&idArchivo=dd732ff4-58a3-11dd-b44b-

31450f5b9dd5\&idContArch=fa28e1b6-3b6d-11dd-92fe-

$\underline{31450 f 5 b 9 d d 5 \& i d P r o v i n c i a=f a 28 e 1 b 6-3 b 6 d-11 d d-92 f e-31450 f 5 b 9 d d 5 ~}$

Archivos Administración Local

Ayuntamientos

$\underline{\text { Archivo Histórico Municipal de El Bosque }}$

http://www.elbosqueweb.org/PaginaEstatica.aspx?Tipo=ARCHIVO\%20HISTORICO\&Ico no=/images/noticias.jpg

$\underline{\text { Archivo Histórico Municipal de Alcalá de los Gazules }}$

http://www.alcaladelosgazules.es/opencms/opencms/alcaladelosgazules/resultado.jsp

Archivo Histórico Municipal de Alcalá del Valle

http://www.alcaladelvalle.es/opencms/opencms/alcaladelvalle/resultado.jsp

$\underline{\text { Archivo Histórico Municipal de Benalup-Casas Viejas }}$ 
http://www.benalupcasasviejas.es/

$\underline{\text { Archivo Histórico Municipal de Benaocaz }}$

http://www.benaocaz.es/opencms/opencms/benaocaz/resultado.jsp

Archivo Histórico Municipal de Bornos

http://www.bornos.es/opencms/opencms/bornos/resultado.jsp

Archivo Histórico Municipal de Castellar de la Frontera

http://www.castellardelafrontera.es/index.php?searchword=archivo\&ordering=\&searchphr $\underline{\text { ase }=\text { all } \& \text { Itemid }=100 \& o p t i o n=c o m \_s e a r c h}$

Archivo Histórico Municipal de Espera

http://www.espera.es/opencms/opencms/espera/resultado.jsp

Archivo Histórico Municipal de Grazalema

http://www.grazalema.es/opencms/opencms/grazalema/resultado.jsp

$\underline{\text { Archivo Municipal de Jerez de la Frontera (Cádiz) }}$

http://www.jerez.es/index.php?id=94

Archivo Histórico Municipal de Jimena de la Frontera

http://www.jimenadelafrontera.es/index.php?option=com_content\&view=article\&id=484:1 a-digitalizacion-de-los-fondos-del-archivo-municipal-afronta-su-segunda-fase$\underline{\text { \&catid }=38: \text { cultura } \& \text { Itemid }=63}$

Archivo Histórico Municipal de Paterna de la Rivera http://www.paternaderivera.es/opencms/opencms/paternaderivera/secciones/cultura/archiv ohistorico.html

Archivo Histórico Municipal de Prado del Rey 
http://www.pradodelrey.es/PaginaEstatica.aspx?Tipo=ARCHIVO\%20HISTORICO\&Icono =/images/noticias.jpg

$\underline{\text { Archivo Histórico Municipal de Puerto Serrano }}$

http://www.puertoserrano.es/opencms/opencms/puertoserrano/resultado.jsp

Archivo Municipal de San Roque

http://www.sanroque.es/ayuntamiento/archivo-municipal-de-san-roque

$\underline{\text { Archivo Histórico Municipal de Torre alhaquime }}$

http://www.torrealhaquime.es/opencms/opencms/torrealhaquime/secciones/cultura.html

$\underline{\text { Archivo Histórico Municipal de Ubrique }}$

http://web.ubrique.es/ayuntamientos-i/opencms/ubrique/index.html

$\underline{\text { Archivo Histórico Municipal de Vejer de la Frontera }}$

http://www.vejerdelafrontera.es/opencms/opencms/vejerdelafrontera/ciudadanos/archivohi storico.html

$\underline{\text { Archivo Histórico Municipal de Villamartín }}$

http://www.villamartin.es/opencms/opencms/villamartin/resultado.jsp

$\underline{\text { Archivo Histórico Municipal de Zahara de la Sierra }}$

http://www.zaharadelasierra.es/opencms/opencms/zaharadelasierra/secciones/cultura/archi vohistorico.html

\section{Archivos Estatales}

\section{Militares}

$\underline{\text { Archivo del Real Instituto y Observatorio de la Amada en San Fernando }}$ http://www.armada.mde.es/ArmadaPortal/page/Portal/ArmadaEspannola/ciencia_observat orio/prefLang_es/ 
Archivos Universidades

$\underline{\text { Archivo Universidad de Cádiz }}$

http://www2.uca.es/orgobierno/secretaria/archivo_UCA.html

\section{CÓRDOBA}

Archivos Administración Autonómica

\section{Provinciales}

Archivo Histórico Provincial de Córdoba

http://censoarchivos.mcu.es/CensoGuia/archivodetail.htm?id=51353

\section{Archivos Administración Local}

\section{Ayuntamientos}

$\underline{\text { Archivo Municipal de Córdoba }}$

http://archivo.ayuncordoba.es/

$\underline{\text { Archivo Municipal de Montilla }}$

http://www.montilla.es/areas-municipales/cultura/archivo-historico

Archivo Municipal de Priego de Córdoba

http://www.aytopriegodecordoba.es/Archivo_Municipal.asp?raiz=Cultura

\section{Diputación}

Archivo de la Diputación Provincial de Córdoba

http://www.juntadeandalucia.es/cultura/iaph/nav/contenido.jsp?pag=/portal/Tematicas/Info $\underline{\text { rmacionPH/infdocumental_bibliografica/fuentes/archivodeladiputacion }}$

\section{GRANADA}

Archivos Administración Autonómica

\section{Provinciales}

Archivo Histórico Provincial de Granada

http://www.juntadeandalucia.es/cultura/archivos/impe/web_es/contenido?id=0754eda0-

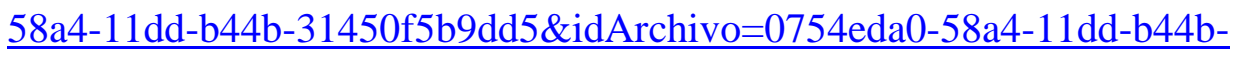
$\underline{31450 f 5 b 9 d d 5 \& i d C o n t A r c h=1922 b 8 c a-3 b 6 e-11 d d-92 f e-31450 f 5 b 9 d d 5}$ 


\section{Otras entidades}

$\underline{\text { Archivo Patronato de la Alhambra y Generalife }}$

http://www.juntadeandalucia.es/cultura/archivos/impe/web_es/contenido?id=c510c229-

41ec-11dd-a9ca-31450f5b9dd5\&idArchivo=e5d316c0-58a4-11dd-b44b-

31450f5b9dd5\&idContArch=c510c229-41ec-11dd-a9ca-

$\underline{31450 f 5 b 9 d d 5 \& i d T i p o=81 f 4 b 1 a 3-e 224-11 d d-a c 81-00 e 000 a 6 f 9 b f}$

\section{Archivos Administración Local}

\section{Ayuntamientos}

Archivo Histórico Municipal de Granada

http://usuarios.multimania.es/proyectosweb8/archivohistorico.html

\section{Diputación}

$\underline{\text { Archivo de la Diputación Provincial de Granada }}$

http://www.cienciayculturaescrita.es/es/index.php?option=com_content\&view=article\&id= 9:diputacion-provincial-de-granada-archivo-general\&catid=3:estancias \&Itemid=8

\section{Archivos Universidades}

$\underline{\text { Archivo de la Universidad de Granada }}$

http://www.ugr.es/ archivo/index.htm

\section{Archivos Estatales}

\section{Generales}

$\underline{\text { Archivo de la Real Chancillería de Granada }}$

http://www.juntadeandalucia.es/cultura/archivos/impe/web_es/ListadoArchivos?id=16557f 09-57e2-11dd-ba1f-31450f5b9dd5\&idContArch=16557f09-57e2-11dd-ba1f-

\section{$\underline{31450 f 5 b 9 d d 5}$}

\section{HUELVA}

\section{Archivos Administración Autonómica}

\section{Provinciales}

Archivo Histórico Provincial de Huelva

http://www.juntadeandalucia.es/cultura/archivos/impe/web_es/contenido?id=127ac794-

58a4-11dd-b44b-31450f5b9dd5\&idArchivo=127ac794-58a4-11dd-b44b- 
31450f5b9dd5\&idContArch=de37fe4f-393e-11dd-97cd-

$\underline{31450 f 5 b 9 d d 5 \& i d P r o v i n c i a=d e 37 f e 4 f-393 e-11 d d-97 c d-31450 f 5 b 9 d d 5 ~}$

Archivos Administración Local

Ayuntamientos

Archivo Municipal de Aljaraque

http://www.aytoaljaraque.es/index.php?option=com_content $\& v i e w=\operatorname{article} \& i d=299: \operatorname{archiv}$ $\underline{\text { o-municipal-de-aljaraque } \& \text { catid=117:archivo-principal } \& \text { Itemid }=375}$

$\underline{\text { Archivo Municipal de Cartaya }}$

http://hispana.mcu.es/ca/comunidades/registro.cmd?id=1384

$\underline{\text { Archivo Municipal de Huelva }}$

http://www.huelva.es/wps/portal/!ut/p/.cmd/cs/.ce/7_0_A/.s/7_0_2ER/_s.7_0_A/7_0_2ER

Archivo Municipal de Lepe

http://www.lepe.es/ciudad/cultura-festejos-y-educacion/archivo-

municipal/presentacion/?searchterm=archivo\%20municipal

$\underline{\text { Archivo Municipal de Palos de la Frontera }}$

http://www.juntadeandalucia.es/cultura/archivos/impe/web/DetalleArchivoPdf?d=pdf\&id= $\underline{1720}$

Diputación

Archivo Diputación de Huelva

http://www.diphuelva.es/web/contenido_basico.aspx?idContenido=106\&idArea=16

Archivos Empresas

$\underline{\text { Archivo Histórico Minero de Riotinto }}$

http://www.parquemineroderiotinto.com/archivo.html 
JAEN

Archivos Administración Autonómica

\section{Provinciales}

Archivo Histórico Provincial de Jaén

http://www.juntadeandalucia.es/cultura/archivos/impe/web_es/contenido?id=000a2afc-

58a4-11dd-b44b-31450f5b9dd5\&idArchivo=000a2afc-58a4-11dd-b44b-

$\underline{\text { 31450f5b9dd5\&idContArch=373c41fc-3b6e-11dd-92fe-31450f5b9dd5 }}$

\section{MÁLAGA}

\section{Archivos Administración Autonómica}

\section{Provinciales}

Archivo Histórico Provincial de Málaga

http://www.juntadeandalucia.es/cultura/archivos/impe/web/contenido?id=cfa8cd88-58a4-

$\underline{\text { 11dd-b44b-31450f5b9dd5\&idArchivo=cfa8cd88-58a4-11dd-b44b-31450f5b9dd5 }}$

\section{Archivos Administración Local}

Ayuntamientos

$\underline{\text { Archivo Municipal de Antequera }}$

http://www.antequera.es/antequera/extranet/verContenido?al_men_pk=1944\&as_ruta_men _. $\mathrm{pk}=2379,1944$

Archivo Municipal de Málaga

http://www.aytomalaga.es/servlet/page?_pageid=308\&_dad=portal30\&_schema=PORTA L30\&_type $=$ site\&_fsiteid $=79 \&$ fid $=13652 \&$ fnavbarid $=117133 \&$ fnavbarsiteid $=79 \&$ fe

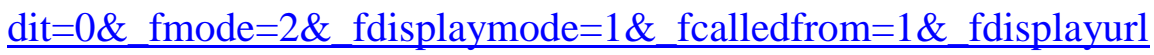

\section{Diputación}

Archivo de la Diputación Provincial de Málaga

http://www.malaga.es/areas/servicios/sede.asp?cod=100

\section{SEVILLA}


Archivos Administración Autonómica

\section{Generales}

$\underline{\text { Archivo General de Andalucía }}$

http://www.recbib.es/book/archivo-general-de-andalucia

\section{Centrales}

Archivo Central Conserjería de Agricultura, Pesca y Alimentación

http://www.juntadeandalucia.es/agriculturaypesca/archivo/barras/barra_archivo.html

$\underline{\text { Archivo Central Conserjería de Turismo Comercio Y Deporte }}$

http://www.juntadeandalucia.es/turismocomercioydeporte/ctcddocs/custom_doc/093 guiaa rchivo.pdf

\section{Provinciales}

Archivo Histórico Provincial de Sevilla

http://www.juntadeandalucia.es/cultura/archivos/impe/web_es/contenido?id=d9f0f1ac-

58a4-11dd-b44b-31450f5b9dd5\&idArchivo=d9f0f1ac-58a4-11dd-b44b-

31450f5b9dd5\&idContArch=02cd09d5-57e2-11dd-ba1f-

$\underline{31450 f 5 b 9 d d 5 \& i d T i p o=02 c d 09 d 5-57 e 2-11 d d-b a 1 f-31450 f 5 b 9 d d 5}$

\section{Archivos Administración Local}

\section{Ayuntamientos}

Archivo Municipal de Puebla de Cazalla

http://www.dipusevilla.es/dipusevilla/opencms/site/web/municipios/la_puebla_de_cazalla/ $\underline{\text { menu_sec/archivo_municipal/ }}$

$\underline{\text { Archivo Municipal de Sevilla }}$

http://www.sevilla.org/impe/sevilla/contenido?pag=/contenidos/cultura/archivo_hemerotec $\underline{\text { a/archivo_municipal\&idActivo }=\mathrm{C} 6100 \& \text { idSeccion }=\mathrm{C} 170 \& v E=\mathrm{D} 4268}$

\section{Archivos Estatales}

\section{Generales}

$\underline{\text { Archivo General de Indias }}$

http://www.mcu.es/archivos/MC/AGI/index.html 


\section{Archivos Religiosos}

\section{Diócesis}

$\underline{\text { Archivo General del Arzobispado de Sevilla }}$

http://www.institucioncolombina.org/archivo/agas.htm

\section{Catedral}

$\underline{\text { Archivo Capitular de Sevilla }}$

http://www.institucioncolombina.org/catedral/capitular.htm

\section{Archivos Parlamentos}

$\underline{\text { Archivo Central del Parlamento de Andalucía }}$

http://www.parlamentodeandalucia.es/opencms/export/portal-web-

parlamento/composicionyfuncionamiento/serviciosadministrativos/documentacionyarchivo $\underline{\text { s.htm }}$

\section{Archivos Universidades}

$\underline{\text { Archivo Histórico de la Universidad de Sevilla }}$

http://bib.us.es/nuestras_colecciones/mas/archivo/index-ides-idweb.html

\section{ARAGÓN}

\section{HUESCA}

Archivos Administración Autonómica

\section{Provinciales}

Archivo Histórico Provincial de Huesca

http://www.aragonesasi.com/huesca/ahphini.php

\section{Archivos Administración Local}

Ayuntamientos

$\underline{\text { Archivo Municipal de Huesca }}$

http://www.ayuntamientohuesca.es/000_estructura/index.php?id=1552

\section{Diputación}

$\underline{\text { Archivo de la Diputación Provincial de Huesca }}$

http://www.dphuesca.es/index.php/mod.pags/mem.detalle/idpag.114/idmenu.66/chk.ab975 $\underline{\mathrm{c} 547 \mathrm{fb} 9 \mathrm{ed} 6 \mathrm{f} 1 \mathrm{a} 65397 \mathrm{f} 8095106 \mathrm{e} \cdot \mathrm{html}}$ 
Fototeca del Alto Aragón

http://www.dphuesca.es/index.php/mod.pags/mem.detalle/idpag.610/chk.daec601613fda2d $\underline{7 \mathrm{e} 2384 \mathrm{bd} 31857 \mathrm{c} 4 \mathrm{e} 5 . \mathrm{html}}$

\section{TERUEL}

Archivos Administración Autonómica

Provinciales

$\underline{\text { Archivo Histórico Provincial de Teruel }}$

http://portal.aragon.es/portal/page/portal/ARCHIVO/AHP_TERUEL

Archivos Administración Local

Diputación

Archivo de la Diputación Provincial de Teruel

http://es.qdq.com/archivo+diputacion/teruel/

\section{ZARAGOZA}

Archivos Administración Autonómica

\section{Generales}

Archivo de la Administración

http://www.zaragoza.es/ciudad/educacion/recursos/detalle_GuiaRecurso?id=2640

\section{Provinciales}

Archivo Histórico Provincial de Zaragoza

http://portal.aragon.es/portal/page/portal/ARCHIVO/ARCHIVOZARAGOZA

Archivos Administración Local

Ayuntamientos

$\underline{\text { Archivo Municipal de Zaragoza }}$

http://www.guiaservicios.com/arag_espacios-palacio-montemuzo.php

\section{Diputación}

Archivo de la Diputación Provincial de Zaragoza

http://www.dpz.es/archivo/ 
Archivos Universidades

$\underline{\text { Archivo Central de la Universidad de Zaragoza }}$

http://wzar.unizar.es/uz/arch/index.html

\section{CANTABRIA}

Archivos Administración Autonómica

Provinciales

Archivo Histórico Provincial de Cantabria

http://www.culturadecantabria.com/archivos.asp

Archivos Administración Local

Ayuntamientos

$\underline{\text { Archivo Municipal de Santander }}$

http://portal.aytosantander.es/portal/page/portal/inet_santander/ficha/ficha_ayto?itemId=20 $\underline{79049}$

Archivo Municipal Torrelavega

http://213.201.90.140/portalTorrelavega/p_20_contenedor1.jsp?seccion=s_floc_d4_v1.jsp

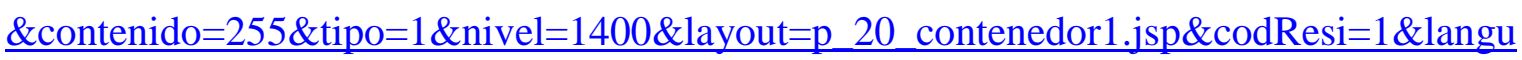
$\underline{\text { age }=\text { es } \& \text { level }=1}$

Archivos Parlamentos

$\underline{\text { Archivo del Parlamento de Cantabria }}$

$\underline{\text { http://videoteca.parlamento-cantabria.es/Web/ }}$

Archivos Religiosos

Diócesis

$\underline{\text { Archivo Diocesano de Santander (Santillana Del Mar) }}$

http://www.santillanamuseodiocesano.com/archivo_documental.htm

CASTILLA LA MANCHA

ALBACETE

Archivos Administración Local

Ayuntamientos

Archivo Municipal de Caudete 
http://www.caudete.es/noticia.asp?idnoticia=72592

\section{Diputación}

$\underline{\text { Archivo Diputación Provincial de Albacete }}$

http://www.dipualba.es/archivo/Principal.htm

\section{CIUDAD REAL}

Archivos Administración Local

\section{Diputación}

$\underline{\text { Archivo de la Diputación Provincial de Ciudad Real }}$

http://www.dipucr.com/cgi-bin/mainbin/index.pl?action=autopage\&page=1214992290

\section{Archivos Universidades}

$\underline{\text { Archivo General de la Universidad de Castilla - La Mancha }}$

http://www.uclm.es/archivo/

\section{CUENCA}

Archivos Administración Autonómica

\section{Diputación}

$\underline{\text { Archivo de la Diputación Provincial de Cuenca }}$

http://www.dipucuenca.es/

\section{GUADALAJARA}

Archivos Administración Local

Ayuntamientos

Archivo Municipal de Guadalajara

http://www.guadalajara.es/es/index.asp?MP=37\&MS=0\&MN=1\&accion=si\&textobusqued $\underline{\mathrm{a}=\operatorname{archivo} \% 20 \text { municipal } \& \text { tipo }=1 \& \mathrm{TR}=\mathrm{A} \& \mathrm{IDR}=11 \& \text { tipo=Contenido } \& \mathrm{id}=184}$

\section{Archivos Estatales}

\section{Militares}

$\underline{\text { Archivo General Militar de Guadalajara }}$

http://www.ejercito.mde.es/Unidades/unidades/Madrid/ihycm/Archivos/index.html 
TOLEDO

Archivos Administración Local

Ayuntamientos

$\underline{\text { Archivo Municipal de Illescas }}$

http://www.illescas.es/contenidos/0104.htm

$\underline{\text { Archivo Municipal Talavera de la Reina }}$

http://archivomunicipal.talavera.org/

$\underline{\text { Archivo Municipal de Toledo }}$

http://www.ayto-toledo.org/archivo/archivo.asp

Diputación

$\underline{\text { Archivo de la Diputación Provincial de Toledo }}$

http://www.diputoledo.es/global/default.php?id_area=4

Archivos Estatales Generales

$\underline{\text { Sección Nobleza del Archivo Histórico Nacional }}$

http://www.mcu.es/archivos/MC/NHN/index.html

Archivos Fundaciones

Archivo de la Real Fundación de Toledo

http://www.realfundaciontoledo.es/html/index.html

Archivos Religiosos

\section{Catedral}

$\underline{\text { Archivo Catedralicio de Toledo }}$

http://www.architoledo.org/catedral/archivos/textoarchivo.htm

\section{Parroquiales}

$\underline{\text { Archivo Parroquial de Santo Tomé y San Salvador de Toledo }}$

http://www.santotome.org/indexnew.html

\section{CATALUÑ̃}




\section{BARCELONA}

Archivos Administración Autonómica

\section{Generales}

$\underline{\text { Archivo Nacional de Cataluña }}$

http://www20.gencat.cat/portal/site/CulturaDepartament/menuitem.a698cbe5a26e56a65a2 a63a7b0c0e1a0/?vgnextoid=d3e57b49f4346110VgnVCM1000008d0c1e0aRCRD\&vgnext channel=d3e57b49f4346110VgnVCM1000008d0c1e0aRCRD

\section{Administración Local}

\section{Ayuntamientos}

$\underline{\text { Archivo Municipal de Barcelona }}$

http://w3.bcn.es/XMLServeis/XMLHomeLinkPl/0,4022,240827346_240851665_1,00.html

Archivo Municipal de Gavá

http://www.patrimonigava.cat/esp/imgpcn/chc.asp

$\underline{\text { Archivo Municipal de Gelida }}$

http://www.gelida.org/arxius.htm

$\underline{\text { Archivo Histórico de Sabadell }}$

http://www.sabadell.cat/websajsab/arxiu/

$\underline{\text { Archivo Administrativo de Tarrasa }}$

http://www.terrassa.org/laciutat/arxiuadm.htm

$\underline{\text { Archivo Histórico del Poble Nou }}$

http://www.educaweb.com/enlaces/enlace-archivo-historico-poblenou-0017458.html

\section{Comarcales}

Archivo Comarcal Alto Penedés 
http://cultura.gencat.net/arxius/fitxa.asp?municipi=0\&comarca=03\&ARXIUS=comarcals\& $\underline{\text { NRegistre }=\& \text { idregistre }=\text { ACAP }}$

$\underline{\text { Archivo Comarcal de L'Anoia }}$

http://cultura.gencat.net/arxius/fitxa.asp?municipi $=0 \&$ comarca $=06 \& A R X I U S=$ comarcals \& $\underline{\text { NRegistre }=\& \text { idregistre }=\mathrm{ACAN}}$

$\underline{\text { Archivo Comarcal del Bages }}$

http://cultura.gencat.net/arxius/fitxa.asp?municipi=0\&comarca=07\&ARXIUS=comarcals\& $\underline{\text { NRegistre }=\& \text { idregistre }=\mathrm{ACBG}}$

$\underline{\text { Archivo Comarcal del Bajo Llobregat }}$

http://cultura.gencat.cat/arxius/Fitxa.asp?NRegistre=\&idregistre=ACBL

Archivo Comarcal del Berguedá

http://cultura.gencat.net/arxius/fitxa.asp?municipi=0\&comarca=14\&ARXIUS=comarcals\& $\underline{\text { NRegistre }=\& \text { idregistre }=\mathrm{ACBR}}$

$\underline{\text { Archivo Histórico Comarcal de Osona }}$

http://cultura.gencat.net/arxius/fitxa.asp?municipi=0\&comarca=17\&ARXIUS=comarcals\& $\underline{\text { NRegistre }=\text { \&idregistre }=\text { ACGAF }}$

$\underline{\text { Archivo Comarcal del Garraf }}$

http://cultura.gencat.net/arxius/fitxa.asp?municipi=0\&comarca=21\&ARXIUS=comarcals\& $\underline{\text { NRegistre }=\& i d r e g i s t r e}=\mathrm{ACM}$

$\underline{\text { Archivo Histórico Comarcal de Mataró }}$

http://www.terrassa.org/ajuntament/arxiu.htm

$\underline{\text { Archivo Histórico Comarcal de Tarrasa }}$ 
http://www.terrassa.org/ajuntament/arxiu.htm

Archivo Comarcal del Vallés Occidental

http://cultura.gencat.net/arxius/fitxa.asp?municipi=0\&comarca=40\&ARXIUS=comarcals\& $\underline{\text { NRegistre }=\& \text { idregistre }=\mathrm{ACVOC}}$

$\underline{\text { Archivo Comarcal del Vallés Oriental }}$

http://cultura.gencat.net/arxius/fitxa.asp?municipi=0\&comarca=41\&ARXIUS=comarcals\& $\underline{\text { NRegistre }=\& i d r e g i s t r e}=\mathrm{ACVO}$

\section{Diputación}

Archivo General de la Diputación de Barcelona

http://www.diba.es/arxiu/default.asp

\section{Archivos Estatales}

\section{Generales}

$\underline{\text { Archivo de la Corona de Aragón }}$

http://www.mcu.es/archivos/MC/ACA/index.html

\section{Archivos Parlamentarios}

Archivo del Parlamento de Cataluña

http://www.parlament.cat/web/avis

Archivos arquitectónicos

$\underline{\text { Archivo Coderch }}$

http://www-etsav.upc.es/arxcoderch/index.htm

Archivo Histórico del Colegio de Arquitectos de Cataluña. Demarcación de Barcelona http://www.coac.net/COAC/centredocumentacio/arxiu/ahistbcn.htm

\section{Archivos fotográficos}

$\underline{\text { Archivos Fotográficos de Cataluña }}$

http://www.ultrafox.com/ct/iafc/afindex.htm 


\section{Archivos económicos}

$\underline{\text { Archivo General del Museo Marítimo de Barcelona }}$

http://www.mmb.cat/

\section{Archivos instituciones culturales}

Centro de Documentación y Museo de Artes Escénicas

http://www.institutdelteatre.org/diputacio/opencms/system/modules/org.iteatre.web/web/ca /AreaInformarse/Area.jsp?PathMenuSelec=/system/modules/org.iteatre.web/web/ca/AreaI nformarse/Centre_de_documentacio/Fons_documental/

\section{Archivos religiosos}

\section{Diocesanos}

Archivo Diocesano de Barcelona

http://www.cultura.arqben.cat/arxiu_cat.php

$\underline{\text { Archivo Diocesano de Vic }}$

http://www.abev.net/

\section{Parroquiales}

Archivo Parroquial de Santa María del Pí

http://www.parroquiadelpi.com/castellano/archivo.html

\section{Archivos sindicales}

Archivo Histórico de Comisiones Obreras de Cataluña. Fundación Cipriano García http://www.fciprianogarcia.ccoo.cat/ciprianogarcia/index.aspx

\section{Archivos Universitarios}

$\underline{\text { Archivo Histórico de la Universidad de Barcelona }}$

http://www.ub.es/ebfil/ueb/archivo.htm

Archivo General y Registro de la Universidad Autónoma de Barcelona http://arxiu-general.uab.cat/

$\underline{\text { Archivo Universidad Politécnica de Cataluña }}$ https://www.upc.edu/arxiu/ 
$\underline{\text { Archivo Administrativo de la Universidad Pompeu Fabra }}$

http://www.upf.es/arxiu/

\section{GERONA}

Archivos Administración Autonómica

\section{Provinciales}

Archivo Histórico Provincial de Gerona

http://cultura.gencat.net/arxius/fitxa.asp?municipi=0\&comarca=20\&ARXIUS=comarcals\&

$\underline{\text { NRegistre }=\& \text { idregistre }=\mathrm{AHG}}$

\section{Archivos Administración Local}

\section{Ayuntamientos}

$\underline{\text { Archivo Municipal de Begur }}$

http://begur.org/web/

Archivo Municipal de Cassá de La Selva

http://www.cassadelaselva.net/

Archivo Municipal de Gerona

http://www.girona.cat/sgdap/cat/arxiu_portada.php

$\underline{\text { Archivo Municipal de Palafrugell }}$

http://ajpalafrugell.org/content/view/52/75/

$\underline{\text { Archivo Municipal de Sils }}$

http://www.webgipal.net/sils/ajuntament/linkats.asp?Id=9486

Comarcales Archivo Comarcal del Alto Ampordá 
http://cultura.gencat.net/arxius/fitxa.asp?municipi=0\&comarca=02\&ARXIUS=comarcals\& $\underline{\text { NRegistre }=\& \text { idregistre }=\mathrm{ACAE}}$

Archivo Comarcal del Bajo Empordá

http://cultura.gencat.net/arxius/fitxa.asp?municipi $=0 \&$ comarca=10\&ARXIUS=comarcals\& $\underline{\text { NRegistre }=\& \text { idregistre }=\mathrm{ACBE}}$

Archivo Histórico Comarcal de Banyoles

http://www.banyolescultura.net/ahcbcat.htm

$\underline{\text { Archivo Comarcal de la Garrotxa }}$

http://cultura.gencat.net/arxius/fitxa.asp?municipi=0\&comarca=19\&ARXIUS=comarcals\& $\underline{\text { NRegistre }=\& \text { idregistre }=\text { ACGAX }}$

$\underline{\text { Archivo Histórico Comarcal de Puigcerdá }}$

http://censoarchivos.mcu.es/CensoGuia/archivodetail.htm?id=51355

$\underline{\text { Archivo Comarcal del Ripollés }}$

http://cultura.gencat.net/arxius/fitxa.asp?municipi=0\&comarca=31\&ARXIUS=comarcals\& $\underline{\text { NRegistre }=\& i d r e g i s t r e}=$ ACRI

$\underline{\text { Archivo Comarcal de La Selva }}$

http://cultura.gencat.net/arxius/fitxa.asp?municipi=0\&comarca=34\&ARXIUS=comarcals\& $\underline{\text { NRegistre }=\& \text { idregistre }=\text { ACSE }}$

\section{Diputación}

Archivo de la Diputación de Gerona

http://www.ddgi.cat/web/home.seam;jsessionid=74eb9691b1d130d04b46cdb390de?nivellI $\underline{\mathrm{d}=412 \& \text { cid }=508202 \& \text { categoriaId }=6}$ 
Archivos religiosos

\section{Catedralicios}

$\underline{\text { Archivo de la Catedral de Gerona }}$

http://www.lacatedraldegirona.com/cat/arxiu/principal/index.html

\section{Diocesanos}

Archivo Diocesano de Gerona

http://www.arxiuadg.org/on_som.php?lleng=cast

Archivos universitarios

Archivo Universitario de Gerona

http://www3.udg.edu/arxiu/

\section{LÉRIDA}

Administración Autonómica

\section{Provinciales}

$\underline{\text { Archivo Histórico Provincial de Lérida }}$

http://cultura.gencat.net/arxius/fitxa.asp?municipi=0\&comarca=33\&ARXIUS=comarcals\&

$\underline{\text { NRegistre }=\& \text { idregistre }=\text { AHL }}$

\section{Regionales}

Depósito de Archivos de Cervera

http://cultura.gencat.net/arxius/Fitxa.asp?municipi=0\&comarca=32\&ARXIUS=comarcals

$\underline{\& N R e g i s t r e}=2 \& i d r e g i s t r e=D A C$

Administración Local

\section{Ayuntamientos}

$\underline{\text { Archivo Municipal de Lérida }}$

http://www.paeria.es/cat/ajuntament/index.asp\#P

\section{Comarcales}

$\underline{\text { Archivo Comarcal de la Noguera }}$

http://cultura.gencat.net/arxius/fitxa.asp?municipi=0\&comarca=23\&ARXIUS=comarcals\& NRegistre $=$ \&idregistre $=\mathrm{ACN}$ 
http://cultura.gencat.net/arxius/fitxa.asp?municipi=0\&comarca=26\&ARXIUS=comarcals\& $\underline{\text { NRegistre }=\& i d r e g i s t r e}=$ ACPS

$\underline{\text { Archivo Comarcal de la Segarra }}$

http://cultura.gencat.net/arxius/Fitxa.asp?municipi=0\&comarca=32\&ARXIUS=comarcals $\&$ NRegistre $=1 \&$ idregistre $=$ ACSG

$\underline{\text { Archivo Comarcal del Solsonés }}$

http://cultura.gencat.net/arxius/fitxa.asp?municipi=0\&comarca=35\&ARXIUS=comarcals\& $\underline{\text { NRegistre }=\& \text { idregistre }=\text { ACS }}$

Archivo Comarcal de Urgel

http://www.urgell.cat/serveis/serveis/indexdet.php?recordID=9

$\underline{\text { Archivo Histórico General Valle de Aran }}$

http://cultura.gencat.net/arxius/fitxa.asp?municipi=0\&comarca=39\&ARXIUS=comarcals\& $\underline{\text { NRegistre }=\text { \&idregistre }=\text { AGA }}$

\section{Diputación}

Archivo de la Diputación de Lérida

http://www.diputaciolleida.net/diputacio/servei-arxiu.html

\section{Archivos arquitectónicos}

$\underline{\text { Archivo Histórico del Centro de Documentación del Colegio de Arquitectos de }}$ Cataluña

http://www.coac.net/COAC/centredocumentacio/arxiu/ahistlle.htm

\section{Archivos religiosos}

\section{Catedralicios}

$\underline{\text { Archivo de la Catedral de Lérida }}$

http://www.archivocatedrallerida.com/

\section{Archivos universitarios}

$\underline{\text { Archivo Universidad de Lérida }}$ 
http://www.udl.es/serveis/arxiu.html

\section{TARRAGONA}

\section{Archivos Administración Autonómica}

\section{Provinciales}

Archivo Histórico Provincial de Tarragona

http://cultura.gencat.net/arxius/fitxa.asp?municipi $=0 \&$ comarca=36\&ARXIUS=comarcals\& $\underline{\text { NRegistre }=\& \text { idregistre }=\text { AHT }}$

\section{Archivos Administración Local}

\section{Ayuntamientos}

$\underline{\text { Archivo Municipal de Cambrils }}$

http://www.cambrils.org/noticias/detall/4141577/1-arxiu-municipal-adquireix-un-albumcambrilenc-datat-a-voltants-de-1900

$\underline{\text { Archivo Histórico Municipal de Constantí }}$

http://www.constanti.cat/arxiu.htm

$\underline{\text { Archivo Histórico Municipal de la Selva del Camp }}$

http://www.laselvadelcamp.org/arxiu/

$\underline{\text { Archivo Municipal de Roda de Bará }}$

http://www.rodadebara.org/xp_es/modules/tinycontent/index.php?id=51

\section{Comarcales}

$\underline{\text { Archivo Comarcal del Alt Camp }}$

http://cultura.gencat.net/arxius/fitxa.asp?municipi=0\&comarca=01\&ARXIUS=comarcals\& $\underline{\text { NRegistre }=\& i d r e g i s t r e}=\mathrm{ACAC}$

\section{$\underline{\text { Archivo Comarcal del Bajo Campo }}$}

http://cultura.gencat.net/arxius/fitxa.asp?municipi $=0 \&$ comarca=08\&ARXIUS=comarcals\& $\underline{\text { NRegistre }=\& \text { idregistre }=\mathrm{ACBC}}$ 
$\underline{\text { Archivo Comarcal el Bajo Penedés }}$

http://www.ccbp.altanet.org/consells/bpenedes/arxiu/

$\underline{\text { Archivo Comarcal de la Cuenca de Barberá }}$

http://www.cccb.net/arxiu/arxiu.php

$\underline{\text { Archivo Comarcal del Priorato }}$

http://cultura.gencat.net/arxius/fitxa.asp?municipi=0\&comarca=29\&ARXIUS=comarcals\& $\underline{\text { NRegistre }=\& \text { idregistre }=\mathrm{ACPR}}$

$\underline{\text { Archivo Histórico Comarcal de las Tierras del Ebro }}$

http://censoarchivos.mcu.es/CensoGuia/archivodetail.htm?id=15792

\section{Diputación}

Archivo de la Diputación de Tarragona

http://www.diputaciodetarragona.cat/houdipu/web-dipu/per_tu/arxiu/index.php

\section{Archivos arquitectónicos}

Archivo Histórico del Centro de Documentación del Colegio de Arquitectos de

Cataluña

http://www.coac.net/COAC/centredocumentacio/arxiu/ahisttar.htm

Archivos portuarios

Archivo Central del Puerto de Tarragona

http://cultura.gencat.net/arxius/Fitxa.asp?municipi $=0 \&$ comarca $=36 \&$ titularitat $=0 \&$ ARXIU

$\underline{\mathrm{S}=\text { directori } \& N R \text { egistre }=10}$

Archivos religiosos

Diocesanos

Archivo Diocesano de Tarragona

http://www.tinet.cat/ msanroma/arxiudiocesa.html

\section{EXTREMADURA}


BADAJOZ

Archivos Administración Local

\section{Ayuntamientos}

$\underline{\text { Archivo Municipal de Aceuchal }}$

http://aceuchal.com/ayuntamiento/saluda.php

Diputación

$\underline{\text { Archivo de la Diputación Provincial de Badajoz }}$

http://www.dip-badajoz.es/cultura/archivo/index.php

\section{Archivos Estatales}

$\underline{\text { Instituciones culturales }}$

http://www.mcu.es/museos/

\section{CÁCERES}

Archivos Administración Local

\section{Ayuntamientos}

$\underline{\text { Archivo Municipal de Trujillo }}$

http://www.trujillo.es/paginas/archivo.htm

\section{Diputación}

$\underline{\text { Archivo de la Diputación Provincial de Cáceres }}$

http://ab.dip-caceres.org/municipales/municipales000.htm

\section{GALÍCIA}

\section{LA CORUÑA}

Archivos Administración Autonómica

\section{Generales}

$\underline{\text { Archivo del Reino de Galicia }}$

http://www.xunta.es/conselle/cultura/patrimonio/arquivos/arquivo\%20reino/index.html

\section{Instituciones culturales}

$\underline{\text { Archivo de la Emigración Galega }}$

http://www.consellodacultura.org/arquivos/aeg/index.php 
$\underline{\text { Archivo Sonoro de Galicia }}$

http://www.consellodacultura.org/arquivos/asg/

$\underline{\text { Archivo de Comunicación }}$

http://www.consellodacultura.org/arquivos/amc/index.html

Archivos Administración Local

\section{Ayuntamientos}

Archivo Histórico Municipal de La Coruña

http://www.coruna.es/servlet/Satellite?c=Page\&cid=1132828895276\&idioma=es\&itemID

$=1149055935071 \&$ itemTemplate=Portal-Entidad-

Detalle\&itemType=Entidad\&pagename=Portal\%2FPage\%2FPortal-SubportadaSeccion

$\underline{\text { Archivo Municipal de Laxe }}$

http://www.concellodelaxe.com/portalcidadan/portada.php?id_language=1

$\underline{\text { Archivo Municipal de Ortigueira }}$

http://www.concellodeortigueira.com/facemos/fac.php?txt=arquivo\&lg=gal

$\underline{\text { Archivo Municipal de Ribeira }}$

http://www.riveira.com/servicios/contidos/4_administracion/4_arquivo/0_intro.htm

$\underline{\text { Archivo Municipal de Santiago de Compostela }}$

http://www.santiagodecompostela.org/casa_concello/servizo.php?txt=ser_arq_muncipal\&l $\mathrm{g}=\mathrm{gal} \& \mathrm{c}=31$

\section{Archivos Instituciones Culturales}

Archivo de la Real Academia Galega

http://www.realacademiagalega.org/catalog/GoToFileInfo.do;jsessionid=C586DE36964D AA8AA4B9122082A66FD8 
Archivos Religiosos

\section{Catedralicios}

$\underline{\text { Archivo Catedral de Santiago de Compostela }}$

http://www.catedraldesantiago.es/

\section{Diocesanos}

$\underline{\text { Archivo Histórico Diocesano de Santiago de Compostela }}$

http://www.ahds.es/

\section{Archivos Universidades}

$\underline{\text { Archivo Histórico de la Universidad de Santiago de Compostela }}$

http://www.usc.es/arquivo/arch.html

\section{LUGO}

Archivos Administración Autonómica

\section{Provinciales}

$\underline{\text { Archivo Histórico Provincial de Lugo }}$

http://www.xunta.es/conselle/cultura/patrimonio/arquivos/lugo/index.html

\section{Archivos Administración Local}

\section{Ayuntamientos}

$\underline{\text { Archivo Municipal de Viveiro }}$

http://www.viveiro.es/

\section{Diputación}

Archivo de la Diputación Provincial de Lugo

http://www.deputacionlugo.org/buscar.asp

\section{ORENSE}

\section{Archivos Administración Autonómica}

\section{Provinciales}

\section{$\underline{\text { Archivo Histórico Provincial de Orense }}$}

http://www.xunta.es/conselle/cultura/patrimonio/arquivos/ourense/index.htm 
Archivos Religiosos

Diocesanos

$\underline{\text { Archivo Histórico Diocesano de Orense }}$

http://www.obispadodeourense.com/inst/archivo/archivo1.html

\section{PONTEVEDRA}

Administración Autonómica

\section{Provinciales}

$\underline{\text { Archivo Histórico Provincial de Pontevedra }}$

http://www.xunta.es/conselle/cultura/patrimonio/arquivos/pontevedra/ah.htm

\section{Administración Local}

\section{Diputación}

$\underline{\text { Archivo de la Diputación Provincial de Pontevedra }}$

http://www.depontevedra.es/?1,5213

\section{Archivos Universidades}

Archivo Universidad de Vigo

http://www.uvigo.es/uvigo_gl/Administracion/Biblioteca/

\section{ISLAS BALEARES}

\section{Archivos Administración Autonómica}

\section{Generales}

$\underline{\text { Archivo del Reino de Mallorca }}$

http://www.caib.es/sacmicrofront/contenido.do;jsessionid=AC86F99521AE4F3616D0322 $\underline{18 C B 0911 \mathrm{~A} \text { ? idsite }=175 \& \text { cont }=5203 \& \text { lang }=\text { ca\&campa }=y e s}$

\section{Instituciones culturales}

$\underline{\text { Archivo del Sonido y de la Imagen }}$

http://www.conselldemallorca.net/biblioteques/fonssoim.htm

\section{Archivos Militares}

$\underline{\text { Centro de Historia y Cultura Militar de la Comandancia General De Baleares }}$ http://www.ejercito.mde.es/Unidades/unidades/Madrid/ihycm/Archivos/index.html 
Archivos Universidades

$\underline{\text { Archivo Universidad de Islas Baleares }}$

http://www.uib.es/ca/infsobre/serveis/

\section{LA RIOJA}

Archivos Administración Autonómica

\section{Generales}

$\underline{\text { Archivo General de La Rioja }}$

http://www2.larioja.org/pls/dad_user/G031.ver_actuacion?p_teletrami=S\&p_act_codi=115 $\underline{47}$

\section{Archivos de la Administración Local}

\section{Ayuntamientos}

$\underline{\text { Archivo Municipal de Logroño }}$

http://www.logro-

o.org/favoritos/asp/web/tercer_nivel.asp?aplicacion=1\&idioma=ES\&enlace=../pub/web_m $\underline{\text { unicipal/arch_principal.shtm } \& \text { nuevo }=1 \& \text { codigo_hijo=22002\&texto=Archivo }}$

\section{Archivos Universidades}

$\underline{\text { Archivo Central de la Universidad de La Rioja }}$

http://biblioteca.unirioja.es/ser/serarch.html

\section{NAVARRA}

\section{Archivos Administración Autonómica}

Generales

$\underline{\text { Archivo General de Navarra }}$

http://www.cfnavarra.es/agn/

Archivos Administración Local

\section{Ayuntamientos}

Archivo Municipal de Pamplona

http://www.pamplona.net/VerPagina.asp?idPag=199

$\underline{\text { Archivo Municipal de Tudela }}$

http://www.tudela.com/cas/ayuntamiento/010104archivomunicipal.asp 
Archivos Universidades

Archivo General de la Universidad Pública de Navarra

http://www.unav.es/archivo/

$\underline{\text { Archivo de la Universidad de Navarra }}$

http://www.unav.es/archivo/

Archivos Religiosos

Archivo Catedralicios

$\underline{\text { Archivo Catedral de Tudela }}$

http://www.palaciodecanaldetudela.com/palacio/archivos_fondos.html

\section{Archivo Diocesano}

Archivo Diócesis de Tudela

http://www.palaciodecanaldetudela.com/palacio/archivos_fondos_diocesanos.html

\section{PAIS VASCO}

\section{ÁLAVA}

Archivos Administración Autonómica

\section{Generales}

$\underline{\text { Archivo General de la Administración Pública de la CAE }}$

http://www.jusap.ejgv.euskadi.net/r47-shomearc/es/

\section{Archivos Administración Local}

\section{Ayuntamientos}

$\underline{\text { Archivo Municipal de Vitoria }}$

http://www.vitoriagasteiz.org/we001/was/we001Action.do?accionGSA=buscarPrimeraVez $\underline{\text { \&accionWe001=buscarWe001Google \&accion=buscar\&tipoArchivo=\&termino=ARCHIV }}$ $\underline{\text { O\&Buscar}=\text { Buscar }}$ 
Archivos Estatales

Provinciales

$\underline{\text { Archivo Histórico Provincial de Álava }}$

http://www.mcu.es/archivos/MC/AHA/index.html

Archivos Parlamentarios

$\underline{\text { Parlamento Vasco. Servicio de Archivo }}$

http://www.parlamento.euskadi.net/pfrm_cm_catc.html

Archivos Religiosos

Diocesanos

$\underline{\text { Archivo Histórico Diocesano de Vitoria }}$

http://www.ahdv-geah.org/cast/archivo2a.html

\section{GUIPUZCOA}

Archivos Administración Autonómica

\section{Generales}

$\underline{\text { Centro de Patrimonio Documental del Gobierno Vasco Irargi }}$

http://www.snae.org/default.es.php

Archivos Administración Local

\section{Ayuntamientos}

$\underline{\text { Archivo del Ayuntamiento de Bergara }}$

http://bergarakoartxiboa.net/

$\underline{\text { Archivo Municipal de Irún }}$

http://www.irun.org/archivo/caste/hist.htm

$\underline{\text { Archivo Municipal de Hernani }}$

http://www.hernani.eu/antCatalogo.asp?nombre $=968 \&$ hoja $=0 \&$ sesion $=1$

$\underline{\text { Archivo Municipal de Rentería }}$

http://www.errenteria.net/es/html/9/1648.shtml 


\section{Diputación}

$\underline{\text { Archivo General de Guipúzcoa }}$

http://www.artxibogipuzkoa.gipuzkoakultura.net/index-es.php

Archivos Estatales

Provinciales

Archivo Histórico Provincial de Guipúzcoa

http://www.mcu.es/archivos/MC/AHG/index.html

Archivos Notariales

$\underline{\text { Archivo Histórico de Protocolos de Guipúzcoa }}$

http://www.gipuzkoakultura.net/oinati/

Archivos Empresariales

Centro de Documentación LENBUR

http://www.lenbur.com/es/servicios.asp?pag=3

Archivos Instituciones Culturales

$\underline{\text { Archivo de la Sociedad de Estudios Vascos }}$

http://www.eusko-ikaskuntza.org/es/fondodocumental/

Archivos Musicales

Archivo Vasco de la Música ERESBIL

http://www.eresbil.com/

Archivos Religiosos

Diocesanos

$\underline{\text { Archivo Histórico Diocesano de San Sebastián }}$

http://www.mendezmende.org/

VIZCAYA

Archivos Administración Local

Ayuntamientos

$\underline{\text { Archivo Municipal de Bilbao }}$ 
http://www.bilbao.net/nuevobilbao/jsp/bilbao/pwegb010.jsp?idioma=C\&color=rojo\&padre $=*$ V8\&tema $=\&$ subtema $=10 \& p a d r e s u b=861$

$\underline{\text { Archivo Municipal de Getxo }}$

http://www.getxo.net/cas/ayu/corpor/corpo10_1.htm

$\underline{\text { Archivo Municipal de Lekeitio }}$

http://www.lekeitio.com/web/castellano/index.htm

\section{Diputación}

Archivo Histórico Foral

http://80.245.0.30/home2/Temas/DetalleTema.asp?Tem_Codigo=2280\&Idioma=CA

Archivos Estatales

\section{Provinciales}

Archivo Histórico Provincial de Vizcaya

http://www.mcu.es/archivos/MC/AHV/index.html

\section{Archivos Políticos}

Archivo Histórico del Nacionalismo Vasco

http://www.ica.org/en/member/archivo_del_nacionalismo_vasco

\section{Archivos Religiosos}

\section{Diocesanos}

Archivo Histórico Eclesiástico de Vizcaya

http://www.aheb-beha.org/

\section{Archivos Universidades}

$\underline{\text { Archivo General de la Universidad de Deusto }}$ http://www.deusto.es/servlet/Satellite?pagename=UniversidadDeusto/Page/PaginaCollTem plate $\& \mathrm{c}=$ Page $\& \mathrm{cid}=1120221806558 \&$ localizador $=\% 231102609955345 \% 2311202218065$ $\underline{58 \& \text { hizkuntza }=\_ \text {cast } \& \text { indPag }=0 \& \text { filtroParent }=0 \& \text { modo }}=$ 
Archivos Administración Autonómica

\section{Generales}

$\underline{\text { Archivo Histórico de Asturias }}$

http://www.archivosdeasturias.info/

Archivos Administración Local

Ayuntamientos

$\underline{\text { Archivo Municipal de Oviedo }}$

http://www.oviedo.es/index.php/es/el-ayuntamiento/archivo-municipal

Archivo Municipal de Gijón

http://www.gijon.es/Contenido.aspx?id=1925\&leng=es

$\underline{\text { Archivo Municipal de Siero }}$

http://www.ayto-siero.es/index.asp?MP=1\&MS=9\&MN=2

Archivos instituciones culturales

Fundación Archivo de Indianos (Colombres)

http://www.archivodeindianos.es/portada_intro.htm

$\underline{\text { Real Instituto de Estudios Asturianos }}$

http://ridea.org/

Archivos sindicales

Archivo Histórico de Comisiones Obreras de Asturias. Fundación Muñíz Zapico http://www.fundacionjuanmunizzapico.org/archivo.htm

Archivos Universidades

$\underline{\text { Archivo Histórico de la Universidad de Oviedo }}$

http://buo.uniovi.es/Buo-Historico.html

COMUNIDAD VALENCIANA

ALICANTE 
Archivos Administración Local

\section{Ayuntamientos}

$\underline{\text { Archivo Municipal de Alcoy }}$

http://apl.alcoi.org/warxiu/index.asp

$\underline{\text { Archivo Municipal de Alicante }}$

http://www.alicante-ayto.es/archivo/home.html

$\underline{\text { Archivo Municipal de Crevillente }}$

http://www.crevillent.es/index.php/cultura/archivo-munucipal

$\underline{\text { Archivo Municipal de Denia }}$

http://www.denia.es/va/cultura/arxiu/index.aspx

$\underline{\text { Archivo Histórico Municipal de Ibi }}$

http://www.ibivirtual.com/web/archivo_historico.htm

$\underline{\text { Archivo Municipal de Pego }}$

http://www.pego.org/cultura/arxiuv.html

$\underline{\text { Archivo Municipal de Villajoyosa }}$

http://www.villajoyosa.com/cultura/concejalia/archivo_municipal.php

$\underline{\text { Archivo Municipal de Villena }}$

http://www.turismovillena.com/noticia.asp?idnoticia=59738

\section{Diputación}

$\underline{\text { Archivo de la Diputación Provincial de Alicante }}$

http://archivo.ladipu.com/ 
Archivos Instituciones Culturales

$\underline{\text { Instituto Alicantino de Cultura Gil- Albert }}$

http://www.dip-alicante.es/ga/gilalbert/pub/inicio.asp

Archivos Personales

Fundación Miguel Hernández

http://www.miguelhernandezvirtual.com/archivos_personales/web/archivos_personales/jua

n_guerrero_zamora/archivo.php

Archivos Políticos

$\underline{\text { Archivo de la Democracia }}$

http://www.arxiudemocracia.ua.es/index.asp?idioma=_esp

Archivos Universidades

$\underline{\text { Archivo General Universidad de Alicante }}$

http://www.ua.es/va/servicios/ayr/archivo_general/index.html

$\underline{\text { Universidad Miguel Hernández (Elche) }}$

http://www.umh.es/servicios/documyreg.htm

\section{CASTELLÓN}

Archivos Administración Local

\section{Ayuntamientos}

$\underline{\text { Archivo Municipal de Villarreal (Castellón) }}$

http://www.amvila-real.com/index_val.php

$\underline{\text { Archivo Municipal de Vinarós }}$

http://vinaros.es/templates/ficha10.php?idsec=46\&idkey=38\&id_idioma=2

\section{Diputación}

Archivo de la Diputación Provincial de Castellón de la Plana

http://www2.dipcas.es/servicio/archivo.asp\#B

\section{Archivos Económicos}

Cámara Oficial de Comercio, Industria y Navegación de Castellón

http://www.camaracs.es/apartados/biblioteca/arxiu/arxiu.asp?id=6 
Archivos Personales

$\underline{\text { Archivo Max Aub }}$

http://www.maxaub.org/

Archivos Universidades

$\underline{\text { Archivo Universidad Jaume I }}$

http://www.uji.es/CA/cd/cas/arxiu/parxiu.thtml

\section{VALENCIA}

Archivos Administración Autonómica

\section{Generales}

$\underline{\text { Archivo Central de la Generalitat Valenciana }}$

http://www.valencia.es/ayuntamiento/infociudad_accesible.nsf/vDocumentosWebListado/ $\underline{\text { B1523051E0E05027C12572C20023B770?OpenDocument\&bdOrigen=\&idapoyo=\&nivel }}$ $=3 \&$ lang $=1$

$\underline{\text { Archivo del Reino de Valencia }}$

http://www.jdiezarnal.com/valenciaarchivodelreino.html

\section{Archivos Administración Local}

\section{Ayuntamientos}

$\underline{\text { Archivo Municipal de Gandía }}$

http://www.gandia.org/web/guest

$\underline{\text { Archivo Municipal de Manises }}$

http://www.manises.es/manisesPublic/manises/ayuntamiento/arxiu.html

$\underline{\text { Archivo Municipal de Moncada }}$

http://www.moncada.es/opencms/moncada/es/servicios/Arxiu_Administratiu/

$\underline{\text { Archivo Histórico Municipal de Sueca }}$

http://sapiens.ya.com/webarchivo/Castellano/Principal.html 
$\underline{\text { Archivo Municipal de Valencia }}$

http://www.valencia.es/ayuntamiento/Infociudad_accesible.nsf/DocumentosWeb/C272B0 $\underline{\text { A7A237D0A6C12572C20023B775?OpenDocument\&lang=1 }}$

\section{Diputación}

Archivo Diputación de Valencia

http://www.dival.es/archivogeneral/http://www.dival.es/isum/Main?ISUM_ID=Left\&ISU $\underline{\text { M_SCR=groupScr\&ISUM_CIPH=ntnBCl!WtMjxQTL43iO5REEtfQTeulqUVvlE6N5fee }}$ $\underline{Y}$

\section{Archivos Parlamentarios}

$\underline{\text { Archivo de las Cortes Valencianas }}$

http://www.cortsvalencianes.es/contenido.jsp?id_nodo=4123

\section{Archivos Universidades}

Archivo Histórico Universidad de Valencia http://biblioteca.uv.es/castellano/bibliotecas/arxiu_his/a_historic.php

Archivo Intermedio Universidad de Valencia http://biblioteca.uv.es/castellano/bibliotecas/arxius/a_intermedi.php

$\underline{\text { Archivo de la Escuela Técnica Superior de Arquitectura de Valencia }}$ http://www.upv.es/entidades/ETSA/indexc.html

\section{MURCIA}

\section{Archivos Administración Autonómica}

\section{Generales}

Archivo General de la Región de Murcia http://www.carm.es/neweb2/servlet/integra.servlets.ControlPublico?IDCONTENIDO=391 9\&IDTIPO $=100 \&$ RASTRO $=\mathrm{c} 791 \$ \mathrm{~m} 3901$

\section{Provinciales}

$\underline{\text { Archivo Histórico Provincial de Murcia }}$ 
http://www.carm.es/neweb2/servlet/integra.servlets.ControlPublico?IDCONTENIDO=383 $\underline{5 \& \text { IDTIPO }=11 \& \text { RASTRO }=\mathrm{c} 791 \$ \mathrm{~m} 3901}$

Archivos de la Administración Local

\section{Ayuntamientos}

$\underline{\text { Archivo Municipal de Archena }}$

http://www.archena.es/archivomunicipal

$\underline{\text { Archivo Municipal de Calasparra }}$

http://www.regmurcia.com/servlet/s.S1?sit=c,373,m,139\&r=CeP-16434-

R_3064_DETALLE_REPORTAJES

$\underline{\text { Archivo Municipal de Caravaca de la Cruz }}$

http://www.caravaca.org/index.php?option=com_content\&task=blogcategory \&id=82\&Ite $\underline{\operatorname{mid}=122}$

Archivo Municipal de Cartagena

http://www.cartagena.es/frontend/ayuntamiento/portales/archivo/_k8YzNWsdhjyhUSzaY5 vlgXcjuwdkaZj-EtYGQNO-ilc

$\underline{\text { Archivo Municipal de Jumilla }}$

http://www.um.es/gtiweb/bibjumilla/archivo.htm

Archivo Municipal de Mazarrón

http://www.mazarron.es/servicios/archivo-municipal.asp

Archivo Municipal de Molina de Segura

http://www.molinadesegura.es:8880/jopac/controladori18n?origen=busquedasimple.jsp\&lo $\underline{\text { cale }=\mathrm{es}}$

Archivo Municipal de Murcia 
http://www.carm.es/neweb2/servlet/integra.servlets.ControlPublico?IDCONTENIDO=436 9\&IDTIPO=11\&RASTRO=c791\$m3901,3925,4546

\section{Archivos Universidades}

$\underline{\text { Archivo de la Universidad de Murcia }}$

http://www.um.es/biblioteca/servicios/index.php?var=archivo_uni 